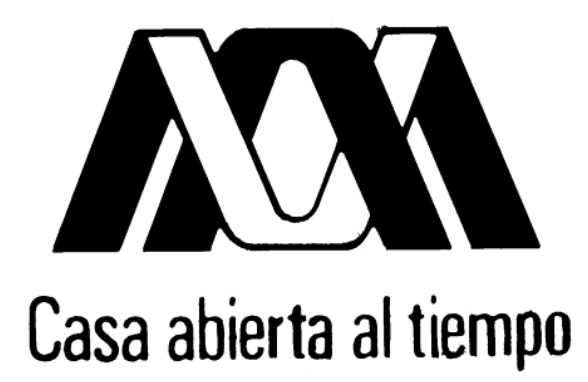

UNIVERSIDAD AUTÓNOMA METROPOLITANA

UNIDAD IZTAPALAPA

DIVISIÓN DE CIENCIAS SOCIALES Y HUMANIDADES

POSGRADO EN CIENCIAS ANTROPOLÓGICAS

\title{
AUTONOMÍA INDÍGENA, VIOLENCIA Y JUSTICIA
}

GIOVANNA GASPARELLO

Tesis de Doctorado en Ciencias Antropológicas

Directora: Dra. Alicia Castellanos Guerrero

Asesores: Dra. Donatella Schmidt

Dr. Paul Hersch Martinez

México, D.F.

Diciembre, 2014 
AUTONOMIA INDIGENA,

VIOLENCIA Y JUSTICIA
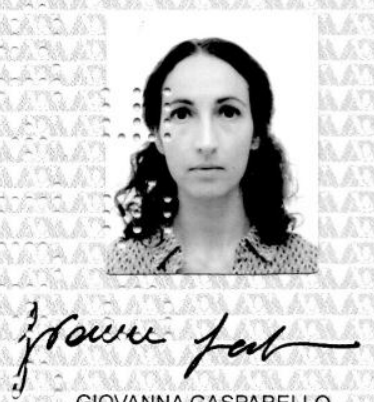

GIOVANNA GASPARELLO ALUMNA

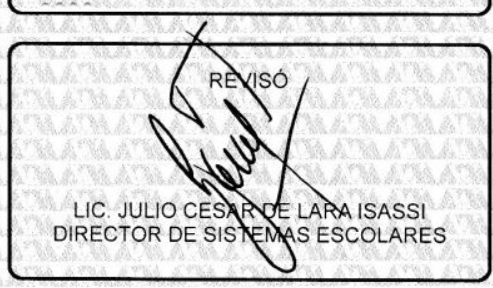

DIRECTQRA DE LA DIVISIÓN DE CSH

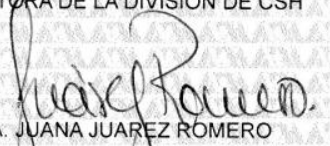

DRA. JUANA JUAREZ ROMERO

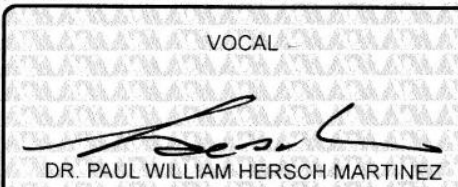

En México, D.F., se presentaron a las 15:00 horas del día 8 del mes de diciembre del año 2014 en la unidad

Iztapalapa de la Universidad Autónoma Metropolitana, los suscritos miembros del jurado:

DRA. ALICIA CASTELLANOS GUERRERO

DRA. MARGARITA DEL CARMEN ZARATE VIDAL

DR. PAUL WILLIAM HERSCH MARTINEZ

DR. GILBERTO LOPEZ Y RIVAS

DRA. ANGELA GIGLIA CIOTTA

Bajo la Presidencia de la primera y con carácter de Secretaria la última, se reunieron a la presentación de la Disertación pública cuya denominación aparece al margen, para la obtención del grado de:

DOCTORA EN CIENCIAS ANTROPOLOGICAS

DE: GIOVANNA GASPARELLO

y de acuerdo con el artículo 78 fracción IV del Reglamento de Estudios Superiores de la Universidad Autónoma Metropolitana, los miembros del jurado resolvieron:

\section{APROBAR}

Acto continuo, la presidenta del jurado comunicó a la interesada el resultado de la evaluación y, en caso aprobatorio, le fue tomada la protesta.

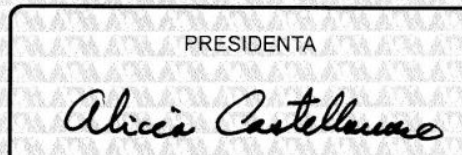

DRA. ALICIA CASTELLANOS GUERRERO
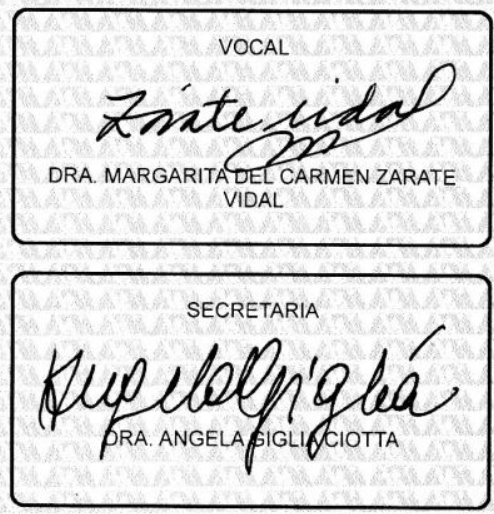
A Paola e Giancarlo per la fiducia incrollabile e l'amore di sempre 
AUTONOMIAINDIGGENA, VIOLENCIAY JUSTICIA 


\section{Agradecimientos}

A los pueblos, comunidades y compañeros zapatistas por seguir enseñando que la democracia, la libertad y la justicia son un derecho que debemos pelear y un deber que debemos cumplir y construir todos los días y en todos los lugares.

El ejemplo de inquebrantable dignidad, de profunda humanidad y de firme perseverancia es una enseñanza que orienta mis pasos, y un compromiso que mueve mi trabajo teórico y social. Agradezco a la Junta de Buen Gobierno de la Zona Selva Fronteriza y a las autoridades autónomas por apoyar en todo momento esta investigación, y a la comunidad de La Realidad por su hospitalidad.

A la cooperativa Yachil Xojobal que permitió dar vida a nuestro pequeño proyecto de café, ya que "si come uno, que coman todos".

A los pueblos, comunidades y compañeros de la Costa Chica y Montaña de Guerrero, por el ejemplo de determinación con el que defienden sus vidas y su territorio, y la fuerza inextinguible para superar los obstáculos y seguir de pie.

A la Coordinadora Regional de Autoridades Comunitarias por la confianza otorgada y la disponibilidad en compartir su trabajo y experiencia.

A los compañeros del Equipo de Comunicación Comunitaria por el gran trabajo que todos juntos realizamos.

A la comunidad y los amigos de Colombia de Guadalupe por su apoyo incondicional y por abrir sus casas y sus corazones.

A los "presos políticos, de conciencia e injustamente presos" y sus familiares, quienes dieron vida a las trascendentales experiencias de organización y lucha al interno de los penales chiapanecos: La Voz del Amate y La Voz de los Llanos.

A los compañeros que crearon el Municipio Autónomo de San Juan Copala en Oaxaca y a Radio Nomndaa en Guerrero, por compartir su experiencia.

A los centros de derechos humanos Tlachinollan, Fray Bartolomé de las Casas y Miguel Agustín Pro Juárez, por su ejemplo en la defensa de los derechos fundamentales y su contribución a la investigación.

A la Universidad Autónoma Metropolitana, al Departamento de Antropología y al Posgrado en Ciencias Antropológicas por darme la oportunidad de realizar los estudios de Posgrado; por 
el apoyo a distintas actividades que impulsé y el soporte a la investigación, en diversas formas y momentos.

A la Secretaría de Relaciones Exteriores, cuya beca me sostuvo durante los primeros tres años del trabajo doctoral.

A mi familia toda y a mis padres, Paola y Giancarlo, por la confianza inquebrantable, el apoyo y el amor profundo, sin los cuales este trabajo no hubiera sido posible.

A Jaime, mi compañero de vida, quien recorrió conmigo mucho del camino andado: sin su ayuda activa en todas las etapas de la investigación y las fundamentales reflexiones compartidas, este trabajo tampoco hubiera sido posible.

A Alicia Castellanos y Gilberto López y Rivas, quienes me orientaron en la investigación y en otras distintas actividades, por el apoyo en todos los sentidos y la confianza en todo momento. A todos los que compartieron su experiencia, sus reflexiones y parte de su vida conmigo, y que con ello me permitieron entender y amar la realidad mexicana, indígena, guerrerense, chiapaneca, y desentrañar las contradicciones que vierten alrededor de las luchas por la autonomía y por la justicia: Valentín Hernández Chapa, Roberto Stefani, Jorge Santiago, Melquiades Martínez, Enrique González Ruiz, Arturo Miranda, Raymundo Sánchez Barraza, Ricardo Montejano, Paul Hersch, Donatella Schmidt, Luis Hernández Navarro y Hermann Bellinghausen.

A mis grandes amigas y compañeras del Posgrado en Ciencias Antropológicas, con quienes compartimos reflexiones estimulantes y experiencias de investigación y de vida diversas: Clara Balderrama, Gabriela Escobar, Florencia Mercado y Olga Picún. Su afecto y su presencia en todo momento me sostuvieron y animaron a seguir en el trabajo de investigación, y fueron referencia y anclaje en mi vida migrante.

A todos los amigos y compañeros de México e Italia, que me acompañan desde hace años en esta gran apuesta: Juan, Matari, Barbara, Adolfo, Paco, Luz y Timo, Moy, Vilma y Vittorio, Serena, Ivan, Eugenio, Duccio y todos los que me olvidé mencionar... 


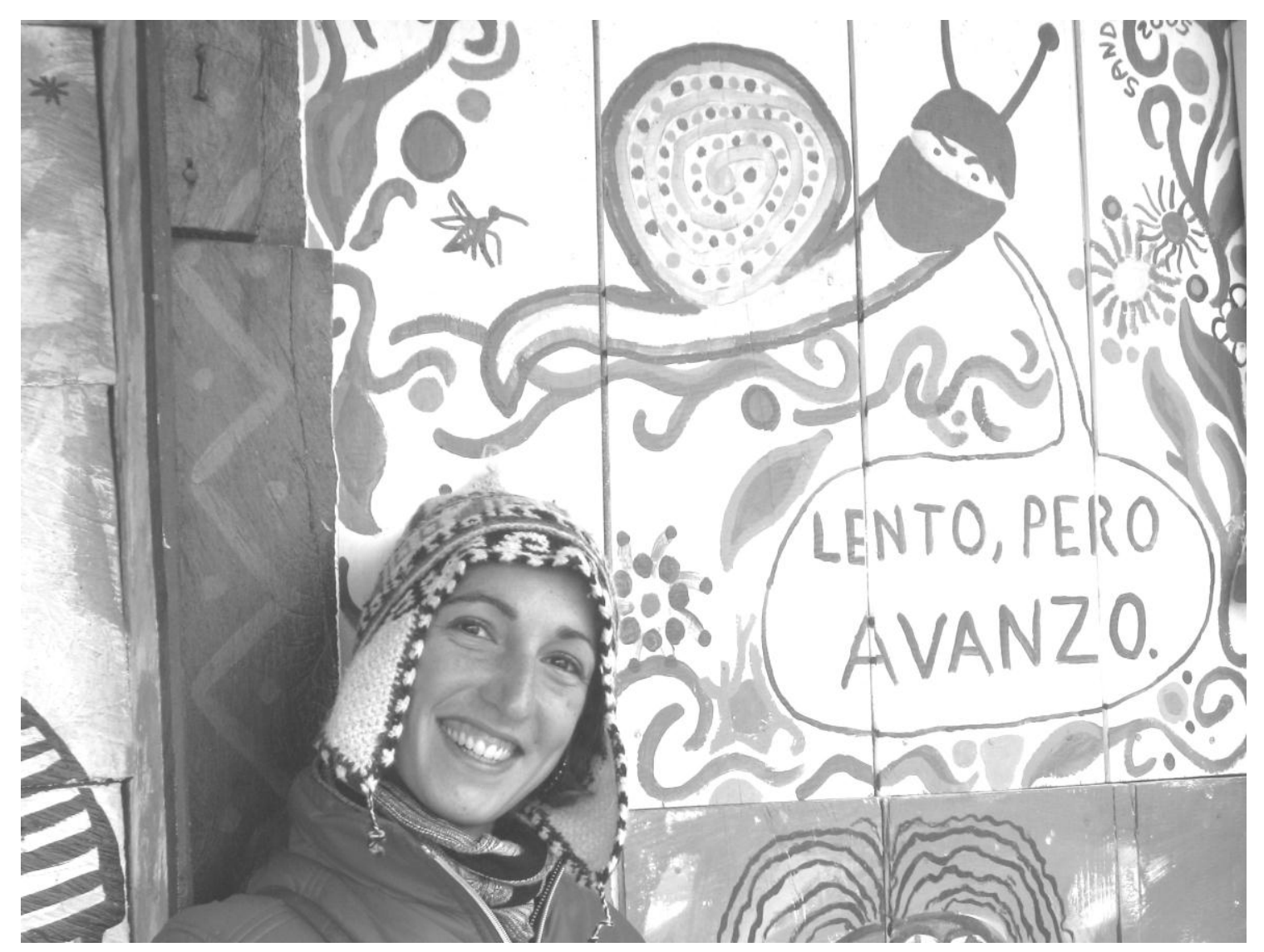

¡MUCHAS GRACIAS! 
AUTONOMIAINDIGGENA, VIOLENCIAY JUSTICIA 


\section{ÍNDICE}

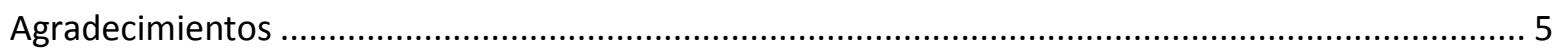

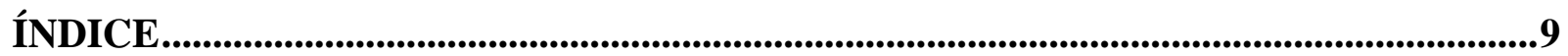

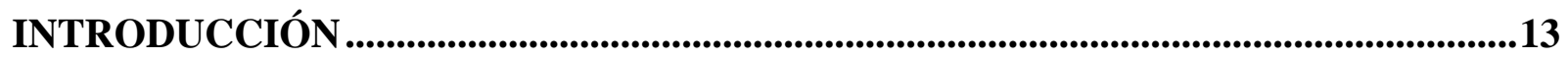

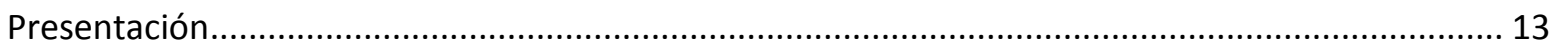

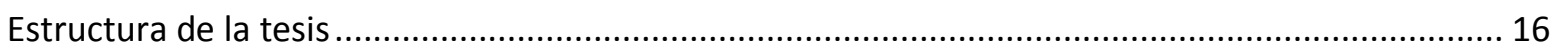

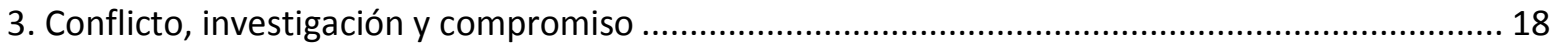

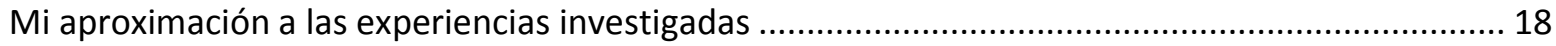

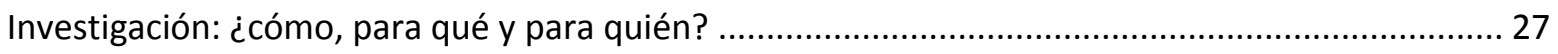

\section{CAPITÚLO 1}

VIOLENCIAS Y PUEBLOS INDÍGENAS.........................................................................35

1. Violencias: horizonte interpretativo y realidad cotidiana ......................................................... 35

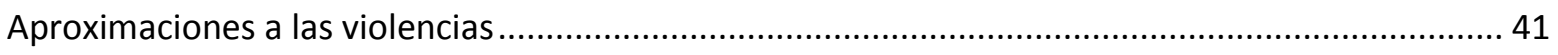

Violencia y política, entre el Estado y el Derecho ........................................................................... 43

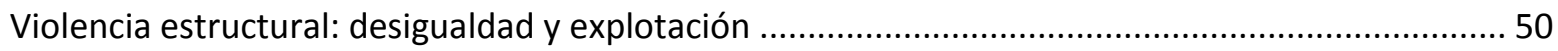

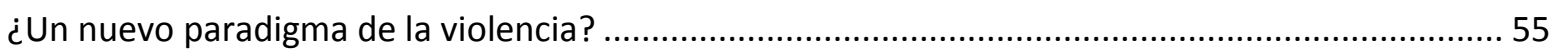

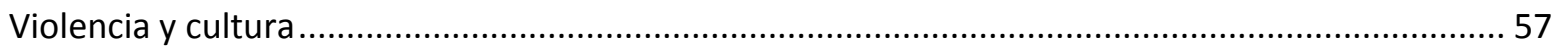

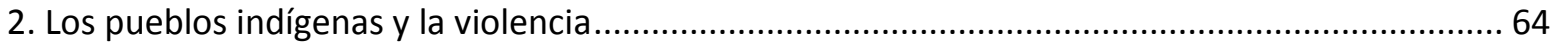

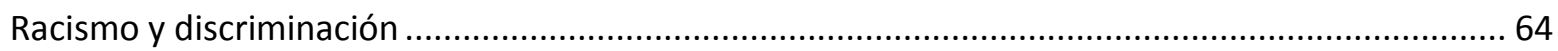

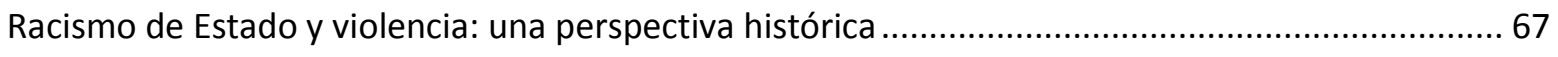

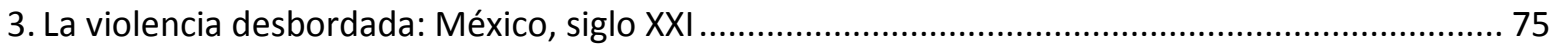

"Guerra" al narcotráfico, militarización de la seguridad pública y violación de los derechos humanos 76

La "guerra" en la sociedad: miedo, criminalización de la protesta social, paramilitarismo .............. 82

Violencia, narcotráfico y organización comunitaria en las regiones indígenas ............................... 92

\section{CAPÍTULO 2}

\section{PUEBLOS INDÍGENAS, NACIÓN Y ESTADO EN MÉXICO .........................................97}

1. Indigenismo, desarrollo, neoliberalismo, participación. Las políticas de Estado en el siglo XX y XXI

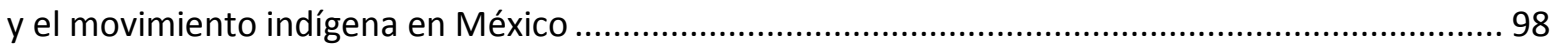

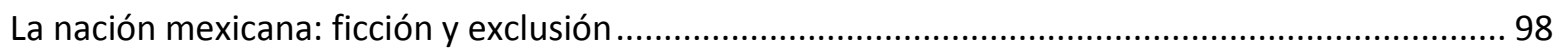




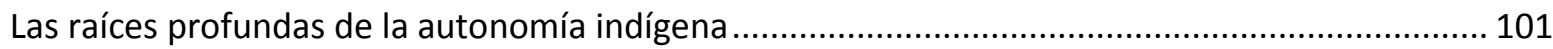

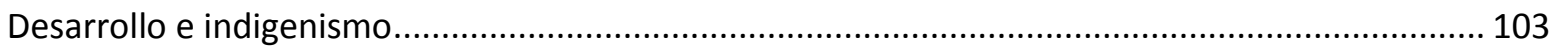

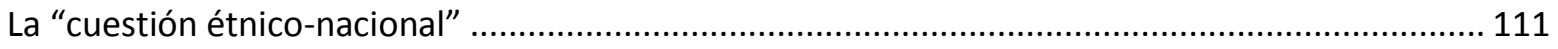

Articulación del movimiento indígena mexicano 1970-1990......................................................... 113

Neoliberalismo y multiculturalismo: maquillar el desarrollo y preservar la desigualdad............... 117

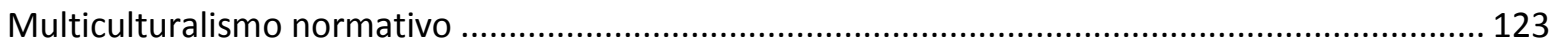

Derechos individuales y colectivos, derechos a la pertenencia y a la diferencia ............................ 130

Multiculturalismo y (neo) indigenismo: ¿a quiénes benefician los derechos culturales? Políticas del

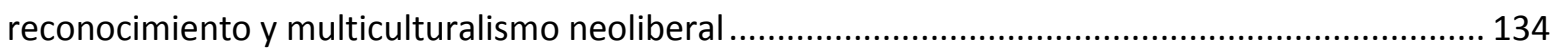

Vertientes organizativas de los movimientos indígenas mexicanos en el siglo XXI ...................... 142

¿A quién quieren que seamos iguales? Ciudadanía y diversidad.................................................. 148

Descentralización y participación ciudadana en el neoliberalismo ............................................... 152

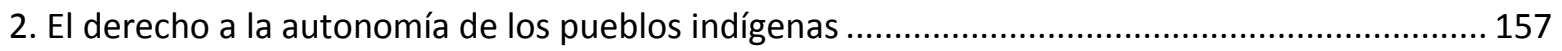

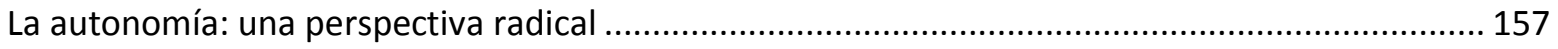

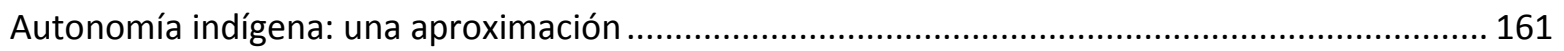

LATAUTONOMY: el sujeto autonómico y las diez hipótesis de sostenibilidad .............................. 165

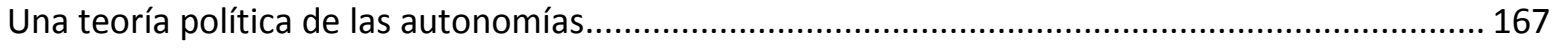

La autonomía a debate: muchas experiencias, diferentes interpretaciones ................................ 169

Los caminos de la autonomía en México. Un largo debate ......................................................... 175

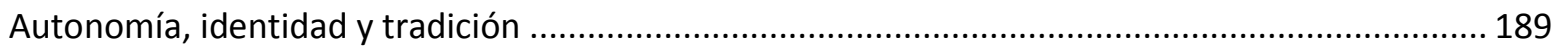

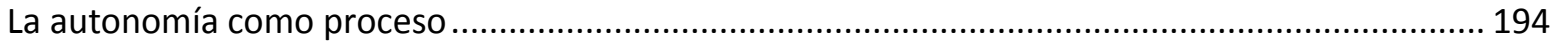

¿Autonomía o autonomías? Del concepto a la práctica y regreso.................................................... 197

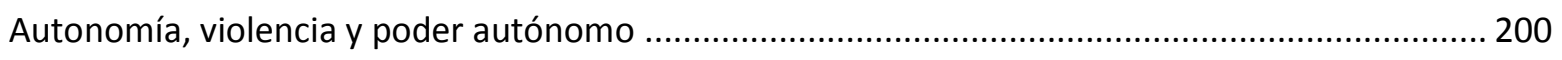

Autonomía, violencia y derecho a la autodefensa .................................................................... 211

\section{CAPÍTULO 3}

\section{LA SELVA LACANDONA: HISTORIAS DE PODER, VIOLENCIA, LUCHA SOCIAL Y AUTONOMÍA .........................................................................................................................217}

La Selva Lacandona: crisol de conflictos y de rebeldía................................................................ 221

La finca, el baldío y la colonización de la Selva como "liberación ................................................. 226

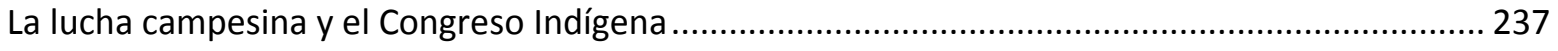

Aumenta la violencia y nace la organización armada ....................................................................... 248

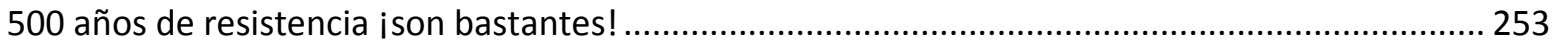


Militarización y paramilitarización: las diversas caras de la violencia de Estado.

Zapatismo y conflicto agrario

2. Chiapas en el siglo XXI: desarrollismo estatal, resistencia indígena ......................................... 271

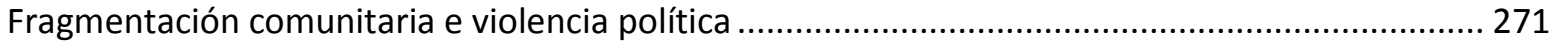

Las violencias "ocultas" del neodesarrollo y el asistencialismo...................................................... 273

La Selva, las Cañadas y la zona Fronteriza: militarización, conservación y explotación .................. 277

\section{CAPÍTULO 4}

\section{JUSTICIA INDÍGENA E INTERCULTURAL: LA JUSTICIA SEGÚN LA JUNTA DE BUEN GOBIERNO ZAPATISTA DE LA ZONA SELVA FRONTERIZA ...................287}

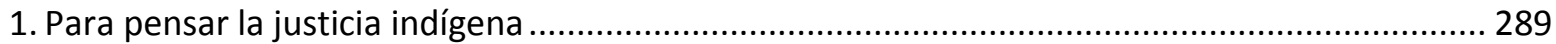

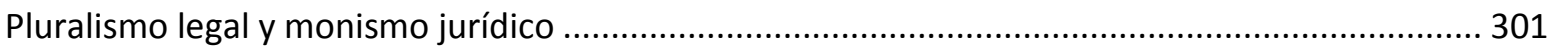

2. Experiencias de resolución de conflictos en Chiapas: conciliación y construcción de la paz........ 305

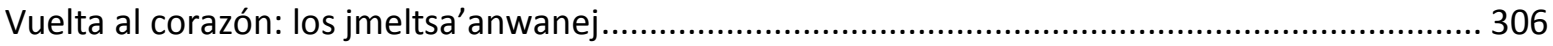

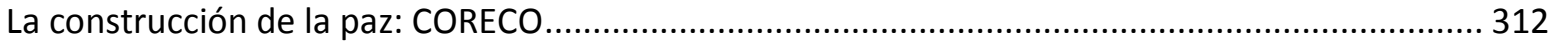

Origen y estructura del gobierno autónomo zapatista. Instancias de resolución de los conflictos 317

La comunidad. Autoridades-concejo, asambleas y acuerdos ...................................................... 317

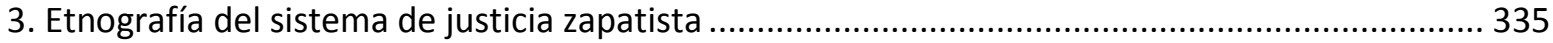

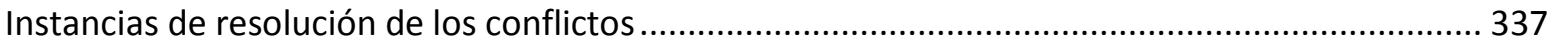

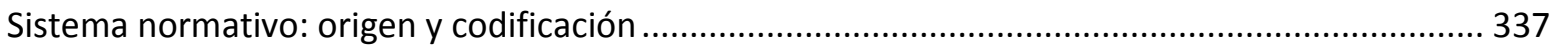

Tipo de problemas que se presentan a las autoridades autónomas ............................................ 341

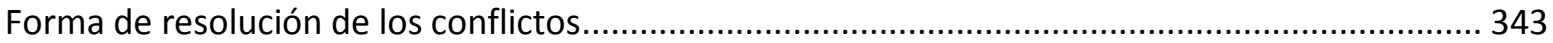

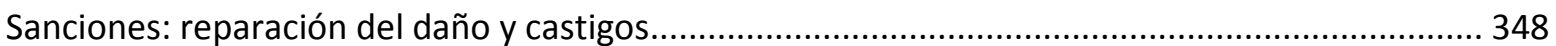

Trato a los castigados, justicia comunitaria y expulsiones........................................................... 352

El "camino del buen pensamiento": valores de la justicia autónoma ............................................. 356

Conflictos políticos y divisiones comunitarias. La disputa con la CIOAC........................................ 363

4. Una experiencia paradigmática: el Sistema de Seguridad, Justicia y Reeducación Comunitaria de

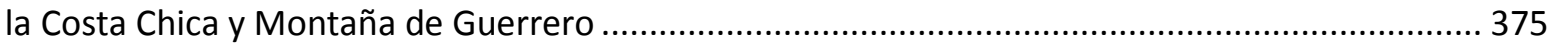

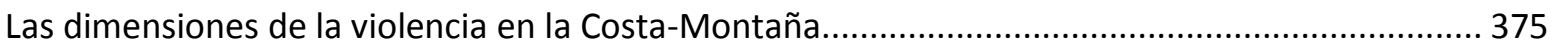

Origen y estructura del Sistema de Seguridad, Reeducación y Justicia Comunitaria ..................... 377

Formas de resolución de los conflictos: conciliación y reeducación ............................................... 382

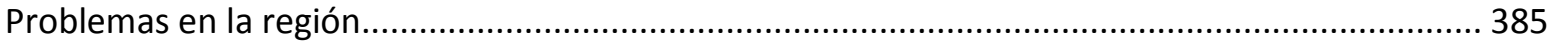

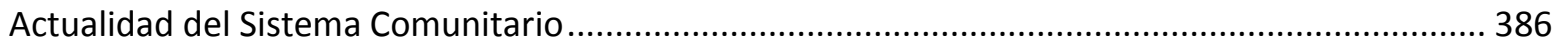




\section{CAPÍTULO 5}

LA JUSTICIA AUTÓNOMA Y LA JUSTICIA DEL ESTADO.......................................389

1. Mecanismos alternativos de resolución de conflictos y justicia para indígenas .......................... 390

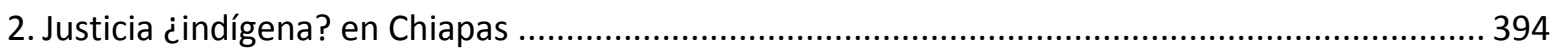

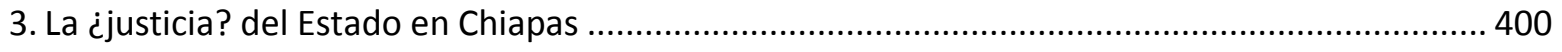

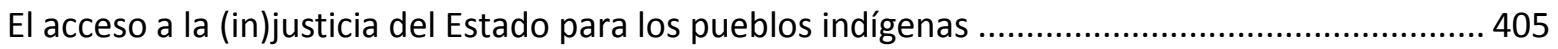

4. Los presos indígenas y la lucha por la dignidad en las cárceles de Chiapas ............................... 415

5. La relación entre la justicia autónoma zapatista y el Estado...................................................... 429

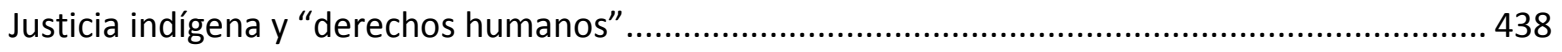

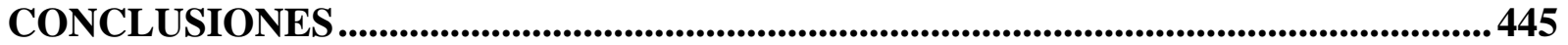

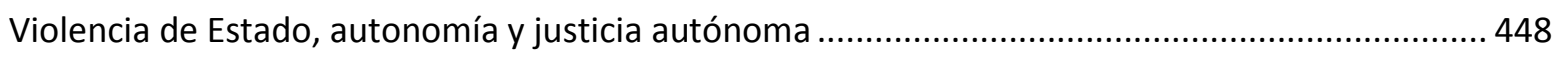

Autonomías contra-hegemónicas en perspectiva y la relación con el Estado .................................. 454

Posdata. Enfoque, encuadre y "fieldwork under fire" ................................................................ 458

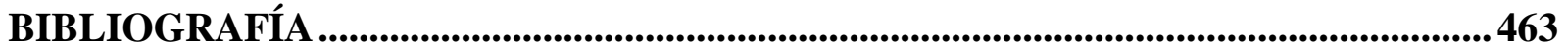

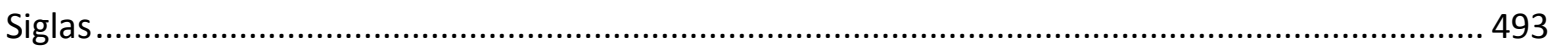

\section{MAPAS}

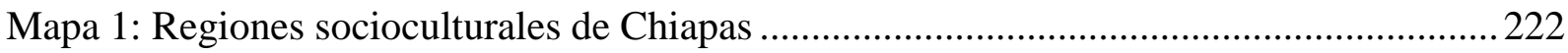

Mapa 2 : Chiapas meridional y Selva Lacandona: división municipal .....................................223

Mapa 3: Rutas de la colonización en la Selva Lacandona …………….....................................2232

Mapa 4: coincidencia entre la Zona Lacandona (Bienes Comunales) y Reserva Integral de la Biosfera de Montes Azules. Poblados originariamente amenazados de desalojo.....................244

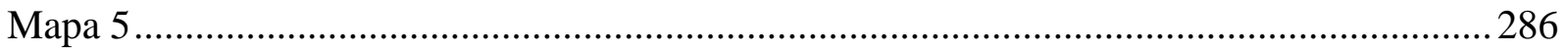

Mapa 6: Caracoles zapatistas. División regional (Zonas) .........................................................328

Mapa 7: Municipios Autónomos de la Zona Selva Fronteriza................................................. 330 


\section{INTRODUCCIÓN}

\section{Presentación}

Esta tesis doctoral analiza una de las muchas experiencias autonómicas presentes hoy en día en el territorio mexicano, enfocando las prácticas de resolución de los conflictos y la administración de la justicia en el marco del ejercicio de la autonomía indígena. La organización que protagoniza el estudio resalta, por su trascendencia y continuidad, en el panorama de las luchas indígenas entre el final del siglo XX y el principio del siglo XXI: se trata de las Juntas de Buen Gobierno, proyecto civil del Ejercito Zapatista de Liberación Nacional (EZLN) en Chiapas.

La hipótesis central es que los procesos autonómicos representan una respuesta positiva a las distintas dimensiones de la violencia que históricamente han padecido los pueblos indígenas. La importancia del tema trasciende en la situación social que caracteriza México hoy en día, pues la violencia desbordada trastoca todos los ámbitos sociales y tiene importantes implicaciones para los procesos organizativos de distintos sectores sociales, entre ellos los indígenas.

En este trabajo documento el desarrollo y los alcances de la autonomía zapatista, situándola en una perspectiva histórica. La importancia del ámbito de resolución de conflictos y de construcción de sistemas normativos, como parte de los procesos de autonomía, ha sido definida por algunos autores como una suerte de "indicador" de la vitalidad de los procesos mismos. El espacio de la justicia adquiere particular relevancia también por el contexto en el cual se desarrolla, caracterizado por múltiples formas de violencia, que van forjando las maneras en las que se ejerce la justicia (tanto por parte del Estado que de los procesos autonómicos) y determinando sus alcances.

Los tópicos de la autonomía indígena (como reivindicación y construcción concreta de espacios de justicia social) y la justicia (como horizonte, sistema de valores y sobre todo como 
experiencias concretas de resolución de conflictos) se entretejen con otro tema, el de la violencia, que representa una suerte de telón de fondo y de leit motif que atraviesa e interviene en todos los procesos estudiados.

Este trabajo se inserta por lo tanto en la rama de estudios denominada antropología de la paz, la cual "no estudia a las sociedades no violentas, sino los contextos violentos o potencialmente tales, y las acciones humanas emprendidas para establecer un poco de paz o mantener la que existe" (Hébert 2006:8).

Este trabajo se fundamenta en cuatro hipótesis generales, ligadas a las temáticas que lo articulan:

1. Violencia. Históricamente, los pueblos indígenas han vivido en situaciones de violencia (violencia de Estado y represión, caciquismo, racismo, violencia inter e intraétnica, delincuencia común, crimen organizado, violencia política y violencia estructural). Los procesos de organización y construcción de autonomía representan una respuesta a estas variadas situaciones de violencia.

2. Autonomía. La experiencia analizada representa un importante proceso autonómico, que contextualizaré comparándolo con otros que tienen alcances distintos en el ejercicio de la autonomía. Los conflictos y los obstáculos, externos e internos, determinan la forma de la autonomía y su magnitud.

3. Justicia. El proceso estudiado cuenta con un sistema jurídico autónomo y autoridades para su ejercicio. Vistas las deficiencias del sistema jurídico y judicial del Estado, los sistemas autónomos para la procuración e impartición de justicia constituyen una respuesta más adecuada a las necesidades de los pueblos indígenas, y les garantizan un mejor acceso a la justicia, representando una alternativa a partir de una concepción distinta de la justicia.

4. Relación con el Estado e institucionalización: La justicia autónoma puede ser una práctica que apunta hacia la democratización de la sociedad y del Estado, pero será trascendente solo si un sujeto autonómico fuerte puede imponer la viabilidad y la legitimidad del autogobierno indígena (en específico, el sistema jurídico indígena) en la negociación con el Estado. De otro modo, después de un tiempo, la justicia autónoma será subsumida por el sistema estatal o por los poderes fácticos a nivel local, perdiendo su autonomía. 


\section{AUTONOMIAINDÍGENA, VIOLENCIAY JUSTICIA}

Formulé cada hipótesis de acuerdo a una serie de interrogantes, que me guiaron para el desarrollo del trabajo. En relación a la violencia, me pregunté:

¿Cuáles "tipos" de violencia se viven en las regiones de estudio, cuál es su origen y cual la reacción de los pueblos?

¿El conflicto intercomunitario, o entre organizaciones políticas, como se articula con la violencia del Estado?

¿Qué impacto puede tener la creciente presencia de la delincuencia organizada en las regiones indígenas (en términos culturales, en el sentido común de la gente, en sus expectativas, y en su vida cotidiana, pero sobretodo en los procesos organizativos de los pueblos) y la correspondiente militarización que conlleva la "lucha contra el narcotráfico"? ¿Se pueden observar herramientas o estrategias defensivas elaboradas por las organizaciones o pueblos indígenas?

Con respecto a la autonomía, las preguntas giraron alrededor de dos ejes. En primer lugar, la aproximación a distintas definiciones de autonomía y a diferentes perspectivas de interpretación y análisis; en segundo lugar, el espacio social y las relaciones de poder y violencia en las regiones vistos como generadores de los procesos autonómicos, y las particularidades de cada proceso. Así, me pregunté:

¿Cómo se han construido históricamente las diferentes interpretaciones sobre la autonomía?

¿En qué ámbitos los procesos autonómicos que destacan en la actualidad (en distintas regiones de México) están construyendo autonomía? ¿Cuál es su discurso y percepción sobre la propuesta autonómica?

En la región de estudio, ¿qué tipo de contexto local y regional determinan la particular forma de autogobierno en construcción (experiencias organizativas anteriores, estructura de gobierno local actual y precedente a la organización autónoma)?

¿Cuáles son las bases ideológicas y culturales de las prácticas y de los discursos políticos que sustentan los diferentes proyectos autonómicos?

¿Cuáles fueron los problemas o necesidades principales que determinaron el inicio de la experiencia autonómica? ¿En qué ámbitos se empezó a construir la autonomía, cuáles fueron los primeros pasos de la organización autónoma?

¿En el ejercicio de la autonomía, en qué coinciden y en qué se diferencian las experiencias? 
Para el tema de la justicia, las principales preguntas de investigación fueron:

¿Cómo se articulan las formas de resolución de los conflictos propias de las culturas indígenas con los elementos del derecho positivo?

¿Qué eficacia y que legitimidad tienen los sistemas de justicia autónoma?

¿Cuáles son los valores que mueven las prácticas de justicia autónoma? ¿De qué forma estas se diferencian de la justicia del Estado?

Finalmente, el tema muy espinoso y en continua transformación que es la relación entre las justicias autónomas y el Estado, ha sido enfocado con base en preguntas como estas:

¿Cómo actúan las autoridades judiciales y ministeriales de la región frente a la población indígena y campesina?

¿La "justicia autónoma” es una alternativa eficaz para resolver los problemas de la población que la aprovecha?

¿Cuál es la relación, en términos concretos, entre el sistema policiaco, judicial y jurídico estatal y las estructuras autonómicas?

\section{Estructura de la tesis}

La tesis consta de una introducción y cinco capítulos. En el texto introductorio explico cuál ha sido mi aproximación a las experiencias investigadas, junto con una reflexión sobre los temas del conflicto, la investigación académica y el compromiso político.

En el capítulo 1 propongo una revisión sobre las principales teorías y conceptualizaciones de la violencia en una perspectiva interdisciplinaria; un breve esbozo general de las principales formas de violencia que viven los pueblos indígenas; la caracterización de la situación actual en el país y de las reformas que se han impulsado en el ámbito penal a nivel nacional. Planteo también la hipótesis de que las experiencias de justicia indígena en el marco de la autonomía representan una alternativa a la "in-justicia" dominante.

El capítulo 2 ahonda en la relación entre los pueblos indígenas, la nación y el Estado en el México contemporáneo, en particular analizando las políticas enfocadas al "desarrollo" y aquellas que se centran en el multiculturalismo, como dos formas de desconocimiento/reconocimiento, siempre parciales, de la diferencia cultural y política. En 
este capítulo abordo uno de los temas centrales de la tesis: la temática del derecho a la autonomía de los pueblos indígenas, analizando el debate sobre el tema y esbozando algunas experiencias de autonomía indígena en México y en otros países latinoamericanos. La discusión teórica se enriquece con experiencias concretas, tanto en el planteamiento de los derechos indígenas como en el análisis de la relación entre las autonomías y el Estado.

El capítulo 3 analiza la construcción del espacio social de la Selva Lacandona en perspectiva histórica, identificando algunos sujetos y momentos determinantes para la región y para el contexto estatal. Visualizo las manifestaciones de la violencia, en particular el racismo y la corrupción institucional, la violencia estructural y el conflicto social, como tres dimensiones de la relación entre instituciones, grupos oligárquicos y pueblos indígenas. En este capítulo utilizo las herramientas teóricas desarrolladas en el Capítulo 1 para caracterizar el contexto regional en el cual florece la experiencia de organización indígena.

El siguiente capítulo representa el núcleo de la tesis y se nutre principalmente del material etnográfico fruto de la investigación de campo en Chiapas y otras regiones del país, en particular la Montaña de Guerrero. En el capítulo 4 expongo y discuto algunas aproximaciones desde la antropología jurídica sobre los temas de la justicia indígena y el pluralismo jurídico. Introduzco unas experiencias de justicia indígena en Chiapas, que me ayudarán a contextualizar el caso específico analizado, es decir la justicia autónoma zapatista en la Zona Selva-Fronteriza. Finalmente, muestro el funcionamiento, la estructura y los valores de dicho sistema de justicia, así como los conflictos de difícil resolución y que representan puntos de quiebre en el sistema (conflictos con otras organizaciones y disputa por el control político el territorio).

En el capítulo 5 analizo la legislación estatal en materia indígena, enfatizando aquella que instituye instancias especializadas para la atención a la población indígena y enmarcándola en el contexto de la reforma al sistema de justicia nacional y la introducción de sistemas alternativos de resolución de conflictos. Expongo las características del sistema de (in)justicia estatal y las múltiples violaciones a las garantías individuales, y a los derechos de los pueblos indígenas, que en tal contexto se llevan a cabo, lo que ha originado fuerte movilizaciones de presos indígenas.

Finalmente, propongo unas conclusiones generales, evidenciando las perspectivas hacia justicias y autonomías integrales. A la luz de lo que he expuesto en los capítulos anteriores, 
argumento las posibilidades y los límites que tienen las autonomías, y en particulares de los sistemas de justicia autónoma, para ser una respuesta y una solución a las situaciones de violencia. Asimismo, frente a las deficiencias del sistema de justicia estatal, busco determinar si los sistemas autónomos representan una alternativa eficaz a partir de un sentido diferente de la justicia, pero sobre todo, desde una perspectiva concreta, de una práctica distinta para la resolución de los conflictos. El análisis de las prácticas jurídicas autónomas proporciona elementos para reflexionar sobre la necesidad y la viabilidad de nuevas legalidades y formas de ejercer la justicia, cuya valoración puede abonar a la apertura de espacios democráticos y a la reducción de las dinámicas violentas que atraviesan la sociedad.

\section{Conflicto, investigación y compromiso}

\section{Mi aproximación a las experiencias investigadas}

El sistema de gobierno autónomo zapatista en Chiapas es una experiencia paradigmática para las nuevas luchas indígenas que caracterizan el México actual. Fue sobre todo a raíz del levantamiento zapatista en 1994 que las luchas indígenas, hasta entonces en muchos casos encubiertas, empezaron a buscar y encontrar las formas para hacerse patentes, ponerse en red entre ellas y con la sociedad a nivel más amplio. Empecé a acercarme a las experiencias de resistencia indígena en ocasión de un momento de apertura y encuentro entre los indígenas zapatistas y la sociedad civil: el Primer Encuentro Intergaláctico Por la Humanidad y Contra el Neoliberalismo realizado en 1996 en la comunidad chiapaneca de La Realidad. El discurso zapatista tuvo desde el primer momento un fuerte impacto entre los movimientos y las experiencias (auto) organizativas que, "desde abajo y a la izquierda", en diferentes rincones del mundo tratan de construir alternativas de participación ciudadana y nuevos derechos. En precedentes investigaciones $(2004,2005)$ he tratado de explicar el importante papel que tuvo el movimiento zapatista en la izquierda alternativa italiana y en el debate sobre autonomía y democracia participativa que se dio en algunos ámbitos de la izquierda institucional italiana. Mi primera estancia larga en La Realidad, en ese entonces sede del Aguascalientes 1 y cuartel general de la Comandancia del EZLN, fue en 1999, cuando participé en el proyecto para la instalación de una turbina para la energía eléctrica, impulsado por la asociación italiana Ya 
Basta, a la que pertenezco desde entonces. A ese viaje se sucedieron otros, siempre ligados a los proyectos de cooperación entre la Junta de Buen Gobierno de la Zona Selva Fronteriza y la asociación Ya Basta, pero también por el proyecto de investigación personal que empezó a tomar forma: la trascendencia del debate sobre la autonomía, en México y en Italia, me empujó a ahondar en la forma en como la estaban construyendo las mismas comunidades zapatistas, realizando sobre el tema mi tesis de licenciatura en Etnología en la Universidad de Padova, Italia. L'autonomia possibile. Chiapas: la costruzione dell'autogoverno nelle comunità indigene della Selva Lacandona es fruto de un trabajo de investigación de aproximadamente tres años, durante los cuales fui conociendo con más profundidad el alcance de las reivindicaciones zapatistas y la importancia de la lucha indígena en México. Así, empecé a interesarme en otras experiencias autonómicas que están construyendo los pueblos indígenas mexicanos, con la preocupación de documentar los diferentes caminos posibles en la búsqueda de alternativas de convivencia entre los hombres, que sean respetuosas y sustentables.

Desde el 1994 a la fecha, el movimiento indígena propuso y experimentó mucho, pero mi interés se fue focalizando en algunas situaciones paradigmáticas por los temas movilizados en su práctica y en su discurso. Así me acerqué al Municipio Autónomo de San Juan Copala, Oaxaca, y acompañé en parte su proceso y su lucha de resistencia, lo que resultó en una relación de confianza y amistad con algunos de sus representantes, al igual que con Radio Ñomndaa de Suljaa', Guerrero. Al mismo tiempo, realicé muchas estancias de trabajo de investigación y de cooperación con la Coordinadora Regional de Autoridades ComunitariasPolicía Comunitaria (CRAC-PC) de la Costa Chica y Montaña de Guerrero. Entrar al Posgrado en Ciencias Antropológicas de la UAM me permitió concretizar el interés hacia este último proceso en la investigación para la Maestría. Empecé el trabajo de campo sistemático para la elaboración de esta tesis en julio 2006; durante más de seis años, realicé repetidas estancias de investigación en la Costa y Montaña de Guerrero, en particular en la cabecera de San Luis Acatlán, en las comunidades de Colombia de Guadalupe y Espino Blanco (zona me'phaa), así como estancias más breves en las comunidades de Zitlaltepec y Chilistlahuaca (zona ñu saavi). En calidad de observadora he participado a numerosas Asambleas Regionales, micro-regionales y comunitarias, así como a los eventos de Aniversario de la Policía Comunitaria. 


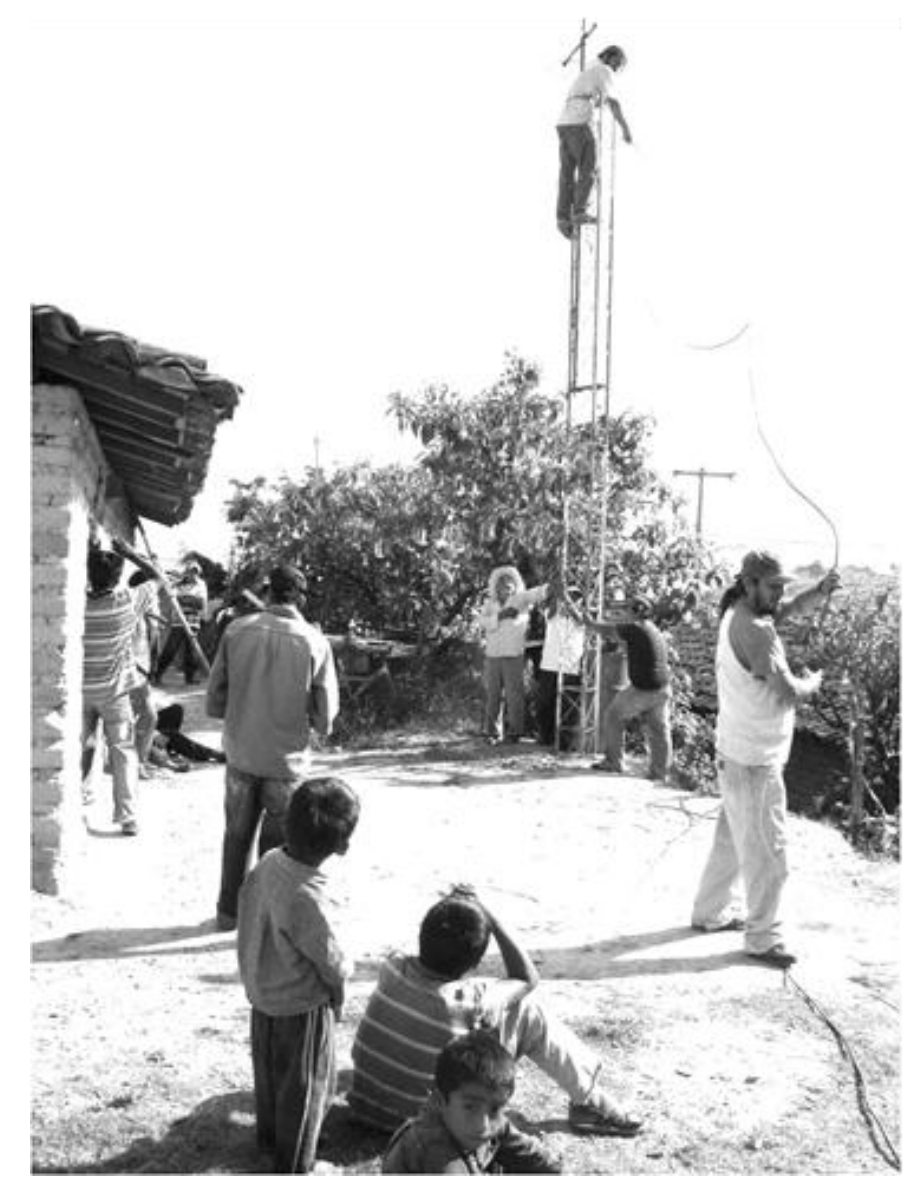

Instalación de Kimi Ndica 2, 2009

Mi acercamiento a esta organización fue, en un primer momento, como antropóloga para realizar mi investigación en la región, pues pedí y obtuve el permiso de los Coordinadores Regionales para acompañarlos en sus actividades cotidianas y realizar entrevistas, formales e informales, a los integrantes de la organización. Sin embargo, después de unos meses, fui invitada a apoyar a la CRAC en la implementación de un proyecto de largo alcance: el proyecto de Comunicación Comunitaria, que se ha concentrado, hasta la fecha, principalmente en el ámbito radiofónico. Mi interés para el mundo de la radio nació hace tiempo, cuando, antes de transferirme en México, trabajé por algunos años en una histórica radio de mi ciudad, Padova: Radio Sherwood, una radio "comunitaria” por su organización y "antagonista" por los contenidos de su programación, desde siempre ligada a los movimientos de izquierda en la región. Después de esa experiencia, mantuve una atención particular a los procesos de organización y comunicación que nacen desde abajo, y acepté con entusiasmo la invitación de 


\section{AUTONOMIAAINDÍGENA, VIOLENCIAY JUSTICIA}

la CRAC. Desde el 2006 iniciamos el diseño del Proyecto de Comunicación Comunitaria, que se ha concretado en la instalación de cuatro radios comunitarias y la creación de una página web, todas herramientas operadas por jóvenes de la región.

El largo proceso de sensibilización de la gente, la organización de incontables talleres de capacitación para los futuros locutores y operadores de las radios, los procesos de instalación, la reflexión sobre los problemas que fueron emergiendo en el proyecto y entre los grupos de locutores, la organización de eventos con otras radios comunitarias: en todos estos momentos tuve la oportunidad de caminar con La Voz de los Pueblos, La Voz de la Costa Chica, Radio Kimi Ndica y El despertar de los Pueblos, creciendo junto a los jóvenes de las radios, y construyendo con la organización responsable -la CRAC- una relación de profunda confianza, que parte del trabajo compartido en un proyecto de común interés. Fruto de esta experiencia es el trabajo "No morirá la flor de la palabra... La radio comunitaria indígena en Guerrero y Oaxaca, México", en el que traté de sistematizar los conocimientos adquiridos y las reflexiones desarrolladas en esta experiencia, ubicándolas en un marco teórico que abarca la antropología y los estudios comunicacionales.

El trato con la CRAC cambió desde una relación externa hacia una posición más interna u orgánica de quien escribe, pues fui asumiendo tareas de largo plazo en el desarrollo de uno de los nuevos proyectos de la organización. Es sabido que una excesiva cercanía a lo que estudiamos puede deformar nuestra mirada impidiéndonos tener un enfoque crítico y fomentando la tendencia a la idealización, y no excluyo que esto haya podido suceder también en este caso. Por otro lado, este posicionamiento de alguna manera "interno" a algunos ámbitos de acción de la organización me ha permitido acercarme a su realidad más allá del discurso público de sus representantes, en muchos casos "edulcorado" con respecto a las dinámicas cotidianas y a los conflictos reales que atraviesan la administración de justicia comunitaria, y determinan su transformación. Esto me permitió una mirada más decantada y honesta, pudiendo apreciar los límites y las posibilidades de las personas con puestos de responsabilidad y de las acciones colectivas promovidas por la organización. 


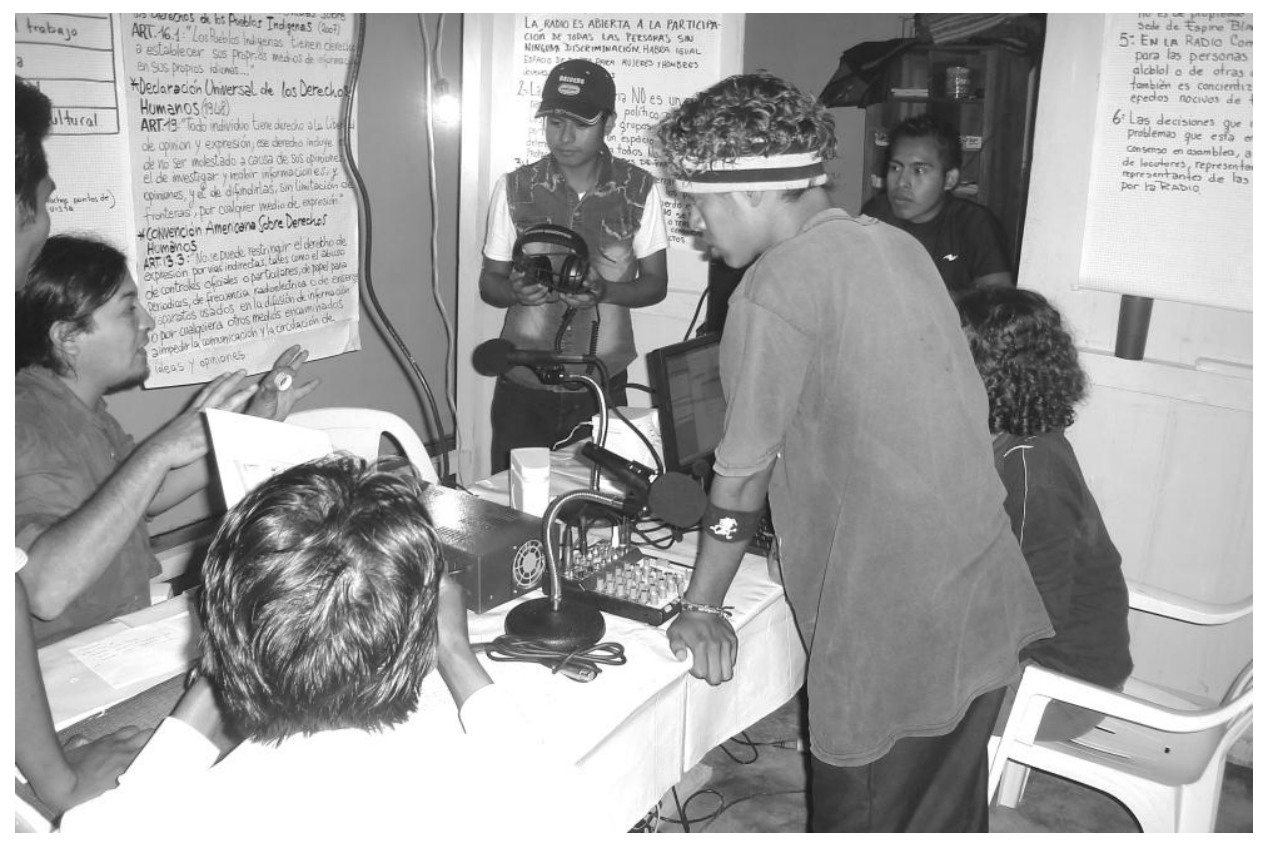

Taller en La Voz de Los Pueblos, 2008.

Desde luego, en todo momento he tenido el cuidado de delimitar mi papel activo al ámbito exclusivo del Proyecto de Comunicación, manteniéndolo separado de mis actividades de investigación sobre el funcionamiento y la trascendencia del Sistema de Justicia Comunitaria. Estas se han desarrollado de manera relativamente "formal", en el estilo más clásico de la observación participante durante la resolución de conflictos a los que pude participar y en las asambleas; con entrevistas formales e informales tanto a las diferentes autoridades de la CRAC (ya que su cargo dura tres años pude conocer ya tres "formaciones") y a los Policías Comunitarios, cuanto a los habitantes de las comunidades y de las cabeceras de San Luis Acatlán y de Tlapa. Al respecto, es necesario observar que mis tareas en el Proyecto de Comunicación me llevaron a acercarme y convivir de forma particular con los jóvenes de las comunidades, ya que la edad de los que se acercan a las Radios va desde los 15 a los 25 años. Compartir experiencias de trabajo, discusiones y momentos de fiesta con los jóvenes me'phaa, ñu saavi y no indígenas, estudiantes o jóvenes profesionistas, en su mayoría sin cargos comunitarios y con una visión de la vida en la comunidades algo distinta a los adultos, ha sido una experiencia muy rica y estimulante.

La comunidad indígena donde más tiempo he permanecido ha sido Colombia de Guadalupe, en la región me’phaa (tlapaneca) de la Montaña. Aquí, la maravillosa hospitalidad 
de una familia cuyos hijos participaron desde el principio en el Proyecto de Comunicación, me permitió pasar largas temporadas en la comunidad; la autoridad del jefe de familia, maestro y profesor, me ayudó a despejar las dudas de los habitantes sobre mi presencia en el pueblo. En Colombia de Guadalupe realicé un trabajo de investigación y documentación fotográfica sobre las fiestas y danzas tradicionales que se realizan en la actualidad. ${ }^{1}$ El proyecto "Fiestas y danzas de nuestros pueblos" me dio la oportunidad de participar, en diversas ocasiones, a los momentos festivos de la comunidad, incluso en ceremonias muy privadas; conversando con los ancianos y los encargados de los momentos rituales, pude apreciar una parte de la vida comunitaria y de la cultura me'phaa que no se veía reflejada en las pláticas cotidianas con los jóvenes y los adultos.

Sobre la organización del Sistema de Seguridad, Justicia y Reeducación Comunitaria (SSJRC) realicé la tesis de Maestría, que concluí en el año 2007. Mis estancias en la región prosiguieron hasta el 2012, ligadas a las actividades arriba mencionadas y también a la intención, para el trabajo doctoral, de contrastar esta experiencia con la justicia zapatista. Sin embargo, decidí finalmente enfocar mi atención en el sistema de gobierno y de justicia zapatista, en primer lugar por ser un aspecto de la autonomía zapatista poco investigado y por lo tanto más interesante para dar a conocer. En segundo lugar, considerando que uno de los temas centrales de este trabajo es la construcción de la autonomía, y la experiencia del SSJRC y sus representantes, la Coordinadora Regional de Autoridades Comunitarias (CRAC) ha perdido en tiempos recientes mucha de la autonomía operativa y discursiva que enarbolaba hace unos años, los dos casos resultaban demasiado disimiles, y cada uno con una complejidad propia tan elevada, que opté por analizar en profundidad solo uno de ellos, utilizando el otro como referente y término de comparación.

\footnotetext{
${ }^{1}$ Junto con Jaime Quintana, quien estuvo conmigo en buena parte de las estancias de trabajo e investigación, así como en las actividades ligadas al Proyecto de Comunicación.
} 


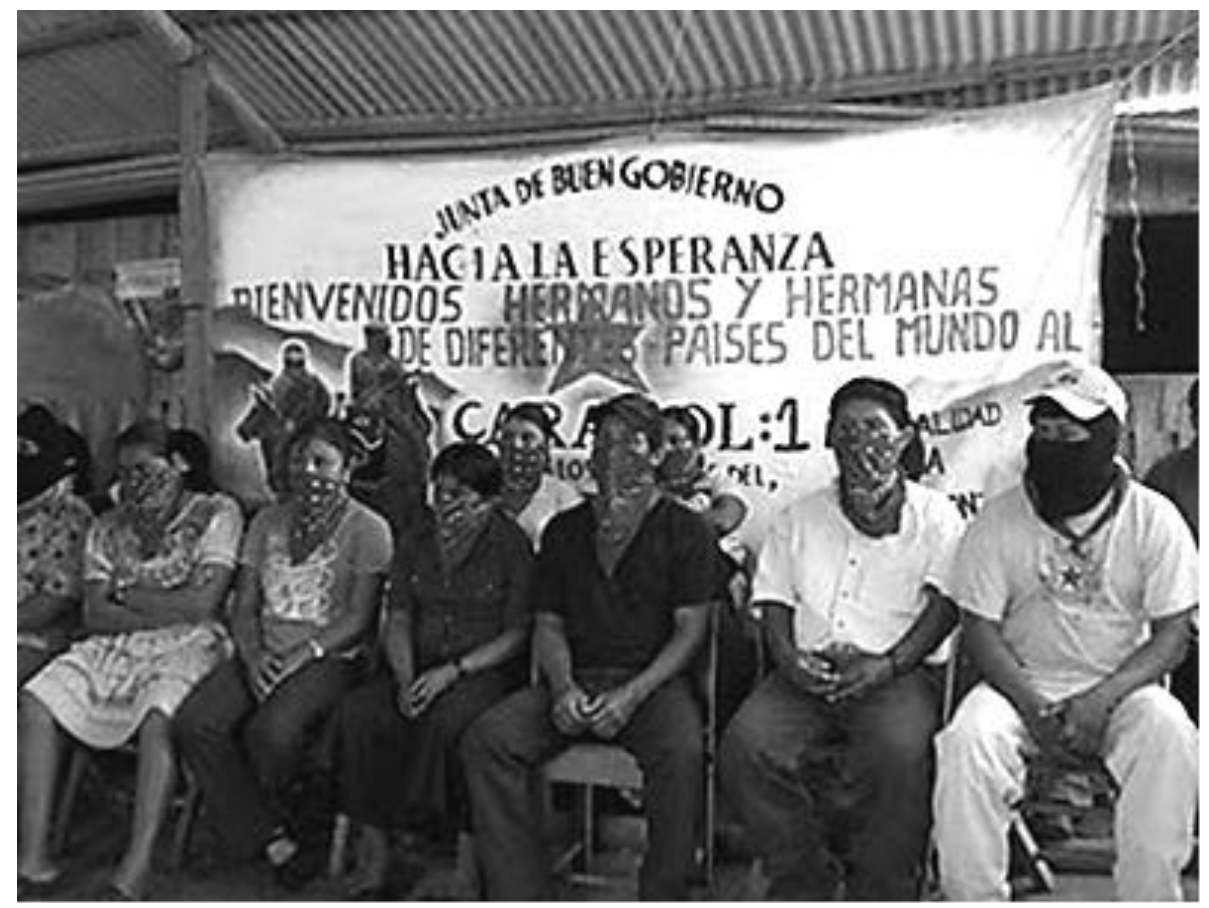

Junta de Buen Gobierno "Hacia la esperanza”, caracol de La Realidad, Chiapas.

La experiencia de investigación el territorio zapatista, en Chiapas, ha sido muy diferente. Mis estancias han sido menos frecuentes pero más largas, debido a la dificultad para acceder a la zona y a las posibilidades para la investigación mismas ofrecidas por la Junta de Buen Gobierno. La situación de conflicto que permanece en la región hace que las autoridades zapatistas sean mucho más cuidadosas con las personas que llegan proponiendo desarrollar proyectos de investigación sobre su sistema de gobierno, rechazando en muchos casos dichos proyectos. Al igual que con la CRAC, me acerqué a la Junta de la Zona Selva Fronteriza presentando mi proyecto de investigación y pidiendo el permiso formal para realizar una serie de actividades. He encontrado una excelente disponibilidad en las autoridades en turno durante las diferentes estancias, quienes aceptaron inmediatamente el proyecto; sin embargo, no tuve el permiso para realizar muchas de las actividades propuestas. Esto depende de varios factores.

La presencia del Ejército y de los grupos paramilitares se combina con un exacerbado conflicto entre las numerosas organizaciones presentes en el territorio de influencia zapatistas, lo que crea una situación muy tensa y delicada. El nivel de violencia es muy alto si se consideran los conflictos que tienen motivaciones políticas. Pero, debido a esta misma naturaleza política del conflicto, las autoridades y los habitantes de las comunidades zapatistas tienen un extremo cuidado al platicar del tema. Las autoridades omiten responder a preguntas que tengan que ver 
con ello, y los habitantes tratan de no expresar opiniones. Hay una parte de la vida comunitaria que parece estar reservada y protegida de ojos externos, creo con la intención de no exacerbar aún más el conflicto. Pero debido a que es la pertenencia política que parece originar la mayoría de los conflictos y la violencia, esto es una gran limitante a la investigación, que gira precisamente alrededor de la resolución de los conflictos.

En este contexto de guerra de desgaste, la etnografía (método por excelencia de la antropología) se puede convertir en un arma de doble filo, pues al presentar descripciones con lujo de detalles de la región y de los miembros del movimiento, o sobre el funcionamiento de los gobiernos autónomos, éstas podrían ser usadas en contra de los militantes zapatistas. Las autoridades autónomas zapatistas seguramente han profundizado mucho en tales reflexiones, viendo el claro carácter "contrainsurgente" que tienen los resultados de varias investigaciones realizadas alrededor del EZLN y al interior de los territorios autónomos.

A diferencia de otras organizaciones y sistemas de autogobierno indígenas, que se abren relativamente- a ojos externos, el sistema de gobierno zapatista es completamente cerrado. Para poner un simple ejemplo, no es permitido permanecer cerca de la oficina de la Junta de Buen Gobierno, lo que impide saber cuáles son sus tareas cotidianas, cuales los conflictos que se le presentan y cómo los resuelve. Pude recaudar la información que se presenta exclusivamente a través de entrevistas formales con las autoridades -comunitarias, municipales y regionales- que manejan un discurso político elaborado y, como es previsible, filtran la información que dan; la entrevista que tuve con los castigados se realizó en la oficina de la Junta de Buen Gobierno con la presencia de una autoridad. Los resultados de la investigación que aquí se presentan han sido revisados y avalados por la Junta de Buen Gobierno en turno en el 2011, quién ratificó su acuerdo a la difusión de la información elaborada.

Las limitaciones a las actividades de investigación (por ejemplo, no tuve el permiso de visitar otras comunidades más allá de La Realidad, sede de la JBG; y en la misma comunidad, crispada por fuertes conflictos internos, la movilidad es reducida, pues no es permitido caminar por doquier ni conversar con cualquiera) determinaron también la reducción de mis estancias en el territorio. Realicé cuatro estancias de investigación de aproximadamente un mes y medio cada una, en 2008, 2009, 2010 y 2011. Quienes escogemos hacer investigación a lado de los 
grupos organizados en luch ${ }^{2}$ (Leyva y Speed 2008: 40) reconocemos los límites que nuestro trabajo puede encontrar y nuestro compromiso ${ }^{3}$ nos orienta en la relación con el grupo. Asimismo, tenemos que reconocer que, en todo contexto de organización social, hay aspectos que son accesibles a observadores externos y otros que pertenecen exclusivamente a los mismos actores; en el desarrollo de una investigación frecuentemente encontramos límites al análisis que no podemos cruzar y que debemos respetar.

Las personas con las que pude conversar o entrevistar formalmente, tanto en Chiapas como en Guerrero, mostraron una gran disponibilidad e interés en la investigación y sus finalidades; cada quien según su tiempo y a pesar de la incomodidad que a veces puede provocar una persona extraña, con una grabadora y haciendo muchas preguntas, todos me apoyaron de manera muy abierta en el trabajo. Encontré una actitud diferente entre las autoridades ministeriales y judiciales, cuyas declaraciones fueron por cierto de gran utilidad para esclarecer la relación entre la institución autónoma y las formales. Tanto en Chiapas como en Guerrero, las entrevistas formalmente solicitadas no siempre fueron otorgadas; en ocasiones, la actitud de la autoridad fue manifiestamente hostil hacia la investigadora; en otros casos, durante las entrevistas se ha expresado la agresividad o el aburrimiento, dos posturas evidentes hacia los temas de conversación. En otras ocasiones, las autoridades han mostrado amplia disponibilidad y también la voluntad de demostrar que su trabajo ya estaba completamente acorde a los preceptos de reconocimiento multicultural que animan las constituciones estatales.

\footnotetext{
${ }^{2}$ La definición se encuentra en Leyva, Xochitl y Speed, Shannon, "Hacia la investigación descolonizada: nuestra experiencia de co-labor" en Xochitl Leyva, Araceli Burguete y Shannon Speed (Coordinadoras) Gobernar (en) la diversidad: experiencias indígenas desde América Latina. Hacia la investigación de co-labor. México D.F., CIESAS, FLACSO Ecuador y FLACSO Guatemala, 2008, pp. 34-59.

${ }^{3}$ Hale se refiere a esto con la necesidad de la "alineación" (alignment) del investigador con los intereses del grupo organizado en lucha. En: Hale, Charles, "Reflexiones hacia la práctica de una investigación descolonizada." Ponencia presentada en la Reunión de Investigación Indígena, organizada por CLASPO, La Paz, Bolivia, 2004.
} 
Investigación: ¿cómo, para qué y para quién?

Son éstas unas preguntas que, probablemente, datan cuanto nuestra disciplina, e inevitablemente se presentan, en algún momento del trabajo etnográfico o de sistematización, al antropólogo que trabaja en situaciones de conflicto social o cultural. Las preguntas metodológicas que se abren al respecto tienen que ver con: la relación entre el antropólogo y los sujetos protagonistas de la investigación; la manera en que se desarrolla la investigación; y el objetivo mismo de la investigación.

En particular, los estudios centrados en los pueblos indígenas se han enfrentado con la permanencia de la dominación, primero aquella colonial y sucesivamente la que han emprendido los Estados nacionales (colonialismo interno, indigenismo, desarrollismo, etc.). Ya desde las Declaraciones de Barbados (1971 y 1977) se ha denunciado la colonialidad del saber producido en la academia, el papel del antropólogo como instrumento de la dominación colonial y la naturaleza extractivista y explotadora de la antropología. En México, la antropología se ha desarrollado, en su inicio y desde el impulso del Estado, como una producción y organización de los saberes sobre los pueblos indígenas tendiente a construir y mantener en condición subalterna partes enteras de la población.

A partir de los años setenta del siglo pasado iniciaron a manifestarse fisuras en esta visión, con los procesos de descolonización y las prácticas intelectuales ligadas a ellos. En México la antropología crítica y comprometida ha puesto en claro la pregunta sobre el papel del antropólogo y su relación con los sujetos estudiados. En la misma época, el sociólogo colombiano Orlando Fals Borda formuló la propuesta de Investigación-Acción Participativa (IAP), que es a la vez una metodología de investigación y un proyecto de transformación social. La IAP propone el análisis de la realidad como una forma de conocimiento y sensibilización de la población, que pasa a ser sujeto activo y protagonista de un proyecto de cambio social; se integran el conocimiento popular y el académico para un común objetivo de transformación.

Los diferentes planteamientos sobre cómo hacer investigación y como construir la relación entre el investigador y los sujetos de la investigación, que retomaré más adelante, tienen que ver necesariamente con un planteamiento epistemológico sobre el tipo de conocimiento generado, y su utilización. El mismo Fals Borda denunció la "arrogancia 
académica", según la cual el saber producido científicamente es superior a los otros tipos de conocimiento. La corriente crítica en las ciencias sociales plantea la complementariedad de los saberes en la interpretación integral de la realidad y en la construcción del conocimiento. "Solo entre todos sabemos todo", afirmaba un marakame wixarríca, y este acercamiento sin presunción es sin duda una herramienta epistemológica, pero también etnográfica, que puede ser clave en el trabajo antropológico.

Por otro lado, reconocer el valor político de la producción del conocimiento ayuda a superar la idea de la "objetividad de la ciencia" que todavía se sostiene en algunos ámbitos de las ciencias sociales; mientras que la histórica y actual servidumbre de la antropología al poder -político o económico, estatal o transnacional- demuestra la falacia de la decantada “autonomía de la investigación”. La pregunta sobre el ¿para qué y para quienes? se genera conocimiento, formulada por Robert Lynd desde $1939,{ }^{4}$ sigue siendo necesaria. Al respecto, concuerdo con la respuesta del historiador Andrés Aubry, quién, después de una larga trayectoria a lado de los pueblos indígenas chiapanecos, afirma que "investigar un problema no es solo indagar como se plantea sino también llegar a resolverlo", y sostiene que el papel de la ciencia social es también la transformación de la realidad. El autor retrata el comportamiento de buena parte de los antropólogos hacia los procesos que estudian: "el antropólogo se interna, a veces penetra, se va con datos e información (no siempre relevante) para escribir su tesis, y si le va bien su libro, regresa un rato para entregar puro papel si tiene un tanto de formalidad, y luego desaparece para siempre sin dejar otra devolución a la comunidad que su literatura ilegible para campesinos" (Aubry 2007: 111-112). Esta descripción resume los comportamientos más comunes y al mismo tiempo más negativos de quiénes hacemos trabajo de campo. En muchos casos, los científicos sociales nos dedicamos a estudiar procesos de organización, resistencia y autonomía de los pueblos, y en nuestros escritos afirmamos la legitimidad de tales luchas; pero se trata de artículos académicos, escritos con un lenguaje muy específico, publicados en revistas especializadas, que se difunden entre un público extremadamente reducido. ¿Es útil o suficiente esta forma de "compromiso", para la transformación de la realidad en la que nos movemos junto con los procesos y movimientos que estudiamos? Seguramente no, han contestado cientos de

\footnotetext{
${ }^{4}$ En su trabajo Knowledge for What? The Place of the Social Sciences in American Culture. Retomo la cita desde Aída Hernández Castillo: 2003.
} 
investigadores que dieron vida a diferentes corrientes de la llamada "antropología comprometida": así, se ha definido la disciplina como "pública", “descolonizada", "activista", "militante", "dialógica”, "crítica”...posiciones cercanas que buscan, en diversa manera, hacer productivo y contundente este compromiso.

En este panorama, el "investigador activista" Charles Hale destaca cuatro posiciones: en primer lugar la antropología pública, que pondría énfasis en la difusión amplia del conocimiento experto, pero que no tiene interés en las metodologías alternativas de investigación. Se mantiene la imagen del científico como una figura con autoridad, pero que escoge sus temas de acuerdo a un compromiso social. Complementaria a esta posición, que enfatiza los resultados de la investigación, estaría la antropología descolonizada, que hace más énfasis en los procesos: parte de la creación de categorías del pensamiento que rompen con la hegemonía occidental, denunciando la "colonialidad del saber". Ambas posiciones se enfocan sobretodo en la producción académica, a diferencia de la antropología activista y aquella militante, que enfatizan las relaciones políticas. La antropología activista, de la cual Hale es sostenedor, pretendería:

Establecer relaciones de colaboración entre investigadores con base en el mundo académico, e intelectuales asociados con un grupo organizado en lucha [...] En vez de una descolonización prioritaria de nuestras categorías del análisis, se propone poner esas categorías y herramientas investigativas al servicio de las luchas subalternas, propiciando el dialogo con los otros saberes, sujetando ambos a una crítica mutua.

Según esta idea, el proceso de la investigación es parte de los resultados; tanto el objetivo, como la metodología y los resultados esperados deberían ser consensados con los "sujetos de estudio", que participarían activamente en el proceso. La necesidad del investigador de tener un análisis crítico y autónomo sobre lo que se estudia, que no sea subsumido por los discursos y las finalidades políticas del "grupo organizado en lucha" es una tensión abierta en este tipo de investigaciones; Shannon Speed trata de resolver la contradicción afirmando que "en el ideal de la investigación crítica y activista, el análisis crítico está dirigido a aterrizar políticamente, y la estrategia política se fortalece por sus resultados" (2006:83). 


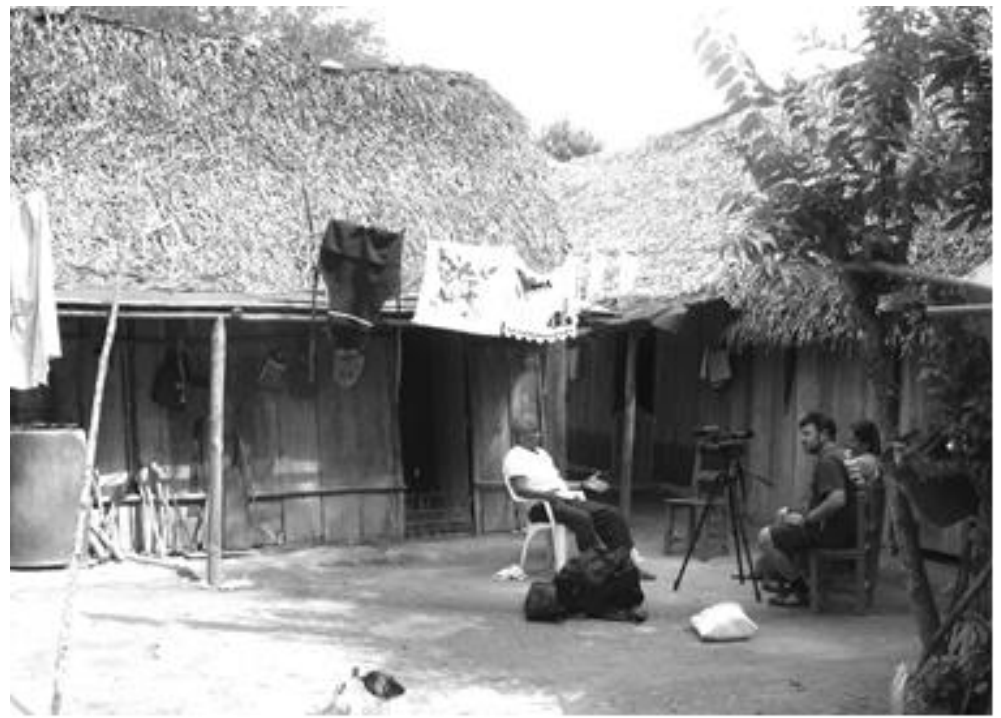

Grabación del largometraje Raíces de Nuestra Justicia, Jaltepec de Candayoc, Oaxaca, febrero 2012.

Finalmente, la investigación militante toma elementos de los tres anteriores puntos de vista, enfatizando particularmente las relaciones cotidianas, la participación directa en el proceso de lucha que hace posible la investigación. Así, enfatizaría más el proceso de investigación que los resultados, que serían comprometidos en cuanto fruto de tal proceso; según Hale, "la apuesta epistemológica de esta
cha: al organizarse, analizar las posición se ubica claramente en el proceso mismo de lucha: al organizarse, analizar las condiciones opresivas, y sobre todo, a luchar en contra de estas condiciones y reflexionar sobre la experiencia misma, se genera una comprensión empírica y teórica de la realidad social que ningún académico convencional podría lograr”.

Lo que es común en todos estos enfoques, y las experiencias de investigación que resultan de ellos, es la voluntad de crear una relación de intercambio con los sujetos estudiados, y realizar investigaciones útiles (en el proceso o en los resultados) a ellos. El ideal propuesto por muchos investigadores activistas sería la "co-teorización” (Rappaport, 2007), lo que implica un profundo trabajo en la planeación misma de la investigación. Si bien la presente investigación sufre de la falta de "co-teorización", no cabe duda que muchas de las pistas estudiadas en adelante surgen de reflexiones aportadas por los entrevistados. Asimismo, lo que animó este trabajo es la voluntad de hacer una investigación cuyos resultados sean útiles a los "grupos organizados en lucha" con los que trabajé, en el entendido que la difusión de sus experiencias puede ser un instrumento didáctico y político para otros pueblos que viven situaciones similares. Esta apuesta fue la que animó otra experiencia paralela a la tesis doctoral, que fue la investigación de campo y la documentación a través de entrevistas audiovisuales de cuatro experiencias de justicia indígenas en México, realizada bajo el 
auspicio del Centro de Derechos Humanos Miguel Agustín Pro Juárez, para la realización de un video documental sobre el tema. Durante la realización del documental, tuve la oportunidad de conocer las prácticas para la resolución autónoma de los conflictos en la comunidad wixarrica Banco de San Hipólito (Durango); la comunidad mixe Jaltepec de Candayoc (Oaxaca); y los jueces tzeltales de Bachajón (Chiapas), lo que me permitió ampliar la visión sobre el tema central de esta tesis.

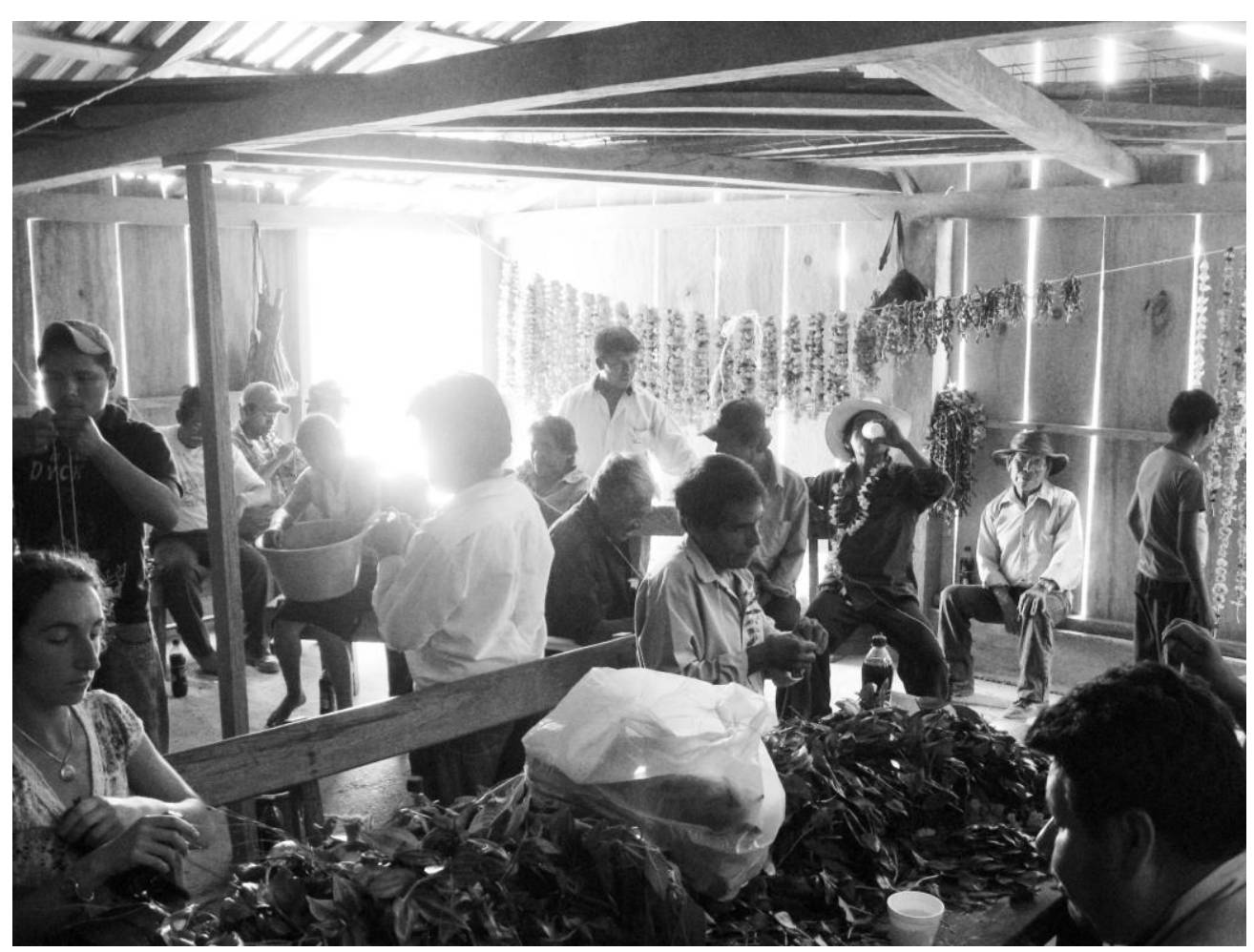

Preparando las ofrendas para Tata Bégó, Colombia de Guadalupe, Montaña de Guerrero, 24 abril 2011.

Así, aunque esta investigación no ha sido desarrollada utilizando alguna metodología "comprometida", la conciencia del compromiso en todo momento ha sido clara en quien escribe, tanto sobre los resultados que se esperan lograr, cuanto en la relación establecida con los sujetos estudiados.

En esto, siempre he tenido claro y quiero reivindicar que el conocimiento que aquí se expresa es por necesidad y por elección "situado", en la acepción adoptada por Donna Haraway. La autora, quien escribe desde los estudios feministas, afirma que el saber siempre es parcial y contingente, y reivindica el "privilegio de la perspectiva parcial", local, desde abajo, pues ésta da consistencia y autoridad a lo que se dice; según esto, la parcialidad se 
distingue del relativismo porque es siempre localizada y crítica. A pesar de las diferentes formas de producción del conocimiento, quien lo produce siempre se sitúa en un lugar y su interpretación es determinada por su posicionamiento: pues precisamente por esto la ciencia social nunca puede ser objetiva. Esto determina por necesidad una relación diferente con el sujeto de estudio: "los saberes situados requieren que el objeto de conocimiento sea representado como actor y como agente, y ciertamente nunca como esclavo del amo que no admite dialéctica atribuyendo sólo a sí mismo el poder de actuar y la autoridad del saber objetivo", afirma Haraway (1995:24). Reconocer el lugar donde nos situamos como investigadores, que puede ser más o menos cercano al rol de activista o al de académico "tradicional", obliga también a reconocer que las posiciones sociales ocupadas por el investigador y por los sujetos estudiados pueden ser diferentes; pues es posible y necesario, en lugar de intentar negar tal diferencia, usar las "posiciones privilegiadas" que gozamos desde la academia para respaldar estos procesos, a través de la difusión de su experiencia y la denuncia de la represión que padecen.

Esta aspiración fue la que animó la realización del libro colectivo Otras geografías. Experiencias de autonomía indígena en México, que coordiné con Jaime Quintana en el 2009. Esta obra fue para mí una experiencia profunda de "co-labor" con representantes de organizaciones indígenas, académicos, periodistas y activistas mexicanos; tratamos de romper la mala costumbre de que los académicos escribimos lo que los otros hacen, y bajo el lema "todos tenemos la palabra" invitamos a las organizaciones que luchan para la autonomía a escribir ellas mismas sobre su lucha, e lo mismo hicimos con los activistas e investigadores comprometidos.

El texto resultó por lo tanto polifónico y realmente representativo, pues todos lo asumieron como suyo; y tuvo también el resultado de fomentar las redes de solidaridad e intercambio entre los que participaron en el proyecto: entre las organizaciones cuyas luchas mostraron sus similitudes, y con los académicos que se acercaron a procesos que no conocían desde cerca. Este resultado se logró en buena medida a través del "plan de diseminación” por

\footnotetext{
5 La "antropología activista" toma conciencia de que el investigador y los "sujetos de estudio" se encuentran inevitablemente en condiciones de poder desiguales, así como desde afuera hay una valoración desigual del "conocimiento científico" producido por los antropólogos sobre el conocimiento producido por los sujetos en sí (Speed:2006).
} 
medio de las presentaciones: además que en las ciudades, organizamos eventos en los territorios indígenas donde actuan las organizaciones que escribieron, y que en cada presentación estuvieran representantes de las demás experiencias autonómicas. Esto se hizo posible en gran medida por la disponibilidad y la visión "descolonizadora" que, sobre este proyecto, tuvo la Universidad Autónoma Metropolitana y su Departamento de Antropología: al donar la mitad del tiraje de la primera edición, permitió que los libros se pudieran vender a precios bajos para financiar los viajes de presentación, y en muchos casos hasta regalar. Concebido como un texto de difusión, pedimos a los investigadores que utilizaran un lenguaje "profano", es decir coloquial y no especializado, y esto abrió la posibilidad de que cualquier persona alfabetizada pudiera aprovechar los contenidos expresados.

Con estas reflexiones reafirmo la convicción de que el investigador, sobre todo aquel que se mueve y trabaja en contextos de conflicto, debe ser flexible y predispuesto para cubrir diferentes roles: activista para plantear la investigación al servicio de los sujetos en lucha, público para hacer valer su autoridad en contextos institucionales, militante para acompañar las luchas y servir de amplificador de las reivindicaciones, crítico para mantener una visión propia y con ella aportar a la reflexión interna de los procesos estudiados, y siempre de acompañante solidario sin caer nunca en la intervención. Lo que mantiene el rumbo del investigador, en todo caso, es precisamente la conciencia de nuestro posicionamiento y la afirmación de nuestra peculiar visión, de las lentes con las que miramos las situaciones que vivimos y estudiamos. 


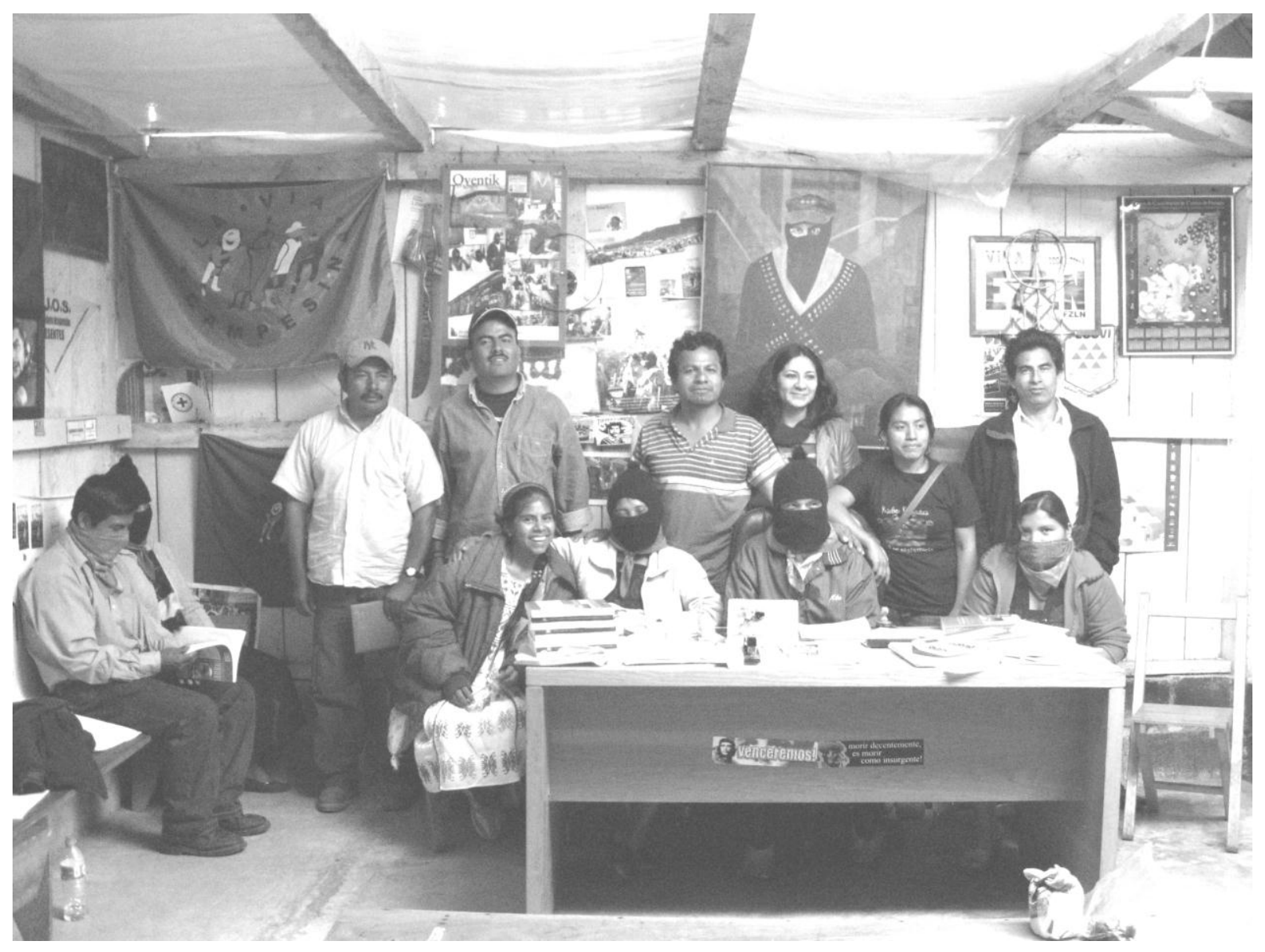

Protagonistas de Otras Geografías con la Junta de Buen Gobierno de Oventik, enero 2010. 


\section{CAPITÚLO 1 \\ VIOLENCIAS Y PUEBLOS INDÍGENAS}

\section{Violencias: horizonte interpretativo y realidad cotidiana}

Inicié hace unos años el trabajo de investigación con la mirada puesta en los procesos autonómicos de los pueblos indígenas y, en particular, en cómo construyen sistemas de justicia; el principal objetivo era indagar si las experiencias de justicia indígena representan una alternativa eficaz para los pueblos, contrastándolas con los (inservibles) sistemas de justicia y seguridad pública del Estado. Sin embargo, después de la inmersión en los casos de estudio por medio de repetidas estancias de trabajo de campo durante casi siete años, y el sucesivo periodo de decantación de las experiencias y los aprendizajes hechos, percibí que las herramientas interpretativas con las que me estaba acercando a los procesos de autonomía y de justicia indígenas no eran suficientes para explicar su importancia. La vivencia cotidiana en este México, la reflexión obligada sobre otros tipos de fenómenos, me acercaron al tópico de la violencia, que finalmente me pareció imprescindible para explicar la trayectoria de los procesos sociales estudiados.

Utilizaré entonces el tema de la violencia como categoría interpretativa que atraviesa los varios bloques temáticos de la investigación; no representa el concepto central de la tesis, pero me sirve para contextualizar y explicar varios de los fenómenos que son el objeto de la investigación. En términos generales, utilizaré la reflexión sobre la violencia para explicar: 1) la emergencia de los procesos de autonomía en la región indígena e intercultural que estudio (la Selva Lacandona en Chiapas); 2) la necesidad y la trascendencia de los sistemas de justicia que se están implementando en éste y otros procesos autonómicos.

Para el primer tema, la hipótesis que pretendo demostrar es que las autonomías, en sus diferentes caracterizaciones, representan una defensa y una respuesta positiva frente a las múltiples dimensiones de la violencia que, en los diversos momentos históricos, han penetrado y atravesado las sociedades indígenas. Violencia como despojo y dominación, o sea violencia 
estructural; violencia política como violencia de Estado, represión y militarización, y como conflicto entre grupos de poder indígenas y mestizos; violencia como resistencia, rebelión e insurgencia; violencia como estigma; violencia común y delincuencia... Frente a todas estas violencias, cuyas características analizaré en el espacio social especifico de la región Selva Lacandona, las autonomías representan proyectos afirmativos de los pueblos indígenas que se sitúan en el espacio central del poder y tratan de romper los mecanismos de dominación; pero el desarrollo de las autonomías también está condicionado y acotado por las violencias mismas, como muestra tristemente la experiencia de los triquis de San Juan Copala, o los golpes que la violencia criminal está actualmente descargando en contra de las comunidades indígenas en varias entidades de la república.

Mi hipótesis trata de demostrar que es posible romper el "efecto espiral" de la violencia, según el cual si el violentador ejerce su acción sobre el objeto de la violencia, este reacciona violentamente, y luego el violentador original responde con más violencia (Concha Malo 1998). Tal modelo proporciona una explicación a las formas de resistencia y de respuesta violenta de los que viven la violencia (en lo especifico la violencia estructural y la dominación), como son los movimientos armados y las rebeliones, que por otra parte también encuentran su justificación en las diferentes teorizaciones sobre la necesidad de la "violencia revolucionaria”. En los procesos de autonomía, si bien no se logra superar con tanta facilidad la polarización social, que es otro de los efectos más evidentes de una situación de violencia, encontramos la voluntad -y la posibilidad- de modificar el entramado de la violencia y desactivarla con la implementación de proyectos propios de gobierno y desarrollo. Esto significa desmarcarse de las estructuras corruptas y de las instituciones ineficientes, no reconocer la autoridad de quien ejerce el poder arbitrariamente, emprender un éxodo del sistema político y económico que discrimina y explota, e intentar la construcción de otras formas de vida y de convivencia.

La idea de justicia social, como el horizonte hacia el cual apuntan los procesos autonómicos cuando buscan salir de los contextos de violencia social y estructural a través de la autorganización y la búsqueda de valores propios, es un concepto amplio que puede representar el espacio de relación entre los propios procesos de autonomía y las prácticas de justicia y de resolución de conflictos que en ellos se desarrollan. 
Para el segundo tema, la normalización de la impunidad, de la corrupción e del abuso de poder en las instituciones, y en particular en aquellas destinadas a garantizar la seguridad pública y administrar la justicia, se ha hecho más evidente en un contexto en que las violencias del Estado y del crimen organizado han llegado a niveles aún no conocidos en esta sociedad, sin olvidar la situación vivida durante la "Guerra sucia", en la década de los setenta. En este aspecto, los territorios indígenas se vuelven espacios de contienda entre los poderes en disputa, mientras el sistema de justicia, cada vez más corrupto y racista, representa más un peligro que una garantía para la población indígena. A partir del análisis de estos fenómenos en el territorio, en la tesis analizaré el sistema de justicia que se está plasmando como parte del ejercicio de la autonomía, y también como respuesta obligada a una situación de falta de acceso a la justicia y de imposibilidad de hacer valer sus derechos.

Queda así ubicado el tema de la violencia como categoría interpretativa al interior de la tesis; en este capítulo propongo un recorrido a través de las diferentes conceptualizaciones de la violencia, tratando de identificar las diversas facetas del fenómeno que, en un segundo momento, utilizaré para la descripción del espacio social en el que se desarrolla la investigación (el oriente de Chiapas).

En este trabajo no se remite a una bibliografía preponderantemente antropológica; las referencias son por elección múltiples, y recupero una visión interdisciplinaria sobre el fenómeno, que es requerida por su misma complejidad; asimismo, me valgo tanto de autores clásicos como contemporáneos, tanto europeos como latinoamericanos. Mi argumentación se desarrolla a partir de la insigne referencia al filósofo e historiador Walter Benjamin, cuyas reflexiones sobre la legalidad/ilegalidad y la legitimidad/ilegitimidad de la violencia, en su relación al Estado y al Derecho, son una herramienta para la interpretación del fenómeno de la violencia, pero también de las justicias que se desarrollan al margen o en contraposición al sistema legal oficial, como las justicias indígenas e interculturales aquí estudiadas. ${ }^{6}$ En la elección de las fuentes y de la bibliografía, he privilegiado el hecho de que ideas y conceptos propuestos por los autores resultaran sugerentes para mi argumento, en la idea de que la especificidad antropológica del trabajo, que reside en el planteamiento del problema, se ve

\footnotetext{
${ }^{6}$ Véase al respecto la reflexión de Sousa Santos sobre la presencia de dos legalidades y dos ilegalidades: la legalidad y la ilegalidad de los poderosos, y la legalidad e ilegalidad de los subordinados.
} 
enriquecida por las aportaciones de otras disciplinas, cuyos puntos de vista pueden contribuir a ensanchar la mirada y la comprensión del problema mismo.

Considero que una aproximación al estudio de la violencia debe valerse de las miradas de todas las ciencias sociales, e incluso puede encontrar un oportuno sustento en las ciencias médicas y naturales: tal como lo muestra el proceso de elaboración de la Declaración sobre la violencia de la UNESCO por parte de un heterogéneo grupo de científicos, animados por el antropólogo Santiago Genovés. En términos generales, creo necesario aprovechar de la estrecha proximidad entre los distintos campos del conocimiento que conforman las ciencias sociales, cuya "contaminación" es benéfica y enriquece todas las disciplinas. El enfoque que he construido en esta investigación se basa en la amplia bibliografía relativa a la llamada antropología de la violencia, ${ }^{7}$ pero también en fuentes de otras disciplinas, que proporcionaron aproximaciones más cercanas al tema tratado y a las hipótesis que se quieren sostener. Retomo la sugerencia de Ferrándiz y Feixa (2004:170), para quienes:

La creciente complejidad de los ámbitos en los que se producen y resuenan las violencias hace aconsejable el fomento de compromisos interdisciplinarios, tanto en la fase de elaboración de proyectos, como en el curso de la investigación, o en la búsqueda de espacios para la divulgación e intercambio del conocimiento producido. [Esto] es, más allá de la retórica, un proceso necesario si de lo que se trata es de investigar, desenmascarar y desarmar las violencias con eficacia.

A pesar de que la violencia (en particular como genocidio y etnocidio) siempre constituyó el "escenario de fondo" de las investigaciones antropológicas, por largo tiempo la disciplina no se interesó del tema, manteniendo un cómplice silencio al respecto; tradicionalmente, los antropólogos no vieron, no escucharon y no reportaron ninguna violencia desde sus trabajos de campo, extremadamente detallados en el estudio de los sistemas de cargo, de parentesco, de

\footnotetext{
${ }^{7}$ Para una revisión crítica de la corriente de la antropología de la violencia, véase Ferrándiz y Feixa (2004) y el excelente texto de Dei (2005). Para una discusión sobre la bibliografía relativa a la violencia y el Estado, véase Nagengast (1994). Entre los textos recientes más relevantes, hay que citar los coordinados por Scheper-Huges y Bourgois (2004); Schmidt y Schröeder (2001); Dei (2005), Héritier (1996; 2005). La antología Fieldwork under fire coordinada por Nordstrom y Robben (1995) se inscribe en esta corriente, enfocándose particularmente a las dificultades éticas y prácticas que deben enfrentar antropólogos e investigadores que realizan sus actividades en contextos de guerra y conflicto armado (seguridad, confidencialidad, búsqueda de fuentes, aproximación a las fuentes, etc). La producción de Maldonado Aranda (2012, 2010, 2009) resulta muy importante para ubicar, en una perspectiva antropológica innovadora, la problemática del narcotráfico y la actual violencia que se vive en México.
} 
los rituales y de los sistemas culturales. Según Scheper-Huges y Bourgois, "las formulaciones teoréticas, las orientaciones epistemológicas, y la identidad burgués de la mayor parte de los profesionales, dirigieron la disciplina lejos de la violencia estructural y de las patologías del poder" (2004:6).

Al lado de esta suerte de ceguera, el tema del conflicto ha estado presente desde ya muchas décadas en la literatura antropológica clásica; sin embargo, como apunta Nagengast (1994:112), se privilegió por mucho tiempo la investigación del fenómeno en las sociedades no occidentales y en los estudios de caso de pequeñas comunidades, estableciendo una diferenciación entre las sociedades históricamente "violentas" y aquellas definidas como más "pacíficas". Algunos estudiosos se han concentrado en el rol de la guerra para la supervivencia y la reproducción de las sociedades primitivas (Clastres 1977) y en la relación entre la violencia, la religión o lo sagrado, para la constitución de la sociedad moderna (Girard 1972). ${ }^{8}$

En tiempos más recientes, se ha desarrollado una mayor atención hacia la violencia políticamente y socialmente marcada, en nuestras sociedades, tanto en los términos micro (relaciones interpersonales) como macro (conflictos y guerras). Schroeder y Schmidt (2001) analizan las directrices que han caracterizado los estudios antropológicos más recientes sobre la violencia, diferenciando entre los enfoques fenomenológicos y las perspectivas teoréticas. En el primer caso, los autores afirman que la violencia es un hecho social que puede ser visto desde tres perspectivas: violencia entendida más ampliamente como una forma de relaciones interpersonales en la realidad cultural cotidiana; como conflicto, enfocada a las causas

\footnotetext{
${ }^{8}$ Para el autor de Arqueología de la violencia, características de la sociedad primitiva son su independencia hacia el exterior, basada en el dominio de un territorio localizado, y su unidad (indivisión/indiferenciación) en el interior. "Cada comunidad necesita, para pensarse en ese carácter -totalidad-una- de la figura opuesta del extranjero o enemigo, tal que la posibilidad de la violencia se inscribe por anticipado en el ser social primitivo; la guerra es una estructura de la sociedad primitiva" para evitar el cambio social. Según Clastres, tal organización es, por su misma naturaleza, contra el Estado, órgano unificador y jerarquizante que llevaría a la desaparición de la sociedad primitiva, múltiple e indivisa. Por su parte René Girard, en la clásica obra La violencia y lo sagrado, a partir de la teoría del deseo mimético afirma que quien ejerce violencia lo hace por la voluntad, frecuentemente no patente, de supeditarse al otro y poseer lo que posee, tomar su lugar o establecer su superioridad en una relación de poder. El autor, siguiendo a Freud, otorga a la violencia un papel fundador en las sociedades primitivas, que se fundan en el mecanismo sacrificial del "chivo expiatorio". El mismo autor estudia la relación entre la violencia y el ámbito de lo sagrado, investigando como la religión, en su aspecto normativo, pasó a ser un elemento regulador de esta violencia "originaria", impidiendo que su fuerza destruyera a la sociedad. El cristianismo, y con él la modernidad, eliminaron este "mecanismo victimario" sobre el que se descargaba la violencia social ritualizada, instaurando una "cultura de las víctimas" y abriendo paso al desarrollo de la violencia en lo individual, en las relaciones íntimas y cotidianas, así como a la violencia desbordada de los genocidios. Para ambos autores, aunque desde enfoques diferentes, la violencia -y su manifestación extrema, la guerra- tiene un papel estructurante en las sociedades primitivas, entre las cuales Clastres incluye también los indígenas no contactados de la Amazonía contemporánea.
} 
materiales y políticas, históricamente medibles; y como proceso que lleva a la guerra. ${ }^{9}$ En el segundo caso, hay tres perspectivas teoréticas que cruzan los enfoques fenomenológicos: la aproximación operacional que conecta la violencia a propiedades generales de la naturaleza humana y la racionalidad; "busca explicar acciones violentas comparando condiciones estructurales como causas que afectan específicas condiciones históricas” (2001:17). La aproximación cognitiva "retrata la violencia en primer lugar como culturalmente construida, como una representación de valores culturales" (2001: 17). Finalmente, la aproximación experiencial "se enfoca en las calidades subjetivas de la violencia. Se ve la violencia como algo que impacta la vida y puede ser reflejada solo a través de la experiencia individual”, lo que, según los autores, puede interferir con una comprensión profunda del fenómeno.

En la literatura revisada, en particular aquella producida por investigadores estadunidenses, he encontrado efectivamente un fuerte énfasis en la experiencia subjetiva ${ }^{10}$, sea de las víctimas que de los testigos (incluidos los investigadores mismos), y una atención particular a la dimensión cultural y simbólica, ${ }^{11}$ en lo que está detrás de manifestaciones opacas de la violencia, como la crueldad y la tortura, ${ }^{12}$ y en sus expresiones extremas como los genocidios y las guerras ${ }^{13}$, temas sobre los que hay una producción muy abundante. Este trabajo se acerca más a otra tendencia, que, según Hébert, "se interesa a las ramificaciones del fenómeno de la violencia social y en ubicar las violencias directamente observadas -o más

\footnotetext{
${ }^{9}$ El enfoque en el nivel interpersonal puede mostrar las estrategias de cierre cultural, que definen nosotros y ellos como entidades claramente y diametralmente opuestas. La imagen de la violencia culturalmente legitimada, puede servir al propósito de exclusión e inclusión social. El enfoque en el conflicto mira más allá de las relaciones de violencia cotidiana y su legitimación discursiva para subrayar las causas del establecimiento de estas formas de comportamiento. La violencia es identificada como una estrategia generada por la competición sobre recursos escasos. Bajo estas circunstancias, la violencia se puede establecer como una estrategia viable y de largo plazo para mantener un grupo y de la reproducción social y física de una población (2001: 13-15). El enfoque en la guerra asume que la violencia es resultado de un proceso de escalation: conflicto/ confrontación/legitimación/guerra (2001:19).

${ }^{10}$ Un ejemplo son los textos incluidos en la antología Fieldwork under fire (Nordstrom y Robben 1995); algunos trabajos de Das (1991, 2005), entre otros.

${ }^{11}$ Dos ejemplos, enfocados en el fenómeno de los cortacabezas en el estado de Chiapas, son Gorza (2002) y Jacorzynsky (2002).

${ }^{12}$ Como ejemplo, véase Talal Asad (2005); Nahoum Grappe (1997).

${ }^{13}$ En varios trabajos, el italiano Fabio Dei articula el tema de la guerra y su memoria, el genocidio y el aspecto ritual de la violencia (una recopilación de muchos textos publicados por Dei se encuentra en <http://www.fareantropologia.it/sitoweb/index.php?option=com_content\&view=category\&id=51\&Itemid=65>). Por otro lado, la estadunidense Sheper-Huges (2005) establece una suerte de continuum entre las violencias masivas y los crímenes de guerra, y los llamados “crímenes de paz” (Basaglia), es decir las pequeñas y grandes violencias perpetradas en la administración cotidiana del poder y en los espacios normativos de la sociedad. Para el caso de África, un ejemplo es el trabajo de Liisa Malkki, Purity and Exile: Violence, Memory, and National Cosmology among Hutu Refugees in Tanzania (1995).
} 


\section{AUTONOMIAINDÍGENA, VIOLENCIAY JUSTICIA}

exactamente las nombraría como 'los efectos de la violencia'- en un contexto más amplio de violencias estructurales, culturales o simbólicas" (2006:12). En los siguientes apartados realizaré una excursión entre algunas caracterizaciones de la violencia, centrándome en las violencias más silentes como la estructural, expresada en la explotación y la desigualdad, así como en la violencia política y la violencia del Estado ("las pequeñas guerras y los invisibles genocidios", en una atinada expresión de Scheper-Huges); en esto, no he privilegiado los aspectos simbólicos cuanto los efectos sociales.

En segundo lugar, he encontrado que una buena parte de la antropología de la violencia estudia situaciones de conflicto "étnico" o religioso, o sea donde la etnicidad y la diferencia cultural son movilizadas como un recurso importante por las partes beligerantes o interesadas en el conflicto, en particular los casos de África y los Balcanes; en mi caso, me detengo en las manifestaciones de violencia social, como el racismo, donde la etnicidad es movilizada por parte de las instituciones o sectores dominantes para justificar las múltiples violencias ejercidas, sin que esto origine un verdadero conflicto armado o situación de guerra. Finalmente, la abundante producción de Colombia, ${ }^{14}$ sea antropológica o sociológica, justificada por la particular situación de conflicto interno que desde hace décadas vive este país, me ha resultado de gran utilidad por la cercanía con el contexto mexicano actual.

Considero que la mirada antropológica, enriquecida con los aportes interdisciplinarios, puede aportar al estudio de la violencia una especial sensibilidad y la posibilidad de desplazarse, como usando un zoom fotográfico, ${ }^{15}$ desde los aspectos macro hacia los aspectos más íntimos y cotidianos, enriquecedor movimiento de ida y vuelta que es caracteristico de nuestra disciplina.

\section{Aproximaciones a las violencias}

Siendo un tema concurrido por todas las ciencias sociales, pensadores de diferentes épocas han elaborado diversas conceptualizaciones de la violencia, que en ocasiones reflejan el momento histórico y su visión política. Para los fines de esta investigación, no pretendo adoptar una definición finita de la violencia, sino más bien ubicar algunas expresiones del fenómeno.

\footnotetext{
${ }^{14}$ Véase los trabajos de Blair, Gros, Hernández, Rodríguez, Sandoval Forero entre otros.

${ }^{15}$ Un excelente ejemplo es el texto de Juan Cajas (2005) sobre Violencia y narcotráfico en la ciudad de Tijuana.
} 
En un interesante estudio, Tosca Hernández proporciona algunos elementos útiles para acercarse al entendimiento de la "violencia" como término, como relación y como fenómeno. En la primera acepción, Hernández afirma que:

Más que un concepto, violencia es un término utilizado en la vida cotidiana para designar comportamientos, situaciones, efectos de comportamientos y sensaciones que se viven [...] la palabra "violencia" expresa diferentes acciones, en diferentes espacios, con diferentes actores, y adquiere nuevas significaciones en distintos tiempos históricos (2002: 59).

La autora advierte que la tendencia a definir más hechos o situaciones como "violentos" lleva a justificar una respuesta violenta antes un número cada vez más grande de comportamientos, especialmente por parte del Estado, en cuanto monopolizador del uso legítimo de la fuerza, ampliando de esta forma los circuitos de la violencia. Esta advertencia va más allá del uso discursivo del término, ya que -por ejemplo- una reflexión sobre la violencia criminal y delictiva "no puede dejar aparte los procesos de criminalización que también los crean, ya que las acciones policiales, las decisiones judiciales y la propia cárcel van definiendo y delineando el tipo de violencia criminal que hoy vivimos y la inseguridad social que la acompaña" (Hernández 2002:61).

En segundo término, Hernández considera que la violencia siempre emerge en espacios relacionales, caracterizados culturalmente y socialmente: "espacios donde predominan las interacciones dinámicas de poder, discriminatorias y de desigualdad y exclusión social" (2002:63). En este aspecto haré especial hincapié al tratar de exponer las diferentes vertientes de la violencia que involucran los pueblos indígenas en las regiones de estudio.

En tercer lugar, la autora enfoca la violencia como fenómeno histórico, mutable en su significado social y en su manifestación; en esta perspectiva se encontraría la posibilidad de su desactivación "al entenderla como una tarea permanente y comprometida que al irse realizando va configurando, a su vez, unas nuevas bases de convivencia social” (2002:67). Recurrir a la historia en una perspectiva analítica permite desnaturalizar la violencia y contextualizarla en el marco de los procesos más amplios que afectan a las regiones y a la nación. En esta perspectiva, las conceptualizaciones sobre la violencia que aquí sintetizo serán las herramientas para reconstruir en perspectiva histórica el espacio social región de estudio, en particular en la relación entre los pueblos indígenas y el Estado. 


\section{AUTONOMIAINDÍGENA, VIOLENCIAY JUSTICIA}

Partiendo de estos presupuestos, y en la necesidad de definir aunque convencionalmente el tema de este apartado, retomo la definición propuesta por Galtung: "la violencia está presente cuando los seres humanos se ven influidos de tal manera que sus realizaciones efectivas, somáticas y mentales, están por debajo de sus realizaciones potenciales”, una definición que incluye múltiples acepciones del fenómeno; además, convengo que "la violencia no se limita al uso de la fuerza...sino más bien en la posibilidad o amenaza de usarla" (Velho 1996, cit. en Ferrándiz y Feixa 2004:161). Unos ejemplos pueden explicar esta definición: actualmente, para los indígenas o los afromexicanos es posible trabajar en igualdad de condiciones que los "mestizos", sin embargo esto no ocurre. Eso es violencia. Actualmente, en México, una persona puede morir por falta de asistencia sanitaria, por no estar afiliado a la seguridad social, y esto es violencia. Cuando es posible algo y no se realiza o ejecuta, eso es violencia. Cuando lo potencial es mayor que lo actual, es por definición evitable y cuando es evitable y no se evita, entonces es violencia.

Como innumerables son las definiciones de la violencia, asimismo lo son los paradigmas y las teorías que buscan su explicación. Aquí retomo la propuesta del antropólogo Philippe Bourgois (2001, cit. en Ferrándiz y Feixa 2004:162), quien divide la violencia en cuatro modalidades: violencia política, estructural, simbólica, y cotidiana. ${ }^{17}$

\section{Violencia y política, entre el Estado y el Derecho}

La violencia política incluiría "aquellas formas de agresión física y terror administradas por las autoridades oficiales y por aquellos que se les oponen, tales como represión militar, tortura política y resistencia armada, en nombre de una ideología, movimiento o estado político" (Ferrándiz y Feixa 2004:162), y vierte necesariamente en torno a la cuestión del poder, ya que históricamente, y desde diferentes posiciones políticas, se ha justificado el uso de la violencia para mantener, tomar o transformar el poder.

\footnotetext{
${ }^{16}$ Se trata de uno de los precursores y fundadores de los peace studies (estudios sobre la paz). La conexión entre esta rama de la investigación, que se ocupa del conflicto y su transformación positiva, y la antropología, dio vida a la llamada antropología de la paz.

17 Un enfoque diferente es el que propone Sanmartín (2006), quien elabora una completa taxonomía de la violencia, que adquiere denominaciones y características diferentes: según las victimas sobre las que se ejerce; según el escenario en que ocurre; según el tipo de agresor; según el tipo de daño causado. El denominador común a todos estos tipos de violencias sería el afán de control y dominio del agresor sobre la víctima.
} 
Desde la perspectiva sociológica y filosófica, Pilar Calveiro discute algunas de las principales interpretaciones de la violencia política: en principio, las que define "visión guerrera" y "visión contratualista", ya identificadas por Michel Foucault en Genealogía del racismo. La visión guerrera, a la que se suscriben algunos trabajos del propio Foucault, evidencia la relación de necesidad entre violencia y política:

Si es verdad que el poder político detiene la guerra [...] no es para suspender los efectos de la guerra o neutralizar el desequilibrio que se manifestó en la batalla final. El poder político, en esta hipótesis, tiene de hecho el rol de inscribir perpetuamente, a través de una especie de guerra silenciosa, la relación de fuerza en las instituciones, en las desigualdades económicas, en el lenguaje, hasta en los cuerpos de unos y otros (Foucault 1992: 29-30, cit. en Calveiro 2008:24).

Por otra parte, la visión contratualista concibe el poder político como fruto de un acuerdo, del cual proviene la legitimidad del poder mismo; la política entonces sería un ámbito de consenso, donde el Estado ejerce el "monopolio de la violencia legítima" (Weber) para garantizar dicho acuerdo. Entre otros, Hannah Arendt ha desarrollado esta concepción en su libro Sobre la violencia, donde considera que la política no está unida a la violencia, sino que ésta se instaura precisamente cuando se crispa el consenso social alrededor del poder.

Para discutir estos supuestos, Calveiro retoma un imprescindible ensayo de Walter Benjamin, Para una crítica de la violencia, en donde el filósofo alemán discute sobre el problema de la legitimidad de la violencia como medio, indagando la articulación de la violencia con el derecho (que pertenece a la categoría de los medios) y con la justicia (que pertenece a la categoría de los fines).

En el texto de 1921, el autor afirma que la teoría positiva del derecho distingue entre la violencia históricamente reconocida, o sea sancionada como poder, y la violencia no sancionada, lo que corresponde a la idea weberiana de violencia legítima e ilegítima. Reconociendo en la violencia el carácter de creadora de derecho, sostiene que cualquier violencia que se manifieste afuera del derecho (entendido como derecho de Estado) representa para éste una amenaza, no a causa de los fines que la violencia persigue, sino porque toda violencia que ocurre por fuera del derecho es potencialmente fundadora de un nuevo orden 
legal. Este tipo de violencia, definida "creadora" o "fundadora", corresponde por excelencia a la violencia revolucionaria.

En muchos aspectos, la violencia "creadora" se diferencia de la violencia "conservadora" del derecho y del Estado. Criticando indirectamente la idea que el contrato social se basa principalmente en el consenso, Benjamin afirma que:

$\mathrm{Al}$ igual que el resultado, también el origen de todo contrato conduce a la violencia [...] el poder que garantiza el contrato es a su vez de origen violento, cuando no es sancionado jurídicamente mediante la violencia en ese mismo contrato. Si decae la conciencia de la presencia latente de la violencia en una institución jurídica, ésta se debilita (1921:9).

En esta categoría de la violencia "conservadora" se incluiría toda violencia que viene desde las instituciones, y de forma evidente la que se conoce como violencia de Estado, que se caracteriza por instaurar el estado de excepción en un territorio. Según Calveiro:

La excepción es como una forma de "alargar" el brazo del Estado, incluyendo lo supuestamente excluido, alcanzando los márgenes y extendiendo la potestad del Estado y su derecho, para legalizar lo ilegal. Las llamadas guerras sucias de los años setenta y las argucias legales de las que se valieron nuestros Estados para violar o "alargar" las legislaciones previas constituyen un claro ejemplo (2008:26).

La autora considera que el estado de excepción, entendido como ámbito externo al derecho donde rige una violencia "regulada"- es un espacio donde la violencia estatal se ejerce de cualquier forma e intensidad; esta condición rige sobre todos los individuos que la sociedad actual considera innecesarios, eliminables: criminales y terroristas, pero también pueblos indígenas y disidentes políticos, por poner solo algún ejemplo. ${ }^{18}$

Según Benjamin, “creación de derecho es creación de poder, y en tal medida un acto de inmediata manifestación de violencia" (1921:15). De este modo queda resuelta la dicotomía aparente entre la violencia que funda y la que conserva, pues ambas hacen referencia al derecho y sobre todo al Estado, para defenderlo o transformarlo; cuando aquellas fuerzas

\footnotetext{
${ }^{18}$ En tiempos recientes, hemos observado la proliferación exponencial de los estados de excepción, en particular en los contextos de guerra: los escenarios centroamericanos y de Oriente Medio, sobre todo a raíz de las más o menos directas intervenciones norteamericanas, se han vuelto espacios donde todo es válido, y lo ilegal ha sido institucionalizado.
} 
oprimidas "predominan sobre la violencia que hasta entonces había fundado el derecho y fundan así un nuevo derecho destinado a una nueva decadencia" (1921:18). Asimismo, resulta evidente la conexión entre la política estatal o revolucionaria y la violencia.

Benjamin propone un tercer tipo de violencia, la violencia "pura"; si bien en su ensayo no termina de esclarecer el concepto, Calveiro busca su aplicación en esas experiencias que “proponen la construcción y defensa de 'espacios' físicos y simbólicos autónomos del Estado y el derecho, ampliando a su vez los alcances de la política. Estas, a diferencia de las lógicas anteriores, operan desde ámbitos externos a lo estatal y evitan la confrontación abierta" (2008:37). Estas violencias "resistentes", por su distanciamiento de la idea de la toma del poder del Estado y su debilidad objetiva frente a éste, no buscan la confrontación; esto les permite obtener resultados políticos (que no excluyen el uso de la fuerza pero no se centran en ella) sin potenciar la espiral de la violencia. Como ejemplos paradigmáticos de las "resistencias", Calveiro propone el movimiento de trabajadores y desempleados argentinos y el movimiento indígena encabezado por el Ejercito Zapatista de Liberación Nacional; con respecto a éste, mucho se ha dicho sobre la paradoja de un ejército que se crea para desaparecer, que toma las armas más para ser visible y denunciar las múltiples violencias que padece, que para usarlas.

En esta somera discusión he hecho referencia a la distinción weberiana entre la violencia legítima, que correspondería a los Estados, y aquella ilegítima. Sin embargo, como se verá en el curso de este trabajo, frecuentemente la violencia que ejerce el Estado no es legítima, pues es utilizada en contra de los derechos fundamentales de las personas; y por otro lado, muchos elementos de legitimidad se encuentran en las violencias "resistentes".

Zimmermann (1983, cit. en Corte Ibañez 2006: 80-81) propone una tipología de la violencia según criterios éticos/jurídicos, articulando sus manifestaciones en los ejes de la legitimidad (violencia legítima y violencia ilegítima) y de la legalidad (violencia legal y violencia ilegal). El cruce entre violencia legal y legítima resulta en la violencia que la tradición weberiana atribuye al Estado. La violencia legal pero ilegítima ocurre, por ejemplo, cuando un gobierno promulga leyes que legalizan formas de acción violenta que vulneran los derechos de los ciudadanos. Ilegal e ilegítima es la violencia usada por los dirigentes que ordenan la agresión o el asesinato de sus opositores políticos; mientras la violencia ilegal, pero utilizada contra un régimen opresivo, puede ser considerada legítima. Sobre tal tipología 
ocurre observar que el concepto de estado de excepción abre un terreno amplísimo para la institucionalización de la violencia "ilegal e ilegítima", pero que el Estado posmoderno práctica de forma sistemática. Por otra parte, la mirada antropológica sobre las guerras y los conflictos confiere matices necesarios a tal esquemática tipología, incluyendo todos los actores que se mueven al interior, al margen o afuera del Estado, pero que interactúan con él cruzando continuamente los linderos de lo legal e ilegal, legítimo e ilegitimo, y creando un sinnúmero de zonas grises.

Una mirada crítica puede ayudar a discernir cuando la violencia ejercida por el Estado es solamente "legal", legitimada por el derecho, más no legítima, porque ha roto el pacto fundador del Estado. Al respecto, el filósofo Enrique Dussel afirma que:

La legitimación no es la legalidad. Legal es el acto que cumple la ley. Se puede cumplir la ley sin convicción subjetiva, por obligación, contra la propia voluntad, hasta con violencia, y sin embargo el acto acorde objetivamente con la ley es legal. Por el contrario, un acto se juzga como legítimo si el sujeto que lo cumple lo cree válido, es decir, si subjetivamente se tiene la convicción, si se cree que el acto pudo realizarse libre y equitativamente. ${ }^{19}$

En términos generales, la violencia política se caracterizaría por ser un elemento de orden o cambio social (se da entre gobernantes y gobernados; entre dominantes y dominados; entre clases); por su naturaleza siempre colectiva y por su carácter vertical y desigual, ya que en principio uno de los antagonistas tendría mejores posibilidades que el otro (poder, recursos, influencia, etc.).

La mayoría de las definiciones de violencia política que he encontrado hacen referencia, en última instancia, a la conservación, la conquista o la reforma del Estado. Sin embargo, en el estudio de la región indígena de Chiapas en perspectiva histórica, se encuentra un alto nivel de conflicto -que frecuentemente se vuelve violencia- entre grupos de población que disputan territorio, recursos y representación en nombre de la militancia en uno u otro partido político, o bien en la organización que reivindica la autonomía (y con eso se aleja de la militancia partidista). En estos casos, si bien para unos la supremacía pueda significar llegar a ocupar puestos en el poder político local, para otros no se vislumbran objetivos o resultados que

19 Enrique Dussel, “¿Fue democrática la elección?”, en La Jornada, 4 de julio de 2012 , <http://www.jornada.unam.mx/2012/07/04/opinion/020a1pol>, consultado el 14 febrero 2013. 
tengan que ver con la participación en la estructura estatal, sino más bien una supremacía en el territorio y el control de los recursos estratégicos. Aquí quizás se revela pertinente la definición de violencia política acuñada por unos estudiosos de la crisis peruana en el decenio de 1980, en el que destacan dos elementos: "primero, dos o más actores sociales que son portadores de proyectos políticos asumidos, al menos por uno de ellos, como irreconciliables; segundo, la apelación a acciones de fuerza, coerción o intimidación como parte dominante de su estrategia o metodología para definir dichos proyectos"(citado en González Calleja 2010:286).

Según Aróstegui, la violencia política se diferencia de la violencia social, en la que los sujetos o grupos se enfrentarían a partir de condiciones más parecidas. Otra interpretación de la violencia social es la que propone Rodríguez Araujo: ésta se expresaría de diversas formas, desde las tomas de tierras, las huelgas, los linchamientos y hasta en la inseguridad pública, sin embargo el autor resalta un aspecto de la violencia social "como praxis social positiva hacia metas de cambios y liberadoras de clases o de fracciones de clases suficientemente significativas. Es el derecho a la rebelión de los pueblos contra el poder instituido" (1998:104) y ejercido sobre y en contra de ello. A este tipo de violencia pertenecerían las revoluciones, las rebeliones y las insurrecciones, movimientos que para otros harían referencia a la violencia revolucionaria.

Otro aspecto de la violencia política es la violencia de Estado, que se ejerce sobre todo en contra de movimientos de inconformidad social. Según Carlos Montemayor, uno de los investigadores mexicanos que con más lucidez se ha acercado al tema:

En la violencia de Estado hay espacios oficiales que poseen mecanismos propios y recurrentes. A nivel policial y militar destaca la creación y continuidad de comandos de elite como fuerzas de choque para enfrentar movimientos populares no armados. A nivel procesal, la acción coordinada del Ministerio Público y de los jueces que obvian procedimientos legales para acusar, castigar y resolver de manera expedita y justa. En la desaparición forzada, la aquiescencia de autoridades políticas, militares, policiales y judiciales a nivel municipal, estatal y federal (2008).

En México, la más evidente manifestación de este tipo de violencia es la estrategia contrainsurgente que se vivió en los años '70 y '80, conocida como "Guerra Sucia”; pero se 
encuentra también en las masacres perpetradas por grupos policiales y militares en Guerrero durante los años '90 (Aguas Blancas, El Charco), en la mal llamada "guerra de baja intensidad" que el Ejército mantiene en Chiapas desde el levantamiento del EZLN en 1994, y en el uso de grupos paramilitares para golpear a organizaciones y movimientos sociales en varias regiones del país (el caso más notorio es la masacre de Acteal, Chiapas, en 1997).

En sus manifestaciones, la violencia de Estado implica una generalizada violación de los derechos humanos y la limitación de las libertades fundamentales, en aras de garantizar la "estabilidad política" frente al peligro de subversión o insurrección, real o imaginado. Es una de las vertientes del "estado de excepción" mencionado arriba por Calveiro. En el mismo sentido, el reconocido filósofo Bolívar Echeverría afirma:

El uso 'informal' de la violencia represiva -el de las guardias blancas, los grupos paramilitares o parapoliciacos, las bandas de jóvenes resentidos, por ejemplo- no es vista por la opinión pública dominante como una ruptura de ese monopolio [que tiene el Estado sobre el uso de la fuerza legítima] sino como un reforzamiento espontaneo o salvaje del mismo. Lo ubica, con razón, junto a las 'extralimitaciones inevitables comprensibles' de la propia violencia estatal (1998:366).

Al reflexionar sobre la emergencia de los movimientos armados rurales en México, y sobre la estrategia adoptada por el Estado en su contra, Montemayor (2008) propone una interesante reflexión sobre otro tipo de violencia, la violencia institucional o legal, que consistiría en:

La pobreza, la desnutrición, el desempleo, al analfabetismo, la marginación, la carencia de servicios de salud, la vivienda deficiente, los servicios públicos insuficientes o inexistentes, la desigualdad social extrema, la pérdida de talla o estatura en núcleos rurales e indígenas, el acortamiento del promedio de vida en zonas rurales y marginadas. Indicadores así, y otros que pueden conformarse de acuerdo con características regionales, gremiales o de legislación local o nacional (podríamos decir caciquismos, corrupción policial, venalidad de jueces, explotación laboral en campos agrícolas, industrias, maquiladoras o sectores de servicios mediante presiones sindicales, indefensión o subcontratación laboral por terceros a niños, mujeres o jóvenes).

Al introducir esta conceptualización de la violencia en una reflexión sobre las guerrillas, los movimientos rurales y la violencia de Estado, el autor subvierte el tópico, común en los 
ambientes de derecha, de que sería a causa de la inconformidad social que se origina la violencia (lo que justifica la represión estatal). Al contrario, la inconformidad social surge precisamente para que cese esta situación de violencia institucional previa.

\section{Violencia estructural: desigualdad y explotación}

La violencia institucional o legal particularizada por Montemayor se parece en muchos aspectos a la que Johan Galtung ha definido como violencia estructural, diferenciándola de la violencia directa y la violencia cultural. ${ }^{20}$ Según el fundador de los peace studies, la violencia estructural sería un tipo de violencia indirecta, que radica en la desigual distribución del poder de decidir sobre los recursos, y produce grandísimas diferencias entre la autorrealización humana real y la potencial. Esta violencia se expresa en la pobreza (que provoca la privación de las necesidades humanas básicas), la represión (que provoca la privación de los derechos humanos), y la alienación (que provoca la privación de los derechos humanos y políticos) (Galtung 1981).

Lo que está detrás de la violencia estructural es la desigualdad, que tiene que ver con los procesos económicos y con el poder de acceso a los bienes públicos y a los producidos por el mercado. Jorge Arzate (2008:137) identifica dos dimensiones de la violencia estructural: una relacionada a los procesos de exclusión social, que se define por la falta de acceso a las oportunidades; la otra ligada a los procesos de explotación, que se define por el acceso inequitativo a los bienes materiales.

El concepto de violencia estructural resulta de gran importancia para describir la realidad de los pueblos indígenas; el racismo y la discriminación que han padecido históricamente y que determinan el acceso desigual al poder -económico y político- y la diferencia en las condiciones de vida, no son más que otras vertientes de este tipo de violencia transversal y multiforme.

Según Martín Hébert, antropólogo que ha utilizado el concepto en un estudio sobre la Montaña de Guerrero:

\footnotetext{
${ }^{20}$ Sin embrago, Galtung diferencia la violencia institucional de la violencia estructural, ya que ésta tendría una "naturaleza más abstracta [...] que no puede ser atribuida a ninguna institución en particular" (Galtung 1975: 173 y 175, cit. en Ferrandiz y Feixa 2004:163).
} 
El concepto de violencia estructural - una violencia indirecta, inmediata y sin agente que produce efectos similares a la violencia directa - sin duda se abrió camino en la antropología (junto con conceptos similares y complementarios, tales como el sufrimiento social, la violencia simbólica, la cultura del terror y otros). Estos tipos de violencia son los que interesan principalmente a la antropología de la paz, porque son los más antitéticos a un estatus social verdaderamente pacífico (2006: 17).

La perspectiva de este autor relaciona el concepto de violencia estructural con la antropología de la paz (una rama de estudios complementaria a la antropología de la violencia), pues parte del presupuesto, planteado ya por Bourgois y Scheper-Hughes (2004) que la guerra y la paz no pueden ser incluidos en una lógica dicotómica, sino como un continuum de violencia social visible e invisible, directa y estructural; y de los planteamientos de Galtung según los cuales la mera ausencia de violencia no garantiza la situación de paz, así como no se puede pensar una sociedad libre y ajena de conflictos (sería una 'sociedad muerta'). Así:

La antropología de la paz no estudia las sociedades no violentas, sino los contextos violentos o potencialmente tales, y las acciones humanas emprendidas para establecer un poco de paz o mantener la que existe. El proyecto neoliberal de la paz perpetua, la paz tan cínicamente explotada por las grandes potencias, la paz como "proceso", la paz como desarrollo, la paz violenta del funcionamiento "normal" de las sociedades injustas, la paz policiaca que se busca imponer en las zonas calientes de las metrópolis del mundo. Abundan los terrenos etnográficos donde se puede documentar empíricamente las diferentes "paces" que se hacen y se mantienen a diario en todo el mundo (Hébert 2006: 8-9).

Scheper-Huges y Bourgois sintetizan algunas conceptualizaciones que resultan muy importantes para enfocar la violencia en estos términos. En primer lugar sugieren pensar la violencia como un continuum que va desde los crímenes de guerra hasta los que Franco Basaglia ha llamado crímenes de paz, cometidos diariamente en los espacios sociales normativos como escuelas públicas, hospitales, guarderías, oficinas del registro civil, y desde luego tribunales y prisiones. Estos espacios son ejemplos de las que han sido definidas por el mismo Basaglia instituciones de violencia oficial y legalizada. La multitud de "pequeñas guerras e invisibles genocidios" muestra que las formas cotidianas de la violencia de Estado son utilizadas para mantener la "paz" y la "estabilidad" interna. Según muestra la 
investigación de Scheper-Huges en favelas brasileñas durante y poco después de la dictadura militar, las prácticas de la "violencia cotidiana" representan otra forma del "terror de Estado": la autora documenta las "desapariciones" perpetradas por los censos públicos que nunca dan cuenta de los habitantes de las favelas, invisibilizados en la vida y también en la muerte, pues en las numerosísimas actas de defunción de niños los registros civiles raras veces especifican la causa de la muerte, que acontece principalmente por la malnutrición crónica y aguda.

En segundo lugar, los autores afirman que una mirada enfocada a las "pequeñas" violencias producidas en las estructuras, los hábitos, y las mentalidades de la vida cotidiana nos permite ver las "patologías" de las de desigualdades marcadas por clase, raza y género (Scheper-Huges y Bourgois 2004:19-20). Concuerdo con esta afirmación, mientras la mirada a lo cotidiano no implique una inmersión en lo subjetivo que puede implicar el riesgo de perder la mirada más amplia hacia los procesos macrosociales, que determinan y significan las expresiones de estos crímenes de paz. Al respecto, un ejemplo excelente es el trabajo de Farmer (2004), quien parte del relato de historias individuales de sufrimiento en Haití, conectándolas al contexto político y económico nacional e internacional, que de manera indirecta está tras su acontecimiento. Para despejar el halo de impersonalidad que puede caracterizar a la violencia estructural, Farmer afirma claramente que hay precisas decisiones humanas detrás de estas acciones -la construcción de una presa que inunda el territorio, la mercantilización y la corrupción, la pobreza, la persecución del régimen hacia la disidencia política- que impactan negativamente y con un efecto "dominó" sobre las vidas de las personas. Para el autor, "las fuerzas económicas y sociales que dictan elecciones de vida en el Altiplano Central de Haití afectan a muchos millones de individuos, y es en este entorno de fuerzas globales que el sufrimiento de los individuos recibe su contexto apropiado de explicación" (2004: 286-7)

Una de las principales críticas al concepto de violencia estructural es que representa la violencia como indirecta, o sea casi como un efecto colateral de las políticas económicas neoliberales, y anónima, lo que ayuda a eludir la tarea de encontrar los responsables. Al respecto, Cejas Minuet afirma que "la desigual distribución del poder de decisión sobre los recursos es fruto de un proceso con protagonistas reconocibles, llámense clase dirigente y sus asociados, grupos de interés económico, etcétera. Negar su 'identificabilidad' sería negar la posibilidad de contestar a los mismos, de producir un cambio" (Cejas Minuet 2000:72). 
Siguiendo este supuesto, la autora analiza la realización y el impacto de las políticas y los proyectos de desarrollo en África, reconociendo en el "desarrollo" los elementos sugeridos por Galtung como componentes de la violencia, y tratando de identificar en todo momento a sus protagonistas. En la misma línea, algunos trabajos incluidos en el volumen Desarrollo, ciudadanía y violencia estudian la aplicación y los resultados de los proyectos de "desarrollo" en México, sin dudar en definir como violencia tanto los mecanismos para su aplicación como sus consecuencias entre la población "beneficiaria". ${ }^{21}$ Igualmente, es oportuno mencionar el trabajo de Pierre Becauge (2008) quién estudia las políticas del Estado hacia los cafeticultores indígenas en dos regiones de México, evidenciando como éstos son objeto de una violencia estructural ejercida por el mercado global, y de una violencia definida "institucional" porque producto de las diferentes políticas desarrollistas del Estado.

Desde las perspectivas de la filosofía, la ciencia política y la sociología, varios autores analizan esta violencia estructural, congénita al capitalismo y al neoliberalismo. En términos generales, el filósofo Bolívar Echeverría propone un análisis marxista que evidencia la falacia del supuesto carácter pacificador del crecimiento capitalista. El autor ubica el origen de esta violencia en el capitalismo mismo que, para poder funcionar, reproduce artificialmente la condición de escasez "primitiva", poniendo a la sociedad humana, en principio, "como constitutivamente insaciable o infinitamente voraz y, al mismo tiempo, a la riqueza como siempre faltante o irremediablemente incompleta" (1998:378). Así, el Hombre está a punto de convertirse en "un animal de voracidad sin límites, irremediablemente insatisfecho e insaciable, y por lo tanto a la Naturaleza en un reservorio constitutivamente escaso; en una simple masa de "recursos no renovables"” (1998: 382).

En un análisis realizado a finales del siglo pasado, Marcos Kaplan (1998) considera que "una tradición multisecular de poder concentrado y violencia estructural, que recorre como un hilo rojo la historia latinoamericana, culmina en el siglo XX con la multiplicación y el refuerzo de viejas y nuevas formas el uno y de la otra y sus combinaciones”, encarnados sobre todo en las dictaduras del Cono Sur, el narcotráfico y el crimen organizado. Según el autor, el neoliberalismo supone un crecimiento (económico y social) cuyos beneficios son

\footnotetext{
${ }^{21}$ Considerando que una de las perspectivas para analizar la violencia institucional hacia los pueblos indígenas es abordar las políticas públicas que los involucran, como el indigenismo y las políticas multiculturales, y que éstas han sido orientadas por la ideología del desarrollo, abordaré este tema con más profundidad en el capítulo 2.
} 
monopolizados por grupos minoritarios, lo que origina pobreza y marginalización para los grupos mayoritarios, así como polarización social y conflictividad política.

A la sombra de las políticas de ajuste y las reformas del Estado, y favorecidas por la paralización de la actividad agraria e industrial que implica el libre comercio en los países "periféricos", crecen la economía informal, la delincuencia organizada y la economía criminal. La "economía violenta", representada por el modelo neoliberal que crea y reproduce desigualdad, se funde frecuentemente con la "economía de la violencia" y la "economía política de la corrupción”, que:

Se dan la mano en los cruces más espectaculares del tráfico de armamentos y de narcóticos [junto al tráfico de personas], ambos articulados por organizaciones criminales cuya morfología y dinámica las lleva a vincularse con los órganos del Estado y a contaminar el poder político. La producción y el usufructo de este tipo de actividad económica se realizan en función o dependencia del recurso a la violencia (Cordera Campos 1998:253).

Si pensamos en la violencia estructural como enraizada en el modelo económico y de "ingeniería social" que es el neoliberalismo, también es necesario considerar la violencia directa que rodea a este modelo, por ejemplo la violencia de Estado, la violación a los derechos humanos y la militarización que son necesarias para imponerlo en las sociedades.

Estos mecanismos de aplicación de fuerza no sólo impactan a las personas o grupos a los que van dirigidos, con propósito de aniquilamiento, de parálisis, de neutralización; sino que alcanzan a toda lo sociedad, con el objetivo de infundir miedo e inhibir.

Acerca de la situación del Estado, existe un gran consenso en torno a la idea de que es cada vez menos capaz de cumplir sus funciones básicas y que en la práctica la definición weberiana - de monopolio de la violencia física legítima - parece ya no dar cuenta de las características del Estado contemporáneo. Lo que tiende a predominar, en cambio, es la privatización de la violencia, que se suma también a la informalidad, a los mercados negros, a la evasión fiscal, al trabajo clandestino y al déficit en la aplicación de la justicia que son moneda corriente en la mayoría de los países del mundo. A todo esto se agrega el aumento de la violencia ilegítima de parte de los propios aparatos del Estado que se constata por el aumento de la represión y la tortura. Por otra parte existe la sensación en la población de que los crímenes quedan impunes, lo que revela una aguda crisis en las formas de acción de los sistemas judiciales (Riella 2001:191). 
¿Un nuevo paradigma de la violencia?

Desde la perspectiva sociológica, Michel Wieviorka analiza las transformaciones y las formas que asume la violencia en la sociedad contemporánea. Según el autor, la crisis de la modernidad $^{22}$ ha originado el declino y la progresiva pérdida de importancia de la arena política y, por ende, de la violencia pensada a partir de sus dimensiones políticas. Partiendo de este supuesto, el autor elabora un nuevo paradigma de la violencia con el que trata de explicar las manifestaciones de la actual violencia difusa, fruto de la rabia y de la frustración, una violencia que no es solamente un conjunto de prácticas objetivas sino también una representación (2003:109).

Reconociendo que la violencia puede seguir ocupando el nivel político, Wieviorka introduce dos conceptos para describir las vertientes de la violencia contemporánea. La violencia infrapolítica deriva de la creciente privatización de la economía, y la consecuente privatización de la violencia hace que su carácter político sea atenuado o diluido. "La principal característica de la violencia infrapolítica es su asociación con el declino de los Estados y con las prácticas que son parte del crimen organizado [...] Esto no parece ser el preludio hacia conflictos sociales y políticos. La criminalidad organizada es frecuentemente asociada, entre la población, con una opinión muy negativa hacia el Estado, sus leyes, y su policía, pero es difícil interpretar esto como una expresión de revuelta" (2003:129) pues están ausentes ideologías políticas. La violencia infrapolítica sería entonces fruto de un proceso de degeneración, en el que sus características políticas son superadas por la privatización de la violencia, con el objetivo de controlar recursos económicos y territorios. La privatización de la violencia se expresaría también en el uso ilegítimo que de ella hacen quienes controlan también el uso legítimo - policía y ejército- abusando de sus privilegios y su inmunidad.

Cuando la violencia se extiende más allá de lo político, para vehicular "significados que son intransigentes por naturaleza -algo innegociable, una dimensión religiosa, ideológica o ética que parece ser absoluta" (Wieviorka 2003:130), se vuelve metapolítica. Este tipo de violencia no sería apolítica, sino que sus instancias políticas son asociadas y subordinadas a otras instancias definidas en términos culturales o religiosos, que no admiten ninguna

\footnotetext{
${ }^{22}$ Que se encarna en la definitiva separación de sus dos polos constitutivos (el mundo de la técnica, los mercados liberales y la ciencia de un lado, y del otro la identidades culturales y comunitarias).
} 
concesión. En trabajos recientes (2007) el autor se ha preocupado por analizar esas expresiones de la violencia en las que la identidad y la cultura subordinan lo político, como por ejemplo el "terrorismo" contemporáneo.

Finalmente, el autor ubica la violencia contemporánea en la intersección entre lo social, lo cultural y lo político, y considera que se puede mover de un nivel a otro. ${ }^{23}$ Pero sobre todo, esta nueva violencia parece ser lo contrario de lo teorizado por Weber, y representar la derrota de lo político, la marca de descomposición del Estado. Esta perspectiva es muy controvertida, ya que de alguna forma la podemos encontrar en las caracterizaciones hechas por funcionarios estadounidenses de los estados latinoamericanos como "Estados fallidos”, donde el Estado pierde el control y los actores violentos y la economía ilegal toman las riendas de la sociedad. Varios analistas, por ejemplo en el caso de la actualidad mexicana, consideran esta visión como una mistificación, enfatizando que el Estado no pierde el control sobre la sociedad, sino lo transforma, ${ }^{24}$ dejando deliberadamente espacios para que otros actores los controlen. Una sugestiva corriente de estudios antropológicos, surgida en años recientes, ${ }^{25}$ se ocupa de estudiar al Estado desde sus márgenes, entendidos no como espacios ajenos a su control, sino como supuestos necesarios al funcionamiento de los Estados mismos (zonas de excepción, periferias, economías “ilegales", sujetos sociales invisibilizados, etc.). Trataré este punto más adelante, al abordar la actual política del gobierno mexicano en relación con la emergencia del narcotráfico.

\footnotetext{
${ }^{23}$ Puede iniciar en el nivel social y subir al nivel político, o ser una violencia política que se privatiza adquiriendo un objetivo exclusivamente económico, o bien iniciar como una frustración social que se carga de características culturales y metapolíticas.

${ }^{24}$ Al respecto, López y Rivas (2010: 6) afirma que México "lejos está de ser un Estado fallido. Lo cierto es que el Estado transnacional, mientras se sustrae de sus obligaciones sociales, no "falla" en sus tareas esenciales: a) Coerción y represión de las luchas sociales; b) Cambios en los marcos jurídicos internos para la extraterritorialidad de las guerras del imperio o la protección de sus fronteras e intereses estratégicos; y c) Rescate de los capitalistas en las crisis recurrentes y cada vez más profundas. Así, el desmantelamiento del Estado es sólo parcial, ya que se fortalecen en gran medida los aparatos represivos que por naturaleza son violatorios de los derechos humanos".

${ }^{25}$ Como ejemplo, véase el volumen coordinado por Das y Poole, Anthropology in the Margins of the State (2004).
} 


\section{Violencia y cultura}

Susana Devalle propone una interpretación de la violencia estructural entendiéndola como dominación, lo cual le permite enfocarse también a las resistencias que se oponen a ella. El volumen Poder y cultura de la violencia analiza como esta se ejerce "en acciones desarrolladas por los sectores dominantes de una sociedad, por sectores que respaldan ideologías exclusivistas y racistas, y por el Estado sobre sectores de la población que se consideran 'subordinados' o por subordinar y controlar" (2000:15). Devalle introduce en el análisis de la violencia el elemento cultural, al afirmar que:

En situaciones de dominación, la violencia marca el orden existente y se convierte en un sistema significativo, en un lenguaje [...] Donde la violencia se desarrolla, esta adquiere para las clases dominantes el peso de un 'valor', es decir, de condición normal de la vida, necesaria para mantener el orden existente, legitimada como 'el derecho' de los que tienen el poder (2000: 21-22).

La autora define tal orden de ideas como cultura de la opresión: esta sería "el agregado de valores dominantes, acompañados por prácticas en las cuales la violencia y la coerción entran como elementos constitutivos de importancia en la reproducción del orden hegemónico" (2000:21). A este orden cultural, fundamentado en la violencia, se contrapone la cultura de la resistencia, cuya manifestación más significativa es la "voluntad colectiva de los sectores subordinados por vivir, por ser, no solo por sobrevivir, tanto en términos físicos como también en términos sociales e históricos" (2000:21). Ilustraré como esta voluntad afirmativa está en la base de los procesos autonómicos, que se caracterizan por un lado como expresiones de resistencia, pero se desarrollan en términos propositivos y creativos.

El debate sobre la relación entre violencia y cultura es de gran relevancia para los estudios antropológicos, en los que tiene raíces muy profundas. Por la amplitud y la especificidad del tema, me propongo señalar algunos de los tópicos que considero más relevantes, y que me llevan a introducir en este análisis el sujeto de la investigación, los pueblos indígenas.

Desde una perspectiva antropológica clásica, que manifiesta un cierto legado evolucionista, la violencia y la cultura serían contrapuestas, siendo la primera expresión de las 
pulsiones animales y primitivas del hombre, una suerte de "esencia natural" de los seres humanos. $^{26}$ Esta visión, que vuelve a proponer la dicotomía entre natura y cultura, refleja también el paradigma hobbesiano según el cual, en una sociedad primitiva, las relaciones interpersonales se regularían a través de la violencia, hasta la instauración del contrato social que delega al Estado, una entidad impersonal y superior a todos los hombres, el uso legítimo de la fuerza, erradicando así el uso de la violencia en las relaciones individuales. Fabio Dei considera que, según este enfoque, las sociedades, las instituciones comunitarias y la cultura compartida tendrían la función de neutralizar los impulsos agresivos y violentos de los hombres. Sin embargo, y como sostiene Benjamin en el ensayo analizado, "hay otros puntos de vista, [...] según los cuales la sociedad y la cultura no son tan inocentes, y fundan su arraigo en los individuos precisamente sobre la gestión de la violencia" (Dei 1999). Dei discute al respecto tres autores, Frazer, Freud y Girard, que muestran desde diferentes enfoques como "la civilización contemporánea, fundada sobre la remoción de la violencia física [...] también se funda en un acto originario de violencia" (1999).

Otra aproximación asume que "la violencia que se manifiesta en la historia y en la vida social no es el contrario de la cultura sino el producto de cierto tipo de cultura" (Dei 1999). De esta se pueden derivar dos enfoques: uno, muestra que "la violencia y la agresividad se manifiestan en el comportamiento humano, al interno de determinadas sociedades y civilizaciones, en maneras culturalmente e históricamente plasmadas” (Dei 1999). En la misma dirección, el estudio de Tosca Hernández citado anteriormente apunta que:

No son aspectos biológicos los que determinan la violencia, [...] ya que es en el espacio relacional donde ésta emerge, se particulariza, se asienta culturalmente y se nos hace evidente en sus consecuencias [...] En la producción de la violencia es fundamental el sistema fenoménico generador (sociocultural) y por lo tanto ella expresa características de la sociedad en donde emerge (2002:62).

El otro enfoque, muy cercano al primero pero con importantes diferencias, invita a pensar en la presencia de una "cultura violenta", o, dicho de forma más sutil, una cultura de la violencia

\footnotetext{
${ }^{26}$ Tal visión es ampliamente refutada en el Manifiesto de Sevilla sobre la Violencia (Conferencia General de la UNESCO, 1986) que se funda sobre estas proposiciones básicas: 1. La violencia no está genéticamente determinada; 2. La violencia no está inscrita en nuestro cerebro; 3 . La violencia no viene de nuestro pasado animal; 4. En el proceso de la evolución no ha habido una selección mayor hacia el comportamiento agresivo o violento, que hacia otros tipos de comportamiento, y 5 . La violencia no es hereditaria.
} 
que caracterizaría determinadas sociedades o estaría presente en algunos sectores de éstas. Esta aproximación, si bien útil para cuestionar los paradigmas positivistas basados en la raíz biológica de la violencia, ha sido también muy criticada, pues ha llevado a interpretaciones igualmente deterministas sustentadas ahora en criterios culturales. Elsa Blair ha analizado el debate que se ha desarrollado en el contexto colombiano, donde los estudios sobre el tema son numerosos, de acuerdo a la situación que el país vive desde hace varias décadas. La autora menciona que el concepto de "cultura de la violencia" ha sido generalmente rechazado en ámbito académico durante mucho tiempo, ya que implicaría asumir que:

Hay en Colombia un sino fatal que puede provenir de fundamentos atávicos de profunda raigambre histórica y constitutivos de una personalidad colectiva que construyen la omnipresencia de la violencia: se puede adjudicar así la paternidad de ésta a factores étnicos, geográficos o de cualquier índole metasocial que la convierten en inevitable [y, sobretodo, inmodificable] (Camacho 1991, cit. en Blair 2003:17).

Sobre la base de esta explicación de los fenómenos violentos se han construido los estigmas que marcan de manera persistente enteros contextos o grupos sociales, en una colusión profunda con prejuicios racistas basados en la discriminación étnica o económica. Es el caso del tópico del Guerrero bronco que, si bien puede ser usado para sintetizar un contexto violento por motivaciones políticas e históricas claramente determinables -como lo hace Armando Bartra en el libro que lleva el título homónimo-, con mayor frecuencia es utilizado como una adjetivación sustancial y definitiva de todos los que habitan en la entidad. Esto es, que el ánimo intrínsecamente violento de los guerrerenses explicaría en buena medida cualquier manifestación de la violencia en el estado; así, políticos o analistas se evitan la tarea de buscar las reales causas -económicas, políticas, sociales- de la violencia, y de fincar las debidas responsabilidades. En el contexto guerrerense, las manifestaciones de la violencia hunden profundas raíces en el autoritarismo, la corrupción de las instituciones y la discriminación hacia grandes sectores de la sociedad. Aquí cabe subrayar que, utilizado de la forma citada, el argumento de la "cultura de la violencia" es una cómoda herramienta que justifica el desinterés y la represión institucional, una definición autocontenida que muestra una situación violenta como inevitable e inmodificable. 
Esto se relaciona a una visión esencialista (casi una "segunda naturaleza") de la cultura entendida como estática e inmutable, lo que finalmente es "todo lo contrario de lo que significa cultura, es decir, historia y por tanto procesos largos de intercambios y de cambios" (Martin Barbero 1998, cit. en Blair 2003:18). Considerar siempre la capacidad de los sujetos de interactuar en los cambiantes contextos cotidianos, y de transformar su propia cultura, es necesario para no caer en simplificaciones esencialistas y, en muchos casos, en prejuicios racistas.

Sin embargo, a la luz de un interesante recorrido teórico alrededor de las conceptualizaciones de la cultura y las aproximaciones al concepto de la violencia en Colombia, Blair admite que:

aún no se sabe muy bien de qué manera abordar la incidencia de lo cultural en la producción de la violencia o de qué manera situaciones de violencia pueden construir nuevas significaciones sociales. O como construyen diversos actores sociales - en un contexto de violencia- sus tramas de significación" (2003:12).

Un enfoque muy sugerente, que se opone a todos los paradigmas esencialistas, es el que propone la antropóloga colombiana María Clemencia Ramírez, para quién la relación entre cultura y violencia es de doble vía, en tanto "la violencia en lugares donde se ha vuelto parte de la vida cotidiana puede incidir en la construcción de significados culturales, y no necesariamente es una cultura dada la que explica el comportamiento de los individuos" (Ramírez 1997, cit. en Blair 2003: 25). Este enfoque se revela mucho más adecuado para el entendimiento de las manifestaciones de la violencia (no para la conceptualización apriorística de ellas): habrá entonces que estudiar como las situaciones y las manifestaciones de la violencia generan modificaciones en la cultura y crean visiones y productos culturales, que reflejan, responden a, y reproducen la realidad de violencia.

En esta misma visión se puede ubicar la noción, elaborada por Taussig, de cultura del terror, que expresa el poder de las narrativas de la violencia como herramienta de dominación. ${ }^{27}$ Reflexionando sobre la construcción y la permanencia del sistema colonial, el

\footnotetext{
${ }^{27}$ Taussig analiza algunos aspectos de la relación presentada en 1910 por el diplomático irlandés Roger Casement sobre las atrocidades cometidas contra los indígenas en las plantaciones de caucho en el Putumayo peruviano. El documento no se limita a denunciar el trabajo forzoso y los abusos perpetrados por la Amazon Peruvian Company, sino que ilustra el entramado de relaciones culturales y de poder sobre las que se había construido esa
} 
autor evidencia la importancia de "pensar a través del terror, que además de ser un estado fisiológico, es también un hecho social y una construcción cultural cuyas dimensiones barrocas le permiten servir como mediador par excellence de la hegemonía colonial" (2004:39). Taussig esplica que:

La característica verdaderamente fundamental radica en crear una realidad incierta afuera de la ficción, una realidad de pesadilla en la cual la interacción oscilante de verdad e ilusión se vuelve una fuerza social de dimensiones horrendas y fantasmales. En una medida importante todas las sociedades viven de ficciones tomadas como realidad. Lo que distingue las culturas del terror es que el problema epistemológico, ontológico, y por otra parte puramente filosófico de realidad-e-ilusión, certidumbre-y-duda, se vuelve mucho más que un problema "meramente" filosófico. Se vuelve una herramienta muy poderosa para la dominación y el principal medio de la práctica política (2004:50).

La presencia masiva de soldados y paramilitares armados en comunidades indígenas remotas de la Selva y Los Altos de Chiapas crea y mantiene una cultura del terror, que se perpetúa por el miedo instaurado por el poder, fundado en la violencia ejercida, y en la posibilidad (real o ficticia) de ejercerla, que unos individuos adquieren sobre otros.

Se puede fácilmente tender un puente entre la perspectiva interpretativa de Taussig y la teoría de Galtung, para quién hay una relación de interdependencia entre las violencias directa, estructural, y cultural. El autor utiliza el término violencia cultural para definir "aquellos aspectos de la cultura, la esfera simbólica de nuestra existencia -ejemplificada por la religión y la ideología, el lenguaje y el arte, las ciencias empíricas y las ciencias formales (lógica, matemáticas)- que pueden ser usadas para justificar o legitimar la violencia directa o estructural" (1990:291).

No obstante defina la violencia cultural como una invariante, una "permanencia", para el autor ésta no tiene ninguna característica esencial o apriorística, pues no se puede entender sin conectarla a las otras dos formas de violencia, de las que depende, o que encubre:

sociedad de la explotación y del miedo. La "cultura del terror" se ubica en el contexto de lo "salvaje", tal se puede describir el entorno selvático, los hábitos de los indígenas y las acciones de los empleados de la compañía contra ellos, justificadas por el mismo pretexto de su "salvajez". Esta narrativa del terror y lo salvaje originaba y se alimentaba del miedo a las rebeliones de los indígenas (que nunca tuvieron lugar) y el miedo a su supuesto canibalismo. Los empleados de los campamentos caucheros vivían obsesionados con la muerte. Veían peligros en todos lados. Esa idea de muerte, que golpeaba constantemente su imaginación, los aterrorizaba y los hacía capaces de cualquier acto. 
La violencia cultural permite que la violencia directa y estructural aparezca, o se perciba, justa, o por lo menos, no errónea [...] Por un lado la violencia cultural trabaja para cambiar el color moral de un hecho desde el rojo/malo al verde/bueno o por lo menos al amarillo/aceptable. Por otro lado hace opaca la realidad, de tal manera que no vemos el acto o hecho violento, o no lo vemos como violento (1990:291-292).

Es destacable la teoría de Galtung porque proporciona una crítica aguda desde el interior del sistema capitalista, evidenciando el carácter estructuralmente violento de las relaciones que éste impone a todos los sujetos "otros", y los mecanismos que tal sistema utiliza para su legitimación. ${ }^{28}$ En una perspectiva que se acerca a la que propone Devalle cuando refiere a la violencia como cultura de la opresión, Galtung muestra que, en algunos casos, la violencia directa ejercida hacia un grupo social -por ejemplo, los africanos esclavizados en las Américas- se sedimenta en violencia estructural masiva -desigualdad y explotación-, la que produce y reproduce violencia cultural en forma de una ideología racista y discriminatoria. En otros casos es la raíz cultural -por ejemplo la idea del pueblo elegido por Dios- que funciona como origen y justificación última de la violencia estructural y directa -el ejemplo propuesto es la política de Israel hacia el pueblo palestino-. A través de diversos ejemplos, el autor explica como algunos elementos de la cultura pueden ser utilizados para legitimar la violencia directa o estructural; su argumentación muestra que los universos culturales son construidos y transformados de acuerdo a las necesidades de los sectores dominantes de las sociedades, en las diferentes épocas y contextos.

Desde otra perspectiva, también el concepto de violencia simbólica propuesta por Pierre Bourdieu se ubica en el cruce de las manifestaciones culturales y las estructuras que subyacen a las relaciones de dominación. Un ejemplo de violencia simbólica es la violencia de género, presente en todas las prácticas sociales; su reproducción se basa por un lado desconocimiento, pues su cotidianidad y familiaridad la hacen invisible. Es una violencia "que extorsiona sumisiones, que ni son percibidas como tales porque se apoyan en expectativas colectivas, creencias inculcadas culturalmente" (Bourdieu 1994, citado en Becauge 2008: 83).

\footnotetext{
28 "La cultura predica, enseña, amonesta, incita y adormece para hacernos ver la explotación y/o la represión como normal y natural, o para no hacérnoslas ver completamente (en particular la explotación). Luego viene la erupción, el intento de usar la violencia directa para salir de la caja de acero estructural, y la contra-violencia para mantener la caja intacta" (Galtung 1990:295).
} 


\section{AUTONOMIAINDÍGENA, VIOLENCIAY JUSTICIA}

Quiero cerrar este apartado con un ejemplo que articula algunos de los elementos y características de la violencia que he mencionado. Analizando el contexto actual de Guatemala, definido "el paraíso de los sicarios" por los altísimos niveles de violencia e impunidad, Michelle Bellino considera que:

La impunidad legal por los criminales del pasado [políticos y militares responsables de la violenta represión en contra de los opositores durante más de 40 años] ha generado una 'cultura de la impunidad' que penetra la vida cotidiana de los guatemaltecos, disminuyendo su confianza en el gobierno, en el sistema de justicia, y el papel de los ciudadanos aparentemente sin poder [...] para muchos, la impotencia cívica lleva a la apatía respecto la violencia, mostrando una suerte de resignación (2010:14).

Una explicación generalizada a esta situación es "que Guatemala es un país violento con una cultura violenta" (el sino fatal que caracterizaría los colombianos, o los guerrerenses broncos). Esta lectura establece una continuidad necesaria entre la guerra y la violencia actual, como dos ejemplos de la misma realidad, asumiendo que "una historia de violencia implica una cultura de violencia”. En esta lectura está presente el pasado reciente de guerra, represión y masacres, vivido por tres generaciones de guatemaltecos -en su mayoría indígenas y que provocó alrededor de 150.000 muertos; se enfatiza que la violencia ha sido socializada, interiorizada y aprendida por todos los actores involucrados en el conflictos (soldados, paramilitares, guerrilleros, población civil), que ahora reproducen automáticamente métodos y relaciones violentas. Esta visión es en parte certera, pero es un engaño creer que la criminalidad contemporánea puede ser entendida simplemente como una consecuencia de la violencia histórica; en esta visión de la historia no se enfatiza la continuidad en el poder y la desigualdad estructural que, antes y ahora, siguen marcando el país.

La falta de justiciabilidad para la violencia del pasado y del presente ha creado un ambiente en donde la violencia es permitida, si no es que provocada, por la garantía implícita de impunidad. Y la criminalidad actual involucra frecuentemente criminales del pasado, que han sido beneficiados por amnistía oficial” (Bellino 2010:16).

Otra interpretación a la realidad violenta del país centroamericano es la que abunda en los discursos del poder: relega la guerra en un pasado completamente desconectado del presente, 
olvida la violencia histórica que ha marcado cientos de miles de personas, y justifica la violencia de la posguerra con la aserción de que la naturaleza de los guatemaltecos es inherentemente violenta. Esta interpretación, sumamente reductiva, asegura que la violencia es endémica porque es intrínseca; además, negando el carácter político del conflicto, asume que no es posible una solución política.

Este ejemplo confirma algunas consideraciones que he propuesto a lo largo de este apartado. En primer lugar, que para la comprensión de las violencias es necesario situarlas siempre en su dimensión histórica, diacrónica; la violencia es un proceso, y reificarla es un error de perspectiva. En segundo lugar, que el elemento cultural es fundamental, más como una manifestación de la violencia que como su origen; y adquiere relevancia en relación con la dimensión estructural de la violencia. Finalmente, que ésta es la más importante manifestación de la violencia en la modernidad, alrededor de la cual giran todas las violencias diversamente adjetivadas.

\section{Los pueblos indígenas y la violencia}

\section{Racismo y discriminación}

Una primordial manifestación de la violencia en los países latinoamericanos es la que se ha ejercido históricamente hacia los pueblos indígenas, en la forma de ideologías, políticas y comportamientos racistas. Esquemáticamente, se puede identificar el racismo "cuando existe una situación social y económica de desigualdad, junto con una serie de representaciones del grupo dominado" (Carrillo Trueba: 2011, cursivas mías). Según los elementos de esta definición, el racismo representaría una combinación de violencia estructural y violencia cultural, tal y como aparecen en la teoría de Galtung.

Para entender el fenómeno del racismo, varios especialistas proponen una primera diferenciación entre el racismo como una "ideología que mantiene ciertos mecanismos de categorización y de exclusión para ejercer el poder sobre sectores subalternos" (Paris Pombo 2002:292), y las prácticas que de ella resultan. Una de las más reconocidas estudiosas del tema en México, Alicia Castellanos, señala que, en términos generales, el núcleo básico de la ideología racista "está fuertemente asociado con la creencia acerca de la 
superioridad/inferioridad biológica de las razas, sustentada ésta en una jerarquización que se manifiesta inexorablemente en una superioridad/inferioridad cultural y social" (Castellanos 2000). Así, el racismo es el fundamento ideológico de los procesos de dominación, legitimando el predominio político de un grupo definido a partir de sus características étnicas y que se identifica con la nación.

La ideología racista se traduce en prácticas sociales legitimadas, que van desde el prejuicio y la discriminación, pasando por la segregación y la violencia racial, hasta los episodios de etnocidio. La práctica racista más difusa es la discriminación, que consiste en el trato diferencial hacia ciertos sectores sociales, en "una suerte de difusión institucional de la ideología racista que provoca la desigualdad social en la escuela, en el sindicato, en la empresa, en el hábitat, etc.” (Paris Pombo 20012:305).

Otra categorización es la que distingue prácticas racistas asimilacionistas, que tratan de negar la Otredad e incorporar su identidad en los esquemas sociales y culturales dominantes, y prácticas diferencialistas, que se caracterizan por su sentido excluyente y de segregación, exacerbando las fronteras étnicas al interior de las sociedades, así como las vetas de la dominación. Con frecuencia, en las relaciones sociales y en las políticas públicas, las dos vertientes se combinan, generando complejos mecanismos de inclusión/exclusión de los pueblos indígenas en la sociedad: por ejemplo, se favorece la inclusión de los indígenas en el mercado laboral como fuerza de trabajo barata pero se los excluye del acceso a los derechos laborales y ciudadanos; o se propugna la inserción de los territorios indígenas y de sus manifestaciones culturales a la industria del turismo, y a la vez es vetado a los indígenas controlar, dirigir o definir autónomamente los mismos proyectos turísticos.

Para la reflexión que aquí se formula, que trata de mostrar el racismo y la discriminación como expresiones generalizadas y multiformes de violencia hacia los pueblos indígenas, es necesario señalar que no se pueden explicar sin la intervención directa o indirecta del Estado; esto es, según Castellanos, que "la violencia física y simbólica, con la que se han producido las políticas segregacionistas y asimilacionistas, no hubiesen sido posibles sin esa intervención estatal” (2001a). Por otra parte, la legitimación de ideologías y prácticas racistas sustentan la conformación política y social de la nación, “imaginada" generalmente sobre la exclusión de algunos sectores. Es cierto que no todas las formas de racismo son una política directa del Estado, sin embargo “el Estado interviene institucionalizando ciertos discursos y prácticas de 
exclusión y no sancionado otras prácticas", o también fomentando un racismo que se manifiesta más en las prácticas que en los discursos (Castellanos 2001a).

Según la misma autora, las representaciones y prácticas del racismo cambian en el tiempo y en el espacio, pero a partir de un sustrato anterior (para las sociedades latinoamericanas, la historia y el imaginario coloniales) que revela la persistencia de ciertos estereotipos. En la actualidad, este racismo institucionalizado:

Conforma políticas del Estado mexicano, las cuales impulsan y coadyuvan a la desaparición de los pueblos indígenas, al abandono de su cultura, su modo de vivir y pensar, su emigración para trabajar en el norte. Tal es el caso de la promulgación de las reformas al artículo 27 de la Constitución, que pareciera la realización del sueño de los liberales del XIX de convertir a los indígenas en pequeños propietarios, de acabar con la propiedad colectiva; el despojo de tierras para levantar proyectos turísticos, tornándolos mano de obra para la construcción y servicios asociados; o bien los paquetes tecnológicos, inadecuados para su medio, que pretenden reemplazar el cultivo de maíz por cultivos comerciales, y un largo etcétera" (Carrillo Trueba 2011).

A lo largo de la dominación colonial, la imagen y las relaciones con los indígenas, basadas en los supuestos de su inferioridad biológica, derivaron en políticas de segregación e incluso exterminio (Castellanos 2001a:166). Después, en la historia reciente de México, el racismo se manifestó principalmente en su acepción asimilacionista, que supone la disolución y desaparición de la identidad indígena (desindianización) en el proceso de mestizaje, por medio de las políticas indigenistas de la primera mitad del siglo XX. Según la autora, "desde el siglo XIX, el mestizaje es símbolo de la nacionalidad y prueba irrefutable para negar la existencia del racismo hacia los indios de México. Sin embargo, éste ha sido un proceso violento que ha ocultado desde la asimilación forzada hasta el etnocidio" (Castellanos 2000a). En la actualidad, la aceptación del multiculturalismo y las políticas que apuntan hacia el fortalecimiento de la interculturalidad representan esfuerzos importantes pero limitados, ya que en el sentido común, en las instituciones, y en los funcionarios públicos permanecen arraigadas prácticas como la discriminación. ${ }^{29}$

\footnotetext{
${ }^{29}$ No voy a ahondar en el argumento aquí, pues es en el capítulo 1 donde realizo una breve exposición critica de las principales políticas del Estado hacia los pueblos indígenas en los siglos XX y lo que va del XXI.
} 
Racismo de Estado y violencia: una perspectiva histórica

Pero más allá de esto, observando en perspectiva histórica las relaciones entre los pueblos indígenas y el Estado mexicano, me atrevo a avanzar una hipótesis un tanto radical pero no infundada, o sea que con frecuencia la violencia ha sido utilizada como política de Estado hacia los indígenas. La violencia como sojuzgamiento, explotación y aniquilación sistemática de los pueblos se traslapó desde el gobierno de la Colonia a las instituciones del México independiente, imbuidas de la ideología liberal-positivista, que sostenía la eliminación de todo lo que pudiera representar un obstáculo al "progreso" capitalista en su pleno desarrollo. ${ }^{30}$

El historiador Enrique Florescano afirma que, si se recorre la historia del siglo XIX, "se advierte que desde la Independencia los autores de los proyectos nacionales trataron a los indígenas peor que los conquistadores del siglo XVI" (1996:490). El autor explica como el proyecto político liberal nunca aceptó a los indígenas como pueblos con tradiciones distintas, y por lo tanto nuca se aceptaron estas tradiciones como parte del proyecto político nacional. Al afirmar la superioridad de la cultura de raíz europea, "el ataque a los valores y a las tradiciones indígenas alimentó el nacimiento de una conciencia social excluyente, que condujo a la intolerancia del otro $[\ldots]$ los medios más diversos difundieron una imagen degradada, salvaje y obtusa de los indígenas" (Florescano 1996:491). Podemos afirmar que de esta manera se construyó el prejuicio o la vertiente cultural de la violencia, en la acepción propuesta por Galtung, que justificó el ejercicio recurrente de la violencia directa por parte del Estado contra los pueblos que reivindicaban la legitimidad de una cultura y la propiedad sobre un territorio. Así, "cuando los pueblos indios se atrevieron a resistir a esta avalancha impositiva, los declararon enemigos de la civilización y no vacilaron en promover guerras exterminadoras contra ellos" (Florescano 1996:491).

Las más de cien ${ }^{31}$ rebeliones indígenas, o mal llamadas "guerras de castas", que se prolongaron por todo el siglo XIX y los primeros años del siglo XX, fueron la respuesta a una durísima política de expropiación de las tierras comunales, así como de desconocimiento de las identidades y formas de organización indígena. Frente a la violencia estructural ejercida

\footnotetext{
${ }^{30}$ Para José María Luis Mora, uno de los más destacados pensadores liberales de la época, los indígenas no eran más que "cortos y envilecidos restos de la antigua población mexicana", que no podían considerarse la base de una sociedad mexicana "progresista" (cit. en Florescano, 1996:363).

${ }^{31}$ El dato fue elaborado por Coatsworth, cit. en Florescano (1996:37).
} 
por el Estado, vuelta a minar definitivamente las bases de reproducción social y cultural de los pueblos, éstos defendieron sus reivindicaciones con una insurgencia generalizada en todo el territorio nacional. Sin embargo, en lugar de abrir espacios de negociación, el Estado volcó contra los pueblos indios el peso de su aparato represor, en una dinámica que, grosso modo, sigue invariada hasta la fecha. La eliminación física de enteros pueblos indígenas "rebeldes" fue una práctica constante del Estado decimonónico. La memoria de estas "guerras" puede ayudar a la comprensión del desarrollo y la actualidad de la relación entre los pueblos indígenas y el Estado, porque muestran la continuidad del conflicto y de sus motivos, así como de las prácticas del Estado mismo. La excelente investigación de Leticia Reina sobre Las rebeliones campesinas en México (1819-1906) explica que las principales demandas que animaron las innumerables rebeliones campesinas -e indígenas- en el siglo XIX (la tierra, la cultura, la historia, el aspecto económico, el aspecto político, el aspecto religioso, la denuncia del racismo y la identidad étnica) siguen presentes en los actuales movimientos, lo que muestra que los elementos estructurales no han desaparecido.

Los tres grandes movimientos de corte netamente indígena fueron la lucha del pueblo yaqui en Sonora, la "guerra de castas" en Yucatán y la rebelión de 1868 en Chiapas. Aquí, en el territorio tzotzil al norte de San Cristóbal de Las Casas, los indígenas adoptaron en 18671868 un nuevo culto religioso (a las "piedras parlantes") y se apartaron de las redes de explotación comercial a las que los sometían los ladinos. "Su independencia inesperada alarmó a los curas, comerciantes y políticos ladinos, quienes desataron una guerra feroz en su contra" (Womack 2009:143), que terminó en la masacre de todos los indígenas "levantados".

A lo largo de su historia, el pueblo yaqui -que se reconoce como una nación- ha emprendido una infatigable lucha para la defensa de su identidad cultural, de su gobierno tradicional y de su territorio. Según Hernández Silva, los yaquis protagonizaron una verdadera insurgencia cuyo objetivo era la autonomía política, y "los levantamientos armados fueron el punto extremo de una lucha política desarrollada de manera cotidiana en todo el siglo XIX" (1996:147-148).

Los gobiernos liberales y el de Benito Juárez, de Porfirio Díaz e incluso los gobiernos posrevolucionarios mantuvieron una sanguinaria guerra de exterminio contra los yaquis, rebeldes al despojo de su territorio comunal y de sus recursos (en particular el agua del Río

\footnotetext{
${ }^{32}$ La novela Oficio de Tinieblas, de Rosario Castellanos, se basa en este episodio de la historia chiapaneca.
} 
Yaqui) para favorecer el "progreso" y la naciente industria sonorense. La llamada "Guerra del Yaqui" es uno de los conflictos armados más largo de la historia de México: la primera rebelión estalló en 1825, y la última en 1926; en su larga insurgencia, el pueblo yaqui se enfrentó a las fuerzas armadas de los gobiernos federal y del estado de Sonora, y a las guardias blancas de los terratenientes. Ni la militarización del territorio y las múltiples batallas emprendidas por el Ejército contra los combatientes indígenas; ni la masiva deportación (a principios del siglo $\mathrm{XX}$ ) de miles de familias enteras, enviadas como esclavos a trabajar en las plantaciones henequeneras de la península de Yucatán y en Valle Nacional, Oaxaca; ni el bombardeo de la Fuerza Aérea Mexicana en 1928 sobre la sierra del Bacatete y varios poblados, pudieron doblegar la determinación de los indígenas en defender su autonomía.

En el otro extremo de la recién formada "nación” mexicana, la mal llamada "Guerra de Castas” sacudió la península de Yucatán más o menos en el mismo periodo: inició en 1840 y terminó alrededor del 1910. Mal llamada porque, de acuerdo a las interpretaciones vigentes en la historiografía actual, la denominación se concentra en el odio étnico de los indígenas hacia los criollos, contribuyendo a la estigmatización de los indígenas como "barbaros" que rechazan la civilización, mientras pasa por alto la discriminación social y la explotación económica de los mayas. La aversión hacia los blancos estaba presente, pero las reales motivaciones del levantamiento se encuentran en el creciente deterioro de las condiciones de vida de los mayas peninsulares. A la explotación y la presión fiscal propias del periodo colonial, se aunaron nuevos elementos, como la instauración de las primeras grandes plantaciones de monocultivo (caña y henequén). Según Barabas (2002:172):

La causa económica de la guerra maya debe buscarse en la expropiación territorial (de la tierra, el monte y el agua) provocada por las plantaciones, lo que implica también la desaparición de los pueblos absorbidos por éstas; en la apropiación de la fuerza-trabajo de los mayas convertidos en siervos y peones [acasillados]; y en los impuestos excesivos que ataban a los trabajadores a la plantación a través del endeudamiento continuo.

Sucesivamente, la rebelión se fortaleció al incluir el elemento religioso: la Cruz Parlante que se dirigía a los indígenas en contra de los blancos, y alrededor de ella se formó una suerte de territorio "autónomo", con autoridades civiles, religiosas y militares propias; la ocupación, por parte del Ejército mexicano, del área de Chan Santa Cruz y la derrota de los cruzoob, en 1901, 
marcó el fin de la sangrienta guerra en la cual perdió la vida el 50\% de la población peninsular, y miles de mayas rebeldes fueron vendidos como esclavos a Cuba.

El movimiento revolucionario de 1910 surgió también, y sobre todo, de las reivindicaciones por tierra y territorio enarboladas por los pueblos indígenas, duramente afectados -en su forma de organización colectiva y comunal- por las políticas de desamortización propugnadas por el Estado liberal. La instauración del Estado posrevolucionario implicó cambios profundos en el discurso y en las políticas públicas hacia los pueblos indígenas, rompiendo (aparentemente) la espiral de insurgencia y represión que había marcado el siglo XIX. Por un lado, la reforma agraria y el reparto de tierra desactivaron -en un primer momento- la conflictividad ligada a este tema; sucesivamente, las múltiples fallas e inequidades que incurrieron en el reparto, y la sucesiva interrupción del mismo, generaron muchísimos episodios de inconformidad y conflicto que vieron como protagonistas las comunidades indígenas, movilizadas otra vez en la lucha por la tierra.

Este contexto, en el que la tierra se volvió el centro de las reivindicaciones hacia el Estado, propició la formación de organizaciones orientadas, en mayor o menor medida, por la ideología marxista, adaptada al contexto latinoamericano. Aquí, el sujeto de cambio o revolucionario era el campesino, y desde 1930 a 1990 fue la lucha agraria la que representó el mayor motivo de conflictividad en las regiones rurales. Como se ha abundantemente reflexionado, los que se vieron involucrados en las luchas campesinas eran en su mayoría indígenas, que por supuesto no dejaron de serlo, pero no utilizaron la identidad indígena con fines de movilización política, lo que sucedió a partir de la década de los noventa.

Por otra parte, durante ese largo periodo la identidad indígena fue objeto de una poderosa intervención por parte del Estado y de sus instituciones: las políticas indigenistas crearon la imagen del indígena como pobre, atrasado y marginal, alguien a quien había que incorporar al proyecto nacional y a las filas del progreso económico. Siendo así el panorama, las reivindicaciones basadas en la especificidad indígena se desdibujaron para dejar el paso a las más propiamente agrarias; lo que no cambió sustancialmente, fue la estrategia de represión operada por las instituciones del Estado ahora "democrático".

Para explicar las relaciones entre los pueblos indígenas y el Estado en esta época que el sociólogo Pablo González Casanova acuñó el término de "colonialismo interno" (1965), que considera que las relaciones y las condiciones de explotación a los que están sometidos los 
indígenas en el capitalismo son la prolongación del periodo colonial. En un libro publicado en el mismo año, Franz Fanon afirma que el colonialismo es una forma explícita de violencia que destruye las condiciones sociales autóctonas y la economía local, imponiendo la cultura del colonizador. El colonialismo interno se puede entender como una forma de actuar, hacia los pueblos indígenas, del Estado y de los actores sociales que de una u otra manera se vinculan con él; articula la violencia estructural socioeconómica y la violencia directa ejercida por el Estado, su ejército y sus policías; la violencia de los terratenientes y sus grupos armados, que por décadas han saqueado y sometido a los indígenas con la violencia y el terror, protegidos por la connivencia del Estado; y por los grupos paramilitares que representan una perversa imbricación de los intereses del Estado y de las élites locales.

En la bibliografía analizada sobre insurrecciones y levantamientos indígenas, o sea contextos en los cuales los pueblos utilizaron el recurso de la violencia y de la fuerza, no se encuentran referencias a episodios de este tipo ocurridos durante el periodo 1930-1990. Al parecer, durante la larga noche del nacionalismo, del indigenismo y del corporativismo, se desactivaron los conflictos directamente ligados a la reivindicación de la diferencia. Christian Gros y José Bengoa proponen una reflexión al respecto, a partir de una mirada amplia sobre el continente latinoamericano, en el cual (a diferencia de África o de algunos países de Europa) la historia reciente no registra conflictos que surgen a partir de una movilización política de la identidad y de las fronteras étnicas. Observa Bengoa que:

Las relaciones de dominación étnica en Latinoamérica han sido más dominadas por la violencia institucionalizada, que las ha reproducido, que por la violencia de resistencia [...] La característica de los movimientos propiamente de la emergencia étnica latinoamericana ha sido su condición pacífica. En cambio la violencia institucional y sobre todo la represión contra los movimientos indígenas es una realidad posible y actual (2005: 131-133).

Es notable que un sujeto político (los pueblos indígenas) que, particularmente en las últimas décadas, se ha movilizado en la arena política con acciones contundentes, manifieste una reserva o incluso el tajante rechazo al uso de la violencia; considerando que, entre los pueblos indígenas latinoamericanos, se pueden observar los mismos elementos que, en otros contextos, contribuyen a la explosión de sangrientos conflictos definidos como "étnicos". Reflexionando sobre esta "anomalía" latinoamericana, Gros se pregunta si: 
¿Acaso no priva en América Latina una indiscutible discriminación, una estigmatización, un conjunto de injusticias estructuralmente organizadas que se ejerce contra grupos o comunidades definidos por su pertenencia étnica o cultural, es decir, acaso no se halla presente la conspicuous distinction a la que Ted Gurr señala como la raíz de muchos conflictos étnicos en el mundo entero? (Gros 2005:108)

El mismo autor cita a Bengoa para afirmar que una de las razones que explican esta opción política y rara vez violenta de las movilizaciones indígenas, es el "relativo éxito" del modelo integracionista impulsado por los regímenes nacional-populistas que se desarrollaron en varios países latinoamericanos. Según esta lectura, los modelos nacionales integradores -como el que surgió de la Revolución Mexicana- y las relativas políticas indigenistas con tintes asimilacioncitas, aunque ahondan la discriminación, impiden que los pueblos subordinados tomen la opción de la violencia. Más recientemente, en lo que ha sido definido como neoindigenismo, ${ }^{33}$ el Estado abriría espacios de negociación, en los cuales ahora sería posible luchar políticamente por la autonomía, esto es, una nueva forma de participación y de relación con el Estado.

Otros dos factores que, según estos autores, dan cuenta del carácter relativamente pacifico de las movilizaciones indígenas en América Latina son la índole no religiosa de los intereses implicados, y la opción por la negociación y la apelación a la justicia y a la ley que, desde la época colonial, ha caracterizado la acción de los pueblos indígenas. Para defender sus derechos, en la actualidad, las organizaciones indígenas se apropian con gran destreza de los instrumentos jurídicos, del derecho nacional e internacional.

Como corolario a estas argumentaciones, quisiera apuntar algunas consideraciones sobre el tema de los "conflictos étnicos" que, aún si no corresponde directamente al caso de estudio, es un tema recurrente en nuestra disciplina. Se ha profundizado sobre el uso de la violencia, y sus manifestaciones, en conflictos en los que se utiliza como pretexto o justificación la pertenencia y la diferencia étnica. Entre ellos, se pueden citar varios trabajos incluidos en la obra coordinada por Héritier (1997), para los casos de África y de los Balcanes; y el notable texto de Stavenhagen (2000). Este autor define así la emergencia de los conflictos étnicos: cuando las diferencias étnicas "se utilizan de manera consciente o inconsciente para distinguir

\footnotetext{
${ }^{33}$ La aceptación "forzada" o retórica de demandas étnicas, especialmente en el ámbito cultural, para hacer frente al desmoronamiento del modelo proteccionista y corporativista vigente antes de la imposición del neoliberalismo.
} 
a los actores rivales en una situación de conflicto, sobre todo cuando se convierten en poderosos símbolos de movilización, como es frecuente, la etnicidad pasa a ser un factor determinante para la naturaleza y la dinámica del conflicto" (Stavenhagen 2000, cit. en Castellanos 2001b: 168).

Al respecto, quiero manifestar mi desconfianza en el uso demasiado generalizado $-\mathrm{y}$ generalizador- del concepto de "conflicto étnico". El análisis atento de la realidad y el estudio de la literatura antropológica y sociológica correspondiente, advierte que los conflictos surgen siempre por un conjunto de motivaciones: las más profundas suelen ser las relacionadas al ámbito económico, o territorial, o las que atañen al control de los recursos, o aún las que se inscriben en la esfera específicamente política. Si bien es frecuente que la etnicidad sea también movilizada como una de las reivindicaciones en el conflicto, muy raras veces se encuentra en la raíz de ello. Sin embargo, la naturaleza del discurso sobre la etnicidad permite interpretaciones muy diferentes: abre a la convivencia pero también puede ser manejado en términos esencialistas, intolerantes y excluyentes. La "opacidad" del discurso étnico permite que en muchos casos venga utilizado - por uno u otro de los actores- para invisibilizar las motivaciones profundas del conflicto, y para justificar la conducta igualmente opaca o injustificable de los involucrados en el conflicto. Me refiero por ejemplo a la polémica sobre la masacre de Acteal, acontecida en Chiapas en 1997, cuando, como parte de la estrategia de contrainsurgencia del Estado mexicano en contra del EZLN, grupos paramilitares -entrenados y armados por el Ejército- asesinaron a 45 indígenas. Políticos e intelectuales cercanos a las esferas del poder siguen afirmando que se trató de un conflicto de índole religiosa, y que las atrocidades cometidas por los paramilitares se inscriben en la cultura y en la idiosincrasia indígena. Asimismo, el conflicto que desde hace décadas involucra a varias organizaciones triquis, que sostienen proyectos políticos encontrados y que se disputan el control político del territorio y de los recursos, ha sido frecuentemente resuelto, en la prensa y en la literatura, con la afirmación de que "los triquis son violentos y de por sí se matan entre ellos".

En este somero análisis quise mostrar como las expresiones y las representaciones discursivas del conflicto entre pueblos indígenas y Estado pueden ser muy diversas, dependiendo de las configuraciones históricas de las regiones y de las mismas sociedades indígenas. Sin embargo, me parece que se demuestra la validez de la hipótesis que avancé al inicio de este apartado, o sea que la violencia es una suerte de política de Estado hacia los 
pueblos indígenas. En primer lugar, el uso de la fuerza o de la violencia directa por parte del Estado es recurrente cuando los indígenas se levantan en defensa de su territorio o de su autonomía. Las luchas agrarias del siglo XX, protagonizadas en buena medida por indígenas campesinos, en muchos casos recibieron también una respuesta violenta.

En segundo lugar, mientras las luchas indígenas (en general) han tenido y tienen un carácter pacífico, es necesario recordar que la violencia (y así aquella del Estado) no sólo se manifiesta como violencia directa: el racismo se relaciona con la dominación y la explotación, expresiones de la violencia estructural. Así, durante el siglo XX:

Las prácticas discriminatorias y etnocidas fueron promovidas por ideologías y políticas desarrollistas del Estado, la construcción de las grandes obras de infraestructura y de los proyectos turísticos justifican el despojo de sus territorios de origen y la destrucción de las bases de su reproducción cultural, y subsisten sistemas de categorizaciones de raíz colonial que se renuevan y revelan las relaciones de desigualdad y el racismo hacia los indios (Castellanos 2001b: 168).

En tercer lugar, hay que considerar que la violencia del Estado se manifiesta también de forma indirecta, esto es, con su apoyo a los sistemas regionales de dominio, muchas veces construidos sobre racismo e impunidad históricamente arraigados. El estudio de los contextos sociales y políticos de las regiones indígenas en el estado de Chiapas, por ejemplo, pondrá a relucir una profunda connivencia entre las instituciones, el poder político, los grupos de poder económico locales, las élites regionales, etc. En este sentido podemos interpretar el apoyo y la legitimación a los caciques y las guardias blancas por parte de los gobiernos estatales, como eficaz contención de los conflictos locales.

Asimismo, la perpetuación de situaciones de desigualdad y violencia estructural -me refiero por ejemplo a las fincas en Chiapas donde los indígenas permanecían toda su vida acasillados, prácticamente en calidad de esclavos, a través del enganche y sometidos a todo tipo de violencia por parte del patrón, o a la falta endémica de servicios como centros de salud en gran parte del estado de Guerrero- son otro aspecto de la violencia institucional hacia los pueblos indígenas.

Como observa Bengoa, la inevitable conflictividad generada por esta violencia estructural se manifiesta frecuentemente en "conflictos cerrados", esto es: 
Aquellos en que el Estado y la sociedad, sobre todo local, recubren y ocultan la demanda indígena bajo la apariencia de una causa diferente: por lo general, construcción de un camino, represa, infraestructura, explotación de recursos, etc. En estos casos el planteamiento indígena es oscurecido y se emplean los métodos tradicionales [...] para resolver las cuestiones confrontacionales en el continente (2005:126).

Si bien hay una infinidad de conflictos que involucran pueblos indígenas, que reivindican de una u otra manera el respeto a sus derechos individuales o colectivos, no siempre se moviliza la identidad indígena, lo que transformaría los conflictos en "abiertos". ${ }^{34}$ Será interesante retomar esta diferenciación entre "conflictos abiertos" y "cerrados", de acuerdo a las estrategias de invisibilización del Estado, y considerando las motivaciones del conflicto, en el estudio de las movilizaciones indígenas en Chiapas.

\section{La violencia desbordada: México, siglo XXI}

Hasta este punto he tratado de realizar una somera tipología de las formas y tipos de violencia y del debate alrededor de ellas, en particular esas violencias que, históricamente, se han ejercido y se ejercen hacia la población indígena. Por ello, hice un énfasis particular sobre la violencia estructural, el racismo y la violencia institucional o violencia de Estado, pues representan unas de las más importantes vertientes de los conflictos que involucran a los indígenas. Este conflicto, aún irresuelto, entre los pueblos indígenas y el Estado mexicano, a lo largo del siglo XX, será objeto de discusión en el capítulo 2. El contexto de violencia en la región de estudio será analizado en el capítulo 3, en el cual realizaré un recorrido histórico sobre las formas específicas de la dominación y la violencia hacia la población indígena de la Selva Lacandona.

En este apartado me propongo esbozar la situación que se vive en el país en el momento en que estoy redactando este trabajo, pues la omnipresencia de la violencia y su aparente ineluctabilidad obligan a reflexionar sobre los cambios en la sociedad y en el campo de las ideas que están transformando la realidad mexicana, y con ella el debate sobre los pueblos

\footnotetext{
34 "Los conflictos abiertos serían aquellos en los que la cuestión étnica se plantea directa y explícitamente como reivindicación por parte de los indígenas frente a la sociedad y al Estado. En estos conflictos los indígenas buscarán, como lo han hecho, aliarse con la población no indígena buscando métodos de acción adecuados y que les permitan a la mayoría apoyar sus demandas" (Bengoa 2005:126).
} 
indígenas. Por un lado, la creciente penetración de los grupos de narcotraficantes en las regiones indígenas está rápidamente modificando las formas de vida de la población, y obligando a las organizaciones a elaborar nuevas estrategias para defenderse de la cooptación, las amenazas, las ejecuciones selectivas y masivas, así como para defender su territorio. Por otro lado, la mayor presencia de las Fuerzas Armadas en las ya militarizadas regiones indígenas, también conlleva crecientes riesgos de violaciones a los derechos humanos individuales y colectivos de la población, y sirve para mermar los procesos organizativos que se oponen al despojo de recursos naturales y a la pérdida de identidad. Así, es necesario dibujar el escenario, cada día más complejo, en el que se desarrollan y al que responden las experiencias de organización indígena que apuntan hacia la autonomía y a la construcción de otras formas de resolver los conflictos y entender la justicia.

"Guerra" al narcotráfico, militarización de la seguridad pública y violación de los derechos humanos

En la última década, México ha asistido al crecimiento desbordado de las actividades y de la visibilidad de los grupos de delincuencia organizada, en particular aquellos ligados al tráfico de droga y de personas. Entre las causas de este fenómeno se encuentran: la transnacionalización creciente del crimen; una crónica impunidad y deficiente comportamiento del aparato de justicia; la carencia de un marco normativo adecuado para hacer frente a la delincuencia organizada desde la perspectiva de seguridad ciudadana; y la posición geográfica de México y la inserción del país en la globalización (Acosta 2011: 49).

La presencia de la delincuencia organizada ligada al narcotráfico no es nueva en el país, sin embargo ha aumentado su poder debido a las causas mencionadas, y ha adquirido mayor visibilidad a partir de la alternancia partidaria en la Presidencia de la República. Según Acosta (2011: 55), durante el largo período hegemonizado por los gobiernos del Partido Revolucionario Institucional (PRI):

La política de tolerancia en el contexto de un sistema presidencialista autoritario, mantuvo bajos los niveles de violencia durante mucho tiempo. Sin embargo, tal política debilitó el estado de derecho y propició la corrupción entre autoridades civiles y militares. A la larga fortaleció a los cárteles y debilitó la capacidad del Estado para controlarlos. 
Así, el crimen organizado ha penetrado la economía legal, el ámbito político y las instituciones locales, contando además con el apoyo de sectores sociales empobrecidos. Las dimensiones más visibles de las organizaciones criminales son las milicias de sicarios al servicio de los diferentes cárteles; las empresas clandestinas dedicadas al tráfico de drogas, secuestros y extorsión; y las élites mafiosas que venden protección e influyen en las decisiones institucionales.

En un interesante artículo donde compara la realidad de varios países latinoamericanos, Maldonado argumenta que el problema de la producción y tráfico de sustancias ilícitas, y las luchas para erradicarlo, no es nuevo, y tampoco se resuelve con la interpretación del Estado fallido, o sea de un poder estatal que ha perdido el control sobre sus territorios o su población. Según el autor, el narcotráfico no es un fenómeno distintivo de regiones poco integradas al Estado y la globalización. De hecho, es una respuesta compleja a los proyectos estatales y privados de colonización y mercantilización de las economías regionales, relacionados con la formación de los Estados-nación. Para Maldonado (2010: 347):

Estos procesos son la base sobre la cual nacieron determinadas economías ilegales, transnacionalizándose a partir de que los Estados cambian sus políticas asistenciales de desarrollo regional por otras de tipo neoliberal, al mismo tiempo que utilizan la fuerza armada y civil para contrarrestar la resistencia de la gente abandonada por el asistencialismo y las elites que controlan las regiones de droga.

Para su análisis, Maldonado se basa en la idea que "el derecho del Estado crea sus contrapartes: zonas de ambigüedad e ilegalidad. Submundos criminales, piratas, mercados negros, migrantes ilegales, protección especial, etc., no son puntos aparte del Estado; son parte sustancial de él” (2010:349).

En contraste con lo que ha sido definido como una suerte de "pacto" entre el Estado y los grupos criminales, ${ }^{35}$ vigente en el periodo priista, el gobierno presidido por Felipe Calderón Hinojosa, perteneciente al Partido de Acción Nacional (PAN), que gobernó a México entre el 2006 y el 2012, operó un cambio importante en las estrategias políticas, policiacas y militares hacia el crimen organizado, implementando la confrontación directa a

\footnotetext{
${ }^{35}$ Ricardo Monreal, entrevista, en "Renovar el decálogo criminal?" Milenio, 10 de noviembre de 2010, citado en Acosta 2011:55.
} 
los cárteles mediante operaciones político-militares. La Estrategia Nacional de Seguridad, nombre asignado a la que es comúnmente definida como "guerra al narcotráfico", se basa en una creciente influencia e injerencia por parte de Estados Unidos en la política y la seguridad interna; políticas de mano dura y operativos militares y policiacos vistosos; el empleo de las fuerzas armadas en tareas policiacas, lo que ha llevado a una mayor militarización de la seguridad pública; la transición del enfoque de la seguridad pública hacia al de seguridad nacional y la consiguiente voluntad de modificar el marco legal al respecto; la voluntad de reforma a la legislación y al sistema penal.

Según Mariclaire Acosta, quien realiza un estudio basado en un cuidadoso análisis de datos estadísticos y hemerográficos, México es el escenario de tres guerras: las que libran los cárteles al interior y entre ellos (una entre grandes cárteles y otra entre bandas delictivas de narcomenudeo en localidades), y la tercera es la que despliega el gobierno federal. Para la autora, "es probable que alrededor y entre estas guerras, el papel de las autoridades locales (gobernadores, alcaldes, cuerpos de seguridad locales) tenga distintos niveles de involucramiento, lo cual está mediado por la corrupción y la penetración del narcotráfico en dichos gobiernos" (Acosta 2011: 58).

Es importante considerar que el aumento de la violencia visible ligada a las guerras entre, para y contra el narcotráfico, coexiste con las violencias más arraigadas e institucionalizadas como la impunidad, la corrupción y la discriminación sistémica; el uso excesivo de la fuerza por parte de la policía, la represión y la criminalización de la protesta social se profundizan en el nuevo contexto de "inseguridad" generalizada.

La "guerra contra el narcotráfico" inició oficialmente en 2005, cuando el Gobierno federal, en ese entonces encabezado por el panista Vicente Fox, anunció la puesta en marcha del Operativo México Seguro, con la participación de las secretarías de Gobernación, Seguridad Pública, Defensa Nacional, Marina, así como la Procuraduría General de la República. Sin embargo, el mayor impulso a los operativos a gran escala fue proporcionado por el gobierno sucesivo, iniciando en 2006 con los Operativos Conjuntos Michoacán, Tijuana, Guerrero, Sierra Madre, Chihuahua, etc. Estos operativos implican el envío de miles de efectivos militares para cumplir, junto con las fuerzas policiales federales, actividades de control de la delincuencia. En esta tarea, el gobierno mexicano recibe financiamiento, 
armamento y entrenamiento, junto con la injerencia en la política interna, desde Estados Unidos, a través del convenio establecido en 2008 y denominado Iniciativa Mérida.

En lugar de reformar profundamente los cuerpos de seguridad ineficaces, la estrategia de los gobiernos panistas consistió en preconizar la política de la "tolerancia cero" mediante el despliegue de numerosos contingentes de Ejército y Marina con funciones de seguridad pública, justificado por el hecho de que las policías locales están profundamente penetradas por los intereses de los cárteles.

El saldo de este nuevo rumbo en la política y la seguridad es espeluznante: entre 2007 y 2012 el Sistema Nacional de Seguridad Pública (SNSP) y la Procuraduría General de la República (PGR) han contabilizado 121.683 defunciones accidentales y violentas, ${ }^{36}$ a las que se suman al menos 29 mil 417 homicidios dolosos perpetrados entre diciembre de 2012 y el 30 de julio de $2014 .^{37}$

A las muertes violentas se suman las desapariciones forzadas, perpetradas tanto por grupos delincuenciales que por instancias de seguridad del Estado (policías y Ejército): una tragedia que llegó a su ápice con el secuestro y desaparición de 43 estudiantes de la Escuela Normal de Ayotzinapa, en Guerrero, el 26 de septiembre de 2014, por mano de policías municipales en colaboración con sicarios de un cártel local. El Registro Nacional de Datos de Personas Extraviadas (parte del SNSP) ha contabilizado, entre diciembre 2006 y octubre 2014, 22.322 desaparecidos. $^{38}$

Finalmente, en 2013 han sido contabilizados al menos 160.000 desplazados internos, 135.000 ligados a la violencia generada por el crimen organizado trasnacional ${ }^{39}$ y 25.000

\footnotetext{
${ }^{36} \mathrm{La}$ cifra, que corresponde a un resumen de los datos recabados por el Instituto Nacional de Geografía y Estadística (INEGI), correspondientes a los registros administrativos generados por cada entidad federativa, es proporcionada por el semanario Proceso el 30 de julio 2013. En < http://www.proceso.com.mx/?p=348816>, consultado el 4 de noviembre 2014.

${ }^{37}$ El Semanario Zeta, cotejando la información difundida por el INEGI (sobre la base de los datos del SNSP) con los datos proporcionados por las fiscalías y procuradurías estatales y con fuentes hemerográficas, afirma que la cifra fue mayor, es decir 36.718 homicidios dolosos. Véase <http://zetatijuana.com/noticias/reportajez/9373/losmuertos-de-epn-36-mil-718>, consultado el 1 de diciembre 2014.

${ }^{38}$ De los cuales 12.532 entre 2006 y 2012, y 9.790 sólo en el bienio 2012-2014.

${ }^{39}$ Según Fidel López, coordinador de la mesa de desplazamiento interno del Instituto Mora, "la población más vulnerable es víctima de esta situación y se encuentra entre dos fuegos (el del crimen organizado y el de las fuerzas federales), por lo que se ve obligada a huir de sus territorios y dejar atrás su poco o mucho patrimonio, renunciando a sus raíces para salvaguardar su seguridad.. Ante la incapacidad que ha demostrado el gobierno federal para atender el problema, paradójicamente se expone a los desplazados a ser cooptados por el crimen organizado", en Emir Olivares Alonso, "La guerra antinarco agravó el problema del desplazamiento en diversas comunidades", La Jornada, 19 de septiembre 2012.
} 
chiapanecos en "desplazamiento prolongado" como secuela de la guerra en contra del EZLN en los años noventa del siglo pasado. ${ }^{40}$

Esta realidad ha sido denunciada con valentía por decenas de organizaciones de la sociedad civil, así como por los familiares de las víctimas, aglutinados en el Movimiento Por la Paz con Justicia y Dignidad, que recorrió el entero país en el 2011 y el 2012. No obstante la necesidad urgente de cambiar el rumbo político en la estrategia de seguridad, los representantes institucionales mantuvieron una posición cerrada e inamovible frente a las demandas del Movimiento.

En el otoño de 2014, la desaparición forzada de los 43 estudiantes en la ciudad de Iguala originó un movimiento espontaneo a nivel nacional, inédito por su magnitud y por la radicalidad de sus demandas y de sus formas de protesta, que generó una grave crisis política en el país. La exigencia de presentación con vida se aunó a la denuncia de la responsabilidad directa del Estado en lo que ha sido definido un crimen de lesa humanidad, evidenciando a nivel internacional la gravedad de la crisis humanitaria que México está atravesando.

Recientemente se produjo una gran cantidad de documentos, análisis y denuncias relacionadas a esta problemática. Los puntos clave de la discusión coinciden en la mayor parte de estos trabajos, donde se evidencia que las políticas de mano dura son acompañadas por la introducción de nuevos conceptos en el debate político y legislativo, que se reflejan también en la voluntad de reformas legales. Así, la presencia de la delincuencia organizada es definida, por el gobierno federal, como un problema de seguridad nacional, lo que justifica el uso de las Fuerzas Armadas en su combate (lo que no sería permitido por el marco constitucional, que hace una distinción entre la seguridad nacional y la seguridad pública, sancionando asimismo la supremacía del poder civil sobre el poder militar). La iniciativa de Ley de Seguridad Nacional, impulsada fuertemente por el poder Ejecutivo durante el mandato de Calderón, con la fórmula de seguridad interior crea una peligrosa zona gris entre los dos conceptos anteriores, y el mecanismo de alerta de afectación a la seguridad interior correspondería de hecho a un estado de excepción irregular (Cantú 2011).

El uso de las Fuerzas Armadas en tareas de seguridad pública y la consiguiente militarización del espacio público y de la vida cotidiana, tanto en contexto rurales como

\footnotetext{
${ }^{40}$ La cifra es proporcionada por el Internal Displacement Monitoring Centre (IDMC). La misma cifra había sido documentada en 2011 por el Alto Comisionado de las Naciones Unidas para los Refugiados (ACNUR).
} 
urbanos, ha comportado un aumento exponencial de las violaciones a los derechos humanos entre la población. Las FFAA son entrenadas en un modelo de guerra que postula la aniquilación del enemigo, pero su acción en contextos de paz conlleva el riesgo de que todos los civiles sean considerados como posibles enemigos, sospechosos; y que los métodos de guerra, vigentes en ese contexto donde se considera legítima la suspensión de las garantías, se trasladen a los operativos cotidianos en barrios y comunidades. Ejemplo de esto es la masacre de 22 jóvenes, hombres y mujeres, perpetrada por soldados en el municipio de Tlatlaya, Estado de México, el 30 de junio de 2014. El hecho, inicialmente enmascarado como un enfrentamiento en el cual los presuntos delincuentes perdieron la vida, se reveló una ejecución extrajudicial masiva en la cual los elementos del Ejército actuaron en contra de los "enemigos" bajo un esquema bélico, en lugar de arrestarlos y someterlos a un proceso que fincara o deslindara sus responsabilidades y su calidad de delincuentes.

En un informe difundido a finales del sexenio de Calderón, la organización defensora de los derechos humanos Amnesty International ha documentado un aumento de las violaciones graves de derechos: confesiones obtenidas bajo coacción, incluidas ejecuciones extrajudiciales desapariciones forzadas, detenciones arbitrarias e ilegales, con violencia contra las mujeres y los migrantes, uso excesivo de la fuerza y tortura, cometidas por funcionarios públicos federales, estatales y municipales.

El despliegue de 50.000 efectivos del Ejército y la Marina para desempeñar funciones policiales ha contribuido a este aumento de los informes de tortura y otros malos tratos a manos de militares. Amnistía Internacional no tiene conocimiento de que en alguno de los casos que ha documentado se haya dictado sentencia condenatoria por un delito de tortura. ${ }^{41}$

Según los datos difundidos por la Comisión Nacional de Derechos Humanos (CNDH) sobre las denuncias de violaciones graves de derechos humanos, como tortura y otros malos tratos, en las que están implicados funcionarios públicos federales, éstas son aumentadas del $500 \%{ }^{42}$ Asimismo, las quejas presentadas ante la CNDH donde la Secretaría de la Defensa Nacional (SEDENA) es señalada como autoridad responsable, en 2011 aumentaron del 893\% con

\footnotetext{
41 "Culpables conocidos, víctimas ignoradas. Tortura y maltrato en México", Amnesty International, octubre 2012, <http://www.amnesty.org/en/library/asset/AMR41/063/2012/en/fdd33aa6-4226-407f-bf8ea8d7ff8bf6e6/amr410632012es.pdf>, pág. 3, consultado el 30 de octubre 2012.

${ }^{42}$ Pasando de 392 en 2007, a 1669 en 2011.
} 
respecto al 2006. ${ }^{43}$ En el periodo 2006-2013, la Comisión Nacional de Derechos Humanos $(\mathrm{CNDH})$ recibió 8.150 denuncias de abusos cometidos por miembros del Ejército. Por su parte, el número total de quejas registradas por la Comisión Interamericana de Derechos Humanos contra el Ejército desde el comienzo de la "guerra a las drogas" bajo la administración de Calderón es de 5.055 hasta mediados del 2011; sólo se han emitido 78 recomendaciones. Debido al alto nivel de impunidad, que representa uno de los principales problemas de la justicia en México, es mínimo el número de las denuncias que han proliferado en acciones penales, también porque el fuero militar ha protegido a los integrantes de las Fuerzas Armadas impidiendo su presentación frente a las autoridades civiles. Carlsen denuncia que:

El Ministerio de Defensa ha intentado minimizar la gravedad de esta situación, declarando que debido a su ofensiva contra el crimen organizado, "hay quejas que son presentadas por miembros del crimen organizado para difamar a este instituto militar y de ese modo limitar sus operaciones". [...] Hay todas las razones para ver con alarma el número de declaraciones del gobierno que asocian las denuncias de violaciones a los derechos humanos con vínculos con el narcotráfico, ya que apuntan a una actitud de ensuciar o criminalizar a los defensores de derechos humanos, lo que los coloca en una posición de mayor riesgo. ${ }^{44}$

En este contexto el sistema de justicia penal ha permanecido altamente ineficaz y corrupto, y albergando un altísimo nivel de impunidad para los crímenes cometidos ahora y los de las décadas pasadas. Las reformas constitucionales en materia de justicia penal y al Código de Procedimientos Penales, impulsadas entre 2008 y 2011, en lugar de resolver estos problemas, abren más espacio para la actuación arbitraria de las autoridades y la violación de los derechos de los detenidos.

\section{La "guerra" en la sociedad: miedo, criminalización de la protesta social, paramilitarismo}

\footnotetext{
${ }^{43}$ En 2006 recibió 182 quejas mientras que en 2011 la cifra ascendió a 1,626. Tan solo el primer semestre de 2012 la CNDH ha registrado 1,164 quejas en contra de la SEDENA. Informe conjunto que presentan la Red Nacional de Organismos Civiles de Derechos Humanos "Todos los Derechos para Todas y Todos" (RedTdT) y la Organización Mundial Contra la Tortura (OMCT) en vista de la consideración del $5^{\circ}$ y $6^{\circ}$ informe consolidado de México ante el Comité contra la Tortura de las Naciones Unidas, $49^{\circ}$ periodo de sesiones 29 de octubre al 23 de noviembre de 2012, <http://redtdt.org.mx/media/descargables/Informe_CAT_Mexico_RedTdT_OMCT.pdf>, consultado el 30 octubre 2012.

${ }^{44}$ Carlsen, Laura "Falso Dilema de México: Derechos Humanos o Seguridad", Programa de Las Américas, 1 de junio 2012, <http://www.cipamericas.org/es/archives/6897>, consultado el 4 de junio 2012.
} 
Según encuestas realizadas en los últimos años (Encuesta Nacional sobre la Percepción de Inseguridad Ciudadana en México) el miedo entre la población va aumentando. ${ }^{45}$ Estos datos muestran dos aspectos de la cuestión: en primer lugar, la amplia publicidad en los medios masivos de comunicación que reciben estas encuestas $-\mathrm{y}$ todas las noticias de sangre ligadas a la guerra entre cárteles y contra ellos- contribuye a aumentar el clima de miedo realmente existente, y esto genera un ambiente propicio para que el gobierno pueda implementar medidas represivas, justificándolas como necesarias: un proceso similar al estudiado por Taussig (2004) en el citado trabajo sobre la cultura del terror. Al respecto, afirma el analista político Carlos Fazio:

Instalado en el discurso del miedo - que como arma mediática legitimadora del accionar oficial utiliza un lenguaje maniqueo que enfrenta a los malos criminales con las fuerzas del Estado bueno-, Calderón ha permitido y fomentado la burocratización de la tortura, la desaparición forzada y los homicidios dolosos extrajudiciales [...] La realidad ha sido encubierta, en parte, mediante campañas de intoxicación (des)informativa. [...] Como elementos de control social, la manufacturación de enemigos fantasmales y la exhibición de la violencia caótica en los medios buscan evadir y ocultar la responsabilidad estatal en flagrantes violaciones a los derechos humanos. ${ }^{46}$

En segundo lugar, sin embargo, la violencia se ha hecho tan visible -son a la orden del día los cuerpos destazados y encontrados por montones, o las solas cabezas u otras partes del cuerpo esparcidas en lugares públicos de las grandes ciudades como Acapulco, Guadalajara o Veracruz-, tan penetrante en los varios ámbitos de la vida cotidiana, que ésta se ha visto profundamente alterada: los hábitos han sido trastocados, se han impuesto restricciones a la circulación y modificaciones relevantes a los estilos de vida. "Este incremento del clima de violencia guarda una estrecha relación con violencias simbólicas y reales como el aislamiento de zonas residenciales, la contratación de guardias personales y el aumento de la violencia

\footnotetext{
${ }^{45}$ Decima Encuesta Nacional sobre la Percepción de Inseguridad Ciudadana en México, marzo 2012, México Unido Contra la Delincuencia A.C.- Encuestas Mitofsky <http://consulta.mx/web/images/mexicoopinapdf/Decima\%20Encuesta\%20Nacional\%20sobre\%20Percepcion\%2 0de\%20Inseguridad\%20Ciudadana.pdf $>$, consultado el 30 octubre 2012.

${ }^{46}$ Fazio, Carlos “Sobre guerra y verdad", en La Jornada, 9 de enero 2012.
} 
contra las mujeres, quienes están actualmente en situaciones de mayor riesgo y vulnerabilidad" 47 .

Por otro lado, la misma Encuesta sobre la Percepción de Inseguridad reporta también la convicción generalizada que "los operativos establecidos por el gobierno federal para combatir al crimen organizado han sido un fracaso". De acuerdo a los datos recogidos por la Comisión Interamericana de Derechos Humanos en 2011, entre 2008 y 2010 la violencia criminal ha aumentado del $50 \%$ cada año. ${ }^{48}$ En esto, concuerdan los principales organismos de defensa de los derechos humanos del país, para quienes las políticas de mano dura no han logrado promover descensos sustanciales en los índices de delincuencia, que han alcanzado niveles insospechados desde el inicio de la Estrategia Nacional de Inseguridad, ${ }^{49}$ pero sí han aumentado los riesgos para los civiles de padecer violaciones a sus derechos personales, civiles y políticos; asimismo, las medidas de mano dura "se prestan para ser abusadas por las autoridades que recurren al sistema de justicia penal como una herramienta de represión hacia los que protestan contra las acciones gubernamentales" (ProDH 2008:3).

Mientras se descalifican las organizaciones sociales y sus líderes acusándolos de vínculos con el narcotráfico, se observa una tendencia creciente a asociar o asimilar muchas formas de protesta social con la delincuencia organizada, y en consecuencia a aplicar a los movimientos civiles las mismas disposiciones judiciales (la reciente reforma del Código Penal prevé unas medidas extremadamente represivas y violatorias de los derechos humanos precisamente para los acusados de delincuencia organizada). El problema de fondo reside en que la estrategia represiva frente a la delincuencia reduce el problema a una visión que privilegia el mantenimiento del orden social pese a que éste ha propiciado durante muchos años desigualdad, injusticia y exclusión.

En estas circunstancias, cualquiera puede ser acusado de colusión con el narco, sin que haya la necesidad de probar con detalle tal acusación; así, organizaciones y líderes sociales son desprestigiados y reprimidos con una estrategia análoga a la que ha usado Estados Unidos

\footnotetext{
47 "10 mitos para justificar una estrategia equivocada frente a la violencia. Una crítica sustentada desde las organizaciones de la sociedad civil”, 2011, pág. 3, $<$ http://www.centroprodh.org.mx/index.php?option=com_docman\&task=doc_details\&gid=108\&Itemid=28\&lang $=$ es>, consultado el 10 junio 2012.

${ }^{48}$ Camacho Servín, Fernando "La desaparición forzada es el delito más preocupante en México: CIDH", en La Jornada, 1 de octubre 2011.

${ }^{49}$ Idem.
} 
después del 11/09, al promulgar leyes "antiterrorismo" que en efecto limitan las libertades ciudadanas. Un ejemplo de esto, ubicado en una región de recién incorporación a la Policía Comunitaria, ha sido el asesinato de dos dirigentes de la Organización para el Futuro del Pueblo Mixteco, del municipio guerrerense de Ayutla de los Libres. En febrero de 2009, los dos indígenas defensores de derechos humanos, fueron secuestrados mientras presenciaban a un acto oficial organizado por el gobierno municipal, y sus cuerpos encontrados en un basurero diez días después. Se trata de un hecho de gravedad por el nivel de impunidad que pone de manifiesto, en una zona que desde hace mucho tiempo sufre la represión del Estado en su manifestación más despiadada. ${ }^{50}$ Lo que sobresale fue que las instituciones, en un primer momento, deslindaron cualquier responsabilidad afirmando que los dos indígenas fueron "levantados", insinuando su inclusión en actividades delictivas. Como documenta un estudio sobre el tema:

La acción represiva del Estado tiende a transformar la cuestión social en cuestión penal [...] La ubicacióndel1@s excluid@s como amenaza, y de sus acciones como delitos, interfiere la simbología que consideraba el luchador o la luchadora social como militantes solidarios, justicieros. Cuando est@s militantes populares eran reprimidos o encarcelados, nadie dudaba en solidarizarse. Sin embargo hoy quienes luchan son presentados como delincuentes, y su prisión es señalada como un castigo ejemplificador (Longo y Korol 2008: 47- 56).

Paralelamente al incremento de la militarización y de las estrategias de lucha frontal contra la delincuencia organizada, se han registrado en años recientes acciones igualmente agresivas en contra de organizaciones y movimientos sociales que reivindican el respeto a los derechos humanos básicos (salud, vivienda, educación, territorio, etc.), sistemáticamente desatendidos por los gobiernos en turno. ${ }^{51}$ Por otra parte la creación de un clima de miedo e inestabilidad

\footnotetext{
${ }^{50}$ Los habitantes de las comunidades ubicadas en el municipio de Ayutla de los Libres reconocen al Ejercito culpable de la masacre de civiles en la comunidad de el Charco, el 7 de julio 1998 y de la violación de dos mujeres en 2002, así como el caso de los 14 hombres de El Camalote que fueron sometidos a esterilización forzada en 1998 y 2001.

${ }^{51}$ Según la información recogida por el Observatorio de la Conflictividad Social en México, la criminalización de la protesta social se expresa en tres fases: "1. Existe una tendencia a la invisibilización de los conflictos sociales por parte del Estado, así como al no reconocimiento de la legitimidad de los actores. 2. La invisibilización provoca un escalamiento social de la conflictividad en el que se generan formas de confrontación más radicales. 3. A partir del cierre de canales de diálogo y el escalamiento en la confrontación, se genera una tendencia de respuesta por parte del Estado en torno a la represión y judicialización que tiene como objetivo el desgaste de los
} 
entre la población también funciona como arma política, con el fin de desmovilizar a los movimientos de protesta incipientes.

Pero no solamente se criminaliza quien protesta, sino que asistimos a una tendencia a la criminalización de sectores enteros de la sociedad:

1. Las y los migrantes son puestos bajo sospecha, detenidos arbitrariamente, maltratados y extorsionados, por las bandas y por los representantes de las instituciones. Son vistos como potenciales delincuentes porque se internan al país ilegalmente, y sus movimientos en muchos casos son controlados por las mismas redes de la delincuencia.

2. Las mujeres y hombres jóvenes son discriminados y tratados como posibles o futuros delincuentes. 52

3. Los pueblos y las comunidades indígenas, cuyos territorios son militarizados desde hace varias décadas, son amenazados y hostigados porque defienden su tierra y los recursos que allí se encuentran.

He mencionado que la violencia estructural es congénita al sistema neoliberal, que en México se muestra en una creciente concentración de la riqueza y del poder, y en el correspondiente aumento de la desigualdad, la pobreza y la exclusión de gran parte de la población. Según Rodríguez Rejas:

La concentración de dicha estructura de poder opera sobre la eliminación de los mecanismos de mediación mientras recurre a la represión como garantía del orden ante el agotamiento de los controles ideológicos y la legitimidad. Se apela entonces a las instituciones encargadas del uso legal de la violencia para restablecer el Estado de Derecho que no es otro que el derecho de las minorías. De esta manera, la violencia de Estado -e incluso el terrorismo de Estado- es parte de la gobernabilidad actual. Desde esta perspectiva, la militarización es pieza esencial de la reproducción del patrón de acumulación neoliberal y su estructura de poder (2010: 1).

movimientos". Observatorio de la Conflictividad Social, Reporte sobre la Criminalización de la Protesta Social, SERAPAZ, México, 2008.

52 "En un gran número de los asesinatos de jóvenes en el contexto de la guerra contra el narcotráfico, autoridades locales, estatales y sobre todo las federales se han apresurado a descalificar a las víctimas, señalando que se trata de jóvenes que participan en bandas de delincuentes o que están vinculados con el narcotráfico. Con ello buscan justificar los errores que comete el Ejército o los cuerpos de seguridad pública” (Nerio Monroy 2011:19). 
Es evidente que, en este contexto, la guerra no es solamente contra el narco, sino que incluye todo lo que implique un riesgo para esta gobernabilidad tan endeble y corrupta. El estado de excepción vigente de facto permite el control violento y la represión de las organizaciones sociales y políticas; y al mismo tiempo facilita la emergencia y la reactivación de grupos paramilitares, guardias blancas y grupos de "seguridad" del narcotráfico. En México, como en otros países de América Latina, los grupos paramilitares han sido utilizados históricamente con funciones contrainsurgentes, en contra de las guerrillas o de los movimientos civiles de protesta. Según López y Rivas (1999:2):

Los grupos paramilitares cuentan con organización, equipo y entrenamiento militar, a los que el Estado delega el cumplimiento de misiones que las fuerzas armadas regulares no pueden llevar a cabo abiertamente, sin que eso implique que reconozcan su existencia como parte del monopolio de la violencia estatal. Lo paramilitar consiste en el ejercicio ilegal e impune de la violencia del Estado y en la ocultación del origen de esa violencia.

En México los grupos armados irregulares jugaron un papel importante en la llamada Guerra sucia, durante los años setenta del siglo pasado, en concomitancia con las acciones de contrainsurgencia realizadas por el Ejército mexicano, que ocupó enteras zonas del país. En fechas más recientes, el paramilitarismo se desarrolló en el estado de Chiapas, a raíz del el Plan de Campaña Chiapas 94, lanzado por el Ejército en contra del Ejército Zapatista de Liberación Nacional y sus bases de apoyo. En el estado de Oaxaca, los grupos paramilitares, ligados a las élites políticas locales, siguen actuando en contra de los movimientos que plantean el cambio social: es el caso de los grupos de choque impulsados por el exgobernador de Oaxaca Ulises Ruiz que asesinaron a 20 militantes de la Asamblea Popular de los Pueblos de Oaxaca (APPO), o de los grupos armados ligados al MULT-Partido de Unidad Popular y a UBISORT, facciones políticas opositoras al proyecto autonómico de los indígenas triqui, el Municipio Autónomo de San Juan Copala, que causaron decenas de muertos desde 2008 a la fecha. En el estado de Guerrero, se observa una continuidad entre las guardias blancas al servicio de los terratenientes, la estrategia de militarización social de los años setenta y la persistencia de grupos paramilitares, ligados a élites políticas corruptas y a la delincuencia organizada, presentes en regiones donde son activas organizaciones guerrilleras y movimientos sociales, como en las regiones Costa Grande y el municipio de Ayutla. 
Actualmente, algunos analistas denuncian que "a los brotes de paramilitarismo regional ya existentes bajo el mando de cacicazgos o políticas contrainsurgentes con objetivos locales y precisos" se están sumando grupos paramilitares organizados a nivel nacional, "incluso contra el poder oficial que le dio origen". 53 Maldonado analiza, para el caso de Michoacán pero también para el de Colombia o Perú, que el fenómeno del narcotráfico encuentra parte de sus orígenes en las defensas armadas de hacendados y finqueros, que luego se transformaron en organizaciones clandestinas, ejerciendo la coerción y protección a cambio del pago de sus servicios. Estas asociaciones, "típicas del bandolerismo o de los brokers, siguieron existiendo en medio de un proceso de expansión del Estado nacional porque el gobierno necesitó siempre de hombres fuertes (caciques) en las regiones para mantener el control político y la estabilidad". Estas asociaciones de "seguridad privada" permitieron "una cierta expansión del narcotráfico moderno cuando determinados individuos necesitaron de sus servicios para proteger sembradíos y comercialización” (Maldonado 2010: 359-340). En fechas recientes, se ha reavivado el debate sobre la presencia de grupos paramilitares en el país. ${ }^{54}$ Según Eduardo Buscaglia se contarían en México 167 grupos paramilitares, cuya proliferación se debe a "una fragmentación cada vez mayor de la estructura del Estado. Existen porciones del Estado que han sido compradas al por mayor por grupos empresariales oligopólicos y monopólicos; otros pedazos del Estado están en manos de grupos ilegales. [...] Cada trozo le pertenece a un cártel" ${ }^{, 55}$ y cuando estos pedazos del Estado inician a limpiar los territorios de los grupos criminales adversarios, se produce una orgia de violencia donde se enfrentan grupos paramilitares del Estado, y grupos paramilitares de empresarios que pagan mercenarios para su seguridad. ${ }^{56}$ Buscaglia define entonces como paramilitares tanto a los grupos de seguridad privada, como aquellos "pagados por los propios gobernadores, para limpiar territorios y salvar los mercados de la droga". 57 A este complejo mosaico se añaden también "policías municipales o estatales que realizan el trabajo sucio a los grupos criminales, limpiando las

\footnotetext{
${ }^{53}$ Rascón, Marco, "Paramilitarismo”, La Jornada, 4 de mayo 2010.

${ }^{54}$ A raíz del hallazgo, en septiembre 2011, de 35 cadáveres en la ciudad de Veracruz, asesinatos reivindicados por un grupo que se autodenominó "Matazetas", lo que fue interpretado por las autoridades como un ajuste de cuentas entre carteles rivales, identificando a los muertos como ligado al grupo de sicarios Los Zetas.

${ }^{55}$ Ricardo Ravelo, "La multiplicación de los 'paras"”, Proceso, 1 de noviembre 2011.

56 Edgardo Buscaglia, entrevista en Noticia MVS, 21 de septiembre 2011, <http://ww2.noticiasmvs.com/entrevistas/primera-emision-con-carmen-aristegui/edgardo-buscaglia-especialistaen-seguridad-y-crimen-organizado-324.html >, consultado el 30 de octubre 2012.

${ }^{57}$ Ricardo Ravelo, "La multiplicación de los 'paras"”, Proceso, 1 de noviembre 2011.
} 
regiones de grupos adversarios. Eso sucede en todo el país, son extensiones del Estado, policías que utilizan activos, vehículos o dependencias del Estado para llevar a cabo esas tareas". ${ }^{58}$ Esta realidad salió a flote en la masacre de Iguala, Guerrero, donde el 26 de septiembre 2014 policías municipales, en coordinación con un grupo de sicarios de un cártel local, asesinaron a seis personas y desaparecieron a 43 jóvenes estudiantes de la Escuela Normal Rural de Ayotzinapa.

Por otro lado está el ingente número de militares y policías que desertan para involucrarse en los grupos criminales, cuyo ejemplo más notorio, y ampliamente documentado, ha sido el grupo de Los Zetas, creado por el cártel del Golfo a partir del "alistamiento" de 40 miembros de los GAFE (Grupo Aeromóvil de Fuerzas Especiales del Ejército, un grupo de élite ya de por sí encargado, dentro del Ejercito, de acciones poco transparentes). Al respecto Lorenzo Meyer, en un breve texto, analiza precisamente la cercanía entre estos grupos “de choque”, liminales en la estructura del Ejército, los grupos paramilitares que se desprenden de la misma matriz (en específico el grupo de Los Kaibiles guatemaltecos), y los "escuadrones de la muerte" del narcotráfico. ${ }^{59}$

En contraste con la visión de Buscaglia, el periodista José Gil afirma que los únicos paramilitares que se pueden definir tales, de acuerdo a la definición de López y Rivas citada arriba, son aquellos activos en Chiapas, mientras que los demás grupos serían más bien "guardias blancas y los escuadrones de la muerte que, apoyados por caciques y gobiernos, han sido usados para eliminar a dirigentes sociales", y en otros casos "la nueva versión de 'escuadrones de la muerte', esto es, grupos subvencionados o apoyados por algún cártel y sus cómplices gubernamentales utilizados para eliminar a otro grupo del crimen organizado y quedarse con la plaza". A pesar de las diferentes interpretaciones, queda claro el involucramiento directo (en forma de entrenamiento por parte del Ejército) o indirecto (el apoyo de grupos en el poder político) de las estructuras institucionales en el impulso de grupos armados que operan de manera ilegal, con diferentes funciones.

La aparición, en años recientes, de grupos paramilitares en muchas más partes del país muestra la conexión que existe entre la "guerra al narcotráfico" y las políticas represivas hacia

\footnotetext{
58 Ignacio de los Reyes, "México, bajo el fantasma de los paramilitares", BBC Mundo, <http://www.bbc.co.uk/mundo/noticias/2011/10/111006_mexico_paramilitares_matazetas_irm.shtm>, consultado el 5 de noviembre 2012

${ }^{59}$ Meyer, Lorenzo, "México: la Guerra Fría y la del narco se enlazan”, Reforma, 29 septiembre 2011
} 
la protesta social. Según Carlos Fazio, junto a la militarización del territorio por la llamada estrategia contra el crimen organizado hay un proceso de paramilitarización en el que reaparecen las torturas, ejecuciones, desapariciones y otras prácticas de la guerra sucia, que son el tipo de violaciones a los derechos humanos con que se tipificó el terrorismo de Estado cuando estaban implantadas las dictaduras en América del sur. ${ }^{60}$ El límite entre la violencia "legal" y la ilegal, en esta situación de "estado de excepción" no declarado pero vigente, se hace muy sutil; así, mientras las fuerzas armadas "legales" perpetúan el utilizo de métodos violentos e ilegales, se impulsa también la actuación de grupos armados "ilegales", que protagonizan un uso de la violencia aún más feroz: los paramilitares, según la lectura de Fazio, serían un desdoblamiento clandestino de la función, legal, de las fuerzas armadas y policiacas.

En contextos de conflicto social, los paramilitares son utilizados por el Ejército para ponerse en una "tercera posición" y permitir su estancia en el territorio: los militares serían "la solución al conflicto" entre dos partes (paramilitares y organizaciones civiles). Maldonado explicita la relación entre el paramilitarismo y la militarización en presencia de la delincuencia, afirmando que:

la ilegalidad produce violencia porque supone territorios bajo disputa. Por tanto, la militarización puede concebirse como una medida contra la exteriorización estatal de lo ilegal en términos de seguridad nacional, lo cual significa que los Estados o sus elites no son ajenos al control de espacios ilegales para sus propios intereses (Maldonado 2010: 349).

Abordar este tema, y el debate que se ha generado en México recientemente, se hace necesario para el argumento de esta tesis, que se enfoca hacia la legitimidad de experiencias de seguridad y justicia que nacen, de forma autónoma y a veces en conflicto con el Estado, por iniciativa de los pueblos indígenas organizados, y como respuesta a situaciones de violencia en sus varios aspectos.

En la situación actual, no han sido aislados los casos donde los gobiernos locales han instado grupos o partes de la sociedad a organizarse para su autodefensa, lo que ha llevado a la creación de grupos de seguridad privada a sueldo, o bien grupos de ciudadanos armados con el beneplácito de las autoridades, como ha sucedido en 2009 en la comunidad Le Barón, en Chihuahua, y de forma masiva a partir de inicio del 2013 en los estados de Guerrero y

\footnotetext{
${ }^{60}$ David Carrizales, "Resurgen prácticas de la guerra sucia”, La Jornada, 14 de mayo 2011.
} 
Michoacán. Sin embargo, en las regiones donde es más alta la pobreza, la violencia estructural y con ello la conflictividad social, los experimentos de autodefensa son regularmente reprimidos por las autoridades, que a veces intervienen militarizando el territorio, como es el caso de los Comités de Seguridad Ciudadana creados en 2012 en los municipios guerrerenses de Huamuxtitlán y Olinalá. Frecuentemente el argumento del paramilitarismo viene usado, desde los ambientes más reaccionarios, para deslegitimar estos procesos de organización popular que surgen de necesidades innegables. Sin embargo, el análisis anterior deja clara la diferencia entre los procesos basados sobre la organización comunitaria indígena, y los grupos paramilitares o de seguridad privada -mercenarios-, o aún más de los grupos que, enarbolando legítimas reivindicaciones ciudadanas a la paz y la seguridad, son armados y dirigidos por los grupos de poder local -autodefensas-.

En el curso del 2013, la emergencia, a lo largo y ancho del país, de grupos de civiles armados que declararon levantarse en contra de la delincuencia organizada y en defensa de las comunidades -grupos de autodefensa, en su mayoría no respaldados por la institucionalidad comunitaria- complicó el debate y favoreció la difusión de muchos lugares comunes y análisis apresurados. Los actores institucionales no titubearon en igualar la Coordinadora Regional de Autoridades Comunitarias-Policía Comunitaria (CRAC-PC), los paramilitares y las autodefensas, además acusadas frecuentemente de ser emanaciones de los mismos cárteles del narcotráfico. Surgidos en casi todo el territorio nacional por una suerte de efecto dominó, ${ }^{61}$ dichos grupos de autodefensa responden a dinámicas diversas en los diferentes contextos, aunque por lo general comparten la situación dramática de haber alcanzado los límites de su seguridad como comunidades, frente a la corrupción e ineptitud del Estado hacia la delincuencia que aniquila a las comunidades rurales, ya asoladas por la pobreza y el saqueo de los recursos naturales. ${ }^{62} \mathrm{El}$ análisis al respecto debe ser muy cuidadoso y rebasa los límites de este trabajo. ${ }^{63}$ Para el particular caso de Guerrero, el surgimiento de muchos grupos de

\footnotetext{
${ }^{61}$ Véase el mapeo elaborado por La Jornada del Campo en el número monográfico sobre el tema, núm. 68, mayo 2013, en <http://www.jornada.unam.mx/2013/05/18/cam-grupos.html>, consultado el 20 mayo 2013.

${ }^{62}$ Como un ejemplo de la denuncia de esta realidad, véase "Purépechas: pobreza e inseguridad obligan a crear grupos de autodefensa", La Jornada, Domingo 13 de octubre de 2013, <http://www.jornada.unam.mx/2013/10/13/sociedad/030n2soc>, consultado el 13 de octubre 2013.

${ }^{63}$ Entre la copiosa producción periodística y de opinión sobre el tema, me limito a citar algunos textos de reflexión cuyo enfoque comparto, publicados en el periódico La Jornada: de López y Rivas, G., "Paramilitarismo, grupos armados y autodefensas comunitarias" (29/03/2013); Dussel, E., “¿Son legítimas la policía y la justicia comunitarias según usos y costumbres?” (15/01/2013), “¿Son legítimas las policías
} 
autodefensa en las regiones de la Costa Chica, ligados a la Unión de Pueblos y Organizaciones de Guerrero (UPOEG, con una trayectoria de cercanía al ejecutivo local) ha provocado, junto a otros factores, un deterioro de las relaciones entre la CRAC-PC y el gobierno.

Estas reflexiones remiten nuevamente al tema, ya abordado, de la violencia de Estado y de las múltiples maneras que éste utiliza para ejercerla. El Estado mexicano, actualmente, estaría actuando en términos "delincuenciales", utilizando el monopolio de la violencia "legítima" en contra de los derechos de las personas, lo que vuelve dicha violencia ilegítima, utilizando también todas las formas de violencia ilegal a su alcance. Así, para López y Rivas (2011):

Una nueva modalidad de Guerra sucia se impone actualmente al pueblo mexicano, en la modalidad de la llamada "guerra contra el narcotráfico". Utilizo el término de "guerra sucia" para definir un tipo de crimen de Estado que -al margen de la Constitución y las leyes- tiene como propósito el aniquilamiento de los considerados "enemigos internos" por medio de su localización, seguimiento, captura, interrogatorio a través de la tortura, mantenimiento en cárceles clandestinas, desapariciones forzadas y ejecuciones extrajudiciales, todo ello llevado a cabo por integrantes de las fuerzas armadas, agentes de policía y de inteligencia, grupos paramilitares (que actúan bajo las órdenes -usualmente- de la Sección Segunda del Ejército, Inteligencia Militar), o pandillas del crimen organizado que constituye la cara ilegal, clandestina, supletoria y complementaria de la acumulación capitalista en nuestro país.

\section{Violencia, narcotráfico y organización comunitaria en las regiones indígenas}

Si asumimos, con López y Rivas, que el narcotráfico no es más que otra faceta de las corporaciones del capitalismo neoliberal, tendencia que actualmente mueve el accionar político de los Estados, su presencia en las regiones indígenas aparece claramente como una fuerza más que apunta hacia el control de los territorios y el despojo de los recursos que en ellos se encuentran. Las formas de organización propia de los pueblos indígenas, y la estrenua defensa de sus territorios culturales, representan en esta lectura un obstáculo para la 


\section{AUTONOMIAINDÍGENA, VIOLENCIAY JUSTICIA}

apropiación y de la tierra y de la fuerza de trabajo que la población campesina representa, elementos codiciados tanto por las economías legales como por aquellas ilegales.

Las regiones indígenas, en México así como en otros países de América Latina, están siendo fuertemente trastocadas por estas nuevas facetas del "colonialismo interno". Los grupos de la delincuencia organizada buscan controlar los territorios indígenas, estratégicos para la producción de plantas ilegalizadas, o para controlar el paso de las mercancías y el tráfico de personas. Frecuentemente, se trata de territorios ricos en recursos naturales, y pobres de infraestructura comunicativa, lo que favorece el desarrollo de actividades ilícitas. La pobreza generalizada que priva en el mundo rural representa una ventaja para el crimen organizado: frente a la falta de oportunidades económicas, las comunidades campesinas son inducidas a cultivar amapola o mariguana en sus terrenos, a cobijar a los traficantes, mientras jóvenes y adultos, en alternativa a la migración, se alistan en las redes del narco como correos y vigilancia, o para transportar y distribuir la mercancía que se produce o transita por sus territorios. La violencia estructural, la pobreza y la marginación, hacen entonces a los habitantes de comunidades indígenas y campesinas más vulnerables a la penetración de la delincuencia organizada.

Las luchas entre grupos adversos para el control de los territorios crean un aumento de la violencia visible entre los pueblos indígenas y campesinos, que son obligados a escoger si someterse a los que se imponen con el poder de las armas, e integrarse a la economía ilegal, o desplazarse abandonando sus tierras. En el norte del país, han sido denunciados casos de comunidades indígenas que se organizaron para expulsar de su territorio a los grupos de delincuentes y sicarios; en varias ocasiones, la respuesta de éstos fue ocupar las comunidades, asesinar a pobladores, e incendiar todas las casas. ${ }^{64}$ A lo largo de la otra frontera, en la Selva

\footnotetext{
64 Jicamorachi, comunidad en la sierra tarahumara, fue ocupada y quemada, y 6 de sus habitantes fueron asesinados en mayo 2011. En diciembre 2010, habitantes de San Francisco de Ocotán, en El Mezquital, Durango, repelieron el ataque de un grupo de delincuentes. En el mismo municipio, en enero 2011, habitantes de la comunidad de Tierras Coloradas, expulsaron a un grupo de pistoleros que mataron a dos vecinos. Como respuesta, la comunidad fue incendiada y la población se vio obligada a abandonarla. El presidente del municipio de El Mezquital denuncia que "la gente ve que el Gobierno no puede con el grupo criminal, entonces se defiende como puede" y que "la gente no informa, porque hemos vivido una crisis de inseguridad, no sabemos con quién estamos hablando y por eso la gente tiene ese temor, no tiene el valor de decir qué está pasando en su propia comunidad". El Siglo de Durango, 14 de enero 2011, <http://www.elsiglodedurango.com.mx/noticia/298528.

revelan-otro-ataque-a-comunidad-indigena.html>. Una situación similar se denunció en la región de Barranca de Pueblo Nuevo, también en Durango: véase El Siglo de Durango, 14 de enero 2011, <http://www.elsiglodedurango.com.mx/noticia/298445.alarma-exodo-de-comunidades.html>, consultado el 12 de septiembre 2012.
} 
Lacandona en Chiapas y en Tabasco, también se conocen casos de comunidades enteras sitiadas y obligadas a alojar y respaldar a los traficantes de drogas y personas. Según López y Rivas:

Han sido denunciados grupos del narco operando en zonas indígenas con mayor frecuencia en Michoacán, Jalisco, Sonora, Guerrero, Durango, Chihuahua, Oaxaca, Chiapas, Veracruz, y en las cárceles de estos estados se registran centenares de presos indígenas acusados por delitos contra la salud [...] Se calcula que alrededor de 50 mil indígenas han sido víctimas de las redes del narco en al menos 60 comunidades del país.

Esta situación plantea muchas interrogantes y temas necesarios para futuras investigaciones. Una de estas preguntas vierte sobre el impacto que puede tener la creciente presencia de los grupos del narco en las regiones indígenas (en términos culturales, como impacto en los modos de vida, en la visión de la gente, en sus expectativas, y en su vida cotidiana). Sin duda, hay quién es abrumado por el miedo y quien se involucra en las actividades ilegales tomándolas como una oportunidad de sobresalir. Entre los efectos más visibles, está el aumento de la desigualdad entre los habitantes (ya es común ver sofisticadas camionetas del año adquiridas por indígenas en las regiones más penetradas por el narcotráfico) y el consecuente aumento del miedo y la desconfianza entre quienes viven en la misma comunidad. También se observa el aumento del consumo de drogas entre jóvenes indígenas, elemento que tiene un fuerte potencial desintegrador del tejido social.

Es evidente que el Estado y las élites económicas (locales, nacionales o trasnacionales) favorecidas por los gobiernos en turno aprovechan la situación de violencia y de impunidad generalizada. Por un lado, se acusan las organizaciones y los líderes indígenas incómodos de estar coludidos con el narcotráfico, con objetivos contrainsurgentes (un ejemplo de ello es el ya mencionado caso de Ayutla, en Guerrero, o las repetidas acusaciones -que siempre se revelaron infundadas- de que en los territorios controlados por el Ejército Zapatista de Liberación Nacional, en Chiapas, se cultiva mariguana). La militarización justificada con el pretexto de la lucha contra la delincuencia significa, en los hechos, el control de territorios extensos, que puede ser utilizado también para dar campo libre a la prepotente irrupción de 


\section{AUTONOMIAINDÍGENA, VIOLENCIAY JUSTICIA}

grandes proyectos de explotación de los recursos naturales, como la madera, el agua o los minerales.

Otra de las preguntas que surgen al respecto es qué herramientas pueden desarrollar los pueblos y las comunidades indígenas frente a estas amenazas, que ponen en riesgo no solo los derechos humanos y la vida misma de las personas, sino también las estructuras colectivas de organización y reproducción económica y cultural.

En la Montaña de Guerrero, región donde opera la Policía Comunitaria, se observa la reciente penetración de las redes del narcotráfico, problema que la organización comunitaria está enfrentando con muchas dificultades; a la vez, la región es amenazada por dos inminentes proyectos de explotación minera a gran escala, que también son objeto de rechazo entre la mayoría de la población. He podido observar como estos dos elementos ejercen presión en la organización comunitaria y miran a la desarticulación de las estructuras colectivas, lo que facilita su aceptación y penetración, favorecida también por la falta de oportunidades entre la población. En este caso, la fuerte organización comunitaria ha impedido la presencia del Ejército, que sin embargo presionó a las comunidades, cuando éstas enfrentaron autónomamente a una banda de narcotraficantes. El desenlace ha sido diferente en las comunidades de Olinalá y Huamuxtitlán, que en la segunda mitad del 2012 denunciaron la presencia de bandas de narcotraficantes y secuestradores y organizaron Consejos Ciudadanos armados para su autodefensa. Dichos Consejos fueron rápidamente desmovilizados por la intervención del Ejército que se hizo presente para controlar el territorio. No obstante, la ciudadanía ha expresado su desconfianza hacia las autoridades y ha formado Policías Comunitarias, sucesivamente integradas a la Coordinadora Regional de Autoridades Comunitarias. También en los municipios indígenas de Ostula y Cherán, en el estado de Michoacán, la presencia de grupos armados ligados al tráfico de droga y de madera ha estimulado la organización comunitaria y la creación de nuevas estructuras de gobierno y de autodefensa; sin embargo, también en este caso los pueblos han tenido que negociar con las Fuerzas Armadas que se instalaron en el territorio. ${ }^{65}$

Estos acontecimientos, que discutiré más adelante, abren la reflexión sobre el alcance que puede tener la organización de los pueblos (que es el paso que muchos de ellos están escogiendo, frente a la ineficacia de las instituciones para garantizar la seguridad) frente a los

\footnotetext{
${ }^{65}$ Marina en Ostula; bases de operaciones mixtas en Cherán.
} 
grupos de delincuencia organizada, cuya potencia de fuego y número parece a veces rebasar hasta las mismas Fuerzas Armadas. Así, la población se encuentra muchas veces "entre la espada y la pared", amenazada por un lado por la violencia delictiva y por otro lado por los abusos cometidos por los militares, cuya presencia muchas veces tiene precisamente el objetivo de controlar la emergencia popular. ${ }^{66}$ La organización colectiva, frecuentemente en términos autonómicos, representa una de las formas más eficaces para controlar la penetración de estos actores de la violencia en los territorios indígenas.

66 Las denuncias sobre este tema son numerosas. Citaré aquí solo algunas referencias: "Organizaciones campesinas denuncian militarización de la Huasteca. Bajo apariencia de combate al crimen encubren contrainsurgencia", 1 de marzo 2009, en <http://zapateando2.wordpress.com/2009/03/01/organizacionescampesinas-denuncian-militarizacion-de-la-huasteca/>; "Denuncian operativos militares contra comunidades indígenas y campesinas", enero 2011, Agencia Internacional de Prensa India AIPIN. 


\section{CAPÍTULO 2 \\ PUEBLOS INDÍGENAS, NACIÓN Y ESTADO \\ EN MÉXICO}

En el México actual, la condición de las comunidades y pueblos indígenas, y la reivindicación compartida por los diferentes sujetos indígenas organizados, expresa la necesidad de que el poder central actúe con políticas concretas de reconocimiento, al interior de un nuevo pacto social, de una nueva relación entre el Estado y la sociedad, en donde éstos sean reconocidos como sujetos de derecho, y puedan ejercer la autonomía, como articulación interna de la libre determinación. ${ }^{67}$

En este capítulo esbozaré, enfatizando algunos pasajes históricos y debates políticos que los caracterizaron, la trayectoria de la conflictiva relación entre los pueblos indígenas y el Estado mexicano. Mencionaré las políticas públicas aplicadas a la población indígena del país, relacionándolas con el debate en continua evolución sobre la necesidad del desarrollo, y con el crecimiento del movimiento indígena nacional. Considero importante exponer la evolución de las políticas del Estado hacia los indígenas, ya que estas pueden estimular las acciones políticas de los propios pueblos para replantear su participación en el Estado, como es el caso de los proyectos autonómicos.

En segundo lugar, abordaré el complejo debate sobre la autonomía indígena, entendida como la propuesta política de una parte importante del movimiento indígena hacia el Estado mexicano; describiré tanto la lucha por el reconocimiento, como las prácticas de construcción de autonomías -en diversos territorios del país- que representan una de las vertientes más profundas de la actual relación entre los pueblos indígenas y la institución estatal.

\footnotetext{
${ }^{67}$ Acuerdos de San Andrés, Documento 1, en Hernández Navarro y Vera: 1997.
} 


\section{Indigenismo, desarrollo, neoliberalismo, participación. Las políticas de Estado en el siglo XX y XXI y el movimiento indígena en México}

\section{La nación mexicana: ficción y exclusión}

Hasta fechas recientes, el proyecto nacional del Estado mexicano ha marcado la pauta de su relación con los muchos pueblos que viven al interior del territorio. La voluntad de aniquilar la fuerza cultural y política de los pueblos indígenas ha caracterizado a los sucesivos gobiernos a partir de la administración colonial, cuya estrategia fue fragmentar en comunidades y territorios discretos la unidad de los pueblos.

Pero en esta discusión debemos considerar que la relación entre las estructuras dominantes (administración colonial y, luego, Estado nacional) y los pueblos indígenas siempre ha sido dialéctica, y que una lectura de tal relación que enfatice solamente los procesos de represión y dominación dejaría de lado los igualmente importantes procesos de resistencia y adaptación que han protagonizado los pueblos. Precisamente en los términos de cómo los mismos pueblos indígenas han construido y siguen modificando su relación con el Estado, está la clave para entender la fuerza política de sus reivindicaciones y de las instituciones propias con las cuales se gobiernan. Con respecto al periodo colonial, Stern afirma que "el proceso de colonización «desde arriba» generó también una colonización 'al revés'. En ésta, son los pueblos indígenas quienes van invadiendo el laberinto del Estado, la iglesia y los mercados coloniales, tratando de hacerlos suyos y así protegerse" (2000:77).

En el siglo XIX, a pesar de que la lucha por la Independencia rompía con el pasado colonial, el mismo proyecto nacionalizador liberal produjo un nuevo racismo sobre lo diverso, debido a que se pretendía una "igualdad" ciudadana retomada de las ideas de la Revolución francesa, que superara las divisiones estamentales que habían caracterizado la sociedad de la Colonia. Pero en un territorio donde había múltiples culturas, dicha idea implicaba la imposición de un solo pensamiento (el liberal y, más en general, el producido por la civilización occidental) y, por tanto, una intolerancia y negación de todo aquello que no promoviera la homogeneidad. En pocas palabras, desde su acto fundacional (el primer Congreso del México independiente, en 1824) el país se organizó partiendo del supuesto que los pueblos indígenas no existían. 


\section{AUTONOMIAINDÍGENA, VIOLENCIAY JUSTICIA}

Según López y Rivas, "la nación es esta construcción histórico- social que por un lado dota de identidad al Estado pero lo desborda al estar constituida por sujetos cuya identidad es negada por la hegemonía de la consolidación estatal" (2004:63). En el amplísimo debate sobre las configuraciones que debiera y que ha adquirido la nación a lo largo de su evolución histórica, un tema de central importancia atañe al lugar que, en la política nacional, han ocupado y están disputando los pueblos indígenas. En los estados que se han creado a partir de procesos de colonización y ocupación territorial y cultural, la lucha de los Otros históricamente discriminados- para participar y reconocerse en la estructura nacional ha marcado la evolución de las estructuras políticas y culturales; asimismo, el trato reservado desde las instituciones a estos Otros subalternos ha marcado su relación, más o menos conflictual, con el aparato estatal. Según Villoro, desde su constitución, el Estado nacional mexicano ha sido marcado por la "contraposición entre dos corrientes que responden a ideas distintas de la nación: la construcción del Estado nación moderno, que había imaginado el grupo fundador; y la resistencia de las comunidades que no encajan en este proyecto" (Villoro 1998: 34).

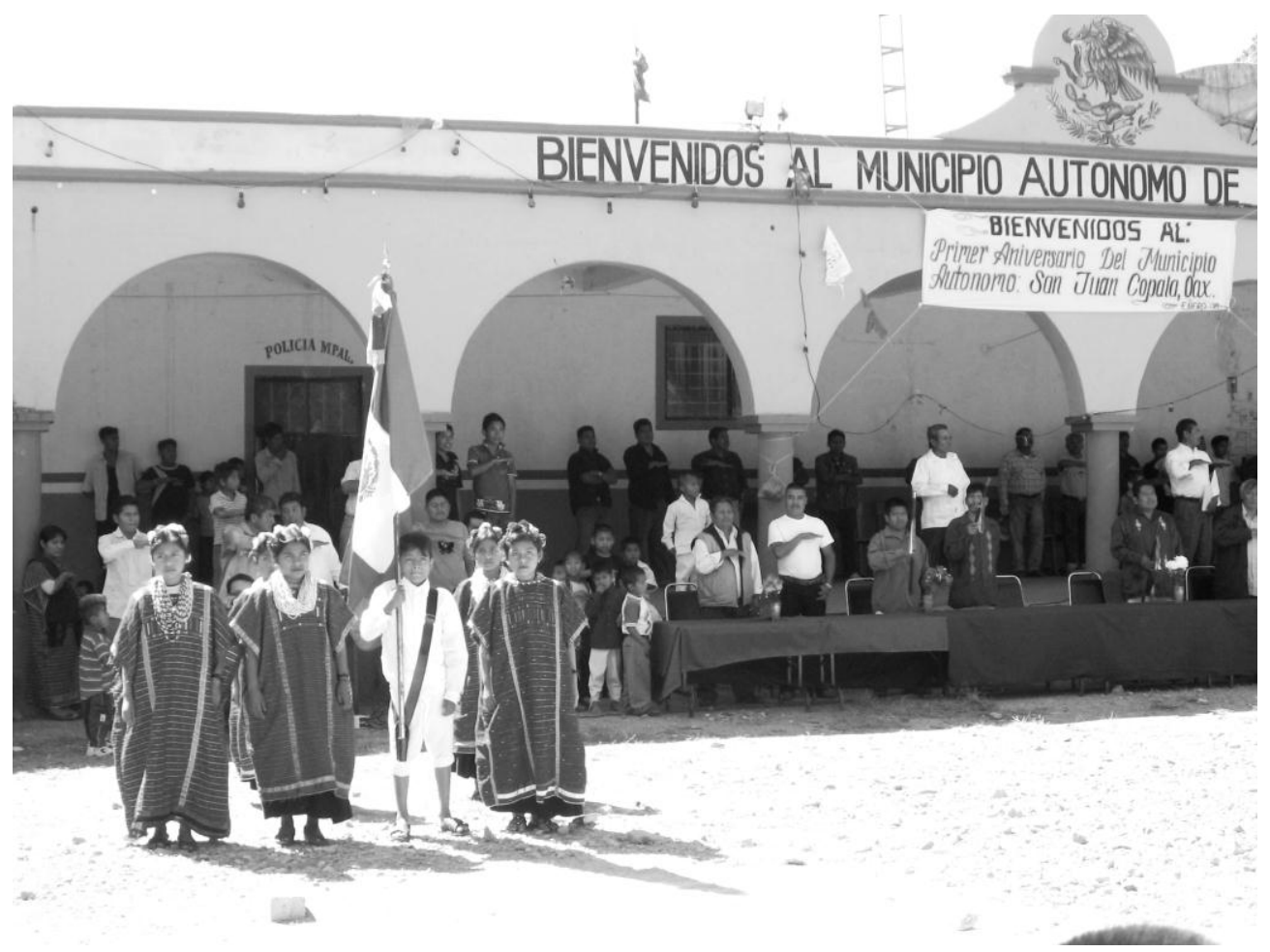

Autonomía y nación, el futuro en sus manos. Primer Aniversario del Municipio Autónomo de San Juan Copala, Oaxaca, enero 2008. 
Alicia Castellanos muestra que las políticas del Estado hacia sus Otros internos han sido orientadas por dos enfoques fundamentales. El enfoque diferencialista admite la diferencia del Otro afirmando implícitamente su inferioridad, y se expresa en los gobiernos coloniales y liberales; en sus formas extremas, puede traducirse en políticas segregacionistas y de exterminio. Por otro lado, el enfoque universalista afirma la "unidad del género humano", y se expresa en políticas asimilacionistas, miradas a "erradicar la cultura del otro y absorberla" (Castellanos 2012). También este enfoque puede llegar al etnocidio, como ocurrió en el México independiente: en aras de la construcción de iguales, que suponía el aniquilamiento de todas diferencias raciales y culturales, se implementó la eliminación física de los indios rebeldes e insumisos.

Los gobiernos liberales que siguieron a la Independencia de México, con más esmero se dedicaron a la tarea de constituir la "comunidad imaginada" nacional (Anderson: 1993) a costa de la desestructuración de las comunidades indígenas, reales y concretas. La Constitución de Cádiz (1812) y luego la primera de la República (1824) perfilaron un nuevo concepto de ciudadanía, proclamando la igualdad de -casi- todos los habitantes de México; ${ }^{68}$ tal igualdad implicaba que los bienes poseídos en forma comunitaria debían pasar a ser propiedad privada, un supuesto que fue ratificado en la Constitución del 1857. Esta Carta Magna, “al declarar ciudadanos iguales a todos los habitantes de la República, privó a los grupos étnicos del derecho consuetudinario que amparaba sus formas de vida comunitaria, los despojó de personalidad jurídica para defender su tierra y no proveyó ninguna legislación social en su favor" (Florescano 1996: 487). En el texto constitucional se destruía uno de los pilares de la organización de los pueblos, el territorio, que actualmente está al centro de todos proyectos políticos de autonomía y autodeterminación, quitando a los pueblos indígenas el derecho de propiedad sobre las tierras comunales. "De allí provinieron el afianzamiento del régimen de las haciendas, el latifundismo porfiriano y el comienzo de un rampante capitalismo liberal" (León Portilla 2011:75).

Según el antropólogo Andrés Medina, las características de los aparatos estatales del nuevo Estado independiente y de su base nacional respondían en términos globales a las exigencias de un proyecto de desarrollo capitalista; la política racial de "blanqueamiento", que

\footnotetext{
${ }^{68}$ La Constitución de Cádiz excluía claramente de la calidad de ciudadanos a los originarios de África, que en casos especiales podían adquirir la ciudadanía por méritos particulares y calificados (art. 22)
} 
expresaba este proyecto de nación dominante, "tiene su reverso en la desenfrenada violencia etnocida generadora de los grandes y sangrientos levantamientos de los pueblos indios" (Medina 1987a: 172). Durante la dictadura porfirista, el papel protagónico por parte del Estado hacia los pueblos indígenas corresponde al Ejército; frente a esto, la única alternativa posible es la resistencia armada, y la identidad étnica encierra un explosivo potencial de violencia (Medina 1987b: 8).

\section{Las raíces profundas de la autonomía indígena}

En todo el continente, las autonomías hunden profundas raíces en la historia de los pueblos indígenas y la relación entre estos y el poder dominante, sea colonial o del Estado nacional. En México, la fundación del Estado independiente se realiza desconociendo la diversidad de la nación; sin embargo, para Leticia Reyna, al son de protestas, levantamientos y rebeliones los pueblos indígenas lograron en el siglo XIX un proceso de reconstrucción interna, de adecuación a la nueva lógica del gobierno nacional, estableciendo inéditas estructuras que permitieron la permanencia de su autonomía.

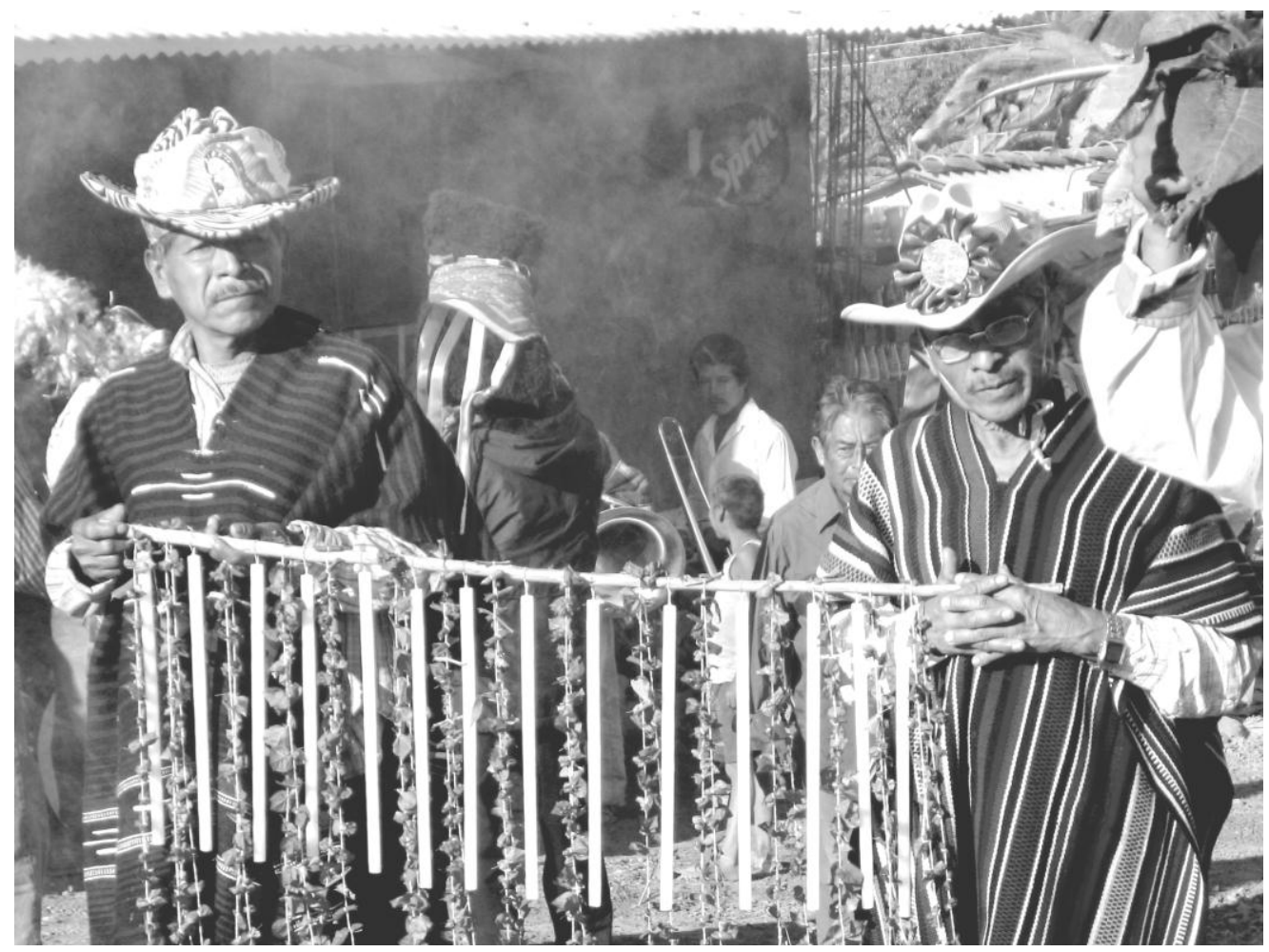

Mayordomos y ofrenda de flores y velas, Colombia de Guadalupe, Montaña de Guerrero, Semana Santa, 2008. 
La historiadora encuentra en el municipio, la mayordomía y el ciclo festivo-religioso, y el sistema de cargos que lo administra, "instituciones que se apropiaron y transformaron los pueblos para construir un autogobierno. Esto es, un sistema autónomo y clandestino e inserto, paradójicamente, en la legalidad del modelo liberal republicano" (Reyna 2000: 247). En particular, el sistema de cargos estructuraba y daba sentido a las comunidades.

Al margen de la legalidad y de las políticas liberales por separar lo religioso de lo político, los pueblos refuncionalizaron lógicas de reproducción social que mantuvieron unidos estos dos ámbitos. La nueva organización social indígena decimonónica generó una cultura de resistencia clandestina [...] y este es el secreto por medio del cual pudieron sobrevivir, conservando una relativa autonomía al margen de lo dispuesto por las leyes liberales. (2000: 266-267)

En la interpretación de Reyna, fue el mismo marco racista que caracterizó a la sociedad postindependentista que ahondó la separación entre los pueblos indígenas y los demás sectores sociales, reafirmando sus formas de organización social y de autogobierno.

La participación de los indígenas en la Revolución del 1910 se debe la voluntad de cambiar tal situación de privación material y simbólica; la lucha agrarista encabezada por Emiliano Zapata planteaba de hecho la restitución de las tierras según los confines presentes en los títulos prehispánicos y amplias autonomías locales ${ }^{69}$. El Articulo 27 de la Constitución de 1917 retoma este espíritu, volviendo a legalizar la propiedad comunal y colectiva, y por varias décadas ha fungido como protección para la población campesina e indígena mexicana, hasta su modificación en sentido profundamente neoliberal durante el mandato presidencial de Carlos Salinas de Gortari, en 1992.

Intricadamente vinculados con la división clasista de las sociedades capitalistas, anclados en modo profundo en el pasado cultural, mezclados con desigualdades regionales [...], reclamos y propuestas de carácter y de origen étnicos se enfrentan a modelos de organización política de tipo "nación" y se tienen que articular con ellos. Tal enlace es de carácter altamente conflictivo, porque este modelo siempre pretende, en virtud de su propia naturaleza, reducir al máximo y, de ser posible, eliminar la diversidad en todas las esferas. [...] En América Latina, esta situación se agudiza por el pronunciado autoritarismo que, según algunos estudiosos,

\footnotetext{
${ }^{69}$ Ley Agraria de la Soberana Convención, Cuernavaca, 22 octubre 1915.
} 
constituye una compensación característica de sistemas nacionales faltos de concentración de poder real (Krotz 1993: 20).

Siguiendo las sugerentes afirmaciones de Krotz, podemos considerar como, para las regiones de estudio, la relación entre los pueblos indígenas y los poderes del Estado no ha sido marcada solamente por la actitud racista de este, sino que se ha articulado según lógicas "premodernas", con arreglos entre estructuras de poder locales (cacicazgos, latifundistas y sus "guardias blancas" o "bandoleros") que sustituían o suplantaban las instituciones estatales débiles o ausentes; y estas mismas instituciones reconocían y se apoyaban en dichas estructuras de poder para el gobierno de los territorios, aunque no ejercieran sobre éstos ninguna forma de control político, el cual estaba en las manos de los poderosos locales. Podemos afirmar que en las zonas rurales de Guerrero o de Chiapas, el Estado ha sido en buena medida ausente en cuanto garante del bienestar y de los derechos básicos de los ciudadanos; pero no ha sido ausente la estructura política corporativista que aseguraba la continuidad del sistema unipartidista del Partido Revolucionario Institucional. Por estos motivos, los representantes de las instituciones generalmente han ejercido su función de forma autoritaria y corrupta, entendiendo su poder más en forma personal que como funcionarios públicos.

\section{Desarrollo e indigenismo}

En la historia reciente del país, el despojo de recursos y propiedades se unió a la voluntad de desaparecer la diferencia cultural de los pueblos indígenas: el Estado pos-revolucionario, en su misión homogeneizadora, se propuso desarrollar e integrar los indígenas a la nación a través de un conjunto de teorías, políticas públicas e ideología: el indigenismo. Como ideología, éste se identifica en la época de consolidación del Estado-nación mexicano, que se enfrentaba a grandes mayorías de la población que no se reconocían en tal proyecto nacional y que se necesitaba integrar; asimismo, sirvió para contrarrestar, al menos formalmente, las políticas abiertamente discriminatorias que caracterizaron la segunda mitad del siglo XIX.

No obstante, hay una continuidad entre ese periodo y el indigenismo pos-revolucionario: en ambos casos la idea del otro es permeada por un racismo de marca asimilacionista, que se expresa en el mito del mestizaje; éste no será fruto de un proceso de intercambio, sino de la 
implantación de la "cultura nacional" (blanca y criolla) sobre las culturas de los pueblos indígenas: su "aculturación", según el teórico Aguirre Beltrán. La integración racial, que debería combatir la discriminación, reconoce la especificidad étnica pero mirando a su desaparición; asimismo, favorece una nueva polarización: el mestizo sustituye al blanco en el lugar dominante y privilegiado culturalmente, mientras el indígena permanece en el lugar subalterno, atrasado, que se necesita desarrollar.

La definición de indio elaborada por el Congreso Indigenista Interamericano ${ }^{70}$ como aquel "individuo económica y socialmente débil" expresa claramente esta visión. Con el indigenismo, el procedimiento para suprimir la diferencia cambia desde la represión violenta al empleo de recursos políticos y científicos, en primer lugar los de la disciplina antropológica. A nivel teórico y a nivel concreto, los esfuerzos para "mexicanizar el indio" más bien han ido haciendo más hondas las fracturas que caracterizan la sociedad mexicana, juntando nuevos argumentos a viejos racismos ${ }^{71}$. Para el historiador Andrés Aubry, "el indigenismo no es sino una respuesta del sistema a una pregunta de blancos: ¿por qué los países pluriétnicos están atrasados? Encubre una hipótesis: el indígena es un freno al desarrollo. En vez de cuestionar la sociedad global y su modelo de desarrollo, desprecia la cultura indígena" (Aubry, 1982: 15).

El discurso integracionista escondía una infantilización del sujeto indígena, que era considerado como incapaz e inadecuado a participar en la vida pública, lo que evidencia una concepción racista profundamente arraigada. Como ejemplo, cabe resaltar que, en el código penal de Chiapas, los indígenas fueron considerados hasta 1980 como minusválidos y retrasados mentales (París Pombo: 2000).

En esta etapa de las políticas indigenistas gran importancia fue otorgada a la asimilación cultural, impulsada a través de los programas educativos. Según una tendencia que aún encontramos en las actuales políticas "multiculturalistas" o "neoindigenistas", no se rechazan por completo las culturas indígenas, sin embargo se asigna al Estado y a sus instituciones la facultad de decidir cuáles son los aspectos positivos que hay que "proteger" paternalisticamente (en lo general las lenguas y las manifestaciones artísticas y culturales) y cuáles deben ser eliminados por ser incompatibles con los valores de la sociedad nacional (por ejemplo las formas de organización política o económica).

\footnotetext{
${ }^{70}$ Evento realizado en Pátzcuaro en 1940, y que marca la institucionalización de la ideología indigenista.

${ }^{71}$ Por un análisis de las políticas indigenistas véase Oemichen 1999; Del Val 2004; Saldívar Tanaka 2008.
} 
Me interesa aquí enfatizar la imbricación entre el racismo del mestizaje y de la integración, que planteaba la "evolución” de los pueblos indígenas, desde el "atraso" que los caracterizaba hacia su incorporación a la "sociedad nacional", y la idea del desarrollo, que desde la mitad del siglo XX ha orientado las políticas sociales del Estado. De hecho, el indigenismo como política de Estado nace apenas unos años antes ${ }^{72}$ que el concepto mismo de desarrollo, ${ }^{73}$ que tiene más o menos la misma función: un conjunto de ideología, prácticas y políticas públicas miradas a regular la población. Política formulada por los no indígenas para resolver los problemas de los indígenas, ${ }^{74}$ el indigenismo integracionista coincidió en términos temporales con el desarrollismo más marcadamente economicista. Las acciones miradas a la disolución de las diferencias culturales en la identidad nacional se implementaron conjuntamente con políticas de industrialización y modernización.

Dada la trascendencia de este enfoque (el desarrollo) en la elaboración de las políticas indigenistas, pasadas y presentes, considero necesario aclarar someramente lo que representa. Según Esteva, en el imaginario común "la palabra sugiere siempre un cambio favorable, de lo inferior a lo superior, de lo peor a lo mejor. Indica que uno lo está haciendo bien, porque avanza en el sentido de una ley necesaria, ineluctable y universal hacia una meta deseable" (2001: 71). Pero esta acepción vagamente positiva es mermada por la complementaria cara negativa de la misma moneda: para las dos terceras partes de la población mundial, la palabra desarrollo es un recordatorio de lo que no son (según el pensamiento dominante), de lo que no han alcanzado todavía. El mismo concepto de desarrollo ha creado su complemento, el subdesarrollo: una condición indefinible e indigna, que denota una situación de carencia e inferioridad, definida por los "desarrollados". La etimología de la palabra desarrollo, propuesta por el geógrafo brasileño Porto-Gonçalvez, explica la vocación del desarrollo para suprimir lo "Otro". Des-arrollar implica abrir, romper, extender lo que está arrollado, envuelto. Development, sviluppo, desenvolvimiento: en diferentes idiomas el significado es lo mismo, quitar algo de lo que lo envuelve, que lo enrolla, que lo contiene e involucra. Ya que

\footnotetext{
${ }^{72}$ Se institucionaliza en el Primer Congreso Indigenista Interamericano, en 1940.

${ }^{73}$ El desarrollo fue públicamente lanzado como proyecto innovador por el presidente estadunidense Harry Truman, en su discurso de investidura, en 1949. Premisa básica del desarrollo es que aquellos países con altos niveles de pobreza son países atrasados, cuya única vía posible de transformación es la acumulación del capital y el modo industrial de producción: se trata de un proyecto de sentido marcadamente liberal (Bárcenas y Sauceda 2007).

${ }^{74}$ La definición fue acuñada por el célebre antropólogo y animador del indigenismo, Gonzalo Aguirre Beltrán.
} 
estamos hablando de los hombres, lo que los envuelve es la naturaleza, un territorio propio, su cultura, que finalmente orienta también las formas de relacionarse con la naturaleza y el territorio. En este sentido, el desarrollo entonces impone a las colectividades humanas salir de la naturaleza, instrumentándola; despegarse de su territorio y de su cultura, de su diversidad, para alcanzar un modelo universal.

Desde su origen, la noción de desarrollo estuvo marcada por una visión economicista, que sirvió para impulsar el modelo económico de los países dominantes e imponerlo como parte del sentido común universal. También se trata de una idea rigurosamente colonial: en el contexto de las revoluciones y los movimientos anticolonialistas que se desencadenaron después de la segunda Guerra Mundial, Estados Unidos -quién se asumió como el campeón de la economía y de la política a nivel mundial- acuñó un nuevo termino para dividir el mundo, una vez más, en un abajo y un arriba, en los que eran desarrollados y los subdesarrollados, estableciendo que éstos debían seguir el modelo de aquellos. "Así, con un sesgo universalista, aunque con un origen bien provinciano, el occidental, se presentaba a la ciencia occidental como una panacea, independiente de los contextos socio-geográficos específicos donde fuera a insertarse" (Porto-Gonçalvez 2009: 11). ${ }^{75}$ En consecuencia de esto, la condición de subdesarrollo implica también la de dependencia por tiempo indefinido: habrá que entregarse a la guía de "expertos" y sacrificar conocimientos tradicionales, sabidurías y cosmovisiones en el altar del desarrollo, que por cierto nunca se alcanzará a plenitud.

Como expresión del llamado "pensamiento único", la noción de desarrollo, ya que es univoca y unidireccional, implica la cancelación de la diversidad cultural, social, política y productiva. Esto significa que otras formas posibles de hacer las cosas - de alimentarse, de producir, de intercambiar bienes, de relacionarse con la naturaleza- no son percibidas como expresiones de diversidad sino como la incapacidad de actuar de acuerdo con el modelo visto como universalmente válido, esto es, el occidental (Agostino 2009:14). De manera análoga, el

\footnotetext{
${ }^{75}$ La noción de desarrollo, en todas sus acepciones, tiene un sesgo positivista: las sociedades subdesarrolladas pueden progresar si se entregan a las soluciones científicas y técnicas propuestas por quien detiene la solución a sus problemas, o sea los países "desarrollados". En una crítica a las políticas de desarrollo rural, hace ya 30 años, Díaz-Polanco considera que estas han sido caracterizadas en un sentido ahistorico y tecnicista. Según el autor, "la insistencia en lo técnico y, aún más, en la neutralidad técnica de los proyectos de desarrollo rural puestos en práctica en América Latina, implica en los hechos que se parte del presupuesto, nada obvio, que el desarrollo que deseamos para nuestro mundo rural es el desarrollo capitalista o dentro del esquema capitalista" (Díaz-Polanco 1981: 17). Cuando lo técnico cobra esta desmedida importancia, las relaciones sociales de producción y los mecanismos de funcionamientos propios de las sociedades en que se aplican las políticas de desarrollo, se pierden por completo.
} 


\section{AUTONOMIAINDÍGENA, VIOLENCIAY JUSTICIA}

indigenismo integracionista implementado por el Estado mexicano en su etapa "desarrollista" (desde 1948 hasta 1980 aproximadamente) propugna la “desindianización” y la consiguiente proletarización de los indígenas, favoreciendo su tránsito -según la interpretación de los propios integracionistas- desde una situación de castas hacia una situación de clase, como paso necesario para su articulación dentro de la sociedad (capitalista) moderna. Esto se hizo por varios medios: desde la enseñanza forzada del idioma español y la denigración de las lenguas indígenas, o la generación de demandas por productos, como fertilizantes, semillas, etc.

La interpretación del "problema indígena" como una situación reducida a regiones particulares (las "regiones de refugio" según la definición acuñada por Aguirre Beltrán) orientó la atención de las instituciones en tales localidades, a través de los Centros

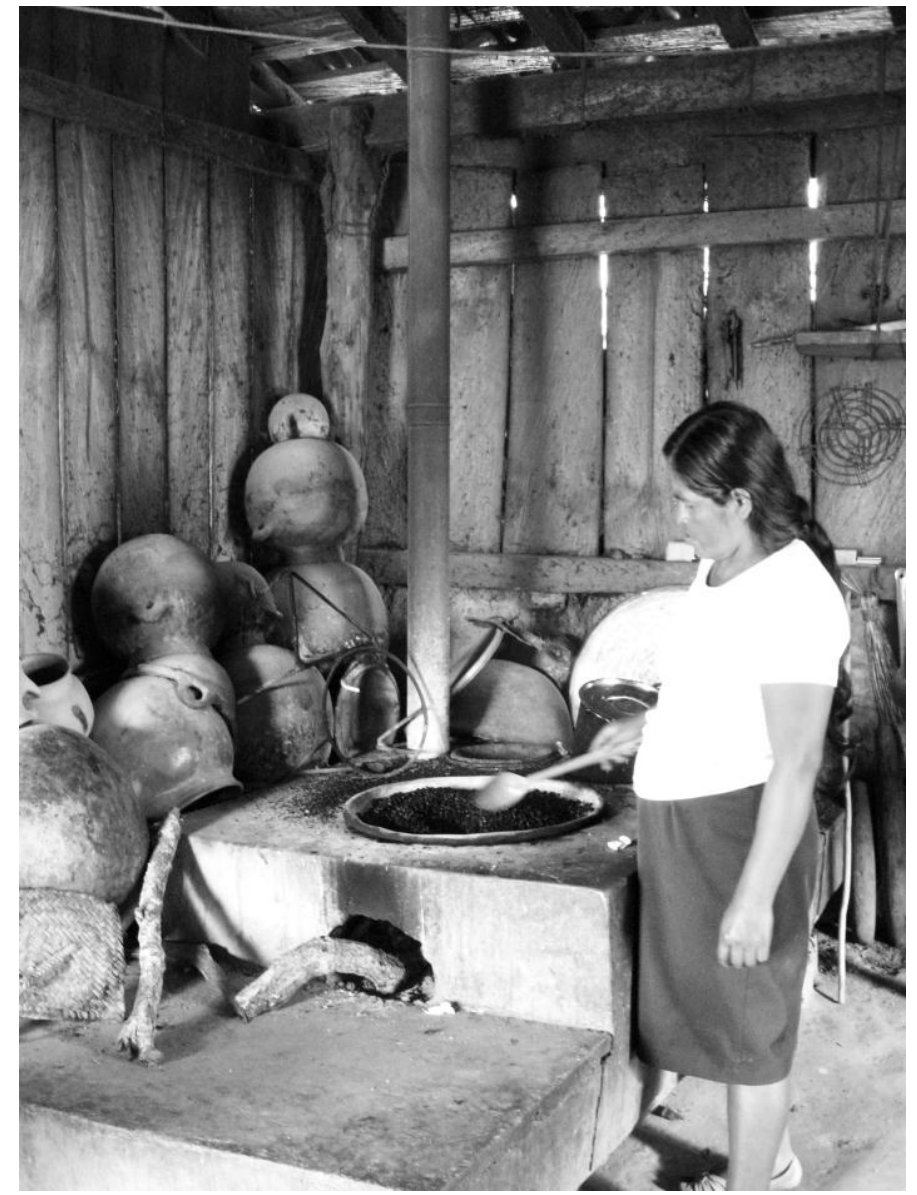

Coordinadores Indigenistas.

También esta "espacialización" y localización de la problemática étnica responde al énfasis puesto sobre el aislamiento de los pueblos indígenas y la necesidad de incorporar los territorios ocupados por ellos al espacio nacional. Según Medina, "no es que la política indigenista aporte los mecanismos para el mantenimiento de las especificidades étnicas, sino más bien contribuye a que las regiones donde actúa cumplan con las determinaciones políticas y económicas impuestas por el Estado en su estrategia de desarrollo" (Medina 1987a: 193).

Tostando café. Hogar indígena, Colombia de Guadalupe, Montaña de Guerrero, marzo 2011 
Entre 1955 y 1975, las políticas autoritarias y paternalistas se acompañaron a la implementación de megaproyectos (creación de presas) mirados a explotar los recursos naturales de los territorios indígenas. ${ }^{76}$ Durante este tiempo el indigenismo recibió una fuerte influencia de las políticas desarrollistas impulsadas por la CEPAL y de los programas de cooperación internacional que se aplicaron en América Latina.

A partir del año 1968 inicia a tomar fuerza un cuestionamiento difuso hacia las instituciones y a las políticas del Estado, e incluso hacia las agencia de desarrollo internacionales, tras la evidencia que los proyectos de desarrollo habían fallado en su propósito. Así, tanto a nivel internacional como nacional, se inició a tomar en cuenta (aunque con frecuencia solo aparentemente) la realidad social y cultural de los grupos a "desarrollar". La visión economicista y tecnicista del desarrollo empezó a mostrar sus límites, ${ }^{77}$ pero el concepto se mantuvo. Se inició a considerar la integración de los objetivos económicos con los aspectos sociales, y en los organismos internacionales (ONU, UNESCO) se acuñaron nuevos términos: desarrollo participativo, desarrollo integrado, otro desarrollo y desarrollo endógeno. ${ }^{78}$

En correspondencia a las primeras críticas al desarrollo, junto con el despertar de las movilizaciones indígenas, también la perspectiva integracionista del indigenismo fue criticada por muchos intelectuales y académicos, coincidiendo con un cambio de tendencia en la reflexión antropológica. La siguiente estrategia, el indigenismo de participación, representó una actualización de los mecanismos de control del Estado. Las políticas hacia los pueblos indígenas siguieron siendo caladas desde arriba, y no se modificó la voluntad de fondo que mira a desaparecer la diversidad. Es en este contexto cultural y ideológico que se desarrolla con más fuerza el debate sobre la "cuestión étnico-nacional", empezándose a plantear posibles formas de interacción que reconocieran la diversidad cultural de la sociedad mexicana.

El llamado indigenismo de participación se despliega desde finales de los años setenta hacia finales de los ochenta, y nace en un momento de fuerte movilización indígena y

\footnotetext{
${ }^{76}$ Véase Arze Quintanilla (1988: 112).

${ }^{77}$ Un informe de expertos convocados por las Naciones Unidas en 1969 afirma que el desarrollo crea de alguna manera grandes zonas de pobreza, estancamiento y marginalidad (Naciones Unidas, "Report of the 1969 meeting of experts on social policy and planning", citado en Esteva 2001:75).

${ }^{78}$ Sin embargo, este énfasis en dar al desarrollo una perspectiva más amplia fue frenado en la década de los ochenta del siglo pasado, llamada "década perdida para el desarrollo". El "proceso de ajuste estructural" implicó para muchos países abandonar o desmantelar muchos de sus logros previos en términos de políticas púbicas y de bienestar social (Esteva 2001: 79).
} 


\section{AUTONOMIAINDÍGENA, VIOLENCIAY JUSTICIA}

campesina, provocada por una importante crisis de la producción agrícola. Según explica Saldivar Tanaka en un estudio sobre la evolución del Instituto Nacional Indigenista, ahora:

Además de ser entendidos desde su aislamiento, los pueblos indígenas fueron vistos desde su pobreza y marginación. En esta etapa la asimilación cultural fue desplazada por la idea de llevar bienestar económico y organizar a las comunidades. [...] Haciendo eco a las demandas de las organizaciones indígenas y bajo la influencia de la crítica antropológica, el INI [...] jerarquizará el fortalecimiento de la producción local sobre la incorporación a los mercados regionales y nacionales (Saldivar Tanaka 2008:88-89)

En términos de políticas públicas, se sustituyó la integración cultural por la integración productiva y la incorporación política; a tal propósito, aumentó la cantidad de recursos canalizados a las comunidades a través del Plan Nacional para Zonas Deprimidas y Grupos Marginados (Coplamar), bajo la idea de que los indígenas deberían “desarrollarse a sí mismos".

Este programa en extremo desarrollista inició a modificarse en la medida en que la institución indigenista se vio mayormente influenciada por una corriente del pensamiento antropológico que partió de la "antropología crítica" para llegar a una propuesta denominada etnicista o etnopopulista, que inició a promover el concepto de etnodesarrollo. Una vez más fue importante el papel de los antropólogos, dentro y fuera del Instituto Nacional Indigenista, que cuestionaron los efectos homogeneizadores de la integración económica que se pretendía para los indígenas a través de los proyectos de "desarrollo comunitario". Esta corriente recibió un fuerte impulso de las reuniones realizadas en Barbados en 1971 y 1977, ${ }^{79}$ y nació con una profunda censura al indigenismo integracionista y homogeneizador, subrayando la pluralidad o diversidad sociocultural de las naciones latinoamericanas. Este planteamiento, de gran fuerza política, fue sin embargo criticado por enfatizar una vez más la dualidad de las sociedades pos-coloniales $^{80}$ (que serían compuestas por indígenas y no-indígenas, con proyectos nacionales forzosamente excluyentes), y por proponer una visión básicamente esencialista (los pueblos indígenas serían portadores de una esencia étnica inmutable) que

\footnotetext{
${ }^{79}$ En particular la $\mathrm{I}^{\circ}$ Declaración de Barbados marcó un parteaguas al denunciar el etnocidio de los indígenas a nivel internacional y al fincar su responsabilidad en los Estados, las congregaciones religiosas y los antropólogos.

${ }^{80}$ Véase el clásico México profundo. Una civilización negada (1987) de Guillermo Bonfil, quién fue el principal representante de esta corriente.
} 
descalifica el devenir histórico de las sociedades indígenas. Como consecuencia de esto, la otra crítica que proviene desde la corriente denominada "etnomarxista" es que el etnicismo concibe los indígenas como ajenos a la estructura clasista de la sociedad moderna, y, por lo tanto, las luchas indígenas como intrínsecamente distantes y diferenciadas de las luchas realizadas por los otros sectores sociales en defensa de sus derechos. No obstante estas críticas, el planteamiento etnicista fue fundamental para posicionar el debate sobre la diversidad y los derechos de los pueblos indígenas, en un momento histórico en que la mayoría de los gobiernos latinoamericanos los desconocían y reprimían deliberadamente.

La perspectiva etnicista fue paulatinamente perdiendo su radicalidad al ser incorporada al planteamiento indigenista, con la integración al INI de algunos antropólogos e intelectuales “críticos” y de líderes indígenas. Estos encarnaban la política de "participación”, que se redujo a la implementación de programas siempre diseñados desde el Estado, y a favorecer la constitución de organizaciones indígenas acordes a la visión institucional, que sirvieran como interlocutores entre los pueblos indígenas y el Estado, y así reducir la posibilidad de conflictos o la necesidad de vinculación entre los indígenas y otros sectores sociales organizados. Un ejemplo es la creación (1975), impulsada desde las instituciones, ${ }^{81}$ de los Consejos Supremos Indígenas, uno por cada pueblo, reunidos en el Consejo Nacional de los Pueblos Indígenas.

La propuesta misma de etnodesarrollo, que en una de sus formulaciones más conocidas supone la "ampliación y consolidación de los ámbitos de cultura propia, mediante el fortalecimiento de la capacidad de decisión de una sociedad culturalmente diferenciada para que guíe su propio desarrollo y el ejercicio de la autodeterminación", 82 mantuvo el afán intervencionista de las instituciones sobre las sociedades indígenas. En México, después de la incorporación oficial del etnodesarrollo, su discurso fue además simplificado y banalizado, reduciéndose a "la promoción y defensa de las culturas indígenas", lo que significó el impulso a programas para la compra de instrumentos musicales, vestimentas para danzas tradicionales, etc. Según Sarmiento (1998a:109), “el etnodesarrollo fue el argumento central del sexenio de Miguel de la Madrid para despolitizar las reivindicaciones indias que se generaron durante los años setenta". Las instituciones gubernamentales, sostiene el autor, mostraron su disposición a apoyar la defensa de los derechos culturales (se impulsa la educación bilingüe y las

\footnotetext{
${ }^{81}$ Instituto Nacional Indigenista, Secretaria de la Reforma Agraria y Confederación Nacional Campesina.

${ }^{82}$ Declaración de San José sobre etnodesarrollo y etnocidio en América Latina, 1981.
} 


\section{AUTONOMIAINDÍGENA, VIOLENCIAY JUSTICIA}

organizaciones de profesionales en dicha área), con la condición de que los indígenas se alejaran de las reivindicaciones que el gobierno no estaba dispuesto a negociar, como el derecho a la tierra y a los recursos naturales, los derechos políticos, etc. Para tal efecto, el Estado siguió impulsando, como lo hacía desde hace décadas, la formación de organizaciones de la "sociedad civil" creadas desde arriba y leales a los intereses gubernamentales, como el Consejo Nacional de Pueblos Indios (CNPI, 1975) y la Asociación Nacional de Profesionistas Indígenas Bilingües A.C. (ANIPBAC, 1977) ${ }^{83}$.

El indigenismo de esa época, lejos de mejorar la situación de los pueblos indígenas, aceleró su deterioro a causa de las medidas de ajuste estructural y de austeridad introducidas a nivel nacional. El proyecto neoliberal de modernización de la economía conllevó una fuerte recesión en el campo y la supresión de los subsidios y créditos para los pequeños campesinos. En tal contexto:

La población rural puso en funcionamiento su capacidad de resistencia, dio forma a una amplia gama de estrategias de sobrevivencia, para tratar de superar las terribles condiciones en que la ponía la crisis económica. Para los pueblos indios esto representó esmerarse en tareas de recomposición de sus estructuras fracturadas, para seguir existiendo como grupos y con identidad propia (Sarmiento 1998a: 103).

\section{La "cuestión étnico-nacional"}

Con este nombre se identifica un profundo debate intelectual que tuvo lugar entre la segunda mitad de los años setenta y los años ochenta del siglo pasado. Tal y como es definida, la cuestión etnico-nacional es una aproximación marxista al problema de la relación entre los pueblos indígenas y el Estado, que retoma la discusión abierta a principio de siglo por Rosa Luxemburgo y la corriente socialdemócrata sobre la relación entre las distintas nacionalidades, históricamente oprimidas y negadas por los Estados imperiales europeos, y el proyecto de

\footnotetext{
${ }^{83}$ Véase el sucesivo apartado Articulación del movimiento indígena 1970-1990. Una documentada crítica a las políticas indigenistas de los años ochenta y al etnodesarrollo es elaborada en el texto citado de Sarmiento Silva (1998a, pp. 107-114).
} 
Estado revolucionario que se estaba gestando. ${ }^{84}$ A partir de este debate el etnomarxismo elabora una articulada crítica a las políticas indigenistas oficiales, retomando después, en la práctica, la propuesta de autonomía como una nueva forma de relación entre el Estado y los pueblos indígenas, en el contexto de una transformación de la sociedad en su conjunto. No es casualidad que tal propuesta, proveniente de una larga y articulada reflexión marxista, se concretice por primera vez en la construcción de la autonomía regional en la Costa Atlántica de Nicaragua, precisamente al interior de un Estado nacido de un proceso revolucionario.

Frente a las políticas oficiales vueltas a transformar desde el Estado la vida de los pueblos indígenas, los etnomarxistas afirman de manera contundente que el "problema del indio" no es una condición particular de los indígenas sino que atañe a toda la sociedad nacional, y su resolución pasa por una amplia democratización de las estructuras del Estado y una refundación del proyecto nacional, no por la aplicación de "acciones indigenistas" restringidas. La afirmación del carácter nacional de la cuestión étnica es una clara respuesta a la teoría de las regiones de refugio, elaborada por el teórico del indigenismo Gonzalo Aguirre Beltrán, que restringe a estas áreas la problemática ligada a la desigualdad y la explotación de los indígenas, desmarcándola de la política nacional. ${ }^{85}$

Por otro lado, se define la cuestión étnico-nacional como profundamente política, oponiéndose a la visión "culturalista" del indigenismo oficial que, mientras promueve las manifestaciones culturales y folclóricas de los pueblos, estigmatiza las manifestaciones que considera incompatibles con el proyecto dominante, como la organización política, económica y social de los pueblos.

Así, la cuestión étnica deviene necesariamente parte fundamental de la cuestión nacional. Los grupos étnicos se enfrentan, en rigor, al proyecto de sociedad de las clases dominantes y explotadoras, un proyecto que asume el carácter de nacional; a este proyecto sólo puede enfrentarse un proyecto contrahegemónico alternativo, también nacional, que agrupe a los indígenas junto a los demás sectores explotados y dominados de la sociedad. Como corolario

\footnotetext{
${ }^{84}$ Véase Rosa Luxemburgo, "La cuestión nacional y la autonomía" (1908), en Textos sobre la cuestión nacional, Madrid, Ediciones La Torre, 1977, en <http://www.upf.edu/materials/fhuma/ nacionalismes/nacio/docs1011/9luxemburg.pdf>, consultado el 10 diciembre 2012.

${ }^{85}$ En el documento llamado "Declaración de México. La cuestión étnico-nacional en America Latina" (1984), manifiesto fundador del Consejo Latinoamericano de Apoyo a las Luchas Indígenas, se encuentra una síntesis de las críticas y de las propuestas de la corriente etnomarxista.
} 
de lo anterior, la solución de la problemática étnica requiere de la acción política de los indígenas (López y Rivas 2009: 10)

Es importante notar que estos planteamientos se volverán centrales en la propuesta que emergerá de los Diálogos de San Andrés entre el EZLN y el gobierno mexicano, en la demanda de establecer una "nueva relación entre los pueblos indígenas, el Estado y la sociedad" como única forma para resolver el conflicto estallado en Chiapas, pero emblema de la situación de la población indígena en todo el país.

\section{Articulación del movimiento indígena mexicano 1970-1990}

El movimiento indígena mexicano, que fue creciendo por dos décadas y sobresalió al inicio de los años noventa, debe verse en su continuidad con el fuerte movimiento agrarista, al interior del cual se desarrolló paulatinamente la reflexión sobre la identidad indígena de la gran mayoría de los sujetos campesinos mexicanos, y se construyó una propuesta política que no se limitara a las reivindicaciones agrarias sino que incluyera también las culturales y las sociales; esto es, la apuesta política de autonomía. ${ }^{86} \mathrm{Al}$ respecto, Bartra y Otero afirman que las identidades indígena y campesina, y por ende las demandas materiales (tierra) y de identidad (cultura) son históricamente superpuestas e inseparables; pues "la etnia y la cultura indígenas son simplemente los puntos clave de la lucha por la tierra" (2008:402).

En la década de los setenta, cuando el movimiento campesino tuvo mayor auge, se empezó a reflexionar sobre lo indígena como identidad cultural y también política; sin embargo, el centro de las demandas siguió siendo la tierra y la cuestión agraria. Acontecimientos importantes en este proceso de reflexión fueron, en primer lugar, el Congreso Indígena que tuvo lugar en 1974 en San Cristóbal de Las Casas, Chiapas, impulsado por la Iglesia Católica y el magisterio rural, que representó el primer momento público de discusión entre los pueblos indígenas a nivel regional, donde la comunicación se realizó en las lenguas indígenas habladas en el territorio; sin embargo, las conclusiones, articuladas alrededor de los

\footnotetext{
86 No es mi intención aquí realizar un recuento exhaustivo de la trayectoria organizativa indígena, sino simplemente mencionar algunos momentos y actores importantes para la construcción de las propuestas políticas. Entre la abundante bibliografía consultada sobre el argumento, hago referencia, en particular, al extenso trabajo de Sarmiento (1998a) y al artículo, más acotado, de Bartra y Otero (2008), así como a lo señalado por López Bárcenas (2009).
} 
temas de tierra, comercio, salud y educación, no reflejaban aun plenamente una especificidad indígena. En segundo lugar, el Congreso Nacional de los Pueblos Indígenas organizado en 1975 por el gobierno federal en Pátzcuaro, Michoacán, a pesar de su marco oficialista fue también un importante momento de encuentro de representantes indígenas a nivel nacional.

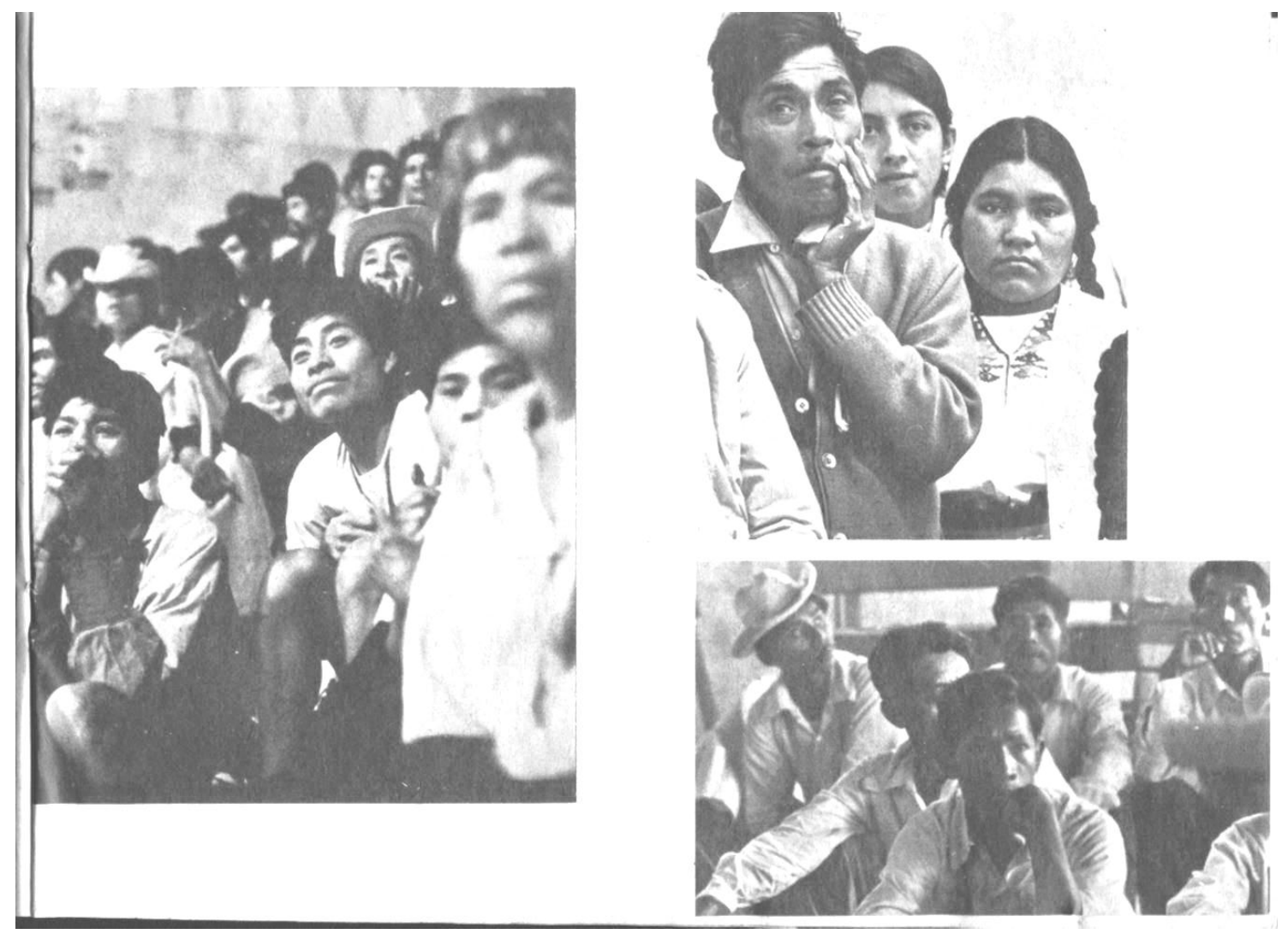

Congreso Indígena, San Cristóbal de Las Casas, 1974. Foto: Rogelio Cuellar, en García de León y Rumazo, s/f

Entre las primeras organizaciones propiamente indígenas que surgieron en este periodo, algunas responden a la política del Estado de generar sujetos afines a él como canales privilegiados de interlocución con los sectores de la sociedad que iniciaban a movilizarse: ejemplo de ello son el Movimiento Nacional Indígena (MNI; 1973), integrado principalmente por profesores bilingües; la Asociación Nacional de Profesionistas Indígenas Bilingües A.C. (ANPIBAC, 1977), y el Consejo Nacional de Pueblos Indígenas (CNPI, 1975), integrado por los representantes de los Consejos Supremos, nombrados en el Congreso de Pátzcuaro. Estas organizaciones se crearon tras el impulso estatal, y les fue otorgada desde arriba la representatividad de los pueblos indígenas del país, a cambio de su acción legitimadora de las políticas indigenistas. El CNPI intentó desarrollar una trayectoria autónoma, y fue entonces 
sustituido por la Confederación de Pueblos Indígenas (1985). En ese momento, la "indígena" era una identidad que ciertas estructuras del Estado aún manipulaban y hegemonizaban, en lo que se estaba incubando el desarrollo de un sujeto político indígena con reivindicaciones y un proyecto específico.

Pero en este mismo periodo inició a producirse una ruptura con el integracionismo y, sin la tutela del Estado, se formaron organizaciones campesinas de carácter regional y nacional, que planteaban un discurso de autodeterminación propio de su práctica política, pero también surgido en los Congresos Indígenas de 1974 y 1975. Mezcladas a las reivindicaciones más específicamente agrarias y campesinas, se iniciaron a formular los reclamos de poder nombrar autoridades propias, y sobre todo el cese a la represión en contra de organizaciones y pueblos, y a la violencia del Estado en algunos territorios. La guerra sucia perpetrada en Guerrero en contra de enteras comunidades campesinas e indígenas, acusadas de respaldar al Partido de los Pobres y a la Asociación Cívica Nacional Revolucionaria, y la criminalización de las organizaciones agraristas en Chiapas, deben entenderse como una faceta más de las políticas estatales hacia la población rural e indígena.

En la década de los ochenta, en un contexto de grave crisis económica que prefiguraría las políticas neoliberales, mientras el reparto agrario había de hecho terminado, se fortalece el movimiento campesino y nacen organizaciones de base étnica, pero cuyo propósito era impulsar proyectos productivos propios. Estos procesos ya iniciaban la reflexión sobre la autonomía entendida como independencia de los partidos políticos y las instituciones, así como autogestión y control del proyecto productivo.

En el desarrollo de las organizaciones campesinas durante los años '80 es importante la progresiva superación de la lucha comunal, local, y la creación de redes de movilización a nivel más amplio: sobre estas mismas redes se conformará y movilizará el movimiento indígena de la década siguiente. Así se formaron a nivel nacional la Coordinadora Nacional Plan de Ayala (CNPA), que tuvo su primer Encuentro Nacional de Organizaciones indígenas Independientes en 1982, y la Unión Nacional de Organizaciones Regionales Campesinas Autónomas (UNORCA). Otras importantes organizaciones, que como las anteriores no postularon con fuerza la cuestión étnica pero cuya base era mayoritariamente indígena, son la Central Independiente de Obreros Agrícolas y Campesinos (CIOAC); la Unión de Ejidos Quiptic Ta'lecubtesel y la Unión de Uniones Ejidales y Grupos Campesinos Solidarios, en 
Chiapas; la Alianza de Organizaciones Campesinas Autónomas de Guerrero y la Coalición de Ejidos Cafetaleros de la Costa Grande, en Guerrero, entre otras.

A principio de la década de los setenta, en Oaxaca se formó el mayor número de organizaciones regionales indígenas. Bartra y Otero (2008: 412) citan una declaración conjunta de tres organizaciones ${ }^{87}$ fechada a principio de los años ochenta, donde ya era explicita y articulada la demanda de "absoluto respeto por nuestra autodeterminación comunitaria sobre nuestras tierras, sobre todo por nuestros recursos naturales y sobre las formas de organización que deseamos darnos", en una reflexión de sorprendente actualidad.

En términos organizativos, fue importante la trayectoria de la Coalición Obrero Campesina Estudiantil del Istmo (COCEI), también en Oaxaca, organización que desde los años setenta constituyó una amplia red a nivel regional, luchando contra los cacicazgos e impulsando la recuperación de la tierra comunal ocupada por éstos. La COCEI, junto con el Partido Socialista Unido de México (PSUM), en 1980 logró acceder al poder político y estableció el Ayuntamiento Popular en Juchitán, Oaxaca, respaldado por un amplio movimiento popular cuya columna vertebral fueron los campesinos indígenas juchitecos. "Con esa fuerza gobernamos en aquel entonces, surgida de la lucha por la tierra y su recuperación", sostiene Leopoldo de Gyves (1995), quien fue presidente municipal del Ayuntamiento Popular. Aunque la excepcional experiencia terminó en 1983, fue un ejemplo muy importante para los movimientos populares en el país y su lucha para lograr espacios de representación a través de la movilización: fue "el primer ayuntamiento libre de México".

Es así como la articulación de la lucha indígena se convierte en una apuesta política que madura al interior del movimiento campesino en la década de los setenta y ochenta, ${ }^{88}$ en tanto que articula y transforma la demanda por la tierra en la demanda por el territorio, término que incluye también los derechos culturales y simbólicos y no sólo los económicos. Es aquí donde se traslapa el discurso desde lo campesino a lo indígena, con el impulso del debate que se estaba dando sobre la figura de "pueblo indígena", y las atribuciones de éste, en el marco del Grupo de Trabajo sobre Poblaciones Indígenas, parte de la Comisión de Derechos Humanos

\footnotetext{
${ }^{87}$ Se trata de la Organización para la Defensa de los Recursos Humanos y el Desarrollo Social Sierra de Juárez (Odrenasij), también zapoteca; el Comité de la Defensa de los Recursos Naturales y Humanos (Codremi); y el Comité de Organización y Consulta para la Unión de Pueblos de las Sierras del Norte de Oaxaca (Codeco).

${ }^{88}$ La organización política regional de los ochenta presenta la construcción de bases étnicas que darán fruto más adelante a la formación del movimiento indígena (Mattiace 2002).
} 
de las Naciones Unidas. Este grupo sirvió como tribuna para la discusión y la denuncia sobre la situación de los pueblos indígenas a nivel internacional, y trabajó por 22 años a la Declaración de Derechos de los Pueblos Indígenas que incorpora la autonomía como derecho fundamental de los pueblos. Igual importancia tuvo la difusión, en 1989, del Convenio 169 sobre Pueblos Indígenas y Tribales, elaborado por la Organización Internacional del Trabajo ${ }^{89}$ y que México formalmente adoptó inmediatamente, en 1990.

Durante la década de los ochenta y a principio de los noventa se mantuvo la tendencia a la formación de organizaciones regionales independientes, y se celebraron varios encuentros: el Primer Encuentro de Organizaciones Indígenas Independientes fue realizado en Puxmecatán, Oaxaca, en 1980; el segundo en Cherán, Michoacán. En 1989, durante el Primer Foro Internacional sobre los Derechos Humanos de los Pueblos Indígenas realizado en Matías Romero, Oaxaca, se acordó la realización de la Campaña Mundial 500 años Resistencia Indígena, Negra y Popular. En 1990, se conformó el Consejo Mexicano de 500 Años y, como parte de él, el Frente Nacional de Pueblos Indios (FRENAPI).

En 1988 fue importante la conformación del Frente Independiente de Pueblos Indios (FIPI), que se planteaba articular luchas diversas en el ámbito nacional, y que inició a impulsar el reconocimiento constitucional de los derechos indígenas; esta organización se afiliará prontamente al oficialista Congreso Indígena Permanente (CIP) y confluirá después en la Asamblea Nacional Indígena para la Autonomía (ANIPA), impulsora de la autonomía regional pluriétnica al estilo nicaragüense y de un proyecto de reforma constitucional sobre el tema, en 1991.

Neoliberalismo y multiculturalismo: maquillar el desarrollo y preservar la desigualdad

A partir de la segunda mitad de los años ochenta en México se observa un cambio en las políticas indigenistas, que se hará más evidente bajo el gobierno de Carlos Salinas (19881994). En términos generales, se profundiza la tendencia a investir los pueblos indígenas de la responsabilidad de su propio desarrollo (siempre, claramente, en los términos definidos por las

\footnotetext{
${ }^{89}$ A la fecha es la herramienta del derecho internacional más utilizada para sustentar la legalidad de las luchas y los derechos indígenas. A pesar de que México fue el segundo país en adoptarlo, nunca se implementó realmente ni se tomó en cuenta en el marco legal y en las decisiones políticas del país.
} 
instituciones), lo que responde al precepto neoliberal de reducir la participación estatal y las políticas redistributivas, y aumentar la presencia del mercado y de los actores privados en la cobertura del bienestar social. Para leer claramente los cambios importantes acontecidos en las políticas del Estado hacia los indígenas, hay que ubicarlas con precisión en el marco de la crisis profunda que involucró los países latinoamericanos (y no solamente ellos) y que dio pié a la instauración del proyecto neoliberal que, con pequeños ajustes, sigue vigente (y se está expandiendo profundamente en los países europeos, a consecuencia de la crisis económica iniciada en 2008).

El modelo político y económico neoliberal se impone definitivamente a finales de los años ochenta, justificando el desmantelamiento del sistema de políticas públicas y económicas comúnmente conocido como Estado de Bienestar. Para el contexto latinoamericano, varios analistas definen el extinguido modelo como Estado nacional-desarrollista y populista (Assies 1999; Castro, Mussali, Oliver 2005); dichos investigadores mencionan la coincidencia entre la crisis de la deuda externa y la época de las "transiciones democráticas" en diversos países de América Latina, lo que impuso en la agenda política el tema de la "reforma del Estado". Tal cuestión, necesaria en ese entonces como ahora, fue utilizada instrumentalmente por las élites políticas conservadoras y las lobbies económicas, que hicieron suyo el supuesto de las organizaciones financieras internacionales (sobre todo el FMI, el BM y el BID) de que el Estado se había convertido en un obstáculo al crecimiento económico de la región. ${ }^{90}$

A esta visión respondió el primer intento de invertir la marcha en las políticas indigenistas mexicanas; condenando los enfoques asistencialistas y enfatizando el valor de la "participación” en los proyectos de desarrollo, nacen el Programa Nacional de Solidaridad (PRONASOL) y los Fondos Regionales de Solidaridad. En línea con la tendencia general de depositar la responsabilidad de desarrollo social en la sociedad civil, los proyectos promovidos

\footnotetext{
${ }^{90}$ Según Castro, Mussali y Oliver, "las principales tesis del neoliberalismo sobre el Estado han girado en torno a las siguientes ideas básicas: 1) El Estado nacional-desarrollista entró en una crisis terminal porque su dinamismo económico estuvo basado en el gasto publico discrecional y populista, en el intervencionismo del Estado que impidió el desarrollo del mercado y la eficiencia económica. 2) Los estados deben dejar su lugar a las fuerzas del mercado y acabar con la regulación política de la acumulación, con el intervencionismo en la economía y con el proteccionismo industrial y comercial. 3) Se deben desarrollar programas focalizados y compensatorios de política social hacia los núcleos marginados de la población" (2005:19-20). En términos generales, las reformas neoliberales implican restauraciones fiscales y monetarias, la mercantilización de los sistemas judicial, electoral y, en mayor medida, de educación y salud; así como la privatización de servicios públicos como agua, luz, etc. Tales reformas se dan acompañadas por políticas de descentralización, en particular de servicios públicos sociales, que pasan a ser asumidos como responsabilidad de la "sociedad civil" (Organizaciones No Gubernamentales y empresas privadas).
} 
entre 1988 y 1998 perdieron el carácter "benefactor" y privilegiaron la constitución de organizaciones de productores y el financiamiento a proyectos productivos. Estos proyectos no modificaron la situación de dependencia de los beneficiados desde la institución financiadora, que establecía los como y cuando de la participación; asimismo, intervinieron en las estructuras comunitarias, ya que se trataba de proyectos en beneficio de un grupo de individuos y no de la comunidad en su conjunto.

Según Saldívar Tanaka, el objetivo de las políticas indigenistas en este periodo fue, por un lado, la introducción de criterios económicos y de productividad en los programas estatales para los pueblos indígenas; por otra parte, afianzar la presencia institucional e introducir mecanismos organizativos que podían ser manipulados por las instituciones indigenistas (disciplinamiento), tras la máscara de favorecer el empoderamiento y la participación. Según la autora:

El proceso de individualización y disciplina -como grupos de interés y/o ciudadanos- que se inició con Salinas, se agudizó en las administraciones subsecuentes de Ernesto Zedillo y Vicente Fox, donde el liberalismo social promulgado por la administración de Salinas abandona las pretensiones sociales y se vuelve abiertamente una política de liberación económica en todos sus sentidos (2008:146).

A diferencia del modelo desarrollista, la propaganda neoliberal se orientó en sostener que el eje del desarrollo es el libre juego de las fuerzas de mercado. Resultado de tal tendencia es la creciente pauperización de grandes sectores sociales: así, mientras en línea teórica los planes asistencialistas desaparecen, el desarrollismo sale de la puerta y entra por la ventana, ya que ahora se impulsan programas de "lucha contra la pobreza extrema", auspiciados en particular por el Banco Mundial. En México, ejemplos de tales políticas focalizadas son, entre otras, el programa Progresa-Oportunidades y el Proyecto de Desarrollo Rural en Áreas Marginadas, junto con el Proyecto de Desarrollo Municipal en Áreas Rurales, que mira a la descentralización. ${ }^{91}$

Tales estrategias de focalización no implementan derechos universales, sino que se concentran en determinados sectores sociales, buscando -otra vez- su desarrollo o

\footnotetext{
${ }^{91}$ Análisis críticos sobre el impacto de tales políticas se encuentran en Nahmad 2004; Arzate 2008; Pérez 2008; Velasco 2008.
} 
empowerment ("formación de capital humano") para que después puedan participar en el mercado competitivo que los rodea ${ }^{92}$. En la mayoría de los casos las políticas focalizadas, a la par de los programas de desarrollo, no toman en consideración la diferencia cultural y la posibilidad que existan diversas visiones del mundo y del futuro por parte de los grupos sociales y los pueblos. Por otro lado, no cuestionan la relación estructural de desigualdad entre los grupos a los que se dirigen y las élites que concentran la mayor parte de la riqueza.

Las políticas neoliberales de atención a la pobreza extrema parecen reproducir el viejo esquema de las políticas asistencialistas y neocorporativistas latinoamericanas de antes de los ochentas, pero ahora revestidas por un discurso ideológico de naturaleza dogmática (productoras de capacidades, ciudadanía, empoderamiento, capital social) y cientificista, que las hace aparecer como políticas y programas pulcros, objetivos y justos (Arzate 2008:120).

Las políticas focalizadas son también espejo de un modelo de desarrollo individual e individualizador, para el cual la "pobreza" es un problema que cada persona debe superar fortaleciendo sus capacidades. Esto implica la descontextualización del individuo de su entorno social, que determina la condición individual, de la misma manera en que el paradigma generalizador de la "pobreza", en su opacidad, impide ver y apuntar a la resolución de sus causas más profundas (exclusión, desigualdad, es decir violencia estructural). Según Restrepo (2003: 6), “el asistencialismo clientelista neoliberal perpetúa la dependencia de los beneficiarios de las políticas sociales. Individuos dispersos compiten por demostrar la postración en la que se encuentran sumidos, y grupos de personas elaboran proyectos específicos para ser meritorios de la benévola atención de los subsidios".

En términos generales, de acuerdo a la bibliografía consultada, he observado como las directrices indicadas por los organismos internacionales indiquen dos caminos, aparentemente contradictorios, para las políticas públicas nacionales. Por un lado, como acabo de mencionar, las políticas focalizadas hacia la pobreza extrema, que despojan el sujeto de intervención de cualquier característica identitaria (indígena, campesino, afrodescendiente, migrante, etc.), recubriendo a todos de la caracterización homogeneizadora de "pobres" o "marginales" (una

\footnotetext{
92 Otro ejemplo para México es el de las Ciudades Rurales en Chiapas, financiado por la ONU y el Banco Mundial, que tiene como objetivo reorganizar el territorio y los asentamientos humanos de acuerdo a los planes geopolíticos y económicos transnacionales (como el Plan Puebla Panamá) en los cuales el estado se está insertando activamente.
} 
tendencia ya presente en el programa Solidaridad impulsado durante el gobierno de Salinas y que se encuentra inmutada en la muy criticada Cruzada Nacional contra el Hambre promovida por el gobierno mexicano en el periodo 2012-2018). Por otro lado, políticas enfocadas culturalmente que tratan de reincorporar en las redes institucionales demandas potencialmente desestabilizadoras (indígenas, feministas, etc.), reconociendo y enfatizando algunos aspectos culturales de las reivindicaciones, y desviando la atención de las demandas más profundamente políticas (multiculturalismo neoliberal), incluso por medio de la inclusión en estructuras institucionales y en la burocratización de las demandas originariamente políticas. A partir de una interpretación muy parecida (sustentada en el análisis de varias experiencias a lo largo del continente Latinoamericano), Zibechi llega a definir las políticas de "combate a la pobreza" como "contrainsurgencia", pues según el autor eluden los cambios estructurales, bloquean la emergencia de los conflictos y se apropian de las prácticas auto-organizativas de "los de abajo"; en esto, el papel de las ONG como operadores del poder estatal es determinante (Zibechi 2010).

En este último sentido se sitúan las directrices del Banco Interamericano de Desarrollo (BID) y el Banco Mundial (BM), que en los años noventa empezaron a concretizarse en específicas políticas del Estado hacia los pueblos indígenas. ${ }^{93}$ En particular el BM implementó un programa de fondos directos que motivara a los gobiernos latinoamericanos a descentralizar sus sistemas políticos-administrativos para promover el desarrollo de las poblaciones marginales en los aspectos sociales, ecológicos, de género y étnicos. Al respecto, hay que preguntarse por qué el BM, los gobiernos nacionales y las demás instancias del aparato de desarrollo iniciaron a considerar una parte de las demandas de los pueblos indígenas, quienes en las décadas anteriores eran considerados como la traba a la modernización y al "progreso" del campo latinoamericano. Desde una visión "externalizadora", Van Cott argumenta que:

Los organismos multilaterales, presionados por las redes internacionales por los derechos indígenas, sobre todo de EEUU y Europa, han modificado sus políticas de préstamos y de desarrollo de tal manera que se exige a los gobiernos que protejan a las culturas indígenas y mantengan consultas con sus representantes. Las élites políticas, conscientes de los cambios en

\footnotetext{
${ }^{93}$ Véase la compilación de Hernández, Paz y Sierra, El estado y los indígenas en tiempos del PAN, donde se detallan las tendencias políticas que caracterizan al Estado mexicano en la última década.
} 
las pautas y el discurso en defensa de los derechos humanos a escala global, y que desean ser vistas como cumplidoras de los mismos, se muestran cada vez más receptivas a estas demandas (2004:156).

Aportando elementos complementarios, Bretón (2007: 97) afirma que:

La apertura y sensibilidad hacia las demandas étnicas constituye, en primer lugar, una respuesta al vigor y a la capacidad de movilización demostrada por las organizaciones indígenas ya plenamente establecidas al inicio de la década de 1990. La aparición en escena de esos nuevos movimientos indianistas como actores políticos recurrentes, en segundo lugar, se dio paralelamente al colapso del desarrollismo estatalista de viejo cuño, bajo la égida de los preceptos del Consenso de Washington y en un marco en el que la izquierda estaba atravesando acaso la crisis más profunda de su historia.

El autor identifica dos grandes hitos a escala continental (los levantamientos indígenas de 1994 en Chiapas y en Ecuador) que evidenciaron "de qué manera variables consideradas desde el dogma neoliberal como meras 'externalidades' al modelo -los costos sociales- podían llegar a convertirse en verdaderas 'internalidades' capaces de dificultar la consolidación y desarrollo libre y sin trabas de los designios del mercado" (2007: 97). Por tales motivos se impuso una reconsideración de algunos aspectos de las políticas públicas supranacionales, para reconducir estas fuerzas transformadoras hacia caminos compatibles con las metas del desarrollo neoliberal. En el contexto del llamado "Post-Consenso de Washington" (medidas para hacer más flexibles las directrices en materia de desarrollo), el Banco Mundial impulsó "nuevos" discursos como el de capital social o desarrollo con identidad.

Por lo que concierne el discurso del desarrollo, en los años noventa éste ha cobrado nueva énfasis y se ha maquillado con nuevos adjetivos, como el de desarrollo humano acuñado por el Programa de las Naciones Unidas para el Desarrollo (PNUD), y el de desarrollo sustentable o sostenible. El concepto de desarrollo humano representa sin duda un cambio importante, ya que “considera al desarrollo más allá de un asunto únicamente económico y político, y se preocupa por ampliar las capacidades de las personas". 94

\footnotetext{
${ }^{94}$ Informe sobre el Desarrollo de los Pueblos Indígenas en México, CDI, 2006.
} 
Lamentablemente, el énfasis en la productividad y en la apertura de capacidades económicas, ${ }^{95}$ y la óptica economicista en los parámetros de medición del Índice de Desarrollo Humano, reducen la novedad del concepto. Con respecto al desarrollo sostenible, "precisamente en el momento en que el concepto de desarrollo era minado en sus cimentos, mostrándose insustentable, observamos paradójicamente un intento por recuperarlo a través del adjetivo 'sustentable' asociado al 'desarrollo', tal como se consagra en la relación del informe Brundtland de 1987, bajo los auspicios de la ONU" (Porto-Gonçalvez 2001:7). Anteriormente, la necesidad de la sostenibilidad de las relaciones entre la sociedad humana y su entorno había sido impulsada por organizaciones y movimientos ambientalistas, ante la indiferencia de las instituciones. $^{96}$

\section{Multiculturalismo normativo}

La instauración del régimen neoliberal implicó importantes modificaciones en las políticas de Estado hacia los pueblos indígenas. En los años ochenta y noventa del siglo XX, una poderosa ola de movilizaciones indígenas en casi todo el continente impuso en la agenda internacional el debate sobre la necesidad de transformar el paradigma monoétnico que históricamente rigió los Estados nacionales. En esta nueva coyuntura política la ideología del multiculturalismo ganó espacio y legitimidad.

En América Latina, podemos entender como multiculturalismo "una dinámica entre las demandas políticas, culturales y socioeconómicas de los pueblos indígenas y sus aliados, y las respuestas de los Estados, las agencias internacionales y el mercado frente a ellas" (Sieder

\footnotetext{
${ }^{95}$ Como se puede ver en el Plan Nacional de Desarrollo 2007-2012 de México, que adopta en un sentido marcadamente cosmético lo humano, manteniendo el interés principal en el crecimiento económico, en la creación de una economía competitiva, y en la garantía de los derechos de propiedad privada. El documento se puede consultar en www.presidencia.gob.mx

${ }^{96}$ Según Esteva el desarrollo sustentable "se ha concebido como una estrategia para sostener el 'desarrollo', no para apoyar el florecimiento y la perduración de una vida cultural y social infinitamente diversa" (Esteva 2001: 80). No es ninguna novedad que los ámbitos de poder se apropien de los discursos de la resistencia vaciándolos de su contenido subversivo y ajustándolos a la lógica dominante, o que creen términos y discursos que se mimetizan con las reivindicaciones contestatarias para acercar al ámbito institucional los sectores sociales que están planteando cambios radicales. En este sentido, el termino desarrollo sostenible ha encontrado un gran favor por parte del Banco Mundial y del Foro Económico Mundial de Davos, que así pretenden combatir aquella desigualdad que el mismo BM y el Fondo Monetario Internacional están causando a través de sus políticas macroeconómicas. Quiero dejar en claro que mi crítica no se refiere al concepto de sostenibilidad, que promueven movimientos, organizaciones ambientalistas e incluso académicos reconocidos por su compromiso social, sino al de desarrollo, que aparece irremediablemente marcado por su etnocentrismo.
} 
2006); el adjetivo normativo define el multiculturalismo como una política del Estado "para la superación de las desigualdades que se generan en la sociedad como producto de las diferencias culturales" (Bello 2006:91-92).

La ideología multiculturalista incluye el reconocimiento por parte de los Estados de la diversidad étnica y cultural y, como elemento de éste, la necesidad de otorgar algunos derechos específicos al respecto.

Aunque aparezcan frecuentemente como sinónimos, hay una diferencia sustancial entre multiculturalidad y multiculturalismo. Hablamos de multiculturalidad "para referirnos a las situaciones de hecho en las que coexisten pueblos y culturas diversas"; el término por lo tanto tiene un valor descriptivo de la realidad que, actualmente, comparten la mayoría de los países del mundo. Consecuencia de la generalidad del fenómeno, es que no haya un único tipo de multiculturalidad, sino diferentes procesos de acuerdo al desarrollo histórico y político de las sociedades. León Olivé identifica al menos tres tipos de sociedades multiculturales: en un caso, las comunidades cuentan con territorio propio, como los quebequenses en Canadá, o los pueblos que integran España o el Reino Unido. Otro caso que se considera es principalmente el de Estados Unidos y de los países europeos (aunque con importantes diferencias en los dos casos), donde las comunidades de inmigrantes de diferentes nacionalidades comparten espacios públicos y servicios con el resto de la población, y no hay una separación geográfica neta. Aún diferente es la multiculturalidad en los países latinoamericanos: aquí la mayoría de los pueblos indígenas comparten territorios con otros pueblos y con mestizos, aunque las zonas donde viven sean relativamente delimitadas y no compartan de hecho servicios y espacios públicos con otros sectores de la población (debido también a que frecuentemente son territorios que carecen de estructuras y servicios básicos).

A las diferentes articulaciones de la diversidad en las sociedades deberían corresponder diferentes modelos normativos: a esta dimensión se refiere el término de multiculturalismo, como un modelo propuesto para el gobierno de la multiculturalidad. Hay que recordar que tal concepto nació al principio de los años setenta del siglo XX en América del Norte y se trasladó sucesivamente a Europa y América Latina; sin embargo tanto las conformaciones de las sociedades cuanto el nivel de democracia de los Estados son profundamente diferentes, lo que determina los límites y los alcances de las políticas multiculturales adoptadas. 


\section{AUTONOMIAINDÍGENA, VIOLENCIAY JUSTICIA}

En el debate filosófico alrededor de la diversidad cultural se han definido por lo menos dos maneras de entender el multiculturalismo, que Olivé (1996) define como el "multiculturalismo liberal individualista" y el "multiculturalismo comunitarista". 97 Estas se diferencian por las concepciones que tienen alrededor de la propia diversidad cultural y de las relaciones entre las culturas, así como entre la colectividad y el individuo, y entre los grupos y el Estado. Las cuestiones centrales que animan el debate son, a mi entender, dos: la afirmación de valores universales vigentes en todas las culturas, o más bien la idea que cada cultura tiene una identidad inconmensurable (universalismo vs. relativismo), lo cual produce diferentes modelos para el reconocimiento. En segundo lugar hay quien afirma la legitimidad del reconocimiento de derechos colectivos y de grupo a los pueblos, objetando la idea que basta con los derechos otorgados por los regímenes liberales a todos los individuos (comunitarismo vs. liberalismo), lo que da forma a marcos jurídicos y políticas públicas estatales.

Un importante debate que atañe las políticas multiculturales es el que se refiere a las políticas adoptadas para tratar de equilibrar las profundas desigualdades económicas y sociales ocasionadas por el manejo negativo de la diferencia cultural y la jerarquización étnica que históricamente ha estructurado las sociedades. Estas medidas -llamadas discriminación positiva o acciones afirmativas- son incluidas, con algunos matices, en la política de la diferencia de la postura comunitarista, y en la ciudadanía diferenciada planteada por Kymlicka. Hay quienes sostienen la necesidad de tales medidas ya que "se configuran como un camino necesario para alcanzar la igualdad social", según afirma Bernardino-Costa para la realidad de la población negra en Brasil afectada por "la hiperdesigualdad racial, la cultura racista y el techo de vidrio que impide la ascensión social de negros" (2012:209). Analizando la composición de estudiantes en las escuelas superiores y las medidas adoptadas por las instituciones para abrir cuotas especiales (para pobres, para negros, para habitantes de las favelas), el autor concluye que, de no ser por las políticas de acción afirmativa, "una nueva

\footnotetext{
${ }^{97}$ En el debate propio del mundo anglosajón, se pueden insertar en la primera corriente los trabajos de Joseph Raz. Con matices diferentes, la propuesta de Will Kymlicka (quien elaboró una amplia reflexión sobre la realidad multicultural y propuso con más fuerza el planteamiento de la ciudadanía diferenciada) se puede ubicar también en la esfera filosófica del pensamiento liberal. Por otra parte, destacados pensadores comunitaristas son Michael Walzer y Charles Taylor. En México el debate sobre el tema es también muy amplio, aunque con matices diferentes al que se diera en América del Norte. Entre los principales protagonistas están los filósofos Ernesto Garzón Valdés, Fernando Salmerón, León Olivé y Luis Villoro; así como los antropólogos Rodolfo Stavenhagen y Guillermo de la Peña.
} 
generación de jóvenes negros no tendría chance de acceso a la educación pública superior y, consecuentemente, [...] a las posiciones de prestigio económico, político y académico" (2012:209).

Por otro lado, hay quienes critican la "política de la diferencia", cuyo planteamiento cultural central es que el reconocimiento a la identidad del grupo o del individuo se realiza marcando la diferencia entre éste y la sociedad mayoritaria; El concepto de identidad fue central en el desarrollo de esta corriente, pues en "la política de la diferencia, lo que pedimos es la identidad única de este individuo o este grupo, el hecho que es distinto de todos los demás" (Taylor 1993:61). Según los críticos, el énfasis en la identidad puede llevar a un manejo esencialista de la misma por parte de los sujetos de políticas compensativas, lo cual más que a la armonización de la sociedad llevaría a una mayor fragmentación. ${ }^{98}$ Esto es, políticas basadas en el reconocimiento de la diversidad cultural y orientadas a la reducción de la desigualdad política y económica, históricamente causada por la discriminación de la cual han sido objetos los grupos al interior de la sociedad dominante, podrían llevar a que tales grupos enfaticen su particularidad para acceder a los recursos especiales.

Según este argumento, enfatizando el concepto de cultura también se enfatizan las fronteras entre las diversas culturas presentes en un territorio, pues las políticas de acción afirmativas suponen "objetos" identitarios delimitados y definidos sobre los cuales ejercerse (Dietz y Mateos 2009). Se fomentaría así una separación más que un dialogo entre culturas, así como una noción de cultura estática y esencializada, lo cual beneficia más quienes desde "afuera" aprovechan la diferencia cultural (mercado) que los mismos sujetos "culturalizados". 99 Como bien argumenta Villoro, "lo que destruye la identidad de un pueblo no es el cambio en sus formas de vida o de pensamiento, sino la negación de su capacidad para proyectar y realizar una imagen ideal de sí mismo, en la que el pasado se integre con la realidad actual" (1998:150). ${ }^{100}$ El planteamiento de la interculturalidad ${ }^{101}$ trata también de resolver dicha tensión, apuntando al dialogo y a la apertura de espacios compartidos.

\footnotetext{
98 Al contrario, en mi interpretación, las identidades sociales y culturales son contextuales, modificables, múltiples.

99 A esta visión se contrapondría la interculturalidad, enfocada a promover una "cultura política pública para fomentar las relaciones interétnicas de integración positiva [...] establecidas estas en una justicia distributiva y una justicia cultural" (Pérez Ruiz 2009: 272).

100 En el mismo sentido, el autor propone una noción de "autenticidad" que difiere cabalmente de la de "peculiaridad": una cultura seria auténtica "cuando está dirigida por proyectos que responden a necesidades y
} 


\section{AUTONOMIAINDÍGENA, VIOLENCIAY JUSTICIA}

En los últimos veinte años, casi todos los países latinoamericanos modificaron su legislación para adecuarse a lo establecido en el derecho internacional en materia de derechos indígenas (la principal referencia, de profunda importancia para las organizaciones indígenas, es el Convenio 169 de la OIT): tal política, auspiciada por los organismos multilaterales (el inevitable Banco Mundial y el Banco Interamericano de Desarrollo) ha sido llamada multiculturalismo constitucional (Van Cott 2000). Tales reformas se dieron en el contexto de la llamada "doble transición": la transición hacia gobiernos civiles y hacia la democratización de los Estados latinoamericanos, y la transición hacia un nuevo modelo de desarrollo, a través de las políticas de ajuste estructural marcadas por el neoliberalismo. Así, junto al reconocimiento de la diversidad cultural, implicaron también la transformación de las estructuras estatales en términos mercantilistas y privatizadores. El nuevo multiculturalismo se encaja en el proceso de desmantelamiento de los estados nacionales desarrollistas y la transformación de las políticas sociales, de por sí deficientes, mediante programas focalizados que pretenden "ayudar a los pobres a ayudar a sí mismos".

El multiculturalismo, como política pública de la diferencia, ha sido definido "la lógica cultural del capitalismo multinacional”, o del neoliberalismo (Žižek 1998), implicando la redefinición de lo que entendemos por “ciudadanía”. En México el multiculturalismo constitucional se inauguró en 1992, cuando se reformó el artículo $4^{\circ}$ de la Constitución, para adecuarlo $^{102}$ al Convenio 169 de la Organización Internacional del Trabajo (recién firmado por México). Esta reforma, que se ubica en el contexto del ascenso del movimiento indígena a nivel nacional y continental, cuya expresión más reciente era la Campaña 500 Años de Resistencia Indígena Negra y Popular, responde a la presión política del mismo movimiento indígena y de una parte de la izquierda mexicana, que desde hace tiempo exigía abordar el tema de los derechos indígenas en ámbito legislativo. ${ }^{103}$

\footnotetext{
deseos colectivos básicos y cuando expresa efectivamente creencias, valoraciones y anhelos que comparten los miembros de esta cultura", pero también debe saber "responder en forma renovadas a necesidades variables que exigen a menudo tareas insólitas" (pp.75-77).

${ }^{101}$ Expresado en México, entre otros, por Olivé (2004), y más recientemente, por varios de los artículos incluidos en Pérez Ruiz, Valladares y Zárate :2009

${ }^{102}$ En realidad tal adecuación no se logró por completo, como se vio en los reclamos indígenas manifestados durante los Diálogos de San Andrés.

${ }^{103}$ En el marco del proceso de reforma, iniciado en 1990, los entonces diputados del Partido de la Revolución Democrática López y Rivas y Ruíz presentaron-sin éxito- ese mismo año una iniciativa de Ley para el reconocimiento de las autonomías regionales pluriétnicas (proponiendo la reforma a los artículos 53,73 y 115.
} 
En el marco del proceso de reforma constitucional se modificaron los artículos 52 del Código Penal (que considera los usos y costumbres de los indígenas inculpados) y 28 del Código Federal de Procedimientos Penales (que permite a los indígenas nombrar un traductor en los juicios). A más de veinte años de haberse introducido, en muchas regiones de México estos derechos son sistemáticamente inaplicados e incluso desconocidos por las instituciones de justicia, como demostraré en detalle para el estado de Chiapas. La reforma, que tardó dos años para realizarse, aparece limitada en sus alcances y sesgada por la visión indigenista y asistencialista oficial (donde el Estado sigue siendo el promotor del desarrollo de los pueblos indígenas). Sin embargo, el reconocimiento del carácter pluricultural de la nación mexicana fue un hito histórico, y por eso la reforma fue apoyada por la misma izquierda autonomista, y considerada un necesario avance hacia el reconocimiento de los derechos que derivan de la diversidad cultural.

Los limitados avances de esta reforma fueron contrarrestados por la modificación al artículo 27, en el mismo año, que dio por terminado el reparto de tierras, y transformó el carácter de la propiedad social de la tierra, abriendo las posibilidades para la mercantilización de las áreas comunales y ejidales. Mientras la reforma al artículo $4^{\circ}$ no significó ningún cambio en la realidad concreta de los pueblos indígenas, la nueva Ley Agraria impactó profundamente en su relación con la tierra, elemento inseparable de la vida socioeconómica, política y religiosa indígena (Echánove 2000:155). Esta reforma responde a directrices impulsadas por organismos internacionales, como el Banco Interamericano de Desarrollo (BID) y el Banco Mundial (BM), y se inscriben en el intento de la clase política de proyectar a México como un país "del primer mundo", entre otras cosas por medio de la negociación del Tratado de Libre Comercio de América del Norte (TLCAN).

Sucesivamente, tras la presión ejercida por el levantamiento indígena chiapaneco de 1994, guiado por el Ejercito Zapatista de Liberación Nacional, se volvió a reformar la Constitución. La Reforma en Materia de Derechos y Cultura Indígena del $2001^{104}$ representa un ejemplo del proceso, común a muchos países latinoamericanos, llamado reconocimiento retorico del multiculturalismo (Van Cott 2000a). En primer lugar, los derechos formalmente reconocidos no son implementados concretamente, a través de leyes secundarias y políticas

Los mismos legisladores presentarán una propuesta muy similar en 1992, proponiéndola como Ley reglamentaria al artículo $4^{\circ}$, que tampoco fue aceptada.

${ }^{104}$ Haré mención de dicha Ley, con más detalles, en el capítulo siguiente. 
públicas, quedándose las reformas en declaraciones de intentos. En segundo lugar, el giro multicultural representa la estrategia del Estado para administrar la diversidad depurándola de su contenido contestatario. Implícita en muchas de las "políticas de reconocimiento", la reducción a un nivel mínimo de la autonomía formalmente reconocida revela la renuencia de los gobiernos a reconocer realmente las formas y estructuras del gobierno indígena.

Sin embargo hay que considerar que, no obstante en muchos casos el reconocimiento cultural formal no dé lugar a desarrollos efectivos y no se implemente políticamente, los instrumentos legales, tanto a nivel de los diferentes Estados como en el plano internacional, son en buena medida fruto de un potente proceso de movilización de los pueblos y las organizaciones indígenas. Estos logros han permitido que el "sujeto colectivo indígena" siguiera creciendo y articulara de forma cada vez más efectiva sus reivindicaciones.

En un estudio publicado en 1993, cuando la tendencia legislativa hacia el reconocimiento del multiculturalismo y de los derechos indígenas se estaba apenas desarrollando, Schmidt argumenta que, para el pueblo Mbya Gauaraní en Paraguay y Argentina, la promulgación de leyes que reconocían sus derechos culturales y territoriales representó una oportunidad para que los indígenas llevaran a la arena nacional su lucha de resistencia y fortalecieran los vínculos entre la sociedad y los grupos étnicos, en el marco del fin de las dictaduras militares que sometieron ambos países en las décadas de los setenta y ochenta. En Argentina, el debate generado alrededor de las demandas indígenas se inscribió en el proceso de democratización y lo enriqueció, mientras que en Paraguay aportó elementos de continuidad histórica al proceso de (re)construcción de la identidad nacional (Schmidt 1993).

Pese a la existencia de una gran distancia entre las declaraciones jurídicas y la implementación de políticas públicas que las actualicen, la presencia de derechos colectivos de base indígena comunitaria han permitido no solamente romper, por lo menos en ciertos ámbitos "formales" o "discursivos", con la lógica monocultural ${ }^{105}$ del Estado-nación, sino también dotar de una base jurídica y política a las demandas de derechos culturales y lingüísticos, así como, lo que constituye un salto cualitativo, de la autonomía y autogobierno territorial. Al respecto, en México se ha distinguido entre una primera etapa (1992-1995) en la cual el movimiento indígena se formó y probó su fuerza a partir de demandas basadas en la reivindicación de la diversidad en cuanto pueblos, demandas centradas en el reconocimiento

\footnotetext{
${ }^{105}$ Un Estado = una nación = un pueblo = una cultura = una lengua.
} 
constitucional de los derechos culturales y educativos; y una segunda etapa (1996-1998) en la que la autonomía y la autodeterminación se convierten en las demandas centrales del movimiento indígena tras el impulso determinante del Ejército Zapatista de Liberación Nacional (Trejo 2000).

\section{Derechos individuales y colectivos, derechos a la pertenencia y a la diferencia}

En el diálogo entre posiciones liberales y comunitaristas, un elemento central es el tema de los derechos colectivos, su relación con el sistema de los derechos individuales y la legitimidad de su reconocimiento.

Los derechos colectivos de los pueblos indígenas se diferencian de los derechos civiles y políticos, individuales por excelencia ${ }^{106}$, llamados de "primera generación”; y también de los de "segunda generación", económicos, sociales y culturales. Cuando se habla de derechos de “tercera generación” se hace referencia a derechos difusos ${ }^{107}$ y colectivos. La definición de derechos colectivos se relaciona con una amplia gama de conceptos como 'derechos de minorías', 'grupos de derechos diferenciados', 'derechos culturales', 'derechos consociativos', etc., que encarnan diferentes visiones acerca de la diversidad. Un lugar especial en la caracterización de los derechos colectivos los ocupan los derechos de los pueblos indígenas, definidos por algunos autores como “derechos étnicos” (Thompson 1997; Kymlicka 1996).

En el debate filosófico, político y antropológico, los derechos colectivos han sido muchas veces contrapuestos a los individuales. La principal crítica avanzada en contra de los derechos colectivos es la llamada "teoría de la redundancia", que los define superfluos, ya que los derechos individuales colmarían todas las necesidades de libertad y justicia.

Otro argumento es que los derechos colectivos pondrían en peligro el respeto a muchos derechos individuales, o en todo caso, al principio esencial de la igualdad. Al respecto, la primera interrogación que deberían hacerse los críticos es si y en qué medida, hasta la fecha, la

\footnotetext{
${ }^{106}$ Gran conquista de la sociedad civil en los siglos XIX y XX.

${ }^{107}$ El Derecho Internacional de los Derechos Humanos considera que algunos derechos colectivos son el derecho al desarrollo, a la paz, al patrimonio artístico y cultural, a un medio ambiente sano, así como los derechos de los consumidores. Los derechos colectivos se distinguen de los difusos porque es relativamente posible determinar quienes concretamente pueden reclamarlos o son afectados por su violación, tendiendo a referirse a grupos más específicos. Al revés, los derechos al desarrollo o a la paz son derechos difusos porque su violación nos afecta a todos pero no es posible determinar específicamente a quiénes.
} 
presencia teórica de los derechos individuales ha beneficiado a la condición de los pueblos indígenas; para ello habría que tener una perspectiva histórica del problema, o sea un enfoque procesual. Cuando se habla de derechos colectivos como "redundancia", se considera implícita la conclusión de que los grupos y sujetos que reivindican los derechos colectivos están en un marco consolidado de derechos individuales, mientras en la realidad la proclamación teórica y constitucional de los mismos no ha sido garantía para su disfrute universal. Es más, los derechos individuales se han gozado en muchas ocasiones merced a la exclusión del otro o "lo otro".

Afirma Magdalena Gómez, con respecto a la coyuntura mexicana:

Suele responderse a la demanda por el reconocimiento de derechos a los pueblos indígenas que la Carta Fundamental contiene un avanzado capítulo sobre garantías fundamentales para todos los individuos, incluidos, por supuesto, los indígenas. Por lo tanto, pedir reconocimiento de derechos diferentes es cuestionar el principio de universalidad, es crear inaceptables regímenes de excepción, derechos especiales, establecer discriminación positiva y, en última instancia, vulnerar uno de los pilares del orden jurídico. Todo ello sería válido si se plantearan derechos para los indígenas en cuanto personas. Sin embargo, se está buscando el reconocimiento constitucional a una realidad social que permanece a contrapelo de la pretensión de homogeneidad y de igualdad [cursivas mías]. Los pueblos indígenas persisten, han practicado y practican formas de organización social y política, y cuentan con culturas diferentes que por lo demás están en nuestras raíces como Nación. Ninguna de las llamadas garantías individuales permite la adaptación a estos derechos colectivos, a estos derechos de pueblo, a este nuevo sujeto jurídico (2002: 270-271).

En la interpretación que aquí se sostiene, el reconocimiento de los derechos de los pueblos indígenas en el ámbito estatal no debe ser subordinado a una precedente efectividad de los derechos individuales y a la provisión de acceso igualitario a los recursos. Estos tres elementos son derechos fundamentales de los pueblos indígenas y a la vez se les deben reconocer. Para que puedan disfrutar de los derechos individuales necesitan la reducción de la condición de desigualdad y el reconocimiento de sus derechos colectivos: todo este conjunto se puede resumir en el proyecto político de autonomía.

Con respecto a la discusión entre derechos colectivos e individuales, otro punto que preocupa a muchos pensadores es éste: ¿los derechos colectivos preceden a los derechos 
individuales? ¿Cuál de los dos debería tener preeminencia? Se trata de una discusión bastante estéril, ya que considero los dos tipos de derechos como complementarios. De todos modos, esto no excluye la posibilidad de conflicto entre las dos definiciones de derechos.

Según Villoro “el Estado moderno nace con una tensión interna entre el poder central que intenta imponer la unidad y los pueblos diversos que componen una realidad social heterogénea; [...] nace a la vez del reconocimiento de la autonomía de los individuos y de la represión de las comunidades a las que los individuos pertenecen" (1998:80). El autor argumenta que el derecho de los pueblos a su autodeterminación es anterior a la constitución del Estado-nación, y en esto reside la necesidad de su reconocimiento incondicionado. En oposición a Villoro, Clavero (1994) sostiene que no debe presumirse y darse por sentado ningún derecho de la colectividad sobre el derecho de los individuos, y que son siempre los derechos individuales los que pueden originar los derechos colectivos.

Un autor peruano, Montoya Rojas, resuelve esta contradicción afirmando que:

La prioridad atribuida a lo individual en desmedro de lo colectivo dentro de la órbita occidental capitalista, es un error comparable al que resulta de priorizar lo colectivo en desmedro de lo individual, que fue lo que ocurrió en el caso de los países del llamado socialismo realmente existente. Oponer lo individual a lo colectivo ha sido y sigue siendo un gravísimo error en la política occidental. No hay sociedad sin individuos ni individuos sin sociedad. Si se reconoce este hecho de la realidad es perfectamente posible fundar un derecho colectivo al lado y no en oposición del derecho individual" (1998: 56).

Villoro, como otros autores (entre ellos Olivé), admite la necesidad de unos derechos fundamentales o derechos humanos básicos, que de ninguna forma pueden ser discutidos ${ }^{108}$. Entre los que Villoro presenta como derechos fundamentales o básicos está el de pertenencia a una comunidad cultural. Concuerdo con el autor en que "nadie puede elegir su plan de vida más que considerando el conjunto de fines y valores realizables a que puede tener acceso; este conjunto está dado por una cultura" (2002:222). Por lo tanto el derecho a la pertenencia

\footnotetext{
108 Según Olivé tales principios se construyen en la interacción de los miembros de los diferentes pueblos que participan en la acción política. Se tratará de principios puestos sobre la mesa de discusión, cuya definición precisa debe determinarse en común y revisarse constantemente, aunque una vez establecidos no serán pasibles de violación por ninguno de los participantes al acuerdo. En lo que pertenece al argumento de los derechos humanos, esta propuesta me parece muy útil, debido a la necesidad que tales derechos sean construidos en un marco respetuoso de la diversidad, precisamente por su pretensión de validez universal.
} 
(derecho colectivo y a la vez individual) puede estar en la base de cualquier derecho del individuo, ya que presupone la subsistencia del todo social al que pertenece. El derecho a la autonomía de las personas, ${ }^{109}$ fundamento de los derechos humanos individuales, implica el derecho a la autonomía de las comunidades culturales a las que se pertenece: esto es, el derecho a la autodeterminación de los pueblos, entendido entonces como derecho humano fundamental. En el mismo sentido, Sousa Santos afirma que "la falta de legitimidad cultural es una de las causas principales de las violaciones de los derechos humanos" (1998:219).

Con respecto al debate sobre la necesidad y la primacía entre los derechos individuales y los colectivos, Olivé propone un punto de vista diferente, introduciendo el concepto de derechos del grupo. Éstos se diferencian de los derechos colectivos (un ejemplo es el derecho a hablar un idioma particular), y son finalmente derechos de los individuos en cuanto pertenecen al grupo. El derecho a la diferencia es un derecho de los individuos. Según la definición del autor, "se trata del derecho de los miembros de cierto grupo social a ser reconocidos como tales y a gozar de determinados beneficios en favor de ello" (2004:82). Pero si hablamos del derecho de un pueblo a la autodeterminación, esto no se puede reducir a los derechos de los individuos, aunque surge de ellos. Cuando hablamos de derechos de grupo, nos estamos refiriendo a sujetos colectivos (en estos términos se refieren a los pueblos indígenas los tratados internacionales que les reconocen tales derechos, y también el texto de los Acuerdos de San Andrés), sujetos jurídicos y políticos, aunque no morales. En consecuencia, "el reconocimiento de un derecho de grupo podría dar lugar a que se otorgue cierta prioridad a la comunidad, por encima de los individuos" $" 110$ (2004:83). Las dos clases de derechos serían pues complementarias. En este argumento, las conclusiones de Olivé recalcan las de Villoro: reconocer el derecho a la diferencia (comparable al derecho a la pertenencia de Villoro) en cuanto derecho colectivo de los individuos, conlleva la necesidad de reconocer el derecho del grupo a la autodeterminación o autonomía.

\footnotetext{
${ }^{109}$ Para una exhaustiva discusión sobre el derecho a la autonomía individual y su relación de necesidad con la autonomía de los grupos, véase Villoro 1998; Olivé 2004.

${ }^{110}$ Hay que considerar que no necesariamente las atribuciones de los derechos de grupo se superponen o substituyen los derechos individuales. También hay que valorar el hecho que muchas veces se observa en los pueblos indígenas una propensión o hábito a ceder parte de los derechos individuales a favor del buen funcionamiento de la vida comunitaria; esto no necesariamente es considerado una imposición o violación de los derechos del individuo, sino más bien un efecto positivo, que caracteriza la vida comunitaria. Por lo contrario, también hay muchos hábitos impositivos y que violan los derechos individuales, y algunos integrantes del grupo se rehúsan a seguir aceptándolos. Sobre esto hay una tensión que podría en parte resolverse adoptando la visión de dialogo intercultural, que menciono en el apartado ¿A quién quieren que seamos iguales?.
} 
Multiculturalismo y (neo) indigenismo: ¿a quiénes benefician los derechos culturales? Políticas del reconocimiento y multiculturalismo neoliberal

Quiero adentrarme brevemente en un debate que en mi consideración aporta elementos fundamentales para el análisis de las actuales políticas públicas hacia los pueblos indígenas en México, y las relaciones entre éstos y los diferentes aparatos del Estado.

Sin negar que la reivindicación de la diferencia ha sido un elemento madurado por la subalternidad como parte de la crisis del Estado-nación, lo cierto es que, al ser un significado social, en las últimas décadas los Estados se han apropiado de este capital simbólico y lo han puesto en el centro de lo que se considera políticamente correcto (Paz Patiño: 2004).

Sustentando su afirmación en un análisis de las políticas de reconocimiento en varios países de América Latina, las cuales identifica como políticas "neoindigenistas" nacidas de la crisis del modelo integracionista, Gros afirma que frecuentemente es el mismo Estado el que crea etnicidad y produce la necesidad de la autonomía, en aras de la institucionalización de la frontera étnica. Advierte que esto no pasa de forma igual en todos los países (México sería en parte una excepción), y menciona como "las nuevas políticas indigenistas bajo la voluntad de otorgar y reconocer la autonomía, lograrían de un modo 'perverso' controlarla, limitarla o, simplemente, negarla" (Gros 2000:183). Esta estrategia ha sido bien definida como “diesmpowerment by boundaries" para el caso boliviano (Booth, Clisby e Widmark 1997).

El meollo de esta última crítica a las políticas multiculturalistas adoptada por varios Estados es que "el multiculturalismo se ocupa de la diversidad en cuanto diferencia 'cultural', mientras repudia o deja de lado las diferencias económicas o sociopolíticas que, de aparecer, tendrían como efecto marcar la disparidad respecto al liberalismo económico que está en su base" (Díaz-Polanco:2005). Esta crítica se refiere ya no al multiculturalismo como postura teórica sino como política pública, y en su carácter de complemento sustantivo del modelo neoliberal. Speed y Sierra (2005) notan cómo, mientras el Estado define derechos colectivos estableciendo políticas multiculturales, lo ha hecho frecuentemente como manera de limitar las reivindicaciones más radicales de los movimientos indígenas. En el mismo sentido, Sousa Santos afirma que "el multiculturalismo desplazó la energía contestataria del ámbito económico-social al ámbito sociocultural, hecho que, de algún modo, contribuyó a considerarlo inofensivo y hasta funcional para la reproducción del capitalismo" (2012: 150). 
La observación de los procesos organizativos indígenas lleva, sin embargo, a matizar estas visiones, pues en una dinámica dialéctica, también los pueblos se apropian de las políticas y de los espacios instituidos por el Estado. Ejemplo de ello es la utilización, para fines propios y colectivamente determinados, de proyectos ofrecidos por las instituciones indigenistas; lo es también la apropiación de espacios en las radiodifusoras del sistema indigenista, entre otras estrategias. En el campo de la justicia, ha sido documentado como, en ocasiones, la organización indígena penetra y transforma los juzgados indígenas, constituidos por el Estado con el intento de suplantar las estructuras propias de los pueblos. ${ }^{111}$ En la arena política, mientras el Estado trata de disputar la legitimidad de los procesos indígenas y comunitarios englobándolos a su proyecto, los sujetos indígenas organizados se hacen fuertes de los avances en el reconocimiento de sus derechos y buscan moldear y ocupar los espacios institucionales a los que pueden tener acceso.

Según el análisis de diferentes autores, ${ }^{112}$ la globalización ${ }^{113}$ ha encontrado la manera de aprovechar la diversidad sociocultural a su favor, ya sin la necesidad de violentas políticas homogeneizadoras y abiertamente etnocidas, ni apelando exclusivamente a la igualdad de deberes como medio para acceder a igualmente universales (y etnocéntricos) derechos democráticos. El modelo democrático neoliberal parece no imponer un estricto modelo cultural y de ciudadanía; aunque los aparentes espacios concedidos a los sujetos son condicionados a no contradecir los intereses imperantes del mercado (Hale: 2004). Para Hardt y Negri (2002), el momento diferencial "implica la afirmación de diferencias aceptadas dentro del espacio del imperio". Por lo regular, las diferencias exaltadas son las consideradas "culturales", no conflictivas ni peligrosas para el mantenimiento del (des)orden globalizado,

\footnotetext{
${ }^{111}$ La experiencia de Cuetzalan (Puebla) ha sido documentada por Terven $(2005,2009)$.

${ }^{112}$ Hale 2004; Hardt y Negri 2002; Hardt y Negri 2004; Díaz-Polanco 2005, Žižek 1998. Según este último autor, "la "tolerancia" liberal excusa al Otro folclórico, privado de su sustancia (como la multiplicidad de "comidas étnicas" en una megalópolis contemporánea), pero denuncia a cualquier Otro "real" por su "fundamentalismo", dado que el núcleo de la Otredad está en la regulación de su goce: el "Otro real" es por definición "patriarcal", "violento", jamás es el Otro de la sabiduría etérea y las costumbres encantadoras".

${ }^{113}$ Me parece pertinente la interpretación avanzada por García Canclini, quien afirma: "lo que suele llamarse globalización se presenta como un conjunto de procesos de homogeneización y, a la vez, de fraccionamiento articulado del mundo, que reordenan las diferencias y las desigualdades sin suprimirlas" (1999:49).
} 
cuanto aprovechables en diferentes términos (etnicidades "positivas", folclor) ${ }^{114}$ y "excitadas para incorporar al mercado [a] los disidentes" (García Canclini 2004:77). ${ }^{115}$

Sin embargo, también en este caso el proceso nunca es unívoco, pues con creciente frecuencia la cultura es utilizada como un instrumento político, para la defensa legítima de los mismos pueblos y de sus territorios (es el caso del discurso adoptado por el pueblo wixárrica en contra de la explotación minera, por ejemplo). Los "disidentes" de los que habla Canclini no son incorporados sistemáticamente, sino que, más bien, el ámbito de la cultura es disputado por varios sujetos, entre ellos los mismos indígenas que asumen la dinamización de las culturas propias.

Implícita en muchas de las "políticas de reconocimiento", la reducción de la autonomía formalmente reconocida a un nivel mínimo revela la renuencia de los gobiernos a reconocer realmente las formas y estructuras del gobierno indígena. Las políticas de reconocimiento cultural permiten incorporar las reivindicaciones identitarias en los mecanismos del Estado, como documentan Regalsky y Quisbert (2008) para el caso de Bolivia.

En este sentido van las numerosas críticas avanzadas al multiculturalismo como política de Estado, entre ellas la formulada por Hale (2004), quien habla de multiculturalismo neoliberal. Este autor menciona como actualmente la tendencia de los Estados sea abrir espacios limitados y controlados (permitidos, en las palabras de Hale) de "autonomía”, así como reconocer y hasta exaltar ciertos niveles de diferencia, lo cual sirve al Estado para mejorar su imagen y las bases de su legitimidad. En el ámbito jurídico, la política "multiculturalista" se hace explicita en la relativa disponibilidad de los Estados en reconocer la legitimidad de los sistemas normativos indígenas, pero limitando su vigencia al ámbito interno al grupo indígena y acotando su alcance a los delitos menores.

Por otro lado, frente a organizaciones o grupos que salen del ámbito permitido reivindicando efectivamente la autonomía como facultad de autogobierno o de administración

\footnotetext{
${ }^{114}$ Según Žižek, el multiculturalismo es la forma ideal de ideología del capitalismo global, la cual establece una distancia eurocentrista condescendiente y/o respetuosa con las culturas locales, un "racismo con distancia", negado, que "respeta" la identidad del Otro, como una forma de reafirmar la propia superioridad.

${ }^{115}$ En el contexto mexicano, asistimos a la proliferación de organizaciones y grupos que tratan revivir hipotéticas tradiciones indígenas con fines comerciales (para incrementar el turismo, o vender productos artesanales), y que encuentran apreciación en diversos sectores de la sociedad. Un simple ejemplo. Una visita a Tepoztlán nos puede mostrar la comercialización para los turistas del baño de temascal, práctica higiénica y curativa usada desde siglos por los pueblos indígenas de la región. Pero los que se ofrecen a los turistas, juntos con "masajes mayas" en una zona nahua, y cursos de yoga, son temascales frecuentemente de forma cuadrada y construidos con bloques de concreto, que nada tienen que ver con el tradicional temascal redondo y de adobe.
} 
de la justicia, cuestionando las dinámicas políticas existentes (autonomías contrahegemónicas), la represión militar o policíaca es la estrategia prioritaria adoptada por el Estado. Tales políticas de reconocimiento funcionarían pues con la añeja lógica de la “zanahoria y el garrote". Al mismo tiempo que constituyen un espacio político recientemente abierto, imponen una disciplina a aquellos que ocupan este espacio. En palabras de Hale, el multiculturalismo neoliberal "abre el espacio político suficiente para desalentar una oposición frontal, pero insuficiente para permitir el cambio importante desde dentro. La lucha frontal se convierte en una negociación a puerta cerrada" (2007: 317).

La "culturización" de las luchas por el reconocimiento puede así tener efectos de desmovilización política y social: las antiguas luchas indígenas agrarias o laborales, o las luchas de los afrodescendientes contra la discriminación racial, en tal contexto se vieron frecuentemente rebasadas o arrinconadas por el auge de las reivindicaciones identitarias.

El meollo de todo este debate recae otra vez en la crítica marxista, ya elaborada en el marco de la "cuestión étnico nacional" en contra del "etnopopulismo", en que no se puede desligar el ámbito cultural e identitario de la situación económica y social en el cual este se encuentra ubicado. Resume este aspecto el sociólogo Sousa Santos: “el capitalismo y el colonialismo son dos modos de opresión distintos, pero se pertenecen mutuamente y las luchas contra ambos deben ser articuladas". Con la premisa de que "el colonialismo no terminó con el fin del colonialismo político" sino que se mantiene como modelo de relaciones entre naciones y a su interno (colonialismo interno), afirma que "la injusticia histórica originada en el colonialismo coexiste con la injusticia social propia del capitalismo. Por esta razón, el reconocimiento de la diferencia cultural que subyace a la demanda intercultural -la lucha por la diferencia- no es posible sin una redistribución de la riqueza -la lucha por la igualdad" (2012: 151-152) ${ }^{116}$.

\footnotetext{
${ }^{116}$ En otro trabajo (2003) Sousa Santos explica que en la modernidad capitalista la regulación social se basa sobre dos sistemas de pertenencia jerarquizada: la desigualdad (que es un fenómeno socioeconómico, situada en la desigualdad fundamental entre el capital y el trabajo) y la exclusión (que es un fenómeno cultural y social, de civilización, situada en la prohibición). A la luz de las transformaciones del Estado en tiempos de globalización (perdida de la capacidad de regulación entre la política nacional- desnacionalización del Estado- y articulación entre público y privado -desestatalización del Estado nacional), estaríamos asistiendo a una metamorfosis del sistema de desigualdad en un sistema de exclusión, y por lo tanto a la "culturización" de las desigualdades. El mecanismo de exclusión opera en distinguir aquellas formas que deben ser objeto de asimilación, o por el contrario, objeto de segregación o exterminio. Así, las desigualdades "culturalizadas" pasan al campo de lo prohibido, lo que puede servir para interpretar el mayor énfasis culturalista, fundamentalista y racista que adquieren los procesos sociales.
} 
El Estado mexicano ha seguido la tendencia multiculturalista de forma diferente a otros países latinoamericanos -en particular los andinos, como Colombia, Ecuador, Bolivia, Venezuela -, que en la reforma de sus constituciones reconocieron los derechos de los pueblos indígenas en términos bastante amplios y específicos, aunque en muchos casos hay fuertes dificultades para realizar en los hechos lo que está sentado en el papel. En México se ha venido aplicando una versión limitada de la política del reconocimiento, cuyo ejemplo es la reforma constitucional en materia indígena aprobada por el gabinete del presidente Vicente Fox en 2001, en la cual se reconoce formalmente el derecho a la libre determinación pero se impide en los hechos su ejercicio por medio de limitantes y candados presentes en la misma ley. Donde sí es muy presente la atención a la diferencia es en los discursos públicos de los funcionarios y de los políticos, que continuamente se refieren al carácter multiétnico y multicultural de la nación mexicana, pero en términos puramente instrumentales, superficiales y erráticos (Gutiérrez Chong: 2004). En los mismos términos retóricos esta visión ha entrado en las acciones culturales, educativas y más directamente en las políticas del Estado. Un ejemplo de de ello es la reiterada voluntad del Estado para incluir la Policía Comunitaria, institución autónoma de los pueblos de la Costa Montaña de Guerrero, en las estructuras policiales locales. Tal propuesta ha sido rechazada por la misma organización ya que, aunque les traería evidentes ventajas cesando la represión y el hostigamiento, acabaría también con la autonomía decisional de la organización misma. En segundo lugar, la inclusión de la Policía Comunitaria en el sistema policial, apunta a la desaparición del otro órgano, la Coordinadora Regional de Autoridades Comunitarias, que en realidad es el mayor logro de la organización de esos pueblos indígenas.

En términos de políticas públicas, la implementación del multiculturalismo en México ha tomado tintes neo-indigenistas. La constante de los indigenismos de viejo y nuevo cuño es que sirven como política para excluir el sujeto indígena como actor político y definirlo como objeto de desarrollo. En el neoindigenismo mexicano "las viejas políticas integracionistas y modernizadoras se han revestido de un nuevo discurso que combina la exaltación de la diversidad cultural con programas para formar capital humano e impulsar el desarrollo empresarial de las comunidades indígenas” (Hernández, Paz y Sierra 2004: 10, 18).

En el México neoliberal la distinción entre lo permitido y lo no permitido funciona de manera bastante burda: florecen los programas institucionales vueltos a "preservar" o 


\section{AUTONOMIAINDÍGENA, VIOLENCIAY JUSTICIA}

"rescatar" las manifestaciones culturales indígenas (enfatizando lo folclórico) y la producción artesanal. Por otro lado, entre los programas de atención social y de atención a la pobreza extrema no hay ninguno dirigido en especial a la población indígena, lo cual refleja que la condición indígena no es considerada un criterio importante para la definición de la política social.

El Instituto Nacional Indigenista fue disuelto en 2002, y en su lugar fue creada la Comisión Nacional para el Desarrollo de los Pueblos Indígenas (CDI), que actualmente administra un presupuesto muy reducido, encargándose más bien de coordinar y canalizar hacia algunas regiones indígenas los recursos y los proyectos impulsados por otras secretarías. En los últimos años de existencia del INI, su presupuesto se repartía mayormente en financiar los Fondos Regionales y los albergues escolares. Desde la creación de la CDI, los principales canales de inyección de recursos públicos en regiones indígenas o interculturales son actualmente el Programa de Infraestructura Básica para la Atención de los Pueblos Indígenas (PIBAI) $^{117}$ operado directamente por la CDI, y el programa Desarrollo HumanoOportunidades, operado por las Secretarías de Educación Pública (SEP), Desarrollo Social (SEDESOL) y Salud (Núñez Rodríguez :2009).

Por otro lado la CDI, y por su medio la SEDESOL, financia actividades y proyectos productivos de varia índole. Se trata de pequeñas inversiones por parte del Estado, que sin embargo implican un gran esfuerzo por parte de las personas o de las organizaciones en la elaboración de los proyectos. Este "proyectismo" mantiene la vía asistencialista de intervención en las comunidades, al mismo tiempo que encauza en los dédalos burocráticos la lucha para los derechos políticos. Es decir que, en lugar de ser reconocidos derechos que las instituciones deben garantizar, cuya implementación no debería ser sujeta a "pedidos", se anclan tales derechos a la solicitud de proyectos, frecuentemente pequeños e individualizadores, poniendo entre el Estado y las demandas indígenas una multitud de programas y proyectos a solicitar, como única vía de negociación ${ }^{118}$.

En este contexto se recuperaron y legitimaron los conceptos de etnodesarrollo y autodesarrollo, relacionado a "proyectos de nivel comunitario que se dirigen a los sectores

\footnotetext{
${ }^{117}$ La infraestructura básica se refiere a agua potable, electrificación, carreteras, alcantarillado, puentes, escuelas, albergues, telecentros y plantas solares.

${ }^{118}$ Esta situación ha sido observada también en otros países latinoamericanos, como es el caso de Ecuador estudiado por Bretón (2007).
} 
más pobres de la población -tales como los pueblos indígenas- en un efecto por mitigar los efectos de las políticas de ajuste estructural y promover su autodesarrollo" (Assies, van der Haar y Hoekema 1999:513). La idea de etnodesarrollo nació cuestionando la unilateralidad y el etnocentrismo del desarrollo, ${ }^{119}$ pero muy rápidamente -al igual que el desarrollo sustentable- ha sido adoptado en los discursos de las instituciones supranacionales, como el Banco Mundial y la Comunidad Europea. Así, los proyectos que se definen con tal nombre no miran a resolver las causas estructurales de la pobreza, sino que son paliativos que tratan de mitigar los impactos negativos de las políticas actuales entre los pueblos indígenas.

Tales estrategias de focalización dirigidas a los pueblos indígenas, además de conservar un sesgo asistencialista, son implementadas para menguar la organización autónoma de los pueblos, y con fines (neo) corporativistas:

Las instituciones buscan legitimarse frente a los sectores más golpeados por las crisis económica, y a la vez usan los programas con fines electorales (condicionando la entrega de las ayudas a la adhesión a uno u otro partido político). Estos programas han tratado de introducir una componente de participación social relevante (al menos en el diseño y discurso de los programas sociales); pero en la práctica los resultados son todavía muy decepcionantes, pues la mayoría de las veces la inclusión y operación dentro del programa de los beneficiarios se maneja en forma vertical $\mathrm{y}$ autoritaria, pero siempre legitimada por discursos seudodemocraticos que ponen el acento en la generación de capacidades democráticas, generación de capital social, entre otros discursos ideológicos (Arzate 2008:111-112). ${ }^{120}$

En México, el Plan Nacional de Desarrollo (PND) 2006-2012 incorpora la búsqueda del Desarrollo Humano Sustentable, al cual define como "el proceso permanente de ampliación de capacidades y libertades que habrá de permitir a todos los mexicanos y mexicanas tener una vida digna sin comprometer el patrimonio de las generaciones futuras". ${ }^{21}$ Vemos aquí una interpretación extremadamente neoliberal del concepto de desarrollo que, al enfatizar las

\footnotetext{
${ }^{119}$ Véase Bonfil Batalla (1995).

${ }^{120}$ En diversos casos se ha documentado como las "acciones de desarrollo desde la óptica del gobierno" han generado, entre otras cosas, conflictos en las comunidades "beneficiadas". Velasco, a partir de un estudio en la Región de la Mariposa Monarca en el Estado de México, afirma: "Dichos conflictos sociales se traducen en desacuerdos, envidias, ambiciones entre las familias, ya que las obras e inversiones que llegan con el desarrollo, en primer lugar, no siempre se ajustan a las necesidades sentidas y, en segundo, no les otorgan a todos por igual. [...] Observamos cada vez más localidades divididas y desorganizadas" (2008:276).

${ }^{121}$ Programa para el Desarrollo de los Pueblos Indígenas 2009-2012, Diario Oficial, 4 de diciembre 2009
} 
“capacidades y libertades", no ataca la causa de la violencia estructural que viven los pueblos indígenas, es decir la desigualdad como exclusión social y como explotación.

Con referencia especial a la población indígena, el PND propone el desarrollo con identidad, lo cual implicaría "respeto y reconocimiento a las culturas, las lenguas y los derechos de las personas, los pueblos y las comunidades indígenas del país”. Al terminar el sexenio, tal declaratoria se quedó muy grande con respecto a lo logrado, mientras la relativa atención a la temática de la diversidad cultural va de la mano con proyectos y acciones de intervención del Estado y de las empresas en los territorios indígenas cada vez más fuertes, en aras del aprovechamiento indiscriminado de los recursos naturales y estratégicos presentes en éstos. Un ejemplo son los proyectos de "desarrollo" infraestructural, comercial y turístico, que en la mayoría de los casos no llevan a los pueblos ningún beneficio y tienen como consecuencia directa el aumento de la marginación y la migración desde los territorios "beneficiados".

Los ejemplos son innumerables; entre los que han destacado está el revivido Plan Puebla Panamá, cuyas nefastas consecuencias han sido advertidas por varios investigadores, como Harvey (2004); el proyecto de la presa La Parota, en el estado de Guerrero, que ha aglutinado una fuerza resistencia de las comunidades indígenas y campesinas afectadas; y la iniciativa exhibida por el gobierno de Chiapas, que mira a aprovechar turísticamente la zona norte del estado. Se trata del proyecto de autopista San Cristóbal de Las Casas-Palenque, y del Centro Integralmente Planeado Palenque-Cascadas de Agua Azul, un plan de gran impacto ambiental y social, orientado por una visión mercantilista que trata de incorporar los campesinos indígenas al sector de los servicios.

Hasta donde es posible, el Estado trata de disfrazar como positivas tales acciones, pero cada vez que se encuentra con la resistencia de los pueblos para defender sus territorios y sus culturas, no titubea en utilizar contra ellos la amenaza, la cooptación y, frecuentemente, la represión violenta. Según el Informe sobre el Desarrollo Humano de los Pueblos Indígenas de México, las Naciones Unidas han impulsado medidas que garanticen "el acceso de estos grupos a los beneficios del desarrollo". El problema es que "los beneficios del desarrollo" siguen siendo pensados e implementados desde otras dimensiones, externas a los contextos de organización y decisión de los pueblos indígenas, los cuales sólo deberían “acceder” a ellos de forma acrítica. 
Vertientes organizativas de los movimientos indígenas mexicanos en el siglo XXI

Contra tal tendencia política del Estado, en los últimos veinte años el movimiento indígena se ha fortalecido, cobrando fuerza organizativa y poder de negociación. En este apartado mencionaré solamente algunos elementos, pues analizo en detalle la articulación y la lucha indígena en relación al proyecto de autonomía en el capítulo sucesivo.

A principio de los años noventa la Campaña 500 Años de Resistencia Indígena, Negra y Popular ${ }^{122}$ representó un momento aglutinador para las organizaciones indígenas, que crearon redes de discusión y movilización a nivel nacional e internacional, y empezaron a articular una propuesta política común: la de autonomía. En este contexto fue relevante la ratificación, por parte del Estado mexicano en 1990, del Convenio 169 de la Organización Internacional del Trabajo, que reconoce derechos específicos para los pueblos indígenas y tribales. Tal movilización difusa permitió la transformación de importantes organizaciones de campesinos indígenas que, a partir de ese momento, iniciaron paulatinamente a hacer patente su composición indígena y articular demandas de carácter étnico.

Se pasó de una condición de representación campesina y obrera a una identificación indígena como nueva posibilidad política. Una de las motivaciones principales es que hasta los años ochenta la representación indígena fue institucionalizada y hegemonizada por el discurso estatal, mientras en el umbral entre los años ochenta y noventa las organizaciones integradas por indígenas adquirieron la fuerza política y simbólica para reapropiarse del discurso indígena. Esto no significa solamente enfatizar la identidad, sino reivindicar con base en ella acciones como ocupaciones de tierras e instituciones, reivindicación de espacios en las comunidades y en el ámbito institucional, y gestión de las actividades comerciales y productivas.

El proceso de reapropiación de la identidad indígena como elemento de dignidad y riqueza llegó a su ápice con la emergencia del movimiento zapatista, como lo explica Luis Hernández Navarro, periodista y anteriormente asesor de la Coordinadora Nacional de Organizaciones Cafetaleras (CNOC):

\footnotetext{
${ }^{122}$ Para un recuento detallado de este proceso véase Sarmiento: 1998a; testimonios y documentos producto de esa coyuntura se encuentran en Sarmiento: 1998b.
} 
Yo venía trabajando desde hace muchos años con pequeños productores de café, en varios estados de México. Cuando estalla la rebelión [zapatista] se da una situación muy complicada porqué una parte de nuestros compañeros queda de un lado y la otra queda del otro. Pero el resto de la gente estaba casi completamente de acuerdo en la necesidad de apoyar los que se levantaron, entonces organizamos a los pocos días una reunión de solidaridad en San Cristóbal. Siempre la gente, hablando en asamblea, empezaba su intervención apelándose a los “Compañeros productores de café..." El presidente de la organización, la CNOC, en aquel entonces el mazateco Humberto Juárez, que tenía como los otros muchos años de lucha, comienza la reunión hablando -por primera vez en la historia de la organización- en mazateco, y luego traduce, y entonces sus primeras palabras son "Hermanos indígenas..." De allí en adelante hubo alrededor de quince intervenciones de personas que venían de toda la república, todas en su lengua indígena, no en español. En aquel momento son rebasados por su identidad indígena, fue entonces que se atrevieron a exponerla, mientras antes no lo hacían. Esto sucedió en una organización construida hasta la fecha alrededor de la identidad de productores de café que se transforma en otra cosa, creo que pasó en todo el país, y más aún en Chiapas.

La verdadera autonomía nace del reconocimiento interior de ser autónomos. Por ese dirigente indígena, que antes no te miraba a los ojos, bajaba la mirada, el levantamiento representa una enorme sacudida que permite la salida del orgullo de ser. ${ }^{123}$

El siguiente momento clave fue el levantamiento zapatista de 1994, que contribuyó a revitalizar las redes organizativas preexistentes y convirtió la discusión sobre los derechos de los pueblos indígenas en un debate político de relevancia nacional.

La demanda de autonomía se volvió el proyecto político de los pueblos y organizaciones indígenas a nivel nacional, bandera del nuevo espacio de discusión y organización formado en 1996, el Congreso Nacional Indígena (CNI). A partir de 1994, el EZLN será el referente obligado para la mayor parte de las organizaciones indígenas, y servirá como elemento aglutinador por su enorme poder de convocatoria y su indiscutible legitimidad política. Desde el levantamiento y hasta 2006, fecha en que se realizó la Otra Campaña, el calendario indígena

${ }^{123}$ Luís Hernández Navarro, entrevista realizada el 27 abril 2004. Es actualmente director de Opinión del periódico La Jornada; ha trabajado como asesor en la Coordinación Nacional de Organizaciones Cafetaleras (CNOC); ha sido asesor del EZLN en los Diálogos de San Andrés y cuenta con varias publicaciones sobre el tema de la autonomía indígena y el movimiento zapatista. 
nacional fue marcado, principalmente aunque no exclusivamente, por las iniciativas lanzadas desde el EZLN y el CNI, espacio que desde su formación comparte el planteamiento zapatista.

El proceso de los Diálogos de San Andrés entre 1995 y 1996; la Marcha de los 1,111 indígenas zapatistas que, haciendo etapas en las regiones indígenas, llegó a la Ciudad de México en 1997; la Consulta Nacional por el Reconocimiento de los Derechos de los Pueblos Indios y por el Fin de la Guerra de Exterminio en 1998; la llamada Marcha del Color de la Tierra o de la Dignidad Indígena del 2001 que atravesó gran parte de la geografía indígena mexicana para terminar, después de un mes de recorrido, con la intervención de representantes del CNI y del EZLN en el Congreso de la Unión, reclamando la reforma constitucional en materia indígena; la Otra Campaña de 2006, otro gran recorrido de denuncia del despojo y visibilización de la realidad indígena nacional; el Primer Encuentro de Pueblos Indígenas de América celebrado en 2007; La Cátedra Juan Chávez en 2013, son algunas de las principales actividades impulsadas por el EZLN y el CNI en su conjunto, además de las numerosas Asambleas Nacionales del CNI que, desde su fundación a la fecha, han abordado temáticas de gran relevancia en los diferentes momentos: la postura sobre la construcción de la autonomía en los hechos, la organización contra el despojo de los recursos y los territorios, el derecho a la autodefensa de los pueblos, entre otros.

El movimiento indígena y el EZLN rompieron la práctica política corporativista que mantuvo atrapadas a las organizaciones por mucho tiempo, a partir de la capacidad del gobierno de desarticular las grandes convergencias organizativas y negociar demandas específicas con los diferentes sectores de la sociedad, lo que sigue funcionando hasta la fecha. Las reivindicaciones enarboladas en los Diálogos de San Andrés y después apuntan a la reforma del Estado y al reconocimiento de derechos fundamentales, lo que permitió que no se tratara de una lucha sectorial, sino de demandas compartidas que sumaron muchos actores sociales a la lucha indígena y zapatista, precisamente porque podían incluirse en tal lucha con su propia especificidad.

Por su parte, los gobiernos que siguieron el levantamiento no supieron ni quisieron convertir en norma constitucional las demandas de reconocimiento de los derechos indígenas; las que han sido planteadas por el movimiento no en términos aislados, sino en el marco de una profunda reforma y democratización del Estado. 


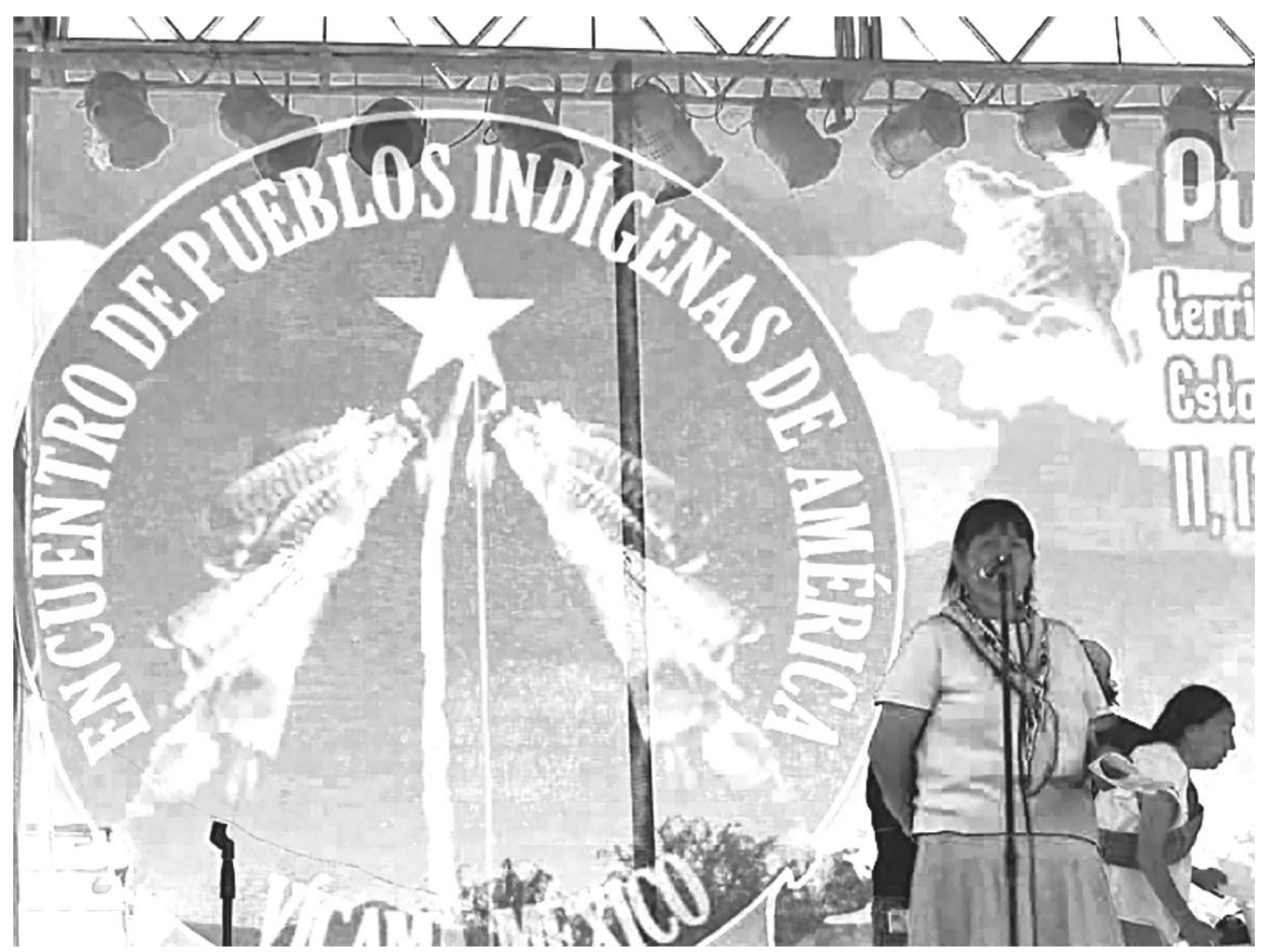

Encuentro de Los Pueblos Indígenas de América, Vícam Estación, Territorio Yaqui, Sonora, octubre 2007.

Actualmente, estamos asistiendo a una reactivación de los movimientos indígenas: son innumerables las experiencias de resistencia, organización y construcción de espacios autonómicos a lo largo del país; una vertiente muy importante son las luchas para la defensa de los recursos naturales y territoriales contra la embestida gubernamental y del capital transnacional. Lo que destaca en todas estas experiencias locales es la visión según la cual llevan a la práctica derechos de los cuales conscientemente afirman la legitimidad, cada experiencia según su particular situación. En muchos casos se trata de organizaciones y movimientos que nacen a partir de la problemática que deben enfrentar, y no articulan sus demandas alrededor de un planteamiento político cual podría ser el de la autonomía; en tal sentido el Congreso Nacional Indígena, que hizo de tal demanda su bandera de lucha, se vio por un momento rebasado por la diversidad de las luchas que nacieron alrededor de su red establecida. En tiempos recientes se observa un esfuerzo de articulación y de reorganización 
para incluir las nuevas problemáticas en el debate político de las organizaciones indígenas de más larga trayectoria.

La situación de violencia difusa, la falta de oportunidades, así como las políticas que favorecen el despojo de los recursos naturales, sociales y culturales, que se vuelven cada sexenio más agresivas, también contribuyen a la emergencia de variadas experiencias de organización de los pueblos indígenas. La identidad indígena aparece como un fuerte elemento para reivindicar la legitimidad de las luchas, en particular en lo que corresponde al manejo del territorio y la representación política. Se observa una proliferación de luchas indígenas cuyo común denominador es la defensa del territorio y los recursos que en él se encuentran, necesarios para la reproducción social, cultural y concreta de los mismos pueblos: la cuestión ambiental y étnica se presentan más que nunca imbricadas, pero a diferencia de los planteamientos de cierto ambientalismo tercermundista de las pasadas décadas, que casi asimilaba los indígenas al buen salvaje roussouiano, ahora se advierte un elemento de radicalidad política que proviene, sin duda, del hecho que las luchas contra el despojo son protagonizadas por los pueblos indígenas pero también por movimientos y organizaciones populares, ciudadanas, estudiantiles, campesinas, que comparten el mismo objetivo e intercambian estrategias de lucha.

Entre las luchas más representativas de esta tendencia, que han surgido en años recientes, se pueden mencionar (con la certeza de omitir muchas) la del pueblo wixárika en contra de la explotación minera y turística, respectivamente, de los territorios sagrados Wirikuta y Haramara; la del pueblo ikoot en Oaxaca en contra de los corredores eólicos; la del pueblo yaqui en defensa del acceso al agua y contra la construcción del Acueducto Independencia; la de las comunidades nahuas de Morelos, Puebla y Tlaxcala contra la construcción del gasoducto en las faldas del volcán Popocatepetl; la de los pueblos me’phaa, na saavi, nahuas y mestizos de la Montaña de Guerrero, así como de los nahuas y totonacas de la Sierra Norte de Puebla en contra de las mineras; la de los pueblos guajirío y komkaak, en contra de la construcción de una presa y del desvío de un río; la de los purépechas y nahuas de Michoacán en defensa de sus bosques, en contra de la tala indiscriminada, los agro-cultivos y el narcotráfico, y un largo etcétera. ${ }^{124}$ El evento realizado en agosto 2013, llamado Cátedra

\footnotetext{
${ }^{124}$ Se han constituido redes de convergencia y coordinación especialmente abocadas a la temática ambiental, donde confluyen organizaciones indígenas y no indígenas, como la Asamblea Nacional de Afectados
} 
Tata Juan Chávez, convocado por el CNI y el EZLN, al que participaron organizaciones y pueblos indígenas de todo el país, fue una muestra de tal situación. ${ }^{125}$ La lucha oaxaqueña en contra de los corredores eólicos es una muestra de las nuevas redes de convergencia para la defensa del territorio; me parece interesante la heterogeneidad de los sujetos reunidos en la Asamblea de los Pueblos Indígenas del Istmo en defensa de la Tierra y del Territorio: las tradicionales instancias de decisión y representación de los pueblos indígenas (Asambleas Generales comunitarias y Comisariados de Bienes Comunales), medios de comunicación propios (radio comunitaria), instancias de autodefensa (Policía Comunitaria), así como instancias ciudadanas y organizaciones de la sociedad civil (Comités ciudadanos y Movimiento contra las altas tarifas eléctricas).

En un análisis que abarca el entero contexto latinoamericano, Bengoa argumenta sobre la transformación de las demandas indígenas desde 1992 a la fecha. Para el autor, el tema dominante al inicio de la "emergencia indígena", es decir en los años noventa, fue la autonomía, como instrumento para ejercer, a través del autogobierno, los derechos a la autodeterminación política, económica y cultural.

Desde el principio del siglo XXI, según Bengoa:

Las reivindicaciones han variado según sea la situación de los indígenas en cada una de las sociedades nacionales. En aquellas en que los indígenas son mayoría, como Guatemala, Ecuador, Bolivia, por ejemplo, las organizaciones étnicas se han situado en la perspectiva de lograr el control del Estado nacional. En los casos en que los pueblos indígenas constituyen mayorías locales o regionales, pero son minorías nacionales, la estrategia ha sido el apoderarse de las instituciones estatales locales, como forma de ejercicio de la autonomía y la autodeterminación consagrada en los documentos internacionales. [...] La primera fase del ciclo de la Emergencia Indígena permitió instalar la cuestión de la etnicidad en América Latina. La segunda fase que observamos recién comienza, y planteará el desafío de construir una nueva forma de ciudadanía indígena. Es una segunda fase del proceso de "descolonización interna" (2009:11).

Ambientales (ANAA), la Red Mesoamericana en contra de la Minería (REMA), el Movimiento de Afectados por las presas y en Defensa de los Ríos, entre otras.

${ }^{125}$ Véase el Pronunciamiento en <http://enlacezapatista.ezln.org.mx/2013/08/19/

pronunciamiento-de-la-catedra-tata-juan-chavez-alonso/>, consultado el 10/10/2013. 
A esta acertada afirmación, hay sin embargo que añadir que la práctica de la autonomía no ha sido abandonada, sino que se ha enriquecido y ha adquirido formas más variadas y complejas. Asimismo, hay que añadir la vertiente de lucha para la defensa del territorio y de los recursos naturales y culturales, que también representa una constante en todo el continente latinoamericano. ${ }^{126}$

El movimiento indígena y sus organizaciones, actuando en los espacios locales, no se encierran en ellos sino que inscriben su proyecto y sus reivindicaciones en el ámbito nacional, arena política donde se deben articular las diferentes experiencias y en la cual se han de dar las reformas sustanciales. De hecho, el movimiento indígena está creando y fortaleciendo una nueva identidad nacional, a partir de las transformadas relaciones de fuerza entre espacios locales, nacionales y supranacionales creadas por los procesos globalizantes. Los movimientos indígenas muestran saberse mover con agilidad en los diferentes contextos (reivindican la legitimidad de sus prácticas locales con base en el Derecho Internacional, y tienen una fuerte presencia en los foros y las instituciones internacionales) remarcando siempre su identidad, indígena y mexicana; a partir de su diferencia apuntan a la apertura de espacios democráticos -desde abajo- en la nación de la cual se reivindican parte integrante.

\section{¿A quién quieren que seamos iguales? Ciudadanía y diversidad}

"Los pueblos indígenas, en Indoamérica, plantean una doble exigencia: autonomía para decidir respecto de sus formas de vida y participación en la unidad del Estado" (Villoro 1998: 103); esto es, quieren ser diferentes y al mismo tiempo iguales. En estos términos, la propuesta de "ciudadanía diferenciada", avanzada por el liberal Kymlicka, aparece inadecuada para acoger la amplitud de esta reivindicación que desborda los límites de la simple afirmación de la diferencia cultural. No está demás reafirmar que otro límite de estas políticas es ser en cierta medida "caladas desde arriba" o fruto de una negociación parcial, que no incluye un diálogo

\footnotetext{
${ }^{126}$ Baste mencionar la organización en contra de la explotación minera en Guatemala que pasó por el novedoso uso jurídico del derecho a la consulta por parte de las autoridades locales y comunitarias; la aguerrida, y fuertemente reprimida, resistencia contra las mineras en Perú; el complejo proceso de lucha y jaloneo con el Estado ecuatoriano en contra de la explotación petrolera en los territorios ocupados por los indígenas no contactados; o la defensa del territorio reconocido a los indígenas por el Estado boliviano y sucesivamente concesionado para una gran obra carretera.
} 
amplio y una transformación radical de las estructuras estatales. Lo que plantean los pueblos indígenas es ser incluidos en la "ciudadanía común” pero en un marco que no incluya ningún derecho u obligación que ellos no reconozcan. Para pensar seriamente el derecho a la diferencia, es indispensable reconocer que los seres humanos no somos todos iguales: podemos ser iguales en muchas cosas y diferentes en otras. Por eso necesitamos de una noción restringida de igualdad; o sea, restringir la universalidad de la noción de igualdad como condición para pensar el derecho a la diferencia. Asimismo, Villoro propone restringir el concepto de ciudadanía a términos compatibles a todos los grupos, a partir de una idea de igualdad que consiste en la atribución a todos de las mismas oportunidades para elegir su plan de vida y sus valores, aunque éstos difieran entre sí (1998:103-104). En este sentido, igualdad y diferencia, ciudadanía y autonomía, no serían contradictorias, sino coexistentes en el mismo razonamiento.

La consigna fundamental del discurso zapatista (unos de los más sugerentes movimientos políticos indígenas activos en México), el somos iguales porque somos diferentes, es espejo de un sentimiento que busca la interacción con los otros sujetos de la sociedad para construir un espacio de ciudadanía igualitaria, en que sea garantizado para todos el acceso a los recursos básicos, tanto materiales cuanto culturales. Ya estamos muy lejos de las concepciones multiculturalistas y diferencialistas: éste es, en mi interpretación, el espacio tan buscado de la interculturalidad, caracterizado por intercambio y comunicación, pero también donde los sujetos logren "ser incluidos, llegar a conectarse sin que se atropelle su diferencia ni se los condene a la desigualdad" (García Canclini 2004:53)

El reconocimiento de derechos autonómicos implica necesariamente una profunda reforma, tanto de la estructura estatal como de la relación entre los sujetos que componen la "nación”, reconociendo de cada uno su historia, su presente y su proyecto. Esto, a la luz de la realidad en que los sujetos construyen normatividades híbridas, que rompen con la dicotomía entre liberalismo individualista y tradiciones comunitarias que inhiben a las personas.

Los pueblos indígenas están planteando la necesidad de abrir el modelo "democrático" a nuevas definiciones de la democracia, que articulan prácticas innovadoras con las que históricamente han coexistido al lado de los modelos hegemónicos de la democracia 
representativa y liberal ${ }^{127}$. Según Yashar (2005), actualmente en todo el continente latinoamericano los nuevos movimientos indígenas se están movilizando para redefinir los límites de la ciudadanía (quién es ciudadano) y su contenido (cuales derechos y prácticas contempla la ciudadanía), oponiéndose a la idea que existan una única cultura política abarcativa (sea nacional o cívica), una representación social unitaria, un modelo único de sistema legal, y que exista un único tipo de Estado que puede o podría regular las relaciones sociales. Lo que está en juego es superar las barreras políticas representadas por concepciones excluyentes y exclusivas de la diferencia y de la igualdad, y actuar hacia la interculturalidad. El concepto de la interculturalidad va más allá de la diversidad, el reconocimiento y la inclusión.

La propuesta pluralista, o dialogo intercultural, elaborada por el filósofo León Olivé, indica la posibilidad de construir acuerdos razonables sobre normas de convivencia política que puedan ser consideradas como válidas por todos los sujetos, desde los distintos puntos de vista, y a partir de concepciones del mundo que incluyen diferentes normas y valores morales y cognoscitivos. Por lo tanto, la legitimidad compartida provendría del contexto externo, del proceso de negociación común -intercultural-, aunque después cada cultura encuentre internamente una diferente razón para reconocer que tal norma es legítima de acuerdo con sus principios y valores.

El modelo de práctica política propuesto por Olivé es la negociación, la discusión, tanto de principios como de acciones sobre problemas comunes, en el marco de un proceso que mira a construir consenso alrededor del tema en la mesa de discusión, no a partir de los distintos supuestos o los sistemas de valores que caracterizan los participantes al diálogo. Se pone énfasis en la cooperación para la realización de acciones coordinadas, el éxito de las cuales es independiente de que haya un acuerdo total sobre lo que los diferentes actores consideran importante. Claro está que para que cualquier acción coordinada se pueda realizar, se requiere de algunos acuerdos mínimos, basados en la disposición al diálogo que deben compartir todos los participantes. Tales acuerdos mínimos son las normas de convivencia logradas mediante la

\footnotetext{
127 “Las comunidades locales, regionales y nacionales en diferentes partes del mundo emprenden experimentos e iniciativas democráticas basadas en modelos alternativos de democracia, en los que las tensiones entre democracia y capitalismo, entre redistribución y reconocimiento, se avivan y se convierten en la energía positiva que respalda los pactos sociales más justos y abarcadores, no importa que tan circunscritos sean por el momento" (Sousa Santos 2001: 61).
} 
negociación. Vemos pues que la práctica de la negociación informa tanto el nivel de la construcción de las "normas básicas de procedimiento" necesarias para hacer posible el diálogo, cuanto el nivel sucesivo que se dedica a construir interacciones que interesen a todas las partes y a la resolución de problemas concretos. Me refiero a normas y acuerdos y no a principios universales, ya que no se requiere que sean completos y abarquen todos los asuntos de orden moral; eso sí, serían normas que una vez reconocidas por todos los actores, tendrían para ellos valor vinculante, o sea todos las deberían respetar.

Esta forma de construir ámbitos de consenso a través del diálogo tiene la ventaja de ajustarse a la realidad social, donde los sujetos, tanto individuales como colectivos, son insertados en contextos que se van transformando constantemente. Por eso, se manifiesta la necesidad de construir marcos normativos susceptibles de ser transformados, para incluir respuestas a los problemas que con el pasar del tiempo van emergiendo. Claro está que el sistema de valores sobre el cual se va construyendo el sistema normativo debería quedar firme en la aceptación de todos, confiriendo estabilidad y continuidad a las normas, mismas que evolucionarían de acuerdo a las situaciones.

En el mismo sentido, el sociólogo Boaventura de Sousa Santos reflexiona sobre los principios que deberían animar a los procesos constitucionales en los Estados que se están refundando a través del reconocimiento de su carácter plurinacional, lo que conlleva la interculturalidad y la poscolonialidad. Para el autor, la cultura compartida es la base de la interculturalidad; sin embargo, el objetivo no debe ser un consenso sobre la uniformidad, sino sobre el reconocimiento de las diferencias. "Y aquí hay un principio fundamental para el constitucionalismo intercultural: las diferencias exigen instituciones apropiadas, las semejanzas exigen instituciones compartidas. Por eso el Estado deberá tener instituciones compartidas e instituciones apropiadas a la identidad cultural de las nacionalidades dentro del Estado" (2009: 169). Por su parte, el reconocimiento de la poscolonialidad implica acciones de justicia histórica hacia los pueblos indígenas: dejar la actitud paternalista del Estado y abrir espacios para la acción autónoma, sin poner condiciones o candados al desarrollo que las autonomías puedan llegar a tener.

La idea es un modelo de organización social basado en el respeto (antes que en el reconocimiento); ideal todavía lejano de la realidad, donde con frecuencia las relaciones entre 
las autoridades indígenas y las estatales son conflictivas, no respetando estas últimas el derecho a la libre determinación de los pueblos.

Una postura abierta a la negociación haría más sencilla la construcción de contextos políticos y jurídicos donde las competencias estatales se articulen con los espacios autónomos de los pueblos indígenas. Con respecto a la administración de justicia, sería el marco para reconocer la efectividad de los sistemas indígenas en cuanto legítimos para sus miembros, aunque puede que no respondan a las necesidades de otros sectores de la sociedad. Los sistemas jurídicos indígenas, así como sus instituciones políticas, tendrían el carácter de instituciones de gobierno, equiparadas y complementarias a los otros órdenes de la administración estatal; el respeto a la autonomía de sus sistemas normativos permitirá que las autoridades tradicionales no sean consideradas enemigas de las autoridades del Estado. Así, las relaciones entre los dos sistemas jurídicos deberán basarse en acuerdos de coordinación fundamentados en el respeto mutuo. En este marco se podrá establecer un criterio para el respeto de los derechos humanos como garantía de las personas: pero la definición precisa de éstos debe determinarse en común y revisarse constantemente.

\section{Descentralización y participación ciudadana en el neoliberalismo}

Frente a la generalizada crisis de la democracia representativa, y como respuesta a fuertes movilizaciones sociales, en varios países latinoamericanos se han implementado formas de descentralización y democracia participativa, que en línea teórica aspiran a ampliar el modelo político y con esto el espacio público y las demandas sociales que lo constituyen.

Un cierto nivel de descentralización ${ }^{128}$ es favorecido por las agencias internacionales de desarrollo, ya que parte de la estrategia neoliberal consiste en adelgazar la esfera pública, otorgando mayor autonomía administrativa a los gobiernos locales, pero sin otorgarles las facultades para tomar decisiones en los ámbitos más importantes, como el ámbito político. Al mismo tiempo, el suministro real de los servicios y la administración de los inextinguibles programas de desarrollo han tendido a ser privatizados o entregados al "tercer sector" de ONG

\footnotetext{
${ }^{128}$ La descentralización tiene antecedentes directos en la tradición anglosajona moderna, donde self-government y local autonomy expresan la forma en que se articula el funcionamiento de las unidades locales a la administración estatal. Asimismo, las políticas de home rule o indirect rule, fueron los pilares del colonialismo inglés.
} 
y otras organizaciones sin motivos de lucro. Según Assies, los procesos descentralizadores actualmente se desarrollan en el marco del "post-consenso de Washington", en un esfuerzo para contener los problemas sociales generados por las políticas neoliberales. "Como alternativa al estado neoliberal y el estado social-burocrático, se propone un estado socialliberal, o un estado social de derecho, donde las organizaciones públicas no estatales desempeñen un papel central en un nuevo modo de suministro de servicios públicos" (Assies 2003).

En algunos países latinoamericanos los procesos de descentralización han acompañado el desarrollo de políticas multiculturales, en aras de abrir espacios de participación a nivel local para los sujetos históricamente marginados. Frente a experiencias exitosas, han sido documentados muchos otros casos (Colombia, Bolivia, Ecuador) donde se ha publicitado el reconocimiento del tan aclamado derecho a la autonomía indígena pero reducido en el nivel local, lo que encubre sustancialmente medidas de descentralización política y administrativa que de manera excelente hacen el juego del poder estatal.

Como señala Van Cott, "la descentralización de la entrega de servicios públicos a nivel municipal justifica la restricción geográfica de la participación [indígena] a ese nivel” (2000a: 235).

Por otro lado, la descentralización puede actuar en cierta medida como una reedición del gobierno indirecto, como lo asevera Gros:

En un tal contexto, el reconocimiento de las autoridades indígenas en el ámbito comunitario se convierte en una necesidad para la acción pública -ella elige interlocutores y nuevos mediadores- y estos últimos volens nolens se ven conducidos por el Estado al rol de agentes locales del desarrollo. Una lógica de intervención de baja intensidad que recupera las demandas indígenas y las nuevas formas de organización para orientarlas en una lógica macro que se quiere moderna y en correspondencia con los nuevos imperativos democráticos y de gestión (2004:125).

En tercer lugar, como lo demuestra la debacle sobre las "autonomías departamentales" en Bolivia, un proyecto autonómico derechista cuyo núcleo se encuentra precisamente en la descentralización política y fiscal, "la descentralización puede alterar la distribución de los recursos y, a su vez, una estructura de desigualdad territorial de recursos y niveles de 
desarrollo puede favorecer la selección de diseños institucionales descentralizados e insolidarios que, a su vez, reproducen ampliamente la estructura de la desigualdad" (Maíz 2008:28).

En el marco de la democratización neoliberal en el umbral de los siglos XX y XXI, se generó un gran énfasis alrededor de la "sociedad civil", que de forma más espontanea y desinteresada se encargaría de administrar el sector público: por un lado, hicieron su fortuna empresarios que se maquillaron con aspiraciones filantrópicas; el desarrollo del "privado social" y del "tercer sector" en Brasil ocuparon el vacío que dejó el Estado social y encontraron que su imagen y sus entradas mejoraban mucho al incluir en la empresa preocupaciones sociales (Paoli 2002).

Por otro lado, proliferaron un sinnúmero de Organizaciones No Gubernamentales. Muchas de éstas "pasaron de jugar un papel contestatario a convertirse en colaboradores de los gobiernos, especializándose en [...] gestionar o impulsar la participación popular a escala local, pero sin cuestionar las políticas macroeconómicas de ajuste estructural" (Zibechi 2008: 283). La participación así entendida, más que favorecer la inclusión popular en las instancias deliberativas y ejecutivas de los gobiernos, sirvió en varios casos para dividir las organizaciones indígenas (cuyas comunidades se pelean para el control de los escasos recursos) y cooptar los dirigentes, insertándolos en las instituciones estatales con cargos públicos. El resultado es muy similar al que se obtiene con la implementación de programas de "desarrollo" y políticas "focalizadas" para atención a la pobreza: conflictos sociales que se traducen en desacuerdos, envidias, ambiciones entre las familias, división y desorganización en las comunidades.

Esta nueva gobernabilidad "descentralizada y participativa” empodera (o sea que inviste del poder de arriba) a la sociedad civil, para que ésta actúe como Estado (desmovilizando y despolitizando las experiencias organizativas que construyen poder desde abajo). ${ }^{129}$ Según Restrepo, "la oferta de participación neoliberal debilita la autonomía y la organización social

\footnotetext{
129 Diferentes autores latinoamericanos están documentando los "lados obscuros" de las políticas de participación: Zibechi (2008) documenta los casos de Ecuador -que vivió la CONAIE- y el de Uruguay impulsado por el gobierno del Frente Amplio-; Assies (2003b), Regalsky y Quisbert (2008) el de Bolivia -la Ley de Participación Popular-; Bastos, Hernández y Méndez (2008) el de Guatemala, con el movimiento maya; García (2009) el de Colombia -el Laboratorio de Paz en Antioquia-; Burguete (2008) y muchos otros el caso de México.
} 
de las comunidades atendidas; [ya que] busca desactivar el potencial radical de las ansias de participación social y popular, mediante el quiebre de la externalidad entre el mercado y el Estado con los sectores populares" (Restrepo 2003: 6). La noción de participación y de empowerment -anteriormente reserva de los movimientos sociales- ha sido adoptada por el discurso oficial (Assies, van der Haar, Hoekema 1999:511). Según Thwaites:

Si la participación comprende una gama que va desde consultarle a alguien si está de acuerdo con lo que se va a hacer, y hacerlo de todas maneras, pasando por la participación en la gestión de programas, hasta llegar a la autogestión de los interesados en la definición, implementación y control de sus proyectos, lo que ha primado, cuanto más, es la primera variante, que asegura el control social de los involucrados (2011: 183). ${ }^{130}$

Thwaites señala también que la pretensión neoliberal de ahorrar el gasto público se esconde tras los impulsos al voluntariado (trabajo no remunerado) y a las asociaciones civiles, que substituyen "la provisión de bienes universales entendidos como derechos, con la donación caritativa y la auto-procuración de bienes y servicios básicos para la subsistencia” (2011:182). Tambien de esta forma se despolitizan las demandas sociales, redireccionandolas desde el reclamo al Estado hacia la auto-responsabilización. En una visión aún más radical, Zibechi afirma que las organizaciones sociales "son instituciones creadas por la gubernamentalidad para el control de los gobernados [...] en un mecanismo de control construido 'con' los militantes sociales y las organizaciones 'para' el Estado y el mercado” (Zibechi 2010: 69-70).

Estas consideraciones son necesarias para iniciar a "separar la paja del trigo" cuando hablamos de "participación" confiando en su intrínseco sentido positivo (al igual que el multiculturalismo, el reconocimiento y los derechos humanos, se trata de conceptos y políticas que pueden ser utilizadas e implementadas en sentido funcional o contra-hegemónico), y ayudan a comprender los procesos organizativos de los pueblos indígenas que deciden desarrollarse afuera o al margen de las instituciones, generando nuevas institucionalidades de acuerdo a diferentes visiones de la política y el gobierno. Según Munting, "las reivindicaciones de los pueblos, los valores que defienden van más allá de los intereses

\footnotetext{
${ }^{130}$ En el mismo sentido se dirige el citado análisis de Saldívar Tanaka sobre las recientes políticas neoindigenistas en México.
} 
estrechamente comunitarios. Constituyen una afirmación de valores que permiten una adhesión universal y trascienden los límites de la etnicidad” (2008: 144).

Históricamente, los pueblos indígenas se organizaron sobre el principio del consenso, una práctica colectiva de toma de decisiones que se aleja mucho de la democracia representativa impulsada como mejor forma de gobierno por la sociedad occidental. A través del consenso instauran alianzas y proyectos comunes con otros pueblos, construyendo sociedades interculturales y participativas.

Se creó un sistema político capaz de desarrollar sus estructuras desde abajo en el marco de un concepto de regionalización que parte de la igualdad de las comunidades con la organización política regional [...] En lugar de crear jerarquías políticas como existen en los sistemas de democracia representativa, la lógica de la política de la diversidad se basa en la realidad de las asambleas comunitarias, donde es mucho más fácil crear estructuras de democracia participativa que en el ámbito nacional. Esta lógica de las asambleas también se aplica al ámbito regional. [...] Mientras que el sistema del Estado federado solamente delega algunas de las competencias jurídicas en el marco de la descentralización, las autonomías multiculturales parten de las iniciativas locales para tomar sus decisiones. [...] Aprovecha del carácter participativo de las comunidades locales para crear un orden político en que las decisiones permanecen con la población y no se delegan a los representantes (Gabriel 2008:31-32).

A partir de esta práctica política que es expresión de una cultura participativa, innumerables experiencias organizativas indígenas rechazan la inclusión en los mecanismos institucionales, y crean sus propias instituciones de gobierno. El proceso más emblemático en este sentido es, sin duda alguna, el de las comunidades zapatistas en Chiapas. A partir de una reflexión interna sobre las necesidades reales y la posibilidad de satisfacerlas, las comunidades zapatistas han organizado por sí mismas sus propias políticas sociales, las estructuras que proporcionan servicios básicos a la población, en las cuales todos participan para su mantenimiento y mejoramiento. Están construyendo alternativas al desarrollo, alternativas que, desde una visión propia, buscan establecer el bienestar social y cultural para todos. 

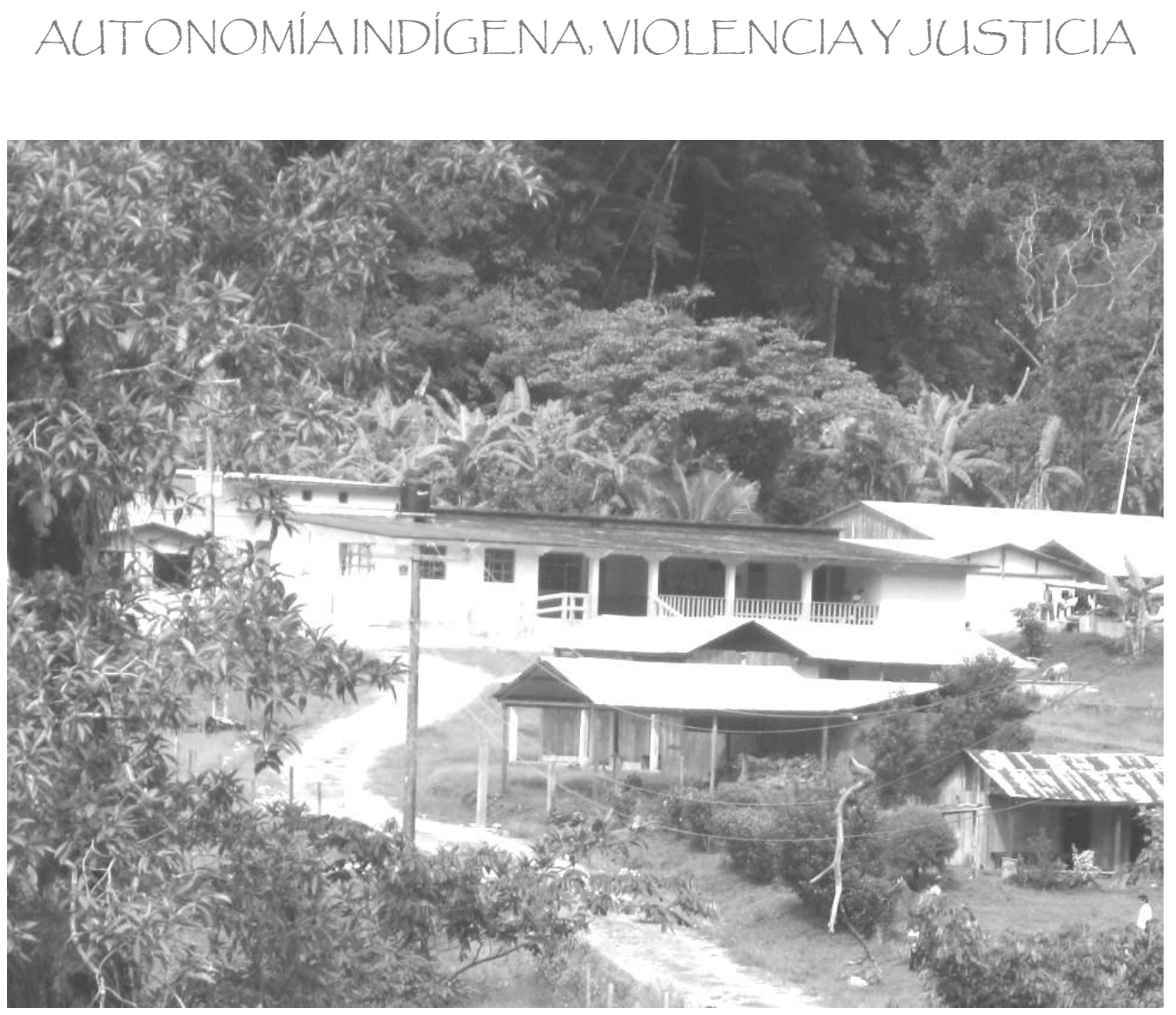

Hospital Autónomo Rebelde Zapatista, San José del Río, Chiapas, agosto 2011.

\section{El derecho a la autonomía de los pueblos indígenas}

\section{La autonomía: una perspectiva radical}

El debate sobre el concepto de autonomía indígena, y la forma en la que éste debería articularse políticamente y jurídicamente, cuenta con un sinnúmero de propuestas y posiciones diferentes, así como innumerables son las publicaciones sobre el tema. En este primer apartado es mi intención mencionar algunas entre las heterogéneas acepciones políticas que adquiere el término autonomía -en particular referida a los pueblos indígenas.

La noción de autonomía tiene una historia política bastante larga: ligada al concepto de autodeterminación, remite al amplio debate iniciado por Rosa Luxemburgo y continuado por Lenin, sobre el futuro de los pueblos y nacionalidades de Europa oriental y de los que integrarían la URSS. A lo largo del siglo XX, muchas han sido las teorizaciones, así como los procesos de construcción y lucha política, que de formas diferentes hicieron referencia a esta noción; en un reciente trabajo, la politóloga Mabel Thwaites (2011) propone un intento de sistematización de las definiciones teóricas y de las posturas ideológicas y políticas, junto con 
un análisis de los elementos que definen la autonomía en la práctica, sus límites y potencialidades. Entre las definiciones teóricas, Thwaites distingue la autonomía: del trabajo frente al capital; en relación con las instancias de organización que representan intereses colectivos (partidos, sindicatos); con referencia al Estado; de las clases dominadas respecto de las dominantes; y la autonomía social e individual. En un plano distinto pone algunas posturas políticas e ideológicas, que identifica en:

-la autogestión y el autogobierno popular como horizonte de organización social superadora del capitalismo;

-la ampliación de las formas autonómicas como anticipatorias del socialismo;

-la ruptura completa y presente de las formas de organización social capitalista, en la que se descarta la toma o la participación en el Estado, se postula el contra-poder y el valor constructivo de la resistencia. En esta vertiente la autora ubica, aunque se hace necesario establecer las debidas distinciones, a la "ola larga" del pensamiento autonomista italiano que va desde los años setenta hasta la actualidad (me refiero en particular a Antonio Negri), a la corriente argentina que próspera desde el 2001 (Colectivo Situaciones y otros), al pensamiento de investigadores latinoamericanos como Ceceña y Zibechi ${ }^{131}$ y hasta a la autonomía practicada por el movimiento indígena. Aunque estos referentes teóricos no sean visibles claramente en el discurso y la práctica de la autonomía indígena, creo que es correcto ubicarlos como telón de fondo, pues proporcionan herramientas adecuadas para el análisis y también elementos de prefiguración.

A partir del esclarecimiento de las diversas tradiciones que han moldeado el concepto de autonomía, Thwaites afirma que su nueva vitalidad desde finales del siglo XX reside precisamente en la expansión del modelo neoliberal globalizado, lo que puso fuertemente en cuestión al Estado-nación, cada vez más incapaz de implementar políticas públicas. Al respecto, afirma Guillermo Almeyra: "el abandono de las funciones asistenciales y la ruptura del contrato social con la sociedad crea la conciencia generalizada de la ilegitimidad de ese Estado [...] En las grietas que deja el Estado se abre camino la auto-organización, la autonomía de enteras poblaciones, la autogestión” (2009:81).

Las actuales luchas "por la autonomía" hacen referencia a "la idea de que la construcción política alternativa no tiene que tener como eje central la conquista del poder del

\footnotetext{
${ }^{131} \mathrm{~A}$ los que añadiría sin duda los mexicanos López y Rivas, antropólogo, y Villoro, filosofo.
} 
Estado, sino que debe partir de la potencialidad de las acciones colectivas que emergen de y arraigan en la sociedad para construir «otro mundo»" (Thwaites 2011:153). Creo que esta idea general de la autonomía es adecuada también para caracterizar los procesos políticos indígenas que se definen con tal nombre, y que se insertan en la arena más amplia de las luchas para la transformación de la sociedad actual.

La perspectiva esbozada por Thwaites permite establecer una conexión de fondo entre las luchas por la autonomía indígena y las que protagonizan otros sectores sociales, una conexión ligada al sentido radical ${ }^{132}$ de las autonomías: para muchos de sus más destacatos analistas, éstas no son el objetivo, "sino una forma de lucha, de organización, en funcion de un objetivo superior que es la transformación de las relaciones sociales y la construcción de un modelo alternativo al sistema neoliberal" (Santiago, en Gasparello y Quintana 2009:137). Ubicar las autonomías indígenas en su contexto histórico ayuda a entender la necesaria vocación transformadora de estas luchas: "desde el punto de vista socioeconómico, la mundialización neoliberal ha reforzado las reacciones de los pueblos autóctonos, dada la doble agresión económica y cultural" (Houtart 2008:13). En tal contexto, las autonomías resultan ser, aún cuando no lo planteen abiertamente, una clara alternativa -de gobierno, de economía, de sociedad, de cultura- al capitalismo neoliberal, pues oponen a éste una lógica autoorganizativa de la sociedad, una "civilización contra sistémica" (López y Rivas 2010). Sin idealizar tales procesos, que no son exentos de contradicciones, puedo afirmar que representan la más constructiva crítica a los contrasentidos de la democracia neoliberal.

Para tratar de establecer una historicidad en la evolución del concepto y de las luchas por la autonomía indígena en América Latina, encuentro sugerente la interpretación de Burguete (2010), quién destaca tres fases en este proceso. En la primera, que inicia en la década de 1970, se da la apropiación del derecho a la autodeterminación de los pueblos, en el contexto de aumentada sensibilidad de las Naciones Unidas hacia los temas de la descolonización y los derechos colectivos. ${ }^{133}$

\footnotetext{
${ }^{132}$ Utilizo el término radical en sus diferentes acepciones: la que expresa una actitud enérgica y "revolucionaria", y la que remite a la raíz, el origen que viene desde abajo, desde la historia.

${ }^{133}$ En 1966 fueron proclamados el Pacto Internacional de derechos civiles y políticos, y el Pacto Internacional sobre derechos económicos, sociales y culturales; en 1970 la "Declaración Universal de los Derechos de los Pueblos", que sin embargo no incluían abiertamente a los pueblos indígenas. El Informe Martínez Cobo, comisionado al homónimo relator en 1970 y publicado en 1983, abre el camino para el reconocimiento internacional de los derechos de los pueblos indígenas.
} 
La segunda fase también inicia en 1970 y se desarrolla en la década siguiente, con la emergencia de organizaciones indígenas independientes -a menudo movimientos indígenas armados, que surgieron bajo regímenes autoritarios o en concomitancia con los movimientos de liberación nacional (Escárzaga 2005)- y de un movimiento indígena continental; en tal contexto la autonomía fortalece su carácter de resistencia, en oposición a las políticas asimilacionistas. El movimiento indígena que surge en tal periodo se fortalece en los años ochenta y aparece con toda su fuerza política a partir del inicio de los años noventa. En este panorama destacan algunos momentos clave, a nivel continental: el establecimiento constitucional de un régimen de autonomía en la Costa Atlántica de Nicaragua, en 1987, "que mostró que las autonomías constituyen una alternativa viable para que los Estados nacionales puedan remontar situaciones de conflicto interno, incluso armado" (López y Rivas 2005: 49). El segundo evento fue la gran ola de movilizaciones en ocasión del quinto centenario de la Conquista, en 1992, que incidió profundamente a nivel teórico y político en el movimiento indígena y en la sociedad entera. Remarcando el carácter de resistencia de estos acontecimientos, López Bárcenas afirma que “desde el año 1992 los movimientos indígenas son movimientos de resistencia y emancipación: resistencia para no dejar de ser pueblos, emancipación para no seguir siendo colonias (2011:82). Finalmente, sabida trascendencia la tuvo el alzamiento armado del EZLN en 1994, y el Levantamiento Indígena Nacional de 1990 en Ecuador, que logró, entre otras cosas, el reconocimiento del carácter plurinacional del Estado.

La tercera fase que destaca la autora correspondería a los procesos de reconstitución de los pueblos en oposición a la evidente inoperancia de las políticas multiculturalistas. En este contexto podríamos ubicar los múltiples procesos de construcción de la autonomía en la práctica, y que muestran claramente su carácter de resistencia y de transformación.

Según la experiencia, el carácter de resistencia une en la actualidad las autonomías indígenas con muchas otras luchas en defensa del territorio y los recursos naturales, y en defensa de derechos como la educación, la salud, etc. Sin embargo, para las autonomías la práctica de resistencia no significa exclusivamente la defensa de lo propio (incluidos los espacios sociales de decisión), sino una permanente búsqueda de alternativas, una continua construcción y reconstitución de su presente y de su futuro. De tal manera, los pueblos indígenas ejercen otras formas de resolver conflictos y establecer la paz en sus sociedades, 


\section{AUTONOMIAINDÍGENA, VIOLENCIAY JUSTICIA}

otras formas de aprender y enseñar, de curar-se, de comunicar-se, de trabajar y producir lo que necesitan.

\section{Autonomía indígena: una aproximación}

La etimología de la palabra autonomía nos remite a las dos palabras griegas auto (mismo) y nomos (norma). Esbozando una definición de la autonomía desde una perspectiva diferente a la que he expuesto con anterioridad, Luis Villoro explica que:

Autonomía es un término que proviene de la teoría ética. En ese campo se refiere a una voluntad que sigue las normas que ella misma dicta y no las promulgadas por otros. [...] Pero en el campo de las relaciones políticas [...] se refiere a un grupo social o una institución que tiene el derecho de dictar sus propias reglas, dentro de un ámbito limitado de competencia" (1998: 94-95).

Las dos caracterizaciones de la autonomía mencionadas hasta ahora (el anhelo de transformación social y la reivindicación de lo propio) son visibles en el proyecto político que une las más importantes luchas indígenas contemporáneas, en México como en muchos países latinoamericanos: esto es, la reivindicación de la autonomía como expresión interna de su derecho a la libre determinación o autodeterminación ${ }^{134}$.

En términos generales, entonces, la autonomía es un derecho colectivo e individual, que implica la libertad de acción -económica, política, jurídica y social- de la colectividad al interior del Estado-nación, garantizando sus derechos de participación y representación, y no se debe confundir con los conceptos de independencia o de soberanía (de competencia exclusiva de los Estados); pero es también una práctica cotidiana de los pueblos.

En cuanto derecho, la autonomía es reconocida y definida en el derecho internacional Convenio 169 sobre Pueblos Indígenas y Tribales de la Organización Internacional del Trabajo (ratificado por el Estado mexicano en 1990); Declaración de Derechos de los Pueblos Indígenas de las Naciones Unidas (2006)- y en la legislación mexicana: en primer lugar en los

\footnotetext{
${ }^{134}$ Este derecho de los pueblos presupone tanto la facultad de decidir su propio destino en el marco de un Estadonación (autodeterminación interna), como el establecimiento de su propio Estado nacional (autodeterminación externa).
} 
Acuerdos de San Andrés ${ }^{135}$, y, aunque de manera parcial, en el artículo 2 de la Constitución federal (reformado en el 2001) y en algunas constituciones estatales.

Ya que la autonomía es expresión del derecho a la libre determinación, los gobiernos mexicanos -para descalificar las reivindicaciones autonómicas- han largamente abonado a la confusión entre la acepción externa e interna de tal derecho, acusando a las organizaciones indígenas de querer destruir la unidad nacional creando territorios completamente independientes (el tan abusado espectro de la "balcanización"). Desde luego, todos los pueblos y las organizaciones que reivindican la autonomía siempre lo han hecho reclamando también el derecho a ser reconocidos como parte de la identidad nacional (en contra del sentido común racista y mestizofílo), y el derecho a una ciudadanía plena (lo que significa poder acceder a los servicios que tal derecho implica, como la salud, educación, trabajo digno, etc., de los que han sido históricamente privados). Al respecto, Olivé afirma que "hacer modificaciones estructurales en el Estado mexicano para que puedan ejercerse efectivamente estos derechos colectivos y estos derechos de grupo, no implica ninguna revolución en los fundamentos del Estado, sino tan sólo asumir las consecuencias propias de sus propios principios ${ }^{136}$ [liberales]”" (2004:94).

En cuanto derecho, el reconocimiento de la autonomía implica la democratización del Estado, lo cual debería armonizar los derechos colectivos e individuales para satisfacer los intereses de todos sus integrantes, sean ellos sujetos individuales o colectivos (los pueblos, que son el sujeto de la autonomía). La autonomía, a través del reconocimiento de tales derechos, “organiza los mecanismos de participación de los autogobiernos indígenas en los espacios regionales y municipales; es decir, que distribuye las distintas formas en que se expresa la autoridad indígena sobre espacios tanto locales, como regionales y municipales" (López y Rivas 2004: 40).

\footnotetext{
135 Acuerdos sobre Derechos y Cultura Indígena firmados por el Gobierno mexicano y el Ejercito Zapatista de Liberación Nacional en 1996.

${ }^{136}$ Las tradiciones políticas liberales han marcado la práctica de los pueblos indígenas, tanto que el concepto de autonomía (más no las prácticas, que residen en la historicidad de los pueblos) tiene sus raíces en las tradiciones jurídicas occidentales; en este sentido no niega sino que afirma el pacto social como el modelo de convivencia ciudadana, pero sobre la base de la re-conceptualización de los criterios que dan forma a la democracia, agregando a dichos criterios el de una identidad colectiva, cultural y política, con antecedentes históricos.
} 


\section{AUTTONOMIAINDIGGENA, VIOLENCIAY JUSTICIA}

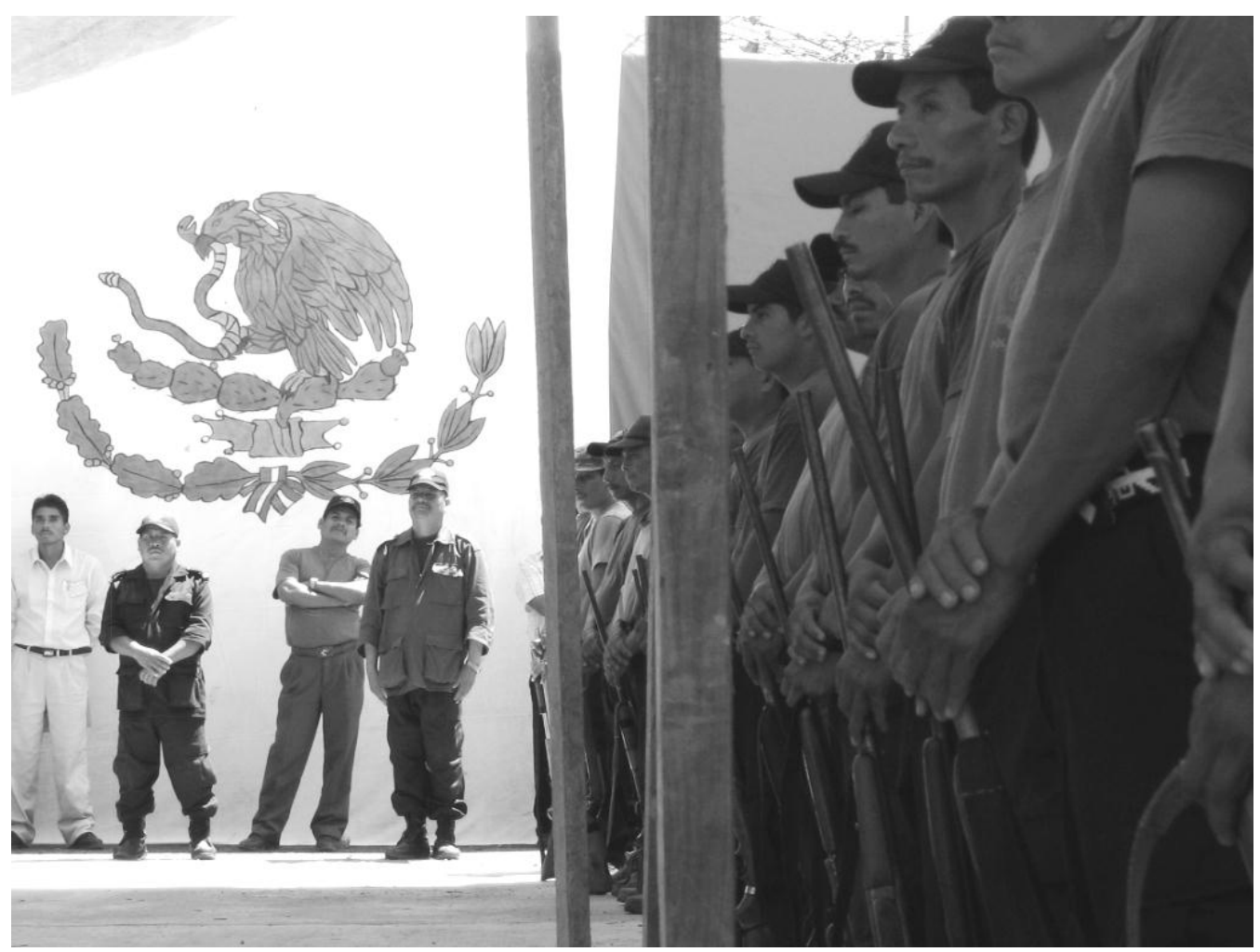

Resguardo de la Patria. 13 Aniversario de la Policía Comunitaria, Tilapa, Guerrero, octubre 2008.

Para trazar una ruta de análisis, sin el afán de buscar una definición, se puede decir que la autonomía ha sido asumida como fin, en término de régimen autonómico legalmente reconocido (aunque con modalidades diferentes, como es el caso de Nicaragua, Colombia o Panamá) o como parte constitutiva de nuevos Estados nacionales o, más bien, plurinacionales (los casos de Bolivia y Ecuador). En ambos casos, la autonomía expresa el reconocimiento legal en el marco de los estados mediante el establecimiento de un régimen político. Aquí, el derecho a la autonomía se desarrolla en términos formales; en este ámbito, se pueden analizar los niveles de las autonomías territoriales, sus competencias y formas de articulación jurídica con el poder estatal.

Por otro lado, la autonomía se expresa como práctica -contrahegemónica- de los pueblos, práctica de resistencia y de construcción, expresión histórica de su determinación, que se encarna en las luchas para conquistar mayor libertad, control territorial y cultural, y espacios de autogobierno. El derecho a la autonomía se conquista y se desarrolla en un contexto contradictorio, a veces a contracorriente y a veces bajo el empuje de cooptación del 
Estado; en tal visión se ubica el análisis de las autonomías como proceso y el énfasis en su carácter transformativo de las relaciones sociales.

Estas dos formas de pensar las autonomías no son opuestas o contradictorias, sino que se integran en los diversos procesos autonómicos, y la expresión de ambas vertientes es necesaria para la construcción y fortalecimiento de la autonomía. Sin embargo, en términos de conceptualización, priorizar una u otra visión lleva a la elaboración de herramientas interpretativas diferentes (quién prioriza el análisis de los arreglos formales; quién se enfoca en las luchas y los movimientos) y complementarias. Para el análisis de los procesos autonómicos en México, considerando que la voluntad política ha rechazado reiteradamente la elaboración de un marco legal y el reconocimiento formal de los procesos de autonomía, resulta más útil empezar el análisis por lo que hay (las experiencias autonómicas) que por lo que aún no se consigue (un marco legal que establezca niveles y competencias). Asimismo, si la intención fuera la elaboración de una propuesta formal, sería de todos modos prioritario el análisis de los procesos para que, sobre su realidad concreta, se pudiera elaborar un marco de reconocimiento adecuado. Estas consideraciones, que antepongo aquí en términos generales, en México fueron objeto de un encarnizado debate, iniciado a la mitad de los años noventa, y que expondré en un siguiente apartado.

En una definición “formal”, López y Rivas afirma que las demandas de autonomía (entendida como derecho):

Implican que los pueblos indígenas puedan ser reconocidos como sujetos de derechos políticos colectivos e individuales, con capacidad para definir sus propios procesos económicos, sus formas comunitarias y regionales de gobierno, su participación en los órganos de jurisdicción estatales y representación popular, el aprovechamiento de sus recursos naturales y la definición de sus políticas culturales y educativas, respetando los usos y las costumbres que les dotan de identidad" (2005b: 63).

A estos elementos fundamentales, Esteva añade también el de un régimen agrario que responda a la forma específica de relación con la tierra y la organización social, y la capacidad de autodefensa (1998: 310). En otro contexto, el mismo López y Rivas expresa una interpretación mucho más "práctica" de la autonomía, entendida básicamente "como un proceso de resistencia mediante el cual las etnias o pueblos soterrados, negados u olvidados 
fortalecen o recuperan su identidad a través de la reivindicación de su cultura, derechos y estructuras político-administrativas" (2010).

Varios analistas han tratado de establecer los elementos formales de la autonomía: sin embargo, es imposible tener una única formulación, ya que dichos arreglos formales reflejan las negociaciones que se logren entre los Estados y los pueblos indígenas, de acuerdo a las necesidades de éstos y la disposición a abrir espacios democráticos de aquéllos. En varias investigaciones, se han subrayado las dimensiones de la autonomía, o sea los ámbitos en los que éstas se desarrollan principalmente: la dimensión territorial, política, económica y cultural (véase los estudios relacionados con el Proyecto LATAUTONOMY, en Gabriel y López y Rivas 2005; 2008).

Centrándome en las herramientas de análisis que han sido elaboradas, más que en la amplísima bibliografía y hemerografía, quiero destacar dos modelos interpretativos elaborados en años recientes, que responden grosso modo a las dos maneras de aproximarse a la autonomía (como práctica contra-hegemónica y proceso; como marco jurídico o como fin).

\section{LATAUTONOMY: el sujeto autonómico y las diez hipótesis de sostenibilidad}

En primer lugar está el modelo elaborado en el marco del Proyecto LATAUTONOMY, un estudio realizado en varios países latinoamericanos y europeos, cuya hipótesis central es: "Autonomías multiculturales en América Latina: una condición necesaria para el desarrollo sostenible".

El marco analítico y teórico elaborado por los investigadores es muy profundo: se estudian los procesos autonómicos en el contexto nacional, y a lo largo de cuatro ejes principales (autonomía, cultura, desarrollo y sostenibilidad, que representa el eje articulador). En un segundo momento, se analizan los factores internos y externos que contribuyen, de manera positiva o negativa, en el desarrollo de los procesos autonómicos, llegando a elaborar un modelo teórico comparativo para la investigación y el análisis de diversos procesos autonómicos. Según Leo Gabriel, uno de los animadores del proyecto, "se trata de crear a partir de las diferentes experiencias de los equipos de investigación de LATAUTONOMY una estructura común de las autonomías multiculturales que puede servir como punto de referencia para todos aquellos que se han encomendado al difícil camino de la autonomía” (2008:25). Tal 
modelo para la comparación, aunque enfatice los elementos comunes por su mismo método estructural, también resalta el carácter histórico y particular de las autonomías y advierte sobre la necesidad de que la autonomía se desarrolle en sus distintas dimensiones.

En LATAUTONOMY se considera que una condición básica de las reivindicaciones autonómicas está en la existencia y la fuerza del sujeto autonómico, y en su capacidad de afirmación hacia adentro y hacia afuera. Se entiende por sujeto autonómico "una red de comunidades basada en una identidad étnica y/o cultural, que está luchando en determinadas regiones para el establecimiento o la conservación de un espacio vital común y autodeterminado", donde la identidad se entiende más bien como multidimensional, ya que es configurada también por las variables económicas, políticas, ecológicas. La atención puesta en el sujeto autonómico, ya presente en escritos anteriores de Gilberto López y Rivas (también integrante del proyecto) tiene particular relevancia para el estudio de las articulaciones de las autonomías con los otros sujetos sociales (Estado, grupos de poder locales, nacionales o trasnacionales, etc.), ya que:

Según las coyunturas, el contexto estructural y su nivel de desarrollo, la afirmación autonómica o identitaria supone una capacidad de movilización, negociación, propuesta, alianza y articulación de demandas. Estas proyecciones hacia el exterior son posibilitadas por la fuerza interna del sujeto autonómico [que] se fundamenta en su cohesión interna, su representatividad y legitimidad democrática, su posibilidad de construir consenso (Munting 2008:125).

El modelo comparativo se articula en "Diez hipótesis de la sustentabilidad", expuestas en el volumen El universo autonómico (Gabriel y López y Rivas 2008). De forma muy resumida, se afirma:

1. la necesidad del equilibrio entre la dimensión política-jurídica, la dimensión culturalintercultural y la dimensión económica-ecológica;

2. la necesidad de vincular el nivel de las comunidades locales con una estructura regional de manera horizontal e interactiva, como requisito de la sostenibilidad de un sistema autonómico;

3. que un proceso autonómico se caracteriza por una interdependencia permanente entre la dimensión política y la dimensión económica de las autonomías, y ambas tienen que basarse en una cultura común; 


\section{AUTONOMIAINDÍGENA, VIOLENCIAY JUSTICIA}

4. que el mayor grado de identidad cultural aumenta la efectividad de un sistema autonómico;

5. que el mayor grado de multi/interculturalidad amplía la posibilidad del sujeto autonómico de consolidarse como fuerza pluriétnica y de conseguir la autonomía político-jurídica por la vía de la negociación con el Estado nacional;

6. que la sostenibilidad ecológica depende en gran medida del grado de multi/ interculturalidad;

7. que el mayor control de un sistema o sujeto autonómico sobre un territorio, reduce el peligro de una destrucción de los recursos naturales, y por lo tanto es más grande la sostenibilidad del sistema;

8. que la eficiencia de los mecanismos de solución de conflictos aplicando el derecho consuetudinario, aumenta la sostenibilidad política de un sistema;

9. que cuanto más la disponibilidad de los recursos se regula por las fuerzas del mercado y no por procesos de decisión basados en el conocimiento local, menor es la sostenibilidad de los recursos naturales;

10. y finalmente, que aunque la Autonomía Multicultural no es de por sí una garantía para un desarrollo sostenible, se puede afirmar que el Estado nacional y el sistema económico neoliberal conducen necesariamente a la inestabilidad de los sistemas políticos y a la pérdida definitiva de cualquier posibilidad de un desarrollo sostenible.

Una teoría política de las autonomías

Las "XI tesis para una teoría política de la autonomía” de Ramón Maíz argumentan que "el principio de la autonomía constituye un vector normativo irrenunciable de una democracia plural y equitativa. Y, como tal, este principio teórico-normativo precisa una teoría política sustantiva" (2008:17). Este "modelo normativo" elaborado por Maíz, si bien proporciona elementos útiles para el análisis de los procesos autonómicos, se presenta como muy teórico, ya que no se relaciona constructivamente con la experiencia concreta de las autonomías, y revela tener como referentes, en buena medida, a las autonomías del Estado español, que difieren en múltiples formas del contexto latinoamericano. 
En primer lugar se afirma que la autonomía supone autogobierno, no mera autoadministración (tesis 1), pues "nada tiene que ver con la simple desconcentración administrativa", ya que "una comunidad autónoma supone un auténtico centro de decisión política diferenciada" (2008:19).

La tesis 2 afirma que la autonomía implica gobierno compartido, no soberanía; esto es, que "la autonomía no es un proyecto de cierre unilateral en un espacio propio de decisión frente al Estado, sino de restructuración pluralista del Estado [...] desde la simultanea unidad y pluralidad de gobiernos" (2008:21).

Autonomía supone competencia, no jerarquía, afirma la tesis III, indicando que a la idea de un centro prístino de poder, del cual desciende el mandato político, "la autonomía opone la lógica de la distribución competencial en ámbitos distintos, ni superiores ni inferiores, de apoderamiento" (pág.22) Esto implica también mecanismos facilitadores del disenso, de garantías de su posible contestación, de la asunción de la posibilidad del conflicto.

La tesis IV recuerda que la autonomía es un proceso, no una estructura, de interacción y negociación constante entre los actores y las instituciones.

Según la tesis V, la autonomía postula la unidad en la diversidad, institucionalizando democráticamente "el pluralismo ideológico, cultural y territorial, no sólo como un hecho irremediable, sino como un auténtico valor político-constitucional, que [...] hay que construir entre todos; [...] aporta una lógica de lo plural cómo valor capital de la democracia” (p.26). Asimismo, "la autonomía implica [...] un reconocimiento activo de las varias identidades étnicas o nacionales, en una perspectiva de encuentro, negociación y pacto; [...] resulta por completo ajena a las identidades cerradas, cristalizadas". De esta manera, se genera "un campo abigarrado de identificaciones, de tal suerte que faculta conciliar las identidades particulares con una identidad estatal-nacional más amplia, acogedora de aquellas” (p.26). Esta visión se puede expresar también en una reivindicación de la interculturalidad entendida como necesario dialogo intercultural.

La tesis VI explica porque la autonomía implica igualdad interterritorial: "la redistribución territorial de los recursos económicos permite el desarrollo del autogobierno y la cohesión, siguiendo criterios de solidaridad entre las diferentes comunidades". Según esta idea, la autonomía promueve la renegociación de los equilibrios internos al Estado; por este motivo son inaceptables propuestas que se autodefinen "autónomas" y que simplemente 
reivindican que los capitales generados dentro de un determinado territorio, más rico en recursos naturales y políticos, se queden en su interior y se auto-administren localmente (es el argumento que caracteriza las "autonomías departamentales" en Bolivia, por citar solamente un ejemplo).

Las tesis siguientes afirman que las instituciones autonómicas no expresan, sino que producen identidades (VII); que la autonomía requiere un sistema de actores complejo, descentralizado en partidos y movimientos (VIII); que requiere un discurso autonomista plenamente compartido (IX); que la autonomía forma parte central de los procesos de democratización $(\mathrm{X})$, poniendo en discusión el sistema de la representación y abriendo la puerta al reforzamiento de la participación, configurándose come espacio de deliberación de la misma cultura nacional, y aportando una dimensión de democracia inclusiva.

La tesis XI, Autonomía: ¿un modelo para armar?, reafirma que el esquema teórico propuesto quiere aportar simplemente unos mínimos normativos, ya que la autonomía se caracteriza por su gran elasticidad.

La autonomía a debate: muchas experiencias, diferentes interpretaciones

El debate sobre la relación entre los pueblos indígenas y el Estado se ha desarrollado en contextos muy diferentes, tanto a nivel internacional -Latinoamérica y Europa- como en México.

Las experiencias concretas se originan a partir de particulares contextos sociales, históricos, territoriales y políticos; implican disímiles relaciones entre el Estado y los pueblos indígenas, así como particulares discursos y prácticas políticas por parte de los sujetos colectivos indígenas de acuerdo a su nivel de organización y su relación con el conjunto de la sociedad nacional. Por lo tanto, son las diversas situaciones en las que se han venido construyendo procesos autonómicos las que determinan diferentes conceptualizaciones de la autonomía.

En todo el continente latinoamericano los movimientos y organizaciones indígenas han impuesto en el debate político de las últimas dos décadas, de maneras diferentes, el tema de la autonomía; asimismo, han sido variadas las formas en como los Estados han enfrentado esta reivindicación. Miguel González (2010: 38-39) explica la diferencia entre el reconocimiento 
de un régimen de autonomía como nuevo orden de gobierno, que implica la modificación de la estructura del Estado, y el reconocimiento de autonomías territoriales mediante legislación secundaria, pero sin conferir derechos de autogobierno. En el primer ordenamiento se inscriben los casos de Nicaragua (regiones autónomas), Colombia (resguardos), Bolivia (entidades territoriales indígenas originarias campesinas) y Ecuador (gobiernos autónomos descentralizados). En el segundo ordenamiento están Panamá (reservas y comarcas) y Venezuela (como un nuevo tipo de municipio, el indígena).

En particular, Bolivia y Ecuador viven una radical transformación del Estado, de Estado nacional a plurinacional e intercultural, y en ambos países se ha dado un proceso constituyente que ha modificado radicalmente sus estructuras, ampliando el espacio de los derechos reconocidos para los pueblos indígenas. ${ }^{137}$ Los múltiples conflictos que atraviesan estos países andinos se relacionan, entre otros, con la dificultad de desplazar las élites dirigentes de los espacios privilegiados de dominio político y económico, e incluso territorial; por otro lado, el "socialismo andino", aunque haya establecido un mayor control del Estado en la economía y amplios programas de redistribución de la riqueza, no ha cambiado el modelo productivo basado en la explotación de los recursos naturales y en un agresivo extractivismo, lo que ha provocado serios conflictos con los pueblos originarios. ${ }^{138}$ En Ecuador el conflicto entre el gobierno de Correa y la Confederación Nacional de Organizaciones Indígenas del Ecuador (CONAIE) explota en 2009, con masivas protestas en contra de la Ley minera, la Ley de Privatización del agua y la explotación petrolera. En Bolivia, el más recién conflicto entre el Estado y los pueblos originarios, que tuvo gran relevancia a nivel internacional (hubo enfrentamientos y una violenta represión de la policía), estalló en 2012 con la oposición de los indígenas asentados en el TIPNIS (Territorio Indígena Parque Nacional Isiboro-Sécure) a la

\footnotetext{
${ }^{137}$ Véase los capítulos relativos a Bolivia y Ecuador en los libros coordinados por Gabriel y López y Rivas (2005); Escárzaga y Gutiérrez (2005, 2006); Gutiérrez Chong (2008); Martínez (2009); González, Burguete y Ortiz-Tejeda (2010), entre otros.

${ }^{138}$ Algunas opiniones (seguramente no representativas) de este debate, han sido expresadas por: Pablo Stefanoni y Hugo Blanco, "Debates en torno al «pachamamismo»", 2010, <http://opsur.wordpress.com/2010/06/16/debates-en-torno-al-pachamamismo/>; Börries Erek Nehe, "Territorios en disputa. Movimientos sociales y la producción del espacio. El caso de Pando y la Media Luna en Bolivia", $X$ Congreso Centroamericano de Historia, UNAN-Managua, Nicaragua (12 al 15 de julio del 2010), <http://www.hcentroamerica.fcs.ucr.ac.cr/Contenidos/hca/cong/mesas/

x_congreso/hist_social/pando-medialuna.pdf>; Carmen Martínez Novo "El ataque a los derechos indígenas y el retorno del indigenismo en el Ecuador post-neoliberal", Coloquio Internacional Los retos de la diversidad cultural y política en América Latina, UAM, México D.F. (5 y 6 noviembre 2013)
} 
construcción de una carretera que atravesaría el Territorio. La demanda general es para el respeto al derecho a la consulta para los pueblos indígenas (Convenio 169 OIT). En Bolivia hubo incluso una propuesta de autonomías "departamentales" (que se refiere más bien a una descentralización política, administrativa y financiera), impulsada por los terratenientes y las élites políticas y empresariales de los departamentos orientales de Santa Cruz, Pando y Beni, donde se concentra el poder económico. En 2008 el conflicto entre los "autonomistas" y el Estado boliviano estalló, con un saldo de más de 30 campesinos e indígenas muertos.

Estos acontecimientos muestran como el camino de las autonomías siempre es en subida, pues la institucionalización de derechos no garantiza su real reconocimiento o implementación; asimismo, el control sobre los territorios y los recursos que en ellos se encuentran es uno de los temas más conflictivos, pues estos son objeto del interés económico tanto de los Estados cuanto del capital privado nacional y trasnacional. Al igual que en los países andinos y en México, el problema del control sobre su territorio por parte de las comunidades y pueblos indígenas es de gran importancia también en la Costa Atlántica de Nicaragua. Esta es la primera experiencia de construcción de institucionalidad autonómica en América Latina; por la trascendencia que tuvo en su momento y por los elementos que sigue aportando al debate, dedicaré algunos párrafos en ilustrar el desarrollo y los desafíos actuales que enfrenta la autonomía regional nicaragüense.

Tras una fuerte movilización de los habitantes afrocaribeños e indígenas (en particular los miskitos) que, en la década de los ochenta, enfrentaron al gobierno sandinista reivindicando sus derechos históricos como pueblos, dicho gobierno se abrió al diálogo y promovió una amplia consulta nacional e internacional en la cual participaron tanto representantes indígenas, campesinos y sindicales, como expertos y académicos con experiencia sobre el tema ${ }^{139}$. Fue así que en 1987 se reformó la Constitución Política de la Republica de Nicaragua estableciendo los marcos para un régimen de autonomía regional para los pueblos indígenas (miskitos, sumos/ mayangnas y ramas) y comunidades étnicas (creoles, garífunas y mestizos) de la región caribeña (Brunneger 2007; Hooker 2010; Ortega Hegg 2005).

\footnotetext{
${ }^{139}$ Entre ellos, Héctor Díaz-Polanco y Gilberto López y Rivas, quienes hicieron de la autonomía uno de sus temas privilegiados de investigación, aunque con enfoques diferentes.
} 
Es necesario ubicar el proceso de autonomía nicaragüense en el contexto de la revolución sandinista y de la guerra de contrainsurgencia en contra del gobierno revolucionario, guerra en la que las organizaciones miskitas participaron como uno de los principales grupos -armados- opositores al sandinismo. Los argumentos de la contra, y el intervencionismo de Estados Unidos, se mezclaron con las reivindicaciones históricas de derechos propios para los pueblos indígenas, inicialmente desconocidos por los gobiernos sandinistas (Fruhling et. al. 2007:42). Con el pasar del tiempo y frente a una situación de conflicto interno muy cruento, entre 1984 y 1985 maduró entre los dirigentes revolucionarios la idea de que la negociación y el establecimiento de un régimen de autonomía territorial representaba la única manera para desactivar la guerra en esta región del país, reconociendo las demandas históricas de los indígenas y abriendo espacios de autorganización para un sector muy empobrecido de la población.

Así, se establecieron dos Regiones Autónomas (Norte y Sur) que juntas cubren el $46 \%$ del territorio nacional; en el diseño institucional se tuvo particular cuidado en garantizar la participación y equidad de todos los grupos al interior de regiones multirraciales y multiétnicas, para evitar una hegemonía de los miskitos (el pueblo indígena con mayor población, y más fuertemente opuesto al sandinismo). ${ }^{140}$

En el mismo año -1987-, se aprobó el Estatuto (o Ley) de Autonomía de las Regiones Autónomas de la Costa Atlántica de Nicaragua, que establece las atribuciones específicas de dichas regiones y define de forma detallada los procedimientos para la coordinación entre éstas y las instituciones del gobierno central. Asimismo, la Ley de Municipios establece a éstos como las entidades del Estado responsables de la administración y el gobierno del territorio municipal, definiendo los mecanismos de colaboración con los gobiernos regionales autónomos.

Las Regiones autónomas tienen la particularidad de coordinar decisiones y acciones de cuatro diferentes organismos: el gobierno nacional, el gobierno regional, el gobierno municipal y el gobierno comunal [...] es el único caso en que existen gobiernos regionales ubicados entre el gobierno central y el gobierno local, así como una nueva instancia de administración

\footnotetext{
${ }^{140}$ Según Hooker, "la cuestión de cómo configurar los espacios autónomos -tanto en regiones multiétnicas como en territorios propios por separado para cada grupo- ha sido uno de los aspectos más controversiales e importantes del debate acerca de la autonomía en Nicaragua" (2010: 185).
} 
comunal. ${ }^{141}$ En el resto del país sólo existe el gobierno nacional y los municipales" (Ortega Hegg 2005:228).

En Nicaragua se instauró un arreglo autonómico institucionalizado y detalladamente definido a nivel jurídico; se trata de un verdadero "régimen que establece una forma de gobierno específica que son los Consejos Autónomos con un Ejecutivo". Otra característica es el ser una autonomía de naturaleza territorial (López y Rivas 2002:118).

A pesar de este reconocimiento institucional, el proceso de las Regiones Autónomas de la Costa Atlántica se ha visto afectado por el contexto macro-económico que involucra a Nicaragua: mientras casi la mitad de la población se encuentra en situación de pobreza, el modelo económico neoliberal, las políticas de ajuste estructural y de "lucha contra la pobreza" impulsadas por los gobiernos derechistas después de 1990 han agudizado los problemas específicos de las regiones autónomas, que presentan bajo Índice de Desarrollo Humano y bajo Índice de Condiciones de Vida (PNUD 2000, 2005; Ortega Hegg 2005). Asimismo, el involucramiento de los partidos políticos en la conformación de los gobiernos, la corrupción en la clase política, la escasa y nula relación de las instancias locales con las regionales, y el narcotráfico, han puesto en un predicamento esta experiencia autonómica.

No obstante, la experiencia nicaragüense es un referente en el proceso de construcción de las autonomías, por sus importantes aciertos y avances (fortalecimiento de la identidad nacional y al mismo tiempo de la identidad indígena, construcción de instituciones autónomas de educación superior y universidades como la URACCAN); al mismo tiempo sus dificultades muestran cómo tales procesos no pueden ser completamente exitosos si no combinan la institucionalización con la formación de conciencia autonómica desde la base, es decir, sin la construcción de un sujeto colectivo indígena. Este problema de fondo se ha hecho visible en problemas de orden político y en problemas de gobernabilidad; en el primer rango está la preponderancia de los mestizos en ambos gobiernos regionales, lo que contradice el objetivo de que indígenas y mestizos ejerzan el autogobierno en la región; así como la ya mencionada influencia de los partidos políticos nacionales, por ejemplo en las elecciones de las autoridades

\footnotetext{
141 La Constitución nicaragüense reconoce a los territorios y comunidades indígenas en las regiones autónomas como sujetos de derecho público, con competencias sobre administración de recursos naturales, ordenamiento territorial y planificación al desarrollo.
} 
regionales y municipales que siguen eligiéndose según el sistema partidista, lo que mantiene atadas las regiones "autónomas" al poder político central.

Por otro lado se observa la falta de voluntad política por parte del gobierno central para el reconocimiento y avance del régimen autonómico (Díaz-Polanco 1997a, Ortega Hegg 2005); la falta de coordinación y los conflictos entre los distintos niveles institucionales operantes en las regiones, sobre todo la débil institucionalidad de los gobiernos regionales y la falta de articulación de las autoridades tradicionales comunitarias. Estos desaciertos han provocado conflictos sociales como la fuerte migración y las rupturas inter-generacionales, que los gobiernos regionales no han sabido enfrentar de forma dinámica y positiva; por otro lado, la fuerte injerencia del narcotráfico contribuye a la descomposición del tejido social (Ortega Hegg 2005; PNUD: 2005).

Finalmente, una problemática que me parece de gran relevancia es la falta de autonomía efectiva sobre el control de los territorios y de los recursos naturales, ya que las instituciones centrales mantienen la prerrogativa de otorgar concesiones para su explotación; aunque los consejos regionales tienen considerable poder de veto sobre las concesiones, éste no siempre se ejerce en favor de las comunidades indígenas. Esta situación inició a cambiar a partir del fallo emitido por la Corte Internacional de los Derechos Humanos a favor del derecho de propiedad comunal de la comunidad de Awas Tigni. La Ley de Propiedad Comunal emitida en 2002 reconoce explícitamente a las comunidades afrodescendiente e indígenas como unidades administrativas; además, establece los mecanismos para la demarcación y titulación de las tierras comunales. La mayoría de las comunidades indígenas han iniciado el proceso de titulación de los territorios comunales como mecanismo de defensa frente al Estado, a los mestizos y a los mismos gobiernos regionales; sin embargo, a la fecha muchas todavía carecen de títulos de propiedad (como la misma Awas Tigni). ${ }^{142}$ Por lo tanto, se puede observar como a través del proceso de defensa de los recursos y de re-apropiación del territorio, se está también revitalizando la identidad comunitaria y étnica. ${ }^{143}$

La experiencia nicaragüense es un referente en el proceso de construcción de las autonomías, por sus importantes aciertos y avances (fortalecimiento de la identidad nacional y

\footnotetext{
142 Véase Sergio de Castro Sánchez, “Autonomía indígena y autonomía regional en la Costa Atlántica de Nicaragua", Rebelión, 29/04/2008, <http://www.rebelion.org/noticia.php?id=66694>, consultado el 15 noviembre 2013.

${ }^{143}$ Como afirma Hooker (2010) para el caso de las comunidades afrocaribeñas.
} 
al mismo tiempo de la identidad indígena, construcción de instituciones autónomas de educación superior); al mismo tiempo sus dificultades muestran cómo tales procesos no pueden ser completamente exitosos si no combinan la institucionalización con la formación de conciencia autonómica desde la base, es decir, sin la construcción de un sujeto colectivo indígena; este sujeto colectivo, impulsando un movimiento social fuerte, tiene la función de presionar a los partidos políticos y al Estado para la profundización del proceso de democratización y autonomía. ${ }^{144}$

\section{Los caminos de la autonomía en México. Un largo debate}

En el contexto mexicano la discusión sobre la autonomía indígena emerge con fuerza en concomitancia con el debate sobre la cuestión étnico nacional, a la mitad de los años ochenta. Sin embargo, el tema no es completamente nuevo y tiene como antecedente la discusión que se da en los años treinta sobre la cuestión nacional y los indígenas, tras los análogos debates surgidos en la Unión Soviética. Según Medina (1987), fue Vicente Lombardo Toledano quien dio a conocer las posiciones estalinistas en México, y basándose en ellas elabora una propuesta para abordar "el problema de las nacionalidades oprimidas en México" (cuya resolución se dará solamente "cuando exista un gobierno proletario"). Al propósito, Toledano propone modificar "la división política territorial de los municipios y estados habitados por indígenas", que en la actualidad dividen "arbitrariamente a la masa indígena en diversas jurisdicciones". En segundo lugar, propone la "autonomía política absoluta de las entidades pobladas por indígenas; que las autoridades de los indígenas sean indígenas invariablemente, en todos los casos" (1973). Asimismo, plantea el fomento a los idiomas indígenas, la colectivización del trabajo agrícola y la supresión de la propiedad individual de la tierra en zonas indígenas.

Ya en los años ochenta, diversos sectores debatían sobre la autonomía, desde luego dando al concepto interpretaciones diferentes. Según Luis Hernández Navarro, intelectual

\footnotetext{
${ }^{144}$ González, en un breve ensayo comparativo entre las autonomías "con y sin permiso" de Nicaragua y Chiapas, afirma que "la autonomía regional no se agota en sus instituciones representativas regionales [...] y los desarrollos legislativos no lo resuelven todo - está visto que el avance legislativo o el estancamiento relativo del régimen autonómico ha estado en buena parte sujeto a los acuerdos políticos de los principales partidos nacionales" (2004: 41).
} 
mexicano que cuenta con profunda experiencia sobre el tema, en esa época representaban una vertiente del debate:

Las organizaciones campesinas, cafetaleras, que entendían la autonomía básicamente como autogobierno, asociándola a la apropiación del proceso productivo. Planteábamos por eso la necesidad que las organizaciones campesinas crearan sus propios aparatos y empresas, de tal manera que los recursos, el excedente de lo que se venía produciendo se quedara en las comunidades permitiendo generar procesos de desarrollo autónomo. ${ }^{145}$ Había muchas organizaciones indígenas embarcadas en ese proceso, incluidas las que luego se convirtieron al zapatismo. $^{146}$

Bartra y Otero afirman que el concepto inició a generalizarse después de 1984, cuando unas cincuenta organizaciones rurales se constituyeron en la Unión Nacional de Organizaciones Regionales Campesinas Autónomas (UNORCA), y con el desarrollo del movimiento urbanopopular. 'Los campesinos 'autónomos' rechazaron la vigilancia del Estado y se dispusieron a 'apropiarse del proceso productivo' -autoadministración-, mientras los vecindarios y las comunidades se organizaron alrededor de la provisión auto-administrada de servicios básicos como escolaridad y seguridad" (Bartra y Otero 2008:409). Las luchas indígenas radicalizaron esta visión de la autonomía como independencia organizativa y autoadministración socioeconómica apuntando a la autodeterminación y al autogobierno, invocando una historicidad y una normatividad propia, por lo cual "el concepto subyacente de autonomía afiló su connotación de alteridad, de alternativa, de proyecto hegemónico popular-democrático y multicultural" (Bartra y Otero 2008:409).

Sobre la acepción indígena del concepto de autonomía, afirma Hernández Navarro:

Una segunda vertiente eran las organizaciones etnopolíticas que venían pensando la autonomía como recuperación de lo propio en cuestiones como la fiesta, la lengua, los sistemas normativos ("usos y costumbres”). En este ámbito ellos vinieron desarrollando experiencias prácticas.

La tercera vertiente son las personas que se activaron en el 1992 alrededor de los 500 Años de Resistencia y se vincularon con la experiencia de autonomía que provenía básicamente de

\footnotetext{
${ }^{145}$ En las décadas anteriores, fue el concepto de "independencia” que se utilizó por parte de las organizaciones como un símbolo de la oposición democrática al corporativismo del Estado mexicano y del partido de Estado.

${ }^{146}$ Luís Hernández Navarro, entrevista realizada el 27 abril 2004.
} 


\section{AUTONOMIAINDÍGENA, VIOLENCIAY JUSTICIA}

Nicaragua. En este ámbito fueron muy importantes las experiencias de algunos académicos que participaron en el proceso nicaragüense; algunos de ellos sobre el ejemplo de este proceso se encontraron con dirigentes indígenas para proponer al movimiento indígena la propuesta de las Regiones Autónomas Pluriétnicas. Aquí se entendía la autonomía como un régimen, la transferencia de un conjunto de facultades, competencias, funciones y recursos de una instancia oficial de gobierno a otra, los pueblos indígenas. El marco en que se entendían las autonomías era muy formal. ${ }^{147}$

Las dos últimas "vertientes" someramente mencionadas por Hernández Navarro representan los grandes ejes del debate mexicano, que comúnmente se identifican como "comunalista" y "regionalista". Las diferencias de visión y de postura no se limitan al debate teórico sino que han aparecido al interior del movimiento indígena mexicano y en éste se expresan, según algunos analistas, en la tensión establecida entre líderes oaxaqueños y chiapanecos, que tendrían distintas lecturas sobre lo indígena. Estas originan diferentes propuestas autonómicas, que se desarrollan a partir de trayectorias diferenciadas de apropiación de lo étnico, tradiciones distintas de negociación con el Estado, y desequilibrio de experiencias en el campo intelectual. Desde luego, no se trata simplemente de una diferencia ideológica entre líderes, sino de una diversidad de tradiciones organizativas y trayectorias políticas colectivas, así como de distintas estructuras locales de organización social.

La diferencia fundamental entre las dos propuestas reside en la escala en la que se considera la autonomía y en consecuencia cuál es el sujeto de Derecho y su relación con el Estado. Con la advertencia que tal debate es muy amplio y delicado, trataré de resumirlo en sus puntos fundamentales.

La propuesta de autonomía regional empezó a ser planteada en México por el Frente Independiente de los Pueblos Indios (FIPI) ${ }^{148}$ a partir de la homónima experiencia nicaragüense, recogiendo también el breve intento de instaurar una Región tojolabal en Chiapas, realizado en 1988. La autonomía regional se centra en la identificación de un territorio, adscribiendo a dicha región autónoma la cualidad de sujeto de Derecho: propone la implantación de un cuarto piso de gobierno en la organización político-territorial del Estado, el de la región como entidad política distintiva. El proyecto de autonomía regional, como se ha

\footnotetext{
${ }^{147}$ Luís Hernández Navarro, entrevista realizada el 27 de abril 2004.

${ }^{148}$ El FIPI se crea en 1988 y desparece luego del levantamiento zapatista, confluyendo en la ANIPA.
} 
venido elaborando en México, pone un énfasis particular en garantizar la representación de los pueblos indígenas en el sistema político y en la elección de sus representantes en los congresos estatales y en el federal, así como en la construcción de administraciones autónomas. Tal propuesta es criticada principalmente por representar una concepción demasiado formal de la autonomía, donde el "autogobierno" sería "un orden de gobierno especifico, constitutivo de un sistema de poderes verticales que conforma la organización del Estado" (Díaz-Polanco 1996:109), lo cual se limitaría a conceder facultades administrativas a la entidad regional. ${ }^{149}$ Pero, como señala acertadamente Villoro, "establecer un nivel suplementario de gobierno exige una reforma constitucional radical y modificaciones en las leyes fundamentales de los estados con población indígena. Para ello se requieren circunstancias políticas precisas que son difíciles de prever, por lo menos en corto plazo" (Villoro 1998:97). ${ }^{150}$

Como se vio en los años siguientes al inicio de esta polémica, el reto en la actual lucha indígena en México no es sólo el reconocimiento constitucional de los derechos indígenas, sino la recreación del proyecto nacional; el establecimiento de un nuevo pacto social entre los pueblos indígenas y el Estado mexicano; el alto a la indiscriminada explotación y saqueo de los territorios y de los recursos - naturales, culturales, humanos- de los pueblos indígenas, así como el fin de la violencia de todo tipo que desde el Estado, las corporaciones y el crimen organizado se ejerce contra los pueblos. Cuestiones que implican el fortalecimiento de la autonomía, pero que van mucho más allá de la instauración de regímenes autonómicos aislados (como enseña el caso de Nicaragua y la actual situación de las regiones autonómicas).

Tal vez el único intento de poner en práctica la propuesta regional en México tuvo lugar en Chiapas, cuando el 12 octubre de 1994 la Asamblea Estatal del Pueblo Chiapaneco $(\mathrm{AEPCH})$ y el Consejo Estatal de Organizaciones Indígenas y Campesinas (CEOIC) proclamaron siete Regiones Autónomas Pluriétnicas (RAP) en el Estado, iniciativa que duró

\footnotetext{
${ }^{149}$ Esteva (1998: 313) distingue entre la descentralización, característica del self-government como tradición anglosajona y también de la administración colonial, que "tiene como premisa una noción del poder que lo centraliza en la cúspide, para delegar hacia abajo competencias" y el descentralismo, que sería característica de un real proceso autonómico y "busca retener el poder en mano de la gente, devolver escala humana a los cuerpos políticos y construir, de abajo hasta arriba, mecanismos que deleguen funciones limitadas en los espacios de concertación que regulen la convivencia de las unidades locales y cumplan para ellas y para el conjunto tareas específicas"

${ }^{150}$ Villoro escribía estas líneas en 1998. Los sucesos políticos siguientes (principalmente la reforma constitucional del 2001 que desconoce los Acuerdo de San Andrés), han demostrado la clara oposición de los actuales gobiernos a crear tales condiciones políticas.
} 
apenas pocos meses. El clima de movilización generalizada creado por el levantamiento zapatista explica la inicial adhesión al proyecto de las RAP, creado por una convergencia de organizaciones muy diferentes entre ellas, en un momento en que el proyecto de autonomía zapatista estaba en gestación (será hasta dos meses después que se declararán los Municipios Autónomos Rebeldes Zapatistas- MAREZ), pero el debate sobre la autonomía a nivel nacional ya había adquirido mucha relevancia. En este marco se pueden ubicar los dos municipios autónomos también declarados por la AEPECH y el CEOIC en diciembre 1994: Che Guevara (después englobado por la organización zapatista) y Sibacjá, en la región de Ocosingo. ${ }^{151}$ Otro acontecimiento que enmarca este proceso, es la declaración -por parte de la AEPECH- de Amado Avendaño como Gobernador en Rebeldía, después de las cuestionadas elecciones de julio 1994 que llevaron a la gubernatura a Eduardo Robledo. Las Regiones Autónomas, protagonizadas por organizaciones como la Central Independiente de Organizaciones Campesinas (CIOAC) y la ORCAO (Organización Regional de Cafeticultores de Ocosingo), se declararon en tal contexto de movilización estatal y afirmaron reconocer únicamente la autoridad de Avendaño y su gobierno. A los pocos meses, la capacidad operativa de las RAP, reconocida informalmente por las instituciones oficiales (como el entonces Instituto Nacional Indigenista, que les cedió algunos locales para representación en su sede de San Cristóbal de Las Casas), disminuyó hasta su desaparición.

Se hizo vocera de la propuesta regionalista la Asamblea Nacional Indígena por la Autonomía (ANIPA), organización creada en 1995, también sobre la ola de atención a la cuestión indígena levantada por la insurrección del EZLN, y en la cual convergieron muchos líderes indígenas que jugaron un papel importante en las movilizaciones de los 500 Años de Resistencia en 1992 y en los circuitos internacionales. En los primeros años, la ANIPA tuvo bastante capacidad de convocatoria, aunque ha sido siempre una organización formal y con tendencia institucionalista, de corte tradicional y con estructura vertical. ${ }^{152}$

\footnotetext{
${ }^{151}$ Sus impulsores, pertenecientes a la CIOAC, mencionan que el debate sobre la creación de instituciones de gobierno autónomas tenía ya por lo menos dos años. En: José Gil Olmos, "Che Guevara y Sibajcá, nuevos municipios autónomos", La Jornada, 18/12/1994.

${ }^{152}$ ANIPA se constituye tras la iniciativa de algunas organizaciones indígenas, ONG's, intelectuales indígenas y algunos sectores del PRD. Muestra del corte institucionalista que tuvo desde el principio es que la primera reunión se realizó en la Cámara de Diputados, en abril 1995 (Sarmiento 1998a:302). En la actualidad, varios de sus integrantes o impulsores cubren puestos en las instituciones gubernamentales y de representación política en el Congreso (véase López Bárcenas 2005: 181).
} 
Mientras la propuesta "regionalista" toma ejemplo del proceso nicaragüense y se articula sobre las experiencias chiapanecas, la propuesta "comunalista" se origina principalmente en los procesos presentes desde hace años en el estado de Oaxaca. El comunalismo oaxaqueño es una de las corrientes protagónicas del movimiento indígena mexicano, por la capacidad de elaboración teórica, la preparación de sus líderes y los alcances logrados en la negociación con el Estado, con respecto al reconocimiento de sus formas de gobierno por "usos y costumbres" en la Constitución estatal. ${ }^{153}$

La propuesta comunal, a diferencia de las regiones autónomas, se ha articulado en el tiempo sobre la base de las prácticas cotidianas de organización política y social que estructuran las comunidades indígenas del estado de Oaxaca. Ha sido enfatizado por muchos investigadores el importante arraigo, en esta región, de las formas de organización propia de los pueblos, que a pesar de los violentos cacicazgos han luchado para permanecer y desarrollarse con particular fuerza, sin dejar de renovarse. Considero importante el carácter vigente y de "experiencia" colectivamente construida que tiene la propuesta comunal, pues su legitimidad proviene del hecho de que ya es práctica y vida de los pueblos. Así se refiere a la autonomía uno de los teóricos de esta propuesta, Floriberto Díaz, antropólogo mixe: “los académicos están imaginándose utopías, posibilidades. Para el caso mixe no es utopía, es realidad en el ámbito comunitario" (2007: 156).

La propuesta de las regiones autónomas es un planteamiento muy articulado y con interesantes posibilidades de desarrollo entre los pueblos, que políticamente puede abrir necesarios espacios de diálogo intercultural al plantear el carácter pluriétnico de las regiones; sin embargo, son escasas las experiencias concretas que lo sustentan, siendo más bien una propuesta elaborada por intelectuales y líderes indígenas. Según los testimonios recogidos por Mattiace, los sostenedores de las RAP en Chiapas trataron de fortalecer la identidad del pueblo tojolabal, por encima de las identidades locales - pertenencia a un ejido o a una comunidadque consideraban como desarticuladoras. Si esto por un lado es cierto, considerado el número

\footnotetext{
${ }^{153}$ La Constitución del Estado de Oaxaca fue la primera en reconocer ciertos derechos colectivos de los pueblos indígenas. Asimismo, el Código Electoral del estado reconoció, a partir de 1992, la validez del nombramiento en asamblea (denominado Usos y Costumbres) para las elecciones de las autoridades municipales. Las elecciones del 1995, cuando 412 municipios eligieron sus autoridades de esta forma, fueron determinantes en la relación entre Estado y pueblos indios a nivel nacional, y una referencia básica en las negociaciones de San Andrés (Hernández Navarro: 1997; Barabas: 2005).
} 
de conflictos intercomunitarios, sobre todo ligados a problemas agrarios, que existen en la región, sin embargo:

En la práctica, casi todos los tojolabales, pese a su filiación regional, también continúan identificándose con espacios locales. [...] Si se acepta que el contacto con la tierra ha sido fuente de continuidad de los pueblos indígenas, una cuestión clave para el movimiento indígena reside en cómo robustecer las identidades regionales y pan-étnicas (Mattiace 2002:110).

En esta región chiapaneca la autonomía tiene profundas raíces, pues se ha documentado una larga historia de elecciones de líderes locales y de ejercicio de formas propias de justicia y tomas de decisiones por la comunidad. No obstante, Mattiace afirma que:

Los líderes locales de la CIOAC en la unión ejidal Pueblos Tojolabales me dijeron que no podían hacer comentarios sobre la RAP que había sido proclamada en la región donde viven y trabajan, porque "no sabemos nada de eso" (entrevista, 18 de diciembre de 1995). [...] Entre los tojolabales, dice[n], "la gente ha sido autónoma, pero de su manera. Desde su comunidad, desde como ellos la ven" (entrevista, 22 de noviembre de 1995). (Mattiace 2002:108-109).

Por su parte, la propuesta comunal se gesta entre las organizaciones oaxaqueñas, que surgieron a principios de la década de los ochenta:

Como resultado del trabajo organizativo y pastoral de varios sectores, como el magisterio y la iglesia católica, así como de la experiencia de lucha campesina de la década anterior [...] Son dos las principales condiciones que confluyeron para dar vida a estas organizaciones regionales con demandas y propuestas claramente étnicas: la lucha local contra caciquismo y explotación y el surgimiento de intelectuales indios (Maldonado 2002:94) ${ }^{154}$

\footnotetext{
154 "La región donde surgen estas organizaciones pioneras es la Sierra Norte de Oaxaca, y son formadas básicamente por zapotecos y mixes, también por chinantecos. Ellas son: la Organización para la Defensa de los Recursos Naturales y Desarrollo Social de la Sierra Juárez (ODRENASIJ), el Comité de Defensa de los Recursos Naturales y Humanos Mixes (CODREMI), el Comité Organizador y de Consulta para la Unión de los Pueblos de la Sierra Norte de Oaxaca (CODECO). Sus más destacados intelectuales son dos antropólogos: Floriberto Díaz Gómez. mixe de Tlahuitoltepec, y Jaime Martínez Luna, zapoteco de Guelatao, quienes fueron también unos de sus más activos y comprometidos impulsores. Y son precisamente ellos dos quienes formulan la perspectiva de la comunalidad. [...] A su vez, la lucha comunalista librada por los zapotecos de Yalálag contra décadas de caciquismo en esa zona de la Sierra Norte, llegaba también a principios de los 80's a uno de sus momentos cruciales cuando recuperó el pueblo el poder (Vásquez y Aquino, 1995). En esta lucha y otras dirigidas en la zona
} 
En la propuesta comunal, como sugiere su nombre, la comunidad adquiere un papel central tanto en el ámbito simbólico como en el político y organizativo; el proceso por el que se propone construir la autonomía no es la construcción de estructuras formales de gobierno, sino la reconstitución de los pueblos, a partir de elementos constitutivos que, en una perspectiva histórica, muestran su permanencia.

Los teóricos y líderes indígenas que impulsan esta visión afirman que el elemento central de las sociedades indígenas es su ser comunal, su existencia como colectivo, lo que se refleja en todos los aspectos de la vida comunitaria y da cohesión a la comunidad misma. De aquí se desprende el concepto de comunalidad, que es "actitud humana hacia lo común" (Regino s/f), o bien "una forma de nombrar y entender el colectivismo indio [...] Es la lógica con la que funciona la estructura social y la forma en que se define y articula la vida social" (Maldonado 2002:92). A su vez, la comunalidad se basa en cuatro elementos centrales:

1. la tierra y el territorio comunal, entendida en dos sentidos: "como espacio material en donde se reproduce nuestra existencia, y en donde trabajamos para obtener nuestros alimentos y sustento general; y como espacio espiritual, dado que en ella viven nuestras raíces, nuestros ancestros, nuestros nahuales" (Regino s/f). El espacio territorial por excelencia, donde se concreta el vínculo entre la persona, la colectividad que la integra y la tierra, es la comunidad.

2. El poder comunal (no centrado en el individuo sino en la comunidad) y la asamblea como poder constituyente, “quizás el reflejo más contundente de nuestra existencia como comunidad, se da en lo que atañe a la toma de decisiones que afectan a la comunidad y al ejercicio de las mismas. Aquí juegan un papel fundamental las Asambleas como el espacio común para cumplir esas funciones" (Regino s/f).

3. El trabajo comunal, como energía creativa en el que se expresa la relación entre las personas y la Tierra: "es mediante el trabajo familiar y comunitario, como los indígenas recreamos a la tierra, a la naturaleza y a nosotros mismos" (Regino s/f).

4. La fiesta (como el espacio para recomponer el conflicto y fortalecer los lazos sociales). Según Maldonado:

por la Asamblea de Autoridades Zapotecas y Chinantecas de la Sierra -organización derivada del Codeco-, participaba activamente Juan José Rendón [...] y quien realizara aportes teóricos y metodológicos relevantes a la idea de la comunalidad y su difusión" (Maldonado 2002:94) . 
Desde su formación, la idea de la comunalidad ha estado ligada a la idea de autodeterminación, que en el lenguaje actual es la autonomía. Es precisamente la comunalidad la que constituye y es capaz de crear (recrear) las condiciones necesarias para la autonomía: la reciprocidad basada en el principio de la ayuda mutua, el poder en manos del colectivo constituido en asamblea, la voluntad de servir gratuitamente durante años a la comunidad en diversos cargos a pesar de ser onerosos, la defensa de un territorio histórica y culturalmente propio, son elementos suficientes para un régimen de autonomía en condiciones propicias, y esas condiciones son las que confisca el Estado: dependencia administrativa, economía de mercado, no decisión sobre el territorio comunitario y un sistema de vinculación con los municipios basado en el despojo de poder a través de caciques, delegados de gobierno y diputados (2002:97).

En el estado de Oaxaca, desde hace mucho tiempo la autonomía y el autogobierno en el ámbito comunitario son una realidad concreta: de aquí que se proponga la comunidad como elemento básico de la organización política indígena y que ésta sea el sujeto de Derecho a reconocerse; también que se plantee el reconocimiento de derecho del autogobierno que ya es realidad de hecho en las comunidades. ${ }^{155}$ Considerando que, a lo largo de más de 500 años de colonización externa e interna, económica y cultural, las estructuras de organización, de gobierno y la espiritualidad de los pueblos indígenas han permanecido (adaptándose y transformándose), en algunas ocasiones se entiende esta permanencia y resistencia como la autonomía en sí. ${ }^{156}$ Sin embargo, creo que la presencia de estructuras e instituciones propias de los pueblos es una condición necesaria pero no suficiente para la construcción de la autonomía, que entiendo más como un proyecto político de transformación y democratización de la sociedad.

Este proceso político de autonomía como reconstitución de los pueblos no se ha limitado solamente al ámbito comunitario, pues muchas organizaciones indígenas lo trascienden apuntando a una articulación en términos de pueblo. Al respecto, una experiencia interesante que busca fortalecer la estructura de gobierno comunitaria alargándola al contexto regional fue la Asamblea de Autoridades Mixes (ASAEM, 1984-1988) que avanzó propuestas para resolver problemas sociales y culturales, logrando hacerse interlocutor ante las instituciones gubernamentales. Según esta propuesta, la autonomía constituye un objetivo y a la vez el

\footnotetext{
155 Una interesante critica al comunalismo en cuanto ideología política que idealiza estratégicamente la comunidad y el ámbito comunitario de ejercicio del poder se encuentra en Zarate (2005).

${ }^{156}$ Véase por ejemplo Gledhill (2004).
} 
medio para construir una ciudadanía regional consciente (Vargas 2005:127), representando una propuesta autonómica regional articulada ya diez años antes que la zapatista.

Para el caso de la región mixe, es necesario contextualizar la complejidad y el arraigo de la propuesta autonómica con la larga historia de dominación caciquil en la zona. Las comunidades resistieron al poder de los caciques, imbricados con el sistema político surgido del periodo revolucionario y con los núcleos de poder regional, y a sus guardias armadas (Kraemer Bayer 2003, Díaz Gómez 2007). A partir de los años setenta, cuando se formaron las primeras organizaciones rurales independientes, la lucha de los pueblos se reforzó y paulatinamente logró romper la estructura caciquil, proceso que alcanzó altos niveles de violencia y costó muchas vidas. La autonomía nace de este proceso, casi como una necesidad de defender lo logrado a través de una estructura organizativa muy fuerte, colectiva y horizontal, como explica el abogado mixe Adelfo Regino: "cuando muere el poder caciquil, a fines de los años setenta, lo que empieza a tener fuerza es el papel de las autoridades, de la asamblea. La gente empieza a hablar de la necesidad de la autonomía comunitaria y empiezan a darse experiencias locales y regionales, como la Asamblea de Autoridades Mixes" (cit. en Kraemer Bauer 2003).

Analizando las propuestas autonómicas en correspondencia con los contextos en las cuales se plasman, podemos afirmar que, con respecto a las formas de relación con el Estado, las organizaciones indígenas oaxaqueñas y chiapanecas presentan trayectorias históricas diferenciadas, que muestran caminos de negociación (en el caso de los primeros) y de confrontación (en el caso de los segundos). La presencia de caciques indígenas capaces de negociar posesión de tierras y autoridad en Oaxaca es de larga data, llegando a construir relaciones de fuerza que las organizaciones campesinas e indígenas han sabido aprovechar. Por el contrario, en amplias zonas de Chiapas (en particular en la región de la Selva, pues la situación de Los Altos de Chiapas es radicalmente diferente) no se consolidó una tenencia comunal de la tierra que permitiera el desarrollo de identidades comunitarias; la historia de los indígenas chiapanecos está marcada por los procesos migratorios que muy a menudo generaban confrontación con el Estado por la tenencia de la tierra, y por la condición de peonazgo en las grandes fincas. En este contexto de falta de negociación, la rebelión parece representar la única salida; y el sujeto indígena que se constituye es más ligado a una 
reivindicación territorial amplia y pluriétnica que a una concepción comunitaria y como "pueblo".

Diversos analistas mencionan que el debate y la práctica de la autonomía indígena en México empiezan a cobrar importancia en ocasión de la movilización alrededor de la Campaña por los 500 Años de Resistencia Indígena, Negra y Popular de 1992 que, como otros Estados latinoamericanos, impulsa a la organización y movilización de los movimientos indígenas, ${ }^{157}$ y alcanzan trascender con el impulso y la apertura de espacios de discusión facilitados por el levantamiento zapatista de 1994.

Las dos posturas sobre la autonomía mencionadas entraron en conflicto en el contexto de los Diálogos de San Andrés ${ }^{158}$, donde la tarea para los asesores del EZLN fue redactar un texto que sirviera como base para una reforma constitucional sobre derechos indígenas. Para esto, había que definir la reivindicación central del movimiento indígena, la autonomía, de una forma que reflejara todas las demandas y las aspiraciones de los pueblos.

La discusión que se dio durante los Diálogos de San Andrés puso en evidencia el carácter histórico y local de las formas de gobierno indígenas, ligadas a las identidades de los pueblos. De acuerdo con José del Val, "la diferencia cultural no constituye en sí misma un orden de procesos de carácter general o exclusivo, y deberemos de buscar siempre en situaciones concretas, especificas en tiempo, espacio y modalidad, las determinantes de cada relación" (2004:78). Por lo tanto no puede existir un modelo único de autonomía ni una cristalización de los sistemas políticos y jurídicos de gobierno presentes en los diferentes

\footnotetext{
${ }^{157}$ En Guerrero se formó en esta ocasión la más importante organización indígena a nivel estatal, el Consejo Guerrerense 500 Años de Resistencia Indígena, Negra y Popular.

${ }^{158}$ Proceso de negociación entre el EZLN y el gobierno federal, que se llevó a cabo entre octubre 1995 y febrero 1996 en la comunidad de San Miguel, en San Cristóbal de las Casas y finalmente en la comunidad tzotzil de San Andrés Sakamch'en de los Pobres, cabecera del homónimo Municipio Autónomo Zapatista. Durante el Dialogo se llevó a cabo el Foro Nacional Indígena, importante convergencia de representantes indígenas y de la sociedad civil de todo el país, semilla de lo que será después el Congreso Nacional Indígena. En el contexto de los Diálogos se fortalecen los lazos entre los muchos pueblos indígenas organizados, configurándose éstos como un sujeto político o actor colectivo indígena con propuestas específicas alrededor de un proyecto distinto de nación, con una proyección en todos los espacios políticos del país, y comprometido que lo acordado entre el EZLN, sus asesores y el gobierno debía beneficiar a todos los indígenas mexicanos.

Los Diálogos se concluyeron con la firma de los Acuerdos de San Andrés sobre Derechos y Cultura Indígena entre el EZLN y el gobierno federal; estaban planeadas otras cuatro mesas de negociación -democracia y justicia; bienestar y desarrollo; conciliación en Chiapas, derechos de la mujer- sin embargo, apenas instalada la segunda, el gobierno rompió el dialogo, que nunca se volvió a abrir. Tampoco los Acuerdos nunca fueron realmente respetados ni implementados.
} 
contextos indígenas. Tal imposibilidad se vio expresada en el marco de los Diálogos de San Andrés que llevaron a la redacción de los Acuerdos homónimos.

En el proceso de negociación se dio un duro debate entre los muchos intelectuales y representantes de organizaciones indígenas presentes como asesores del EZLN. Proviniendo de diferentes lugares del país, en donde las experiencias de autogobierno se han construido históricamente en términos distintos, cada quien reivindicaba la legitimidad de su práctica; el debate se dio sobre cuál debía considerarse el sujeto de la autonomía y a qué nivel reconocerse el "cuarto piso de gobierno", si comunidad, municipio o región. A pesar de las diferencias que se manifestaron entre los asesores del EZLN, y las muchas complicaciones que entorpecieron el dialogo entre éste y la representación gubernamental, ${ }^{159}$ creo que lo pactado en el texto de los Acuerdos de San Andrés es lo más útil para pensar las autonomías en un país con tanta diversidad cultural como México:

La autonomía es la expresión concreta del derecho a la libre determinación, expresada como un contexto que forma parte del Estado nacional. Los pueblos indígenas podrán, en consecuencia, decidir su propia forma de gobierno interna y sus propios modos de organizarse política, social y culturalmente. Al interior del nuevo contexto constitucional de autonomía se respetará el derecho a la libre determinación en cada uno de los ámbitos y niveles que lo hagan valer; pudiendo comprender uno o más pueblos indígenas, de acuerdo a las circunstancias particulares y específicas de cada entidad federativa. ${ }^{160}$

Luis Villoro propone un interesante análisis de la propuesta "regional" en oposición a la "comunitaria", que en mayor medida ha sido acogida en el texto de los Acuerdos de San Andrés. Este autor considera más viable que la comunidad, y no la región, sea reconocida como entidad de Derecho: "habría así una forma para llegar a regiones autónomas constituidas por un pueblo, sin necesidad de reformas legales radicales, planificadas desde arriba. Para ello, es menester reconocer el derecho de autodeterminación de los pueblos". Sobre la base de un marco general, se propone "no una reforma repentina, diseñada en el papel, sino un proceso paulatino, cuya progresión estaría marcada por las mismas comunidades indígenas” (Villoro 1998: 98).

\footnotetext{
${ }^{159}$ Para mencionar solamente una, baste con recordar que en pleno dialogo -febrero 1995- el Ejercito realizó una durísima ofensiva militar que puso literalmente a fierro y fuego las comunidades zapatistas.

${ }^{160}$ Acuerdos de San Andrés, Documento 2, pág.2.
} 


\section{AUTONOMIAINDÍGENA, VIOLENCIAY JUSTICIA}

Los acuerdos de San Andrés han sido definidos "acuerdos mínimos”, ya que, en cuanto fruto de una negociación, no recogen satisfactoriamente todas las demandas del movimiento indígena, como las que se refieren a la cuestión agraria y al reconocimiento de los sistemas jurídicos indígenas ${ }^{161}$. Los partidarios de la autonomía regional, como Díaz Polanco (1997b). Por otro lado, un comunalista como Esteva afirma que "en San Andrés se aceptó este alcance radical de la autonomía y se rechazó la propuesta que la mutila” (1998:314).

A pesar de los innegables límites, la propuesta autonómica forjada en los Acuerdos es suficientemente compleja y logra abarcar las principales demandas de los pueblos indígenas organizados que participaron en ella.

El texto de los Acuerdos de San Andrés reúne análisis profundos y propuestas fundamentales para intentar dar una resolución a las históricas demandas indígenas, prospectando una transformación de los valores nacionales y de las estructuras del Estado: "un pacto social constituyente una nueva relación entre la sociedad, los pueblos indígenas y el Estado [que] sólo podrá arraigar y culminar con la participación de los propios indígenas y la sociedad en su conjunto, en el marco de una profunda Reforma del Estado". ${ }^{162}$ Por esto siguen siendo, a 18 años de su redacción y aunque se encuentren en algunos puntos rebasados por los acontecimientos recientes, la reivindicación que acomuna a todo el movimiento indígena mexicano. El proceso político que ha seguido a la firma de los Acuerdos ha visto, por un lado, el crecimiento y la estructuración del movimiento indígena, con la constitución del Congreso Nacional Indígena (CNI), espacio de discusión y organización a nivel nacional, hasta llegar a la excepcional movilización del 2001, con la Marcha zapatista que llevó a la tribuna parlamentaria representantes indígenas abogando por el reconocimiento constitucional de sus derechos. Por otro lado se demostró la completa cerrazón del gobierno sobre el tema, con la

\footnotetext{
161 "Punto y seguido", documento del CCRI-CG y asesores del EZLN al terminar la tercera fase de la mesa 1 de los Diálogos de San Andrés, en Ce Acatl n.78-79, 1996.

${ }^{162}$ Acuerdos de San Andrés, Documento 1, pág. 1. "Efectivamente, ahí está la fuerza de este texto de San Andrés: hasta ahora, sociedad, gobierno e indigenistas decían que el indígena tenía que cambiar para acomodarse a ellos y así progresar; pero en San Andrés se dice lo contrario: los atrasados son la sociedad racista, el gobierno discriminatorio y sus indigenistas paternalistas porque siempre consideraron al indígena como objeto (sea como beneficiario o como víctima); ellos son los que tienen que cambiar no el indígena. Este cambio San Andrés lo llama "una nueva relación" porque hace que el indígena, de objeto venga a ser sujeto (hasta de derecho público), actor de las transformaciones necesarias, instaurando así un "nuevo pacto social", un "nuevo federalismo" que cambiarán nuestra anacrónica forma de gobierno", Andrés Aubry, "Los desacuerdos de San Andrés", La Jornada, 16 de febrero 2004, <www.jornada.unam.mx/2004/02/16/017a1pol.php?origen=opinion.php\&fly=1> consultado el 2 de junio 2013.
} 
aprobación de las reformas constitucionales en materia de Derechos y Cultura Indígenas ${ }^{163}$ que desconocen lo pactado en los Acuerdos y plasmado en la propuesta de ley elaborada por la Comisión parlamentaria para la Concordia y la Pacificación (COCOPA), mientras ratifican la discriminación y la desigualdad. Las principales críticas a la reforma constitucional de 2001 se refieren a que los derechos indígenas son sólo parcialmente reconocidos, pues se introducen una multitud de "candados" y acotaciones legales que de hecho impiden su ejercicio.

Establecido en términos generales, se afirma que el reconocimiento se hará en las leyes de las entidades federativas, lo que si por un lado puede permitir una legislación más fina y adecuada a las experiencias concretas, no toma en cuenta la realidad de los estados, gobernados por poderes fácticos y añejos cacicazgos regionales, históricamente enemigos de la población indígena. Asimismo, el texto constitucional no reconoce el derecho de las comunidades a asociarse en municipios y los municipios entre sí; asimismo, en lugar de reconocer a los pueblos como sujetos de derecho público, considera las comunidades como entidades de interés público, lo que implica una atomización del sujeto político (de pueblos a comunidades) y el regreso a la visión asistencialista y paternalista del Estado hacia ellos: todo lo contrario a la autonomía. Se establecen las acciones que las autoridades deberían implementar para abatir las carencias y rezagos de los indígenas, pero se limitan las posibilidades políticas de los pueblos para actuar ellos mismos sobre tales carencias. Los derechos de los pueblos son en todo momento acotados: el ejercicio de la justicia propia, por la validación de las autoridades estatales; la propiedad de la tierra, a lo establecido en el art.27 y a las necesidades de la economía nacional; etc. ${ }^{164}$

Ante esta realidad, la posición declarada por los integrantes del CNI ha sido que los pueblos indígenas:

Sin reconocimiento o con reconocimiento legal seguirán impulsando el ejercicio de su autonomía y de sus derechos [...] Haremos efectivos los Acuerdos de San Andrés mediante el ejercicio cotidiano de la autonomía indígena, la construcción de autonomías comunales, municipales, regionales y la reconstitución integral de nuestros pueblos. Impulsaremos la

\footnotetext{
${ }^{163}$ Reforma Constitucional en Materia de Derechos y Cultura Indígenas, conocida también como Ley BartlettFernández, aprobada por el Congreso de la Unión el 28 de abril de 2001. Se reformó el artículo 4, integrando el tema indígena en el artículo 2.

${ }^{164}$ Para un análisis de los debates desde los Diálogos de San Andrés hasta la reforma constitucional de 2001, y un recuento de los principales eventos políticos acontecidos, véase Gómez (2005).
} 
elaboración de estatutos comunales como instrumentos legales básicos para el reconocimiento del ejercicio de nuestra autonomía. ${ }^{165}$

En el México actual, la experiencia autonómica más desarrollada es sin duda la que están construyendo en Chiapas los indígenas zapatistas. A partir de la declaración de más de treinta Municipios Autónomos Zapatistas en Rebeldía en diciembre 1994, los pueblos zapatistas han sabido lograr la autonomía en muchos aspectos de la vida social. Empezando a construir el autogobierno en los ámbitos municipales sobre la base de las prácticas de gobierno comunitarias, han realizado un innovador proceso de remunicipalización, de acuerdo a las exigencias prácticas y culturales de los pueblos. En 2003, otro paso cualitativo ha sido la regionalización de los gobiernos autónomos, con la institución de las cinco Juntas de Buen Gobierno, instancias superiores de coordinación, dirección política e impartición de justicia. ${ }^{166}$

\section{Autonomía, identidad y tradición}

Las autonomías, tal como las concebimos en nuestra América Latina, son procesos de resistencia mediante los cuales pueblos o etnias soterradas y negadas recuperan o fortalecen su identidad, a través de la reivindicación de su cultura, el ejercicio de derechos colectivos y el establecimiento de estructuras político-administrativas con diversas competencias, ámbitos y niveles de aplicación y una base material propia [...], respetando los usos y las costumbres que les dotan de identidad y les permiten resistir la hegemonía de un estado y un régimen político que los ha mantenido olvidados y marginados durante siglos (López y Rivas 2005: 33-34; 63).

Tenemos aquí una mención al valor de la identidad al interior de las reivindicaciones autonómicas. Esto se ha de entender no necesariamente en términos esencialistas, cuanto considerando la identidad como un elemento que concierne a los ámbitos de la pertenencia y de la diferencia, constantemente redefinidos por los procesos históricos y sociales, para adecuarse a las necesidades de quien se identifica con ella. Como bien afirma Villoro, "la identidad así concebida no detiene necesariamente a una colectividad en la reiteración de sus

\footnotetext{
165 Congreso Nacional Indígena, Declaración Final de la Octava Asamblea Nacional, México DF, 18-20 noviembre 2001.

166 Son muchos los textos del mismo EZLN que explican el proceso y la forma de la autonomía en territorio zapatista, así como la bibliografía de autores mexicanos y extranjeros que analizan tal experiencia. He tratado de elaborar un análisis más detallado en Gasparello (2005).
} 
formas de vida heredadas, sino que la obliga a reinterpretar continuamente el pasado para integrarlo en proyectos de vida colectivos" (1998:149).

Un debate interesante sobre el uso estratégico del discurso sobre la identidad y la tradición ha aparecido hace algunos años entre Sierra y Zúñiga. Sierra nos advierte sobre los riesgos que puede tener el discurso con tintes esencialistas y de idealización de su pasado que a veces utilizan los movimientos indígenas, como arma política y en respuesta al racismo también esencialista de muchos sectores de la sociedad mexicana. La autora propone como más valiosos los discursos que tratan de replantear las tradiciones de acuerdo a las nuevas necesidades y escuchando las voces calladas de algunas partes de las sociedades indígenas. En respuesta, Zúñiga afirma que el trabajo de Sierra, abogando por un enfoque dinámico y situacional, destina lo sustantivo de su análisis a desmentir el discurso indígena, intentando probar que los rasgos sustantivos y absolutizadores (la costumbre y la tradición) que transmite, no están vigentes, no corresponden a la realidad, sin interrogarse acerca de las funciones específicas que tiene este discurso y estos recursos argumentativos en el contexto de las luchas étnicas de las que son sólo una faceta :

Si las sociedades indígenas han podido resistir el embate de las acciones integradoras y desestructuradoras, es en parte gracias a la solidez y fuerza simbólica de su discurso. Si sus dinámicas sociales están más orientadas, desde nuestra perspectiva, a la recomposición que a la fragmentación, es también resultado de dichas estrategias identitarias, de las que los discursos son sólo una dimensión (Zúñiga: 2000).

Siempre hay que considerar el discurso y la acción social en el contexto que los produce, de acuerdo a las funciones que tienen y a los fines que persiguen, pues nos referimos a herramientas que han permitido a los pueblos indígenas posicionarse en la arena política internacional, saliendo de la jaula particularista, y en cierto sentido racista, construida tanto por los Estados como por la academia y la sociedad. Como el discurso es el principal medio de adquisición y socialización de las ideologías racistas (Van Dijk 2002, 2004), también el discurso elaborado por los pueblos, organizaciones o movimientos indígenas instituye y refrenda identidad. Asimismo, las tradiciones, por ser inventadas, adaptadas o reformuladas (Hobsbawm 1983) no carecen de legitimidad y de fuerza simbólica y política. 
Todo lo anterior refuerza la afirmación de Villoro (1998:150), para quien “el respeto a la identidad de las otras culturas no conduce a la preservación de sus notas distintivas, sino al mantenimiento irrestricto de su capacidad de decisión y de cambio": esto es, a su existencia en un ámbito de autonomía.

Pero el discurso sobre la tradición y los usos y costumbres no sólo ha representado un arma estratégica para los movimientos indígenas; también ha sido utilizado por el Estado y sus intelectuales para descalificar a las culturas indígenas acusándolas de ser premodernas y antidemocráticas. Al estallar el levantamiento zapatista y el debate sobre la legitimidad de la reivindicación de derechos colectivos por parte de los pueblos indígenas mexicanos, el Estado mexicano, a través de los medios de comunicación, desató una campaña dedicada a minar la legitimidad de tales reivindicaciones. En ella se pueden identificar dos principales directrices: "una abiertamente racista que presenta las culturas indígenas como primitivas y atrasadas, y una liberal que las presenta en términos de 'inauténticas', usando la historia para demostrar el origen colonial de las culturas indígenas" (Hernández Castillo: 2002). Este argumento, aunque más sutil, demuestra su debilidad ya que la legitimidad de las culturas indígenas -y de los procesos autonómicos que éstas construyen- no viene de su supuesto carácter "tradicional", sino de su capacidad de responder a las necesidades de los pueblos, respetando su visión y su cultura.

Un conocimiento, aunque somero, de la historia mexicana demuestra que tales reivindicaciones y prácticas autonómicas existen en forma más articulada por lo menos desde el siglo XIX. Según Beaucage:

La situación de los indígenas en México se encuentra actualmente en un proceso de rápido cambio y cualquier intento de balance resultaría fútil y rebasado por los acontecimientos. Sin embargo, se puede considerar que por la misma dinámica histórica, la autonomía local, aunque recortada por la injerencia de poderes superiores, constituye uno de los ejes más duraderos del proceso de resistencia y de afirmación identitaria de los indígenas de México. Los vastos movimientos agrarios, políticos y económicos de los años setenta y ochenta [del siglo XX] permanecen hasta hoy en la medida en que echaron raíces. A la vez, asistimos a la revitalización de instituciones que parecían caducadas, como los consejos de ancianos y la administración indígena de la justicia; las reivindicaciones actuales por la autonomía 
municipal, comunal, y la defensa del ejido, parecen inscribirse dentro del mismo proceso (2000:311-12).

La representación del sujeto indígena en la propuesta de autonomía es una reivindicación de los sentidos y los criterios de diferencia que a veces se concretan en nociones relacionadas con la "tradición" y los "usos y costumbres". Sin embargo, la diferencia, al igual que la identidad y el sujeto, no significa ningún sentido inmutable, ningún rasgo singular persistente en el tiempo. ${ }^{167} \mathrm{Al}$ contrario, la diferencia es una significación social que está inscrita en un doble juego: designar alteridad (cuando es apropiada propositivamente por la subalternidad y construye resistencia) y excluir y discriminar al sujeto (cuando es apropiada por el poder).

En este caso, la diferencia reflejada en la reivindicación de "la tradición" o de "usos y costumbres", al ser alimentada desde el poder, ha generado formas específicas de articulación de los sujetos indígenas con un sistema de dominación local que se conoce como caciquismo indígena y que tiene articulaciones regionales y nacionales. La referencia a "usos y costumbres", al apelar al carácter unificador de la comunidad, ha sido en algunos casos funcional a la ideología del corporativismo político mexicano, a la visión de filiación partidaria que se ha desenvuelto en el marco del unipartidismo.

En fechas recientes, se levantaron fuertes críticas hacia el sistema de elección de autoridades y gobierno por "usos y costumbre" vigente en el estado de Oaxaca. Se ha denunciado que el recurso a la representación de los sistemas normativos indígenas como tradicionales y democráticos, fundamenta la autonomía comunitaria, que en algunos casos permite albergar un régimen político tan nefasto como es el caciquismo. No cabe duda que, en contextos donde las estructuras organizativas colectivas de los pueblos son fragmentadas y por esto fácilmente manipulables, se puede imponer el poder individual, de la misma manera que en un contexto que se rige por el sistema partidista de elecciones y gobierno. Entre los casos denunciados está el de Santiago Tutla (Itrurralde Blanco 2012), del que pude recabar información etnográfica directa, que ha llamado la atención por la presencia de una Policía

\footnotetext{
${ }^{167}$ La identidad colectiva se construye y se reconstruye constantemente en los intercambios sociales (Bartolomé 1997; Giménez 2000), o sea es un proceso dinámico.
} 


\section{AUTONOMIAINDÍGENA, VIOLENCIAY JUSTICIA}

Comunitaria Armada oficialmente reconocida por el estado, que respondería al neo-cacique local. $^{168}$

Por otro lado, asistimos frecuentemente a un uso instrumental de la tradición por parte de las "élites" indígenas para fines de acumulación de riqueza, prestigio o de exclusión política, actuando como mecanismos de discriminación, intolerancia y dominación hacia algunos sectores de la sociedad indígena (por ejemplo las mujeres o los jóvenes, que no gozan de iguales derechos debido a los arraigados privilegios patriarcales y sexistas; o los disidentes religiosos, como por ejemplo los expulsados protestantes de San Juan Chamula, que en 1984 denunciaron la "tradición injusta").

No cabe duda que las sociedades indígenas siguen atravesadas por conflictos de orden económico, social y político. El autoritarismo de los caciques, las disputas por los linderos comunitarios y municipales, la discriminación religiosa y de género, marcan muchos territorios indígenas. En cierta medida, se puede sostener que tales conflictos y situaciones de desigualdad tienen su raíz en la relación sostenida con la sociedad dominante, que a partir de la Colonia ha actuado con mecanismos de dominación y despojo, minando las estructuras y los lazos comunitarios; ahora tales procesos son acelerados por la privatización de los recursos y las experiencias migratorias.

Al respecto, propongo dos consideraciones: en primer lugar, las experiencias de autorganización y autonomía indígena de facto no deben ser idealizadas; hay contextos más polarizados y al mismo tiempo hay procesos que buscan replantear la organización social de forma más igualitaria, tratando de superar las situaciones de discriminación, a partir de la reflexión interna y considerando las influencias "externas". En segundo lugar, el reconocimiento de un marco de autonomía, aunado a procesos de empoderamiento y de construcción del sujeto autonómico, ${ }^{169}$ podría representar una oportunidad para el desarrollo de las sociedades indígenas. Esto es, permitiéndole elaborar estrategias sociales y económicas

\footnotetext{
168 Este caso despertó una áspera polémica a raíz del hecho que, en 2012, dicha Policía impidió la salida del pueblo al religioso y defensor de los derechos humanos Alejandro Solalinde.

169"Las autonomías, reconocidas dentro del marco político-jurídico del Estado nacional, suponen fundamentalmente el establecimiento de un autogobierno que asuma las competencias y haga uso de los recursos públicos para el ejercicio de derechos reconocidos en la Constitución y en las leyes secundarias. Esto significa, y es el principal elemento constitutivo de un proceso de autonomía, la conformación de un sujeto autonómico, o sujeto colectivo de transformación social, con base territorial y con identidad socio étnica, no sólo con la capacidad de representar por consenso los intereses de la colectividad, sino también para constituirse en un interlocutor legítimo implicado en el proceso de negociación y dialogo” (López y Rivas 2004:169).
} 
más adecuadas a las exigencias que las mismas perciben como prioritarias, garantizando el respeto de determinados derechos indígenas (como la propiedad colectiva, territorio propio etc.), dando la posibilidad de mantener y al mismo tiempo transformar instituciones tradicionales, abriendo la participación y el acceso a cargos políticos a jóvenes y mujeres.

\section{La autonomía como proceso}

La literatura reciente sobre el tema de las autonomías indígenas ${ }^{170}$ enfatiza su carácter procesual. Según mi análisis, tal caracter tiene dos sentidos:

1. En primer lugar, que el reconocimiento en el marco jurídico-constitucional de los Estados es un punto de partida y no de llegada, y las autonomías constituyen también procesos permanentes de negociación, en los que la garantía de continuidad y desarrollo es la existencia o la construcción del sujeto autonómico. Esto es, no pueden existir autonomías exitosas caladas desde arriba o construidas en ámbitos ajenos a donde se implantarán; tampoco se puede pensar en construir instrumentos jurídicos que de una vez y para siempre establecerán alcances y competencias en términos fijos, como es el modo del derecho positivo. Los procesos autonómicos, por su naturaleza, tienen un carácter dinámico; se desarrollan y adaptan a contextos en continua mutación; se presentan a veces como experiencias inacabadas o en desarrollo, otras veces en crisis. Este problema ha sido enfatizado por algunos autores con respecto a los sistemas normativos indígenas: Assies afirma que "lo que a menudo consideramos como 'justicia y derecho' coincide en la práctica con la mayor parte de la estructura social de las sociedades indígenas" (2000: 1). Sin embargo, con la necesidad de codificar en forma estricta los procedimientos y prácticas vivenciales que se recrean constantemente en el curso del tiempo, existe la tendencia a generalizar y homogeneizar la interpretación del "deber ser"; pues existe por un lado la posibilidad que la legalización fortalezca la burocratización, y por otro la contradicción que en codificar el derecho indígena se trasladaría una parte sustancial de las prácticas y normas indígenas al terreno de la cultura occidental y a la autoridad legal del Estado.

Tales contradicciones no tienen fácil solución, y mucho menos si se quieren resolver con la corta mirada que caracteriza el Estado: o sea como un proyecto que se limita a añadir la

\footnotetext{
${ }^{170}$ Véase, entre otros: Gabriel y López y Rivas (2005 y 2008); Burguete et al. (2010).
} 
diferencia cultural a la norma dominante existente, estableciendo derechos e instituciones aparte, sin repensar el proyecto estatal y nacional en su totalidad.

2. En segundo lugar, el carácter procesual de las autonomías destaca que cada pueblo tiene una historicidad propia, y las formas en que ha construido sus dinámicas de autogobierno, auto-organización y administración de la justicia son diferentes en los diversos lugares, además que cambian en respuesta a las particulares presiones y modificaciones del contexto político-social tanto interno como externo.

Al respecto, Floriberto Díaz, destacado intelectual mixe, ya fallecido, escribía: “por higiene mental, la discusión de las autonomías no puede provenir solamente de disertaciones teóricas sino, y sobre todo, de la reflexión de las realidades concretas en las cuales se matizan ciertas prácticas autonómicas, conservadas a pesar, y aún en contra, del Estado-nación dominante" (2007:34). Por lo tanto será en la praxis concreta y a partir de ella, en medio de procesos de diálogo y negociación, en que se determinarán formas y modos de las autonomías, sin pretender un marco de universalidad en ellas ${ }^{171}$.

Esto no excluye la urgente necesidad de un marco constitucional que deberá establecer los ámbitos generales de ejercicio de las facultades autonómicas; tal marco general debe ser fruto de una negociación a nivel nacional y conllevar una profunda reforma de las estructuras del Estado mismo.

En este sentido, la reivindicación central de los Acuerdos de San Andrés, "la construcción de un nuevo pacto social constituyente, una nueva relación entre los pueblos indígenas, la sociedad y el Estado" ${ }^{\prime 172}$ apunta a una reforma radical de toda la nación, en una redistribución de derechos, competencias y recursos para todos los sujetos de la sociedad. Por lo tanto, no concuerdo con Del Val, quien afirma que "las autonomías aislarán definitivamente los pueblos indios del debate por la democracia nacional; [...] constitucionalizan su ubicación marginal en la disputa por la nación" (2004:211-12). Al contrario: según la posición que aquí se expresa, autonomía no significa aislamiento sino participación igualitaria en el diálogo nacional a partir de una identidad social diferente, compartida: una identidad a la vez indígena, que implica el derecho a la diferencia, y mexicana, la cual significa derecho a la igualdad en el acceso a los recursos y participación ciudadana plena.

\footnotetext{
${ }^{171}$ Olivé propone que las autonomías sean fruto de una interacción transcultural (2004:103).

172 Acuerdos de San Andrés, Documento 1.
} 
Uno de los principales temores hacia el reconocimiento del derecho a la autodeterminación es el que las prácticas normativas indígenas pueden ser lo suficientemente ajenas al Derecho estatal y a los derechos universales, llegando a ser degradantes de la personalidad individual. Estas argumentaciones a veces son fundamentadas en prácticas reales; otras veces son manipulaciones de los gobiernos para no tener que respetar los derechos de autonomía. Es cierto que la obligación de todo individuo y colectividad de respetar los valores de convivencia trasciende la realidad política de un país: ya es un sentir común entre organizaciones indígenas, académicos, organizaciones no gubernamentales, etc., la necesidad de respetar unos derechos humanos definidos como fundamentales o universales, independientemente si se viva en una región autónoma, en una ciudad o en una aldea campesina. Es más: precisamente en los contextos donde es más fuerte el proceso organizativo interno y la movilización de las diferentes subjetividades indígenas -mujeres, jóvenes, etc.- es donde aparecen propuestas innovadoras para fortalecer el respeto y la convivencia, modificando activamente las instituciones y las costumbres consideradas dañinas para la sociedad misma. En los contextos donde los pueblos indígenas están construyendo procesos autonómicos, hay que poner énfasis en la constante reinvención y resignificación de las tradiciones, en un sentido que amplía la plataforma de los derechos sociales, nutriendo de sentido alternativo a las definiciones locales de democracia. ${ }^{173}$ Para avanzar propuestas y diseñar políticas, es necesario tomar en cuenta los procesos internos a través de los cuales los sujetos autónomos negocian nuevos derechos, apropiándose de espacios hasta la fecha negados, a través del manejo de discursos políticos y sociales "ajenos" (en el sentido esencialista) a sus tradiciones culturales. Las Juntas de Buen Gobierno en el territorio autónomo zapatista en Chiapas representan, junto con otras en el contexto nacional, experiencias sumamente interesantes por el nivel de conexión que las prácticas tienen en los diferentes ámbitos de la sociedad y su aptitud para responder a los cambios (internos y externos), así como su capacidad de "autocrítica" (reflexión y poder de cambio sobre las prácticas mismas).

\footnotetext{
${ }^{173}$ Ejemplo de esto es la Ley Revolucionaria de las Mujeres vigente en la zona zapatista: a través de una consulta, las mujeres de las diferentes regiones zapatistas han impuesto su papel en la construcción del proceso autonómico, imponiendo la valoración de los derechos de género en una tradición local discriminatoria.
} 


\section{AUTONOMIAINDÍGENA, VIOLENCIAY JUSTICIA}

\section{¿Autonomía o autonomías? Del concepto a la práctica y regreso}

En la amplia literatura sobre el tema, ya sea que se refiriera a la autonomía como proceso, práctica o régimen, he encontrado una visión más o menos generalizada que tiende a considerar autónomas aquellas experiencias que abarcan de forma integral todos los aspectos de la vida de un pueblo: el gobierno y la vida política, la administración de justicia, el control del territorio y el aprovechamiento de los recursos, la cultura, la educación, la salud, la economía.

Esto depende de una particular forma de entender la autonomía que agrupa a muchos estudiosos del tema, claramente expuesta por Barabas: "la autonomía debe entenderse como una totalidad multidimensional que tiene que ser reconocida y ejercida integral y no parcialmente" (2005:165). Esta posición puede ser aceptable como marco ideal al cual deberían apuntar los procesos autonómicos, o como marco jurídico no restrictivo o limitante para el reconocimiento de los derechos de los pueblos.

Pero la realidad es otra. Frente a contadas experiencias de autonomía "integral" (en México la más ejemplar en este sentido es la de las comunidades zapatistas en Chiapas) se observan innumerables procesos organizativos que construyen y ejercen autonomía en ámbitos específicos de la vida social, sin alcanzar los otros aspectos que siguen funcionando según las reglas políticas y económicas del sistema dominante.

Encontrándonos frente a tales procesos, las conceptualizaciones corrientes quedan demasiado estrechas, o más bien demasiado anchas. Si se piensa en el Sistema de Seguridad y Justicia Comunitaria de la Costa Chica y Montaña de Guerrero, donde hay un alto nivel de autonomía en los campos de producción normativa, de administración de la justicia, y de control del territorio en términos de seguridad, pero en otros ámbitos organizativos no se vislumbran avances, la pregunta que problematiza el análisis es: ¿hay aquí autonomía?

La pertinencia de tal pregunta se impuso durante el proceso de elaboración del libro Otras Geografías. Experiencias de autonomías indígenas en México, que coordiné -junto con Jaime Quintana- en 2009. En el texto, relatan su propia experiencia el pueblo yaqui, la radio comunitaria Ñomndaa, la Coordinadora Regional de Autoridades Comunitarias y el Municipio Autónomo triqui de San Juan Copala. Cada experiencia evidencia una problemática particular, que de alguna manera atañe también a las demás y adquiere un valor generalizador. Los yaquis 
son el único pueblo indígena en México al que se ha reconocido un territorio propio: "para el pueblo yaqui, el carácter autonómico nos lo da tener nuestro territorio", y "la aspiración es no depender del exterior", menciona un dirigente (citado en Lerma Rodríguez 2009:90). Sin embargo, el pueblo no tiene los medios para poder aprovechar económicamente el amplio territorio, cuyos recursos son sistemáticamente saqueados (el agua del río Yaqui es un ejemplo paradigmático) y sus instituciones dependen de los intereses políticos locales: por esto, definen su autonomía como "relativa". Radio Ñomndaa, La Palabra del Agua, que transmite en territorio amuzgo, nace de un complejo proceso organizativo, y actualmente ejerce la autonomía de manera radical, pero circunscrita al ejercicio del derecho a la comunicación. El Municipio Autónomo triqui de San Juan Copala reclamó al Estado competencias territoriales, administrativas y económicas, pero no logró imponer en la región el poder de su estructura colectiva.

Las experiencias de organización indígena incluidas en este libro describieron el camino recorrido, los retos que enfrentan y los objetivos pendientes por alcanzar. Se definen como procesos en construcción, entendiéndolos como un trayecto donde las debilidades y los límites evidenciados pueden representar los eslabones de una escalera hacia la construcción integral de la autonomía, la cual se desarrolla por etapas y de acuerdo a las condiciones, internas y externas, en continua transformación. En esta óptica, podemos ubicar a muchas experiencias organizativas indígenas que se desarrollan en el México actual, cuya permanencia y desarrollo depende de las múltiples presiones a las que son sujetas.

Al respecto, quiero avanzar dos consideraciones. En primer lugar, cabe recordar que cada experiencia de autonomía, en cuanto proceso en el cual los pueblos se apropian de partes o aspectos del poder político y de decisión, nunca se da afuera o independientemente del contexto nacional (donde el ejercicio del poder, el uso de la fuerza, el control del territorio, de los procesos económicos y de las estructuras para el bienestar de la población, son competencia del Estado). Como bien afirma Barabas, "no existe autonomía en un vacío de relaciones ni en el seno de relaciones de subordinación, por lo que su ejercicio se realiza no sólo al interior del ente autónomo, sino también en la articulación de los entes autónomos entre sí y con el Estado" (2005:165).

Puesto que cada proceso autonómico se desarrolla dentro del Estado y en una continua relación con éste, los logros y los alcances de la organización de los pueblos siempre se 
pueden medir en correspondencia con las particulares políticas estatales, con la presión (política, militar, económica) que el Estado ejerce hacia el proceso y en el territorio, con el nivel de madurez y peso político que tiene la organización (lo que determina la calidad de la negociación).

La autonomía pues se construye desde dentro de los procesos, sobre la base de problemas y exigencias concretas, cuya resolución por parte de los pueblos organizados constituye la fuerza de las instituciones autónomas. Tal fuerza la utilizarán en las negociaciones con el poder estatal y con los poderes fácticos (élites locales, grupos de poder nacional e internacionales) que se podrán dar en términos de diálogo o de conflicto. Llega a conclusiones parecidas Astrid Ulloa que, en Colombia, estudia las "autonomías indígenas en ejercicio" en las vertientes del control territorial, la jurisdicción propia, los planes de vida y el manejo ambiental. La autora define tales procesos como autonomía relacional, pues a pesar de ser legalmente establecida como "régimen autonómico", en Colombia la autonomía y los derechos indígenas se ven restringidos por decisiones estatales, por intereses de las empresas o de los varios grupos armados. Así la autonomía política y territorial resulta ser parcial y limitada, y su alcance depende de la capacidad de los pueblos de establecer e imponer relaciones, negociaciones y decisiones con los diferentes actores (Ulloa 2010).

La segunda consideración que quiero proponer se desprende de lo que he definido como el carácter procesual de las autonomías. Hablo de "autonomías" en plural ya que "como no hay una cultura india ni un movimiento indio, no puede haber un tipo de autonomía que convenga a todos los pueblos indios ni a todos los países" (Becauge 2003: 317-318). El mismo autor llega a una afirmación interesante, aunque parezca obvia, o sea que el proceso real hacia la autonomía sigue caminos múltiples: las cientos de organizaciones de productores indígenas que buscan (y a menudo logran) procurar la subsistencia de sus miembros, las radios indígenas, los maestros bilingües que actúan como 'intelectuales orgánicos' de los pueblos, etcétera. Ahí me parece que están presentes los elementos que esbozan lo que podría ser una autonomía real, a nivel económico, político y cultural (2003:319).

Los ejemplos hasta aquí mencionados muestran algunos elementos comunes a los procesos autonómicos en construcción: la institución de instancias de poder, de gobierno y de representación nuevas y propias, de carácter colegiado; la recuperación de la tierra (como recurso económico) y el control del territorio (como recurso cultural y simbólico); la 
instalación de medios propios de comunicación, en particular radios. Lo que une todos estos "caminos autonómicos" es su calidad de procesos en continua construcción, no acabados; y el hecho que, aunque diferentes entre ellos, tienen como común denominador la apuesta hacia una nueva relación entre el Estado y los sujetos colectivos que conforman la sociedad nacional.

Aunque sean procesos limitados a ámbitos específicos de la vida social, esto es, parciales, su calidad autonómica reside en que son sin duda acciones concretas en los ámbitos y formas que la sociedad local necesita, de acuerdo a sus problemáticas y exigencias: son prácticas situadas y en esto reside su gran importancia. Así, la visión procesual imprime el carácter de autonomía a todas estas que aparecen como prácticas aisladas, y que representan más bien dimensiones de un sistema autonómico. Según la investigación Latautonomy, el fortalecimiento de las autonomías depende precisamente del equilibrio entre las dimensiones cultural, territorial, político-jurídica y económica, ya que el equilibrio "incide fuertemente en la correlación de fuerzas entre el Estado nacional y el sujeto autonómico [...] refleja el grado de la cohesión social y política del sujeto autonómico" (Gabriel 2008:28) y, sin embargo, en muchos casos representa más una aspiración que una realidad.

\section{Autonomía, violencia y poder autónomo}

La presente investigación apunta, en particular, a demostrar el lazo de necesidad entre contextos de violencia (cuyas múltiples acepciones se expresaron en la Introducción) y la construcción de la autonomía. Analizaré en los capítulos siguientes el caso de la autonomía zapatista, haciendo hincapié también en el ejemplo del Sistema de Seguridad, Justicia y Reeducación Comunitaria de Guerrero, procesos que transitaron por caminos diferentes; en este espacio, mencionaré brevemente otras experiencias paradigmáticas en este tema. Las unen las condiciones de discriminación por parte de los gobiernos locales y los grupos de poder mestizos, que dominan la economía y la política; las situaciones de violencia extrema, con diversos orígenes: delincuencia común y descomposición social, violencia del Estado como represión y como violencia estructural (que se traduce en histórica injusticia social), conflicto interno a los pueblos debido a divisiones entre organizaciones y militancias políticas. En los 
casos expuestos, los pueblos han enfrentado la violencia y han buscado la forma de resolver sus causas, a través del ejercicio de la autonomía.

Analizando las manifestaciones de la violencia estructural, en la que podemos ubicar tal escenario, Hébert (2006a) afirma que:

En esta era en la cual la frontera entre la paz y la pacificación se ha vuelto tan tenue, las formaciones sociales y culturales locales que emergen de formas de violencia a menudo y relativamente invisibles (como, por ejemplo, la violencia económica entre otras) pueden presentarse, con fines estratégicos, como fallos en la realización del proyecto neoliberal de paz perpetua; fallos para los cuales los actores locales son frecuentemente increpados. Nos encontramos aquí un paso más allá del relativismo cultural mal planteado que valoriza las consecuencias de la violencia. Las víctimas de violencias sociales -como lo son la violencia estructural, económica o simbólica- se adaptan y encuentran estrategias para eludir las mismas [...]. No obstante, las estrategias de las víctimas se apartan a menudo del marco normativo y legal que sirve de armazón ideológica al proyecto de paz perpetua que se intenta imponer a esos individuos (cursivas mías).

El primer municipio autónomo declarado afuera de la zona zapatista fue el de Suljaa' (Xochistlahuaca), en el extremo oriente del estado de Guerrero. Las comunidades de la región, pertenecientes al pueblo amuzgo, cuentan una larga historia de dominación por parte de caciques locales, hombres blancos o mestizos hasta los años ochenta, y luego indígenas -en dos ocasiones mujeres- con la llegada de la "democratización” y el multipartidismo (Gutiérrez Ávila 2006). Después de varias experiencias de organización, reprimidas por el cacique en turno, a principio de la década del 2000 las comunidades se sublevaron en contra del poder caciquil de la familia Rocha, que por años controló el municipio, gracias a una sólida alianza con el PRI. Reivindicando el derecho a nombrar sus propias autoridades, y sacudiéndose del poder opresivo ejercido desde hace décadas por el cacicazgo mestizo y el partido de Estado, en 2002 se declaró el Municipio Autónomo, gobernado por un Consejo de autoridades independientes de los partidos y de acuerdo a los sistemas normativos propios, que funcionó hasta el 2005. Los partidos políticos (en particular el PRD) lograron quebrar el proceso, cooptando las autoridades tradicionales hacia intereses partidistas, restándole representatividad y transformado esta instancia en una herramienta de gestión hacia las instituciones. Radio Nomndaa, heredera de esta experiencia, define la autonomía como una forma de vida que, sin 
embargo, no se puede alcanzar en su plenitud mientras haya divisiones políticas en las comunidades.

La construcción de autonomías en contextos de violencia implica la re-apropiación del poder de decidir sobre su futuro como pueblos, y la construcción de nuevas formas de poder más horizontal y plural. Un ejemplo paradigmático fue el Municipio Autónomo de San Juan Copala, experiencia autonómica del pueblo triqui, directamente ligada al contexto de violencia política y paramilitar; lamentablemente, el desenlace del proceso -desplazamiento de la población ligada al grupo autónomo, cooptación de líderes e instrumentalización del conflicto por parte de los partidos- muestra la dificultad que las autonomías tienen para consolidarse, y las múltiples estrategias que puede desplegar el poder estatal en contra de tales procesos. ${ }^{174}$

La situación de violencia que padece el pueblo triqui es un hecho innegable, pero se ha también transformado en un estigma (al igual que el "Guerrero bronco") y en una justificación apriorística de la realidad, utilizada con gusto por las autoridades estatales como pretexto para desentenderse de sus responsabilidades en la región. ${ }^{175}$ Sin embrago, es necesario tratar de explicar -aunque someramente- las raíces y los impactos de la situación de violencia generalizada que desde hace décadas se vive en la zona, ya que es imposible entender la insurgencia social sin insertarla en tal contexto arraigado de represión, impunidad, relaciones clientelares y discriminación étnica.

El racismo es el elemento fundador del mito del triqui violento, y la dominación lo que ha llevado a la descomposición de las relaciones sociales internas a este pueblo indígena. Los grupos de poder regionales acompañaron el desprecio hacia la población indígena con un gran interés hacia sus recursos: las fértiles tierras -cultivadas a café y plátano- y el potencial de una fuerza de trabajo muy barata. Así, los conflictos agrarios iniciaron cuando las élites de las ciudades mestizas usurparon tierras comunales triquis; para quebrar la resistencia indígena usaron por un lado el terror y el exterminio de los líderes naturales, y por otro la cooptación de otros líderes más accesibles, fomentando el surgimiento de facciones opuestas para su

\footnotetext{
${ }^{174}$ Para una visión más detallada de este proceso, véase López Bárcenas 2009b; De Marinis 2009.

175 Como lo demostraron en ocasión de las dos Caravanas de Solidaridad, realizadas en abril -en la que fueron asesinadas dos personas por los paramilitares- y en junio de 2010. Con respecto a esas iniciativas, las autoridades estatales se empeñaron en fortalecer esta visión de violencia irremediable, afirmar que no hay las condiciones para realizar acciones de respaldo al Municipio Autónomo, dando a entender que el estado nada puede con la fuerza paramilitar. Por otro lado, es evidente que este argumento encubre si no una complicidad con estos grupos, seguramente una actitud de desinterés hacia un "conflicto interno a la etnia" (o sea, que se maten entre ellos).
} 
estrategia de dominación. El proceso de introducción de cultivos para la venta, que se vivió en todas las regiones rurales del México posrevolucionario, en la región triqui se pervirtió: con frecuencia las cosechas no eran pagadas en dinero sino con alcohol, armas y municiones, facilitando que la envidia entre vecinos se resolviera, cuando posible, con el asesinato. Asimismo, se formaron bandas de pistoleros y se fomentó el cacicazgo interno al pueblo triqui. En un texto sobre la Montaña de Guerrero, Hebért (2006) analiza la implementación de políticas de "desarrollo" y la introducción de cultivos comerciales (también el café) como una estrategia que busca reforzar la presencia de estructuras estatales en regiones "violentas", pero que no trae beneficio para los habitantes; en efecto, puede lograr desplazar momentáneamente la violencia directa hacia una más profunda violencia estructural, que incrementa en la fragmentación comunitaria, la desigualdad, la competencia y el caciquismo.

Esta situación de "violencia", antes como ahora, es particularmente funcional a los poderes económicos y políticos: sustentándose en ella en los años cuarenta se desmantelaron los dos municipios triquis ${ }^{176}$ y en los cincuenta se impuso la militarización del territorio indígena, que fue bombardeado en 1956. Al mismo tiempo, el PRI se instalaba con fuerza en la región, imponiendo su autoridad sobre el sistema tradicional de gobierno indígena e impulsando en la región proyectos de "desarrollo". ${ }^{177}$

En contra de las múltiples vertientes de la dominación, el pueblo triqui comenzó a

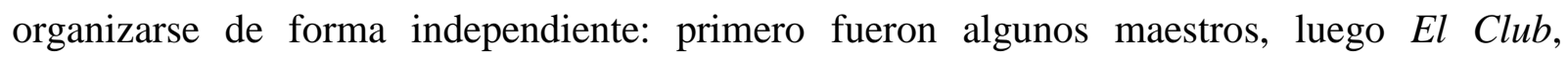
agrupación que luchaba para el control de los recursos y de la producción, y la defensa de las tradiciones. Violentamente reprimidas, estas organizaciones heredaron sus ideales y proyectos al Movimiento de Unificación y Lucha Triqui (MULT), formado en 1981, organización que luchó con valor por una década contra la dominación, y resistió a la violenta represión del Estado y de los grupos de poder locales. El MULT logró imponerse políticamente en la región, por lo que en 1994 el PRI impulsó la formación de la Unión de Bienestar Social Triqui (UBISORT), organización que entró inmediatamente en conflicto con la otra.

Los choques violentos marcaron la historia de las dos organizaciones, en particular la del MULT que reclama centenares de muertos. Cuando los líderes del MULT comenzaron a corromperse y su lucha se limitó a la gestión de recursos, en un rápido acercamiento a la

\footnotetext{
${ }^{176}$ Cuyas cabeceras corresponden a los centros ceremoniales, Copala e Chicahuaxtla.

${ }^{177}$ Como el aprovechamiento del Río Balsas.
} 
estructura priista que siempre mantuvo el poder en el estado, un grupo de inconformes creó el MULT-Independiente, que se forjó durante las movilizaciones magisteriales de 2006 y participó en la creación de la Asamblea de los Pueblos de Oaxaca (APPO). Apenas dos meses después de la violenta represión que cimbró esta experiencia organizativa estatal, en San Juan Copala se anunciaba la institución de un Municipio Autónomo, “integrado por todas las comunidades y barrios que han roto o en el futuro rompan la subordinación a las organizaciones del gobierno o ligadas a él". ${ }^{178}$

Mientras una parte del pueblo triqui inició la construcción de espacios de autodeterminación y de dialogo, otra parte, ligada a las dos organizaciones mencionadas, recrudeció el uso de la violencia como arma política, fortaleciendo grupos paramilitares que actualmente mantienen con las armas el control en la región. Esta descripción somera del conflicto en la región triqui baja ayuda a entender el significado y la forma particulares que adquieren la reivindicación y la práctica de la autonomía en este contexto.

La primera vertiente de la violencia es representada por la discriminación y el desprecio. Así, las autonomías son también, y sobre todo, una necesidad para la defensa de la identidad de los indígenas. Repropiándose del poder que tienen, como colectividad, de decidir y construir su futuro, los pueblos afirman su derecho de ser, de existir en tanto pueblo. En este sentido, la lucha por la autonomía es una lucha para la sobrevivencia de la colectividad. Atrapados en una disputa sin límites de violencia entre las organizaciones políticas de la región, los triquis se veían en la perspectiva de perder sus propias formas de gobernarse, crear acuerdos, resolver los conflictos, y dejarse arrastrar en una guerra intestina que terminaría por quebrar el ya fragmentado tejido social.

Elemento fundamental para la reproducción de la cultura y de la identidad, así como para el sustento material, es el territorio. Suelo para la siembra, pacha mama que alimenta, la tierra, definida simbólicamente y culturalmente, se vuelve territorio, cuyo sentido es inextricable de la identidad del pueblo que allí tiene sus raíces, sus mitos, sus fiestas y su alimento. A través de la dominación colonial y de la ocupación de tierras por las élites mestizas, lentamente la tierra ha sido arrebatada al pueblo triqui. La imposición de cultivos comerciales impuso el control ajeno sobre sus recursos. Asignando a tres distintos municipios mestizos la autoridad administrativa sobre el espacio que, políticamente y culturalmente, para

\footnotetext{
${ }^{178}$ Declaración del Municipio Autónomo de San Juan Copala, enero 2007.
} 
los triquis es de competencia del Chuman ' ${ }^{179}$ de San Juan Copala, el estado trató de arrebatar al pueblo el control político sobre su territorio. Si el territorio es la raíz de la identidad, su defensa implica la autonomía. Recuperar la unidad territorial apuntaba entonces a la reconstrucción integral del pueblo, para sacudirse de la secular opresión de las élites mestizas y de la corrupta clase política estatal.

Sin embargo, las divisiones políticas y partidistas han fragmentado y enfrentado radicalmente al pueblo triqui, lo que representa la otra vertiente de la violencia, la más desgarradora. "Antes de formar el Municipio Autónomo, se convocaron a las comunidades triquis de varias organizaciones. El tema de las pláticas era cómo evitar el baño de sangre en la región y avanzar por el bien de la comunidad. Varios ancianos que participaban dijeron que formar otra organización era seguir dividiéndonos; en un corto tiempo habría que comprometerse con un partido político. Al final de varias discusiones, decidimos no crear ninguna organización, sino mejor rescatar la cultura, los usos y costumbres de la región para construir nuestra propia autoridad, nombrar nuestro presidente. En ese momento no se mencionó la autonomía, solo se decidió trabajar a nuestro modo", comentó en una entrevista Jorge Albino, vocero del Municipio Autónomo. ${ }^{180}$

En un contexto polarizado, en el cual las relaciones entre las personas se estaban corrompiendo, donde el miedo empezaba a dominar la vida cotidiana, una parte del pueblo triqui decidió romper con la dinámica de las organizaciones políticas, que al reproducirse generaban cada vez más divisiones y conflictos. Para esto, vieron que era necesario recuperar y revitalizar las estructuras que forman parte de la "tradición", marcadas por los valores de colectividad e inclusión, una vez que constataron la peligrosidad de las organizaciones políticas para la vida y la cohesión comunitaria.

Para detener la violencia construyeron un nuevo poder, que se impusiera política y simbólicamente como una referencia para el territorio al ser construido sobre el consenso y no sobre la exclusión. El Municipio Autónomo quiso ser una institución que gobernara para todos los que están en el territorio, sin importar su militancia política. Este poder "alternativo" que construyen las autonomías se basa en el consenso, porque quien lo ejerce son las asambleas, comunitarias o municipales: espacios colectivos de discusión y tomas de decisiones, donde

\footnotetext{
${ }^{179}$ Centro ceremonial, político y religioso que aglutina a las comunidades (o barrios) triquis.

${ }^{180}$ Entrevista personal, San Juan Copala, septiembre 2008.
} 
son representadas todas las diferencias, que en estos espacios no desaparecen, pero que se redondean lo suficiente para permitir la creación de un consenso y la toma de acuerdos. Una característica de estos procesos de empoderamiento indígena, que llamamos autonomía, es el carácter colegiado de la toma de decisiones y del ejercicio del poder: los individuos son fundamentales en la construcción de las propuestas, pero la asamblea es quien decide sobre el destino de la colectividad.

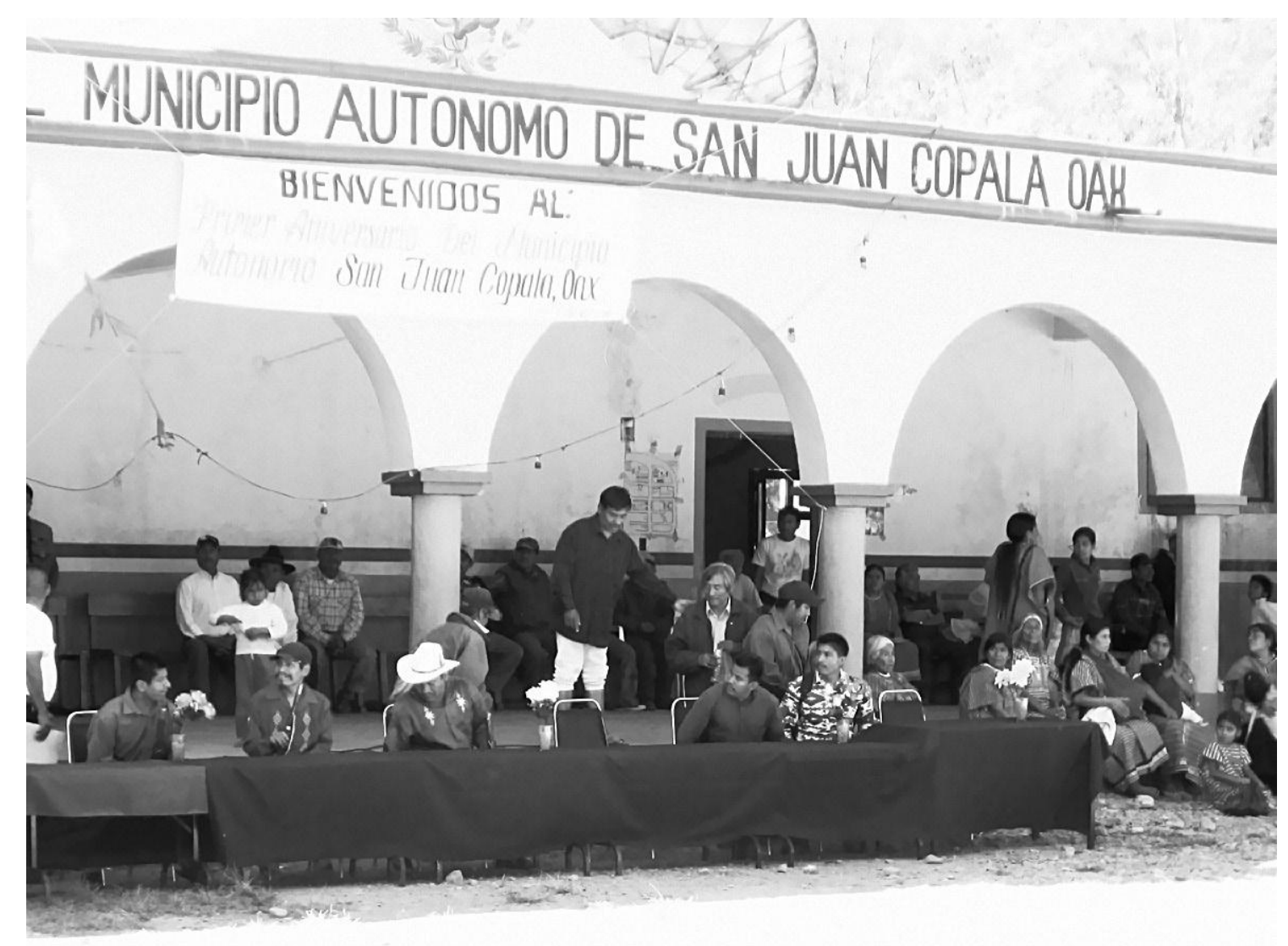

Palacio Municipal, $1^{\circ}$ Aniversario del Municipio Autónomo de San Juan Copala, Oaxaca, enero 2008.

Como comentó Jorge Albino, esta nueva forma organizativa se pensó en oposición a la que prevalece en la región: organizaciones políticas que, de una u otra forma, dependen de los partidos. ${ }^{181}$ UBISORT es una organización de directa filiación priista; por su lado, después de una larga temporada de lucha social, también el MULT optó por la lógica partidista, fundando en 2003 el Partido de Unidad Popular (según ellos, “el primer partido indígena” del país).

\footnotetext{
${ }^{181}$ Comunicado del Municipio Autónomo, 28 de mayo del 2010, <autonomiaencopala.wordpress.com>.
} 
Uno de los elementos que concretamente representaron la autonomía para Copala fue la constitución de la policía comunitaria, inspirada en la conocida experiencia guerrerense. Para Copala, instaurar una forma de seguridad propia, controlada por la autoridad autónoma y la asamblea, representaba una necesaria respuesta a la situación de violencia provocada por las varias facciones armadas.

Otro elemento clave de la autonomía triqui es el proceso de rescate de las formas indígenas de organización y gobierno. Lo que destaca de esta tradición organizativa que se está recuperando es el carácter colectivo de la autoridad (Cabildo y Consejo de ancianos), y la colegialidad en la toma de decisiones (asambleas).

El tercer fundamental logro de la autonomía triqui ha sido recuperar la palabra y el derecho a la comunicación, instalando la Radio Comunitaria "La Voz que Rompe el Silencio", en la que se involucraron los jóvenes de las comunidades. Lamentablemente, quienes no aceptan la idea de la pacificación de la región no dudaron en usar, una vez más, la violencia para callar La Voz: a los pocos meses de su instalación (7 de abril de 2008) dos jóvenes locutoras -Teresa y Felicitas- fueron asesinadas en una carretera de la región, y la radio dejó de funcionar.

La reivindicación de la facultad de gobernarse según usos y costumbres también fue el gran logro del pueblo de Cherán, comunidad purépecha de Michoacán. Sin embargo, no fue por este derecho que se levantó la comunidad, en abril 2011, sino porque ya no podía tolerar el sistemático saqueo de los bosques comunales, impulsado desde hace años por compañías madereras, ligadas a la delincuencia organizada. Además de la tala de bosques, los delincuentes extorsionaban buscaban controlar la población, llegando al asesinato de varios comuneros y comerciantes del municipio de Cherán. ${ }^{182}$ Tras el "levantamiento", la comunidad organizó un sistema de control territorial a través de puestos de control y una Ronda Comunitaria, integrada por pobladores armados, e inició a funcionar Radio Fogata. 17 comuneros fallecieron a lo largo de dos años de resistencia, durante los cuales la comunidad

\footnotetext{
182 Véase "Se regulariza la vida en Cherán, tras alzamiento de indígenas en abril pasado", en <www.jornada.unam.mx/2011/10/22/politica/002n1pol>; "Alta incidencia de delitos en zonas de bosques, aseveran productores y ONG”, <www.jornada.unam.mx/2011/10/22/política/003n1pol>, La Jornada, 22 octubre 2011.
} 
logró recobrar, al menos en parte, el control de su territorio y la tranquilidad para sus habitantes ${ }^{183}$.

Creo que la autonomía la empezamos a adquirir desde el momento en que decidimos enfrentar a esas personas. Y ¿por qué no queremos presidentes municipales y todo eso? Porque sabemos que son parte de ellos. Si los aceptáramos, estaríamos aceptando nuevamente que nuestros bosques se estuvieran destruyendo aún más que ahora. Los políticos van de la mano con el narco.184

Tras argumentos como este, la comunidad purépecha buscó la vía institucional para el reconocimiento de su autonomía de gobierno: solicitó - y obtuvo- por el Tribunal Federal Electoral la facultad de nombrar sus autoridades por usos y costumbres, y en 2012 se nombró el primer Consejo Mayor, que gobierna de forma colegiada.

Desde luego, el problema de la violencia y del narcotráfico está lejos de resolverse, pues en la región es día con día más violenta. En una decisión que no corresponde con las ideas más “ortodoxas" de la autonomía, las autoridades de Cherán solicitaron la presencia de las fuerzas armadas en su territorio para controlar los grupos criminales; para tal fin, se instalaron dos Bases de Operaciones Mixtas que, sin embargo, no tuvieron los resultados inmediatos esperados. $^{185}$

Las experiencias mencionadas, exitosas o no, muestran que hay una relación inversamente proporcional entre la organización comunitaria y la violencia, por esto la necesidad de fortalecer las estructuras de gobierno y de representación propias, que son expresión de la historia y de la cultura compartidas, y que funcionan como elemento de cohesión. Como expresaré con más detalle en los casos estudiados, el fortalecimiento de la organización a nivel regional y comunitario, y la cohesión que deriva del proceso organizativo, actúan de manera positiva sobre la fragmentación del tejido social y las divisiones internas a las comunidades. La disminución de la violencia interna, permite entonces desarrollar una mejor capacidad de enfrentar y defenderse de las múltiples violencias

\footnotetext{
${ }^{183}$ Véase <desinformemonos.org/2012/02/cheran-2/>

184 Testimonio de un poblador de Cherán, en< www.colectivocasa.org/story/noticias/ cheran-keri-caminando-firme-hacia-la-autonomía>, consultado el 25 junio de 2013.

185 http://desinformemonos.org/2012/08/cheran-el-ejemplo-vivo-de-la-inoperancia-de-la-politica-de-seguridaddel-estado/
} 
que atraviesan las comunidades indígenas: el narcotráfico y la violencia estructural, la militarización y la violencia política, etc.

Este es precisamente el camino que ha emprendido una trascendente experiencia organizativa: el movimiento indígena del Cauca en Colombia, que ha podido y debido conformarse como sujeto político y bloque regional de poder en respuesta y en medio de la violencia de todo tipo, en particular aquella originada por los actores armados (guardias armadas de los terratenientes -pájaros-, paramilitares, sicarios del narcotráfico, diferentes guerrillas, Ejército), presentes en la región desde hace por lo menos cinquenta años (Villa y Houghton 2004). La respuesta indígena al poder violento de estos actores no ha sido ni el acatamiento ni el silencio, sino la constante movilización y la autonomía, reivindicada y construida con un sentido profundamente radical. ${ }^{186}$ Esto no es privativo del movimiento indígena del Cauca, sino que es una reivindicación compartida a nivel nacional: así, para la Organización Nacional Indígena de Colombia (ONIC), "autonomía no significa que nos aislemos del país: el conflicto se da en nuestros territorios, se presiona a nuestras comunidades, se disputan nuestros recursos; es imposible que no tomemos una posición en defensa de nuestros intereses, de nuestro territorios, de nuestra cultura". ${ }^{187}$ Asimismo, las organizaciones indígenas de varias regiones del país comparten el rechazo al reclutamiento, participación y apoyo a cualquier fuerza armada; se han declarado al margen del conflicto adoptando distintos modos de organización territorial (comunidades de paz, comunidades de autodeterminación, zonas humanitarias, o, para el caso del Cauca, instituyendo el Territorio de Convivencia, Diálogo y Negociación en la María Piendamó), pero con un elemento común: su negativa a colaborar de ninguna forma con los combatientes, tanto legales como ilegales. En este generalizado proceso de construcción de la paz, la autonomía es un medio para ello, y para la defensa de los recursos territoriales, naturales y culturales que están claramente en la mira de todos los actores armados.

La experiencia del pueblo nasa (o páez) del Cauca resalta por la larga trayectoria y la profundidad y particularidad de su proceso organizativo. Nacido en 1971 con el objetivo de la

\footnotetext{
${ }^{186}$ En la Resolución de Vitoncó (1985, en ONIC 2002: 7), uno de los primeros documentos que reivindican la autonomía como defensa a la violencia y la guerra, se resuelve hacer valer "el derecho a la autonomía, es decir, el derecho que los cabildos y las comunidades tienen de controlar, vigilar y organizar su vida social y política al interior de los Resguardos y de rechazar las políticas impuestas venidas desde afuera".

${ }^{187}$ Congreso de los pueblos indígenas de Colombia, 2002, en Villa y Houghton 2004: 244.
} 
lucha agraria y la recuperación de tierras -tema que sigue fundamental en las reivindicaciones de autonomía- el Consejo Regional Indígena del Cauca (CRIC) desarrolló paulatinamente un proyecto integral que incluye el programa político, educativo, cultural, económico y de comunicación, fortaleciendo la coordinación entre las instancias comunitarias de gobierno (Cabildos), todo en el marco de la autonomía. ${ }^{188}$ Frente a la agudización del conflicto y a los ataques violentos de los actores armados en las comunidades, que dejan muertos y desplazados, a partir de 1998 se ha profundizado el ejercicio de la autonomía con el fortalecimiento de la Guardia Indígena Nasa, organismo civil desarmado instituido como guardias permanentes con el objetivo de "seguir el camino de vigilancia, control, alarma, protección y defensa de nuestra tierra, en coordinación con las autoridades tradicionales y las comunidades". ${ }^{189}$ La Guardia Indígena“se concibe como organismo ancestral propio y como un instrumento de resistencia, unidad y autonomía en defensa del territorio y del plan de vida de las comunidades indígenas. No es una estructura policial, sino un mecanismo humanitario y de resistencia civil", ${ }^{190}$ actúa armada sólo con los bastones tradicionales y es integrada principalmente por jóvenes, pero también por hombres y mujeres de las comunidades que han realizado incluso tareas de desalojo de trincheras y bases de la Policía y el Ejército, y simultáneamente de los campamentos de las FARC y de laboratorios clandestinos, incautación de armas y erradicación de cultivos ilícitos. ${ }^{191}$

En su excelente estudio sobre La violencia política contra los pueblos indígenas en Colombia, Villa y Houghton afirman que, a diferencia de la tendencia en el movimiento indígena colombiano a caracterizarse cómo víctima, el discurso del CRIC afirma la necesidad de la acción directa, y se centra en el fortalecimiento de la autoridad de los cabildos y en la organización, las Mingas y las Asambleas regionales masivas, y en el afianzamiento de la identidad étnica, elaborando un discurso de resistencia activa (2004: 105). El fuerte protagonismo indígena es alimentado por la instrumentación política de la identidad étnica,

\footnotetext{
${ }^{188}$ La Constitución colombiana, reformada en 1991, reconoce amplios derechos para los pueblos indígenas.

${ }^{189}$ Documento de las guardias indígenas del Cauca, 2002, en ONIC 2002:58.

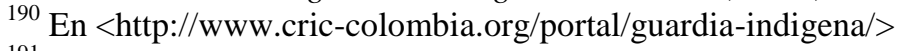

191 Véase Pronunciamiento de Toribío, Consejo Regional Indígena del Cauca, julio de 2011, <http://www.viva.org.co/cajavirtual/svc0264/pdfs/Pronunciamiento\%20Toribio\%2020\%20de\%20julio\%202011 \%20CRIC.pdf>; Pronunciamiento de las autoridades tradicionales del Plan de Vida Yu Lucx de la Cxhab Wala Kiwe-ACIN, agosto 2013, en <http://www.nasaacin.org/comunicados-2013/5994-pronunciamiento-de-lasautoridades-y-comunidades-indigenas-del-plan-de-vida-yu-lucx-de-la-cxhab-wala-kiwe-acin>. Un detallado y excelente estudio sobre la Guardia Indígena es realizado por Sandoval Forero (2008).
} 
que deviene estrategia de poder en espacios de conflicto; la afirmación identitaria se da en términos regionales (CRIC, Asociación de Cabildos Indígenas ACIN) y fortalece la autonomía territorial (Cabildos y Planes de Vida).

En un contexto en el que la población y los líderes indígenas son víctimas de los enfrentamientos o de asesinatos selectivos por los opuestos actores en conflictos, y en su territorio se enfrentan las jurisdicciones del Estado y la insurgencia, a partir de 1996 el movimiento indígena del Cauca da un paso adelante en su proceso de soberanía e inicia a juzgar con los mecanismos de la justicia tradicional propia a los actores armados (milicianos del ELN, FARC y también a soldados del Ejército) responsables de homicidios de indígenas de la región. La afirmación de la justicia propia en ámbitos que trascienden la justicia comunitaria tradicionalmente ejercida, denuncia la ilegitimidad tanto de la justicia oficial como de la justicia ordinaria, y representa una herramienta también política para defenderse de la violencia y la impunidad a la que siguen sometidos los indígenas de la región.

Finalmente, me parece útil retomar aquí la consideración que, para los nasa del Cauca, la violencia política fortaleció dos imaginarios que devinieron estructurantes de identidades étnicas. El primero apunta a la continuidad entre la guerra de Conquista europea, el conflicto contra los terratenientes en los años setenta y el conflicto contemporáneo, donde los indígenas permanecieron como víctimas recurrentes de violencias estructurales caracterizadas por la explotación y el despojo. En contraposición, se plantea otra continuidad histórica: la de los pueblos que persistieron cultural y políticamente a pesar de la violencia, los pueblos en pie de lucha (Villa y Houghton 2004:119). Este imaginario "resistente" ha evolucionado en el conflicto contemporáneo, dando vida a la sugerente imagen de los “guerreros de paz".

\section{Autonomía, violencia y derecho a la autodefensa}

Las experiencias de los nasa colombianos, así como la del pueblo triqui y la de los purépechas de Cherán, muestran claramente un elemento que es clave en la actualidad de las autonomías: la necesidad de garantizar la defensa del territorio propio y de la población que se involucra en la lucha por la autonomía, que en casi todos los casos significa la aguerrida defensa de recursos naturales, calidad de vida, cultura y dignidad de los pueblos, frente a los poderes fácticos y depredadores más o menos institucionalizados, más o menos criminales. El ejemplo 
de la Policía Comunitaria de Guerrero ha sido retomado y adaptado a contextos muy diferentes: la referencia a Cherán se hace obligatoria ya que la conformación de la Ronda Comunitaria fue entre las primeras acciones organizadas por el pueblo, y quizás la más necesaria. En contextos de violencia encarnizada, la autonomía brota como necesidad incontenible y se debe defender con fuerza frente a la violencia misma.

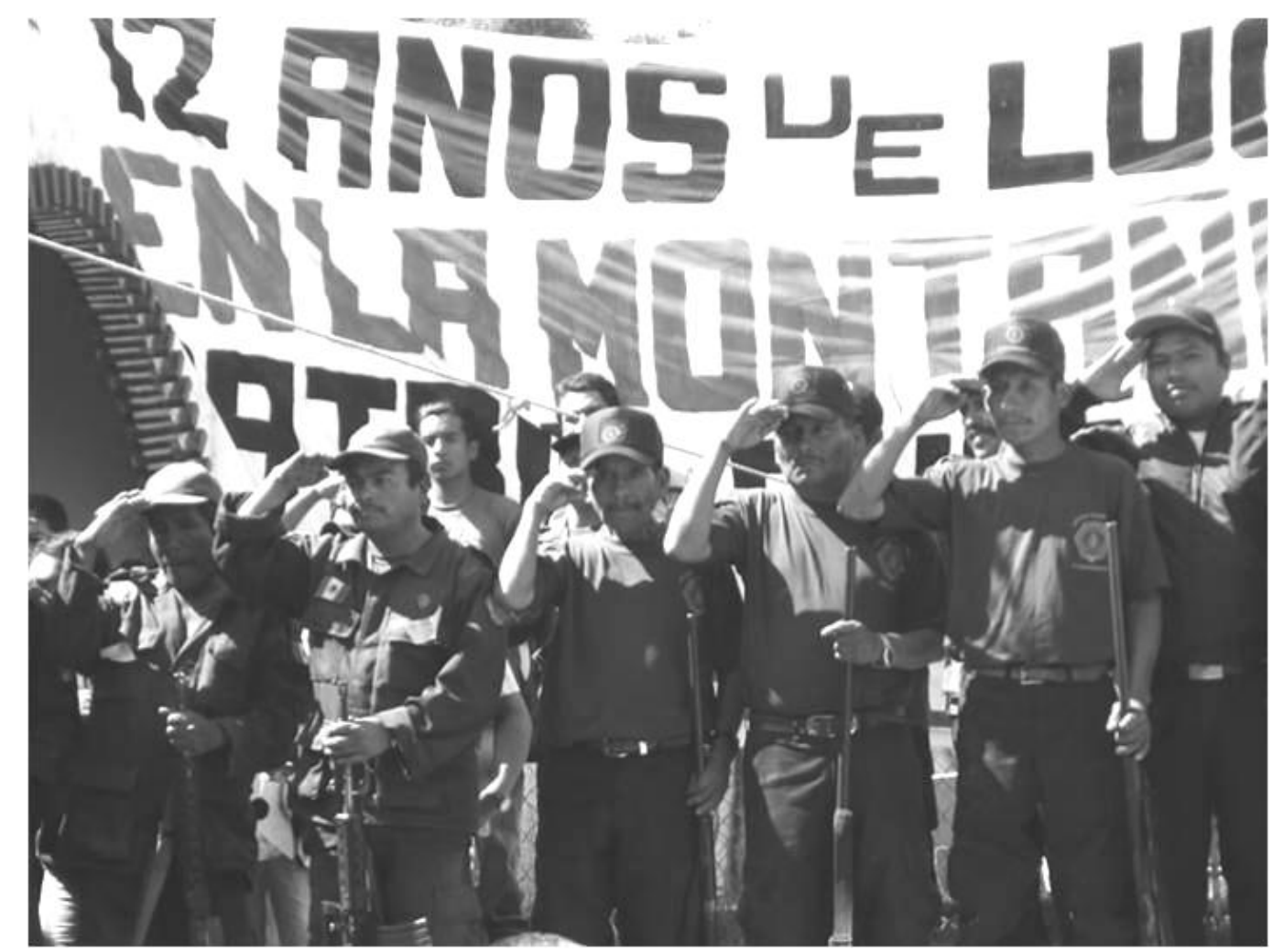

Policía Comunitaria, $12^{\circ}$ aniversario, Zitlaltepec, Montaña de Guerrero, 2007.

En el año 2013 este tema se ha tornado de interés nacional, pues en casi todo el territorio han surgido decenas de grupos civiles, diversamente armados, que reivindican el derecho de la ciudadanía a protegerse de los abusos del crimen organizado, frente a la impotencia o el desinterés del Estado. El debate que se ha desarrollado en los medios y en los espacios institucionales gira alrededor de la legitimidad de tales procesos, la posibilidad de su regulación, el riesgo del traslape entre los grupos de ciudadanos armados y los mismos cárteles de la delincuencia, o la consolidación del paramilitarismo cuando se reciba el velado apoyo de instituciones o grupos de poder. 
Para orientar la reflexión al respecto, es relevante la experiencia de la comunidad nahua de Santa María Ostula, en la costa de Michoacán, que, después de una larga y tenaz labor organizativa, en 2009 emprendió la recuperación de más de 700 hectáreas pertenecientes a su territorio comunal, desde hace décadas ocupadas por rancheros no indígenas, y disputadas por narcotraficantes, inversionistas inmobiliarios y empresas mineras. Después de agotar todos los recursos legales, los comuneros organizados decidieron actuar $\mathrm{y}$ fundaron en la tierra recuperada el paraje de Xayacalan, enfrentando una violenta respuesta de los supuestos "pequeños propietarios". 192 "Posteriormente la recientemente formalizada Policía Comunitaria de Ostula repelió el ataque y consiguió que los comuneros llegaran al predio en disputa. De inmediato se instaló un campamento y aproximadamente 500 guardias comunitarias comenzaron la vigilancia de todos los alrededores, previniendo nuevas provocaciones". ${ }^{193} \mathrm{El}$ reconocimiento de la Policía Comunitaria fue entonces la otra gran reivindicación del movimiento, junto con el reconocimiento de la totalidad de su territorio originario.

Tan importante es la conexión que allí se estableció entre el derecho al territorio y el derecho a defenderlo, que el Congreso Nacional Indígena hizo propias estas reivindicaciones y, en el marco de la XXV Asamblea Nacional celebrada el 14 de junio 2009, emitió el Pronunciamiento sobre el Derecho a la Autodefensa Indígena. ${ }^{194}$ El documento explica cómo, a lo largo de la historia, los pueblos indios han creado formas legítimas y legales para su autodefensa, y afirma que "actualmente la guerra de exterminio neoliberal desatada en contra de nuestros pueblos ha alcanzado un grado de destrucción, despojo y explotación nunca antes visto que pone en grave riesgo la existencia, la seguridad y los territorios correspondientes a los pueblos originarios". Por lo tanto, declara que:

Nuestros pueblos, tribus y naciones, así como las comunidades que los integran, tienen el inalienable derecho, derivado del artículo 39 constitucional, para organizarse y realizar la defensa de su vida, de su seguridad, de sus libertades y derechos fundamentales y de su cultura y territorios $[\ldots]$ en tanto no atente contra el respeto de los derechos humanos; por lo que la

\footnotetext{
${ }^{192}$ Violencia que, en los siguientes dos años, cobró 28 vidas entre los comuneros. Fuente: Contralínea, 10 de diciembre 2011, <http://contralinea.info/archivo-revista/index.php/2011/12/10/ostula-28-activistas-asesinadosen-dos-anos/>

${ }^{193}$ Gloria Muñoz Ramírez, "Ostula, pueblo en vilo”, en < contralarepresion.wordpress.com/2009/ 07/14/ostula-pueblo-en-vilo/>, consultado el 30 de junio 2013.

194 En <http://enlacezapatista.ezln.org.mx/2009/06/17/pronunciamiento-sobre-el-derecho-a-la-autodefensaindigena/>, consultado el 30 de junio 2013.
} 
creación, en el marco de nuestra cultura y organización tradicional, de policías comunitarias, guardias comunales u otras formas organizativas comunales para la autodefensa indígena, son legales, legítimas y, sobre todo, necesarias frente a la profunda corrupción y descomposición de las instancias encargadas de impartir justicia.

Las experiencias expuestas muestran que la seguridad y la resolución de conflictos están en la base de cualquier intento de organización autónoma. Garantizar la seguridad de los propios pueblos, marcar un alto a la violencia, significa restituir la libertad a los individuos y a la colectividad. Una vez que hayan reconstituido las relaciones de convivencia y la confianza, los pueblos pueden edificar su futuro: organizarse para construir sus instituciones educativas, de salud, producción y comercio. Pero todo esto no es posible mientras los pueblos estén amenazados en su cotidianidad por la violencia y el miedo que los inmoviliza.

Según Gledhill, que analiza las trayectorias de Cherán y Ostula:

Se trata, en los dos casos, de un movimiento autonomista que se definía explícitamente en términos de instituciones de autodefensa local, es decir, instituciones armadas, cuya necesidad surge del hecho que las autoridades "autorizadas" no pueden garantizar la seguridad de los ciudadanos ni depurarse de la influencia del crimen organizado. A la vez, se plantean las tradiciones de autogobierno indígenas como la base de una reforma política de profundidad. En la práctica hay un grado importante de re-significación en la definición de "usos y costumbres", apropiación de prácticas cuyos orígenes no son indígenas, e incluso invención, casi inevitable para desempeñar funciones administrativas contemporáneas de una manera eficaz. Sin embargo, tanto en Cherán como en Ostula existen formas de organización arraigadas en la historia, capaces de apoyar nuevas prácticas de autogestión (2013: 16).

En años recientes, el tema de la seguridad se ha vuelto central en el discurso oficial de los gobiernos en muchos países del mundo. Para los Estados, ignorar estratégicamente los conflictos sociales, alimentar el miedo de la población y después aplicar políticas represivas que limitan las libertades y violan los derechos de todos los individuos, se ha vuelto una eficaz estrategia de control que permite el avance del proyecto neoliberal.

En un sentido opuesto, los pueblos indígenas enseñan que la seguridad se obtiene creando relaciones de respeto y diálogo entre los individuos, y tratando de resolver los conflictos sociales. Cuando toda la población se involucra en la construcción de los acuerdos, 
la paz será verdadera. Este proceso implica alejarse de las instituciones estatales, corruptas y racistas, que no pueden ni quieren garantizar la seguridad y el acceso a la justicia para la población indígena. Implica también la re-invención de sistemas jurídicos propios, que juntan prácticas tradicionales con nuevas normatividades, las que nacen como respuesta a nuevos problemas.

Sin embargo, la observación de la realidad cotidiana que se vive en muchas regiones del país, entre ellas Michoacán y Guerrero, vuelve muy difícil mantener una mirada positiva y una perspectiva de análisis constructiva, cual he tratado de articular en este trabajo. El panorama es, cuanto menos, sombrío. Los enfrentamientos entre bandas criminales y grupos de civiles armados, que aparentemente no son estructurados sino más bien animados por la falta de alternativas de sobrevivencia, se vuelven cada día más frecuentes y más sangrientos. Y si el estudio de la prensa es desalentador, los trabajos de investigación -en este caso antropológica, como los de Maldonado y Gledhill- que se abocan al análisis del tema dejan en la boca un sabor todavía más amargo. Si bien es cierto que la práctica de la autonomía se erige como respuesta necesaria y natural de los pueblos frente a situaciones de violencia, también es cierto que en muchas ocasiones los poderes violentos rebasan y arrasan la capacidad de resistencia de la autonomía, como fue el caso citado del Municipio Autónomo de San Juan Copala.

En un artículo recién, Gledhill (2013) analiza la experiencia mencionada de Ostula, resumiendo el desenlace actual de su trayectoria autonómica en el contexto de la transformación "de un Estado neoliberal a un Estado delincuente", partiendo de la pregunta: "si la capacidad de resistir de esta comunidad tan "resistente" está llegando a su fin, ¿qué ha cambiado en el escenario últimamente?" En Ostula, después de la demostración de fuerza en la que la comunidad fue respaldada por el CNI, inició una campaña de asesinatos selectivos de los líderes comunitarios más importantes, frente a la indiferencia o colusión de las policías y fuerzas armadas presentes en la zona; en tal persecución, se entrelazan los intereses agrarios de los rancheros desalojados, así como turísticos y mineros de consorcios trasnacionales, actores que pueden llegar a utilizar las redes y los servicios de los grupos criminales, por su parte también interesados en el control de la zona. Según Gledhill, jóvenes indígenas fueron cooptados, de manera más o menos encubierta, por las organizaciones delictivas, aprovechándose de su interés en el discurso de la autodefensa. La comunidad, cada vez más 
dividida y con un gran número de desplazados, ha perdido gran parte de la fuerza organizativa que tenía en 2009: la autonomía política que reivindicó en ese entonces rechazando la instalación de casillas electorales, fue resquebrajada por los poderes fácticos de la economía criminal.

Frente a este ejemplo, y a la luz del cuadro general esbozado en el capítulo anterior, se impone de manera contundente la preocupación por lo que implica, en un contexto marcado por tan fuertes intereses sobre los territorios indígenas, la embestida criminal y la indolencia de las instituciones. Me parece que resume bien este panorama la interrogante con la que Gledhill cierra su artículo:

Parece necesario preguntarse si la falta de respuesta de los distintos niveles de gobierno contra la escalada de violencia en la costa michoacana no indica que la destrucción definitiva de sus comunidades indígenas, objetivo principal de las élites regionales y extranjeras en el siglo diecinueve, no haya vuelto a ser el proyecto de las élites domésticas, extranjeras y transnacionales que hoy en día codician sus recursos (2013:19). 
CAPÍTULO 3

\section{LA SELVA LACANDONA: HISTORIAS DE PODER, VIOLENCIA, LUCHA SOCIAL Y AUTONOMÍA}

Ser pueblo es hacer historia, ser hombre es ser actor o víctima de una historia; ser sociedad es asumir o soportar lo que resulte de la historia; ser sociedad es asumir o soportar lo que resulte de la historia; la cultura es lo que queda de los golpes o de las conquistas de la historia, y la política es construir la historia -o dejar que otros la construyan. Andrés Aubry, Chiapas a contrapelo

Supuesto de este trabajo es que la autonomía representa un recurso organizativo y político a través del cual los pueblos indígenas enfrentan situaciones de violencia (en sus múltiples significaciones) y de despojo, articulando procesos de resistencia y de construcción de identidades e instituciones propias. La autonomía puede ser una forma para manejar los conflictos de manera positiva y propositiva, ya que busca dialécticamente la transformación y el re-equilibrio de las relaciones sociales. Bajo tal supuesto, la región de estudio -la Selva Lacandona en Chiapas- es emblemática, debido a la histórica presencia de múltiples formas de violencia y conflictos que involucran los pueblos indígenas, pero también por las trayectorias organizativas que éstos han desarrollado para enfrentarlos.

La intención de este capítulo es caracterizar la región como un territorio históricamente construido, ilustrando sus características estructurales y enfatizando los procesos sociales, políticos y económicos que intervinieron en su configuración.

Siguiendo al geógrafo Carlos Walter Porto-Gonçalvez, entiendo el territorio como un espacio hecho propio por las identidades colectivas que lo fundan y cuya existencia es determinada por el territorio mismo, lugar "donde arraiga una identidad en la que se enlaza lo real, lo imaginario y lo simbólico" (Leff in Porto-Gonçalvez 2001: ix). Un primer elemento constitutivo del territorio reside entonces en la relación entre los hombres y la naturaleza, y en el modo en que cada sociedad "marca la tierra o, desde el punto de vista etimológico, geo- 
grafía, vuelve propio, hace común un determinado espacio, adueñándose de él [...] en un largo proceso de apropiación simbólico-material" (Porto-Gonçalvez 2001: 6). El concepto de geo-grafía expresa la significación del espacio concreto por parte de un sujeto colectivo e incluye el elemento cultural en el proceso de construcción territorial.El autor acuña el concepto en el marco de un estudio de gran profundidad, en el cual narra la transformación de un territorio - el estado de Acre, en la Amazonía brasileña- y la configuración de un sujeto colectivo - los seringueiros- cuya especificidad se teje en el cruce del espacio regional, y de los espacios nacionales e internacionales que lo incluyen, en una confrontación entre el mercado capitalista mundial y la cultura local.

Me parece sugerente transferir esta idea del territorio como ámbito marcado culturalmente, socialmente y políticamente, y en continua construcción debido a la influencia de los procesos que lo atraviesan y en él acontecen, al ámbito de la región, unidad espacial de análisis de este estudio.

El concepto de región expresa significados diferentes a según de las distintas disciplinas que lo utilizan y de las perspectivas que lo abordan. En términos generales, implica unas características físicas y naturales distintivas (región natural), y una relativa homogeneidad a su interior (región homogénea), o bien se configura a partir de puntos neurálgicos que estructuran el espacio que los circunda (región polarizada, ej.: relación centro-periferia). ${ }^{1}$ La antropología mexicana ha desarrollado en su interior un largo debate sobre la unidad de estudio, en el que la comunidad y la región representan diferentes enfoques políticos hacia la diversidad cultural (Bohem 1997); asimismo, distintos enfoques tienen a la región como unidad de análisis. Entre ellos, destacan los que entienden a la región como un constructo cultural, producto de la relación entre el medio ambiente físico, la historia y la cultura (Giménez 1999:12), refiriéndose a la región socio-cultural. ${ }^{2}$ Una perspectiva diferente otorga relevancia a las prácticas económicas y de explotación de la naturaleza, y a las relaciones de producción como elemento característico de un determinado espacio regional, y a su relación con los procesos

\footnotetext{
${ }^{1}$ El concepto de "región intercultural" acuñado por Aguirre Beltrán corresponde a este último modelo.

${ }^{2}$ Esta ha sido definida por Bonfil Batalla (1973: 177, cit. en Giménez 1999:40) como "la expresión espacial, en un momento dado, de un proceso histórico particular...". Elaborando el tema en relación a la importancia del territorio y de la identidad, Giménez resalta la importancia de la historia -"la región socio-cultural es un territorio literalmente tatuado por la historia [...] puede considerarse en primera instancia como soporte de la memoria colectiva y como espacio de inscripción del pasado del grupo" (1999: 41); asimismo, es el "espacio de distribución de la cultura etnográfica, es decir, de una variedad de instituciones y prácticas simbólicas" (1999: $42)$.
} 
económicos y las formaciones sociales más amplias (Guerrero y López 1982) ${ }^{3}$. Considerando la gran variedad de significados que puede tener el concepto de región, Viqueira nota que, dependiendo de la "variable fundamental" escogida por los investigadores (actividades económicas, dependencia de algún centro urbano, sustrato cultural, tipo de suelo o de clima, lengua hablada, etcétera), se pueden identificar, en un territorio, regiones definidas y distintas. "Pero basta escoger otra variable, cambiar los intervalos de sus valores u observarla en otro momento histórico para que los espacios cobren nuevas figuras" (Viqueira 1997: 111). Así, muchos investigadores han optado por "fijar su atención en la variable y en el período que mayor interés representan para los fines de su análisis, definiendo así regiones nominales, que son explícitamente creaciones conceptuales" (Viqueira 1997: 111, cursivas mías).

Siguiendo dicha sugerencia, he delimitado mi análisis, en términos temporales, al período que va desde la mitad del siglo pasado hasta nuestros días; asimismo priorizo -como variable- el análisis de los procesos sociales en una perspectiva histórica, integrando los elementos geográficos, demográficos, culturales y aquellos a relativos a las estructuras productivas en dicha perspectiva, para explicar su origen, evolución y permanencia. De tal manera, parto de una región nominal y busco darle consistencia con la articulación de los elementos analizados, entre los que tiene particular relevancia la presencia y el alcance territorial de la organización estudiada. El EZLN, con fuerte presencia en todo el estado, impulsa acciones comunes a todas las regiones pero en cada una se implementan de manera diferente; la región Selva Lacandona es también definida por la acción que ejerce dicha organización, como uno entre los múltiples procesos que la atraviesan.

En la conceptualización de la región, junto con la perspectiva histórica y el énfasis en los procesos sociales, tienen particular relevancia la construcción social del territorio, es decir la relación mutuamente constitutiva entre los procesos y las relaciones sociales y los elementos y procesos naturales, así como las estructuras ligadas a la producción y las formas de dominación ésta que conlleva. Así la región de la Selva Lacandona expresa una definición mutua entre el espacio natural y las colectividades humanas que la habitan; las características

\footnotetext{
${ }^{3}$ Guerrero y López entienden la región "como un espacio delimitado en el cual se configura una determinada relación entre un cierto conjunto de relaciones de producción, a nivel dado de las fuerzas productivas, con una serie de elementos y esferas socioculturales [...] no nos limitamos a entender esta relación per se, sino en gran medida originada y sobredeterminada por el carácter de su relación con el resto de la formación social" (Guerrero y López 1982: 67).
} 
naturales han determinado la evolución histórica y los procesos sociales (colonización luchas campesinas, políticas de conservación); las estructuras de producción analizadas en perspectiva histórica (las fincas y los ejidos) expresan relaciones de dominación y luchas de emancipación. Finalmente el elemento cultural -identidad indígena- no puede que sea relevante, pues determina el aprovechamiento de los recursos y define la geo-grafía del territorio.

Según Baez (1989: 202-203), "la región o lo regional refleja un acontecer y no una estructura". Así, el estudio de la dimensión regional debe siempre relacionarse con los procesos más amplios que involucran la nación en su conjunto; o aún más con los que atraviesan y definen el sistema mundo, tal y como lo hacen Porto Gonçalvez (2001) o el historiador Andres Aubry en su obra Chiapas a contrapelo, elaborada como el modelo de un "análisis histórico sistémico, en el que las partes (una comunidad, o Chiapas) y el todo (la totalidad del sistema como unidad de análisis) interactúan en la materialidad de un espacio y en la dinámica del tiempo" (2005:18). ${ }^{4}$

En este capítulo, más que hacer un recuento exhaustivo, mencionaré algunos procesos, sujetos y momentos que me parecieron determinantes en la creación de este territorio regional, multifacético y en continua redefinición, que es la Selva Lacandona en Chiapas. Los sucesos locales constituyen, en muchos casos, la objetivación de tendencias y procesos vigentes a escala nacional y global, que he analizado en los capítulos anteriores y a los que refiero con frecuencia en el estudio del acontecer regional.

He ubicado la investigación en este espacio por los siguientes motivos. Al estudiar cómo se desarrolla el sistema de justicia autónomo tuve que acotar la investigación a una de las cinco sedes de gobierno (Caracoles) zapatistas, aquella ubicada en la comunidad de La Realidad Trinidad, al interior de la región "Selva Fronteriza" (parte meridional de la Selva Lacandona); una región cuya peculiar historia influye en el proceso organizativo zapatista, en cuanto a formas organizativas y a reivindicaciones específicas.

\footnotetext{
${ }^{4}$ Esta reflexión caracterizaba ya el debate sobre la "cuestión étnico-nacional" en los años ochenta, en la que se afirmaba la necesidad de insertar el estudio de las etnias y de las regiones étnicas al interno del contexto nacional y de las relaciones de dominación capitalistas (contextos supranacionales); véase al respecto Guerrero y López y Rivas (1982). En fechas más recientes, Ayora Díaz (1995) explora el concepto de región en la antropología y las ciencias sociales, llegando a la conclusión de que "un estudio limitado y contenido en las fronteras de cualquier región oscurece el hecho de que existen fuerzas políticas emanadas de fuentes de poder sea internas, externas o ambas, que se relacionan estrechamente con lo que suceda al interior de ese espacio geopolítico".
} 


\section{AUTOONOMIIAINDÍGENA, VIOLENCIAY JUSTICIA}

En este recuento, cuyo objetivo es contextualizar el proceso de autonomía y la práctica de justicia autónoma estudiada, trataré de enfatizar las manifestaciones históricas y sociales de la violencia, en particular el racismo y la corrupción institucional, la violencia estructural y el conflicto social, como tres dimensiones de la relación entre instituciones, grupos oligárquicos, comunidades indígenas y mestizas. Más que realizar un recuento general de los hechos históricos que determinaron la conformación de este espacio social, concentraré mi atención en momentos y procesos paradigmáticos para la definición y articulación de las violencias el territorio.

Utilizo las herramientas teóricas desarrolladas en los capítulos anteriores para caracterizar el contexto regional en que florecen las experiencias de organización indígena, entendidas también como respuesta a la situación vivida.

\section{La Selva Lacandona: crisol de conflictos y de rebeldía}

\section{República Mexicana}

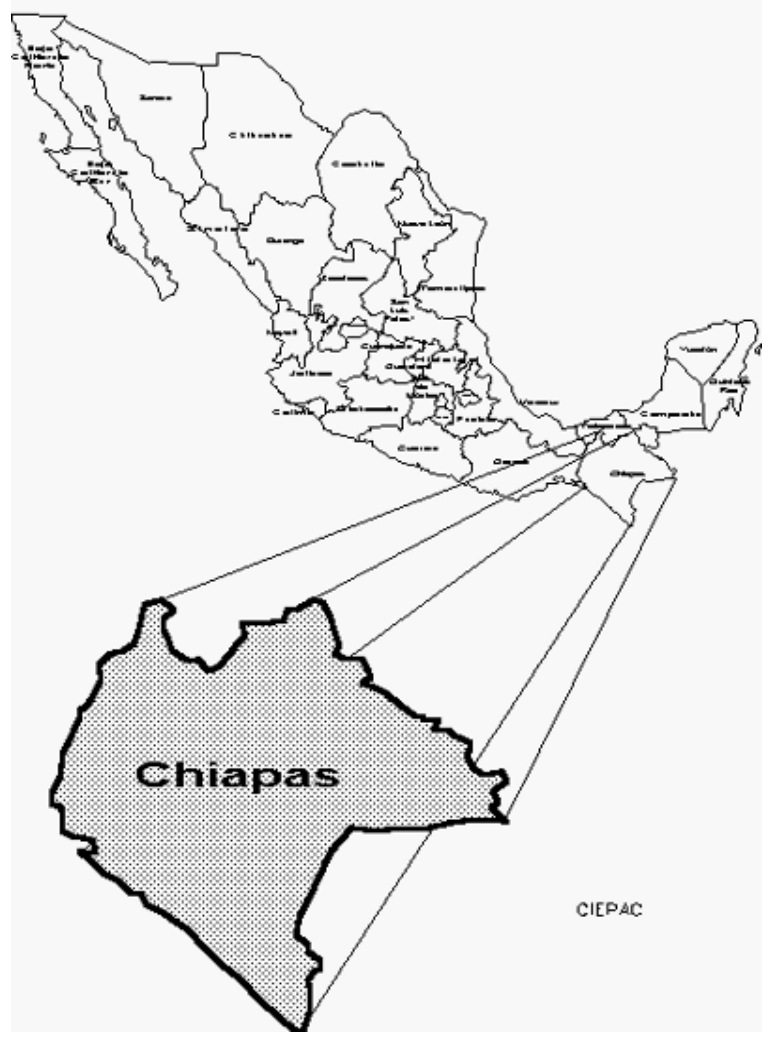

En este capítulo se perfilan los procesos y los momentos claves que caracterizan el espacio social de la región Selva -en particular la zona conocida como Las Cañadas de Las Margaritas- en las últimas cinco décadas. En esto, se pueden distinguir dos corrientes, estrechamente entrelazadas pero de alguna manera diferentes, es decir la cuestión agraria (la explotación en las fincas, la colonización de la Selva, las luchas por el reconocimiento de los ejidos, contra su expropiación y contra los desalojos) y, por el otro lado, la cuestión étnica (la reivindicación de identidad y derechos propios en cuanto pueblos indígenas, y la construcción de procesos organizativos basados en la identidad y la diferencia). 
Finalmente, la cuestión de la tierra atraviesa ambos procesos, como factor central, pues coincide con la reivindicación de territorio de los pueblos indígenas, y representa el necesario sustento para la reproducción, económica pero también cultural y social, de la sociedad indígena. Sin el control sobre la tierra/ terruño/territorio ${ }^{5}$ no sería posible poner en práctica ningún proyecto de autonomía y autogobierno. En cuanto reivindicación histórica de los campesinos indígenas, y en cuanto base necesaria para la construcción de la autonomía, el reclamo de tierra para cultivar ha sido la constante en las luchas y los procesos organizativos en Chiapas, y es central en el proyecto del EZLN. No es casualidad que en las regiones indígenas de Chiapas la conflictividad y la violencia estén ligadas, en gran medida, a viejos conflictos agrarios no resueltos y a nuevos conflictos que mezclan el problema agrario con las diferencias políticas.

\section{Mapa 1: Regiones socioculturales de Chiapas}

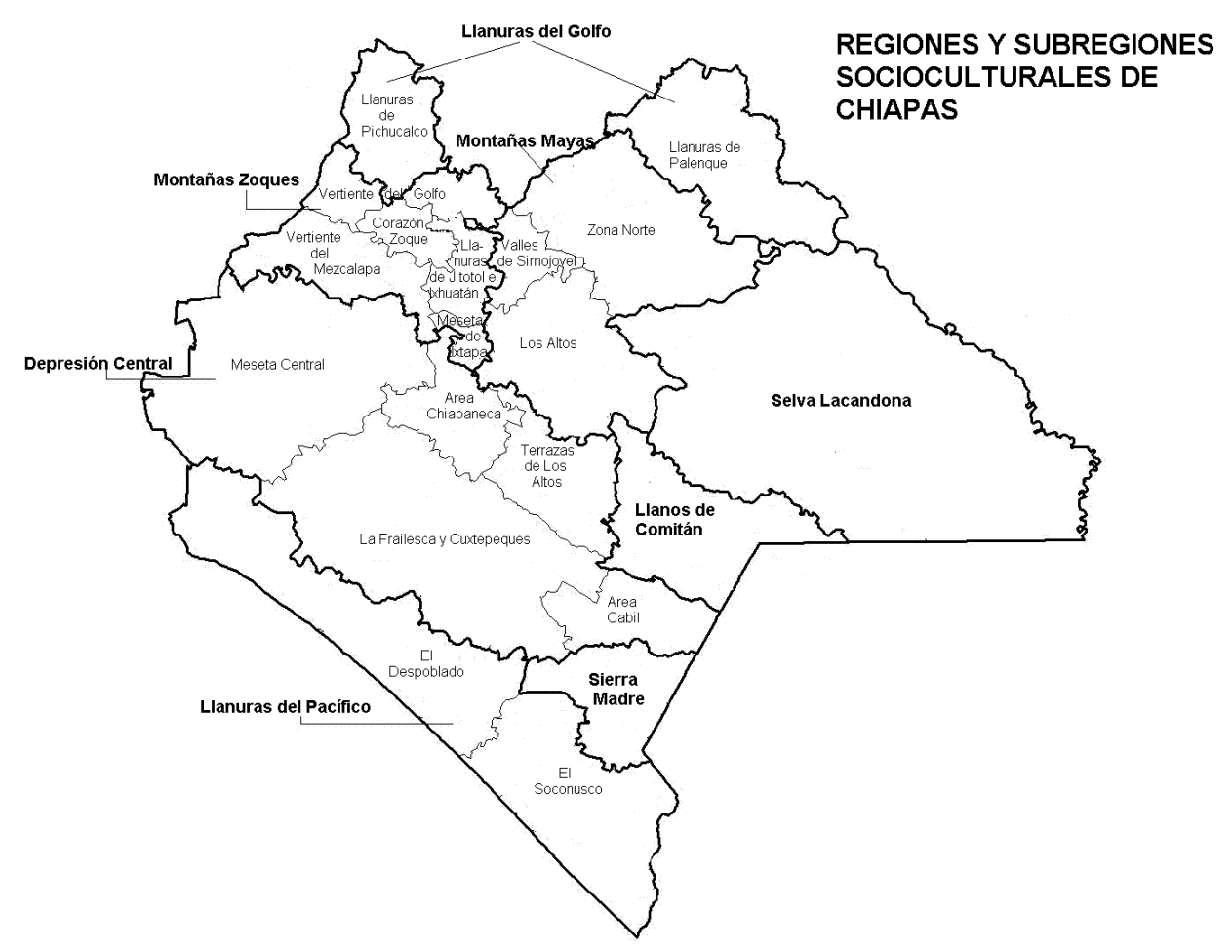

Fuente: Juan Pedro Viqueira, <http://etzakutarakua.colmich.edu.mx/videoteca/eventos/ XXVIIColoquio/resumenes/30JuanPedroViqueira.htm>

\footnotetext{
5 Para la diferenciación y caracterización de los tres términos véase el texto de Andrés Aubry, intitulado precisamente "Tierra, terruño, territorio", en La Jornada, 1/07/2007, <www.jornada.unam.mx/2007/06/01/index.php?section=politica\&article=024a1pol>, consultado el 10 noviembre 2013.
} 


\section{AUTOONOMIIAINDÍGENA, VIOLENCIAY JUSTICIA}

La Selva Lacandona se ubica en la parte meridional del estado de Chiapas, colindando con Tabasco y Guatemala. La regionalización institucional ha cambiado a lo largo de los años y difiere según los enfoques (político, económico, administrativo y judicial); sin embargo, considerando las características geográficas y culturales, y de acuerdo a la amplia bibliografía existente sobre la región, la Selva cubre los municipios oficiales de Ocosingo, Altamirano y Palenque, y parte de los municipios de Las Margaritas, Maravilla Tenejapa y Marqués de Comillas. Al interior de esta región, muy estudiada en años recientes por su importancia estratégica y política, se distinguen convencionalmente seis subregiones: Marqués de Comillas, la Reserva Integral de la Biosfera de los Montes Azules (RIBMA), la Comunidad Lacandona, la Zona Norte, las Cañadas de Ocosingo-Altamirano y las Cañadas de las Margaritas, que colindan con otra región conocida como Los Llanos de Comitán. Una tupida red de ríos y lagos, que pertenecen a la cuenca del Usumacinta, marca la orografía abrupta de Las Cañadas, montañas que se extienden hacia Guatemala y van degradando hacia el estado de Tabasco al norte y en la planicie de Marqués de Comillas en el sureste.

Mapa 2 : Chiapas meridional y Selva Lacandona: división municipal

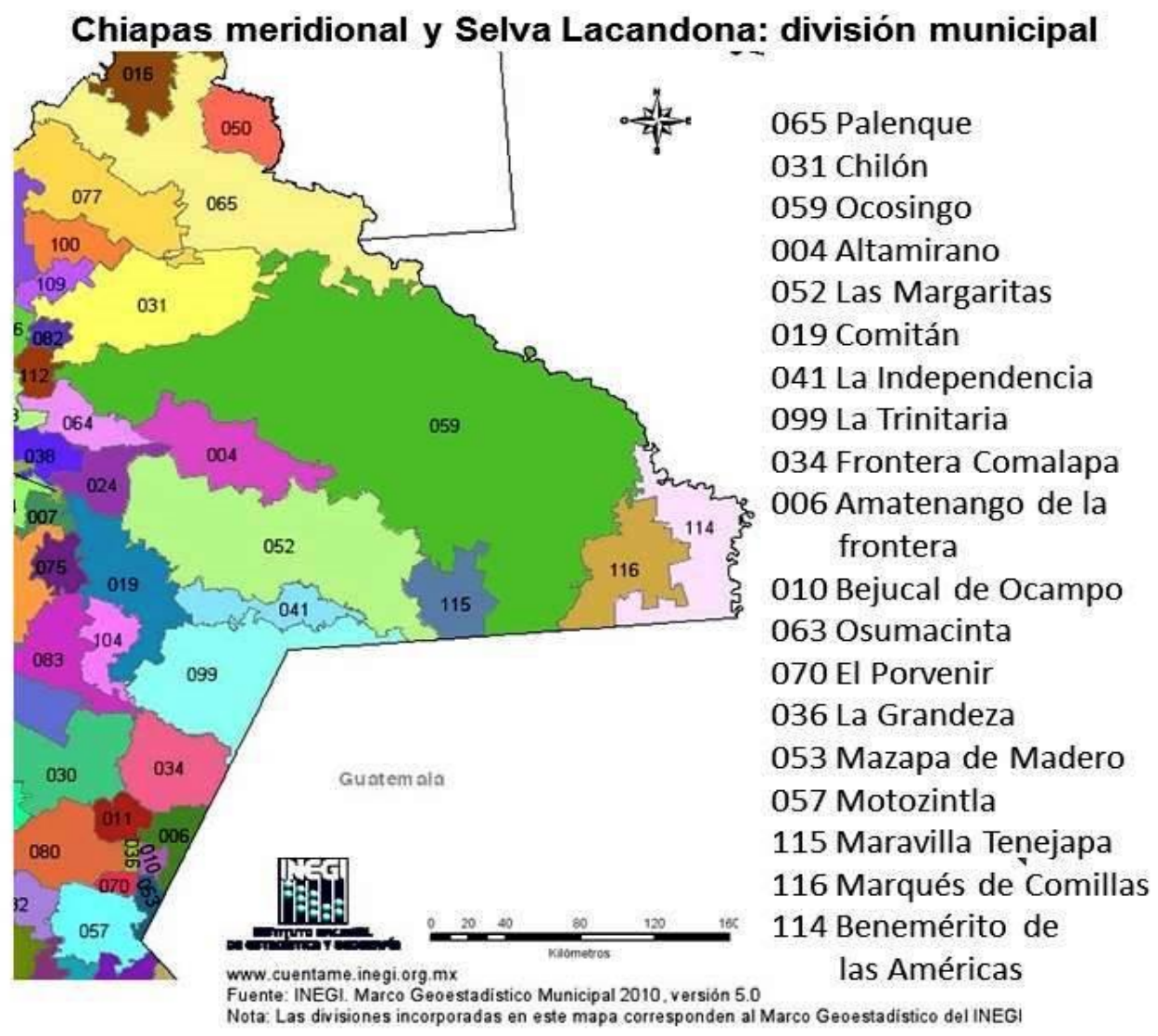


Caracterizan la región la abundancia de agua, la elevada biodiversidad, la riqueza de recursos energéticos, la diversidad cultural, pero también la marcada pobreza y marginación de la población indígena que la habita. Las principales actividades económicas para la población indígena de la región son la agricultura de subsistencia y el cultivo del café, y en menor medida la ganadería, en las propiedades ejidales y pequeñas rancherías. Por otro lado, en las propiedades de mayor extensión (ranchos, reductos de fincas) predominan la ganadería y las plantaciones agroindustriales. Finalmente, en particular en la región de Marqués de Comillas, la explotación petrolera tiene un papel relevante.

Según un documento publicado en 2014 por el Programa de las Naciones Unidas para el Desarrollo (PNUD), Chiapas es el estado de la república con el más bajo índice de desarrollo humano, ${ }^{6}$ que significa la carencia de escuela primaria, agua entubada, drenaje, energía eléctrica, piso de cemento y mucho más. Los pueblos indígenas, que representan más del 30\% de la población estatal, son los que muestran los menores índices de desarrollo. A una tasa de pobreza significativa, por lo tanto, se suma para la población indígena en Chiapas una fuerte inequidad de ingreso, de acceso a los servicios y de participación política, aunado a la ineficiencia de las instituciones y las secuelas de la suspensión de la justicia y de las garantías ciudadanas que implicó la guerra contrainsurgente a partir de 1994. Esta situación de violencia estructural evidente representa, sin duda, uno de los principales motivos que explican la necesidad de la autonomía en los términos de construcción de instituciones y servicios donde no existen, o son profundamente corruptos y manipulados por los intereses políticos.

Los datos siguientes reflejan también la vigencia de los programas neodesarrollistas, cuales la Cruzada Nacional contra el Hambre, en la cual están contemplados todos los municipios de la región de estudio.

\footnotetext{
${ }^{6}$ De acuerdo con la perspectiva del PNUD, "el desarrollo humano supone la expresión de la libertad de las personas para vivir una vida prolongada, saludable y creativa; perseguir objetivos que ellas mismas consideren valorables; y participar activamente en el desarrollo sostenible y equitativo del planeta que comparten [...] El índice de desarrollo humano tiene como objetivo medir el conjunto de capacidades y libertades que tienen los individuos para elegir entre formas de vida alternativas. Para ello, se toman en cuenta tres dimensiones básicas para el desarrollo: 1) la posibilidad de gozar de una vida larga y saludable; 2) la capacidad de adquirir conocimientos; 3) la oportunidad de tener recursos que permitan un nivel de vida digno" (PNUD 2014: 13). A pesar de basarse en la idea del desarrollo, la definición refleja en parte los elementos que son impedidos por la violencia estructural, según la definición de Galtung, y considero por lo tanto el concepto útil para describir algunos rasgos de la condición indígena en Chiapas.
} 


\begin{tabular}{|c|c|c|c|c|c|}
\hline \multicolumn{6}{|c|}{$\begin{array}{l}\text { INFORMACIÓN DEMOGRÁFICA Y ESTADISTICA DE LOS MUNICIPIOS QUE } \\
\text { ABARCA LA JURISDICCIÓN DE LA JUNTA DE BUEN GOBIERNO ZONA } \\
\text { SELVA-FRONTERIZA }\end{array}$} \\
\hline Municipio & $\begin{array}{c}\text { Población } \\
\text { total } \\
2010\end{array}$ & $\begin{array}{l}\text { Población } \\
\text { hablante de } \\
\text { lengua } \\
\text { indígena } \\
2010 \\
\%\end{array}$ & $\begin{array}{l}\text { Grado de marginación } \\
\text { Programa para el } \\
\text { Desarrollo de Zonas } \\
\text { Prioritarias (PDZP), } \\
\text { Cruzada Nacional } \\
\text { contra el Hambre }\end{array}$ & \begin{tabular}{|c|} 
Índice de \\
Marginación \\
2010
\end{tabular} & $\begin{array}{l}\text { Índice de } \\
\text { Desarrollo } \\
\text { Humano } \\
\text { municipal } \\
\quad 2005\end{array}$ \\
\hline $\begin{array}{c}\text { Las } \\
\text { Margaritas }\end{array}$ & 111,484 & $\% 50.14$ & Muy Alto & 1.21918 & 0.6559 \\
\hline Trinitaria & 72,739 & $\% 9.96$ & Alto & 0.56010 & 0.7111 \\
\hline $\begin{array}{c}\text { La } \\
\text { Independencia }\end{array}$ & 41,260 & $\% 4.62$ & Alto & 0.69386 & 0.6884 \\
\hline $\begin{array}{c}\text { Marqués de } \\
\text { Comillas }\end{array}$ & 9,856 & $\% 45.05$ & Muy Alto & 1.29573 & 0.6896 \\
\hline Motozintla & 69,119 & $\% 1.24$ & Alto & 0.47607 & 0.7671 \\
\hline Ocosingo & 198,877 & $\% 80.33$ & Muy Alto & 0.56010 & 0.7111 \\
\hline $\begin{array}{c}\text { Maravilla } \\
\text { Tenejapa }\end{array}$ & 11,451 & $\% 43.03$ & Muy Alto & 1.52703 & 0.6520 \\
\hline TOTAL & 335,786 & & & & \\
\hline Municipio & $\begin{array}{c}\text { Población } \\
\text { en situación } \\
\text { de pobreza } \\
\%\end{array}$ & $\begin{array}{l}\text { Población en } \\
\text { situación de } \\
\text { pobreza } \\
\text { extrema } \\
\%\end{array}$ & $\begin{array}{c}\text { Carencia por acceso a } \\
\text { los servicios de salud } \\
\%\end{array}$ & $\begin{array}{r}\text { Población de } \\
\text { más ana } \\
\%\end{array}$ & $\begin{array}{l}15 \text { años } 0 \\
\text { fabeta }\end{array}$ \\
\hline $\begin{array}{c}\text { Las } \\
\text { Margaritas }\end{array}$ & 92.91 & 60.76 & 29.53 & 25.5 & \\
\hline Trinitaria & 85.27 & 37.36 & 55.60 & 18. & \\
\hline $\begin{array}{c}\text { La } \\
\text { Independencia }\end{array}$ & 92.32 & 49.47 & 52.76 & 16. & \\
\hline $\begin{array}{c}\text { Marqués de } \\
\text { Comillas }\end{array}$ & 92.35 & 48.40 & 17.73 & 24. & \\
\hline Motozintla & 81.33 & 34.74 & 31.49 & 12. & \\
\hline Ocosingo & 90.92 & 59.66 & 41.49 & 27. & \\
\hline $\begin{array}{c}\text { Maravilla } \\
\text { Tenejapa }\end{array}$ & 95.82 & 68.23 & 18.74 & 26. & \\
\hline
\end{tabular}

Fuente: Cedulas de Información Municipal. Dirección General Adjunta de Planeación Microrregional de la Secretaria de Desarrollo Social, http://www.microrregiones.gob.mx/zap/Default.aspx 


\section{La finca, el baldio y la colonización de la Selva como "liberación"}

A diferencia de otras regiones de México, como la Costa-Montaña de Guerrero, cuyo territorio ha sido culturalmente y socialmente construido a lo largo de los siglos (en particular después de la Conquista, convirtiéndose pronto en una "región de refugio" según la clásica definición de Aguirre Beltrán ${ }^{7}$ ), la Selva Lacandona tiene una historia mucho más reciente -menos de un siglo- en cuanto a la presencia estable de comunidades y habitantes indígenas y campesinos. Nolasco (2003) distingue tres grandes momentos en el proceso de colonización de la Selva: el primero corresponde a la promoción gubernamental de este proceso y va desde los años treinta hacia su cancelación oficial con el decreto de 1972 que crea la Comunidad Lacandona; el segundo momento inicia con la lucha contra el desalojo y se extiende hasta el levantamiento zapatista de 1994; el tercer momento comprende el desarrollo del movimiento zapatista y su política agraria y territorial, y la política de contención, represión y contrainsurgencia gubernamental.

Conocida en el siglo XIX como "el Desierto de los Lacandones", ${ }^{8}$ la Selva estuvo en buena medida deshabitada desde la implosión de la civilización maya, en época precolombina, hasta poco antes de la mitad del siglo XX. Hasta la década de los treinta del siglo pasado, la región era ocupada principalmente por compañías madereras ${ }^{9}$ que explotaban los recursos forestales en enormes predios comprados o recibidos en concesión por el Estado, sobre todo a los márgenes de los ríos, que eran utilizados para transportar la caoba y otras maderas preciosas en rollo hacia Tabasco. En las monterías trabajaban, como mano de obra semiesclava y en condiciones de trabajo y de vida infrahumanas, bajo el control de capataces mestizos, indígenas de Los Altos "contratados" con el sistema del enganche o literalmente vendidos como pago por deudas frecuentemente inventadas por los enganchadores. El

\footnotetext{
${ }^{7}$ En palabras de Aguirre Beltrán, "los grupos cuya cultura es menos evolucionada van quedando rezagados en las regiones que por su clima o su topografía, son marginales y en las cuales es posible mantener una vida de mera subsistencia. [...] Estas regiones menos favorecidas, son regiones de refugio, porque su situación marginal y su aislamiento las defienden de la agresión de los grupos más adelantados. En cierta medida podríamos decir que los indígenas fueron empujados a ellas por los movimientos de expansión europea; pero, con mayor rigor histórico, debemos afirmar que en esas regiones lograron sobrevivir las antiguas poblaciones que ahí estuvieron establecidas" (1987:26).

${ }^{8}$ Así es definida la región por Juan Ballinas, quien exploró la región entre 1876 y 1878, y cuyas memorias fueron publicadas en 1950 en un texto que lleva el mismo nombre.

${ }^{9}$ Bulnes, Romano y Valenzuela fueron las familias que controlaban las más importantes empresas madereras, mexicanas en apariencia, pero estadunidense en cuanto a capital invertido.
} 


\section{AUTONOMIAINDÍGENA, VIOLENCIAY JUSTICIA}

enganche consistía en un préstamo o pago anticipado, se convertía en una deuda que usualmente no se extinguía en una sola temporada debido a los ínfimos sueldos pagados, manteniendo a los trabajadores "enganchados" a la montería por medio de débitos inextinguibles $\mathrm{y}$ en permanente aumento. Estos trabajadores no se establecían en asentamientos permanentes, sino que permanecían en los campamentos de las monterías, donde eran sometidos a toda clase de vejaciones y violencias (Benjamin 1981; Blom y Duby 1955; De Vos 1988 y 2002; Washbrook 2005). Posteriormente, se sumaron a las monterías los campamentos chicleros, itinerantes al interior de la Selva, donde trabajadores indígenas y mestizos extraían la savia del chicozapote.

A las orillas de la Selva se ubicaban las enormes fincas, otro enclave de explotación y esclavitud laboral y cultural, en las que se concentraba la población indígena. En los latifundios se concentraba, hasta por lo menos la mitad del siglo XX, la mayor parte de la tierra productiva, ${ }^{10}$ sembrada con grandes plantaciones de café y caña y, sucesivamente, explotadas para la ganadería. La característica de las fincas chiapanecas, sin embargo, no radicaba en su extensión, sino en el tipo de relaciones que articulaban en su interior y en su alrededor. Reducto de las haciendas coloniales, las fincas eran una "unidad económico-social", en la que se reproducían los privilegios de la oligarquía estatal, la "familia chiapaneca" (García de León 1985:64), gracias a una profunda imbricación entre ésta y el Estado. La finca, como complejo socio-histórico que producía y articulaba categorías sociales (racismo y violencia) y laborales (explotación y esclavitud), "siempre se cobijó a la sombra del marco legal y del aparato coercitivo estatal, que en gran medida respondía a sus intereses. Esto es, resultaban espacios muy aislados de procesos sociales externos y donde el propietario tenía un amplio margen de control sobre sus acasillados", al igual que en las monterías aisladas en la Selva, "pero que sólo eran posibles en un campo más amplio de relaciones de poder" (Megchún 2008:103). En este sentido, los nexos entre terratenientes y autoridades formaban parte estructural de un sistema de ordenación del territorio y de la población, que se expresaba en "una particular relación entre terratenientes, autoridades y campesinos" (Megchún

\footnotetext{
${ }^{10}$ Todavía en 1960, los predios menores de 10 hectáreas (42\% de las unidades de producción) ocupaban el 0.9\% de la superficie agrícola, mientras las propiedades particulares mayores de mil hectáreas $(2.4 \%$ de las unidades de producción) ocupaban el 58.2 de la superficie agrícola. Dentro de este último sector, había 44 grandes latifundios que acaparaban más de un millón de hectáreas (20\% de la superficie estatal). Desde luego, las tierras planas, de riego o pastizales, se encontraban por el 80\% en los dominios privados (García de León 1985:228).
} 
2008:201). Erasto Urbina (pionero en la organización de los trabajadores indígenas) denunció en 1944 que, frente a la explotación, "no había ninguna autoridad que le hiciera justicia a los trabajadores $[\ldots]$ todo el engranaje oficial estaba al servicio de los que explotan las razas indígenas" (cit. en García de León 1985: 172).

Varios autores sostienen que la finca mantenía una relación "simbiótica" no sólo con las instituciones políticas y económicas del estado, sino también con los pueblos indígenas y sus comunidades de origen. La manera en que se "empleaban" los indígenas en las fincas definía no solamente categorías "laborales" sino sociales y culturales; situación que, por otro lado, representa una de las más contundentes expresiones de la violencia históricamente ejercida hacia ellos. Los trabajadores temporales o mozos, tzeltales y tzotziles de Los Altos, eran contratados para el periodo de la cosecha también a través del enganche, que los obligaba a regresar año tras año a trabajar con el mismo patrón o permanecer cautivos en la finca (Bartra 1995); la mejor opción, en esa situación, era la de convertirse en peones acasillados o baldíos. Estos vivían en una condición similar a la servidumbre medieval, pues el patrón les concedía cultivar pequeñas parcelas al interior del terreno de la finca, pero en cambio eran obligados a pagarle con dos o tres semanas al mes de trabajo gratuito en todas las tareas de la finca (Gómez y Ruz 1992; García de León 1985: 171-173).

Esta estructura poscolonial de explotación se mantenía precisamente gracias a la abundancia de mano de obra gratuita (o casi), por eso nunca desarrolló su fuerza productiva a tal punto de desestructurar la organización comunal, tanto en las comunidades de origen de los temporaleros, cuanto entre los acasillados (Tejera Gaona 1989). Históricamente se creó una relación de interdependencia entre los habitantes de las regiones Altos y Norte, donde el crecimiento demográfico y la extensión del latifundio provocaron una escasez de tierra cultivable, lo que obligaba (y todavía obliga) a los indígenas a migrar hacia las fincas, cuando éstas requerían mano de obra, y regresar a sus comunidades de origen a trabajar y producir lo necesario para su subsistencia básica el resto del año. Las comunidades representaban entonces una reserva de mano de obra siempre disponible, y que se sustentaba a sí misma cuando no se necesitaba en la finca; "para que todo el sistema funcionara, los indios debían permanecer como tales $[\ldots]$ ya que su calidad de dominados les colocaba en una situación de indefensión extrema" (Nolasco 2003: 392). 


\section{AUTONOMIAAINDÍGENA, VIOLENCIAY JUSTICIA}

Al afirmar que las fincas representaban un sistema de ordenación del territorio y de la población, me refiero también a las familias de los baldíos que nunca se volverían propietarias de las tierras expropiadas a sus antepasados por los ladinos; nunca dejarían la finca a la que estaban atadas por las deudas que incluso se heredaban de padre a hijo, mientras adentro de las fincas lograron recrear las estructuras comunitarias y reproducir sus bases culturales (momentos festivos, culto religioso, relaciones de parentesco), aunque transformadas para adaptarse al sistema de dominación. Esta situación ha sido ampliamente documentada para el caso del pueblo tojolabal, que ya desde la Colonia fue casi completamente reducido en las haciendas (precursoras de las fincas). Según afirma Ruz (1992:19), “el tojolabal no dejó de serlo por perder su tierra e integrarse a la finca", sin embrago, al ser despojado de la tierra (recurso material) y del territorio (recurso simbólico), las raíces identitarias del pueblo fueron profundamente trastocadas. Tal es así, que Ruz testimonia una verdadera inversión entre los espacios territoriales indígenas y de las fincas: los pueblos que antes ocuparon los tojolabales (Balún Canán/Comitán, Las Margaritas) son hoy ciudades consideradas "ladinas", mientras:

el universo tojolabal reivindica como primordialmente suyos los espacios geográficos que recuperó de las antiguas fincas [...] Hablar hoy de comunidades tojolabales es hablar de aquellas surgidas tras el proceso de reparto agrario que afectó a algunas de las fincas situadas en su mayoría en las tierras de los municipios de Margaritas, Altamirano, Comitán e Independencia” (Ruz 1992:18-19).

Los testimonios de ancianos tojolabales recogidos por Ruz y Hernández son ejemplos de la marca profunda que dejó el periodo del baldío en la memoria colectiva de los pueblos indígenas chiapanecos, así como del contexto de violencia que permeaba las relaciones en la finca. Los testimonios tojolabales, al igual que los tzeltales recopilados por Mora (2008), refieren a condiciones de trabajo infrahumanas, pero también al llamado "derecho de pernada" que como regla podía ejercer el patrón sobre las mujeres acasilladas, o de la tortura a la que eran sometidos los que infringían el orden arbitrariamente impuesto por el finquero. ${ }^{11}$

\footnotetext{
${ }^{11} \mathrm{Si}$ un trabajador se rebelaba a las imposiciones y órdenes, o era acusado de brujo, el patrón: "te amarra a un palo, te levanta con todo [y la barreta]. Te amarra los pies y las manos, te cuelga con la barreta. Vas a pagar tu delito, [te deja caer] con todo y barreta al suelo. Si te mueres, te mueres", testimonio de Enrique Espinoza Moreno, Finca Carmen Yaxalá, en Gómez y Ruz 1992:175. Para las mujeres, el castigo eran latigazos y otros castigos corporales. Según el testimonio del sindicalista indígena Erasto Urbina, “observamos, en 1932, huellas
} 
Este sistema de dominación comenzó a agrietarse a raíz de la promulgación de la Ley de Obreros en 1914, que -entre otras cosas- canceló formalmente la servidumbre agraria y las deudas contraídas por los trabajadores, prohibió las tiendas de raya y fijó condiciones de trabajo dignas. Por las particulares condiciones en las que se desenvolvió el movimiento revolucionario en Chiapas, no fue sino hasta los años treinta que, muy lentamente, inició el reparto agrario. En 1937, la legislación agraria nacional reconoció a los peones acasillados el derecho de solicitar tierras en las fincas en las que trabajaron por generaciones. Los primeros ejidos se formaron en las inmediaciones o alrededor de las fincas, que fueron parcialmente afectadas, aunque siguieron aprovechando la fuerza de trabajo de los indígenas asentados en sus alrededores (Reyes Ramos 1992).

No obstante, la legislación agraria chiapaneca cuidó en perjudicar lo menos posible a los grandes terratenientes, y en lugar de afectar fuertemente a los latifundios (que en la Selva siguieron controlando las mejores tierras), las autoridades agrarias pusieron a disposición para el reparto ejidal las inhóspitas montañas y cañadas de la región Selva, en ese entonces totalmente despobladas, en calidad de terrenos nacionales (aproximadamente 45.000 hectáreas). En los años treinta del siglo pasado inició el primer movimiento de migración hacia el interior de las Cañadas, antes en Las Margaritas y una década después en Ocosingo; el $80 \%$ de estos primeros colonos eran peones de las fincas cercanas a la Selva, y frecuentemente se asentaron a poca distancia de éstas (Leyva y Ascencio 1996; De Vos 2002). En ese momento, la colonización fue espontánea y autónomamente organizada: si los colonos encontraban terrenos nacionales los ocupaban e iniciaban una vida ahí independientemente de los años necesarios para realizar los trámites requeridos por la legislación agraria y, si sus recursos se lo permitían, compraban un pedazo de tierra y formaban una ranchería.

En este periodo disminuyó temporalmente la actividad de explotación forestal, y fueron nacionalizados algunos de los territorios en concesión o de propiedad de las monterías (Lobato 1992: 41); en una zona anteriormente controlada por los Bulnes se establecieron, entre otros, los ejidos Guadalupe Tepeyac y La Realidad Trinidad, que se volverían después lugares emblemáticos en la organización política zapatista (Leyva y Ascencio 1991:185; Blom, mapa de 1953). La Realidad Trinidad, ubicada en la zona interior de las Cañadas de Las Margaritas,

de azotes en las espaldas de los indios, y constatamos la existencia de cárceles subterráneas" (cit. en García de León 1985: 173). 


\section{AUTONOMIAINDÍGENA, VIOLENCIAY JUSTICIA}

entre los ríos Caliente y Euseba, se pobló primero con ex peones de la finca Carmen Yaxalá, ubicada mucho más al norte de las Selva (en la cañada del rio Tzaconejá, municipio de Altamirano), y después con migrantes precedentemente instalados en el ejido Rafael Ramírez, ubicado en las orillas de la Selva, cerca de Las Margaritas.

Llegaron a la Selva porque no tenían tierra donde trabajar, estaban en un terreno muy estéril, entonces buscaron un terreno donde vivir, con sus familias. Pero primero vinieron, sin familias ni nada, sino que traían sus tostadas, se metieron un mes acá, y trabajaron, tiraron la milpa; ya que había máiz, entonces fueron a traer sus familias. Fue donde empezó a llegar más gente, más gente, más gente; al año, ya tenían veinte, treinta compañeros acá. ${ }^{12}$

A partir de los años cincuenta, el proceso de colonización se intensificó, ahora ya exclusivamente en los terrenos nacionales y más hacia el interior de la Selva. Aunque si los colonos migraron de forma independiente y sin ningún apoyo gubernamental, y en todo momento fue ausente cualquier política clara de desarrollo para la región, a partir de ese momento el impulso oficial a la población de la Selva fue parte integrante de la política agraria nacional para aliviar la creciente presión campesina y los conflictos agrarios, en la iniciativa conocida como "La Marcha al Trópico", impulsada por la federación. La frontera agraria se abrió en los municipios de Las Margaritas y Ocosingo, entre 1950 y 1970, para 150.000 colonos, repartidos en más de 500 asentamientos de vario tipo (De Vos 1996:335). Las vías de entrada a la región han sido tres: Tenosique (Tabasco) y Palenque; Ocosingo y Altamirano; Comitán y Las Margaritas. Los protagonistas de esta migración fueron, por la mayor parte, indígenas tzeltales y ch'oles provenientes de las zonas septentrionales y orientales de Los Altos, y tzotziles originarios de la zona cercana a San Juan Chamula; la presión sobre la tierra, en esa región sobrepoblada, se había hecho insostenible, al igual que el poder despótico de los caciques y los grupos católicos más tradicionalistas en algunos municipios (en los años sesenta fue importante la migración de evangélicos, seguidos poco después por católicos cercanos a la Diócesis de San Cristóbal).

\footnotetext{
${ }^{12}$ Entrevista con autoridades ejidales de La Realidad, 2008.
} 
Mapa 3: Rutas de la colonización en la Selva Lacandona

Rutas de la colonización en la Selva Lacandona en los municipios de Ocosingo y Las Margaritas 1930-80

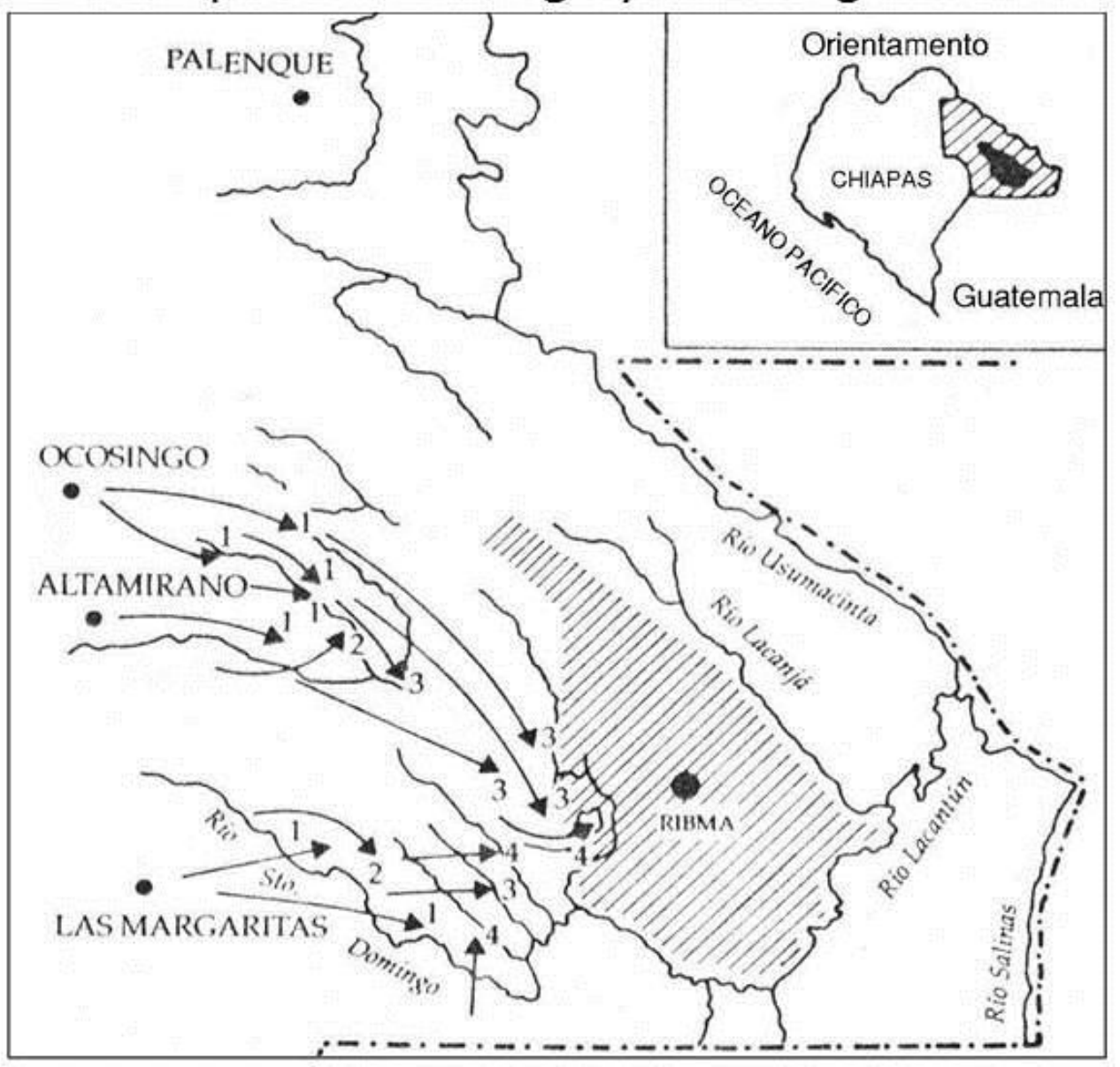

\section{Simbología}

-. Límite internacional

- Cabecera Municipal

- Río

$\rightarrow$ Directrices de colonización
1. $1930-1940$

2. $1940-1950$

3. $1950-1960$

4. $1960-1980$

Fuente: De Vos 1992

Los límites de la Reserva Integral de la Biosfera de los Montes Azules corresponden al proyecto de 1977. 
Otra parte importante de los colonos de la segunda ola (1950-1960) es representada por los trabajadores expulsados de las monterías que cerraron su actividad (Lobato 1992:36), y de las fincas, que a partir de los treinta se abocaron a la ganadería extensiva, actividad favorecida por los gobiernos federales y estatales y que necesitaba muy poca mano de obra. A estos se aunaron campesinos sin tierras provenientes de varios estados de la república, que en mayoría se asentaron en Marqués de Comillas (Leyva y Ascencio 1996:50). Finalmente, migraron selva adentro los hijos o los parientes recién llegados de los primeros colonos, ya que en breve tiempo se saturaron las tierras de aquellos ejidos pioneros. Entre 1964 y 1968, el flujo migratorio hacia la Selva alcanzó su apogeo, combinándose la colonización espontanea con aquella dirigida por el Estado. En el municipio de las Margaritas, la mayor parte de la superficie incorporada a las nuevas dotaciones ejidales se componía de tierras no aptas para la ganadería ni la agricultura, lo que explica la necesidad de los campesinos de buscar siempre nuevas tierras y su persistente condición de pobreza (Acevedo 1995).

La colonización de las inhóspitas Cañadas, cubiertas de selva virgen o casi, fue para los migrantes una empresa épica, vivida como esperanza de liberación (como lo testimonia la toponimia de los ejidos selváticos), pero igualmente "épico" fue obtener la dotación legal de las tierras ocupadas; cuando lo lograron (y en muchas ocasiones no fue así), tuvieron que enfrentar el laberinto burocrático, la corrupción y la extorsión, la dilación por años de los trámites y los incontables "errores", que evidencian un uso discrecional del marco jurídico por parte de autoridades no solamente corruptas sino estructuralmente coludidas con los terratenientes, y expresión de un sistema de relaciones interétnicas basadas sobre racismo y discriminación persistentes. ${ }^{13}$

Junto a la explosión demográfica en territorio selvático, producto del proceso de colonización, se desarrolló en la región una gran diversidad cultural, religiosa y lingüística. La Selva se vuelve el espacio de las confluencias: humanas, de ideas, de tradiciones, y sus comunidades devienen verdaderos crisoles de la diversidad, en las que llegan a asentarse y convivir juntos colonos hablantes de dos o más lenguas diferentes, y provenientes de diversas

\footnotetext{
${ }^{13}$ Tanto el proceso de colonización, su trascendencia en términos sociales, políticos, económicos y religiosos, y las dificultades para lograr la dotación definitiva de los ejidos en la Selva han sido ampliamente documentadas por Acevedo, Aubry, Benjamin, Deichtl, De Vos, Harvey, Leyva y Ascencio, Megchún, Morales, Nolasco, Reyes Ramos, entre otros.
} 
zonas del estado (e incluso del país). A este mosaico se sumaron, en el periodo 1960-1996, pero mayormente a partir de la década de los ochenta, los refugiados que lograron huir de la guerra de exterminio perpetrada por el gobierno de Guatemala en contra de las organizaciones guerrilleras y de la población indígena en general. ${ }^{14}$

Según Nolasco (2002), las comunidades que no presentan esta característica multicultural son la excepción, así que la experiencia de la migración fue lo que unió a los colonos, que debieron negociar la convivencia cotidiana por medio de los elementos que los unían y no de los que los diferenciaban.

A partir del momento de la formación de los ejidos, los pobladores tuvieron que organizar, de nueva cuenta, la dinámica comunitaria y los espacios sociales; el nuevo contexto -eran sumamente diferentes el medio ambiente, el clima, la composición social de las comunidades y la forma de tenencia de la tierra- hacía imposible reproducir las formas de organización anteriores. En tal coyuntura, adquieren importancia dos elementos: el ejido como nueva forma de organización social y productiva, y como elemento de identidad, y la región como espacio de intercambio, organización y reivindicación.

Antes [al momento de crear el poblado de La Realidad] la autoridad no era comisariado, como estamos ahorita nosotros, se llamaban encabezal, que ellos encabezaban pues, dirigían un poquito lo que podían, y el mismo pueblo lo nombró este encabezal: un arreglo, una cosa que tiene que ver con el pueblo, el encabezal es el inmediato. No se llamaba comisariado en aquel entonces. Después se tramitó el ejido, se legalizó, y ahorita tenemos nuestro plan definitivo, nuestra documentación completa. ${ }^{15}$

Las nuevas comunidades, conformadas por ex peones acasillados que en la finca no contaban con una estructura comunal, por tzeltales de la zona Norte y por tzotziles provenientes de las más tradicionalistas comunidades "corporativas cerradas" (según la definición de Eric Wolf) o “revolucionarias institucionales" (como las caracterizó Jan Rus) de Los Altos, reinventan un sistema organizativo que mezcla elementos de las varias tradiciones, y suma nuevos cargos: el comisariado (presidente del comisariado ejidal) y el consejo de vigilancia, el agente municipal, el catequista, los encargados de las comisiones, entre otros. Estas nuevas

\footnotetext{
${ }^{14}$ De los 50.000 refugiados que encontraron asilo en México, el $90 \%$ se asentó en Chiapas, en las regiones selváticas cercanas a la frontera.

${ }^{15}$ Comisariado Ejidal de La Realidad, entrevista, diciembre 2007.
} 


\section{AUTOONOMIIAINDÍGENA, VIOLENCIAY JUSTICIA}

estructuras, menos jerárquicas y más colectivas, en las que la asamblea tiene un papel central (definidas por Leyva con el concepto de "autoridades-concejo"), tienen en el ejido el "punto de partida de la identidad y de la territorialidad, que opera hasta el presente" (Nolasco 2003: 402) encarnando el sentimiento comunitario reconstituido o reinventado; al mismo tiempo, esto fortalece una identidad colectiva en cuanto campesinos, el trabajo sobre la tierra es el que define la naturaleza de las relacione humanas, y frente al melting pot cultural, el discurso que aglutina las diferencias en la región es el campesino, la defensa de la tierra conquistada (Harvey 1998; Leyva y Ascencio 1996).

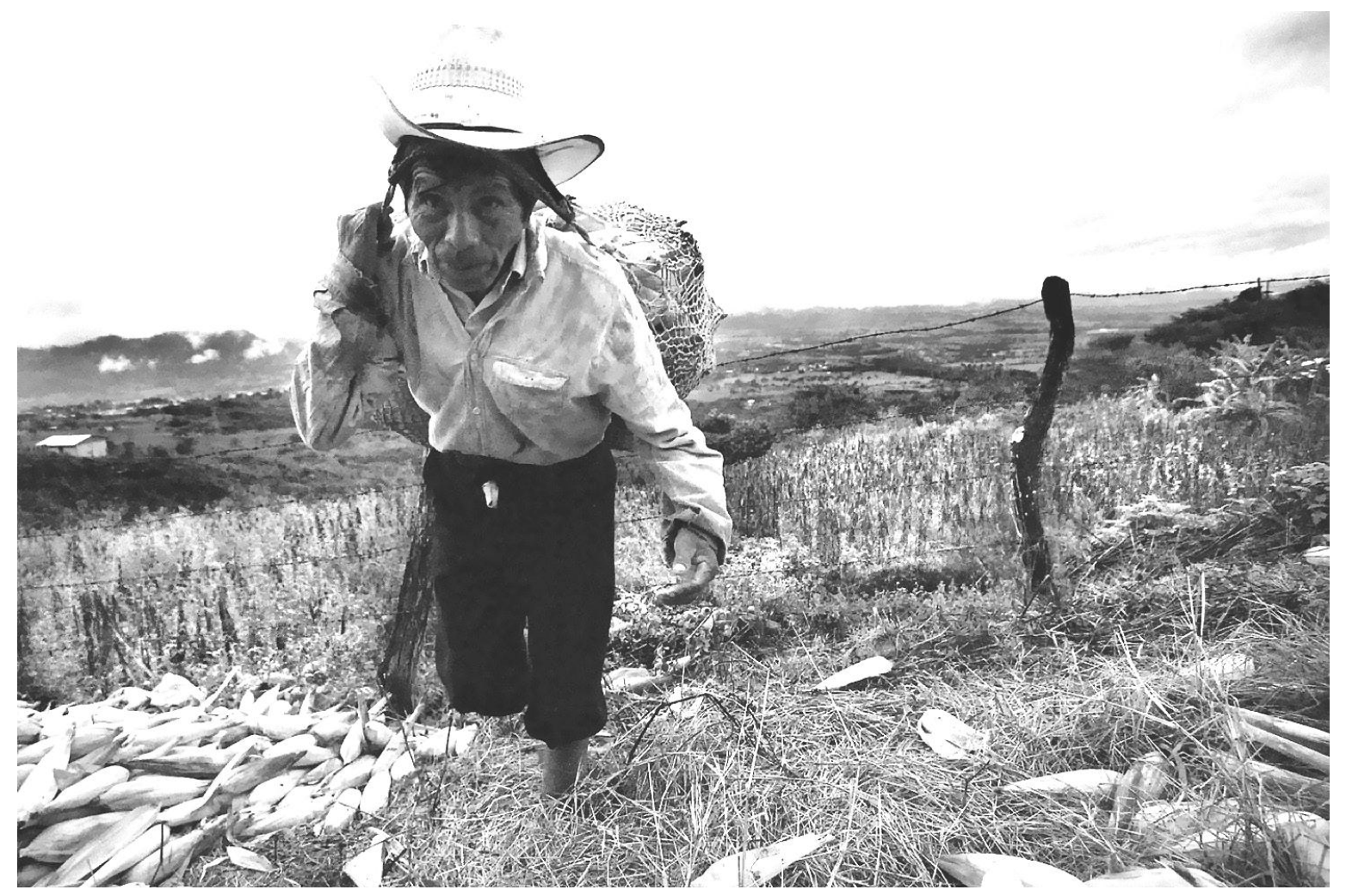

Hombres de maíz, territorio zapatista, Chiapas, México, 2003.

Por otro lado, las comunidades selváticas no quedaron cerradas, como algunas de las de origen, ni aisladas en la profundidad de la Selva.

Si bien lo comunitario sigue siendo un valor irrenunciable e identificador, la referencia ya no es la comunidad sino el pueblo, en su dispersión geográfica de la diáspora y en la diversidad de sus luchas [...] La comunidad hace explosión, transgrede sus fronteras, crea nuevos cargos, promueve un nuevo papel para la mujer" (Aubry 2005: 184). 
Las relaciones entre gente del mismo pueblo o zona de origen, asentadas en varias partes de la Selva, y sobre todo las experiencias organizativas ligadas a la lucha campesina y por la tierra, que se concretaron en las Uniones Ejidales y en las organizaciones en el ámbito regional, así como las redes construidas por la Iglesia católica, fortalecen en el tiempo un tejido social regional e intercultural, que se articula en un primer momento alrededor del elemento agrario y después de una identidad indígena tan multifacética cuanto la diversidad cultural de la región. Tanto las redes regionales de organización, como las novedosas y más horizontales estructuras comunitarias se reflejarán, años después, en el sistema de gobierno autónomo zapatista.

La labor de la Diócesis de San Cristóbal, dirigida entre 1960 y 1999 por el obispo Samuel Ruiz, fue importante en estimular la reflexión de los nuevos habitantes de la Selva sobre la trascendencia, en las trayectorias individuales y colectivas, del proceso de migración, que interpretó como parte del proceso de liberación de la explotación histórica y de la miseria actual, y de la construcción del "reino de Dios" en la tierra. Influida por la Teología de la Liberación, la Teología India de don Samuel y sus colaboradores elaboró la "catequesis del éxodo", ${ }^{16}$ en la que se asimilaba la Selva a la tierra prometida, o bien a "un ensayo experimental de una sociedad campesina alternativa, sin caciquismo y con democracia comunitaria" (Aubry 2005: 184).

Esta visión mística ayudó a los colonos a enfrentar las múltiples dificultades de su experiencia, y además fomentó el sentido de pertenecía a un pueblo, el pueblo de Dios, en el que se identificaban los indígenas en su condición de opresión, más allá de las diferencias étnicas, lingüísticas y religiosas; y promovió el sentido de apropiación y arraigo al territorio. Sobre esta definición de pertenencia a la Selva, los agentes de la Diócesis apoyaron decididamente el fortalecimiento de las nuevas estructuras comunitarias, aportando cargos nuevos que adquirieron trascendental importancia, como el de catequista (rol que es muy respetado en las comunidades, por ser una persona que sabe leer, que funge de mediador interno y de contacto con el externo; los catequistas y sus redes tendrán una participación fundamental en las estructuras civiles del Ejercito Zapatista de Liberación Nacional y de los gobiernos autónomos). Además, los agentes de la Diócesis apoyaron decididamente los

\footnotetext{
${ }^{16}$ Un ejemplo es el catecismo de la parroquia de Ocosingo-Atamirano, de 1976, llamado Estamos buscando la libertado. Los tzeltales de la Selva anuncian la buena nueva (Morales Bermúdez 1998).
} 


\section{AUTONOMIAINDÍGENA, VIOLENCIAY JUSTICIA}

procesos organizativos y reivindicativos, campesinos antes e indígenas después, como lo demuestran, por ejemplo, la organización del Congreso Indígena (1974) o el impulso a la conformación de la Quiptic Ta Lecubtesel, primera organización independiente registrada en Chiapas (1975).

\section{La lucha campesina y el Congreso Indígena}

Según la periodización propuesta por Nolasco (2003), la segunda etapa en la colonización -y yo añadiría en la construcción del espacio social de la Selva- inicia en la década de los años setenta, cuando el Estado decretó el fin oficial de la colonización y del reparto agrario en la región. La formación de organizaciones en esta zona, para reivindicar el derecho a la tierra, se sumó a una situación de insurgencia campesina generalizada y organizada en todo el estado, a la que el gobierno y los terratenientes respondieron con la represión y la cooptación de los campesinos. Hay que recordar que la represión, la guerra sucia y la violencia de Estado marcaron este periodo en el ámbito nacional, bajo el mandato sangriento de Luis Echeverría, que coincidió en Chiapas con la gubernatura de Manuel Velasco Suarez (1970-1976). Según Mendoza Ramírez:

A principios de los años setenta la visión y la práctica del gobierno federal hacia la Selva Lacandona cambió. Se reconoció como una región con grandes potencialidades (forestales, pecuarias, petroleras, hidráulicas) ${ }^{17}$ y se empezó a generar una enorme cantidad de programas y proyectos que intentaban hacer de esa región un "polo de desarrollo económico". Si bien en todos esos estudios y proyectos se destacaba la enorme potencialidad de la Selva, también se señalaba la creciente colonización como un obstáculo para aplicar los diversos proyectos, por lo que su control se convirtió en condición indispensable para la explotación de los recursos [...] Para lograrlo se aplicarán tres medidas: la dotación al grupo lacandón, la concentración de población en dos grandes Centros de Población Ejidal, la reincorporación de la zona Marqués de Comillas al proceso de colonización. Dichas resoluciones llevaron a una nueva organización territorial y a la agudización de los conflictos por la tierra (1995: 119).

\footnotetext{
${ }^{17} \mathrm{La}$ importancia de los yacimientos petroleros descubiertos en la Selva a finales de los setenta han hecho que esta zona sea considerada por Pemex como prioridad nacional, por lo que se han intensificado las tareas de exploración y explotación, con la construcción de una tupida red de caminos y carreteras que modificaron de manera radical la organización espacial de la zona.
} 
En este periodo, el problema agrario en Chiapas siguió siendo dominante. Los terratenientes se mantuvieron prácticamente inmunes a las afectaciones agrarias; controlando a propio beneficio y discrecionalmente los espacios legales y políticos, y gozando de sustancial impunidad cuando excedían incluso los marcos de una legalidad tan laxa, los latifundistas lograron, por ejemplo, mantener por décadas (hasta los noventas) grupos de "guardias blancas" que utilizaron, sobre todo cuando se multiplicaron las invasiones de los campesinos organizados (1970-1990) como grupos de choque contra el incipiente movimiento campesino. La Ley Ganadera, expedida por el Congreso de Chiapas en los años cuarenta, en el contexto de un gran impulso a la ganadería, y refrendada en los años sesenta, permitió la portación de armas para los ganaderos y dio cabida a la formación de grupos de Policía Rural Montada o Policía Auxiliar Ganadera para combatir el abigeato, que era en los hechos una "policía privada" y que dio origen a las "guardias blancas" usadas para defender las propiedades y reprimir las reivindicaciones campesinas (Gómez Cruz y Kovic 1994: 93; Lomelí y Camacho 2000: Reyes Ramos 1992: 64).

En un estudio referido a la organización comunal y el conflicto político en Chiapas, Tejera Gaona (1989: 255) evidencia algunas constantes en la historia de los movimientos campesinos e indígenas, particularmente evidentes en este momento: el carácter violento de la respuesta de las fracciones de la burguesía terrateniente estatal a las reivindicaciones de los indígenas, y de los campesinos en general; la íntima unión de las autoridades de los gobiernos municipales (y estatales) y dichas fracciones; el hecho que la mayoría de las autoridades judiciales se encuentra estrechamente relacionada a la estructura del poder terrateniente.

Simplificando, se pueden mencionar tres casos emblemáticos de lucha campesina en el estado, caracterizados por un alto nivel de organización y un incipiente discurso político que, reivindicando las tierras, reivindicaba también la libertad y la dignidad. Se trata de la lucha de los tzotziles, choles y tzeltales de Simojovel, Huitiupan y Sabanilla que se movilizaron invadiendo tierras, por la dotación de ejidos y por la formación de un sindicato de trabajadores entre los peones acasillados de las fincas cafetaleras; la de Venustiano Carranza en contra de los caciques y de la expropiación de tierras para la construcción de la presa La Angostura; y la de los ejidos de la Selva en contra del reacomodo y la expropiación, conflicto conocido como "La Brecha Lacandona”. 


\section{AUTOONOMIIAINDÍGENA, VIOLENCIAY JUSTICIA}

A principio de los años setenta, los gobiernos federal y estatal buscaron reforzar el control en el territorio de la Selva, por un lado tomando las riendas del proceso de colonización y dirigiendo los migrantes ahora hacia la zona de Marqués de Comillas; por el otro, estableciendo un límite a la colonización de la región selvática. De hecho, la migración Selva adentro fue finalizada oficialmente en 1972, con el decreto presidencial que reconocía los derechos territoriales al pueblo lacandón (en ese entonces integrado por 66 familias), constituyendo los Bienes Comunales de la Comunidad Lacandona con una extensión de más de 600.000 hectáreas.

Esta acción tuvo un sinnúmero de consecuencias que se prolongan hasta la actualidad. Inmediatamente fue patente el carácter instrumental de la medida, a través de la cual el Estado impuso su presencia y su papel determinante en la región; a partir de ese momento, mantuvo una actividad creciente, principalmente a través de programas asistencialistas y de "desarrollo", aunque en ausencia de una propuesta articulada en términos de conservación de la riqueza natural y de bienestar social. El decreto fue acompañado por una propaganda facciosa, según la cual el gobierno apoyaba los antiguos “dueños” de la Selva, restituyéndole su ancestral patrimonio, ${ }^{18}$ pero violentando los derechos de muchas otras comunidades indígenas que allí se asentaron. El decreto no dio cabal respuesta a la solicitud de dotación del pueblo lacandón, ya que de las tres comunidades lacandonas (Lacanjá, Metzabok y Nahá), las últimas dos quedaron afuera del polígono de la Comunidad; por lo tanto, fue evidente que el reducido pueblo lacandón/caribe sirvió de instrumento al gobierno para reinstalar la dominación en una región que se estaba mostrando riquísima en recursos energéticos y estratégicos (en estos años se inicia a descubrir la riqueza petrolera de la región, y en 1976 Pemex inicia la explotación en Marqués de Comillas). Tan es así, que en el mismo año (1972) se instaló en la región la paraestatal maderera NAFINSA-COFOLASA, que estipuló un contrato decenal con la Comunidad Lacandona para la explotación exclusiva de maderas preciosas en todo el territorio, asegurándose el monopolio de su explotación, negocio que en esa fecha habían casi por completo abandonado las empresas extranjeras que lo monopolizaban.

\footnotetext{
${ }^{18}$ Ahora ya se ha ampliamente demostrado que los lacandones son más bien indígenas caribes, es decir maya yucatecos que llegaron a la zona en el siglo XIII (Maderas del Pueblo 2002).
} 
Si las secuelas ambientales impactaron fuertemente en el ecosistema selvático, cada vez más endeble debido a la creciente explotación y deforestación, las consecuencias sociales fueron aún más profundas. La Comunidad Lacandona se encimó en las tierras de treinta ejidos de colonos tzeltales, ch'oles, tzotziles y tojolabales, cuyas solicitudes de tierra estaban en su mayoría en trámite o en vía de aprobación, y de 17 ejidos que ya contaban con resoluciones presidenciales; sus habitantes -más de 4.000 familias- se volvieron de la noche a la mañana "invasores" de las tierras que labraron por más de diez años y que el mismo Estado impulsó a colonizar. Sin ser consultadas ni informadas, estas comunidades se enteraron del decreto cuando desembarcaron en las Cañadas elementos del Ejército, amenazando un inmediato desalojo. La organización intercomunitaria y regional ya era una necesidad impostergable. Así, inicialmente la agregación de un núcleo de comunidades de campesinos-indígenascolonos (las tres facetas más importantes de la múltiple identidad de los habitantes de la Selva), se dio en el "conflicto por la Brecha", que se traducía en la lucha por la tierra y su defensa colectiva. Este conflicto, junto a los diarios enfrentamientos entre los campesinos y los latifundistas ganaderos, contribuyó a consolidar la organización campesina en defensa de las recurrentes expropiaciones, las acusaciones de invasiones y el uso de la violencia en contra de los habitantes de la Selva.

En ese momento, cuando el conflicto en la Selva era incipiente y la organización apremiante, tuvo lugar uno de los eventos que marcaron como un parteaguas la historia de Chiapas y de sus pueblos indígenas: el Congreso Indígena, organizado por la Diócesis de San Cristóbal tras la solicitud de las autoridades indigenistas, y celebrado en esta ciudad en 1974. El evento confirmó el protagonismo de la Iglesia como agente de transformación social; las asambleas y subcongresos previos, que se extendieron por todo el año anterior y en los que se consensaron reivindicaciones y propuestas, sirvieron para ampliar y fortalecer la red del activismo diocesano en las comunidades. Pero el Congreso Indígena debe su trascendencia al hecho de ser el primer espacio de reunión de representantes indígenas y autoridades comunitarias de todo el estado:

Allí se resumió la palabra de 250 mil indios de 327 comunidades (de un total de medio millón que habitaban el estado en esos días), la palabra de un cuarto de millón de pequeños arroyuelos que se vinieron a desbordar en boca de mil 230 delegados (587 tzeltales, 330 tzotziles, 152 tojolabales y 161 choles) que, en un ejercicio de profunda discusión, lograron elaborar 


\section{AUTONOMIA INDÍGENA, VIOLENCIAY JUSTICIA}

ponencias unitarias sobre cuatro temas fundamentales en la vida de sus comunidades, de sus municipios, aldeas y parajes: tierra, comercio, educación y salud. El quinto tema, el de la política, había sido censurado por los organizadores ladinos del evento, aun cuando, sin lugar a dudas, fue el tema que bañaba todos los colores a lo largo del Congreso (García de León 1995).

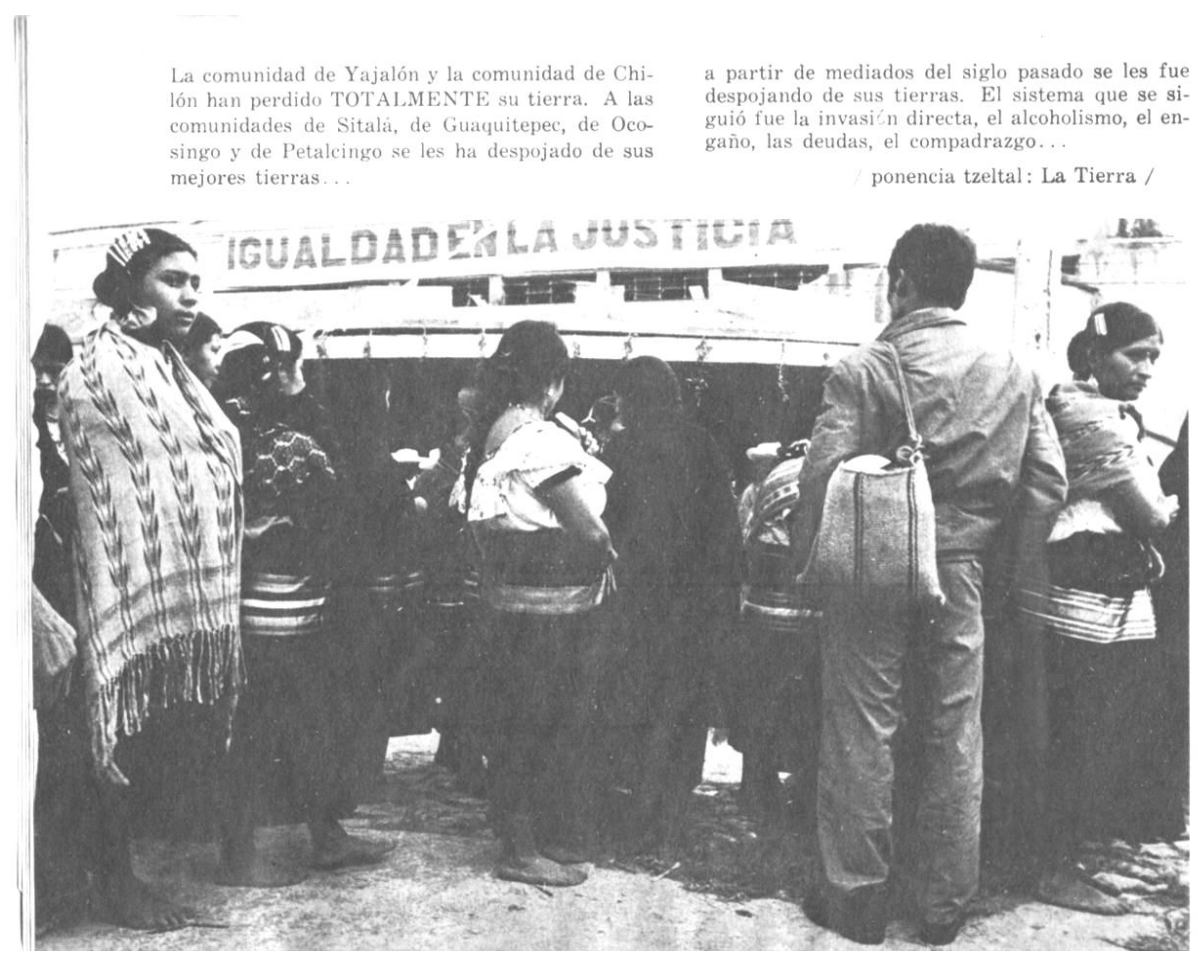

Congreso Indígena, San Cristóbal de Las Casas, 1974.

Foto: Rogelio Cuellar, en García de León y Rumazo, s/f

Los resolutivos del Congreso reflejaban la problemática regional de los pueblos indígenas chiapanecos, pero las propuestas apuntaban a la modificación de estructuras nacionales. En su conjunto, las ponencias representan un detallado diagnóstico de la realidad dramática vivida por los indígenas de todo Chiapas: resaltan las denuncias del trabajo semi-esclavo y de las injusticias padecidas en las fincas, así como la corrupción de la burocracia agraria que extorsiona y engaña en los trámites para la legalización de tierra; finalmente, el alcoholismo como enfermedad social propiciada por los ladinos. La capilar corrupción de las autoridades agrarias se evidencia en todos los niveles: desde los ingenieros, el jefe de zona del Departamento Agrario, los Ministerios Públicos, el forestal y hasta los comisariados de las mismas comunidades; y se manifiestan los problemas intercomunitarios que ya en ese entonces originaban el caos legal y la desorganización. En lo referente a la actuación de las 
autoridades judiciales, los representantes tzeltales denunciaron en ese entonces exactamente lo mismo que los jmeltsawanej'es (jueces tzeltales) entrevistados en 2011 (véase capítulo 4).

Los Ministerios Públicos y los Jueces conocen de causas que no les corresponden para sacar dinero. Muchas veces intervienen en causas netamente agrarias. Y pagan multa el acusado y el acusador, por supuesto sin que se les dé acuse de recibo. Es generalizada esta costumbre de pedir dinero a los dos, haya o no haya culpa, en todos los procesos judiciales, lo que provoca un desprestigio de la autoridad constituida y una serie de problemas internos en la comunidad: resentimiento, venganzas, odios y aún muertes (ponencia tzeltal, en Morales 1991, cit. en Womack 2009: 228).

En los resolutivos del Congreso destaca la temprana denuncia de la militarización en el estado, muy típica de ese periodo en toda la República, pero que en Chiapas, antes para reprimir la insurgencia campesina y después el levantamiento indígena, se volvió una característica congénita: "exigimos que para arreglar nuestros problemas el gobierno no meta el Ejército. Que los problemas se arreglen con la comunidad, no con el Ejército" (Acuerdos: tierra, en Morales 1991, cit. en Womack 2009: 235).

Representando un momento de encuentro y de intercambio de problemas y propuestas comunes (las ponencias de las cuatro regiones presentan denuncias similares), el Congreso despertó entre los participantes la percepción de una identidad compartida y la convicción de que la esencia de su fuerza estaba y estaría en la capacidad de formar comunidad y preservar su propia identidad como indígenas. ${ }^{19}$ Aunque las demandas expresadas en el Congreso tenían un corte identitario marcadamente campesino, pues el problema agrario articulaba la lucha social en ese entonces y quienes luchaban se reconocían como campesinos, en ese evento se iniciaron las reflexiones sobre la especificidad de la explotación y de la lucha de acuerdo a la identidad étnica, con un discurso de reivindicación basado en lo indígena.

Finalmente, la importancia histórica del Congreso reside en el impulso que dio a la organización colectiva, propósito declarado en el discurso conclusivo, del que cito una extensa parte por la profunda fuerza simbólica y política que expresa:

\footnotetext{
${ }^{19}$ Entrevista a Javier Vargas, director de la Escuela de Catecismo de Ocosingo, en De Vos 2002:252.
} 


\section{AUTONOMIAINDÍGENA, VIOLENCIAY JUSTICIA}

Nosotros, los indígenas, ahora es tiempo que empecemos a pensar y a ver si de veras tenemos la libertad que dejó Fray Bartolomé de las Casas. [...] Si nosotros exigimos derecho, o queremos pedir nuestra tierra, no podemos. Es que ya nos quitaron nuestra antigua organización; ahora nos imponen hasta a nuestras autoridades y hasta las federales [...] las autoridades mandan soldados para que nosotros tengamos miedo. Por eso mismo es que hay atropellos de los finqueros, como en San Francisco, Altamirano, en donde fueron quemadas sus casas por los mismos soldados sólo por pedir tierras [...]. ¿Entonces dónde está la libertad que dejó Fray Bartolomé? Hemos venido sufriendo la injusticia durante 500 años y seguimos igual. $\mathrm{O}$ siguen las injusticias sobre nosotros. $\mathrm{O}$ siempre nos quieren manejar como criaturas, porque somos indígenas y piensan que no tenemos derecho y que no sabemos pensar. Bueno compañeros, ahora Fray Bartolomé ya no vive, sólo en su nombre hacernos este Congreso, él ya murió y ya no esperamos otro. ¿Quién nos va a defender sobre las injusticias y para que tengamos libertad? Los ladinos yo creo que no nos van a defender. El gobierno tal vez si, o tal vez no. Entonces, ¿quién nos va a defender? Yo pienso que nuestra única defensa es organizándonos todos para que podamos tener libertad trabajar mejor. Nosotros tenemos que ser todos el Bartolomé. Entonces nosotros mismos nos vamos a defender por la organización de todos. Porque la unión hace la fuerza (cit. en Morales 1991, cit. en Womack 2009: 223224).

Un resultado inmediato de las redes organizativas que movilizó el Congreso fue la constitución, en 1975, de la primera Unión de Ejidos, llamada Quiptic Ta Lecubtesel, ${ }^{20}$ con campesinos mayoritariamente tzeltales, de la cañada de Patihuitz, municipio de Ocosingo, y del valle de San Quintín, entre los municipios de Ocosingo y Las Margaritas (participaron también choles y tzotziles del ejido Emiliano Zapata). Poco después se formó la Unión de Ejidos Lucha Campesina, por indígenas tojolabales del municipio de Las Margaritas. A estas organizaciones pioneras seguirán, en los años siguientes, muchas otras: en las Cañadas de Las Margaritas, la Unión de Ejidos Tierra y Libertad (1979) y la Unión de Ejidos de la Selva (1980).

En particular, la Quiptic -que destacó por la solidez organizativa, debida también al fuerte apoyo de la Diócesis y sus asesores- tuvo como objetivo inmediato la resistencia en contra del desalojo de los ejidos establecidos al interno de la Comunidad Lacandona. En 1976 el gobierno del estado desplazó, con el uso de la fuerza pública, 22 núcleos de población dispersa

\footnotetext{
${ }^{20}$ En lengua tzeltal, "unidos para nuestra fuerza".
} 
e "invasora", "reubicándolos" en dos Nuevos Centros de Población Ejidal, al margen de la Zona Lacandona: Velasco Suárez (hoy Nueva Palestina, con población tzeltal), y Frontera Echeverría (hoy Frontera Corozal, con población ch'ol).

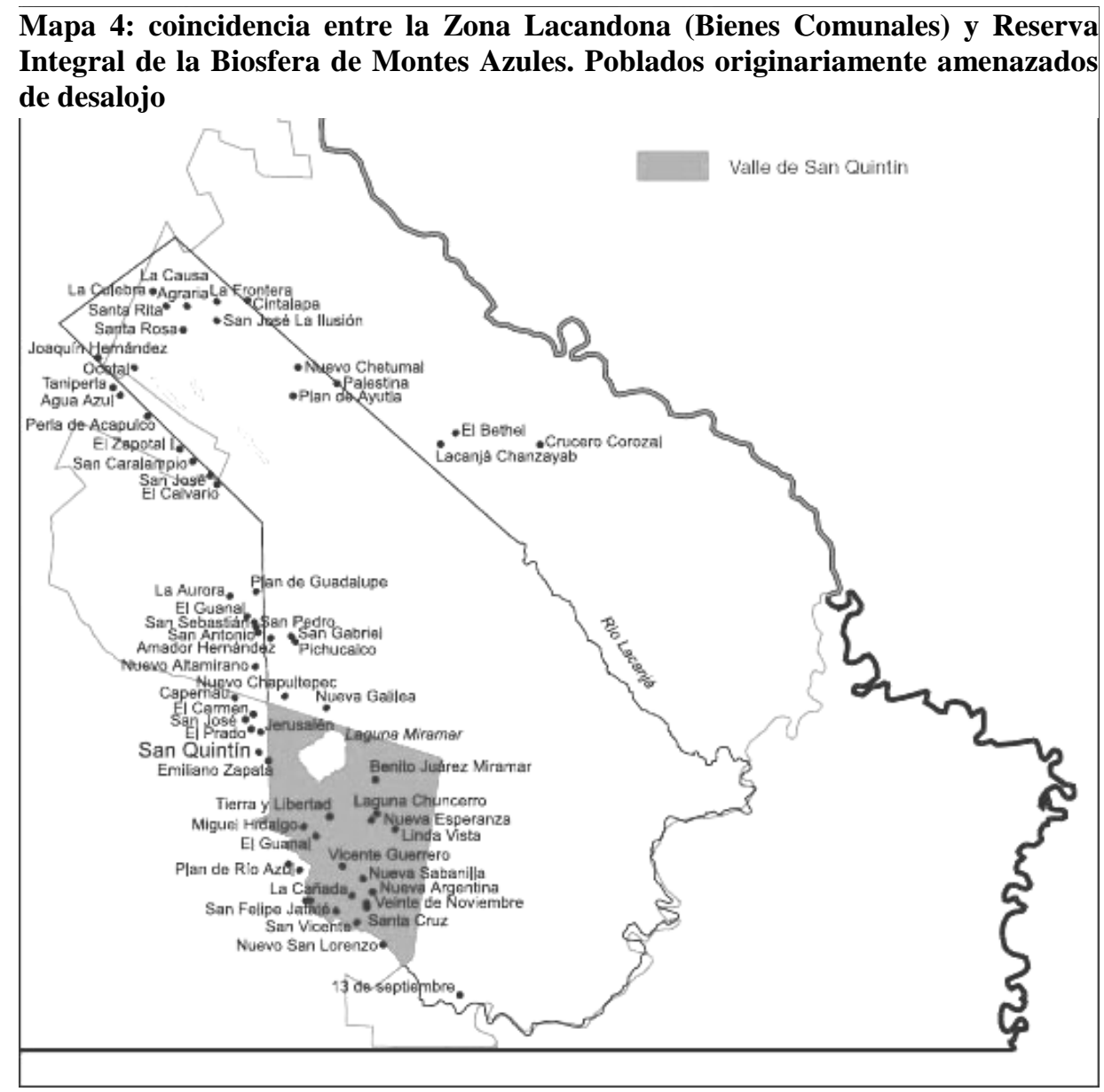

Mapa: Breve historia de la Selva Lacandona, ttp://chiapas.pangea.org/html/item0080.htm

La concentración de la población dispersa ha sido recurrentemente pregonado por las instituciones como la solución a los problemas de la vida rural, como la falta de acceso a los servicios; una y otra vez se ha impuesto a los campesinos, pues los Centros de Población Ejidal de 1976 poco difieren, en su planteamiento, de las Ciudades Rurales impulsadas treinta años después bajo el gobierno de Juan Sabines (2006-2012).

En ambos casos, las instituciones prometieron a los pobladores todos los servicios y un sinnúmero de proyectos productivos; por igual, las promesas se quedaron tales y los asentamientos se volvieron en pocos años inhabitables y la vida en ellos insostenible, provocando el regreso de parte de su población a los pueblos de origen. Por otro lado, los 34 


\section{AUTONOMIAINDÍGENA, VIOLENCIAY JUSTICIA}

asentamientos “irregulares” integrados en la Quiptic, en su mayoría ubicados al poniente de los Bienes Comunales, no accedieron a concentrarse en un sólo poblado (San Quintín) y se organizaron para la defensa de sus derechos. 26 de ellas obtuvieron en 1988 los títulos de propiedad.

Esta situación se volvió aún más conflictiva a raíz de la creación, en 1977, de la Reserva Integral de la Biosfera de los Montes Azules (RIBMA), con el objetivo de detener la acelerada destrucción de los recursos naturales de la Selva Lacandona. El territorio de la Zona Núcleo de la RIBMA, de alrededor de 300.000 ha., coincide por el $70 \%$ con la Comunidad Lacandona; según el decreto, dentro de esta superficie se permitirían solamente trabajos de investigación científica y tecnológica, así como algunas actividades turísticas. Sin embargo, en 1979 se contaban en su interior 14 asentamientos con una población aproximada de 6000 habitantes, y muchas más comunidades presentes en la llamada Zona de Protección Forestal (2.8 millones de ha). La Reserva de la Biósfera representó un elemento de continuidad en la política estatal: en la Zona de Protección siguieron operando en libertad las paraestatales madereras y Pemex, disputando el territorio con los colonos, desalojados de la Zona Núcleo. La deforestación "legal" abría amplias zonas que sucesivamente eran aprovechadas para la siembra tradicional o la ganadería. El conflicto agrario surgido con la titulación de la Comunidad Lacandona aún no ha sido resuelto: hasta la fecha, han continuado los desalojos de ejidos y asentamientos, y la situación de miles de personas que viven en los linderos de la Comunidad Lacandona y de la RIMBA es aún más incierta en la medida en que se multiplican los intereses comerciales y los proyectos de aprovechamiento de la zona.

El proceso de integración del territorio chiapaneco a la economía internacional (explotación petrolera, construcción de presas hidroeléctricas, ganaderización, desarrollo de zonas turísticas, crecimiento de centros urbanos) ocasionó el desplazamiento de miles de campesinos e indígenas, desarticulando sus precedentes formas de reproducción (proceso analizado por Reyes Ramos 1992, 2005; Collier 1998). Este es uno de los motivos que incrementaron la presión sobre la tierra y el surgimiento, y la sucesiva radicalización, del movimiento campesino. En sus inicios, este movimiento se caracterizó por las invasiones y ocupaciones de latifundios en todo el estado, y la proliferación de organizaciones de alcance regional y estatal. 
La creciente organización tuvo como respuesta el incremento de la violencia por parte de las esferas gubernamentales (con las acciones del Ejército federal y las policías estatal y judicial), en connivencia con los propios finqueros (con las guardias blancas), frente a las demandas de tierra, medidas legitimadas por la declaración de la invasión como delito federal (1977). La literatura consultada describe este periodo -desde la mitad de los años setenta y toda la década de los ochenta- como de exasperada violencia institucional, social y de Estado frente a la insurgencia campesina. En la introducción al texto "Cronología. Veinte años de conflicto en el campo: 1974-1993”, Esponda y Pólito (1996) contextualizan así el periodo analizado, caracterizado también por una elevada inestabilidad institucional:

Durante estos veinte años la espiral de violencia ha ido en ascenso [... L La violencia va desde la persecución hasta el encarcelamiento de líderes campesinos. Los casos extremos, y que son un mal endémico en Chiapas, son los asesinatos. El asesinato de campesinos es una práctica cotidiana en el campo; lo mismo se asesina de manera selectiva que colectiva. Son varias las masacres que se han cometido a la fecha. Lo peor de todo es que esta política de violencia se sustenta en la impunidad.

A finales de los años setenta el movimiento campesino chiapaneco se fortaleció con la implantación en el estado de organizaciones políticas activas a nivel nacional, con lo que amplió su resonancia y también el abanico de sus demandas. Primero los maoístas del grupo Unión del Pueblo, y sucesivamente los militantes de Línea Proletaria -una vertiente del grupo seudo-maoísta Política Popular, llamados "los norteños" por ser algunos originarios del norte de México-, iniciaron su labor político-organizativa, en principio a lado de la Quiptic y de la Diócesis, instancia con la que pronto tuvieron importantes conflictos. Tras su labor organizativa en las zonas de Las Margaritas y Ocosingo, las uniones de ejidos Quiptic Ta Lecubtesel, Tierra y Libertad, Lucha Campesina y otras, se asociaron en la Unión de Uniones Ejidales y Grupos Campesinos Solidarios de Chiapas (UU) en 1980. Paulatinamente, la UU estrechó sus relaciones con las instituciones, tras la influencia de su dirigente Adolfo Orive (cercano a los hermanos Salinas de Gortari, exponentes del PRI); hasta transformarse, de un movimiento de oposición política, en una empresa cooperativista cooptada por el gobierno. En 1987, cambió su nombre en Asociación Rural de Interés Colectivo (ARIC) Unión de Uniones, 


\section{AUTONOMIAINDÍGENA, VIOLENCIAY JUSTICIA}

orientándose hacia la obtención de créditos para la producción y la comercialización (Harvey 1998; Esponda y Pólito 1995).

Entre 1978 y 1980, se fortaleció la presencia de la CIOAC, en principio apoyando las demandas sindicales de los peones acasillados en la Zona Norte (Huitiupán, Simojovel, El Bosque) y luego consolidándose en la Selva (en Comitán, Las Margaritas y en la zona Fronteriza, particularmente en la zona tojolabal). En esta región, promovió masivamente las tomas de tierras y la lucha agraria radical. Cercana al PSUM, sucesivamente se integró al PRD.

En 1982 se formó la tercera gran organización campesina de Chiapas, la Organización Campesina Emiliano Zapata (OCEZ), cuya base principal y antecedente fue la lucha campesina en Venustiano Carranza. Más radical que la CIOAC en la toma de tierras, no estableció relaciones permanentes con partidos políticos. Extendió su presencia desde la zona centro hacia Los Altos, Norte y zona Fronteriza (Trinitaria, Frontera Compalapa, Independencia y Chicomuselo); en la Selva, afilió comunidades de Altamirano.

En la región de estudio, en este periodo proliferaron de nuevas organizaciones, en las que a la lucha por la tierra se sumó la lucha para la apropiación del proceso productivo y la comercialización del café, cuyo cultivo había sido recientemente incentivado por el INMECAFÉ y el INI en la región. ${ }^{21}$

Según el Comisariado ejidal de La Realidad, más que en los logros concretos, la importancia del proceso organizativo en las Uniones de Ejidos y en las organizaciones campesinas fue que "nos logramos conocer, logramos hermanarnos y así logramos ampliar el problema de los campesinos". 22

\footnotetext{
${ }^{21}$ En 1980 se conformó la Unión de Ejidos de la Selva, que incluyó varias comunidades de la zona de estudio, en su mayoría tojolabales: Nuevo Momón, Cruz del Rosario y Montecristo, y posteriormente, Flor del Río, El Edén, San Isidro, Vicente Guerrero, San Carlos del Río, San Carlos, Veracruz, San Francisco El Naranjo, San Juan Bautista, Guadalupe Tepeyac, La Realidad Trinidad, Santa María Río Blanco, Río Corozal, Benito Juárez, San Marcos, Rizo de Oro, El Porvenir, Arroyo Nacimiento, San José Nueva Esperanza (Estrada 2006: 121). Las reivindicaciones principales eran la construcción de vías de comunicación, la regularización de la tierra, y estímulos para la producción y comercialización del café. Sucesivamente, varias comunidades dejaron la UES (que existe todavía) para integrarse a la organización zapatistaEn esos años nacieron también laUnión de Ejidos Lucha Campesina (en la zona tojolabal entre Comitán y Altamirano, 1980); y la Unión de Ejidos de los Pueblos Tojolabales, escindida de Lucha Campesina (1986). En las primeras elecciones en Las Margaritas (1982) Lucha Campesina se vinculó al PRI, mientras Pueblos Tojolabales al PSUM y a la CIOAC. Este grupo trató de establecer un gobierno tojolabal en 1981, sin éxito; sucesivamente, entre 1987 y 1989, instauró una experiencia de gobierno indígena, sin embargo efímera (Escalona 2009: 376-77).

${ }^{22}$ Comisariado Ejidal de La Realidad, entrevista, diciembre 2008.
} 


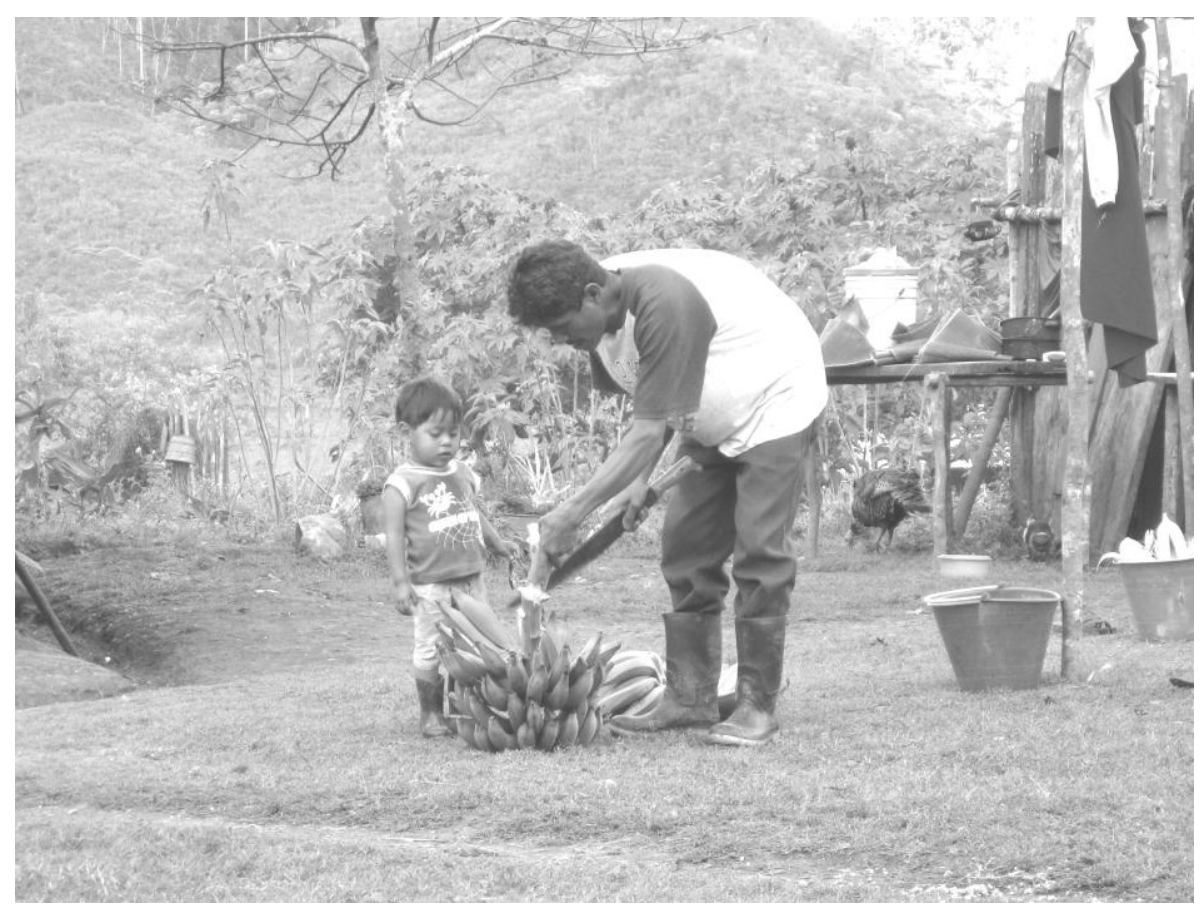

Vida en la Selva, diciembre 2009.

Aumenta la violencia y nace la organización armada

La amplia bibliografía existente sobre las movilizaciones campesinas en Chiapas, y en la Selva en particular, atestigua la ineficacia general de las luchas civiles y reivindicativas, que enfrentaron la corrupción de las autoridades destinadas a atender estas demandas. Esto provocó la radicalización de la lucha, sea a lo interno de las organizaciones "abiertas", sea en el paulatino crecimiento de la "opción armada", que cuajó en el levantamiento del EZLN en 1994.

En la década que incubó el levantamiento, mientras las movilizaciones fueron constantes y masivas, la represión también fue sistemática. El gobierno de Manuel Velasco Suarez (1970-76), que originó el conflicto de "La Brecha Lacandona", inició la militarización de la Selva y los desalojos de ejidos selváticos. Juan Sabines Gutiérrez (1979-1982) se hizo responsable, entre otros actos violentos, de la masacre de 14 indígenas en la finca Wolonchón, municipio de Sitalá (1980) y aumentó el despliegue militar (llegando a 45 mil efectivos en 1982) en Las Margaritas, Tila y Sabanilla. Bajo los gobiernos de Absalón Castellanos Domínguez (1982-1988), general del Ejército y latifundista, y de su sucesor Patrocinio González Garrido (1988-1993), la violencia de Estado alcanzó su ápice (Zebadúa 2001). “El 


\title{
AUTONOMIAINDÍGENA, VIOLENCIAY JUSTICIA
}

gobierno estatal (1982-1988) y el federal fueron sistemáticamente denunciados por aplicar una política profundamente anti-campesina. La represión convertida en un mal endémico provocó el desgaste y la debilidad del movimiento y sus organizaciones que de 1985 en adelante entran en una fase cuyo rasgo principal es el carácter contestatario de su política", afirman Esponda y Pólito (1995). ${ }^{23}$

Durante su mandato, el general Absalón Castellanos se dedicó, por un lado, a aumentar aún más la presencia militar en la frontera, con el propósito de aislar al territorio mexicano de presuntas infiltraciones guerrilleras desde Guatemala, donde ya iniciaba el éxodo de refugiados. ${ }^{24}$ Por otra parte, la ingente presencia militar ${ }^{25}$ se extendió a todas las zonas de conflicto agrario, como una respuesta directa al crecimiento de las organizaciones campesinas independientes. Relata Martha Figueroa, abogada y defensora de los derechos de las mujeres:

\begin{abstract}
Absalón fue un gobernador terrible, ya había estado en Chiapas como jefe militar, y cuando le toca ser gobernador la fama que tiene es de no ser muy inteligente, pero muy represivo y muy servil. La gente comúnmente lo identifica como “el Matón”, más que a Patrocinio [González Garrido] que de hecho fue peor que Absalón en muchos sentidos. Él precipita el estallamiento del conflicto armado: era más selectivo en la represión pero más duro, usaba más las estrategias de contraguerrilla que ya se venían conociendo desde Argentina, Chile, Guatemala... Absalón no, él era de los que arrasaban completamente, sin dejar nada, a pueblos enteros. $^{26}$
\end{abstract}

En el 1982 Chiapas tenía el triste récord de ser el estado más violento del país, mientras llegando al término de su mandato (1987), el gobierno de Castellanos fue acusado por la Academia Mexicana de Derechos Humanos de ser el más represivo de todo México; las violaciones a los DDHH aumentaban al tiempo que crecían las medidas represivas para mantener el control político. ${ }^{27}$ Los habitantes de las cañadas de la Selva poco a poco

\footnotetext{
${ }^{23}$ Los autores fundamentan estas afirmaciones en su detallada "Cronología" (1996); véase también García de León (1994: 21-26).

24 "En este momento se militarizaron muchos lugares, como San Quintín (que no se militarizó ahora luego del levantamiento zapatista, sino mucho antes) o Benemérito de las Américas, que ahora es un 'pueblo de bandidos', con un enorme contrabando de armas", Martha Figueroa, abogada, entrevista, San Cristóbal de las Casas, 17 diciembre 2003.

${ }^{25} 40.000$ efectivos ya estaban presentes en la entidad en 1994.

${ }^{26}$ Martha Figueroa, abogado defensor de derechos humanos y feminista, entrevista personal, 17 diciembre 2003.

27 Siendo Jefe de la 31 zona militar, ordenó a sus tropas el ataque de la comunidad de Wolonchán con ametralladoras y bazucas: 12 campesinos tzeltales fueron asesinados e incinerados en el lugar.
} 
constituyeron grupos de autodefensa para enfrentar las amenazas de desalojos y represión provenientes de las autoridades y también para defenderse de las expropiaciones por parte de los finqueros y sus guardias blancas. El gobernador González Garrido proveyó a éstas nueva legalidad, formalizándolas como Uniones de Defensa Ciudadana, y bajo este nombre las antiguas Policías Auxiliares Ganaderas proliferaron en la Zona Norte y parte de la Selva (Ocosingo, Altamirano y Sitalá): las mismas regiones que, 15 años después, serán asoladas por los grupos paramilitares. La represión se instrumenta entonces de múltiples formas: por medio del ejército y las policías, pero también con la acción coordinada de las "guardias blancas" y con el uso, como grupos de choque, de campesinos afiliados a organizaciones adheridas a la oficialista CNC y a Antorcha Campesina (con corte paramilitar desde su origen), estrategia implementada durante el gobierno de Castellanos y que podemos considerar como precursora de la capilar paramilitarización que caracterizará la guerra contrainsurgente en la segunda década de los años noventa.

Esta situación, donde a la corrupción e ineficiencia de las autoridades para atender demandas básicas como la regularización de la tenencia de la tierra se sumaba una multifacética violencia de Estado -militarización, represión policial, asesinatos selectivos de líderes- y un omnipresente poder fáctico -el de los terratenientes- que se ejercía históricamente a través de la violencia y el despojo, representan una de las más contundentes motivaciones a la raíz de la formación del EZLN, como explican el historiador García de León (1994: 26-28) y el mismo SubComandante Marcos. Éste, refiriéndose al "poder militar alterno al poder civil y que es el poder de los ganaderos, de los finqueros" y sus guardias blancas, advierte: "nosotros siempre lo conocimos y sabemos que existe [...] si el poder civil no puede controlar a esa tercera fuerza que son los ganaderos, no va a haber paz [...] Lo que antes eran los comités de defensa ciudadanos o las uniones de defensa ciudadana, son las sombras que se van a tender sobre el proceso de paz y su concreción". ${ }^{28}$

El gobierno de González Garrido, otro miembro de la oligarquía local, trató de dar un fundamento jurídico a la represión en contra de la población, también a través de reformas al Código Penal (1988 y 1990) que penalizaban cualquier forma de disentimiento político,

\footnotetext{
${ }^{28}$ SubComandante Marcos, conferencia de prensa, 28 de febrero 1994, <http://palabra.ezln.org.mx/comunicados/1994/1994_02_28.htm>, consultado el 25 de febrero 2014.
} 
tipificando como delitos graves las tomas de tierras y las manifestaciones de protesta; ${ }^{29}$ así, en la víspera a la reforma salinista al artículo 27 de la Constitución, pasaron por las cárceles chiapanecas la gran parte de los dirigentes campesinos. ${ }^{30}$

En estos años, la principal causa remota del malestar social (la insuficiente reforma agraria) se sumó al deterioro de la situación económica para el campo chiapaneco: las condiciones laborales regresivas, con la permanencia del peonaje en la Zona Norte; la baja en el costo de la mano de obra debido a la presencia de miles de refugiados guatemaltecos; finalmente, un impacto desastroso tuvo la caída de los precios del café y, a finales de los ochenta, la eliminación de los subsidios para su cultivo, lo que representó la reducción del $65 \%$ de los ingresos de los productores. Al aumento de las demandas sociales correspondió el adelgazamiento del Estado bajo la doctrina neoliberal, el impulso de políticas sociales insuficientes pero fuertemente politizadas (PRONASOL), y una más fuerte militarización del Estado. Aubry denuncia que en los años ochenta, con su capilar presencia sobretodo en la Selva, el Ejército controlaba la cuarta parte del estado, región donde se concentraban, además de los grupos insurgentes, también los recién descubiertos yacimientos de petróleo.

En la trayectoria trazada, el último entre los diversos procesos de organización indígena, que surgieron en la segunda mitad del siglo $\mathrm{XX}$ en el territorio selvático, fue el Ejercito Zapatista de Liberación Nacional.

Cuando llega a nuestros pueblos el Ejército Zapatista, allá por 1984, 1985, nosotros ya habíamos probado otras luchas pacíficas. La gente ya estaba protestando contra el gobierno [...] pero no había modo que nos hicieran caso. Entonces vimos que no hay más que entrarle a luchar con las armas, y así nos organizamos cada vez más y más fuerte. (Comandante Abraham, Comité Clandestino Revolucionario Indígena, en Muñoz 2003: 31-33).

El EZLN hizo su aparición pública el $1^{\circ}$ de enero de 1994, pero contaba ya con una década de organización en la clandestinidad: fue fundado el 17 de noviembre de 1983, cuando un reducido grupo de guerrilleros, integrantes de las Fuerzas de Liberación Nacional (FLN), logró instalar un campamento permanente en las Cañadas de Ocosingo. Dicha organización, de

\footnotetext{
${ }^{29}$ Véase el informe "Codificando represión. El Código Penal para el Estado de Chiapas", Abogados pro Derechos Humanos de Minnesota, Minneapolis, diciembre 1994,

<ttp://www.theadvocatesforhumanrights.org/uploads/codificando_2.pdf>, consultado el 20 febrero 2014.

${ }^{30}$ Un recuento detallado sobre la violencia y las violaciones a los derechos humanos ligadas al conflicto agrario en Chiapas entre 1989 y 1993 se encuentra en Gómez y Kovich: 1994.
} 
orientación marxista-leninista, se diferenciaba de las organizaciones guerrilleras contemporáneas por privilegiar las causas políticas más que las militares y descartar el terrorismo como método de lucha, así como el uso de la violencia para adquirir fondos y armas (Marcos y Le Bot, 1997: 50-55). Las FLN se formaron en 1969 en Monterrey, ampliando sus zonas de influencia y operación hacia los estados de Tabasco, Puebla, Estado de México, Veracruz y, de manera más articulada, en Chiapas. El primer campamento (El Diamante) que instalaron en las Cañadas de Ocosingo, remonta al 1972. En 1974, parte de las estructuras y de las bases de operación clandestina fueron desarticuladas por el Ejército federal; sin embargo, pronto los militantes de las FLN retomaron el trabajo organizativo, el reclutamiento en varias ciudades del país y establecieron lazos con organizaciones chiapanecas, logrando por fin el objetivo de implantarse en Chiapas y constituir no un grupo guerrillero, sino un ejército regular. El grupo fundador del EZLN, constituido por tres insurgentes indígenas y por tres cuadros nacionales de las FLN, entre ellos una mujer, al llegar a las Cañadas se insertó en una dimensión indígena de la cual el Subcomandante Marcos menciona dos grandes rasgos:

un grupo muy aislado, que es el indígena de la Selva, y otro movimiento que podríamos llamar de élite, indígenas politizados, con gran capacidad organizativa, con una experiencia de lucha política muy rica. Estuvieron prácticamente en todas las organizaciones políticas de izquierda que había en ese entonces y conocieron todas las cárceles del país. Se dan cuenta de que para sus problemas de tierra, de condiciones de vida y de derechos políticos no hay más salida que la violencia [...] ese grupo militar, entra en contacto con esa élite indígena, esa élite política, y coinciden en que es necesaria la lucha armada y que es necesario preparar un ejército (Marcos y Le Bot 1997: 56).

Durante los años que siguieron, a través de la mediación de la élite intelectual, dicho núcleo de origen urbano se integró a las comunidades indígenas, y en la medida en que los guerrilleros indígenas iban aumentando de número, también se desarrolló un proceso de integración en la cultura y la realidad de las comunidades. Dicho proceso implicó una progresiva transformación y redefinición de las ideas originarias del grupo armado, bajo la influencia del pensamiento indígena y la experiencia de vida en su contexto; asimismo, por la relación con el movimiento campesino e indígena que ya tenía una larga trayectoria de lucha. 


\section{AUTOONOMIIAINDÍGENA, VIOLENCIAY JUSTICIA}

Y ahí se empieza a dar el proceso de transformación del EZLN, de un ejército de vanguardia revolucionaria a un ejército de las comunidades indígenas, un ejército que es parte de un movimiento indígena de resistencia, dentro de otras formas de lucha. [...] Pero luego el EZLN, a la hora en que se imbrica con las comunidades, pasa a ser un elemento más dentro de toda esa resistencia, se contamina y es subordinado a las comunidades. Las comunidades se lo apropian y lo hacen suyo, lo colocan bajo su férula (Marcos y Le Bot 1997:63).

El proceso de paulatina y mutua integración entre las comunidades indígenas, sus organizaciones y el EZLN se desarrolla de manera clandestina a partir de 1985, logrando reclutar miles de combatientes hasta que en 1989-1990, según el Subcomandante Marcos, la mayoría de los poblados en Los Altos y la Selva se volvieron zapatistas.

La obstinación del gobierno chiapaneco en ocultar la presencia del movimiento rebelde, cuya presencia conocía desde 1988, significó un incremento aún mayor del uso de la violencia militar en contra de sus bases campesinas y de la impunidad para los crímenes cometidos en esta suerte de guerra doblemente sucia, en la que el Ejército también encubría sus acciones militares y llevaba a cabo una represión oculta contra un enemigo cuya existencia negaba.

\section{0 años de resistencia ;son bastantes!}

Durante la manifestación del 12 de octubre de 1992, en el marco de la Campaña 500 Años de Resistencia Indígena, Negra y Popular, 15.0oo campesinos indígenas marcharon por las calles de San Cristóbal de las Casas, protestando en contra del nuevo artículo 27 de la Constitución, en contra del TLCAN y exigiendo respeto a los derechos de los pueblos indígenas.

Vino entonces 1992 y la celebración de los 500 años [de Resistencia]; es cuando en Chiapas se empieza a hablar difusamente de la cuestión indígena [...]. Se dice que la marcha del 12 de octubre fue la prueba general de la toma de San Cristóbal: ${ }^{31}$ fue similar como llegaron los camiones llenos bajando de las comunidades... Y luego se volvieron famosas las imágenes de la gente abatiendo la estatua del conquistador Diego de Mazariegos que estaba frente a la iglesia de Santo Domingo. En la Ciudad de México destruyen el monumento a Colón y a lo que más le pegan es la estatua de un fraile que estaba en el pedestal: Fray Bartolomé de Las

\footnotetext{
${ }^{31}$ La referencia es a la toma de San Cristóbal por el EZLN poco más de un año después, el 1 enero 1994.
} 
Casas... y todos los coletos espantadísimos, revivían sus pesadillas de hace cien o doscientos años, en las que los indígenas tomaban San Cristóbal... ${ }^{32}$

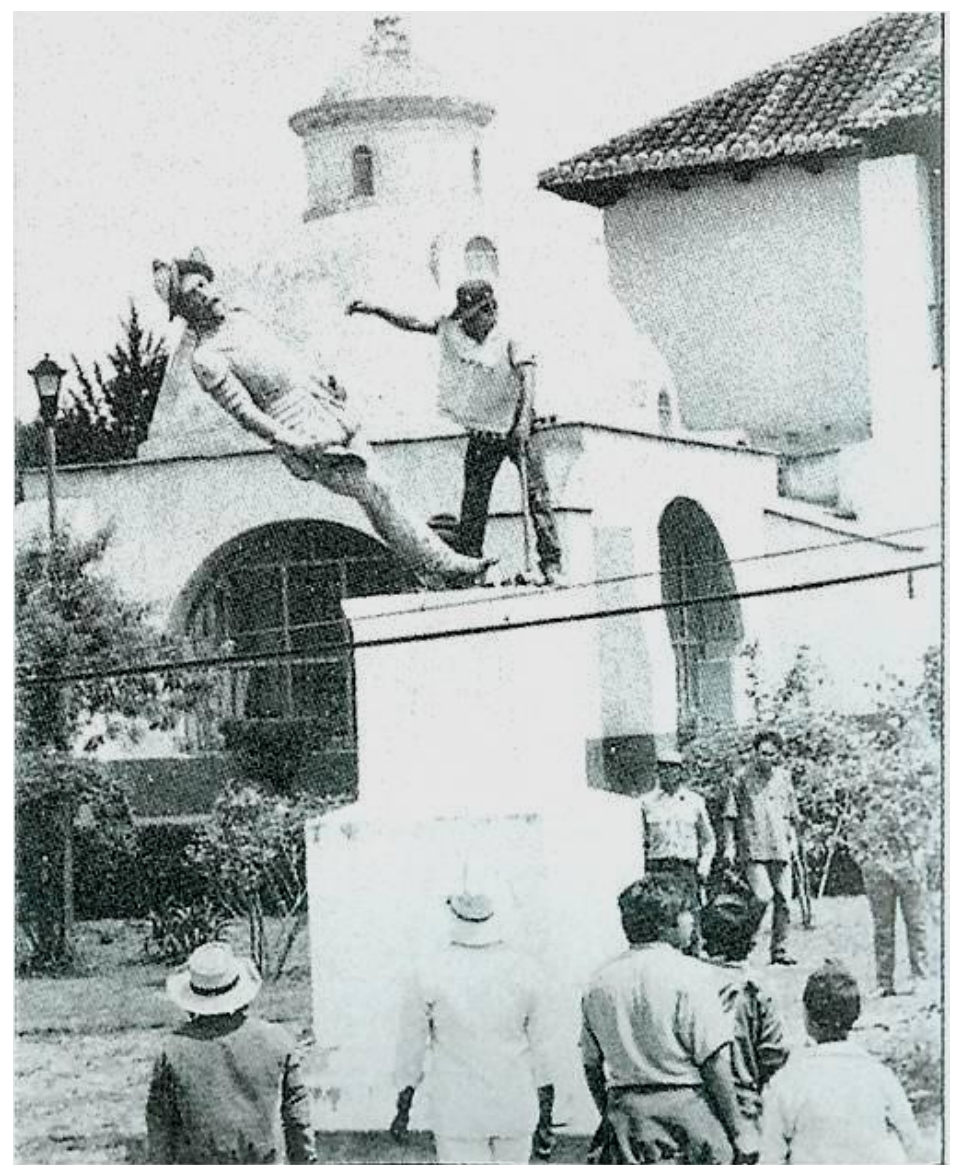

Foto: manifestantes derriban la estatua de Diego de Mazariegos, Plaza de Santo Domingo, San Cristóbal de Las Casas, 12 de octubre 1992.

El relato de Martha Figueroa coincide con la interpretación de Adolfo Gilly, según el cual los acontecimientos de 1992 estaban ya cargados de los elementos fundamentales del conflicto que estallaría poco más de un año después, como la afirmación en la práctica y en la experiencia de la identidad indígena como motor político a nivel regional y estatal. Dicha identidad en positivo era la respuesta a la exclusión de los indígenas como tales, y de sus derechos como ciudadanos mexicanos. Otros elementos visibles ya desde 1992 eran el control colectivo sobre la autoridad, la acumulación de la experiencia colectiva y la formación de dirigentes, producto de al menos veinte años de organización y movilización de todo tipo.

\footnotetext{
${ }^{32}$ Martha Figueroa, entrevista personal, 17 diciembre 2003.
} 


\section{AUTONOMIA INDÍGENA, VIOLENCIAY JUSTICIA}

En el mismo año 1992, en marzo, indígenas de tres organizaciones de Palenque ${ }^{33}$ realizaron la Marcha por la Paz y los Derechos Humanos de los Pueblos Indígenas (Xi' Nich) hacia la ciudad de México, exigiendo solución a problemas políticos, respeto a los derechos humanos y a la dignidad indígena. De esta importante experiencia de movilización nació la Coordinadora de Organizaciones Indígenas $\mathrm{Xi}^{\prime} \mathrm{Nich}$, en su inicio cercana al movimiento zapatista $^{34}$ y que está actualmente presente en varios municipios de las regiones Norte y Selva. Ya en ese momento, la identidad y la defensa de la dignidad indígena eran un elemento central en las movilizaciones y las reivindicaciones de las organizaciones, juntándose a las demandas propiamente agrarias.

En esta coyuntura, el EZLN ya era un sujeto colectivo con raíces profundas en el territorio estatal, y que rápidamente estaba llegando a su madurez en la acumulación de fuerza clandestina. En estos años de gestación del levantamiento, las Fuerzas de Liberación Nacional, estructura que antecedía e integraba el EZLN, crearon una organización "abierta": la Alianza Campesina Emiliano Zapata (ACIEZ, 1989) con base principalmente en la Zona Norte. A principio de 1992, la organización cambió su nombre en ANCIEZ, añadiendo la palabra "nacional" por tener afiliados en seis estados; su objetivo era acercar el proyecto revolucionario a un número más elevado de personas, y, aun siendo una organización abierta, no podía entablar negociaciones u acuerdos con el gobierno (Harvey 2000:204). En 1992 la ANCIEZ se movilizó con otras organizaciones enarbolando demandas de carácter nacional que después caracterizarían el pliego petitorio del EZLN: en oposición a la reciente reforma del artículo 27 Constitucional y al inminente Tratado de Libre Comercio con América del Norte (Esponda y Pólito 1996). Dicha organización tuvo un papel central en organizar las movilizaciones para los 500 Años de Resistencia en Chiapas y, pocos meses después, pasó a la clandestinidad.

La marcha del 12 de octubre, en la que participaron entre cinco y seis mil zapatistas, según Marcos "es percibida como la culminación del proceso de consulta, como un espejo que los indígenas se tienden a sí mismos y en el que reconocen su capacidad de movilización”

\footnotetext{
${ }^{33}$ Comité de Defensa de las Libertades Indígenas (CDLI), la Unión de Comunidades Independientes de la Selva de Chiapas (Ucisech) y la Tsoblej Yu'un Jowocoltic.

34 Véase el pronunciamiento de Xi' Nich a diez años de la Marcha (2002): <http://davidvelasco.files.wordpress.com/2007/11/pronunciamiento-de-xi-nich.pdf>, consultado el 10 de marzo 2014.
} 
(Marcos y Le Bot 1997:81). En ese entonces ya estaba en marcha el proceso de consulta en aproximadamente 500 comunidades de Los Altos, el Norte y la Selva, "sobre las condiciones en las que están en las comunidades, en las etnias, en las que está la situación internacional, la situación nacional, y la pregunta es si es tiempo de empezar la guerra o no" (Marcos y Le Bot 1997:81). En el conteo, realizado después del 12 de octubre, resultó que la mayoría de las personas, en particular en la región de la Selva, votó por la guerra. En enero 1993 se formó el Comité Clandestino Revolucionario Indígena (CCRI), máximo mando del EZLN. Dicho Comité, cuyos miembros tienen el grado de Comandantes, decidió que había llegado el tiempo de declarar la guerra; su preparación ocupó todo el año 1993.

\section{Ejército Zapatista de Liberación Nacional, entre la guerra y la paz}

Hasta aquí he relatado las vertientes de la violencia que han caracterizado la historia reciente de los pueblos indígenas del Chiapas oriental; la cristalización histórica de las múltiples violencias y su impacto en la construcción de los sujetos colectivos y de las identidades sociales, cuya formación se inserta en una relación dialéctica, de respuesta y confrontación, a dichas violencias. La intención de este recuento, como ya he mencionado, es sustentar la tesis de que los procesos de autonomía, en sus diferentes acepciones y determinaciones, son una respuesta organizada de los sujetos colectivos (en este caso, de los pueblos indígenas asentados en un territorio más o menos extenso) frente a una situación de violencia, diversamente caracterizada según los contextos, que atenta a su identidad y sobrevivencia.

El panorama histórico y social de Chiapas y de la Selva Lacandona que he relatado muestra el proceso de desgaste de la sociedad campesina e indígena sometida a múltiples formas de explotación y negación de sus derechos colectivos e individuales, así como una lenta transición de la coerción generalizada (inicio del siglo) a la organización reivindicativa y finalmente a la lucha armada. El proceso de fortalecimiento de los sujetos colectivos ha representado, asimismo, una larga "acumulación de fuerzas”, pero también una acumulación de experiencias fallidas en la lucha social "abierta", que abonaron hacia la opción insurreccional.

PUEBLO DE MÉXICO: Nosotros, hombres y mujeres íntegros y libres, estamos conscientes de que la guerra que declaramos es una medida última pero justa. Los dictadores están 
aplicando una guerra genocida no declarada contra nuestros pueblos desde hace muchos años, por lo que pedimos tu participación decidida apoyando este plan del pueblo mexicano que lucha por trabajo, tierra, techo, alimentación, salud, educación, independencia, libertad, democracia, justicia y paz. ( $1^{\circ}$ Declaración de la Selva Lacandona, 1 de enero 1994).

Los "diez puntos" explicitados en esta Primera Declaración de la Selva Lacandona, con la que se dio a conocer el Ejército Zapatista de Liberación Nacional el primero de enero de 1994, demandan una clara solución a la situación de violencia estructural y violación a los derechos humanos más elementales. En los cientos de textos que siguieron, los voceros del EZLN articulan en múltiples formas esta demanda y la denuncia de la situación vivida por miles de campesinos indígenas. Pobreza, hambre, enfermedades, discriminación y aislamiento: la vida de los indígenas chiapanecos sobresale en las crónicas, junto con las acciones de militares y paramilitares para acallar sus voces. El grito de ¡Ya basta! que miles de indígenas zapatistas levantaron en 1994 denuncia las múltiples violencias padecidas, pero también muestra la dignidad forjada en muchos años de resistencia, organización y lucha social. ${ }^{35}$

La insurrección del Ejercito Zapatista de Liberación Nacional representa un parteaguas en la historia de Chiapas y en la construcción social de sus territorios. Es el momento en que las víctimas históricas de las violencias irrumpen en el escenario político nacional, usando la violencia como herramienta de presión política; sin embrago, desde los días inmediatamente posteriores al levantamiento el EZLN suspendió el recurso a la violencia revolucionaria y las armas, impulsando el diálogo para dar pie al nacimiento de un proceso amplio de construcción de alternativas sociales y políticas en sus territorios: la autonomía zapatista.

\footnotetext{
${ }^{35}$ Como muestra de tal discurso, cito uno de los primeros y más contundentes textos del EZLN, dirigido a los representantes del gobierno federal: “¿De qué nos van a perdonar? ¿De no morirnos de hambre? ¿De no callarnos en nuestra miseria? ¿De no haber aceptado humildemente la gigantesca carga histórica de desprecio y abandono? ¿De habernos levantado en armas cuando encontramos todos los otros caminos cerrados? ¿De no habernos atenido al Código Penal de Chiapas, el más absurdo y represivo del que se tenga memoria? ¿De haber demostrado al resto del país y al mundo entero que la dignidad humana vive aún y está en sus habitantes más empobrecidos? ¿De habernos preparado bien y a conciencia antes de iniciar? ¿De haber llevado fusiles al combate, en lugar de arcos y flechas? ¿De haber aprendido a pelear antes de hacerlo? ¿De ser mexicanos todos? ¿De ser mayoritariamente indígenas? ¿De llamar al pueblo mexicano todo a luchar de todas las formas posibles, por lo que les pertenece? ¿De luchar por libertad, democracia y justicia? ¿De no seguir los patrones de las guerrillas anteriores? ¿De no rendirnos? ¿De no vendernos? ¿De no traicionarnos?” (Comunicado, 18 enero 1994)
} 
No me detendré en detallar la dinámica del levantamiento ni los elementos que lo hacen tan trascendente, pues hay una vasta y excelente bibliografía al respecto. De acuerdo al objetivo de este trabajo, en los siguientes apartados mostraré como se ha modificado el entramado de las violencias después del levantamiento zapatista, haciendo particular énfasis en la región de la Selva. Mientras en los territorios de su influencia el EZLN trata de construir una alternativa social y de convivencia, la violencia del Estado se ha acentuado y diversificado, desde una violencia directa -militar y paramilitar- hasta una agresiva violencia estructural neodesarrollista, y una infiltración en las estructuras políticas y organizativas autónomas.

El Centro de Derechos Humanos Fray Bartolomé de las Casas propone una periodización en etapas de la guerra que involucra las bases de apoyo del EZLN, cada una caracterizada por diferentes formas de violencia. La primera etapa consiste en los 12 días de guerra y confrontación directa entre el Ejército mexicano y el EZLN a principios de 1994; la segunda etapa cubre el periodo entre 1995 y 1999, durante el cual se lleva a cabo la paramilitarización del estado y se perpetran varios crímenes de lesa humanidad; finalmente, la tercera y la cuarta etapa se pueden resumir en la implementación de la guerra integral de desgaste que "consiste en confrontar a comunidades por medio de los programas sociales implementados por el Estado", utilizando todas las formas de violencia y fortaleciendo la violencia estructural sobre las comunidades zapatistas.

La primera etapa de la guerra inicia con el levantamiento mismo, la madrugada del $1^{\circ} \mathrm{de}$ enero de 1994, cuando miles de insurgentes y milicianos del EZLN ocuparon militarmente cinco cabeceras municipales, y atacaron los cuarteles de la policía y el de la $31^{\circ} \mathrm{zona}$ militar en Rancho Nuevo. Los combates y la confrontación directa con el Ejército Mexicano, que respondió con bombardeos aéreos y movilización de tropas, duraron hasta el 12 de enero, con un balance de 46 insurgentes muertos, muchos de ellos caídos en la ciudad de Ocosingo. A partir del cese al fuego, inició un accidentado proceso de dialogo entre el EZLN y el gobierno mexicano, inicialmente facilitado por el obispo Samuel Ruiz y después por la Comisión Nacional de Intermediación (CONAI). La situación de confrontación política en el estado se agravó después de las elecciones para gobernador: las denuncias de fraude propiciaron un excepcional proceso de convergencia entre organizaciones sociales, que llevó al nombramiento del Gobernador de Transición en Rebeldía Amado Avendaño, reconocido 


\section{AUTONOMIAINDÍGENA, VIOLENCIAY JUSTICIA}

también por el EZLN. La intransigencia del gobierno federal en el proceso de dialogo fue la motivación por la que el EZLN, entre el 16 y el 18 de diciembre de 1994 rompiera pacíficamente- el cerco militar alrededor de la llamada "zona de conflicto" y con miles de insurgentes se posicionara en 38 municipios (50\% del territorio estatal), declarando la creación de treinta municipios "rebeldes".

\section{Militarización y paramilitarización: las diversas caras de la violencia de Estado}

La segunda etapa de la guerra, que se extiende desde 1995 hasta 1999, es sintetizada en el Plan de Campaña Chiapas 94 de la Secretaría de la Defensa Nacional (SEDENA). ${ }^{36}$ Inició en febrero de 1995, en el momento del mayor esfuerzo de los mediadores para retomar el dialogo: el 9 de febrero empezó una amplia incursión militar en zonas zapatistas, con la invasión de muchos poblados y comunidades. El EZLN tuvo que replegarse y sus bases de apoyo comenzaron un éxodo hacia la Selva, mientras que otras comunidades no zapatistas se desplazaron hacia otras zonas: inició un largo proceso de desplazamiento interno que involucró a más de 35.000 personas entre 1994 y 1995 (CDHFBC 2003:3). La estrategia militar implicó un aumento exponencial de sus efectivos en el estado, su distribución capilar en ocasiones enmascarada de "labor social" y acciones de "desarrollo", el control de los medios de comunicación, y una poderosa ofensiva destinada a "aniquilar" el EZLN y sus bases de apoyo. En esta etapa, las fuerzas armadas se desplegaron en todo el territorio e incrementaron exponencialmente el número de los efectivos en el estado, pasando de 40.000 en 1994 a 70.000 en $1998,{ }^{37}$ distribuidos en cuarteles y campamentos.

La militarización tuvo (y tiene) un impacto destructivo sobre la sociedad chiapaneca, y en particular sobre el tejido social de las comunidades indígenas y rurales en los aspectos económico, político, social y cultural. ${ }^{38}$ A lo largo de veinte años, conocidas organizaciones defensoras de los derechos humanos -entre ellas Amnesty International, el Centro de Derechos Humanos Fray Bartolomé de las Casas, Servicios Internacionales para la Paz (Sipaz), el

\footnotetext{
36 Disponible en <http://es.scribd.com/doc/68004991/Plan-Militar-Para-Chiapas-1994>, consultado el 10 de marzo 2014.

${ }^{37}$ Datos del PRD citados en Zebadua 2001: 209.

${ }^{38}$ Para un análisis sintético de la estrategia de militarización y su continuidad y evolución a lo largo del periodo 1994-2006, véase Onécimo Hidalgo, "Estrategia actual de la contrainsurgencia y la militarización en Chiapas", VoltaireNet, 12 de abril 2006, en <http://www.voltairenet.org/article137850.html>, consultado el 10 abril 2014.
} 
Centro de Análisis Político e Investigaciones Sociales y Económicas A.C. (Capise), el Centro de Investigaciones Económicas y Políticas de Acción Comunitaria (Ciepac), y el Centro de Derechos Humanos Miguel Agustín Pro-, han denunciado un elevadísimo número de crímenes de lesa humanidad: además del desplazamiento forzado, las Fuerzas Armadas se han hecho responsables de ejecuciones extrajudiciales, asesinatos, desapariciones forzadas, torturas, violaciones sexuales, agresiones físicas y hostigamientos, entre otros.

Asimismo, la estrategia antizapatista implica una fuerte militarización de la seguridad pública, a través del entrenamiento militar de los cuerpos policiacos y la creación de Bases de Operación Mixtas integradas por unidades de la policía y del Ejército.

En la región donde realicé el trabajo de campo más extenso (varias estancias de uno hasta tres meses entre 1999 y 2012), esto es, la zona aledaña a la comunidad de La Realidad Trinidad, sede del Aguascalientes Zapatista y desde 2003 de la Junta de Buen Gobierno y del Caracol $\mathrm{I}^{\circ}$, la presencia militar fue ingente y ostentosa al menos hasta 2003. La carretera (pavimentada en fechas recientes) que conecta la cabecera municipal de Las Margaritas con la comunidad de San Quintín, al límite de la RIBMA y sede de uno de los principales cuarteles militares, atraviesa todas las comunidades donde residí: La Realidad Trinidad, Guadalupe Tepeyac y San José del Río. Hasta el año 2001, convoyes militares de aproximadamente 20 unidades realizaban recorridos dos veces al día entre el cuartel de San Quintín y el campamento establecido en Guadalupe Tepeyac, comunidad anteriormente sede de la Comandancia General del Ejército Zapatista y de la primera iniciativa pública zapatista de gran envergadura, la Convención Nacional Democrática (1994). En 1995, la comunidad fue ocupada por los militares, en abierto escarnio en contra de la dirigencia zapatista, todas sus casas destruidas y la población obligada a refugiarse primero en el monte y después a asilarse en las vecinas Guadalupe Los Altos y La Realidad, donde les prestaron tierra para sembrar.

Durante el periodo más crítico de la militarización, las organizaciones de la sociedad civil, nacional e internacional (entre ellas las chiapanecas Centro de Derechos Humanos Fray Bartolomé de las Casas y Enlace Civil), tuvieron un papel clave en el monitoreo y la denuncia de lo que ocurría en territorio zapatista. En La Realidad y en San José del Río, como en muchísimas otras comunidades, se establecieron Campamentos Civiles por la Paz, donde permanecían observadores voluntarios que, con su sola presencia, podían disuadir operaciones militares particularmente violentas. En La Realidad, el papel de los observadores consistía en 


\section{AUTONOMIAINDÍGENA, VIOLENCIAY JUSTICIA}

registrar los convoyes que transitaban en la carretera, el tipo y número de unidades que los integraban, así como los sobrevuelos de avionetas y helicópteros. Aunque la comunidad no estaba ocupada militarmente, e incluso hasta el año 2001 fue sede de la Comandancia General del EZLN, los patrullajes incesantes en el medio del poblado generaban pavor y constante inseguridad entre la población.

En 1995, tras la ofensiva militar de 1995 y la persecución de los dirigentes zapatistas y de otras organizaciones, fue promulgada la Ley para el Diálogo y la Reconciliación en Chiapas. La Ley abrió el espacio político para el proceso de los Diálogos de San Andrés, que se prolongaron hasta el septiembre de 1996. A pesar de que la ley seguía (y sigue) vigente, entre abril y junio de 1998 ocurrieron cinco operativos policíaco-militares en distintos municipios del estado de Chiapas, cuyo objetivo fue el desmantelamiento de algunos Municipios Autónomos Zapatistas (el Municipio Autónomo Ricardo Flores Magón, en la comunidad de Taniperla -región de Ocosingo; el Municipio Autónomo Tierra y Libertad, con cabecera en Amparo Aguatinta-región Selva; el Municipio Autónomo San Juan de la Libertadregión Altos), así como de otras dos instancias no ligadas al EZLN pero contrarias al PRI y a sus estructuras políticas (el municipio Nicolás Ruiz, gobernado por el PRD, y algunas colonias indígenas en la periferia de San Cristobal, entre ellas La Hormiga) ${ }^{39}$. En Taniperla, un grupo de 45 observadores italianos que se quedaron en la comunidad resguardando a las mujeres (los hombres se refugiaron en el monte a la llegada del Ejército), fueron expulsados del país. El gobierno estatal justificó la acción en contra de los Municipios Autónomos Zapatistas argumentando que estos violaban el artículo 115 constitucional, que señala como facultad exclusiva de las legislaturas locales determinar la división municipal.

Según Inés Castro (2002):

Por la cantidad de efectivos movilizados [mil en cada operativo] que contrasta con los magros resultados que obtuvieron; por la ausencia de avales de carácter legal que justificaran las intervenciones -y porque cuando los hubo, no faltaron irregularidades-; por el saldo de detenidos, desplazados, muertos, ${ }^{40}$ robos y destrucciones, así como por el hecho de tratarse de

\footnotetext{
${ }^{39}$ Dicha colonia, formada principalmente por indígenas expulsados de San Juan Chamula por las autoridades "tradicionales" y ligadas al PRI, ha históricamente respaldado y cobijado la lucha del EZLN.

${ }^{40}$ En El Bosque, cabecera del Municipio Autónomo San Juan de la Libertad se verificó un enfrentamiento entre el Ejército y el EZLN, con un sueldo de ocho zapatistas muertos, cuyos cadáveres fueron entregados a sus deudos en avanzado estado de descomposición.
} 
aparatos e instituciones de los gobiernos estatal y federal quienes impulsaron las acciones, se presenció, claramente, un fenómeno de violencia estatal.

En esta ocasión se instalaron más campamentos militares, junto a los muchos que ya se habían establecido en todo el territorio zapatista a raíz de la ofensiva de febrero 1995. En las comunidades de Amparo Aguatinta y Taniperla, el Ejército llegó para quedarse: los campamentos permanecieron hasta la fecha, sobreviviendo al reacomodo (publicitado como "retiro") de treinta contingentes militares que se realizó entre los años 2000 y $2007 .^{41} \mathrm{El}$ aglutinamiento de los efectivos en un menor número de campamentos inició con el retiro de siete posiciones entre el 2000 y el 2001 (los últimos fueron dos campamentos en el corazón de la Selva zapatista: Guadalupe Tepeyac y Rio Euseba), una de las condiciones exigidas por el EZLN para retomar la negociación alrededor de la reforma constitucional en materia de Derechos y Cultura Indígena.

Según el informe Cara de Guerra elaborado por la ONG CAPISE, de las 79 posiciones militares destacamentadas en el estado en el 2007, cuarenta se encuentran en la región SelvaFronteriza, distribuidas capilarmente en el territorio de influencia zapatista. Según el mismo informe, los cinco campamentos presentes en las cañadas tojolabales (El Edén, Vicente Guerrero, Rizo de Oro, Base Aérea Copalar, Predio Momón) son identificadas como Fuerzas Especiales (GAFEs), con Cuerpos de elite al más alto nivel, adscritos al Campo Militar Número Uno de la Ciudad de México (CAPISE 2007).

La presencia militar es justificada, actualmente, también por el control de la frontera frente al incremento de la delincuencia, de los tráficos de droga y de personas, en el marco de la estrategia que detallé en el capítulo 1, una situación que complica la exigencia de desmilitarización del estado.

Los documentos de referencia sobre la presencia militar en el Estado son los informes elaborados por las citadas organizaciones de la sociedad civil y de defensa de los derechos humanos. Los efectos de la proliferación de grupos paramilitares (fenómeno que abordé, en términos amplios, en el capítulo 1), han sido denunciados por las mismas organizaciones, pero también objeto de diferentes análisis antropológicos. Entre ellos, López y Rivas se ha

\footnotetext{
${ }^{41}$ Las posiciones militares de Taniperla y Monte Líbano son cubiertas, por turnos de cuatro meses, por el $31^{\circ}$ y el $38^{\circ}$ Batallón de Infantería, que tienen los cuarteles generales, respectivamente, en Toniná y San Quintín, ambos en el municipio de Ocosingo. En Amparo Aguatinta se encuentra una Base de Operaciones Mixta.
} 


\section{AUTONOMIAINDÍGENA, VIOLENCIAY JUSTICIA}

enfocado en varios textos al análisis de la paramilitarización en el marco de la estrategia de contrainsurgencia y de guerra integral de desgaste; Hernández Castillo sobre los efectos de la presencia paramilitar en Acteal, con un enfoque de género; Agudo Sánchiz sobre las transformaciones comunitarias que involucraron las comunidades de la Zona Norte de Chiapas, región en la que proliferaron los grupos paramilitares.

La paramilitarización es la otra vertiente de la ofensiva contra el EZLN. El Plan Militar Chiapas 94 hace énfasis en el "adiestramiento y apoyo de las fuerzas de autodefensa u otras organizaciones paramilitares" para actividades militares y de desarrollo, que se reclutarían secretamente entre "ciertos sectores de la población civil, ganaderos, pequeños propietarios e individuos caracterizados con un alto sentido patriótico", con el objetivo de "destruir la voluntad de combatir del EZLN". La ofensiva militar de febrero 1995, después de la consolidación de una miríada de destacamentos y campamentos militares en toda la zona de conflicto, deja el paso a la llamada guerra integral de desgaste (López y Rivas 2004: 113125), que combina las operaciones militares con las de inteligencia, la guerra psicológica y el control de la población; el objetivo no es sólo la victoria militar sino "destruir la voluntad de combatir del EZLN, aislándolo de la población civil”.

Mientras el objetivo declarado de las acciones militares es la guerrilla (aunque la violencia sea ejercida por igual también sobre los civiles), el blanco de los paramilitares es la base de apoyo, la población civil que respalda a los insurgentes, e incluso a las organizaciones neutrales como Las Abejas de Acteal, donde 45 indígenas católicos fueron masacrados en 1997 mientras rezaban por la paz. En dicha estrategia, impulsada desde los años ochenta en Centroamérica, se combinan las acciones de los militares, de los cuerpos policiacos militarizados y de tropas locales irregulares, para llevar a cabo los "trabajos sucios" que el Ejército evita realizar directamente (López y Rívas 2004b). En este aspecto, la contrainsurgencia aplicada en Chiapas durante los años noventa difiere de la guerra sucia desatada en Guerrero en los setenta, donde esencialmente los militares se enfrentaban a los grupos insurgentes y perseguían sus bases de apoyo. A diferencia de los paramilitares colombianos, directamente dependientes de las estructuras militares, los chiapanecos son organizados y entrenados por el Ejército pero de forma oculta; éste los mantiene ilegales y hasta niega su existencia para garantizarles impunidad, y operan en una zona al margen de la legalidad, en esas bolsas de ilegalidad o espacios de excepción que las estructuras represivas 
del Estado crean para proteger los espacios y estructuras legales (evitando denuncias formales y procedimientos judiciales por delitos comunes y violación a los derechos humanos cometidos contra la población). El Ejército Federal no puede actuar directamente contra el Ejército Zapatista de Liberación Nacional (EZLN), pues lo impide la Ley de Concordia y Pacificación por una paz justa y digna en Chiapas.

Con respecto a uno de los efectos sociales más abrumadores de la guerra en Chiapas, el desplazamiento forzado, Hidalgo y Castro afirman que:

Los aproximadamente 12 mil desplazados zapatistas que se registraron durante 1995 fueron resultado directo de operativos militares, principalmente. Como el costo político para la institución castrense ya era demasiado elevado, durante ese mismo año se presume fueron organizados y preparados por el ejército federal los grupos paramilitares [...] que a lo largo de 1996-97 tomarían el relevo en acciones que originaron nuevos conjuntos de población desplazada en las zonas Norte, Selva y Centro (1999: 24-25).

Los desplazados nunca recibieron la atención adecuada por parte de las instituciones, enfrentándose a un Estado que garantizó en todo momento la impunidad de sus agresores, fueran militares o paramilitares. "Esto lleva a que el sentido de justicia desaparezca y el desplazado arrastra no sólo con la pérdida de su identidad, sino con el sentimiento persecutorio que se produce por la ausencia de una forma legal que garantice no más violaciones" (CDHFBC 2003:22).

Por ser reclutados entre civiles de la región, las autoridades han repetidamente negado la existencia de agrupaciones paramilitares, justificando las agresiones como conflictos inter e intracomunitarios, aprovechando para estigmatizar a los pueblos indígenas como intrínsecamente violentos y justificar la presencia militar en los territorios donde la presencia paramilitar generó previamente conflictos sociales extremos.

Una de las paradojas del conflicto en Chiapas es que se han perdido más vidas en actos de violencias, frecuentemente sin detectarse, que en el combate abierto entre tropas gubernamentales y el EZLN. El ejemplo más contundente es la "otra guerra" de los grupos paramilitares (en especial el llamado "Paz y Justica") en los municipios Choles de Tila, Sabanilla, Salto del Agua y Tumbalá (Harvey 2001: 165). 


\section{AUTONOMIIA INDÍGENA, VIOLENCIAY JUSTICIA}

\begin{tabular}{|c|c|c|}
\hline $\begin{array}{l}\text { Principales grupos } \\
\text { paramilitares activos en } \\
\text { Chiapas 1995/2000 }\end{array}$ & Zonas de acción & $\begin{array}{l}\text { Acciones perpetradas, muertos, } \\
\text { heridos y desplazados }\end{array}$ \\
\hline $\begin{array}{l}\text { Mascara Roja } \\
\text { afines al PRI/ Partido } \\
\text { Cardenista }\end{array}$ & $\begin{array}{l}\text { Los Altos: } \\
\text { Chenalhó, Larráinzar, } \\
\text { Chamula, Pantelhó) }\end{array}$ & $\begin{array}{l}\text { 1997/1998: } 81 \text { personas } \\
\text { asesinadas, } 37 \text { desaparecidas y } \\
\text { más de } 10.000 \text { desplazadas. } \\
\text { Tortura } \\
\text { Masacre de Acteal, } 22 \text { diciembre } \\
\text { 1997: } 45 \text { indígenas tsotsiles } \\
\text { murieron y } 26 \text { resultaron heridos, } \\
\text { en su mayoría menores de edad. }\end{array}$ \\
\hline $\begin{array}{l}\text { Desarrollo, Paz y Justicia } \\
\text { afines al PRI y a la } \\
\text { organización Solidaridad } \\
\text { Campesina Magisterial } \\
\text { (Socama) }\end{array}$ & $\begin{array}{l}\text { Zona Norte: municipios } \\
\text { de Tila, Tumbalá, } \\
\text { Sabanilla, Yajalón y } \\
\text { Salto de Agua }\end{array}$ & $\begin{array}{l}85 \text { asesinatos, } 37 \text { desapariciones } \\
\text { forzadas, desplazamiento de más } \\
\text { de } 3.500 \text { personas entre } 1995 \text { y } \\
2000\end{array}$ \\
\hline $\begin{array}{l}\text { Los Chinchulines } \\
\text { Afines al PRI }\end{array}$ & $\begin{array}{l}\text { Zona Norte: } \\
\text { Chilón, (Bachajón), } \\
\text { Yajalón }\end{array}$ & 6 muertos, 1 herido \\
\hline $\begin{array}{l}\text { Movimiento Indigena } \\
\text { Revolucionario Antizapatista } \\
\text { (MIRA) } \\
\text { Afines al PRI }\end{array}$ & $\begin{array}{l}\text { En la confluencia de } \\
\text { varias regiones: } \\
\text { Los Altos, Selva } \\
\text { Lacandona, } \\
\text { Las Cañadas y norte de } \\
\text { La Selva. Municipios: } \\
\text { Las Margaritas, } \\
\text { Oxchuc, Huixtan, } \\
\text { Altamirano, Ocosingo, } \\
\text { Sitalá, San Juan Cancuc }\end{array}$ & \\
\hline $\begin{array}{l}\text { Alianza San Bartolomé de los } \\
\text { Llanos }\end{array}$ & Venustiano Carranza & \\
\hline
\end{tabular}

De los datos expuestos, se observa que en la región de la Selva, donde se concentró la presencia militar, no hay una ingente presencia de paramilitares. Sin embargo, al disminuir la presencia militar, se incrementó en la región la violencia política y agraria, la división entre organizaciones y hasta la paramilitarización de algunas de ellas.

Según Olivera,

Desde el punto de vista cultural y afectivo la guerra de baja intensidad altera la vida cotidiana, las costumbres tradicionales, el arraigo los lugares donde se nace, donde viven los antepasados 
y los dioses protectores y las esperanzas cíclicas de tener con qué alimentarse. Esta estrategia afecta la salud del cuerpo en los afectos y sentimientos intentado arrojar dudas sobre el proyecto político, desmoviliza; en fin, trastoca toda la vida y la cultura, y afecta profundamente las identidades indígenas y genéricas [...] las muertes, asesinatos, secuestros cometidos impunemente, además de los costos humanos y económicos, dieron paso un rompimiento brusco de valores y normas, a un clima de temores y desconfianzas (1998: 116; 120]

Estas estrategias de "ingeniería del conflicto" se insertan en un contexto social en rápida mutación, agudizando conflictos latentes y creando nuevas fracturas en el tejido social. En las últimas décadas, a las preexistentes vertientes del conflicto (conflicto agrario: campesinos y Estado; discriminación y racismo: indígenas, instituciones y sociedad; conflicto de clase que incluye las otras vertientes, involucrando a las élites latifundistas y ganaderas, el poder político, las instituciones y los campesinos indígenas), se han sumado nuevas condiciones diferenciadoras que originan situaciones conflictivas. En primer lugar, se ha transformado la estructura de poder en las comunidades, introduciéndose nuevos elementos de diferenciación, como la económica (nuevas fuentes de ingreso basadas en el control del transporte público, en el comercio, en la migración, los tráficos ilícitos) que ha minado el control de los cacicazgos tradicionales, pero también agudizado las situaciones de desigualdad y de exclusión en las comunidades indígenas. Otras vertientes de diferenciación potencialmente conflictiva son el multipartidismo y la utilización instrumental de la afiliación política a uno u otro partido; las diferentes opciones de incorporación a organizaciones sociales, con frecuencia enfrentadas entre sí; la presencia de muchas confesiones religiosas (tradicionalistas, católicos, presbiterianos, evangélicos, etc.); el acceso a la tierra y la presión demográfica; la adscripción sindical, etc.

En tal contexto, la dinámica organizativa y de participación política de amplios sectores de la población hacia la democratización de las estructuras políticas, económicas y sociales del estado es un movimiento transversal que puede encontrar en dichas vetas de diferenciación elementos favorables o contrarios. Por igual, las estrategias implementadas por el Estado para contrarrestar los procesos de transformación social, en un contexto de conflicto generalizado, pueden utilizar de manera provechosa estos elementos de diferenciación.

Así, la proliferación de los grupos paramilitares responde a una estrategia militar de contrainsurgencia, que encuentra condiciones sociales favorables y aprovecha de las 
diferencias para volverlas divisiones profundas e irreconciliables, que naturalizan la violencia como una condición endémica. Se puede entonces elaborar una lectura de doble sentido (o bien multíplices interpretaciones que se cruzan entre sí) de las violencias que se han desarrollado en las comunidades indígenas chiapanecas después de la insurrección zapatista.

La lectura basada en una perspectiva histórica (Garza y Hernández 1998) explica como el control social y el poder político establecidos en las zonas Norte y Altos de Chiapas se vieron fuertemente amenazados por el surgimiento del EZLN y el potencial transformador y disruptivo de su fuerza política y social. Esto motivó el fortalecimiento de las alianzas entre los grupos de poder en la región (cacicazgos indígenas, ganaderos y las fracciones locales del PRI) y la radicalización del conflicto ya presente entre ellos y las organizaciones de campesinos indígenas. La estrategia de contrainsurgencia basada en la paramilitarización encuentra aliados inmediatos en estos actores, que colaboran con el Ejército en la constitución, el financiamiento y la dirección de grupos paramilitares.

De esta manera, la acción de los grupos paramilitares como elemento clave de la guerra de desgaste es parte también de una situación de violencia política, en la que se enfrentan una multiplicidad de proyectos de gobierno del territorio y de la sociedad local. Si se piensa en la violencia en Chiapas como un conflicto político, se puede identificar una variedad de actores de vez en vez aliados o enfrentados entre sí en los diferentes momentos históricos. Básicamente, se enfrentan entre sí para el control de los recursos el proyecto del Estado y las corporaciones aliadas, el de las organizaciones que buscan apoyo y recursos materiales a través de la negociación con el Estado, y el proyecto zapatista que rechaza esta negociación pero de igual forma ha logrado imponerse en el control del territorio. Analizaré en el siguiente apartado los distintos actores y vertientes de la violencia política en la Selva, en un contexto donde los paramilitares pueden ser la expresión o el "brazo armado" de intereses distintos, pero no son los únicos actores que utilizan la violencia extrema para controlar un territorio.

Desde otra perspectiva, seguramente no afín a la posición zapatista, resulta interesante la lectura antropológica propuesta por Agudo Sánchiz, quien objeta la explicación linear de la violencia paramilitar, pero sin llegar a abrazar la interpretación de los intelectuales de derecha $^{42}$ (que respalda la posición del gobierno mexicano), para quienes los detonadores de la violencia fueron la dinámica intrínsecamente confrontadora de las estrategias zapatistas, o la

\footnotetext{
${ }^{42}$ Véase, por ejemplo, los textos de Hirales Morán o Aguilar Camín.
} 
naturaleza violenta de las relaciones entre los indígenas. En su investigación, desarrollada en comunidades bases de paramilitares de la Zona Norte, Agudo sostiene que las motivaciones estrictamente políticas de la violencia no explican la formación y la actuación de los grupos paramilitares, sino más bien hay proyectos e intereses particulares que se apropian o impugnan las categorías dominantes (zapatistas/perredistas/priistas/paramilitares). Según el autor, tensiones y divisiones sociales precedentes al levantamiento zapatista (por ejemplo las diferencias entre ejidatarios y no ejidatarios sin derechos agrarios, entre las generaciones o entre diversas percepciones religiosas, incluso entre los mismos católicos) se movilizaron al estallar el conflicto político y confluyeron en él. El conflicto en la Zona Norte de Chiapas albergaría entonces, en parte, disputas por la normatividad y el orden comunitario (normas sociorreligiosas que guían la reproducción, la salud y la educación; jerarquías, etc.) y esto explicaría por qué "mucha gente de la región chol, incluso aquellos directamente afectados por el conflicto de mediados de los años noventa, dieron sentido al mismo en términos de viejas percepciones sobre la violencia", como la 'envidia' y la 'brujería”" (2009: 479).

También académicos cercanos a la posición zapatista como Aubry e Inda subrayaron las desigualdades que atraviesan a la sociedad indígena como uno de los factores que permitieron la formación de los grupos de paramilitares en la zona de Los Altos. Éstos:

Aparecen casi exclusivamente entre jóvenes frustrados por las autoridades agrarias. En los 17 parajes de Chenalhó en que logramos documentar la existencia de unos 246 de ellos, la inercia agraria combinada con el crecimiento demográfico no da ni tierra ni trabajo, aun no agrícola, a los jóvenes en edad de ser derechohabientes del ejido. [...] Obligados a vivir como delincuentes, no sólo carecían de medio de subsistencia sino que, además, no tenían por qué sesionar en las asambleas y, por tanto, eran excluidos de las decisiones del ejido del que eran los parias. Primera conclusión, estos criminales son productos del sistema y de sus opciones económicas, agrarias y laborales. De repente, la "paramilitarización” les ofrece a la vez solución (económica) y prestigio (por las armas que llevan). ${ }^{43}$

Finalmente, investigaciones antropológicas con enfoque de género (Hernández Castillo et. al. 1998) abordan el impacto de la paramilitarización en Los Altos y Norte de Chiapas sobre las mujeres, mayormente afectadas, cuyo cuerpo se vuelve blanco fácil para la violencia, ejercida

\footnotetext{
${ }^{43}$ Andrés Aubry y Angélica Inda, “QQuiénes son los ‘paramilitares’?”, La Jornada, martes 23 de diciembre de 1997.
} 


\section{AUTONOMIAINDÍGENA, VIOLENCIAY JUSTICIA}

también como "castigo" para su creciente participación política; y afirman que la violencia paramilitar, sumándose a la violencia estructural ya existente en las comunidades alteñas, deviene en una estrategia etnocida (Hernández Castillo 2001).

\section{Zapatismo y conflicto agrario}

Para entender la evolución del conflicto en el estado y las configuraciones que tomaron las manifestaciones de la violencia, es necesario recordar que la cuestión agraria fue uno de los principales móviles de la insurrección (vimos como el problema agrario representó una creciente fuente de conflicto social en las décadas anteriores) ${ }^{44}$ y que a raíz del levantamiento se desató una ola de ocupaciones de tierras y latifundios, tanto por parte de comunidades ligadas al EZLN cuanto por integrantes de otras organizaciones, justificadas por la necesidad de tierra y por las reformas salinistas al art. 27 constitucional. ${ }^{45}$ Las recuperaciones de tierras de labor por parte de los zapatistas, sustentadas por la Ley Agraria Revolucionaria, sumaron aproximadamente 60.000 ha., en un total de casi 148.000 ocupadas en todo el estado entre 1994 y 1995 (Villafuerte 1999:131-134). ${ }^{46}$ Las tierras tomadas juegan un papel estratégico en el control de la zona de conflicto: son "territorio zapatista" y marcan el espacio de influencia y acción del movimiento. Fueron entregadas principalmente a jóvenes que en sus comunidades no gozaban de derechos ejidales, y que se mantienen firme en la militancia zapatista. En las tierras recuperadas adentro y alrededor del territorio selvático, se crearon decenas de nuevas comunidades.

\footnotetext{
${ }^{44}$ Reyes Ramos (2005: 55) analiza la evolución del conflicto y de la violencia agraria en Chiapas, diferenciando entre los dos conceptos: "el conflicto agrario lo captamos a través de las invasiones agrarias, denuncias, hostigamiento, amenazas, desalojos enfrentamientos y asesinatos, mientras que la operativización del concepto de violencia agraria la limitaremos a los siguientes indicadores: asesinatos y enfrentamientos físicos que provocan heridos. Y la observamos tanto desde los grupos campesinos que participan de una contienda por la tierra contra diversos actores sociales, como desde la violencia institucionalizada, es decir, aquella que se ejerce desde las estructuras del estado (ejército, policía), en tanto, que nuestro interés se centra en conocer los conflictos que devienen en violencia agraria y los participantes de los mismos".

${ }^{45}$ El 26 de febrero de 1992 se publicó en el Diario Oficial de la Federación el Reglamento en Materia de Certificación de Derechos Ejidales y Titulación de Solares, para que legalmente los ejidos y comunidades agrarias, a través de sus asambleas, "adopten las condiciones que más les convengan para destinar, delimitar y asignar las tierras que conforman su patrimonio", incluidas diversas formas de privatización parcial o total de sus tierras como el parcelamiento económico de tierras comunales, dominio pleno individual de parcelas ejidales (anteriormente solo era posible, para los ejidos, la propiedad colectiva, titulación de solares e incluso la desintegración de los ejidos en pequeñas propiedades.

${ }^{46}$ Los municipios donde se registraron más ocupaciones de tierras fueron Altamirano, Ocosingo y Las Margaritas (los tres en la zona Selva).
} 
Para desactivar el conflicto, el gobierno estatal, por medio del Fondo Chiapas 95, indemnizó a muchos propietarios de las tierras ocupadas y a través de los Acuerdos Agrarios promovió su titulación a nombre de los campesinos, y la consiguiente inscripción en el controvertido programa PROCEDE (hoy FANAR). ${ }^{47}$ El EZLN rechazó tal negociación parcial, pues consideraba necesario debatir el tema en un nivel más amplio, ${ }^{48}$ como un importante capítulo de los Diálogos de San Andrés, que nunca se realizó. No obstante, el gobierno indemnizó de todas maneras a muchos propietarios de las tierras ocupadas por el EZLN, y en los años siguientes, como parte de la estrategia contrainsurgente, fue otorgando a otras organizaciones los títulos de tierras ocupadas y cultivadas por zapatistas, lo que sigue ocasionando una miríada de conflictos agrarios entre organizaciones, ejidos y grupos de campesinos indígenas. Estos pequeños, constantes y muy violentos conflictos ligados al derecho a la tierra y al control de los recursos (agua, bosques, grava) todavía representan (2014) una de las principales causas de violencia intercomunitaria, ${ }^{49}$ particularmente en la región de la Selva, y de los principales problemas que deben enfrentar las autoridades civiles zapatistas (Juntas de Buen Gobierno).

\footnotetext{
${ }^{47}$ Según la Secretaría de la Reforma Agraria, "el Programa de Certificación de Derechos Ejidales y Titulación de Solares, PROCEDE, es un instrumento que el Gobierno de la República pone al servicio de los núcleos agrarios para llevar a cabo la regularización de la propiedad social. El objetivo principal del Programa es dar certidumbre jurídica a la tenencia de la tierra a través de la entrega de certificados parcelarios y/o certificados de derechos de uso común, o ambos según sea el caso, así como de los títulos de solares en favor de los individuos con derechos que integran los núcleos agrarios que así lo aprueben y soliciten", <http://www.sct.gob.mx/obrapublica/MarcoNormativo/3/3-3/3-3-5.pdf>, consultado el 20 de junio 2014. Es el instrumento para la implementación de la contrarreforma al artículo 27 de la Constitución (cfr. nota 39). A partir de 2007, cambió su nombre en FANAR (Fondo de Apoyo para Núcleos Agrarios sin Regularizar).

${ }^{48}$ Sus propuestas políticas siempre buscaron tener un alcance nacional; en ese caso, a la problemática originada por la contrarreforma al art.27 constitucional.

${ }^{49}$ De los conflictos analizados por Reyes Ramos (2005) en el periodo 1996-2003, casi la mitad se vincula con situaciones extremas de violencia.
} 


\section{AUTONOMIA INDÍGENA, VIOLENCIAY JUSTICIA}

\section{Chiapas en el siglo XXI: desarrollismo estatal, resistencia indígena}

\section{Fragmentación comunitaria e violencia política}

A partir del año 2000 la estrategia gubernamental hacia el EZLN y sus bases de apoyo se ha parcialmente modificado. En 2001, se reubicaron y retiraron parte de los efectivos militares presentes en el estado, y los grupos paramilitares disminuyeron sus acciones, mas no desaparecieron.

Según el Centro de Derechos Humanos Fray Bartolomé de Las Casas, bajo el gobierno de Pablo Salazar Mendiguchía inicia la tercera etapa de la guerra, disfrazada por los gobiernos federal y estatal de "respeto" hacia el proyecto zapatista. En este contexto, más que armar a grupos paramilitares, el Estado favoreció la confrontación de comunidades y organizaciones por medio de programas sociales, por un lado condicionados a la lealtad política, por el otro implementados con arrogancia en las regiones controladas por el EZLN, que rechaza toda relación y apoyo con el gobierno. "La aplicación de éstos se convierte en estrategia contrainsurgente, a través de la cooptación de dirigentes sociales e instrumentalización de las organizaciones de las que son parte, reduciendo su trabajo en gestores de proyectos de gobierno de las comunidades con intereses partidarios y prebendas políticas" (CDHFBC 2012: 86).

El conflicto, inicialmente protagonizado por el EZLN y el Ejército (y sus aliados ganaderos-caciques-paramilitares-políticos y militantes locales del PRI), se amplía con la intervención -dirigida desde los espacios de poder- de los dirigentes y militantes de los otros partidos (PRD, PAN, y más recientemente el Partido Verde), los integrantes de las organizaciones campesinas, disputándose la hegemonía en una comunidad, municipio o región, el control de los recursos (tierra, agua, bosques, bancos de grava o arena) y de las actividades económicas (comercio, transporte sobre ruedas, turismo). Los actos violentos o coercitivos combinan acciones de corte paramilitar, junto con la ejecución de sentencias o procedimientos judiciales (agrarios y/o penales) como dos estrategias hacia los conflictos agrarios, en abierta confrontación con el proyecto autonómico de las Juntas de Buen Gobierno.

Esta mirada en la raíz política del conflicto es importante cuando observamos la trayectoria y evolución de los grupos paramilitares, hasta aproximadamente el año 2000 
emanados del PRI o de partidos cercanos a él, y luego acompañados por grupos de choque de organizaciones anteriormente no enfrentadas al proyecto zapatista, o incluso aliadas al EZLN en sus inicios (sobre todo en la coyuntura de la toma de tierras en 1994 y en el respaldo del Gobierno en Rebeldía). Mientras en los años noventa los grupos paramilitares eran formaciones claramente instrumentadas por el Ejército y los grupos de poder regionales en contra del EZLN y organizaciones cercanas a él (por ejemplo Las Abejas), en los años dos mil asistimos a la paramilitarización de sectores de organizaciones campesinas de base. La estrategia se basa en la creación de nuevos conflictos agrarios, enfrentando organizaciones que en 1994 participaron en las tomas de tierras junto con los zapatistas, como parte de un acuerdo comunal. El gobierno encabezado por Salazar impulsó la titulación de las tierras como condición para el otorgamiento de programas asistenciales, lo que desató violentos conflictos pues los zapatistas rechazan tanto la negociación con el gobierno, cuanto la titulación a un grupo y la parcelización de las tierras recuperadas colectivamente para su uso comunitario.

Porque ahora no usan soldados, ni policías, usan indígenas de pequeñas organizaciones para que nos provoquen en nuestra organización para enfrentamos entre indígenas. Durante años han ejecutado millones de pesos queriéndonos destruir para regalarles nuestra tierra, de acabar nuestra costumbre, nuestro lengua (Denuncia del Caracol IV Morelia, 18 agosto 2011).

En este contexto se ubican las agresiones, denunciadas al menos desde 2001 por las autoridades zapatistas, ${ }^{50}$ hacia las comunidades y bases de apoyo zapatistas por parte de organizaciones campesinas como la Organización Regional de Cafeticultores de Ocosingo, ORCAO (Caracoles de La Garrucha y Morelia); Asociación Rural de Interés Colectivo, ARIC, en sus dos divisiones, Oficial/Histórica e Unión de Uniones-Independiente (Caracol de La Garrucha); Unión de Ejidos de la Selva, UES (Caracol de La Realidad); Central Independiente de Obreros Agrícolas y Campesinos, CIOAC (Caracoles de Morelia y La Realidad), Xi’ Nich Oficial (Caracol de Roberto Barrios). Agresiones perpetradas, en muchas ocasiones, con el apoyo de cuerpos de policía, por lo que se puede inferir un proceso de paramilitarización de sectores de dichas organizaciones. ${ }^{51}$

\footnotetext{
${ }^{50}$ Véase los comunicados de los Municipios Autónomos difundidos por Enlace Civil A.C. y las denuncias de las Juntas de Buen Gobierno (desde 2006 a la fecha), en 〈www.enlacezapatista.ezln.org.mx>.

${ }^{51}$ Muestra de este tipo de conflicto es la agresión a bases de apoyo zapatistas del Caracol de la Realidad por parte de militante de la CIOAC-Histórica, el 2 de mayo 2014 en la que fue asesinado el zapatista José Luis López,
} 


\section{AUTONOMIAAINDÍGENA, VIOLENCIAY JUSTICIA}

Esta situación muestra una creciente polarización de la sociedad en las Cañadas de la Selva, donde el proyecto zapatista va perdiendo en parte su fuerza representativa y va menguando el número de sus bases de apoyo, lo que genera en las comunidades el enfrentamiento de muchos grupos minoritarios cuando anteriormente el consenso hacia la posición política mayoritaria (la zapatista) garantizaba la gobernabilidad y la resolución pacífica de los conflictos que se originaban. Se han multiplicado las líneas de división en las comunidades, antes articuladas en la dicotomía principal priistas/zapatista; este mayor pluralismo de adscripciones y militancias, en un contexto que sigue siendo de guerra y de cooptación, genera una mayor violencia, incluso intracomunitaria, por la imposibilidad de resolver las diferencias de manera dialéctica.

Por otra parte, a partir del año 2005 en la Zona Norte del estado, en las Cañadas de Ocosingo (hacia la zona norte de la Reserva de los Montes Azules), y en la Cañada de Morelia (Altamirano), se ha fortalecido la Organización Para la Defensa de los Derechos Indígenas y Campesinos (OPDDIC), de claro corte paramilitar (se ha reconocido su filiación del grupo MIRA), aunque formalmente constituida como Asociación Civil. Según el CDHFBC, dicha organización ha generado un elevado repunte de la violencia intercomunitaria; actúa en concomitancia con los grupos de poder y las instancias de gobierno local:

Cooptando personas que son bases de apoyo zapatistas con el ofrecimiento de tierras, proyectos productivos y recursos oficiales. De modo táctico desarrolla una gestión de tierras con agentes de instituciones oficiales, que con pleno conocimiento de la situación social en el Estado, se prestan a esta dolosa forma de adjudicación de tierras. Su dirigencia se encarga de hacer el trabajo de hostigamiento y amenazas para el despojo de los predios que ha ofrecido a sus miembros (CDHFBC 2007:43).

Las violencias “ocultas” del neodesarrollo y el asistencialismo

El gobierno de Juan Sabines Guerrero (2006-2012), abanderado por el PRD, mantuvo una continuidad en lo que respecta a la estrategia destinada a contener y desactivar el proyecto y

Galeano. El 30 de enero 2014, a raíz de un conflicto agrario, integrantes de la CIOAC-Democrática arremetieron contra bases de apoyo zapatistas en la comunidad 10 de abril, Municipio Autonomo 17 de Noviembre (Altamirano). Véase las denuncias de la Juntas de Buen Gobierno en la página <www. http://enlacezapatista.ezln.org.mx/> 
las prácticas de autonomía zapatista, cooptando líderes y bases civiles, manteniendo la impunidad de las autoridades involucradas en violaciones a los derechos humanos, $\mathrm{y}$ criminalizando las víctimas de dichas violaciones, en un mecanismo en que las autoridades responsables de procurar y administrar justicia se colocan de parte de los perpetradores y convierten en sujetos de investigación a las propias víctimas. Como elemento de novedad, el gobierno del estado implementó agresivas políticas de desarrollo económico, con el objetivo declarado de sacar al estado de su "ancestral rezago" y eliminar la marginación, lo que extinguiría, según la lectura institucional, los múltiples conflictos que atraviesan la entidad.

El gobierno de Sabines tuvo como lemas para su política estatal la solidaridad y la competitividad. El primer concepto se tradujo en políticas de contención de la insurgencia social, vueltas a apaciguar los conflictos políticos y agrarios, aunque con discutibles resultados, precisamente porqué las políticas de desarrollo económico y aprovechamiento ambiental contribuyen a aumentar la desigualdad y los conflictos. Los Objetivos del Milenio de las Naciones Unidas se adoptaron como ejes rectores en el Plan Estatal de Desarrollo; sin embargo, el uso retórico de este discurso se hace patente en las actividades impulsadas que siguen siendo de muy corto alcance (la Cruzada para la Erradicación de la Pobreza, antecedente de la actual Cruzada Nacional Contra el Hambre, se concretaba en brigadas de observación que entregaban en las comunidades un paquetes de vitaminas y antiparasitarios; el Programa Anticrisis financiaba pequeñas actividades económicas familiares; etc.). La reiterada y omnipresente propaganda estatal pregonaba un prioritario interés en los derechos humanos, ${ }^{52}$ y buscaba lucir al estado que gobernaba para el desarrollo y según los Objetivos de la ONU; la apropiación del discurso de los derechos humanos desde los espacios del poder tuvo el objetivo de invisibilizar la permanencia de la guerra, de los conflictos, de la violencia estructural e, incluso, el aumento de las violaciones mismas, como si fuera un espejo que refleja la misma imagen de quién mira pero oculta la realidad que está al otro lado de él. En Chiapas se pueden observar los efectos negativos de los programas focalizados de atención a la pobreza, que discutí en el capítulo 2: en este caso, se trata de programas que mantienen un

\footnotetext{
${ }^{52}$ Un ejemplo son los premios otorgados al gobernador: "Reconocimiento de la ONU al gobernador JSG, aval de la política pública contra la pobreza en Chiapas", Diario Tribuna de Chiapas, 26 de octubre, disponible en: <http://www.diariolatribunadechiapas.com.mx/index.php?option=com_content\&task=view\&id=35644>; "Galardonan con "Héroe por los Derechos Humanos 2011" a JSG", El Heraldo de Chiapas, 29 de agosto 2011, en <http://www.oem.com.mx/elheraldodechiapas/notas/n2205737.htm>.
} 


\section{AUTONOMIAAINDÍGENA, VIOLENCIAY JUSTICIA}

corte asistencialista, pero que canalizaron una derrama económica importante, en el intento de "ahogar" a las comunidades entre la alternativa del ofrecimiento de apoyos y programas, por un lado, y la represión, por el otro.

El otro lema del gobierno perredista, la competitividad, busca posicionar el estado en el escenario de la economía nacional e internacional, impulsando la comercialización de todos los recursos (humanos, ambientales, culturales, productivos) que se encuentran en el territorio chiapaneco. En el Encuentro Tejiendo Resistencia y Autonomía Frente a la Contrainsurgencia y la Dependencia, que se realizó en Acteal el 21 de diciembre de 2010, se reflexionó sobre cómo y por qué el gobierno quiere imponer a los pueblos políticas públicas y proyectos de "desarrollo" específicos:

Con su estrategia contrainsurgente y de represión y de apoyos, el gobierno nos quiere volver dependientes, como que nos quiere hacer pensar que no somos capaces de vivir trabajando con nuestras propias manos. Nos quiere acostumbrar a ser mantenidos, le quita a la gente el gusto y el ánimo de trabajar. Quiere que nuestra tortilla no sea el fruto de nuestro trabajo y de la madre tierra, sino que sea su regalo transgénico y que sólo al gobierno agradezcamos y respetemos.

Esta política de desarrollo tiene diversas vertientes, entre ellas el fomento a los monocultivos comerciales y la agroindustria, la extracción de combustibles fósiles en la Selva Lacandona, la concentración de comunidades en las nuevas Ciudades Rurales, ${ }^{53}$ el desarrollo de la infraestructura de comunicación, y un sorprendente impulso al aprovechamiento turístico de casi todas las regiones del estado.

A partir de 2010, se ha impulsado un megaproyecto turístico llamado Centro Integral Palenque (CIPP), que involucra seis municipios de la Zona Norte: Catazajá, Chilón, Ocosingo, Salto del Agua, Tumbalá y Palenque, financiado por la Organización Mundial de Turismo (OMT), la Fundación OMT-Themis, con sede en Andorra, así como los gobiernos estatal y federal. Una red vial eficiente, rápida y capilar que permita alcanzar todos los destinos turísticos, así como un importante número de aeropuertos funcionado, son condición necesaria para alcanzar la anhelada competitividad en el sector. A raíz del proyecto, que implica un alto

\footnotetext{
53 “El gobierno de Chiapas, durante el sexenio de Juan Sabines, creó programas e instituciones para el 'combate a la pobreza y el apoyo a las comunidades indígenas y campesinas en Chiapas'. Primero con la creación del Instituto de Ciudades Rurales Sustentables y actualmente a través del Instituto de Población y Ciudades Rurales" (CDHFBC 2012:25).
} 
costo social y ambiental debido al despojo de tierras ejidales para la construcción de una autopista entre San Cristóbal y Palenque, se han generado violentos conflictos entre ejidatarios bases de apoyo zapatistas o adherentes a la Otra Campaña, que se oponen al proyecto, y grupos favorables: es el caso de las comunidades de Mitzitón, donde el conflicto tomó un tinte religioso, o de Agua Azul/Bachajón, en el que la implicación de la OPDDIC tuvo como resultado al menos tres opositores asesinados entre 2012 y 2014, y la intervención de las fuerzas de seguridad pública devino en violentos desalojos y la encarcelación de decenas de ejidatarios.

La tendencia de las políticas públicas en este campo es esbozada en el Plan Chiapas Solidario 2007-2012, proyecto de gobierno del mandatario perredista Sabines. En el eje 3, llamado "Chiapas competitivo y generador de oportunidades", se considera que "el turismo es uno de los principales sectores productivos, sin embargo, aún se requieren proyectos y acciones institucionales que impulsen su consolidación como polo de desarrollo, y conviertan al turismo en una actividad económica estratégica para el estado". Esta visión ha sido impulsada por una amplia parte de la clase política y empresarial chiapaneca, y en particular por el ex gobernador Roberto Albores Guillen, promotor de la "Declaración de Comitán”, documento suscrito, entre otros, por el entonces candidato a gobernador Juan Sabines, en 2006. En el documento se propone "construir un nuevo Cancún en el norte de Chiapas [...] un programa turístico integral que comprenda Palenque, Agua Azul, Misol-ha Toniná, Yaxchilán, Bonampak y Playas de Catazajá”.

Es evidente el interés de las instituciones y de la iniciativa privada para aprovechar tal potencial, ya que en el mencionado Plan Chiapas Solidario tiene apartados específicos para el "Turismo responsable y el ecoturismo" y el "Desarrollo turístico de la Selva Lacandona". Aquí se menciona la importancia de "definir un corredor ecoturístico y de turismo responsable y desarrollar una imagen corporativa del ecoturismo para el estado”.

El gobierno de Manuel Velasco Coello (quien asumió la gubernatura en 2012), joven exponente de la élite chiapaneca, abanderado por el Partido Verde Ecologista de México (PVEM) y muy cercano al contemporáneo presidente de la República, Enrique Peña Nieto, prosigue en la línea trazada por su antecesor en la mercantilización de la riqueza cultural y natural del estado. Los cuatro ejes del Plan Estatal de desarrollo 2013-2018 son emblemáticos para definir la visión política de Velasco. El "Gobierno cercano a la gente” define políticas en 


\section{AUTOONOMIIAINDÍGENA, VIOLENCIAY JUSTICIA}

el campo de la migración, la seguridad y la justicia, sin mencionar en ningún momento la situación de conflicto y el proyecto de autonomía zapatista (en todo el informe no se encuentra ni una sola referencia a ello, concluyéndose así el proceso de invisibilización por parte de las autoridades). No fue probablemente casual la elección de Las Margaritas, en el corazón de la zona donde desde hace dos décadas los zapatistas están construyendo un modelo de sociedad y de economía alternativos, para la presentación de la Cruzada Nacional Contra el Hambre (2013), iniciativa cosmética e insuficiente frente a la realidad de explotación y despojo que está a la base de las carencias entre amplios grupos de población. El eje dedicado a las políticas de salud y educación lleva el emblemático título de "Familia Chiapaneca", término acuñado ya en el siglo pasado para definir el reducido grupo de familias que controlaban, en beneficio propio, la política y la economía del estado, y que expresa "la unidad formal de la clase propietaria" (García de León 1985: 150). El guiño a la oligarquía de la que es parte y para quién gobierna Velasco es tan evidente hasta aparecer burdo. Los dos ejes siguientes, "Chiapas exitoso" y "Chiapas sustentable", constituyen una unidad donde se enfatiza la competitividad que deberían tener por igual la producción, el turismo y la cultura, en una exacerbada perspectiva neoliberal y economicista. En esto, la Selva Lacandona y sus múltiples riquezas juegan un papel fundamental.

\section{La Selva, las Cañadas y la zona Fronteriza: militarización, conservación y explotación}

La región que conforman la Reserva de la Biosfera de los Montes Azules, la Zona Lacandona y las otras reservas incluidas, juntos con sus alrededores, es actualmente objeto de una estrategia de conservación/explotación impulsada conjuntamente por las instituciones gubernamentales y la iniciativa privada. El discurso ambientalista conservador pregona la necesidad de preservar la integridad de la Selva Lacandona (o lo que de ella queda después de al menos un siglo de agresivo despojo por parte de corporaciones e industrias extractivas), lo que justificara la necesidad de "despejar" el territorio de toda presencia antrópica (indígenas migrantes, desplazados, pequeños campesinos, etc.). Por otra parte, la única actividad "ambientalmente compatible" sería el ecoturismo, que bajo esta visión está recibiendo un fuerte impulso. Las empresas e instituciones que impulsan los programas de conservación son 
las mismas que administran los proyectos "ecoturísticos". ${ }^{54}$ Según la visión institucional, "la amplia riqueza natural de Chiapas acentuada en la región Selva implica un enorme potencial para el desarrollo de las actividades turísticas, que en contraste con los niveles de marginación y pobreza de la región, permitirían generar mayor productividad y empleo" (Plan Estatal de Desarrollo 2006-2012).

En las regiones rurales y selváticas, cuyos habitantes son en su casi totalidad campesinos e indígenas, en lugar de promover la agricultura de autoconsumo (que practica la gente) y fortalecer su sustentabilidad, se propone activar la economía en el campo de los servicios. El modelo para la región selvática es el "ecoturismo", pregonado como éticamente justo y ambientalmente amigable, aunque varios estudios (Machuca 2008, Velasco 2011) denuncian que la cuestión ecológica y sustentable es frecuentemente un maquillaje para centros turísticos que no proponen una relación respetuosa con la población local ni con el medio ambiente. ${ }^{55}$ Actualmente en la región existen por lo menos 13 centros ecoturísticos, y muchos atractivos naturales que se están promoviendo para que sean visitados. Se está desarrollando rápidamente la infraestructura carretera (la construcción de la Carretera Fronteriza, con objetivos militares, ha sido el primer paso en este sentido), mientras se siguen realizando desalojos de comunidades indígenas y campesinas que viven y trabajan la tierra adentro del área protegida.

La presencia militar en la región se ha mantenido elevada, por ser considerada una zona estratégica tanto en la guerra contrainsurgente cuanto por los diferentes intereses de aprovechamiento de la Reserva, que van desde proyectos turísticos, ${ }^{56}$ de explotación del patrimonio biogenético por parte de corporaciones "científicas" trasnacionales, ${ }^{57}$ o de extracción petrolera. $^{58}$

\footnotetext{
${ }^{54}$ Entre las instancias privadas, destacan WWF y la Fundación Carlos Slim; la organización Natura y Ecosistemas Mexicanos; entre las instituciones, la Secretaría de Agricultura, Ganadería, Desarrollo Rural, Pesca y Alimentación, la Secretaría de Medio Ambiente y Recursos Naturales y el Gobierno del estado de Chiapas. Véase <http://www.carlosslim.com/pdf/wwf/fs15-chiapas-lacandona.pdf>, consultado el 20 de noviembre de 2014.

${ }^{55}$ Véase también -"El ecoturismo en Chiapas: Otro engaño a las comunidades indígenas", Maxime Kieffer Asociación EchoWay, Francia, Boletín CIEPAC, 09agosto-2006 - num.514

${ }^{56}$ Como los hoteles de lujo instalados en Estación Tzendales, Las Guacamaya, Chajul, Las Nubes, El Pirú, disfrazados de estaciones para trabajo de investigación científica.

${ }^{57}$ Incluido en el PRODESIS e impulsado por la Agencia de Cooperación Alemana por el Desarrollo Sustentable GIZ.

${ }^{58}$ La zona oriental de la Selva es rica en yacimientos petrolíferos, al igual que la ya explotada región de Marqués de Comillas. En 2008, la Secretaría de Energía afirmó la inminente explotación de yacimientos al interior de la
} 


\section{AUTONOMIAINDÍGENA, VIOLENCIAY JUSTICIA}

En lo que corresponde a la violencia abiertamente ejercida por el Estado, en la zona de la Selva que se identifica con la RIBMA y las regiones aledañas (Cañadas de Las Margaritas y parte meridional de las Cañadas de Ocosingo), ésta se ha manifestado mayormente en términos militares, ${ }^{59}$ mientras el conflicto agrario más violento también enfrenta a las comunidades directamente con las instancias del Estado y las corporaciones paraestatales o privadas que éste favorece.

Por lo que corresponde a la militarización, es conocida la lucha de la comunidad zapatista de Amador Hernández, ubicada en los linderos de la Reserva, en contra de un campamento militar que entre 1999 y 2000 se instaló ocupando las tierras ejidales; se hizo manifiesto el uso de recursos y de la retórica del desarrollo con fines militares (en lo específico, para la construcción de la carretera desde el cuartel de San Quintín hacia Amador Hernández).

Una de las causas principales de violencia en la región es el conflicto abierto alrededor de la RIBMA y de la Comunidad Lacandona (conflicto por la Brecha), ${ }^{60}$ ya que los núcleos agrarios y asentamientos que se encuentran en su interior son considerados "irregulares" $\mathrm{y}$ destinados al desalojo o la reubicación, en aras de la conservación del excepcional espacio natural de la Selva, amenazado por las actividades antrópicas. Siendo necesarias acciones contundentes que frenen la explotación de los recursos en la región, habría que priorizar el peligro ambiental representado por la extracción petrolera, la ganadería extensiva, la tala de maderas preciosas y los monocultivos para generar biocombustibles. Sin embargo, las jugosas ganancias, licitaciones, porcentajes y mordidas que ofrecen estas actividades a las instituciones y sus funcionarios, ${ }^{61}$ justifican que se sigan permitiendo, mientras se persiguen a los campesinos que, en el marco de una agricultura de subsistencia, utilizan unas cuantas hectáreas de Selva, a la que son empujados también por el despojo de tierras realizado por las

Selva (www.jornada.unam.mx/2008/11/24/index.php?article=017n1pol\&section=politica), noticia luego solo parcialmente desmentida (http://www.proceso.com.mx/?p=203682).

59 Según el CDHFBC, “en los casos denunciados durante el año 2000 en la Selva, a diferencia de otras regiones, las amenazas e intimidaciones a los pobladores por parte del Ejército y las diferentes policías ocuparon número más alto" (2001:61).

${ }^{60}$ El territorio de la Reserva corresponde por el $75 \%$ con la Comunidad Lacandona; esta se extiende más hacia el oriente, incluyendo otras seis Áreas Naturales Protegidas.

${ }^{61}$ Como ejemplo, sirve mencionar a la ex titular de la SEMARNAP 1994-2000, Julia Carabias, quien participa en "asociaciones civiles" como Espacios Naturales y Desarrollo Sustentable (Endesu) y Natura Mexicana, impulsoras de grandes proyectos de desarrollo turístico y de hoteles de élite en sus "estaciones científicas", financiados con fondos públicos. 
mismas industrias mencionadas. A esto se añade la falta de políticas públicas de planeación y desarrollo, y la persistencia de la militarización y las acciones represivas por parte del gobierno estatal. ${ }^{62}$

Muchos asentamientos en la Reserva se establecieron hace varias décadas, mientras diez son recientes; la mayoría los integran desplazados de la guerra sucia, a partir de $1995 .{ }^{63}$ Valga como ejemplo el caso de Guadalupe Tepeyac, comunidad zapatista que en 1995 se desplazó tras la ocupación del Ejército; parte de sus habitantes fueron acogidos en comunidades aledañas, otra parte, conformada por jóvenes sin derechos ejidales, en 1998 fundó Nuevo Guadalupe Tepeyac, ahora amenazados de "reubicación". Se han registrado varios poblados más creados por desplazados de la violencia paramilitar. ${ }^{64}$ Según la organización ambientalista Maderas del Pueblo, en 2002 se contabilizaban 45 poblados al interno de la Comunidad Lacandona y de la RIBMA, y por lo tanto considerados irregulares; al menos ocho comunidades son reconocidas como zapatistas.

En el año 2000 las instituciones federales anunciaron el desalojo de los 19 poblados ubicados en la parte de la Reserva que corresponde a la Comunidad Lacandona, en parte tras la presión de fundaciones conservacionistas internacionales; de los cuatro poblados reubicados el mismo año, dos volvieron rápidamente a poblar la Reserva, debido a la mala calidad de las tierras asignadas (municipios Independencia y Trinitaria). En otro caso (2004), los ejidatarios de Marqués de Comillas, región donde se pretendía reubicar la comunidad Santa Martha, se

\footnotetext{
${ }^{62}$ Ya desde 1987 Siegried Dichtl evidenciaba las contradicciones entre las políticas públicas, los intereses económicos y las necesidades de los campesinos.

${ }^{63}$ La nueva ofensiva desatada contra de los pobladores de la Selva, con amenazas de desalojo bajo el cargo de delitos ambientales y con el propósito de conservación, se dirige contra 32 asentamientos situados en la Comunidad Lacandona, en la RIBMA, o en ambas. La problemática de cada uno tiene diversos orígenes. Diez de los 32 ejidos amenazados están totalmente regularizados: 8 cuentan con dotaciones presidenciales ejecutadas y 2 con otro tipo de acuerdos legales; 4 fueron oficialmente dotados antes del decreto a favor de la comunidad lacandona y de la reserva. Otros 6 fueron oficialmente titulados a finales de los ochenta. Cinco ejidos más constituidos oficialmente- solicitaron superficies complementarias, entre otras razones porque sus Resoluciones presidenciales se ejecutaron sólo parcialmente. Cinco casos son ejidos viejos, legalmente constituidos, que solicitaron ampliación debido al crecimiento natural de la población, que fue rechazada. Al menos en dos casos la negativa gubernamental tardó 7 y 10 años. Dos asentamientos solicitaron con anterioridad regularizar su situación agraria, la cual se rechazó.

${ }^{64}$ Lagunas el Paraíso (Ocotal); Lagunas Suspiro (Semental o Iñaki); Nuevo San Pedro (Innominado o Suspiro), fundadas en 1995 por desplazados del grupo MIRA; Nuevo Pichucalco (2001) y Nuevo Cintalapa (1995), debido a divisiones intercomunitarias entre los zapatistas y la ARIC UU-ID; Nuevo Limar (2000), habitados por desplazados de la comunidad El Limar, enclave de los paramilitares Paz y Justicia; Sol Paraíso (2001), habitada por desplazados zapatistas de Chenalhó, 8 de febrero (2002, después dividido en Nuevo San Rafael y San Isidro, 2003), con población zapatista desplazados del municipio de El Bosque, y (Maderas del Pueblo 2003).
} 


\section{AUTOONOMIIAINDÍGENA, VIOLENCIAY JUSTICIA}

opusieron debido a los conflictos agrarios ya existentes y que serían agraviados por la creación de un nuevo ejido. ${ }^{65}$

Entre 2003 y 2012, 43 de los 45 poblados fueron sometidos a reubicación forzosa. Bajo el gobierno encabezado por el "Héroe de los Derechos Humanos", Juan Sabines, se llevaron a cabo los desalojos más violentos, iniciando por el desplazamiento, que culminó en masacre, de la comunidad de Viejo Velasco, situada al interior de la RIBMA. El 13 de noviembre 2006, un grupo de civiles, parte afiliados de la OPDDIC y parte comuneros de la Comunidad Lacandona (Nueva Palestina), acompañados por 300 elementos de la entonces Policía de Seguridad Pública, irrumpieron en Viejo Velasco con un saldo de 7 muertos, 2 desaparecidos y 36 desplazados, hechos que siguen impunes. Esta acción es muestra de uno de los graves conflictos sociales y políticos desde hace años presentes en la región: la hostilidad -que se expresa muchas veces en violencia- de los integrantes de la Comunidad Lacandona hacia los habitantes de los demás poblados. He mencionado como, ya desde 1972, los "lacandones" (indígenas caribes de Lacanjá, Najá y Metzabok, pero también los tzotziles y tzeltales reubicados en Nueva Palestina y Frontera Corozal) han sido cooptados por las instituciones y utilizados como operadores gubernamentales en la región, avalando como "decisiones comunitarias" los proyectos impuestos, en particular aquellos ligados al aprovechamiento turístico del territorio. Recientemente, unos integrantes de la Comunidad Lacandona, también desalojados y arrestados por instalarse en la RIBMA, difundieron un documento en el que se declara:

En el 2008 después de analizar una serie de irregularidades por parte del sector agrario y ambiental decidimos por orden de la asamblea general buscar con los pueblos hermanos una reconciliación firme respetando los derechos de ambos, desafortunadamente por confiar en las instituciones ambientales y agrarias que de mala fe nos confrontaron con otros pueblos creyendo que su intención era buena, pero al final nuestro análisis nos ha llevado a que siempre han lucrado con nuestra comunidad lacandona y que siempre seamos obedientes a sus decisiones y propósitos comerciales. ${ }^{66}$

\footnotetext{
65 <www.frayba.org.mx/archivo/boletines/040923_reubicaciones_montes_azules.pdf>

${ }^{66}$ Noviembre 2013, en <http://www.geopolitica.ws/media/uploads/comunidad_lacandona.pdf>
} 
El 18 de agosto de 2007, pocos meses después de lo acontecido en Viejo Velasco, se realizó un operativo simultáneo para desplazar forzadamente a las comunidades El Buen Samaritano y Nuevo San Manuel (o Nuevo Salvador Allende), en el municipio de Ocosingo, asentadas dentro de la RIBMA. Las violaciones a los derechos humanos perpetradas en el operativo (arresto de cinco personas sin orden de aprehensión, "secuestro" y desplazamiento de los habitantes), han sido denunciadas por el CDHFBC (2007) y la Junta de Buen Gobierno de La Realidad, en cuya jurisdicción se encontraban la comunidad zapatista de San Manuel. Mientras los desplazados fueron obligados a permanecer en una bodega no habitable en la ciudad de Ocosingo, la Junta se pronunció por la resolución del problema: "esta Junta de Buen Gobierno ya tiene lugar donde va a colocar a nuestros compañeros y compañeras que fueron violentamente desalojados. Estamos ya esperándolos para que ya vengan a trabajar y a vivir con nosotros en el lugar donde les vamos a dar y dejen ya de estar enchiqueradas en la casa bodega en Ocosingo". ${ }^{67}$

Sucesivamente, 21 y 22 de enero del 2010 se perpetró el desalojo forzado de las comunidades Laguna El Suspiro o El Semental y Laguna San Pedro o San Pedro Guanil, en el municipio de Ocosingo, ésta última BAEZLN. Esto coincidió con el anuncio, por parte de autoridades ambientales estatales y federales, del impulso al turismo "de naturaleza" en la zona. En tal contexto, la Junta de Buen Gobierno de la Zona Selva Fronteriza expresó una clara postura de defensa del territorio:

Como EZLN no permitiremos un desalojo más, no vamos a tolerar estas acciones y mucho menos que no vamos a dejar; vamos a defender nuestras tierras pase lo que pase, porque para nosotros la tierra, no se renta, no se alquila y mucho menos lo ponemos como un objeto de venta. $^{68}$

En el mes de abril del 2014, las tres comunidades que quedaron en la RIBMA y en la Comunidad Lacandona y amenazadas de desalojo, San Gregorio, Ranchería Corozal y Salvador Allende, pertenecientes a la ARIC UU-ID, llegaron a un acuerdo con los representantes de la Comunidad Lacandona, quienes aceptaron reconocer los derechos agrarios de los tres poblados al interior de la Zona Lacandona. El acuerdo es un paso

\footnotetext{
${ }^{67}$ Comunicado del 10 de septiembre 2007.

${ }^{68}$ Comunicado, 2 de mayo del 2010, en www.enlacezapatista.org.mx.
} 
importante para la solución de un conflicto existente desde hace 35 años, sin embargo, el gobierno estatal lo rechazó tajantemente afirmando que "no podrán regularizarse los asentamientos irregulares existentes dentro de la Reserva de la Biosfera Montes Azules". 69

Siendo los desalojos las acciones más visibles, la acción del gobierno en la región ha sido errática y supeditada a voluntades políticas e intereses comerciales. La política de desarticulación por medio de programas sociales otorgados a discreción por parte de las instituciones gubernamentales (lo que los zapatistas llaman "las migajas del mal gobierno"), fue implementada en la Selva ya desde 1995, con el pionero Programa de Las Cañadas. En el marco del programa, operado por la Secretaría de Desarrollo Social (SEDESOL) con financiamiento del BM, se establecieron 23 Centros de Atención Social (ubicados en comunidades estratégicas y acompañados por la presencia del Ejército, al igual que los “comedores" instalados en 2014 en la Montaña de Guerrero, en el marco del más recién programa de Cruzada Nacional Contra el Hambre). Los programas, de corte paternalista (distribución de despensas, apoyos materiales, etc.) y principalmente dedicados a la construcción de carreteras, trataron de minar las bases sociales de apoyo del movimiento zapatista y de esa forma aislar al EZLN. ${ }^{70}$ El Programa Cañadas ha sido denunciado como "contrainsurgente", pues fortaleció a las organizaciones que, a diferencia del EZLN, aceptaron de buena manera la negociación con el gobierno, aún en un contexto de guerra abierta. En la Selva, una fracción de la ARIC (desde ese momento denominada "oficial") fue el principal aliado en la estrategia gubernamental, logrando por sus pronunciamientos antizapatistas un ingente apoyo económico y político institucional.

Carlos Montemayor, analizando las condiciones para la emergencia y la recurrencia de la guerrilla, afirma que "reconocer la dinámica social como uno de los componentes de los movimientos armados rurales obliga, en principio, a programas gubernamentales de desarrollo que solucionen o atenúen carencias sociales en la zona". Sin embargo, dichos programas de desarrollo pueden implementarse con objetivos radicalmente distintos: "para evitar cualquier surgimiento de movimientos armados en el futuro", pensando en un cambio social a profundidad y aplicándolos paralelamente a una negociación política; o bien "para doblegar de inmediato a un solo y concreto grupo armado", incluso enfrentando a éste los proyectos de

\footnotetext{
${ }^{69}$ Pronunciamiento del Gobierno del Estado, 12 de mayo 2014.

70 Arturo Warman, destacado antropólogo y ene se entonces funcionario del INI, defendió la presunta "neutralidad política" y el desarrollo social llevado a las comunidades con el programa.
} 
desarrollo, "como parte de una estrategia de combate y aún de exterminio de los núcleos armado y su base social” (1999:285). Las consideraciones de Montemayor se suman a la interpretación del "desarrollo" como instrumento de violencia (estructural, institucional, cultural e incluso directa) que he trazado en el Capítulo 1, y contribuyen a definir como violencia tanto los mecanismos para su aplicación como sus consecuencias entre la población "beneficiaria".

Al cambiar la administración federal y estatal (año 2000), el Programa Cañadas se canceló y en su lugar se implementó el Programa Integral para el Desarrollo Sustentable de la Selva (PIDSS), en los municipios de Altamirano, Ocosingo, Maravilla Tenejapa, Marqués de Comillas, Benemérito de las Américas y Las Margaritas; y parcialmente en La Trinitaria, La Independencia y Chilón. Con la participación de varias dependencias federales, el programa buscaba "impulsar el desarrollo", a través de los Centros Estratégicos de Desarrollo y los Consejos Microrregionales con función consultiva sobre las acciones a impulsar. Si ubicamos este "programa de desarrollo" en el entramado de militarización, divisiones políticas exacerbadas por las mismas dependencias gubernamentales, conflictos agrarios, intereses comerciales y amenazas de desalojo, la retórica del desarrollo muestra su carácter de violencia institucional y de fortalecimiento de las desigualdades más que de las oportunidades.

En el 2004, el PDISS se transformó en Proyecto de Desarrollo Social Integrado y Sostenible de la selva Lacandona (PRODESIS), a través de un acuerdo de cooperación entre el Gobierno del Estado de Chiapas y la Unión Europea. Definido como "laboratorio de cohesión social Mex-UE", el programa trata de integrar la participación y el desarrollo social con la sostenibilidad ambiental. Con oibjetivos muy ambiciosos, el programa sin embargo se ha concentrado en el impulso a actividades económicas en la región, mencionando que principal resultado en la Región Selva es que "se avanza en el fortalecimiento de la red de agroindustrias rurales de La Selva, mediante procesos de capacitación para generar sistemas que consoliden las acciones gerenciales de cada uno de los proyectos y de la red en su conjunto". 71 Nuevamente, la visión economicista del desarrollo y el "Chiapas competitivo" que pregonan los últimos gobiernos.

\footnotetext{
${ }^{71}$ Véase la página del proyecto <http://www.prodesis.chiapas.gob.mx/>, y el documento Plan Rector de la Selva Lacandona, <http://www.sedepas.chiapas.gob.mx/docs/programas-sociales/prodesis/Plan-Rector-de-la Selva.pdf $>$.
} 


\section{AUTONOMIAINDÍGENA, VIOLENCIAY JUSTICIA}

Con respecto a la inversión de dinero federal en la región y en la intervención gubernamental en el manejo territorial, es importante finalmente mencionar el Programa Especial para la conservación, restauración y aprovechamiento sustentable de la Selva Lacandona, que la CONAFOR impulsa a partir de 2010. Es en el marco de tal programa que, entre otras acciones (apoyos económicos, formación y capacitación por concepto de reforestación, usos alternativos del suelo, restauración de riberas y arroyos, reforestación con especies pioneras y de valor comercial), se otorga el pago por servicios ambientales (la controvertida estrategia REDD +) a los integrantes de la Comunidad Lacandona, estableciendo un potencial mercado para la venta de bonos de carbono y una nueva vereda para el financiamiento asistencialista hacia las comunidades lacandonas.

Cabe señalar que los actuales proyectos impulsados en Chiapas se insertan en un más amplio proyecto de "desarrollo" trasnacional, el Proyecto Mesoamerica, que prevé el desarrollo de una red de interconexión carretera, energética, y acciones de "desarrollo humano a través de una "alianza público-privada" para el financiamiento. El proyecto abarca toda el área centroamericana, desde México hasta el norte de Colombia. ${ }^{72}$

\footnotetext{
${ }^{72}$ http://www.proyectomesoamerica.org/
} 
Mapa 5

\section{Conflictos generados por la imposición del Proyecto Mesoamerica en Chiapas.}

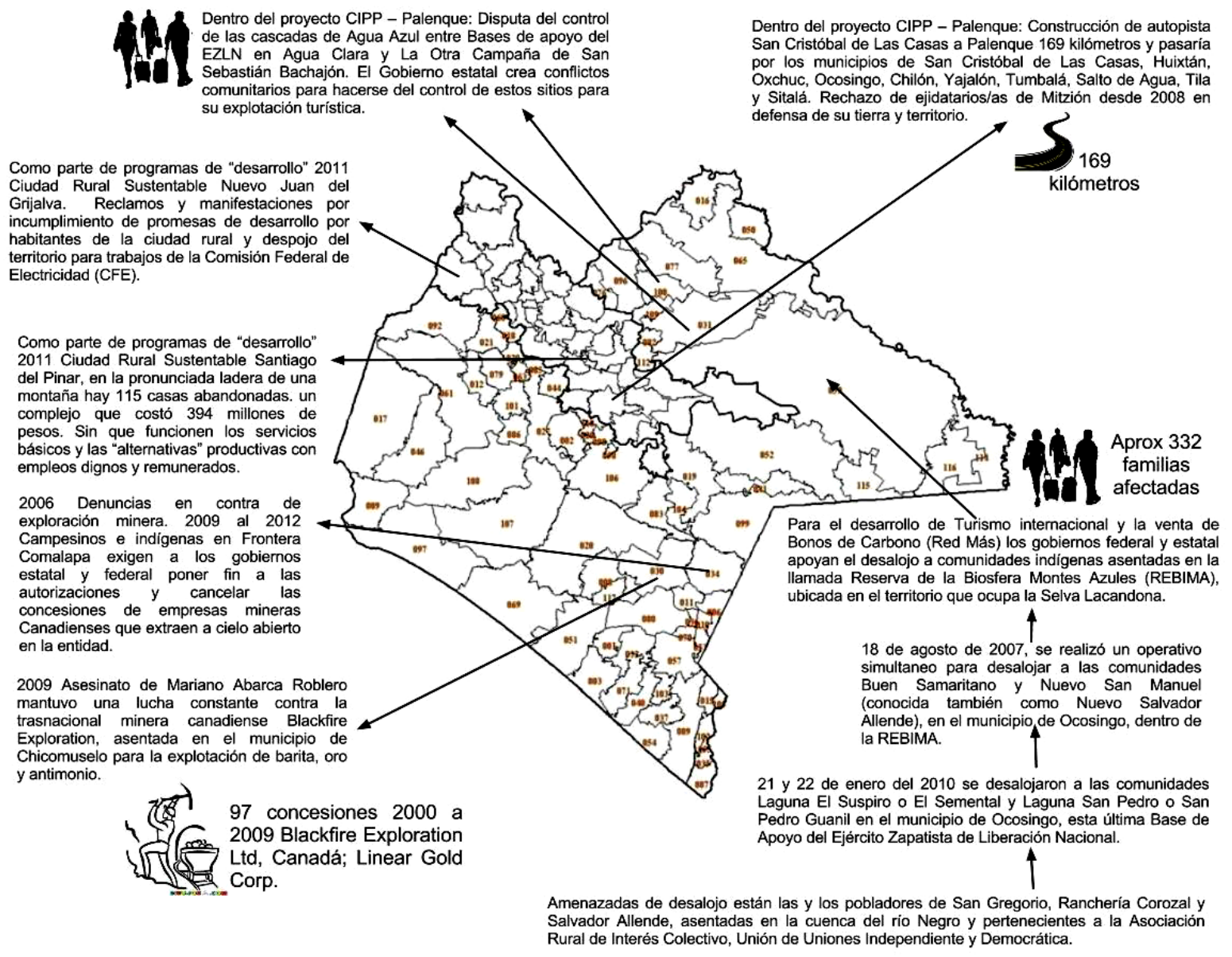

Fuente: Centro de Derechos Humanos Fray Bartolomé de las Casas, 2012:31. 


\section{CAPÍTULO 4}

\section{JUSTICIA INDÍGENA E INTERCULTURAL: LA JUSTICIA SEGÚN LA JUNTA DE BUEN GOBIERNO ZAPATISTA DE LA ZONA SELVA FRONTERIZA}

Tiene tantos nombres la injusticia y son tantos los gritos que provoca.

Pero nuestro dolor y nuestra rabia no nos impiden escuchar.

Y nuestros susurros no son sólo para lamentar la caída

de nuestros muertos injustamente.

Son para así poder escuchar a otros dolores,

hacer nuestras otras rabias y seguir así en el complicado, largo y tortuoso camino de hacer de todo eso un alarido que se transforme en lucha libertadora. Subcomandante Insurgente Marcos, Entre la luz y la sombra, 25 de mayo 2014

Los proyectos de autonomía de los pueblos indígenas incluyen, como un aspecto central, el ámbito de la resolución de conflictos, la administración de la justicia y, eventualmente, la producción de normas jurídicas propias.

En este capítulo describo las características de la autonomía que está construyendo la Junta de Buen Gobierno en la zona Selva-Fronteriza, Chiapas, así como el desarrollo y los resultados que el gobierno autónomo ha obtenido en el ámbito de la administración de justicia y el control del territorio: enfocaré mi análisis en la descripción de las características de la justicia indígena e intercultural, y las diferencias que emergen entre ésta y la justicia del Estado en la región de estudio. La experiencia del Sistema de Seguridad, Justicia y Reeducación Comunitaria de la Costa Chica y Montaña de Guerrero, experiencia que también estudié a profundidad, representa un caso ejemplar en los logros y los límites de los sistemas de justicia autónoma e intercultural, y es un referente para la reflexión en términos de 
Capitulo 4. Justicia indigena e intercultural: la justicia según la Junta de Buen Gobierno de la Zona Selva-Fronteriza

comparación y contraste con la experiencia zapatista. Asimismo, los proceso de los jueces tzeltales en Bachajón, de la Comisión de Apoyo a la Unidad y reconciliación Comunitaria en Chiapas, enriquecen mi análisis con respecto a las formas y ámbitos de resolución autónoma de los conflictos, y al problema de la relación entre las justicias indígenas y las instituciones estatales. En todos los casos, una de las principales demandas hacia el Estado es que éste respete la efectividad y la legalidad de las justicias indígenas e interculturales, como elemento constitutivo de la libre determinación.

El relato de las tensiones, conflictos y negociaciones con las autoridades políticas y judiciales del Estado, me remitirá a una valoración más amplia sobre los límites y alcances de los proyectos de autonomía en contextos donde la violencia impera en múltiples formas y amenaza la construcción de la justicia.

Mi aproximación a los procesos estudiados implica un esquema de análisis sencillo: propongo una descripción de la organización y el funcionamiento de los sistemas de justicia autónoma, así como una reflexión sobre las diferencias entre éstos y el sistema estatal, partiendo de las percepciones expresadas por los entrevistados, y fundamentando la argumentación con datos estadísticos y periodísticos. Enseguida, esbozo los elementos de tensión con el Estado. Sin embargo, mi interés argumentativo no es solo la descripción del sistema en sí, ni el estudio extenso de casos para analizar las normas implícitas o los motivos de disputas y conflictos. Partiendo de la hipótesis que las autonomías estudiadas se construyen también como respuesta particular a situaciones de violencia, me interesa esbozar las manifestaciones de la violencia y los motivos de conflicto en los contextos estudiados, por medio de una perspectiva diacrónica basada en el estudio de material bibliográfico y hemerográfico, de testimonios directos, y de la vivencia personal durante el trabajo de campo; utilizaré, por lo tanto, de manera no sistemática la mención a casos de disputa o conflictos que se presentaron ante los sistemas de justicia estudiados, en la medida en que aportan elementos para el entendimiento de algunos conflictos observados en las regiones.

Pretendo analizar de qué forma y en qué medida los sistemas de justicia autónoma logran -o no- resolver los conflictos y encauzar o desactivar la violencia que caracteriza las sociedades locales, incluida la violencia ejercida por el Estado (represión o cooptación de los procesos autonómicos, racismo, violación a los derechos humanos, despojo). 


\section{AUTONOMIAAINDÍGENA, VIOLENCIAY JUSTICIA}

\section{Para pensar la justicia indígena}

La resolución de los conflictos y la administración de la justicia son una práctica viva y presente entre la mayoría de los pueblos indígenas y las sociedades interculturales del continente latinoamericano, donde han permanecido a lo largo de las épocas históricas, renovando sus principios y formas de actuar. Siendo una realidad de hecho, las más importantes cuestiones que se presentan para su estudio son su pertinencia para la resolución de los problemas que enfrenta, el alcance y los límites de su legitimidad, y las relaciones con las instituciones y el marco jurídico vigente en los distintos contextos.

El estudio de los sistemas jurídicos no estatales, y de los diálogos y articulación entre éstos y el sistema estatal, representa un campo relevante para la disciplina antropológica desde el principio del siglo XX, constituyendo sucesivamente el objeto privilegiado de la antropología jurídica. A lo largo de su desarrollo, esta sub-disciplina ha abordado el estudio de las justicias no-occidentales a partir de diversos enfoques que reflejan las visiones y los debates que, en los diferentes periodos históricos, han atravesado la antropología en su conjunto.

Comaroff y Roberts (1981), establecen una primera diferenciación entre rule-centered paradigm y processual paradigm. El primero, traducido por Sierra y Chenaut (2002) como "paradigma normativo", es profundamente influenciado por los conceptos propios de la jurisprudencia y los estudios del derecho; bajo este enfoque, se desarrollaron estudios centrados en definir el ámbito estrictamente jurídico en los contextos estudiados, y en los que se entendía el derecho en términos de reglas y herramientas de control social. En términos metodológicos, se utilizó el estudio extenso de casos de disputas para llegar a encontrar, a través de la comparación, las normas que subyacen y orientan las decisiones tomadas por las autoridades. De esta manera, se llegó a elaborar descripciones -que se pretendían sistemáticas- de los sistemas normativos en las sociedades estudiadas.

El paradigma procesual, que se afirmó en la década de los sesenta, tiene en su origen una cercanía más profunda con la teoría antropológica que el "paradigma normativo"; muestra de ello es que la herramienta metodológica del estudio de casos de disputa se vuelve central para la reflexión teórica: se desplaza el enfoque desde las estructuras y las instituciones a los procesos e interacciones sociales. Esta transformación implica en primer lugar la evidencia de 


\section{Capitulo 4. Justicia indigena e intercultural: la justicia según la Junta de Buen Gobierno de la Zona Selvar Fronteriza}

que el conflicto y la disputa son parte de procesos sociales más amplios, y se deben entender en el contexto social y cultural en el que se generan y resuelven. Si los procesos jurídicos son parte de la vida social, explica Nader, "los valores culturales subyacentes a los procesos de disputa cambian con el tiempo y con las circunstancias y son profundamente políticos" ([1988] 1998:397). En segundo lugar, como lo muestran las investigaciones de la misma autora, se abrió el estudio de los casos de disputa desde la actuación de las autoridades hacia las acciones de los litigantes, sus motivaciones y el uso que hacen de los espacios judiciales y de resolución de los conflictos (Comaroff y Roberts 1981: 12-13).

Uno de los problemas implícitos en la aproximación procesual sería que, al enfocarse en las interacciones estratégicas de los individuos, desdibuja la importancia que el derecho y los sistemas normativos mantienen para el control, la coerción y el mantenimiento del orden social $^{1}$ (Comaroff y Roberts 1981, Sierra y Chenaut 2002); sin embargo, visibiliza las formas en que las personas se apropian y utilizan las herramientas del derecho, en términos vivenciales y como parte de su cultura, transformando la visión formalista en que los individuos eran más bien objetos pasivos de dominación. Ejemplo de esta corriente son los trabajos realizados en México por Jane Collier y Laura Nader, quienes estudiando los tipos de disputas llegan a enfocar los conceptos jurídicos y las lógicas culturales propias de las sociedades estudiadas. Collier [(1973) 1995], analizando los conceptos "folk" entre los habitantes de Zinacantán (Chiapas) para manejar los conflictos, revela la necesidad de la conciliación y de que todas las partes involucradas estuvieran de acuerdo con un arreglo, debido a la creencia de que las disputas y los conflictos irresueltos causaban enfermedades. Nader [(1988) 1998] identificó en la comunidad de Talea de Castro (Oaxaca) una "ideología armónica", caracterizada también por el énfasis puesto en la conciliación; lejos de ser un pueblo sin conflicto, los taleanos manejan la armonía más bien como discurso de defensa de la autonomía hacia afuera, y para reforzar la solidaridad local e intracomunitaria. Desahogando sus conflictos en el juzgado local sin acudir al juzgado distrital, buscarían reducir la interferencia de las autoridades y del derecho estatal.

\footnotetext{
${ }^{1}$ Así explica Nader su posición: "El análisis [propuesto en Ideología armónica] se aleja de la organización social vista como la interacción de roles sociales y se acerca al campo de los juzgados vistos como escenarios para la competencia entre los valores de los participantes. Son ellos quienes ponen la ley en movimiento" (Nader 1998: 107).
} 


\section{AUTOONOMIIAINDÍGENA, VIOLENCIAY JUSTICIA}

Estos trabajos contienen también elementos de reflexión, aunque no desarrollados en profundidad, que apuntan hacia la imbricación del sistema jurídico estatal y las justicias indígenas, las diferencias entre ellos, y las estrategias de las personas en utilizar uno u otro sistema (problemática que más tarde será central en las investigaciones basadas en el pluralismo jurídico y la interlegalidad), así como en la comprensión en términos históricos de las justicias indígenas, producto de los procesos de dominación colonial y de resistencia y adaptación de los pueblos.

"La preocupación por estudiar la manera en que el poder y la historia moldean a los sistemas jurídicos, y la relación entre ellos" (Collier 1995: 61) marcó algunas investigaciones a partir de los años setenta. Según Collier:

En lugar de suponer que el derecho, el control social y los procesos de disputa benefician a todo el mundo en general, [muchos antropólogos] suponen que los procesos jurídicos y las instituciones benefician más a unos que a otros. En particular, enfocan cómo las instituciones jurídicas ayudan a las élites para mantener sus posiciones dominantes (1995: 61). ${ }^{2}$

Aquí los sistemas jurídicos se entienden como construcciones culturales cuya vigencia revela su eficacia para la regulación y el control social, pero también su capacidad para adecuarse a los procesos sociales. Los sistemas jurídico-culturales indígenas, a pesar de ser definidos "sistemas", son más bien procesos contemporáneos, dinámicos, con una enorme capacidad para incorporar elementos nuevos, renovar y cambiar sus tradiciones. Se trata de normas "performativas", porque se van haciendo a la medida de los conflictos que se producen; y en esto probablemente reside su fuerza y su persistencia en contextos que van cambiando rápidamente.

La historicidad y el carácter dinámico de los sistemas normativos han sido destacados, entre otros, por Starr y Collier (1988) y por Falk-Moore (1986), quien muestra cómo los sistemas normativos indígenas, en muchos aspectos, son productos de procesos de resistencia y adaptación provocados por el colonialismo.

Una vez que los antropólogos jurídicos comenzaron a tratar el derecho como producido y logrado a través del conflicto, buscaron explicaciones de sistemas existentes en luchas

2 De la misma forma operan otras instituciones "legitimadoras", como por ejemplo las educativas; es conocido el papel de la escuela en la estrategia "integracionista" del indigenismo como política de Estado. 


\section{Capitulo 4. Justicia indigena e intercultural: la justicia según la Junta de Buen Gobierno de la Zona Selva-Fronteriza}

históricas por el poder. La preocupación por el poder condujo, inevitablemente, a una preocupación por la historia (Collier 1995:64).

A partir de la investigación realizada en Tanzania con el pueblo chagga, Sally Falk-Moore (1986) abre una importante discusión sobre el llamado "derecho consuetudinario", que identifica como producto de las relaciones de dominación y resistencia durante el periodo de la colonia. En este contexto donde las relaciones de poder se establecían de forma desigual, el derecho era producto de una interacción, en el que los grupos subordinados no eran actores pasivos. Sin embargo, la ley de los chagga, antes de la colonización, era parte integral de una totalidad política, el sistema de gobierno propio, mientras en el proceso de "reconocimiento" y adaptación colonial fue reducida, en su mayoría, a las relaciones de parentesco y a la esfera privada (1986: 317). Más aún, la autora, cuestionando la visión esencialista, demuestra que la "costumbre" nunca fue una tradición inmutable, como el uso común del término suele sugerir, sino más bien una construcción histórica formada y reformada por las fuerzas legales, políticas y económicas nacionales y globales. Dicha reflexión sigue manteniendo una fuerza relevante aún en nuestros días, cuando quienes se oponen al reconocimiento de las autonomías esgrimen argumentos conservadores que estigmatizan las culturas indígenas como portadoras de “costumbres bárbaras".

Los sistemas normativos y las formas de gobierno indígenas han sido ampliamente criticados por su fuerte estructura discriminatoria hacia algunos sujetos sociales, en particular las mujeres. ${ }^{3}$ Sin embargo, tales críticas han de ser matizadas tomando en cuenta los procesos internos a través de los cuales los sujetos subordinados negocian nuevos derechos, apropiándose de espacios hasta la fecha negados, como resultado de la creciente participación pública, politización y empoderamiento, así como a través del manejo de discursos políticos y sociales provenientes de otros órdenes culturales. ${ }^{4}$ Las experiencias aquí analizadas, donde observamos la creación de sistemas de gobierno y de justicia y su aplicación, son sumamente

\footnotetext{
${ }^{3}$ Ya desde su primer estudio en Zinacantán, en el cual exaltaba el valor de la conciliación en la resolución de conflictos, Collier observó la desigualdad que se expresaba en los arreglos relativos a las disputas familiares. "Comencé a preguntarme si servían principalmente para reconciliar a aquellos individuos sin poder con sus posiciones inferiores" (1995: 57). Tal consideración sobre los efectos perversos de la conciliación caracteriza también las posiciones de la autora sobre los mecanismos de resolución alternativa de los conflictos en Estados Unidos.

${ }^{4}$ En México se ha desarrollado una estimulante línea de investigación sobre las relaciones de género y su transformación en relación con las justicias indígenas. Véase los múltiples trabajos de Victoria Chenaut, R. Aída Hérnandez, Morna MacLeod, Mercedes Olivera, M. Teresa Sierra y Rachel Sieder.
} 
interesantes por el nivel de interrelación que las prácticas tienen con los diferentes ámbitos de la sociedad y su capacidad de responder a los cambios (internos y externos), así como su capacidad de "autocrítica" (reflexión y poder de cambio sobre las prácticas mismas).

La capacidad de los sistemas normativos de transformarse, en la medida en que se transforma la sociedad en la que son vigentes, es una característica clave, como lo explica Collier reflexionando sobre las "costumbres tradicionales" de Zinacantan, tachadas de ser dañinas para las mujeres. Según la autora, "no son las costumbres tradicionales las que dañan a las mujeres, sino el contexto socioeconómico más amplio en que éstas se practican" (Collier 2009:94). Como ejemplo, Collier relata que, en la década de 1960, el hecho de que las mujeres no pudieran participar en reuniones políticas no tenía tanta importancia, pues "la mayoría de las decisiones y los casos legales se decidían en el interior de los hogares, en los que las mujeres, ostensiblemente involucradas en la preparación de alimentos, podían ejercer su influencia" (Collier 2009:95), y, en el caso de las mujeres ancianas, vetar lo que no compartían. Fue cuando las reuniones políticas se desplazaron en los espacios "formales" de las alcaldías y comisaría, que se operó la real exclusión de las mujeres, pues la "costumbre tradicional" no logró transformarse a la par de los cambios políticos que intervinieron en la sociedad. Por otro lado, hay que recordar que algunas prácticas de sanción (el encierro por una noche, el cepo, o el fuete, ya residuales en México pero vigentes en Guatemala y en la región andina), son fruto de la herencia colonial de sujeción, ${ }^{5}$ cuando éstos eran los castigos impuestos a los indígenas por los hacendados y las autoridades civiles y religiosas.

Un paso sucesivo en la línea teórica que estoy resumiendo es la formulación del concepto de pluralismo jurídico, que se refiere a la coexistencia e interacción de diferentes sistemas jurídicos en un mismo espacio social. La principal concepción usada para definir los ordenamientos jurídicos plurales es la noción, acuñada por Moore, de "campo social semiautónomo" que "puede generar normas, costumbres y símbolos internamente, pero que [...] es también vulnerable a las reglas y decisiones de otras fuerzas que emanan del mundo más grande que lo circunda" (Moore 1973, cit. in Merry 2007:107). Partiendo de ese argumento, Merry sostiene que "el sistema legal externo penetra al campo pero no siempre lo domina pues allí existe espacio para la resistencia y la autonomía" (1988:106), y realiza un

\footnotetext{
${ }^{5}$ Al igual que parte importante de las estructuras de gobierno y de organización interna (como el sistema de cargos político-religioso).
} 
Capitulo 4. Justicia indigena e intercultural: la justicia según la Junta de Buen Gobierno de la Zona Selva-Fronteriza

amplio excursus entre las investigaciones que, en la década de los ochenta, hicieron énfasis en "la relación mutuamente constitutiva y dialéctica entre el derecho estatal y otros órdenes normativos", en el marco de relaciones de fuerza y de poder cambiantes (2007: 110). Al respecto, el sociólogo Boaventura de Sousa Santos, quien cuenta con una vasta producción teórica sobre el argumento, advierte sobre el riesgo que conlleva la imagen del pluralismo jurídico si no es problematizada (llegando a describir un sistema de convivencia armónica de diferentes sistemas jurídicos). En realidad no hay en la pluralidad jurídica nada intrínsecamente bueno, progresista o emancipatorio (el autor refiere la misma advertencia también sobre el uso del discurso de los derechos humanos), pues hay ejemplos de pluralismos jurídicos reaccionarios, como el derivado de las fuerzas paramilitares (Jaramillo, Villa y Ceballos 2001), de la mafia, del poder de los caciques rurales y urbanos, o el vigente en las cárceles (Correa 2007).

Alrededor del concepto de pluralismo jurídico se ha generado en las últimas dos décadas una abundante literatura, desde la antropología, la sociología jurídica y el derecho. ${ }^{6} \mathrm{Su}$ trascendencia, para el tema que trato aquí, ha sido cuestionar la visión positivista y monista del derecho, según la cual la única fuente de legalidad es el Estado; lo que abrió espacios de discusión importantes sobre las formas en que se debería dar la articulación entre sistemas jurídicos -por ejemplo la justicia del Estado y las justicias indígenas- en el contexto de las reformas constitucionales y los procesos de reconocimiento de la multiculturalidad en América Latina a partir de la primera década del siglo XXI.

Según Sousa Santos, hasta hace poco el tema del pluralismo jurídico se centró en la identificación de ordenamientos jurídicos locales que coexisten de manera diferente con el derecho estatal oficial. Sin embargo, en las sociedades modernas la pluralidad de ordenamientos jurídicos es muy alta y su articulación muy densa: los ordenamientos jurídicos locales y nacionales se combinan con los supranacionales, que no corresponden solamente al derecho internacional convencional, sino a "mecanismos jurídicos concebidos por los Estados hegemónicos, por agencias financieras multilaterales o por poderosos actores trasnacionales [...] e impuestos globalmente" (Sousa Santos 2001: 132). En cada nivel operan lógicas políticas y culturales diversas que movilizan intereses diferentes (por ejemplo, la lógica de una

\footnotetext{
${ }^{6}$ Véase por ejemplo los estudios de Brian Tamanaha, Donna Lee Van Cott, Antonio Carlos Wolkmer y Boaventura de Sousa Santos.
} 


\section{AUTOONOMIAINDÍGENA, VIOLENCIAY JUSTICIA}

comunidad u organización indígena, la lógica del Estado y la lógica de una empresa trasnacional extractiva); asimismo, pueden existir diversos ordenamientos jurídicos en un mismo nivel (justicia penal estatal, justicia indígena reconocida constitucionalmente y mecanismos alternativos de resolución de conflictos pueden representar diversos ordenes jurídicos en el nivel nacional). Esto es, el ordenamiento jurídico estatal se confronta con otros ordenamientos, locales y globales, legales e ilegales, que le disputan la legitimidad. Como he expuesto en el capítulo 1, con respecto a la multiplicidad de las violencias que atraviesan el contexto mexicano y que disputan o contestan la legitimidad del Estado en tal ámbito, asimismo la creciente injerencia de la economía criminal o de las empresas trasnacionales impone normas y sanciones que aparentemente contradicen la normatividad estatal, misma que se transforma rápidamente para dar paso a estas nuevas instancias de poder y englobarlas en una nueva normatividad.

En este contexto complejo, "las fronteras entre los diferentes ordenamientos jurídicos se vuelven porosas" dando vida a hibridaciones jurídicas que pierden la "pureza" y la "autonomía" originarias (Sousa Santos 2001: 133). Dicha hibridación acontece no sólo en el ámbito de los ordenamientos jurídicos, sino también en el de las vivencias y experiencias de los individuos.

Para "designar la multiplicidad de los 'estratos' jurídicos y de las combinaciones entre ellos que caracterizan el 'mundo de la vida", el autor ha acuñado el término interlegalidad. ${ }^{7}$ El fenómeno de la interlegalidad consiste en la forma en que los individuos y los grupos sociales viven la pluralidad jurídica y utilizan los "diferentes y solapados ordenes legales y comunidades legales", que no son sincrónicos, sino "mezclas complejas de diferentes generaciones de leyes" (Sousa Santos 1994:169). La interlegalidad, por lo tanto, representaría la dimensión fenomenológica del pluralismo jurídico.

En la concepción de Sousa Santos, los órdenes jurídicos se combinan siempre con base en una jerarquía, lo que nos remite a la idea de que los espacios interlegales así establecidos son atravesados por relaciones de dominación y de resistencia, a través de las cuales se construyen los sistemas normativos dominantes y los subordinados. En lo específico, los sistemas normativos indígenas son producto de una historia de dominación ante la cual han

\footnotetext{
7 "Los ciudadanos y los grupos sociales organizan sus experiencias de acuerdo con el derecho estatal oficial, el derecho consuetudinario, el derecho comunitario local, el derecho global y, en la mayoría de los casos, según complejas combinaciones de estos diferentes ordenamientos jurídicos” (Sousa Santos 2001: 133).
} 
Capitulo 4. Justicia indigena e intercultural: la justicia según la Junta de Buen Gobierno
de la Zona Selva-Fronteriza

debido responder, adaptarse o resistir, en interacción estrecha y conflictiva con el derecho estatal, pero también con otros sistemas no siempre legales o instituidos, pero que establecían (y establecen) límites importantes a la autonomía organizativa de los pueblos indígenas. Baste pensar, como ejemplo, al sistema "informal" pero vigente y efectivo que regía en haciendas y fincas, que regulaba la vida social e individual de los indígenas acasillados o avecindados, y sancionaba con violencia los que infringían dicho orden (Gómez y Ruz 1992), que contaba incluso con una jerarquía de poder -patrón, mayordomo, caporales- (García de León 1985: 123; Toledo 2004: 93) y cuerpos especializados para el ejercicio de la violencia -guardias blancas-. En la actualidad, otro ejemplo de interlegalidad que ejerce dominación y genera resistencia -y moviliza el uso estratégico de los sistemas normativos nacionales e internacionales por parte de los grupos locales- son los proyectos de explotación de los recursos energéticos -petróleo, electricidad, gas, energía eólica- naturales y mineros en comunidades indígenas. ${ }^{8}$ Aun si la normatividad producida por el Estado nacional garantiza, en ocasiones, los derechos de los pobladores, ésta es constantemente infringida, manipulada y rebasada por una normatividad de facto producida por las empresas extractivas u las mismas dependencias estatales, que se reproduce en los márgenes entre la legalidad y la ilegalidad. ${ }^{9} \mathrm{El}$ capital trasnacional y los actores políticos que lo representan se mueven aprovechando de los espacios o situaciones sin ley (Sousa Santos), ${ }^{10}$ ajenos a cualquier norma establecida y por lo tanto incomprensibles en los términos de legalidad/ilegalidad, o en los estados y espacios de excepción (Calveiro 2008) que son parte de la gobernabilidad del Estado.

Sin embargo, los intereses económicos trasnacionales no se limitan a operar utilizando los espacios legales y, de ser necesario, de manera ilegal, extralegal o a-legal. Estamos presenciando, a nivel global, a un ajustamiento de los ordenamientos constitucionales a las necesidades de la gestión financiera de la crisis (en Europa) y del creciente despojo de

\footnotetext{
${ }^{8}$ Véase, por ejemplo, Navarro, Bravo y López (2013); Cruz Rueda (2013).

${ }^{9}$ Un ejemplo, entre los muchos que se podrían citar, es la oposición de la Tribu Yaqui, en el estado de Sonora, a la construcción del acueducto Independencia, que canalizaría hacia la industria y la agricultura de gran escala las aguas del Rio Yaqui. La Tribu y varios ejidos que le pertenecen interpusieron y ganaron, entre 2010 y 2014, un juicio agrario, dos controversias constitucionales y tres juicios de amparo; sin embargo, las instancias estatales iniciaron y prosiguieron las obras de construcción del acueducto, violando la misma normatividad federal. Tristemente conocido es también el caso de la Mina San Javier, en el estado de San Luis Potosí, que por mucho tiempo ha operado en la ilegalidad.

${ }^{10}$ Boaventura de Sousa Santos, "Para una teoría política de la indignación", conferencia dictada en la Universidad Autónoma Metropolitana-Iztapalapa, México, el 28 de febrero 2012. Véase también la entrevista al autor en <http://www.cronicon.net/paginas/edicanter/Ediciones68/nota001.htm>, consultado el 10 mayo 2013.
} 


\section{AUTONOMIAAINDÍGENA, VIOLENCIAY JUSTICIA}

recursos naturales, energéticos y culturales por parte de las empresas trasnacionales (en América Latina), un proceso que se ha llamado “deconstitucionalización”.

Según López y Rivas, las reformas legales y la intervención en los principios constitucionales responden a la necesidad de cobijar legalmente la ocupación integral, es decir:

El proceso globalizador y privatizador a través del cual de manera abierta o silenciosa las economías de nuestros países, todos los sectores y las ramas del Estado, el patrimonio cultural, los recursos naturales y estratégicos de nuestras naciones van siendo integrados a los tratados de "libre comercio"; [...] a los intereses y condiciones impuestos por las grandes corporaciones transnacionales, bajo la protección y hegemonía política-militar de lo que Samir Amín denomina "imperialismo colectivo", que hoy predomina en el ámbito planetario encabezado por los Estados Unidos de América (López y Rivas, 2013:71).

En México, la Constitución es sometida a un rápido proceso de reformas que pervierten su carácter de instrumento garante de los derechos fundamentales; asimismo, se ve rebasada por leyes secundarias y disposiciones de hecho que contradicen el espíritu constitucional, realizadas sin consultar a la sociedad y a los ciudadanos, constituyendo una nueva directriz de trasformación de los espacios interlegales.

Me parece entonces que la idea de la interlegalidad es útil para analizar los procesos de autonomía y las estrategias de los pueblos indígenas para hacer frente a las amenazas de despojo. Tal despojo se reviste de una "legalidad" que es moldeada sobre los intereses de saqueo cultural y material, como quedó de manifiesto en México con las nuevas modificaciones al art.27 sobre la propiedad de la tierra, y las leyes secundarias ligadas a la reforma energética, impuestas por el gobierno entre 2013 y 2014.

En la antropología jurídica mexicana el concepto de la interlegalidad ha sido ampliamente utilizado (teniendo como antecedente los estudios guiados por el enfoque procesual) y ha orientado un número importante de investigaciones dedicadas tanto a entender de qué manera los diversos órdenes normativos son apropiados, actualizados y combinados por los pueblos indígenas, que desde la diferencia cultural los utilizan para resolver sus problemáticas u exigir sus derechos; y también, en menor medida, de qué manera el dinamismo de los sistemas políticos y normativos indígenas ha incidido en las dinámicas 
Capitulo 4. Justicia indigena e intercultural: la justicia según la Junta de Buen Gobierno
de la Zona Selva-Fronteriza

judiciales del Estado, y ha propiciado el reconocimiento legal de la diversidad cultural o de determinados ámbitos de jurisdicción indígena. ${ }^{11}$

Un límite de la perspectiva interlegal, reconocido por una de sus impulsoras, sería que "al enfatizar en los procesos [...] tiende a perder de vista la especificidad de las lógicas culturales que los sistemas conllevan" (Sierra 2011:392). Este aspecto resulta mucho más definido en los trabajos que hacen referencia a la perspectiva "normativa", también abundantes en México, que sin embargo tienen la falla de construir visiones un tanto abstractas de las justicias indígenas, que son minuciosamente descritas en su estructura pero no son estudiadas en el marco de las relaciones de poder que las enfrentan y atraviesan. ${ }^{12}$ Frente a esta diferencia entre las dos perspectivas, que según Valdivia (2001) ${ }^{13}$ son complementarias más que dicotómicas, Adonon sintetiza la que podría ser una propuesta metodológica enriquecedora para ambas visiones, y que coincide en gran parte con el enfoque y el contenido de este estudio:

Si el cruce de las diferentes escalas legales en el análisis de los fenómenos jurídicos nos parece un ámbito fecundo, la incorporación de diferentes visiones y representaciones de la juridicidad resulta aportar un enriquecimiento necesario (2009:61).

Desde la Colonia, los pueblos indígenas han vivido en un contexto de interlegalidad, que los ha llevado a moverse entre el sistema jurídico impuesto a través de las relaciones de dominación y los sistemas jurídicos propios, conservados como elemento identitario y forma de resistencia. Mientras padecen la inequidad del sistema jurídico formal, también se han apropiado del mismo, desarrollando un conocimiento bastante profundo de normas, códigos y leyes, con el objetivo de defenderse de éstas y salvaguardar sus derechos, utilizando las leyes del Estado. Este proceso ha sido sin duda positivo, y en el mismo camino se sitúa el uso frecuente que hacen las organizaciones indígenas del derecho internacional, del cual tienen

\footnotetext{
${ }^{11}$ Ejemplo de esta producción que se ubica en estudiar las intersecciones y las dinámicas de poder ejercidas desde varios lados son los trabajos sobre los Juzgados Indígenas impulsados por el Estado, como los de Adonon (2009), Aragón (2013b), Buenrostro (2013), Orantes (2007), Terven (2009), Terven y Chávez (2013) y Terven y Maldonado (2008); asimismo, los trabajos de Aragón (2013a), Martínez (2006, 2013) y Sierra (2006, 2013a y 2013b), investigan los usos contra-hegemónicos del derecho, el desarrollo de justicias indígenas y comunitarias, y la relación de fuerza entre éstas y las instituciones del Estado.

${ }^{12}$ Ejemplo de esta perspectiva son los trabajos de Cordero (2001), Valdivia (2010), o los contenidos en los textos coordinados por Estrada y González (1997) y por Alvarado Solís (2010).

13 "En torno al sistema jurídico indígena", Anales de Antropología, Vol. 35, 2001, Instituto de Investigaciones Antropológicas-Universidad Nacional Autónoma de México
} 
claras nociones por lo que este garantiza derechos colectivos que las leyes nacionales no reconocen.

Gracias a la relación frecuente, alternada y creativa, y sin duda conflictiva, con la justicia estatal, las comunidades originarias lograron mantener márgenes y límites entre ambas justicias y a la vez conectarlas. Es decir, no se puede pensar una justicia originaria excluyendo su relación con la justicia estatal, ya sea en la misma construcción local de la justicia, o en la conexión entre ambas. Pero tampoco hay que suponer que esta relación es armónica e igualitaria, sino controversial y desequilibrada, lo cual motiva a las comunidades en hacer esfuerzos de independencia judicial frente a la justicia estatal. Los sistemas jurídicos indígenas se construyen, reconstruyen y actúan en contextos de interlegalidad, lo que los hace más o menos distinguibles de las categorías del derecho estatal. La realidad que se observa al analizar los sistemas jurídicos propios desmiente las interpretaciones esencialistas del "derecho consuetudinario" como aislado del contexto más amplio en el cual actúa, y cristalizado en unas normas ancestrales. Muchas veces los discursos de los mismos pueblos indígenas presentan las identidades y las prácticas jurídicas enraizadas en la tradición, como estrategia para demostrar la legitimidad de los sistemas normativos, para obviar la relación mutuamente constitutiva establecida entre las instituciones estatales y las prácticas indígenas (Sieder 2001). En realidad, la "autenticidad" de las justicias indígenas no deriva de su naturaleza milenaria, sino de su eficacia para resolver, de manera culturalmente apropiada, los problemas que las personas enfrentan en la actualidad.

En conclusión creo necesario hacer hincapié en los términos que, en adelante, utilizaré para definir los procesos que estudio: justicias autónomas e interculturales y sistemas normativos propios. Frente a la gran diversidad terminológica que se encuentra en los textos antropológicos sobre el tema, he optado por usar el término justicias, pues es una palabra sencilla y que pertenece al lenguaje común, no a una terminología especializada; por esto resulta inmediatamente inteligible para cualquier lector, y remite con claridad al tema de estudio, aunque no define puntualmente sus límites. Sin embargo, siendo mi enfoque muy amplio, no necesito un concepto acotado o estrictamente definido; así, la palabra justicia remite tanto al ámbito de las normas que la estructuran y la orientan, cuanto a los procedimientos para su administración y a las facultades de las autoridades que la administran. Utilizo la palabra justicias en plural, pues no existe una justicia indígena en general sino una 
Capitulo 4. Justicia indigena e intercultural: la justicia según la Junta de Buen Gobierno
de la Zona Selva-Fronteriza

diversidad de concepciones y prácticas de justicia incluso al interior de una misma región o pueblo indígena.

He definido a la experiencia de justicia que estudio como autónoma, pues es parte de un proceso más amplio que marca con claridad su diferencia con el sistema estatal; e interculturale, ya que es construidas en una colaboración entre diversos pueblos y comunidades indígenas y no indígenas.

Utilizaré de manera puntual el término sistema normativo indígena, que aparece tanto en la Constitución mexicana, como en el Convenio 169 de la OIT, para designar, cuando sea necesaria una mayor especificidad, el conjunto de normas que orientan la vida de una comunidad, pueblo u organización. Asimismo, utilizaré el término sistema de gobierno para indicar las formas y los mecanismos organizativos y políticos de una comunidad $\mathrm{u}$ organización, que se entrelaza con el sistema normativo pero no coincide con él, a pesar de que no haya siempre una distinción entre las normas relacionadas con la organización y el gobierno, aquellas ligadas al ámbito religioso, y el espacio propio de la justicia. Las mismas autoridades autónomas cumplen diferentes funciones a la vez, y sobretodo abordan colectivamente asuntos y tareas de distinta índole (administración de justicia, gobierno, propuesta de iniciativas territoriales, gestión, representación), aunque se observa en los procesos regionales estudiados una mayor especialización que en las comunidades, por ser creaciones innovadoras y más influenciadas por el derecho del Estado.

En la literatura consultada se utiliza con frecuencia el término sistema jurídico indígena, y hay juristas en México comprometidos en demostrar, desde la teoría del Derecho, la juridicidad de las justicias indígenas. ${ }^{14}$ Sin embargo, he preferido no utilizar dicho término pues me parece un tanto restrictivo; también he rechazado el de derecho (indígena, propio), pues me parece un concepto étnicamente centrado y sesgado, que remite más a la idea de la asimilación o comparación de las justicias indígenas con la justicia del Estado y al procedimiento erróneo de usar la misma medida (en este caso, las mismas palabras) para definir manifestaciones políticas y culturales diferentes.

\footnotetext{
${ }^{14}$ Entre ellos, Oscar Correa explica que la juridicidad reside en que las normas llamadas jurídicas amenazan con una sanción violenta, que implica el uso de la fuerza; ésta debe ser administrada por individuos "autorizados" por una norma superior. Correa demuestra lo ficticio de tal argumentación que remite al Estado como institución generadora, y sostiene que las normas vigentes en las comunidades indígenas son igualmente jurídicas (Correa 2007: 34-40),
} 


\section{AUTOONOMIIAINDÍGENA, VIOLENCIAY JUSTICIA}

Finalmente, he desechado los términos usos y costumbres y derecho consuetudinario, que remiten por igual a una idea esencialista, que busca anclar al pasado las identidades y los derechos culturales. Las citadas reflexiones de Moore sobre el derecho consuetudinario se sitúan desde la tradición jurídica y antropológica anglosajona, que vincula lo consuetudinario a lo ancestral; en tal sentido, lo consuetudinario es, de alguna manera, ilegítimo porque desciende de un pasado pre-estatal y pre- racional, una dicotomía que Moore criticó demostrando las raíces modernas de los derechos consuetudinarios en países poscoloniales. Por otro lado, explica Poole, para el derecho romano (que sustenta la tradición jurídica latinoamericana) la costumbre es contrapuesta a la ley y se caracteriza por ser un proceso espontaneo y descentralizado; lo consuetudinario es ilegitimo porque "siempre queda al margen del racionalismo del proceso legislativo" (Poole 2006: 12). Así, en el lenguaje jurídico latinoamericano, la palabra "consuetudinario" define unas normas supletorias y subordinadas al derecho codificado; tras esta visión, las recientes reformas constitucionales y legislativas realizadas en México y otros países del continente, reconocen el derecho consuetudinario como una categoría residual, que tiene validez "solamente en casos no cubiertos explícitamente por la Constitución, la legislación codificada, los tratados internacionales y su reglamentación" (Zamora et. al., cit. en Poole 2006: 12).

\section{Pluralismo legal y monismo jurídico}

Con respecto al tema de la justicia indígena, la discusión sobre el pluralismo jurídico, sus características y las relaciones entre los diferentes órdenes jurídicos, adquiere relevancia -me parece- fuera del espacio estrictamente teórico, en la práctica de los encuentros, desencuentros y conflictos entre las instituciones indígenas, las estatales y los intereses privados, esto es, en las relaciones de poder que determinan las atribuciones de cada instancia. Asimismo, el análisis de tales relaciones a la luz de las teorías pluralistas es muy valioso para orientar la reflexión sobre la nueva estructura legal que deben construir los países ${ }^{15}$ que emprendieron el proceso de reconocimiento - político, legal y cultural- de la diferencia, bajo los conceptos de la multiculturalidad o de la plurinacionalidad. Vale mencionar, como ejemplo, los estudios de Sánchez Botero para Colombia; de Boaventura de Sousa Santos para Colombia y Bolivia; de

\footnotetext{
${ }^{15}$ En particular Colombia, Ecuador, Bolivia, Perú y Venezuela.
} 
Capitulo 4. Justicia indigena e intercultural: la justicia según la Junta de Buen Gobierno de la Zona Selva-Fronteriza

Xavier Albó para Bolivia y Ecuador; de Raquel Yrigoyen para Guatemala y Perú; de Rachel Sieder para Guatemala y de Willem Assies para México.

Dichos estudios cruzan el estudio de las justicias indígenas en sí, con el análisis de las reformas constitucionales, poniendo énfasis en los elementos de contradicción y conflicto entre ellos, elaborando reflexiones y propuestas hacia una articulación más igualitaria y realmente pluralista. Creo que tal campo de estudio, además de ser muy fecundo, es sumamente necesario, pues los conocimientos antropológicos pueden aportar mucho a los procesos de producción normativa, especialmente en el ámbito del reconocimiento de los derechos indígenas, que es muy permeado de influencias conservadoras. En palabras de Merry, "la existencia del pluralismo jurídico en sí es de menos interés que la dinámica de cambio y transformación" (2007:108).

El modelo pluralista, analizado por los investigadores citados, desde la perspectiva jurídica implica:

1. el reconocimiento del derecho y la jurisdicción especial indígena autónoma dentro del ámbito territorial indígena;

2. derechos especiales de los indígenas ante la jurisdicción ordinaria en consideración de su cultura;

3. mecanismos consensuados de coordinación entre sistemas jurídicos para los conflictos de jurisdicción originados por la situación de interlegalidad.

En estos términos, las resistencias por parte del Estado se dan principalmente hacia el reconocimiento de las autoridades propias y su capacidad de autogobierno; del derecho indígena y su potestad de autorregulación; y finalmente de la jurisdicción especial entendida como capacidad de resolución de conflictos de acuerdo a la cultura y a los sistemas normativos propios, de manera igualitaria y no subordinada a la normatividad estatal.

Se pueden observar los tres tipos de conflictos al analizar la relación entre las instituciones formales y las experiencias estudiadas en esta investigación, que cuentan con un sistema de gobierno propio, formas distintas de control territorial, y sistemas normativos que orientan la administración de justicia por parte de las autoridades regionales y comunitarias. En el contexto de los procesos autonómicos integrales, y enfocando el ámbito de la justicia, se puede afirmar que tanto el Sistema de Seguridad, Justicia y Reeducación Comunitaria cuanto las Juntas de Buen Gobierno ponen en discusión los pilares básicos del orden estatal: la idea 
de que la ley es una, igual para todos, y estrictamente codificada; y la que sostiene que la jurisdicción y el ejercicio de la acción penal son facultad exclusiva del Estado, lo que Yrigoyen (2000) define como la teoría monista del Derecho.

Considerar legítima la producción normativa de los pueblos indígenas supone una ruptura con la concepción clásica de que sólo el Poder Legislativo está legitimado para la producción de normas. Pero tal vez sea dentro del ámbito del sistema penal (principal campo de jurisdicción de la Coordinadora Regional de Autoridades Comunitarias), donde las diferencias y los conflictos se presentan más nítidamente. No sólo porque el derecho penal se encuentra fuertemente influenciado por determinadas valoraciones sociales (al tratarse de cosmovisiones diferentes, son estas valoraciones las que agudizan dichas diferencias), sino porque es uno de los ámbitos más sensibles del ordenamiento jurídico, en donde se hace manifiesta la verdadera fuerza del Estado, ya que éste se considera como la única instancia legitima para la imposición de las penas de acuerdo a las normas emitidas. Con respecto a la jurisdicción indígena, casi todas las constituciones latinoamericanas (incluida la mexicana) y el Derecho Internacional la reconocen, pero la limitan a la resolución de conflictos menores, lo que a nivel epistemológico nos remite a la visión colonial, todavía presente, del indígena como inferior. En el sistema colonial, la ideología de la inferioridad natural de los indígenas estaba en la base del proyecto jurídico de la tutela; el mismo mecanismo ideológico parece funcionar ahora con el discurso de los derechos humanos, que se piensa deber imponer a las sociedades indígenas bajo el supuesto etnocéntrico de que estas no los comprenden y no los aplican ${ }^{16}$. Al contrario, observamos como la temática de los derechos humanos y los mecanismos para su protección, con más frecuencia están siendo incluidos en los sistemas jurídicos indígenas, en aras de una compatibilización con la justicia ordinaria; a partir de la reformulación interna que proviene de una autocrítica positiva.

Al interno de los procesos de reconocimiento, se puede identificar una tensión entre dos modelos de pluralismo, definidos por Griffiths (2007) como pluralismo débil y pluralismo fuerte, y por Hoekema (2003) como pluralismo jurídico unitario e igualitario. En el primer caso se mantiene una relación de subordinación, pues el Estado "reconoce" la existencia de otros sistemas normativos, pero "se reserva la facultad de determinar unilateralmente la

\footnotetext{
${ }^{16}$ Raquel Irigoyen Fajardo, ponencia presentada en el Curso "Los grandes temas de la Antropología Jurídica", organizado por la Red Latinoamericana de Antropología Jurídica, México DF, 13 y 14 de octubre 2006.
} 


\section{Capitulo 4. Justicia indigena e intercultural: la justicia según la Junta de Buen Gobierno de la Zona Selva-Fronteriza}

legitimidad y el ámbito de aplicación de los demás sistemas de derecho reconocidos" (Hoekema 2003, cit. en Sánchez Botero 2009: 37). Por otro lado, el pluralismo igualitario reconoce los otros sistemas normativos "como una parte diferente pero de igual valor al orden político-legal del país" (Ibid.) El tránsito de un modelo al otro, es decir de un reconocimiento "retórico" a un reconocimiento efectivo del pluralismo y con ello de las justicias indígenas (es decir, de su legalidad y de su jurisdicción), no es un camino fácil, pues debería implicar una transformación radical de las estructuras y de los valores fundadores de los Estados (proceso que, en cierta medida, se está intentando en Bolivia y Ecuador). Con frecuencia, los procesos de reconocimiento son parciales y basados en contradicciones, como en el caso de las Rondas Campesinas del Perú, analizado por Piccoli, de las que se reconoce la existencia y la función de administrar justicia, pero no son aceptados sus métodos para ejercerla. Frente a esta situación, la autora afirma que el verdadero dialogo entre la justicia del Estado y la justicia -en este caso- campesina, se juega en los márgenes y los límites entre los dos sistemas:

El conjunto de estrategias y ardides del que se valen quienes hacen la justicia rondera para acercarse lo suficiente al marco general como para que puedan convivir las dos formas de hacer justicia - por ardides entendemos soluciones provisionales para evitar el sistema impuesto y cumplir con una meta diferente a la que parece, pero sin dañar al sistema (Piccoli 2009: 107).

En el estudio de las relaciones entre el Estado y las justicias indígenas e interculturales resaltarán dichas estrategias y "soluciones provisionales" que incluso construyen la práctica de las justicias autónomas, al igual que los momentos de abierto conflicto entre los dos sistemas (estatal y autónomo). 


\section{AUTONOMIAINDÍGENA, VIOLENCIAY JUSTICIA}

\section{Experiencias de resolución de conflictos en Chiapas: conciliación y construcción de la paz}

Al estudiar los procesos de justicia indígena e intercultural con un enfoque centrado en las prácticas, se develan las diversas formas en que los pueblos resuelven situaciones de violencia desde la raíz, antes de que se vuelvan un problema de seguridad comunitaria o pública. Así, si nos remontamos hacia atrás en las respuestas a la violencia, encontramos la resolución de los conflictos y la administración de la justicia, como dos niveles de la misma estrategia para desactivar la conflictividad. En una experiencia organizativa pueden estar presentes ambos niveles, o bien encontrarse solo el nivel de la resolución de los conflictos; dicha dimensión es clave, pues busca desactivarlos de forma pacífica, a través del acuerdo, la conciliación y la concientización de las partes involucradas. Es una constante en todas las experiencias de justicia indígena e intercultural, y es el corazón mismo de éstas.

Hay experiencias que se abocan principalmente a la resolución de los conflictos comunitarios: en el estado de Chiapas destacan los jmeltsa'anwanej de Bachajón, y la Comisión de Apoyo a la Unidad y Reconciliación Comunitaria (CORECO), ambas instancias influidas por el profundo trabajo cumplido en tal sentido por la Diócesis de San Cristóbal. En otras experiencias, la conciliación es parte de un sistema de administración de justicia más complejo que incluye también el juicio de los que cometieron algún error, y su reeducación por medio del trabajo comunitario, como en la Coordinadora Regional de Autoridades Comunitarias en Guerrero o en las Juntas de Buen Gobierno en Chiapas.

En el estado de Chiapas hay diferentes instancias, oficiales y no oficiales, que pueden actuar en la resolución de un conflicto, constituyendo un complejo entramado interlegal. Las instancias no oficiales que estudié son los jmeltsa'anwanej en Bachajón, que se dedican a la resolución de problemas interpersonales, pero rara vez abordan conflictos intercomunitarios o entre organizaciones políticas; organizaciones civiles cercanas a la iglesia como CORECO, que se dedica a mediar en este último tipo de conflictos; y las Juntas de Buen Gobierno Zapatistas, que aspirando a una posición super partes (aunque con dificultad lo logren pues son uno de los actores en el conflicto) dirimen tanto conflictos individuales como intra e intercomunitarios. Del lado de la justicia oficial, la principal autoridad comunitaria, el Agente Municipal, tiene la facultad de resolver los conflictos menores. En el municipio se encuentran 


$$
\begin{gathered}
\text { Capitulo 4. Justicia indigena e intercultural: la justicia según la Junta de Buen Gobierno } \\
\text { de la Zona Selva-Fronteriza }
\end{gathered}
$$

los Jueces Municipales y/o los Jueces de Paz y Conciliación Indígena, que conocen problemas no graves y también privilegian la conciliación. Finalmente, están las agencias del Ministerio Público, la Fiscalía Especial de Justicia Indígena y los Juzgados penal y civil, que como los Jueces Indígenas dependen del Tribunal Superior de Justicia del Estado.

\section{Vuelta al corazón: los jmeltsa'anwanej}

En la conflictiva Zona Norte de Chiapas, en el municipio de Chilón (con mayoría de población tzeltal), se encuentran la misión jesuita de Bachajón y el Centro de Derechos Indígenas (CEDIAC), ligado a ella. Desde principios de la década de 1990 los misioneros impulsaron la revitalización del sistema de cargos comunitarios, en particular en el ámbito de la resolución de los conflictos. Se propició nuevamente el protagonismo de los trencipales (principales), ${ }^{17}$ quienes:

Antes de que llegara la misión arreglaban los problemas que sucedían con sus hijos, hermanos. Cuando llegó la misión [1954] la gente dejó un rato de hacer este trabajo [...] ya retomándolo otra vez después. [...] Pero no se dejó de por sí, sino que seguían trabajando en las comunidades, nomás que sin dar a conocer que arreglaban los problemas, sin dejarse ver. ${ }^{18}$

La figura del trencipal se incluyó en un cargo colectivo de nuevo cuño, los jmeltsa'anwanej, cuya función es "arreglar los conflictos" comunitarios, facilitar la negociación entre las partes en disputa en calidad de mediadores:

Nuestro trabajo es reconciliar los conflictos, para que las problemas (sic) que suceden en las comunidades no lleguen a parar antes las autoridades oficiales como MP o Juez penal, porque nuestras raíces, nuestros abuelos, tienen la forma de arreglar sus problemas, entonces esto es lo que estamos tratando de rescatar. ${ }^{19}$

Esta experiencia de la región de Bachajón está marcada por la recuperación de algunos mecanismos "tradicionales" para dirimir los problemas, filtrados por la reflexión sobre los

\footnotetext{
${ }^{17}$ Personas honradas y reconocidas en la comunidad, en gran parte adultos mayores.

18 Juan Méndez Gutiérrez, coordinador general de los jmeltsa 'anwanej en la región, originario de San Gerónimo Tulijá, entrevista, 1 julio 2011, Xotxothá Las Canchas, Chilón, Curso sobre Derecho Indígena, CEDIAC-ProDH.

${ }^{19}$ Pedro Demeza Gutiérrez, jmeltsa'anwanej bankilal, originario de San Gerónimo Tulijá, entrevista, 1 julio 2011.
} 


\section{AUTONOMIAINDÍGENA, VIOLENCIAY JUSTICIA}

derechos individuales y colectivos, que la misión propicia a través de cursos periódicos de formación en derechos humanos, derechos indígenas, derecho agrario y derecho civil. Al respecto, Juan Méndez, Coordinador general de los jmeltsa'anwanej en la región, afirma: “antes con los principales, al que empezó el problema, al final les daban unos chicotazos, pero ahora no, se cambió un poquito, los jueces no pegan, vamos a reeducación, a darles consejos para que no vuelvan a suceder [problemas]". Asimismo, es una característica de las estructuras de gobierno indígenas -también en otras regiones de Chiapas y de México- que las decisiones siempre se tomen por todo el grupo de autoridades en su conjunto; aunque hay una jerarquía en los cargos, la persona que ocupa el cargo más elevado nunca decide sola, sino que la autoridad y la responsabilidad siempre se asumen de forma colegiada y compartida.

Según explicó Pedro Demeza, bankilal de San Gerónimo, el colegio de jueces es compuesto por: el bankilal, "hermano mayor", y su esposa, que representan el cargo principal; el its 'inal, "hermano menor", y su esposa, quienes suceden al bankilal al terminar su periodo en el cargo (tres años); el xuht, cargo cubierto en su mayoría por jóvenes escolarizados, con la función de "aprendiz": "para ir viendo, conociendo la forma de arreglar las problemas"; el secretario, quien lleva el libro de actas en las que se asientan las reconciliaciones realizadas; y, finalmente, el trencipal, "es como una vigilancia del bankilal, se encarga de velar todos sus trabajos, si está haciendo legalmente, si no está haciendo a cambio de dinero, si no va a favor de ninguna parte [...] ya que el cargo de jmeltsa'anwanej es un servicio que hacemos gratuitamente, no recibimos ningún salario".

Los jmeltsa'anwanej son un cargo nuevo, que recupera algunas atribuciones de los cargos "tradicionales" refuncionalizandolas en una estructura novedosa. Destacan en ella varios elementos: en primer lugar, que son cargos que se asumen en pareja, entre la mujer y el hombre. Las mujeres se encargan, además de participar -al igual que su esposo- en todas las actividades y en todos los momentos de la conciliación, de atender los conflictos que involucran a mujeres: "porque hay cosas que a nosotros como hombres no nos pueden aclarar, el trabajo de las mujeres es ir a platicar con la mujer que tiene problemas, para sacar información". ${ }^{20}$ Se trata de una tarea importante, ya que buena parte de los conflictos que surgen en las comunidades se relacionan con problemas familiares e, incluso, con violencia

\footnotetext{
${ }^{20}$ Pedro Demeza Gutiérrez, jmeltsa'anwanej bankilal, originario de San Gerónimo Tulijá, entrevista, 1 de julio 2011.
} 
Capitulo 4. Justicia indigena e intercultural: la justicia según la Junta de Buen Gobierno
de la Zona Selva-Fronteriza

intrafamiliar. En segundo lugar, destaca la decisión de abrir a los jóvenes la estructura de cargos, tradicionalmente gerontocrática, creando la figura del xhut. La participación de mujeres y jóvenes como sujetos activos en la resolución de los conflictos es clave, pues los jmeltsa'anwanej entrevistados afirman que, junto con los conflictos agrarios, los principales problemas en la región son la drogadicción, el alcoholismo y "el abandono de las mujeres con hijos, o que embarazan a las muchachas y después no las casan"; ${ }^{21}$ esto es, fuentes de conflictos que involucran particularmente los jóvenes y las mujeres. ${ }^{22}$

La función que cumplen los jmeltsa'anwanej es de mediación, y para poderla ejercer es necesario que ambas partes en conflictos estén de acuerdo en su intervención. El colegio de jmeltsa'anwanej, a solicitud de una de las partes, decide intervenir y visita la otra parte en su domicilio para recoger información y verificar su disponibilidad al dialogo. Según Pedro Demeza:

En el primer encuentro que se enfrentan vamos a tratar de tomar sus aclaraciones, después buscamos el camino como reconciliarse este problema. Si en dado caso no llegan a un acuerdo, se pone otra fecha en un lapso de una semana o dos semanas, depende. Estos son los días que le damos para que vayan a pensar de qué forma pueden arreglar sus problemas. En estos tiempos que le damos, visitamos nuevamente a ambas partes, para darles más consejos, para platicar que es mejor que arreglen sus problemas en forma armoniosa, de reconciliación. ${ }^{23}$

La palabra tzeltal jmeltsa'anwanej es en ocasiones traducida como "juez tzeltal”, lo que es erróneo pues éstos no emiten una sentencia, ni tienen una autoridad que implique coerción para hacerla cumplir: "lo que hacemos nosotros es buscar la raíz del problema, donde empezó, como empezó, y buscamos la reconciliación de ambas partes". ${ }^{24}$ De tal manera que:

Si no llegan a un acuerdo, entonces nosotros levantamos una constancia de que vimos este problema, que tratamos de resolver, pero las partes que están en el conflicto no llegaron a un

\footnotetext{
${ }^{21}$ Jerónima Guzmán, coordinadora general de los jmeltsa'anwanej en la región, originaria de San Gerónimo Tulijá, entrevista, 1 julio 2011, Xotxothá Las Canchas, Chilón, Curso sobre Derecho Indígena, CEDIAC-ProDH.

${ }^{22}$ Según cuenta el xuht Felipe Vicente Silvano Moreno, "me escogieron en la comunidad porque hay muchos jóvenes que tienen problemas de alcohol, drogadicción, a veces toman y golpean sus padres, sus madres, por eso me decidí a entrar para dar el ejemplo a los otros jóvenes" (entrevista, 2 de julio 2011).

${ }^{23}$ Pedro Demeza Gutiérrez, jmeltsa'anwanej bankilal, originario de San Gerónimo Tulijá, entrevista, 1 de julio 2011.

${ }^{24}$ Rebeca Gutiérrez Hernández, xhut, originaria de San Gerónimo Tulijá, entrevista, 2 julio 2011.
} 


\section{AUTONOMIAINDÍGENA, VIOLENCIAY JUSTICIA}

acuerdo, entonces ya se dejaría a cuenta de ellos. Y les hacemos saber que si no arreglan sus problemas, si no se preocupan por sus problemas que tienen, deberán ir al MP un día. Pero la problema (sic) de llegar con el MP es que allí deben pagar, deben gastar un dinero; y a veces se arregla la problema en el MP, pero regresando a la comunidad sigue todavía la problema. ${ }^{25}$

Al igual que las otras experiencias de justicia intercultural estudiadas, también los jmeltsa'anwanej enfatizan la diferencia con la justicia del estado, que requiere una discreta disponibilidad económica para acceder a ella (ya sea por los gastos de operación -pago de la fianza, sueldo del abogado, etc.- que por la corrupción de las autoridades judiciales, que requieren de "mordidas" en todos los momentos de la investigación y del proceso). Asimismo, subrayan la diferencia con respecto a la actuación de los Agentes Municipales, quienes, en caso de encontrar a alguien culpable de un hecho, junto con la reparación del daño imponen una multa; por el contrario, "cuando arreglamos un problema no pedimos dinero de la mesa, multas, tampoco castigo: no hay castigos. En cambio, las autoridades municipales dan castigos, piden multas". ${ }^{26}$ Por esto, afirman, muchas personas prefieren acudir a ellos para la resolución de sus problemas.

No obstante la diferencia en los objetivos y en los procedimientos, los jmeltsa'anwanej mantienen una relación de colaboración con las autoridades comunitarias, el Agente Municipal (civil) y el Comisariado Ejidal (agrario): "si nos invitan, llegamos a un acuerdo con ellos, encontramos un común acuerdo, resolvemos el problema conjuntamente", sobre todo en los casos que "enfrentan una comunidad contra otra, o un grupo de habitantes contra otro grupo [...] En mi comunidad hemos resuelto problemas de despojo de tierra como ejidatarios, también problemas sobre cafetales, hay veces que se queman cuando se hecha lumbre a la milpa". 27

Sin embargo, la función de los jmeltsa'anwanej no es reconocida por todos los habitantes de la zona, pues es un cargo marcado por la adscripción religiosa. Su nombramiento se da adentro del ámbito religioso, en las asambleas durante las cuales las comunidades pertenecientes a la región nombran los cargos eclesiales (diáconos, catequistas). Su

\footnotetext{
25 Pedro Demeza Gutiérrez, jmeltsa'anwanej bankilal, originario de San Gerónimo Tulijá, entrevista, 1 de julio 2011.

${ }^{26}$ Rebeca Gutiérrez Hernández, xhut, originaria de San Gerónimo Tulijá, entrevista, 2 julio 2011.

27 José López Guzmán, its ’inal y suplente del Agente municipal, originario de Jkolmujul Há, entrevista, 2 de julio 2011.
} 
Capitulo 4. Justicia indigena e intercultural: la justicia según la Junta de Buen Gobierno
de la Zona Selva-Fronteriza

distribución territorial reproduce la demarcación operada por la misión: hay un grupo por cada "zona", conformada por un promedio de ocho comunidades. ${ }^{28} \mathrm{Su}$ caracterización de cargo ligado a la estructura de la iglesia católica hace que las personas que profesan el credo protestante no acudan a los jmeltsa'anwanej, aunque hay testimonios que relatan la colaboración entre éstos y pastores protestantes en la resolución de algún conflicto que involucre a personas de credos distintos. La dimensión religiosa marca profundamente los mecanismos para la resolución de los conflictos, como cuenta Pedro Demeza:

Nosotros como jmeltsa'anwanej no manejamos la ley -agraria, penal, civil-; trabajamos de acuerdo a las citas bíblicas y a la tradición de nuestros padres. Nos apoyamos en la Biblia, porque todos los casos que suceden, ya sea conflictos de tierras, violaciones, abandono de mujeres o de hijos, todos estos problemas que hay en las comunidades se reflejan en la Biblia. Cuando el quejoso nos viene a decir que tiene tal problema, nosotros nos ponemos a buscar citas bíblicas para leerlas cuando se enfrentan los que están en conflicto. ${ }^{29}$

El énfasis en la "búsqueda de la armonía" para la resolución de los conflictos, resalta la importancia que tiene la espiritualidad y la mística del servicio a la comunidad: "el último caso que arreglamos es de una pareja, que se separa y se volvieron a juntar. Cuando las cosas salen bien, es el regalo, es lo que nos gusta pues". Cuando esto se logra, se celebra con un ritual de conciliación que culmina con la "animación del corazón” (sutesel kotantik), esto es, "los presentes pasan a decir unas palabras a las dos partes para animar su corazón, sin diferenciar que hubo problemas entre ellos [...] Así se demuestra que queda arreglado el problema" (CORECO 2005: 47). En esta visión sobre la resolución del conflicto se refleja el concepto, destacado en investigaciones sobre la cultura tzeltal, de sutesbeyel yo 'tan jtul ants' winik (regresar el corazón a un hombre y a una mujer), que expresa la necesidad que

\footnotetext{
${ }^{28}$ El territorio donde opera la misión está dividido en cinco tsumbales (Tsumbal San Gerónimo, Tsumbal San Sebastián, Tsumbal Chilón, Tsumbal Sitalá, Tsumbal Guaquitepec), que a su vez se dividen en 17 zonas. La misión propicia actividades de oración, formación y organización en los que se reúnen los representantes de cada tsumbal (tsumbal'il) o bien todos los cargos eclesiásticos de todas las 17 zonas (curso interregional). Asimismo, se realizan reuniones de interzona (entre los cargos de las varias zonas que pertenecen a un mismo tsumbal) y de zona (entre los cargos de las comunidades que pertenecen a una misma zona). Según José López, "La divisan en zonas y tsumbales no corresponde a la división administrativa (comunidad) ni agraria (ejido). Es una división que depende de las tradiciones tzeltales, porque en el territorio la lengua tiene características distintas, tienen lugares sagrados diferentes, costumbres un poco diferentes, es una división cultural”.

${ }_{29}$ Pedro Demeza Gutiérrez, jmeltsa'anwanej bankilal, originario de San Gerónimo Tulijá, entrevista, 1 de julio 2011.
} 


\section{AUTOONOMIIAINDÍGENA, VIOLENCIAY JUSTICIA}

familiares, amigos o vecinos, ayuden a la persona que está cometiendo errores o causando

problemas a "volver en sí" o regresar al camino correcto. ${ }^{30}$ La idea de la resolución del conflicto como ayuda y educación de quien está errando se encuentra también en otras experiencias indígenas, como detallaré más adelante.

Cabe recordar que los jmeltsa'anwanej desarrollan su función gratuitamente e incluso aportando de sus propios ahorros: "por ejemplo, si vas a resolver un problema en otra comunidad, a veces te pagan el pasaje, y si no, lo pagamos de nuestra bolsa $[\ldots]$ es un poco difícil, cuando sales dos o tres días a resolver un problema, está lejísimo... pero es tu cargo y lo tienes que cumplir". 31

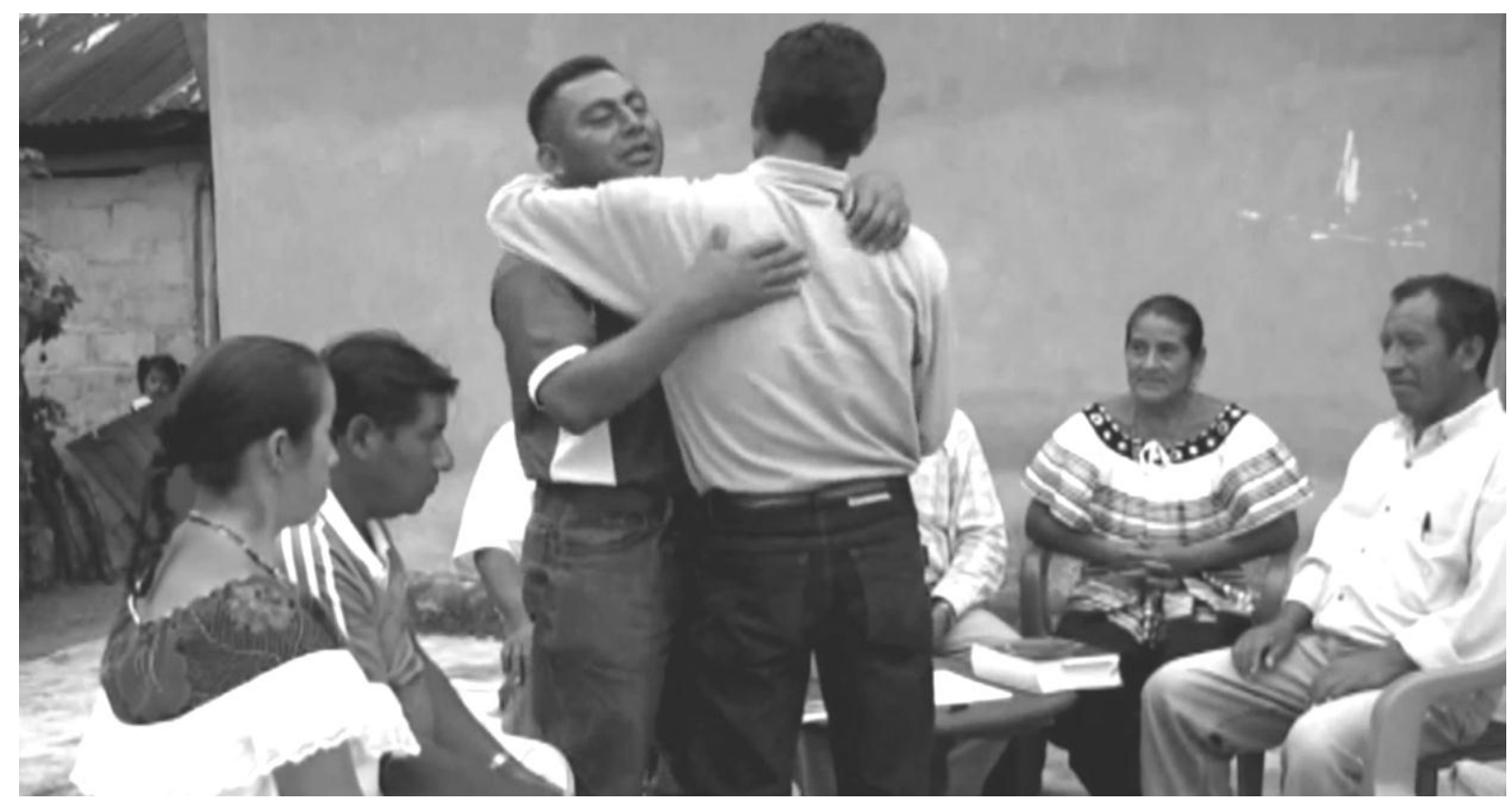

Resolución de conflicto por los jmeltsa'anwanej: Sutesbeyel yo’tan jtul ants' winik, San Gerónimo Tulijá. Foto: Raíces de Nuestra Justicia, Centro ProDh

\footnotetext{
30 "Para regresarle el corazón a alguien es importante que haya una persona que le ayude, ya que sólo no puede hacerlo. Asimismo, si el joven ha aprendido cosas que dañan, si molesta y agrede a otros, entonces, un adulto debe de hablarle, decirle que eso está mal y que no debe hacerle daño a otros, pues se meterá en problemas, irá a la cárcel, gastará su dinero en vano, será la vergüenza y el objeto de chisme ante la sociedad ya que vives en el pueblo y te conocen. [...] después de que el padre le habla a su hijo, éste lo reflexiona y entiende que todo lo que le han dicho es cierto y sigue el buen camino. Entonces, la jsutesbetik yotan a" (le habremos regresado su corazón) (testimonio de Miguel Espinoza, cit. en Pérez Moreno 2012: 127-128).

${ }^{31}$ José López Guzmán, its'inal y suplente del Agente municipal, originario de Jkolmujul Há, entrevista, 2 de julio 2011.
} 
Capitulo 4. Justicia indigena e intercultural: la justicia según la Junta de Buen Gobierno
de la Zona Selva-Fronteriza

La construcción de la paz: CORECO

En Chiapas, particularmente después del levantamiento zapatista y a raíz de la implementación de la guerra contrainsurgente y de desgaste, se han polarizado las diferencias políticas y religiosas ya existentes en el ámbito local, lo que originó una situación de violencia difusa e incrementó la fragmentación del tejido social inter e intracomunitario, escenario que he documentado en el capítulo 3. En este contexto, la Diócesis de San Cristóbal intensificó su actividad de mediación en los diferentes niveles, inicialmente con la creación de la Comisión Nacional de Intermediación (CONAI) en el diálogo entre el EZLN y el gobierno federal, y sucesivamente a través de la Comisión de Apoyo a la Unidad y Reconciliación Comunitaria (CORECO), creada en 1996 en el marco del proceso de dialogo. Según el actual presidente de CORECO, Jorge Santiago, "en ese momento se estaban generando muchos conflictos comunitarios; la idea es que se facilitara su resolución en las mismas comunidades, para que esos problemas locales no se volvieran el punto central de los Diálogos de San Andrés, que debían tener un alcance político nacional". Los conflictos, que se generaron desde ese entonces y que permanecen en muchos casos con las mismas características, eran de carácter político, generados por la hegemonía del proyecto zapatista y las tensiones con otras organizaciones regionales, como la ARIC y la CIOAC, o con simpatizantes de partidos políticos, inicialmente el PRI. CORECO centró sus actividades inicialmente en la mediación en comunidades específicas que requerían su presencia, y sucesivamente impulsó espacios plurales de dialogo y convergencia, convocando a muchas organizaciones sociales para impulsar la resolución de los conflictos que las involucraban: los Encuentros por la Paz y la Reconciliación.

Asimismo, a partir de 1999, CORECO dirigió la capacitación de mediadores comunitarios, cuya función sería propiciar la resolución pacífica de los conflictos en las comunidades, principalmente indígenas, donde los mecanismos y las instituciones propias ya no logran plantear soluciones efectivas a los problemas. Explica Felipe Toussaint, coordinador de CORECO hasta su fallecimiento en 2011:

La mayoría son personas ligadas a las estructura de la Iglesia, gente grande, que tiene cierto peso moral en sus comunidades. La mayor parte de los conflictos que abordan son familiares, entre vecinos; pocas veces abordan conflictos de más envergadura, como conflictos 


\section{AUTONOMIAINDÍGENA, VIOLENCIAY JUSTICIA}

comunitarios, políticos o agrarios, porque ellos quedan muy involucrados en las tendencias políticas de la región, y porque a veces son amenazados por la parte que siente que está perdiendo el privilegio que esperaba obtener de este conflicto. ${ }^{32}$

El proceso de "fortalecimiento del corazón" propicia la reflexión colectiva sobre las diferencias que hay al interior de las comunidades, para "apagar el enojo y el rencor", con la intención de que los mismos habitantes logren solucionar sus problemas y encontrar un acuerdo sin la necesidad de que sea un mediador o una autoridad en proporcionar la solución. ${ }^{33}$ En el proceso de construcción de acuerdos, que puede ser muy largo, los Mediadores, Promotores y Comisiones de Paz y Reconciliación, así como el mismo equipo de CORECO, realizan una labor de acompañamiento para transformar la actitud y las emociones de los individuos involucrados en el conflicto, buscando pasar del rencor y el enojo a sentimientos más positivos y propicios al dialogo. ${ }^{34}$ La transformación positiva del conflicto retoma en gran medida las formas de resolución de conflictos que son práctica común entre los pueblos indígenas de la región, conjuntándolas con el discurso de los derechos humanos y con los mecanismos de resolución alternativa de conflictos. Al respecto, Toussaint comenta:

Alrededor del 2002, en CORECO iniciamos a reflexionar si nuestro trabajo no era "neoliberal", en el sentido de que estuviéramos fortaleciendo una ideología que plantea que cada quien a su modo, que primero es el individuo y las opciones propias, y que la diversidad de productos es lo que genera riqueza... nos preguntamos: ¿será que nosotros estamos metiendo esta idea en los pueblos indígenas? La siguiente pregunta fue: ¿para qué queremos resolver conflictos? La primera respuesta es porque vemos que hay sufrimiento, dolor, tensión en la gente. También vemos que la propuesta que algunos tienen de que se junten otra vez en un solo grupo no es viable. No todas las organizaciones, las religiones, los proyectos políticos están al mismo nivel: algunos están más desarrollados, y otros menos; otros son más liberadores, y otros menos; más desde los pobres y de los procesos de transformación social, o menos. Hay diferencias reales, y no podemos decir que es tan válido el zapatismo que el

\footnotetext{
${ }^{32}$ Felipe Toussaint Loera, coordinador general de CORECO, entrevista personal, 4/02/2010, San Cristobal de las Casas.

${ }^{33}$ Según un Promotor de Paz y Reconciliación de Ocosingo, "reconciliación es unir, pero no unir que ya todos somos uno. Reconciliar es reconocer el otro, llegar en un acuerdo pero respetar nuestras diferencias", en el Cuaderno núm.5 ¿Por qué formamos comisiones?, CORECO, 2005, p.23.

${ }^{34}$ Véase los documentos de CORECO Segundo Encuentro sobre las experiencias por la Paz y la Reconcilación, 2002; Cuaderno núm.3 ¿Qué es el conflicto?; Cuaderno núm. 4 Construyendo soluciones para los conflictos.
} 
Capitulo 4. Justicia indigena e intercultural: la justicia según la Junta de Buen Gobierno
de la Zona Selva-Fronteriza priismo, que sostiene la esclavitud, el indígena sumiso al sistema, obediente, mientras el zapatismo pretende una liberación con dignidad, que la gente se haga más autónoma, que no espere a que el gobierno les resuelva sus problemas... Hay una diferencia real, pero al mismo tiempo hay un conflicto, y esos conflictos se convierten en caldo de cultivo para acciones contrainsurgentes o paramilitares. Nosotros decimos: queremos resolver los conflictos porque vemos el dolor de la gente, y para colaborar en la construcción de la transformación social y del proyecto de paz. ${ }^{35}$

En este caso, el razonamiento crítico y políticamente situado permite mantener un criterio sobre los alcances y los límites de tales procesos de resolución de conflictos, que no en todos los casos son posibles o deseables. El trabajo de CORECO ha buscado mantenerse en todo momento al servicio de los pueblos, representando una instancia de mediación colectiva que se distancia profundamente de las instancias de resolución alternativa de conflictos que se han impulsado en el marco de la descentralización neoliberal del Estado, o de las justicias informales que se desarrollan como respuesta a la ausencia de las instituciones oficiales.

\footnotetext{
${ }^{35}$ Felipe Toussaint Loera, coordinador general de CORECO, entrevista personal, 4/02/2010, San Cristóbal de las Casas.
} 


\section{AUTONOMIAINDÍGENA, VIOLENCIAY JUSTICIA}

\section{Autonomía y justicia según la Junta de Buen Gobierno zapatista de la región Selva- Fronteriza en Chiapas}

"Lento pero avanzo". Esta oración, escrita en un mural que decora una puerta de madera frente a la entrada del Caracol de Oventik, en la Zona Altos, describe bien una de las características del proceso organizativo de las comunidades zapatistas: la paulatina pero continuada construcción de las múltiples estructuras que conforman el sistema de organización social autónoma, proceso que parte de la experiencia para elaborar la teoría, considera los errores como parte de la trayectoria de formación y consolidación política, y trata de privilegiar la horizontalidad más que la especialización de las funciones.

A lo largo de veinte años, desde enero de 1994, el proyecto político zapatista en Chiapas ha evolucionado de manera coherente hacia la construcción de autonomías territoriales e integrales, en las que toda la población está involucrada en algún aspecto de la compleja estructura social y de gobierno, que reivindica su radical y completa autonomía de las instituciones y autoridades del Estado. Lo que caracteriza el proyecto zapatista y lo diferencia de las demás experiencias autonómicas es que se origina a partir de una organización políticomilitar con un proyecto político definido y de alcance nacional; que se realiza a partir de una declaración de guerra y que la guerra misma - en sus modalidades de combate abierto y de guerra de desgaste- influye en su desarrollo; que el EZLN impulsó una relación política y de dialogo con el Estado, que éste traicionó en varias ocasiones. Estos hechos definen la característica central del zapatismo, es decir su completo e intransigente rechazo de cualquier relación -desde lo político hasta los programas asistenciales- con las instituciones federales, estatales y municipales. Este punto es clave para entender la evolución del proyecto zapatista y su relación con la población que habita el territorio gobernado por las autoridades autónomas.

En la actualidad (2014) la autonomía zapatista incluye a "más de 250 mil indígenas tzeltales, tzotziles, tojolobales, choles, zoques y mames en 27 Municipios Autónomos Rebeldes Zapatistas (MAREZ), informa una fuente confiable cercana a la organización. Ellos representan 21.9\% de la población indígena de Chiapas, que es de un millón 141 mil 499, según INEGI". ${ }^{36}$ En el territorio de influencia zapatista, existen aproximadamente 500 escuelas primarias y secundarias y 1500 promotores de educación, y 45.000 personas ya

\footnotetext{
${ }^{36}$ Laura Castellanos, “Gobierna el EZLN a 250 mil indígenas”, El Universal, 2 de enero 2014.
} 
Capitulo 4. Justicia indigena e intercultural: la justicia según la Junta de Buen Gobierno de la Zona Selva-Fronteriza

egresaron del Sistema de Educación Autónoma Zapatista. Transmiten diariamente diez radios comunitarias, y funcionan dos bancos autónomos, decenas de hospitales, clínicas y cooperativas.

Mucho se ha escrito a favor o en contra del proyecto y del proceso zapatista, sobre la historia y la evolución del movimiento armado (EZLN), sobre las prácticas de la autonomía en diferentes aspectos, sobre las iniciativas políticas que ha abanderado y su relación con la "señora sociedad civil" nacional e internacional, sobre su papel en el fortalecimiento del movimiento indígena, sobre el ejemplo utópico de sociedad democrática que ha tratado de construir, y un largo etcétera. Entre los trabajos que, personalmente, considero imprescindibles para quienes quieran acercarse o profundizar el tema, están El sueño zapatista (1997), entrevistas realizadas por Ivon Le Bot al Subcomandante Marcos, al Comandante Tacho y al Mayor Moisés del EZLN, que relatan la larga trayectoria del EZLN y su relación con los indígenas chiapanecos, y explican los principios que orientan el movimiento; 20 y 10: El fuego y la palabra (2003), en el que Gloria Muñoz reúne valiosos testimonios de integrantes del EZLN con una detallada cronología de los primeros diez años después del levantamiento; y Autonomía zapatista. Otro mundo es posible (2008), en el que Cristina Hijar y Juan E. García describen y muestran los diferentes aspectos de la autonomía zapatista en construcción. Un importante "ensayo de interpretación” (así lo define el autor) es el texto "Los 'Caracoles' zapatistas: redes de resistencia y autonomía" (2003) de Pablo González Casanova. En un precedente trabajo (Gasparello 2005) busqué una aproximación histórica, política y antropológica general al proceso de autonomía zapatista, del que mencionaré aquí de manera sintética los elementos principales, pues es necesario esbozar la articulada estructura social autonómica para ubicar y entender las prácticas de justicia que en ella se desarrollan. 


\section{AUTONOMIAINDÍGENA, VIOLENCIAY JUSTICIA}

\section{Origen y estructura del gobierno autónomo zapatista. Instancias de resolución de los conflictos}

La comunidad. Autoridades-concejo, asambleas y acuerdos

El autogobierno zapatista es estructurado en tres ámbitos, que responden a la organización geopolítica del territorio. Como en la mayor parte de los pueblos indígenas, también entre los indígenas zapatistas la estructura de gobierno propia tiene su primer núcleo en los cargos que rigen las comunidades. Por lo tanto, el autogobierno zapatista puede ser muy diferente entre la región de Los Altos, donde existe una forma de gobierno local -el sistema de cargos-que tiene una presencia histórica y está altamente estratificado, con una compleja jerarquía de roles y autoridades, y la región de la Selva, donde las normas que regulan las relaciones entre las familias y los grupos son mucho más sencillas porque nacieron de las exigencias concretas en el proceso migratorio, y la estructura de cargos retoma la que prevé la Ley Agraria para los ejidos.

Según Leyva (2001), "la tradición de los selváticos de los años ochenta estaba cimentada en las uniones de ejidos, las organizaciones micro-regionales legales y clandestinas y en los sacramentos católicos con sus correspondientes fiestas patronales". La autora identifica el eje de la estructura comunitaria, antes de 1994, con las que llama autoridades-concejo, es decir el grupo al que la asamblea comunitaria, máxima instancia de autoridad, delegaba el poder de gobierno. El núcleo de las autoridades-concejo era compuesto por el Comisariado Ejidal, el Agente Municipal y los catequistas católicos, cuyos puestos "estaban al mismo nivel y sus funciones no se reducían a lo meramente político, agrario o judicial” (Leyva 2001), temas que abordaban de manera colegiada. Estos cargos se acompañaban de comités, "ocupados por gente que se distinguía por su responsabilidad, por gente con prestigio", y comisiones, "ocupadas por jóvenes recién casados o solteros que podían caminar largas distancias y trasladarse a las reuniones celebradas fuera de su localidad" (figuras colectivas que el zapatismo retomará para estructurar las áreas sociales como la salud, la educación, la comunicación, etc.); también incluía a los hueseros y las parteras, que se ocupaban de la salud comunitaria. Dicha estructura se diferencia del sistema de cargos alteño pues no es jerárquica, más bien rotativa, de tal manera que llegados a cierta edad todos los hombres de la comunidad habrán cubierto una 
Capitulo 4. Justicia indigena e intercultural: la justicia según la Junta de Buen Gobierno de la Zona Selva-Fronteriza

buena parte de los cargos existentes. Ya en 1983 Ruz daba cuenta, en comunidades tojolabales, de la existencia del comité de salud y del escolar, cargos que se mantienen en las comunidades zapatistas en las figuras de los promotores de educación y de salud.

Destaca el carácter colectivo del gobierno, evidente además en cada espacio de la vida cotidiana: en el concejo de autoridades "el poder no estaba concentrado en un individuo sino en un cuerpo colegiado en el que por lo general estaban representadas las diferentes tendencias, grupos o facciones que coexistían al interior de la localidad" (Leyva 2001), de la misma manera en que las asambleas resolvían problemas comunes pero a su interior albergaban diferentes grupos políticos o de interés, que permanentemente estaban en conflicto y tensión. Después del levantamiento zapatista, la recomposición de los equilibrios políticos regionales trastocó en parte esta estructura, originando la institución de nuevos cargos, provocando divisiones internas y nuevas directrices de cohesión, que no siempre recalcan el ámbito comunitario. Detallaré este tema más adelante.

De las comunidades donde he realizado estancias de investigación a partir del año 2001, La Realidad Trinidad, Guadalupe el Tepeyac y San José del Río están ubicadas en las Cañadas de Las Margaritas e integradas en el Municipio Autónomo San Pedro de Michoacán, mientras La Garrucha es parte del Municipio Autónomo Francisco Gómez y se encuentra en las Cañadas de Ocosingo. La población es casi en su totalidad indígena: en mayoría tojolabal (La Realidad, Guadalupe) y tzeltal (La Garrucha), y las comunidades se formaron aproximadamente en los años cincuenta del siglo XX, es decir en la segunda ola migratoria.

San José del Río es la comunidad más reciente, pues se fundó a finales de los años ochenta ya como parte de la lucha zapatista, por un grupo de peones acasillados en la finca Nuevo Horizonte; formalmente es una ranchería, ya que los campesinos organizados lograron comprar la tierra "con un señor que se llamaba José Jiménez, por eso le llamamos San José”, pero se acordó que la tenencia de la tierra fuera colectiva y se destinó una gran parte del territorio para que también se trabajara de manera colectiva. A la fecha, de las comunidades que he conocido, San José es la única que sigue siendo completamente zapatista.

En los contextos estudiados, el núcleo del gobierno comunitario es constituido por el Comisariado Ejidal y su Consejo de Vigilancia, y el Agente Municipal y sus comisiones o policías. Dichas autoridades son presentes también en comunidades no zapatistas, pues su 


\section{AUTONOMIAINDÍGENA, VIOLENCIAY JUSTICIA}

institución figura en la Ley Agraria $^{37}$ y en la Ley Orgánica Municipal del Estado de Chiapas. En los hechos, sus funciones van más allá de aquellas legalmente atribuidas, pues por razones de lejanía geográfica y cultural las autoridades comunitarias cumplen muchas tareas que corresponderían a un nivel superior (ej. Ministerio Público, Juez Municipal o síndico municipal). El Comisariado se encarga de los asuntos agrarios, de la relación con los ejidos colindantes, del control del territorio ejidal, de sus recursos maderables, hídricos, pétreos y de la vigilancia de los caminos; el Agente Municipal es la autoridad civil, que se ocupa, entre otras funciones, de mantener la seguridad pública y de la resolución de los conflictos. ${ }^{38}$ Estos cargos duran uno, dos o tres años, según el acuerdo de cada comunidad; en las comunidades zapatistas, pueden ser cubiertos tanto por hombres como por mujeres. En ambos casos se trata de autoridades colegiadas, que además se pueden apoyar, en casos difíciles o urgentes, a los principales o consejo de ancianos, cuya autoridad es reconocida en la comunidad, ${ }^{39}$ o convocar una Asamblea general.

Del Agente dependen las comisiones o policías de la comunidad, cuya función es vigilar el interior de la comunidad, auxiliar el Agente en todas sus acciones, realizar las investigaciones necesarias cuando se presenta un conflicto y detener la persona inculpada. Están en función todos los días, porque también vigilan que se respete una de las normas vigente en muchas comunidades: que los animales deben estar amarrados en los solares, para que no causen perjuicio en las propiedades ajenas, invadan las huertas o los patios donde se pone a secar café, maíz o frijol. Al enterarse del daño ocasionado por algún animal, las comisiones se encargan de buscar el dueño y presentarlo ante el Agente municipal. Son coordinados por el comandantes y su cargo dura el mismo tiempo que el Agente (uno o tres años, dependiendo de la comunidad); son nombrados en la misma asamblea que éste. Los

\footnotetext{
${ }^{37}$ Ley Agraria nacional, publicada en 1992, última reforma 09/04/2012, artículos 32 al 40.

${ }^{38}$ Según la Ley Orgánica del Municipio Libre del estado de Chiapas, las Agencias y Subagencias Municipales son creadas por el Ayuntamiento, quien debe ratificar los Agentes y Subagentes nombrados en asamblea. De acuerdo al artículo 52 de dicha Ley, algunas de sus funciones son: "vigilar, mantener y restablecer la tranquilidad, la seguridad y la salubridad pública; cumplir con las disposiciones relativas al registro del estado civil de las personas; practicar en los lugares donde no haya Juez Municipal, rural o Agentes del Ministerio Público, las primeras diligencias de averiguación previa en los casos de conductas que pudieren configurar algún delito, y procurar la captura en caso de flagrancia de los presuntos responsables; y hacer del conocimiento de la agencia del Ministerio Público del Distrito Judicial que corresponda en un término no mayor de 24 horas; coadyuvar con las autoridades judiciales, cuando sean requeridos; [...] actuar como conciliadores en los conflictos que se les presentaren" (Ley Orgánica Municipal del estado de Chiapas, última reforma 28/09/2011, cursivas mías) .

${ }_{39}$ Josué, habitante de una ranchería cercana a La Realidad, entrevista, diciembre 2007.
} 


$$
\begin{gathered}
\text { Capitulo 4. Justicia indigena e intercultural: la justicia según la Junta de Buen Gobierno } \\
\text { de la Zona Selva-Fronteriza }
\end{gathered}
$$

policías o comisiones son un cargo que antecede a la implantación del zapatismo y existen en todas las comunidades de la zona.

Según varios testimonios, el fortalecimiento del autogobierno zapatista ha implicado la creciente participación de las mujeres en las asambleas y en los cargos comunitarios. En La Realidad se instituyó una autoridad femenina, paralela y auxiliar a los cargos que acostumbran cumplir los varones: "hay comisariadas y agentas municipal, tienen sus comisiones también. Cuando nosotros [los varones] no estamos, y surge un problema, pronto lo atiende el agente municipal de mujeres, se reúnen rápido y ya están viendo el problema cuando nosotros regresamos de la chamba" ${ }^{40}$ En comunidades tzeltales y tzotziles del Municipio Autónomo Tierra y Libertad (véase

Mapa 7: Municipios Autónomos de la Zona Selva Fronteriza, pág. 332) las mujeres han cubierto los cargos de Agente y también de policía: "aunque realmente como mujeres no sabemos muy bien todo eso, pero se reconoce como un deber y como un derecho que también como mujeres debemos de cumplir de ser y trabajar como autoridad". ${ }^{41}$ Finalmente, en San José del Río la autoridad es formada por dos personas, un hombre y una mujer.

El fundamento de la organización social y política indígena, en todos sus niveles, es la asamblea comunitaria, en la que actualmente participan mujeres y hombres (estos últimos todavía con una participación más activa) "desde la edad de 15 años, ya estamos dentro de la comunidad, dentro de los acuerdos". ${ }^{42}$ La asamblea es el espacio de discusión, donde se toman las decisiones y se plasman los acuerdos; en ella se nombran los miembros de comités, comisiones y las autoridades, que en cualquier momento pueden ser revocados por la instancia colectiva. La asamblea era central en la vida comunitaria desde la formación de los poblados, ${ }^{43}$ y es una instancia que la organización zapatista incorpora y potencia como instrumento democrático básico. Según los integrantes del Comisariado Ejidal de La Realidad:

\footnotetext{
${ }^{40}$ Comisariado Ejidal de La Realidad, entrevista, 14 de diciembre 2008.

${ }^{41}$ Mujer integrante de la JBG, entrevista, 11 de diciembre 2008.

${ }^{42}$ Comisariado Ejidal, La Realidad Trinidad, entrevista, 30 diciembre 2007.

${ }^{43}$ En la comunidad de La Garrucha, en 2004 (en ese entonces la comunidad era en su mayoría zapatista) pude observar con claridad que, aunque la asamblea general de una comunidad se reúne de vez en cuando, la resolución cotidiana de los problemas se toma por igual colectivamente. En el patio de la iglesia, por lo regular después de la diaria misa vespertina, pero a veces convocados especialmente por el repique de la campana, se reunían los hombres de la comunidad para abordar los problemas ligados a la venta del café, a la compra de material agrícola o a la manutención de los caminos.
} 


\section{AUTOONOMIIAINDÍGENA, VIOLENCIAY JUSTICIA}

En aquel tiempo las autoridades, por ejemplo el comisariado ejidal, hacían sus asambleas generales, cada fin del mes, donde se dan a conocer con el pueblo los trabajos pendientes en la comunidad. Entonces en esa asamblea se hacen acuerdos, que podemos decir nuestra ley indígena. Entonces esa es como una ley, que nosotros tomamos el poder, como autoridad. Porque ya tenemos el acuerdo de la mayoría, donde se dice que este trabajo se va a hacer de esta manera. Entonces en tal fecha, vamos a hacer cumplir. Entonces la autoridad es la que promueve, ya tiene, ora sí, la autorización del pueblo. [...] Ya la autoridad es lo que lo gestiona, hace gestionar todo los acuerdos. Entonces se llaman acuerdos de la comunidad. Es promovido por la mayoría de las personas. ${ }^{44}$

Regresaré más adelante sobre la importancia de los acuerdos de la comunidad, en los que se asientan las normas que rigen la vida colectiva; su legitimidad reside en la asamblea y las autoridades tienen el papel de hacerlos cumplir. Según esto, las autoridades tienen un papel ejecutivo de las decisiones colectivas, no son dirigentes:

en algunas palabras se dice que la autoridad, porque es un término muy rápido; pero dándole un sentido, es un servidor del pueblo, porque no somos una autoridad que mandamos, que nosotros hacemos las cosas, sino lo que nos diga el pueblo, los acuerdos del pueblo, es lo que nosotros agarramos y hacemos cumplir, entonces nosotros somos los inmediatos. ${ }^{45}$

El citado estudio de Ruz (1983) destaca la existencia, en comunidades tojolabales, de una serie de mecanismos que tienden a impedir cierta retención de control individual de poder en manos de una autoridad, "que en ningún momento adquiere un poder tal que le posibilita ser independiente del resto. [El Comisariado] no puede siquiera delegar poder en otras personas; sus propios ayudantes y/o substitutos son elegidos también en asamblea comunal" (Ruz 1983:192). El autor define a estas autoridades como portadoras de un "poder asignado por una unidad de consenso", según la definición acuñada por Adams (1978, cit. en Ruz 1983:192).

Carlos Lenkersdorf, estudioso y conocedor de la cultura tojolabal, argumenta la distinta concepción de la autoridad en la sociedad indígena partiendo del análisis lingüístico: explica que las locuciones con las que se hace referencia a las personas que reciben el cargo en la asamblea, pueden traducirse en "los que tienen su trabajo de responsabilidad por nosotros" o

\footnotetext{
${ }^{44}$ Comisariado Ejidal, La Realidad Trinidad, entrevista, 30 diciembre 2007.

${ }^{45}$ Idem.
} 
Capitulo 4. Justicia indigena e intercultural: la justicia según la Junta de Buen Gobierno
de la Zona Selva-Fronteriza

bien "los trabajadores de la comunidad" (Lenkersdorf 2002: 79-85). El énfasis es en la acepción de trabajar por la comunidad que tiene en tojolabal el verbo gobernar, y la función de trabajadores (o servidores, en palabras del Comisariado de La Realidad) que cumplen las autoridades.

En muchas regiones indígenas se encuentra una estructura comunitaria parecida a la expuesta, y existe la práctica de la autonomía en uno u otro ámbito social, pero el proyecto zapatista es, tal vez, el único ejemplo en México de autonomía integral: se han desarrollado, aunque con distinto éxito, estructuras autónomas para la representación, el gobierno y la administración de justicia, y en el ámbito de la política social, para la educación, la salud, la economía, la agricultura, la comunicación y otras áreas.

El meollo del sistema es la estructura de autogobierno organizada en tres niveles y según una división regional. El autogobierno, más allá del espacio comunitario, fue la primera muestra del proyecto autonómico en ser presentada públicamente cuando, el 19 de diciembre de 1994, el EZLN anunció la ruptura del cerco militar establecido por el Ejército mexicano alrededor de la "zona de conflicto", la penetración de miles de insurgentes en 38 municipios (que representan el 50\% del territorio estatal), y la creación de treinta Municipios Autónomos Rebeldes Zapatistas (MAREZ). ${ }^{46}$ Según el comunicado que anuncia su fundación, "las leyes que deben cumplir y hacer cumplir los nuevos municipios rebeldes en su mandar obedeciendo son: la Constitución Política de los Estados Unidos Mexicanos de 1917; las leyes revolucionarias zapatistas de 1993; las leyes locales del comité municipal que la voluntad popular de la población civil determine ${ }^{47}$ La creación de los Municipios Autónomos tiene en parte el carácter de una operación militar: se dio a conocer en partes de guerra, como acción de una campaña militar vuelta a romper el cerco y demostrar la presencia de zapatistas en la zona controlada por el Ejército y hasta detrás de sus líneas. El mensaje que el EZLN pretendía lanzar era que la solución al conflicto no podía ser militar, porque los zapatistas, tanto

\footnotetext{
${ }^{46}$ En días anteriores, ya se había dado a conocer la formación del Municipio Autónomo San Pedro de Michoacán (en Las cañadas de Las Margaritas), cuya cabecera originalmente se asentaba en Guadalupe el Tepeyac, el 12 de diciembre de 1994; del Municipio Autónomo Che Guevara (Cañadas de Ocosingo) y del Municipio Autónomo de Sibacjá, en la misma zona, éste ligado a la Organización de Cafeticultores de Ocosingo (ORCAO), el 17 de diciembre de 1994. En ese momento, muchas organizaciones chiapanecas pregonaban la necesidad de constituir municipios y regiones autónomas, consigna ratificada el 12 de octubre de 1994 por el Consejo de Organizaciones Indígenas y Campesinas (coalición que tuvo vida breve) y que organizaciones como ORCAO, CIOAC y Unión de Ejidos Tojolabales trataron de llevar a cabo, de manera paralela al EZLN y con poco éxito (cfr. capítulo 2.2.)

47 <http://palabra.ezln.org.mx/comunicados/1994/1994_12_19_e.htm>, consultado el 2 de agosto 2014.
} 


\section{AUTOONOMIIAINDÍGENA, VIOLENCIAY JUSTICIA}

insurgentes como bases de apoyo, estaban en todas partes, y el Ejército estaba, de hecho, rodeado. El carácter militar es visible también en la ceremonia de creación del Municipio Autónomo de San Pedro de Michoacán, donde fueron los Comandantes quienes, a nombre del CCRI-CG del EZLN, hicieron formal entrega del poder civil en el territorio a los ocho hombres elegidos por la Asamblea General de la zona. ${ }^{48}$

\section{Estructura territorial del Ejercito Zapatista de Liberación Nacional (síntesis)}

\begin{tabular}{|c|c|}
\hline Organización militar & Organización política \\
\hline $\begin{array}{l}\text { Ejército Zapatista de Liberación Nacional } \\
\text { (EZLN) } \\
\text { Cada batallón o división actúa en una } \\
\text { determinada Región Militar. Al mando de } \\
\text { cata batallón está un Mayor que es también } \\
\text { la referencia militar para esa región. } \\
\text { En la jerarquía del EZLN el máximo mando } \\
\text { militar es llamado SubComandante, } \\
\text { expresando su subordinación a los mandos } \\
\text { políticos (Comandantes del CCRI). }\end{array}$ & $\begin{array}{l}\text { Comité Clandestino Revolucionario Indígena } \\
\text { (CCRI) } \\
\text { Representa el órgano político (ya que no está } \\
\text { armado) del EZLN. Está conformado por un } \\
\text { número no definido de Comandantes, cada uno al } \\
\text { mando de un Comité de Zona. La territorialización } \\
\text { de los Comités de Zona representa la estructura en } \\
\text { la que están organizadas las comunidades bases de } \\
\text { apoyo zapatistas (BAEZ) y recalca la subdivisión de } \\
\text { las Regiones Militares. Las comunidades que } \\
\text { apoyan un batallón o división pertenecen a una } \\
\text { determinada Zona y son representadas por el } \\
\text { Comité del CCRI. }\end{array}$ \\
\hline $\begin{array}{l}\text { Insurgentes } \\
\text { Soldados en activo del EZLN, entrenados } \\
\text { militarmente, permanecen en los } \\
\text { campamentos para el resguardo del territorio. }\end{array}$ & \multirow[t]{2}{*}{$\begin{array}{l}\text { Responsables } \\
\text { Como lo dice su nombre, son los representantes } \\
\text { políticos del EZLN en las comunidades. }\end{array}$} \\
\hline $\begin{array}{l}\text { Milicianos } \\
\text { Bases de apoyo que viven en las } \\
\text { comunidades, han recibido entrenamiento y } \\
\text { están organizados en una estructura militar, } \\
\text { se movilizan en caso de necesidad, } \\
\text { representando una suerte de "reserva" del } \\
\text { EZLN. }\end{array}$ & \\
\hline
\end{tabular}

Diversos investigadores han enfatizado que los derechos de los pueblos indígenas, la autonomía y los municipios autónomos no formaban parte de las reivindicaciones originarias del levantamiento ni los refleja la forma organizativa que se dio el EZLN en los años de su fortalecimiento como estructura clandestina y político-militar. En la entrevista realizada por Ivon Le Bot, Marcos explica que la resistencia del EZLN al embate militar, y el apoyo de la

${ }^{48}$ H. Bellinghausen, "Instituye el EZLN en Guadalupe Tepeyac el 'municipio zapatista' San Pedro de Michoacán”, La Jornada, 13 de diciembre 1994. 
Capitulo 4. Justicia indigena e intercultural: la justicia según la Junta de Buen Gobierno
de la Zona Selva-Fronteriza

sociedad civil, permitieron que el movimiento no fuera inmediatamente derrocado, y al contrario se fortaleciera y ampliara su consenso, llegando a controlar un territorio al interior del cual no todos los respaldan, donde sin embargo son gobierno y deben asumir la responsabilidad de los problemas o conflictos que surjan en él.

Se dio entonces la necesidad de superar la organización político-militar y propiciar el zapatismo también como un movimiento de organización social. Un antecedente importante son las diez Leyes revolucionarias publicadas en el órgano informativo del EZLN, El Despertador Mexicano, en diciembre de 1993: Ley de Impuestos de Guerra, Ley de Derechos y Obligaciones de los Pueblos en Lucha, Ley de Derechos y Obligaciones de las Fuerzas Armadas Revolucionarias, Ley Agraria Revolucionaria, Ley Revolucionaria de las Mujeres, Ley de Reforma Urbana, Ley del Trabajo, Ley de Industria y Comercio, Ley de Seguridad Social y Ley de Justicia. Aunque muchas de ellas son formuladas para ser aplicadas en un contexto de guerra, otras son documentos fundadores del pensamiento y de la acción política zapatista (como la Ley de las Mujeres y la Ley Agraria). Del conjunto de Leyes, hay varios aspectos que se aplican hoy en territorio zapatista, como la regulación de precios en contra del acaparamiento, o la Ley Agraria Revolucionaria que regula el reparto de tierra, la propiedad y la producción colectivas, incluye a los recursos naturales y también, en el punto 15, la creación de centros de comercio, centros de salud comunitaria, centros de educación y escuelas gratuitas, centros de construcción de viviendas y carreteras, y centros de servicios.

En breve tiempo los representantes de las comunidades y los grupos bases de apoyo asumieron y aprendieron a desarrollar la magna tarea que se abocaron: ser gobierno en un territorio políticamente dividido y en una situación de guerra y de hostigamiento permanente.

Los puntos de fuerza de los gobiernos zapatistas residen en la horizontalidad de su estructura, en los valores que los orientan y en la necesidad de las funciones que realizan. El precepto central que estructura la idea de democracia indígena y revolucionaria es el de mandar obedeciendo, lo cual establece una relación dialéctica entre los ciudadanos y sus autoridades; según esto, unos y otros detienen el poder de mandar y la obligación de obedecer. El mandar obedeciendo se expresa en siete principios: obedecer y no mandar; representar y no suplantar; bajar y no subir; servir y no servirse; convencer y no vencer; construir y no destruir, y proponer y no imponer. 


\section{AUTOONOMIIAINDÍGENA, VIOLENCIAY JUSTICIA}

Asimismo, el ideal de la democracia zapatista rechaza la burocratización de los que cubren puestos de autoridad; por esto, las autoridades de las tres instancias del gobierno autónomo son nombradas públicamente en las asambleas entre las personas que se han distinguido por sus calidades morales, rectitud, sabiduría y compromiso con la organización, y no necesariamente a su experiencia política, que madurarán en el ejercicio del cargo y sobre la experiencia misma; al terminar su mandato, regresarán a sus actividades anteriores. Este sistema, que ha sido criticado por la falta de competencia que pueden tener las personas al inicio del cargo, tiene un significado político de gran trascendencia: cientos de personas se están experimentando en el ejercicio del gobierno local, como si fuera una suerte de "escuela de gobierno" en la que todos tienen el derecho y el deber de participar.

Los Municipios Autónomos constituyen el segundo nivel de gobierno, y la instancia superior a la comunidad para la resolución de los conflictos. El Concejo Municipal, cuyo cargo dura tres años, es compuesto por mujeres y hombres nombrados en asambleas donde participan las aproximadamente treinta comunidades que integran el Municipio. En 2004, el Concejo del MAREZ San Pedro de Michoacán era integrado por diversas Comisiones, que reflejaban las áreas de trabajo:

-Honor y Justicia, cuyo responsable es llamado Ministro o Comisión de Justicia. Tiene el seguimiento de los casos que se presentan, pero no los atiende o resuelve solo, sino que el Concejo en su conjunto escucha las partes, discute, y resuelve el caso. En caso de ausencia del Ministro de Justicia, los demás integrantes del Concejo atienden los casos.

-Educación, cuya función consiste en coordinar con la Junta de Buen Gobierno, las autoridades y las comisiones de cada comunidad la formación de los promotores de educación y el funcionamiento de las escuelas autónomas;

-Salud, que coordina los promotores de salud y en colaboración con la Junta y las comunidades se ocupa de las acciones y la infraestructura en ese ámbito;

-Tierra y territorio o Asuntos Agrarios, que se ocupa de los conflictos agrarios y de la protección ambiental;

-Producción y comercialización, encargada de estudiar las necesidades de las comunidades y coordinar los medios existentes;

-Mujeres, es el referente para la organización femenina, se encarga de dar seguimiento a los colectivos y las cooperativas femeninas activas en las comunidades; 
Capitulo 4. Justicia indigena e intercultural: la justicia según la Junta de Buen Gobierno

$$
\text { de la Zona Selva-Fronteriza }
$$

-Ancianos, órgano consultivo y de conciliación en caso de conflictos;

-Impuestos y finanzas, con la función de recaudar y distribuir los recursos económicos

-Registro civil.

Al igual que en el caso de la justicia, las decisiones importantes que atañen cada área de trabajo son discutidas colectivamente, y el encargado se ocupa de coordinar las actividades específicas. En cada comunidad existen responsables o comisiones para cada una de las áreas mencionadas, que coordinan su trabajo local con la relativas Comisiones del Municipio; éstas se reúnen periódicamente con los responsables locales para discutir los temas de relevancia, y los responsables de cada área llevan la información a las asambleas de su comunidad.

Esta compleja estructura que alterna ámbitos colectivos de decisión y cargos individuales de responsabilidad es el sustento del autogobierno zapatista; permite el fortalecimiento del sujeto político zapatista pues en todo momento remite la información y la decisión al nivel más básico, es decir las asambleas comunitarias.

La estructura territorial zapatista se ejerce en un "territorio de influencia" que se caracteriza por ser discontinuo, pues en él se encuentran comunidades que adhieren al proyecto zapatista y reconocen sus autoridades y otras que no lo hacen; existen comunidades internamente divididas entre habitantes que se reconocen como bases de apoyo zapatistas (BAZ) y otros que se reconocen en las autoridades del Estado; y otros poblados en que las BAZ son una pequeña minoría, una o dos familias.

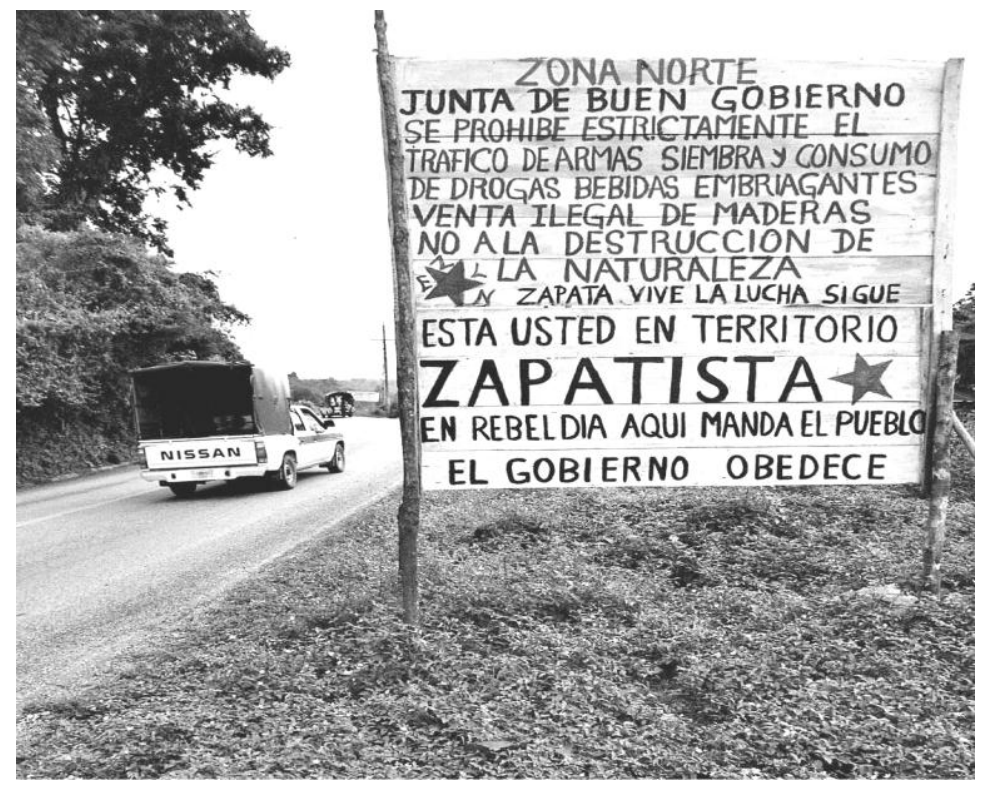

Nuestro territorio. Carretera federal, rumbo al Caracol de Roberto Barrios, 2003. 


\section{AUTONOMIAINDÍGENA, VIOLENCIAY JUSTICIA}

En términos territoriales, los MAREZ reflejan en parte la división establecida por el EZLN para fines de operación militar. En su inicio, entonces, el EZLN representa un actor externo que actúa en el territorio modificando la estructura social, y constituye un elemento de cohesión entre realidades heterogéneas cuales las comunidades indígenas chiapanecas (por otro lado, así como genera identidad, la pertenencia a la organización zapatista genera también división). En una entrevista realizada a principio de 1994, el Subcomandante Marcos enfatiza este proceso:

Por lo general los compañeros jalaban antes por separado, en los ejidos. Un ejido no se metía con el otro más que para pelearse y para poder robarse a las mujeres. ${ }^{49}$ Cuando entra el EZLN y se hacen las regiones, entonces varios ejidos empiezan a entrar en contacto, primero para cuidarse de las guardias blancas o de los judiciales, más adelante para ayudarse en cuestiones de salud y otras necesidades. Posteriormente para cuestiones organizativas, militares y políticas, de estudio, o de organización económica [...]. Luego se da una relación entre una cañada y otra, la zona que decimos. Ésa también es una aportación del EZLN, consistente en el desarrollo de una unidad efectiva, no sólo de representantes sino de las comunidades. Pero ello no significa que el impulso viniera de fuera, sino de los zapatistas de allí mismo, que desde adentro fueron promoviendo la organización, que es lo que nos da cohesión territorial. ${ }^{50}$

Como en el Sistema de Seguridad y Justicia Comunitaria en Guerrero, la pertenencia a la organización genera territorio, un territorio que implica estructuras intercomunitarias y, sucesivamente, regionales. Si una parte de la división militar (región) se refleja en la territorialización municipal, las Zonas se reproducen en los lazos territoriales y organizativos que se van tejiendo alrededor de los cinco centros políticos y de reunión instituidos después de 1995, los Aguascalientes. La presencia de dichos centros, su función de articulación y las

\footnotetext{
${ }^{49}$ Esta afirmación merece ser matizada, pues el testimonio de Josué, habitante de una ranchería cercana a La Realidad, expresa una práctica opuesta: "siempre nos ayudamos entre comunidades vecinas, por si hay algún trabajo, alguna emergencia" (entrevista, diciembre 2007).

50 J. Moguel, V. Ballinas, "Conferencia de prensa, San Cristóbal de las Casas", La Jornada, 26 de febrero de 1994, pág.2.
} 
Capitulo 4. Justicia indigena e intercultural: la justicia según la Junta de Buen Gobierno

$$
\text { de la Zona Selva-Fronteriza }
$$

actividades que permiten realizar en su interior, impulsaron un paulatino proceso de unificación regional, ${ }^{51}$ que permitió el fortalecimiento de los MAREZ más débiles.

Mapa 6: Caracoles zapatistas. División regional (Zonas)

\section{AUTOGOBIERNO ZAPATISTA \\ El territorio zapatista está dividido en cinco regiones, y cada una tiene un centro de go- bierno autónomo de- nominado "Caracol". Los caracoles son las sedes de las Juntas de Buen Gobierno (JBG)}

\section{"Caracoles" del EZLN}

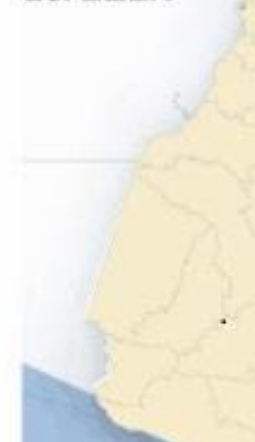

Morelia

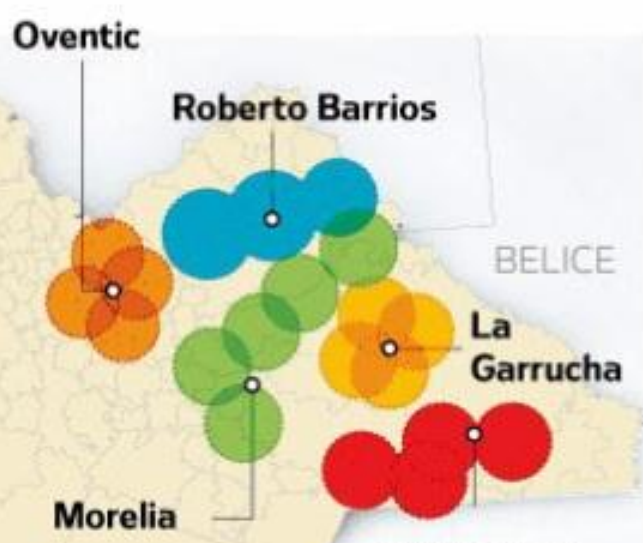

La Realidad

Mapa: El Universal.

De tal proceso surgieron, en 2003, cinco Caracoles, ubicados en los mismos centros antes llamados Aguascalientes. Los Caracoles son los centros políticos de las Zonas (Altos, Norte, Tzotz Choj, Selva Tzeltal y Selva Fronteriza), integradas por varios Municipios Autónomos contiguos. En cada Caracol opera una Junta de Buen Gobierno (JBG), instancia regional que coordina las acciones de gobierno en la Zona, en coordinación con los Concejos Municipales que de ella dependen. Los miembros de las Juntas fueron nombrados, al igual que los Concejos, en las asambleas generales de cada uno de los Municipios Autónomos que integran la Zona. Con la creación de las JBG el EZLN admite su anterior injerencia en los gobiernos autónomos, lo que representaba "por así decirlo, uno de los elementos

\footnotetext{
${ }^{51}$ La primera experiencia en tal sentido es la Región Autónoma Totz-Choj, integrada por los municipios que rodeaban el Aguascaliente de Morelia y que ya desde 1996 iniciaron a experimentar estructuras como la Comisión de Salud y de Educación unificadas para toda la región.
} 


\section{AUTONOMIAINDÍGENA, VIOLENCIAY JUSTICIA}

'antidemocráticos' en una relación de democracia directa comunitaria”, 52 y declara que, a partir de ese momento, los mandos militares (Comités) tendrán solamente una función consultiva y de acompañamiento, así como de vigilancia sobre la correcta actuación de las autoridades autónomas (Comisión de Vigilancia). La estructura civil de gobierno zapatista se desarrolla actualmente en colaboración, más no en dependencia de la estructura política y militar del EZLN. En ocasiones los cargos son completamente separados, en otras las responsabilidades son compenetradas. La progresiva separación entre las estructuras civil y político-militar es clave, pues desde su inicio las JBG apuntan a ser un ámbito de gobierno territorial representativo no sólo para la población zapatista sino para todos los que reconozcan su legitimidad.

.La presente investigación se realizó en La Zona Selva Fronteriza, habitada principalmente por indígenas tojolabales, tzeltales, choles, tzotziles, y no indígenas; incluye aproximadamente 120 comunidades y abarca desde la región de Marqués de Comillas, la región de Montes Azules, y todos los municipios fronterizos con Guatemala hasta Tapachula: Ocosingo, Las Margaritas, Maravilla Tenejapa, La Independencia, La Trinitaria, Frontera Comalapa, e integra comunidades de los demás municipios, llegando hasta el municipio de Motozintla. La Zona agrupa los MAREZ de San Pedro de Michoacán, General Emiliano Zapata (que abarca parte de la RIBMA), Libertad de los Pueblos Mayas, y Tierra y Libertad.

La comunidad de La Realidad Trinidad, además de ser cabecera del MAREZ S. Pedro de Michoacán, es también la sede del Caracol 1 y de la correspondiente JBG, denominada "Hacia la esperanza".

\footnotetext{
52 Subcomandante Marcos, CCRI-Comandancia General del EZLN, comunicado "CHIAPAS: LA TRECEAVA ESTELA. Quinta parte: Una historia”, julio 2003, disponible en <http://palabra.ezln.org.mx/>,consultado el 1 agosto 2014 .
} 
Capitulo 4. Justicia indigena e intercultural: la justicia según la Junta de Buen Gobierno de la Zona Selva-Fronteriza

\section{Municipios Autónomos Zona Selva Fronteriza}

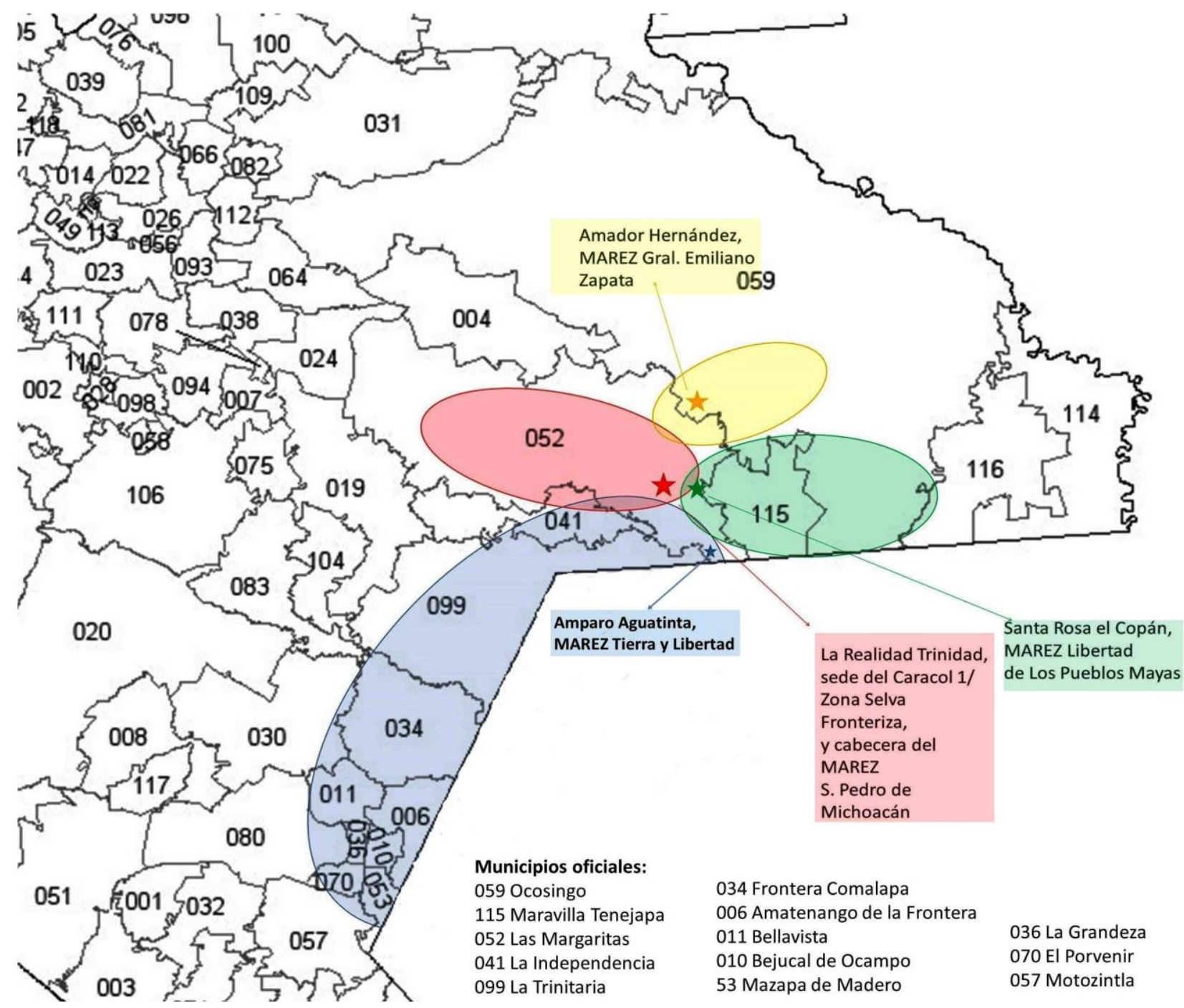

Mapa: elaboración propia 


\section{AUTTONOMIIAINDÍGENA, VIOLENCIAY JUSTICIA}

En esta Zona, antes de la creación de Junta se realizaban asambleas de Concejos Municipales, que en 1997 se formalizaron como Asociación de Municipios Autónomos, con la función de coordinación; sus representantes, los ocho miembros de la Directiva de la Asociación, integraron la primera Junta, en función desde 2003 hasta 2006. El mandato de cada Junta, al igual que los Concejos, dura tres años, y actualmente es compuesta por 24 personas, mujeres y hombres, dividas en dos equipos que se turnan cada 15 días. El cargo es rotativo y el nombramiento de nuevas autoridades se da por partes: al cumplir los dos años de funciones, se nombra al menos una persona por cada MAREZ para que substituyan otros tantos encargados de la Junta, de tal manera que en el siguiente año aprendan el trabajo a realizar, acompañando a los que ya han madurado experiencia. Al pasar los tres años, se nombran los demás nuevos miembros, que serán orientados por aquellos que ya tienen un año en el cargo. Esto garantiza continuidad y eficiencia en el trabajo de gobierno.

Las áreas de trabajo de la JBG son similares a las que mencioné para el MAREZ San Pedro de Michoacán. Unas atañen a la organización política y al gobierno strictu sensu: Justicia, Justicia Agraria, y Derechos Humanos; otras a la "política social autónoma”, es decir salud, educación, comercio, tránsito, administración, campamentistas, comunicación, proyectos, y la organización de los “institutos de crédito": BANPAZ (Banco Popular Autónomo Zapatista) que otorga créditos a bajos intereses para gastos urgentes relativos a la salud, o para el desarrollo de proyectos colectivos, y BANAMAS, dedicado a financiar las actividades colectivas propuestas por mujeres. 
Capitulo 4. Justicia indigena e intercultural: la justicia según la Junta de Buen Gobierno dela Zona Selva-Fronteriza

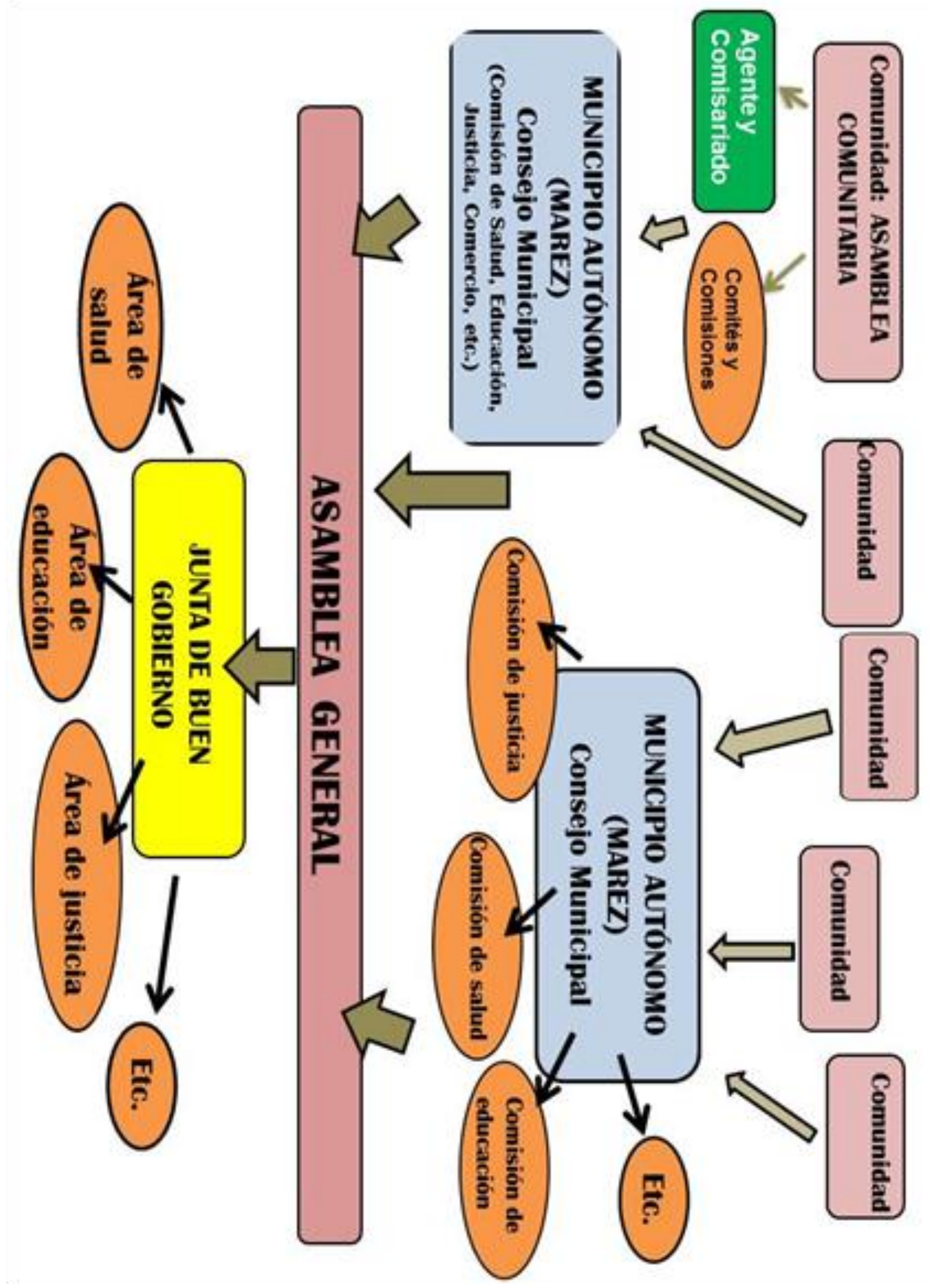

Estructura territorial del autogobierno zapatista 


\section{AUTOONOMIIAINDÍGENA, VIOLENCIAY JUSTICIA}

La situación de empobrecimiento y marginación en la que siempre vivieron los habitantes de la Selva Lacandona -y los indígenas de todo Chiapas-, y que ha motivado su adhesión al movimiento zapatista, es particularmente evidente en las condiciones sanitarias y educativas. Frente a una carencia estructural de servicios, al interno del sistema de autogobierno es prioritario el desarrollo de una "política social autónoma" que, en la medida de sus posibilidades, representa en la actualidad una alternativa concreta para la resolución de las necesidades cotidianas y el mejoramiento de las condiciones de vida de la población. Por lo tanto, las áreas que más desarrollo han logrado son la educación y la salud, que cuentan con una capilar red de escuelas - primarias, alguna secundaria y en Los Altos escuelas para maestros-, consultorios, clínicas y hospitales, dirigidos todos por promotores de educación y salud, organizados en Comités y Comisiones en las tres dimensiones del espacio autónomo (comunidad, Municipio, Zona). Los promotores son indígenas bases de apoyo que se formaron y capacitaron en los múltiples cursos que con periodicidad se ofrecen en la Zona, y que se han especializado en esa función. De tal manera remplazan los servicios gubernamentales que el zapatismo rechaza y que, de todos modos, han sido históricamente erráticos, esporádicos y, cuando existían, eran ejecutados de manera paternalista, sin buscar un verdadero bienestar social. Al igual que en el ámbito de la justicia, también la educación y la salud autónomas se construyen sobre la base de la valorización y la recreación de la identidad indígena; ejemplo de ello es área de salud de la Zona, que retoma los conocimientos tradicionales y femeninos los tres ejes de trabajo se centran en las parteras, las hueseras y las herbolarias- y los complementan con la medicina alópata. Según la JBG:

Nuestra cultura estamos tratando de rescatarla toda, porque cuando se habla de cultura encierra muchas cosas, no solamente de nuestra lengua, de nuestra tradición, no solamente de nuestras vestimentas, abarca muchas cosas lo que es cultura indígena. Por ejemplo tiene que ver mucho de cómo nos organizamos, y también entra mucho lo que es de salud, porque hay compañeros que saben curar con plantas medicinales y sabemos que eso es una buena cultura, que estamos tratando de rescatarla toda, porque como jóvenes no conocemos, pero entonces se hizo una invitación a los ancianitos, a las ancianitas, que ellos tenían un modo de cómo se curaban antes [...] y eso estamos empezando a rescatarlo, y se está ampliando; y no solo eso, sino que también la forma de cómo se organizaban antes, porque muchos de nuestros abuelos no saben 


\section{Capitulo 4. Justicia indigena e intercultural: la justicia según la Junta de Buen Gobierno de la Zona Selva-Fronteriza}

leer, no saben ni escribir, pero sí se saben organizar, ya sea en las fiestas, en los trabajos comunales, en fin, en los acuerdos internos. ${ }^{53}$

La dinámica decisional basada en los ámbitos colectivos que he descrito para los niveles de gobierno comunitario y municipal se vuelve a proponer también en el nivel regional. La Junta, en su conjunto, trata de resolver las necesidades y los problemas que surgen en cada área; cuando no encuentra la solución, busca el respaldo de los Concejos Municipales, o bien remite el asunto a la Asamblea general. Cada tres meses se convocan Asambleas generales con la función de planificación y análisis, en las que participan los Concejos Municipales, todas las autoridades comunitarias y también los Comités y Comisiones encargados de las diferentes áreas de trabajo en el nivel municipal y de Zona. En el caso que la Asamblea no logre el consenso en alguna decisión interviene el mecanismo de la consulta: las propuestas se remiten al debate en las asambleas de cada comunidad, y en la siguiente Asamblea General se retoma la discusión incluyendo las propuestas "de los pueblos". La JBG explica que este mecanismo se está aplicando con respecto a la propuesta de un reglamento para la administración de justicia: "tenemos una propuesta pero no se ha definido todavía, se está analizando en los pueblos y en los Municipios Autónomos. Es una propuesta de las autoridades, de la Junta y de los Consejos. Tenemos que lanzarlo hacia el pueblo, para ver cuál es lo que se quita o cual es lo que se va a arreglar más, estamos en un proceso de reglamentar". ${ }^{4}$

Debido a la diversidad social de las distintas Zonas de Chiapas donde se ejerce la autonomía zapatista, las áreas de trabajo y los resultados son distintos en cada una de ellas. De acuerdo a la necesidad particular de una zona, a la experiencia organizativa y a las condiciones territoriales, la autonomía ha adquirido diferencias regionales: en la Zona Altos se han desarrollado en mayor medida la educación y las cooperativas de producción; en la Zona Norte el trabajo en agroecología; en la Zona Selva Fronteriza, el impulso al comercio, a los créditos y el trabajo en la justicia; en la Zona Selva Tzeltal, la salud; en la Zona Totz-Choj, la organización femenina.

El sistema de gobierno autónomo zapatista representa la fuente de un nuevo sistema normativo; al respecto, el antropólogo Juan Carlos Martínez (2003), afirma que los zapatistas han creado "ámbitos y jurisdicciones para desarrollar nuevas instituciones y sistemas

\footnotetext{
${ }^{53}$ JBG, entrevista, La Realidad, 27 de diciembre de 2007.

${ }^{54}$ JBG, entrevista, La Realidad, 28 de diciembre 2007.
} 
políticos, que si bien pueden cimentarse en antiguos principios y concepciones culturales, tienen que ser nuevos y creativos en función de las dinámicas y circunstancias de los contextos contemporáneos". Por lo tanto, la legitimidad del derecho no hay que establecerla en la procedencia pasada o presente de la costumbre, sino en el derecho de autodeterminación, es decir, en la decisión propia de los pueblos de organizarse de una u otra forma.

\section{Etnografía del sistema de justicia zapatista}

En la Introducción he mencionado las dificultades y limitaciones encontradas para desarrollar el trabajo de investigación en una situación de conflicto latente, sobre todo en lo que respecta a las confrontaciones ligadas a militancias políticas distintas. Realicé las estancias de campo, entre 2007 y 2012, en la comunidad de La Realidad Trinidad, ubicada en la Selva Lacandona, en la subregión Cañadas de Las Margaritas. Debido a que la comunidad está políticamente dividida, pues hay una parte de la población es integrante de la organización zapatista y otra es afiliada al PRI (condición común a muchas comunidades que están en el área de influencia zapatista), el Comisariado Ejidal me comunicó que no podía circular por la comunidad. Los espacios "permitidos" son aquél dedicado al hospedaje de los visitantes, que consiste en una gran cancha de basquetbol alrededor de la cual se encuentran varias cabañas y una cocina para que los grupos preparen sus alimentos; las partes del río donde me bañaba y lavaba la ropa; el comedor comunitario donde podía comer comida preparada; y las tiendas cooperativas cercanas. También frecuentaba la casa de una familia de amigos, muy cerca de la cancha de basquetbol. El amplio espacio del Caracol, donde se encuentran el templete, la oficina de la Junta, la Clínica, la herbolaria y la Comisión de Vigilancia, no es un espacio abierto. Solo se puede entrar por motivos específicos, tras la invitación de la Junta. En la etapa de investigación que realicé para la tesis de licenciatura, que incluyó varias estancias entre 1999 y 2004, la situación ya era parecida, aunque había más espacios "abiertos", como por ejemplo la iglesia. 
Capitulo 4. Justicia indigena e intercultural: la justicia según la Junta de Buen Gobierno de la Zona Selva-Fronteriza

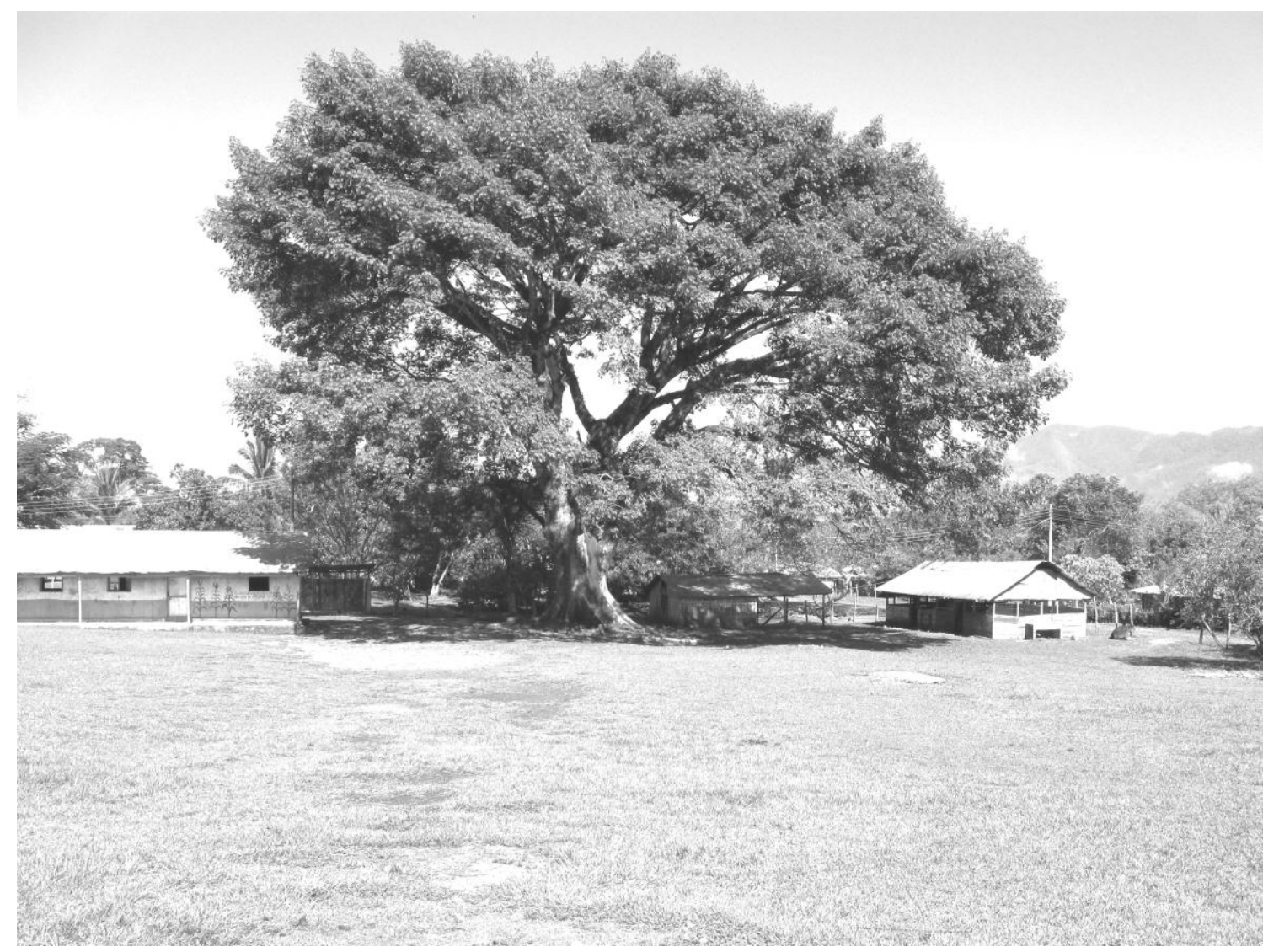

La ceiba y el espacio dedicado a los visitantes. La Realidad, 2009.

En las distintas estancias, abordé el tema de la justicia con todas las personas con las que tuve la oportunidad de platicar. A todos expliqué el objetivo de mi estancia, el propósito de mi investigación, y la experiencia de la Policía Comunitaria con la cual ya había desarrollado distintas actividades. Explicar cómo se están organizando los pueblos indígenas de la CostaMontaña de Guerrero resultó un importante catalizador de la discusión; tal experiencia levantaba gran interés, y a partir de lo que yo platicaba surgían preguntas y comentarios con respecto a cómo se está organizando el autogobierno zapatista en el campo de la justicia.

Los testimonios que cito aquí han sido recogidos en entrevistas colectivas con distintos integrantes de la Junta de Buen Gobierno; integrantes de los Concejos Autónomos; autoridades comunitarias; encargados del comedor colectivo; encargados de la Comisión de Vigilancia (parte del EZLN); y habitantes de la comunidad de La Realidad. Las informaciones contenidas en este apartado han sido revisadas y aprobadas por la Junta de Buen Gobierno de la Zona Selva-Fronteriza, en funciones en noviembre del 2011. 


\section{AUTOONOMIIAINDÍGENA, VIOLENCIAY JUSTICIA}

Instancias de resolución de los conflictos

La justicia autónoma zapatista se ejerce de manera articulada entre los tres niveles del autogobierno ya analizados, que responden a la organización geopolítica del territorio: la comunidad, el Municipio y la Zona. En todos los casos, las últimas instancias de decisión y resolución son las asambleas (comunitaria, municipal, regional), y las primeras instancias son las autoridades que se nombran en las asambleas mismas. En el caso de la comunidad mencioné que el Agente Municipal es encarga de atender los asuntos civiles, mientras el Comisariado Ejidal de los problemas agrarios. En el Municipio, el Ministro de Justicia se encarga de la atención y seguimiento a los casos, pero la discusión y deliberación se ejerce entre todo el Concejo, al igual que en la Junta (en el caso estudiado, no hay un cargo específico para la resolución de los conflictos).

\section{Sistema normativo: origen y codificación}

En los Municipios Autónomos y la Junta de Buen Gobierno de la Zona Selva Fronteriza no hay un reglamento que codifique delitos y castigos; las resoluciones que toman las autoridades dependen de las condiciones particulares de cada caso, y se basan sobre los casos similares ya resueltos. En 2007, las autoridades entrevistadas informaron que se estaba desarrollando un proceso de consulta entre las comunidades para la elaboración de un código o reglamento. Desconozco si dicha reglamentación se ha llevado a cabo del todo, pues en una entrevista sucesiva afirmaron que "se ha discutido, no podemos tener un solo reglamento porque suceden diferentes tipos de errores. Entonces la comunidad acuerda tener más o menos una idea, que si es una gravedad ya dicen cuanto de tiempo"; sin embargo, otros afirmaron que hay castigos establecidos, a grandes rasgos, para los casos de robo, asalto y tráfico de personas, calificados como delitos graves, que resuelve la Junta. En la articulación entre las diferentes instancias, el papel más importante en la decisión sobre el castigo lo tiene la comunidad, cuya autonomía decisional es respetada, en la medida de lo posible, por los niveles de gobierno superiores; probablemente este sea el motivo por lo que no se impuso un reglamento que limitara las resoluciones que, para cada problema, pueden adoptar las distintas comunidades. 
Capitulo 4. Justicia indigena e intercultural: la justicia según la Junta de Buen Gobierno de la Zona Selva-Fronteriza

Las Leyes Revolucionarias, así como otros documentos programáticos, representan un marco jurídico general, ya que establecen derechos y prohibiciones cuya transgresión implica castigos que son determinados de acuerdo al caso específico. Es trascendente la Ley Revolucionaria de las Mujeres, pues establece que estas tienen derecho a participar en la lucha revolucionaria; a trabajar y recibir un salario justo; a decidir el número de hijos que pueden tener y cuidar; a participar en los asuntos de la comunidad y tener cargo si son elegidas libre y democráticamente; a recibir atención primaria en su salud y alimentación; a la educación; a elegir su pareja y a no ser obligadas por la fuerza a contraer matrimonio; a ocupar cargos de dirección en la organización y tener grados militares en las fuerzas armadas revolucionarias; y que ninguna mujer podrá ser golpeada o maltratada físicamente ni por familiares ni por extraños. Los delitos de intento de violación o violación serán castigados severamente. Aunado a esto, rige en todo el territorio la prohibición a la producción, venta y consumo de alcohol y de drogas. En materia agraria y ambiental, la referencia es la Ley Agraria Revolucionaria, que establece la afectabilidad de todas las propiedades privadas de tierra que excedan las 100 hectáreas en condiciones de mala calidad y de 50 hectáreas en condiciones de buena calidad; que las tierras repartidas se deben regir como propiedad colectiva y trabajarse en colectivo para producir bienes de primera necesidad; la preservación de las zonas selváticas vírgenes y los bosques; que los manantiales, ríos, lagunas y mares son propiedad colectiva del pueblo mexicano y se deben cuidar evitando la contaminación y castigando su mal uso.

En el ámbito comunitario sí existe una reglamentación: se trata de los acuerdos internos, orales o escritos, que varían de comunidad a comunidad, y definen las normas de comportamiento y convivencia, las tareas comunitarias, las fiestas, etc.: "es como su ley; si alguien rompe su acuerdo interno, la misma autoridad de la comunidad ejerce la justicia en el pueblo",55 "si hay alguien que no está de acuerdo, que rehúsa hacer los trabajos comunes, si alguien no cumplió los acuerdos, la autoridad tiene que castigar por acuerdo". ${ }^{56} \mathrm{~A}$ veces tales acuerdos son orales, "los tienen en su corazón". Otras veces son escritos:

En la comunidad nos juntamos, hombres y mujeres, y cada uno dice su opinión. Hay acuerdos internos que se escriben en un acta que todos firmamos, quiere decir que todos estamos de acuerdo, a que se corrijan de tal forma los problemas en el pueblo. Ese acuerdo se vuelve una

\footnotetext{
${ }^{55}$ JBG, entrevista, La Realidad, 9/12/2008.

${ }^{56}$ Agente Municipal de San José del Río, entrevista, 15/01/09.
} 


\section{AUTOONOMIIAINDÍGENA, VIOLENCIAY JUSTICIA}

ley, que se tiene que cumplir durante el periodo de esa autoridad. Cuando se cambie la autoridad, se discute si sigue aquel acuerdo o se cambia, se toman otros acuerdos. ${ }^{57}$

Se trata entonces de un sistema normativo cuya base y punto de fuerza está en la dimensión local, en las comunidades, que pueden tener normas internas y formas de resolución de conflictos disimiles, debido a su heterogeneidad cultural. Se trata de un sistema normativo codificado (en la mayor parte de los casos respaldado en las actas de asamblea, escritas y selladas por las autoridades) pero no estable o cristalizado, ya que es sometido a recurrentes revisiones, adaptaciones o refrendos.

El sistema normativo vigente en los niveles de gobierno superiores está caracterizado por unos principios generales fruto del consenso propiciado por la militancia política. Estos principios, en tema de derechos humanos, derechos ambientales o equidad de género, pueden tener validez también para la población que no está integrada en el proyecto zapatista.

En ambos casos, destacan los mecanismos colectivos encargados de la elaboración y revisión de las normas (asambleas) y de su aplicación (autoridades colegidas). Al igual que la elaboración normativa, la administración de la justicia no se puede definir justicia oral, pues se pone particular atención en la elaboración del respaldo escrito de las decisiones tomadas, es decir las actas de acuerdo entre las partes en conflicto que ratifican la conciliación o la sanción.

Diversos autores han llamado la atención sobre los riesgos que implican los intentos de codificar el derecho indígena, sea por parte de las agencias del Estado a fin de asimilarlo a la normatividad positiva, o por los mismos pueblos indígenas en su intento por presentar sus sistemas jurídicos como un conjunto orgánico y digno de ser comparado con el derecho positivo, acción que frecuentemente presenta las tradiciones como la esencia inmutable del ser indígena. "Con la necesidad de normativizar y codificar en forma escrita los procedimientos y prácticas vivénciales que, con los años, han sido constantemente re-creados, viene la tendencia de generalizar y homogeneizar la interpretación del deber-ser" (Walsh 2002). Mientras subraya la procesualidad del orden jurídico, Krotz considera como los estudiosos del derecho, en aras de la sistematización de los sistemas jurídicos indígenas, suelen caer en un etnocentrismo que deforma severamente lo estudiado. "La consecuencia es, en el nivel más

\footnotetext{
${ }^{57}$ Agente Municipal de San José del Río, 15/01/09.
} 
Capitulo 4. Justicia indigena e intercultural: la justicia según la Junta de Buen Gobierno

$$
\text { de la Zona Selva-Fronteriza }
$$

fundamental del análisis, el fortalecimiento no probado de la suposición de que los estudiados ven, piensan y construyen prácticamente su mundo de acuerdo con exactamente la misma racionalidad que la sociedad del estudioso" (1995: 349-50). Estas anotaciones son sin duda acertadas, aunque necesitan ser matizadas en su comparación con los procesos reales en los cuales los sistemas jurídicos indígenas se adaptan constantemente a circunstancias cambiantes; el contexto de interlegalidad y la necesaria interrelación con el sistema jurídico del Estado imponen, en muchas ocasiones, la "concreción" de los acuerdos y los arreglos en documentos tangibles, que puedan ser impugnados o aducidos como evidencias en los inevitables conflictos de competencias con la justicia oficial; pues la codificación en este caso tiene la función de legitimar las autoridades indígenas y sus decisiones frente al Estado.

En una argumentación en defensa de la oralidad, el antropólogo colombiano Herinaldy Gómez afirma que la diferencia entre el derecho oral y el derecho escrito depende, en gran medida, de que el primero es constantemente colectivizado, mientras que el derecho escrito permite la individualización. "El sentido y las formas de justicia indígenas tienen su unidad básica en la palabra y la experiencia socializada a través de ella, mientras que la norma jurídica la tiene en la 'fórmula' escrita y en el saber-poder de quien la aplica” (2008:261). Las experiencias que pude conocer en México contradicen esta visión dicotómica, pues conservan el ejercicio colectivo del poder, e incluso perfeccionan, como en las JBG, los mecanismos de rotación de las autoridades. De tal manera que los espacios de las asambleas y en los grupos de autoridades se mantiene el valor de la palabra socializada, que sin embargo se concretiza en un acta para su mayor validez, en un proceso de creación de mecanismos jurídicos.

La experiencia del Sistema de Seguridad, Justicia y Reeducación Comunitaria de Guerrero es emblemática en tal sentido: a partir de 2001, por el trabajo de delegados de las comunidades y en las asambleas generales se elaboró un Reglamento Interno, cuya función es regular la operación de las autoridades regionales y comunitarias en las tareas de seguridad y justicia, así como sentar las bases de la institución comunitaria; sin embargo, su característica peculiar es el estar en constante proceso de redefinición, para incluir respuestas a los problemas que con el pasar del tiempo van emergiendo.

En el contexto estudiado considero necesario, por lo tanto, prestar particular atención a esta continua renovación del sistema normativo, y valorar cómo y en qué medida se transforma para incluir ámbitos de atención anteriormente no considerados; también habría 


\section{AUTONOMIAINDÍGENA, VIOLENCIAY JUSTICIA}

que analizar cuáles son los nuevos derechos que vienen incluidos (los derechos humanos, los derechos de la mujer, los derechos ambientales).

\section{Tipo de problemas que se presentan a las autoridades autónomas}

Los problemas de cierta relevancia que con más frecuencia emergen en la zona son: problemas familiares, separaciones o divorcios; robo; tráfico de personas; y en mayor medida problemas agrarios, o sea disputas para los linderos de las parcelas ejidales, y divergencias generadas por el control de los programas de ayuda del gobierno federal y estatal. Más raros son los problemas agrarios entre dos comunidades, que pelean los linderos del ejido, o por el control de las tierras recuperadas por el EZLN; sin embargo, este tipo de conflictos han ocurrido y representan "focos rojos" de difícil resolución. En esta zona, son excepcionales los casos de asalto, robos mayores (por ejemplo robo de carros), violación y homicidio.

Según muchos de los entrevistados, esto se debe a una cultura de respeto entre los habitantes de las comunidades, "hermanos indígenas", que siempre ha existido en la región. Además, mencionan que es muy importante la pertenencia a una organización política (el EZLN) para que las relaciones entre los "compañeros" sean respetuosas. El sentido de pertenencia a la organización sirve a la concientización de la gente, y evita el surgimiento de conflictos internos al grupo (más no entre personas con militancias diferentes).

Porque nosotros empezamos a ver como tenemos que concientizarnos, como evitar de estar pelearnos entre nosotros. Porque aunque sí haya un encargado para dar justicia, pero eso no es decisión de la autoridad, sino es del pueblo. ${ }^{58}$

En términos generales se observa una reducida conflictividad debida a problemas cotidianos o de delincuencia común, mientras es más alta aquella ligada a motivaciones políticas, aunque no ha llegado a los picos de violencia paramilitar que se verificaron en otras regiones. ${ }^{59}$ Los entrevistados afirman que, en las comunidades completamente zapatistas, no se verifican

\footnotetext{
${ }^{58}$ JBG, entrevista, La Realidad, 9/12/2008.

59 Cabe destacar que las informaciones directas sobre tales conflictos no son accesibles; sin embargo, los periódicos y las mismas denuncias de las autoridades dan cuenta de los conflictos que emergen, efectivamente en menor medida en esta región que en otras, como por ejemplo la Zona Norte o las cañadas de Ocosingo (correspondientes a la Zona Selva Tzeltal).
} 
Capitulo 4. Justicia indigena e intercultural: la justicia según la Junta de Buen Gobierno
de la Zona Selva-Fronteriza problemas mayores; donde estos acontecen es en las comunidades políticamente divididas. Allí se enfrentan problemas ligados al control de los espacios físicos y simbólicos, y a los recursos de la comunidad; problemas ligados a los planes de desarrollo de la comunidad, que unos piensan realizar con recursos gubernamentales y otros a través de la autogestión y la participación comunitaria; e incluso problemas de riñas entre los vecinos de las dos facciones.

Según los testimonios, entre los zapatistas ya son raros los episodios de violencia ligados al consumo de alcohol; aún son frecuentes entre los que no pertenecen a la organización. Desde antes de 1994, los zapatistas prohibieron la venta y el consumo de alcohol en sus comunidades. Obviamente no todos los vecinos acatan tal prescripción, pero sí lo hace una parte importante de la población. Esto ha disminuido de manera sustancial los episodios de violencia hacia mujeres y niños, y los casos de lesiones u homicidio, que son el principal problema en muchas regiones rurales e indígenas del país.

Las autoridades autónomas han tenido que enfrentar nuevos problemas, como el tráfico de maderas preciosas y aves, y en mayor medida el tráfico de indocumentados centroamericanos, por "polleros" guatemaltecos y de la misma región.

Son muy raros los problemas que ven como única protagonista a una mujer. Se presentan casos de problemas familiares que involucran a la pareja, aunque en la gran mayoría de los problemas los únicos implicados son los hombres. No obstante se esté transformando el trato hacia las mujeres, culturalmente e históricamente construido, he podido recoger algunos testimonios que denuncian como la visión machista pervive y origina conflictos que no se llegan a solucionar al interior de las comunidades. Unas jóvenes mujeres, bases de apoyo zapatistas, aseveran que con frecuencia los muchachos convencen a sus novias a tener relaciones sexuales antes del matrimonio, embarazándolas pues no hay aún la conciencia de usar protecciones. Después ya rechazan el matrimonio, dejándolas como mamás solteras. No obstante varias muchachas hayan acudido a la autoridad para pedir ayuda, según los testimonios ésta ha intervenido tomando la parte del hombre que desmiente su responsabilidad. Las jóvenes, y así su madre, opinan que la autoridad no actúa con justicia, pues debería hacer investigaciones para establecer la responsabilidad del hombre y ayudar a las mujeres engañadas. 


\section{AUTONOMIAINDÍGENA, VIOLENCIAY JUSTICIA}

\section{Forma de resolución de los conflictos}

En todos los niveles, y para todos los problemas, la resolución de los conflictos se desarrolla buscando la conciliación y la reparación del daño. En casos extremos, que perjudican sin remedio las personas o la comunidad, se aplica el castigo.

En las comunidades zapatistas la primera instancia para la resolución de los conflictos es la autoridad comunitaria: el Agente Municipal, o el Comisariado Ejidal en asuntos agrarios.

Tenemos como una escala, por acuerdo de asamblea, estamos claros que hay cosas que a la comunidad le toca resolver, las cosas más pequeñas.

Por ejemplo un perjuicio, que le decimos nosotros, o sea que un animal de alguna familia, o de algún grupo, sale a hacer perjuicio en un trabajadero. No necesariamente tiene que llegar a una autoridad autónoma de un Consejo; el Agente Municipal de un pueblo es el que tiene la capacidad de arreglar ese asunto.

En cuestiones agrarias, cuando es adentro de una comunidad, entre familiares, se presentan por ejemplo problemas que con el tiempo se olvidan de las líneas, de los límites entre un terreno y otro [linderos]. Allí la autoridad es el inmediato, el Agente Municipal o el Comisariado, que tiene que ver estos casos. ${ }^{60}$

El Agente Municipal es nombrado por la mayoría de los miembros y tiene la responsabilidad de resolver. Si el Agente Municipal no lo puede resolver, se va con el Comisariado Ejidal, que convoca una asamblea general, para tratar diferentes puntos, o problemas. Entonces toda la mayoría de ejidatarios da su palabra de cómo va a quedar el asunto, si es real su delito, paga su castigo.

Se van dando pasos, para llegar a un castigo. El primer paso es una llamada de atención que hace el Agente Municipal, como un consejo, que no haga esa acción.

Ya en la segunda que comete algún error ya se ve en el pueblo, el agente ve si lo puede arreglar, lo arregla. A ese compañero se le da una lección, un castigo. Antes, cuando todavía no estábamos como zapatistas, se le cobraba multas en dinero, dependiendo del error que comete. Ahora nuestras reglas zapatistas nos dicen que ya no se cobra en dinero, sino que se cobra en trabajo. Si hay un trabajo de la comunidad, abertura de camino, limpia de una majada, una casa que se va a construir, es el trabajo que se le da. Si el compañero dice 'lo acepto', adelante, el Agente Municipal procede.

\footnotetext{
${ }^{60} \mathrm{JBG}, 11 / 12 / 2008$.
} 


\section{Capitulo 4. Justicia indigena e intercultural: la justicia según la Junta de Buen Gobierno de la Zona Selva-Fronteriza}

Ahora, si no lo acepta o no llega a comprender, entonces ya la misma autoridad, el Agente, levanta un acta donde lo remite al Municipio Autónomo que le corresponde. ${ }^{61}$

Pero a veces hay problemas que salen del alcance de la comunidad:

Por ejemplo un asunto agrario con otra comunidad, y no hubo un acuerdo, entonces acuden a otra instancia, que es el Concejo Municipal; y si se ve que ese asunto no puede resolverse en el Concejo, ellos lo tramitan a la Junta de Buen Gobierno. En la Junta llegan los casos más graves, todo lo que no se puede resolver en la comunidad o en el Municipio, y más de hermanos y hermanas que son de otras organizaciones ${ }^{62}$.

Este proceso ilustra una práctica de la justicia realmente comunitaria: cuando atienden un caso que ya ha sido tratado en la comunidad, las autoridades del nivel superior, Junta o Municipio, tienen exclusivamente la función de mediar, facilitar el dialogo entre las partes y propiciar el acuerdo. La decisión que ellos toman no es arbitraria: cada caso ya ha sido discutido en la comunidad, por las autoridades locales y a veces por la Asamblea de todos los comuneros, que en base a los acuerdos internos ya han elaborado una propuesta de resolución del caso. Las autoridades de la Junta o Municipio avalan la resolución de la comunidad o la modifican; pero lo hacen a partir del proceso que ya se ha desarrollado en la comunidad. Por esto, es fundamental la coordinación entre los tres niveles de gobierno.

Según las autoridades autónomas entrevistadas, los Concejos Autónomos y las Juntas de Buen Gobierno atienden en cantidad mayor conflictos que involucran personas no zapatistas, integrantes de otras organizaciones o partidos. Dicen que estos "no piensan que no tiene caso

pelearnos como hermanos, siempre invaden linderos, asuntos agrarios". ${ }^{63}$ Asimismo, los testimonios afirman que los no zapatistas no tienen mecanismos de resolución de los conflictos al interno de las mismas comunidades. Así que acuden a la JBG o al MAREZ también por resolver problemas menores.

Como no tienen la cultura de ejercer su propia autonomía en la comunidad, ellos son los que más acuden a la Junta porque no intentan resolver los problemas en la comunidad, no dan los

\footnotetext{
${ }^{61}$ Comisariado Ejidal, La Realidad, entrevista, 14/12/2008.

${ }^{62}$ JBG, entrevista, La Realidad, 11/12/2008.

${ }^{63}$ JBG, entrevista, La Realidad, 29/12/2007.
} 


\section{AUTOONOMIIAINDÍGENA, VIOLENCIAY JUSTICIA}

pasos que da el zapatismo para resolver los asuntos en la comunidad, llegan directamente por cualquier asunto hasta la Junta, o al Municipio. ${ }^{64}$

Al contrario, los asuntos que involucran los zapatistas son resueltos en primera instancia en la comunidad, donde se trata de dar prioridad a los procedimientos conciliatorios, así que solo los de gravedad llegan a los niveles superiores para su resolución.

[En la Junta] llevamos un registro: cada año debemos informar a los pueblos que problemas hemos atendido, y hacerle ver que en muchos problemas no se necesita llegar a castigo, más bien se le da orientación para que puedan resolver un problema, y no llegar al grado de aplicar una sanción o un castigo. ${ }^{65}$

También en el Sistema de Seguridad, Justicia y Reeducación Comunitaria de Guerrero existe un trabajo para que los conflictos menores se resuelvan en el ámbito comunitario, lo que implica también la voluntad de desarrollar y empoderar a las estructuras comunitarias, en oposición al sistema político estatal que remite una gran cantidad de funciones a instancias "superiores", externas al territorio y a la cultura indígena.

La Junta de Buen Gobierno valida o corrige las decisiones tomadas por las comunidades, cuando por gravedad o inconformidad de una de las partes el caso llega hasta esta instancia:

La comunidad mete el acta de inconformidad en contra de la persona que está demandada, vienen a hacer entrega a la Junta para que la persona acusada o culpable quede en mano de la Junta, para que el castigo se le aplique aquí. [...] Allí es a través de un acta del pueblo, porque es a la comunidad que le afecta. Ellos exigen o piden que se le aplique tanto tiempo de castigo; pero ya la autoridad determina si es justo lo que el pueblo está pidiendo o es demasiado. Este es nuestro trabajo, valorar si es justo lo que se le va a aplicar al otro o no, si consideramos que un pueblo, quizás por coraje, exige un castigo injusto, para esto estamos nosotros, para decir 'sí, merece castigo Fulano de Tal, pero no como ustedes les están exigiendo'. Se trata de mediar en los asuntos. ${ }^{66}$

\footnotetext{
${ }^{64}$ Concejos Municipales Autónomos, Municipio Emiliano Zapata, entrevista, La Realidad, 14/12/2008.

${ }^{65}$ JBG, entrevista, La Realidad, 11/12/2008.

${ }^{66}$ JBG, entrevista, La Realidad, 9/12/2008.
} 


\section{Capitulo 4. Justicia indigena e intercultural: la justicia según la Junta de Buen Gobierno de la Zona Selvar Fronteriza}

En una entrevista realizada en el año 2004, la primera Junta en el cargo explica su papel de mediación, consejo y corrección de la justicia comunitaria, relatando un caso de violación en el que el castigo dictado por la comunidad dejaba insatisfecha a la agraviada y al sentido común de la justicia. "Entonces se le dijo que esa medida, esa voz del pueblo tiene error, y lo que corresponda aquí, como ya están pidiendo justicia aquí en la Junta, entonces ya no cabe lo que es una medida inmediata de una sola comunidad sino cual es el acuerdo general de la Junta, eso es lo que se va a aplicar". ${ }^{67}$

Sin embargo, no siempre la Junta ejerce el papel de arbitraje; en muchas ocasiones se limita a la mediación. La justicia zapatista es una construcción colectiva, en la que intervienen las autoridades de la Zona, si es el caso; las autoridades comunitarias, la asamblea y las familias. Al igual que las instancias representativas de la comunidad, la participación de los familiares de las partes en conflicto es central en la construcción del acuerdo; hay ocasiones en que las autoridades se limitan a propiciar y luego ratificar dichos acuerdos. Asimismo, a falta de un reglamento que establezca tiempos y modalidades del castigo, esta justicia "procedimental" - después del esclarecimiento de las responsabilidades- privilegia la voz de quien ha sido agraviado; por ejemplo, en el caso de una violación, "si se sienten más ofendidos se les permite pedir más, porque así va quedando conforme el ofendido". ${ }^{68}$

En todos los niveles, la justicia que se ejerce es conciliatoria. Busca el acuerdo y la reparación del daño, a parte que por los casos muy graves, que perjudican sin remedio las personas o la comunidad. Así explica un representante de la Junta de Buen Gobierno el procedimiento que siguen para la resolución de los problemas:

Primero jalamos la parte que está afectada del problema. Y empezamos a hacer la investigación, que así pasó, todas las consecuencias. Y a parte jalamos a la otra parte, el que está afectando, y empezamos también a preguntar.

Entonces ya nosotros como autoridades vemos quien tiene la razón, y a él se le da la razón y se busca la forma de arreglar, la solución. Y el que tiene el error, si es un error grave, pasa 24 horas en la cárcel, pero dándole comida, sacarlo a bañar.

Ya luego, dependiendo de la gravedad del delito, se paga hasta 15 días, o un mes de castigo; y si es muy grave, seis meses o un año. Nunca hemos dado castigos por más de un año.

\footnotetext{
${ }^{67}$ JBG, entrevista por el Colectivo Situaciones, 2004, en Colectivo Situaciones (2005:39).

${ }^{68}$ Integrante del Concejo Autónomo de San Pedro de Michoacán, entrevista, 14 diciembre 2008.
} 


\section{AUTONOMIAINDÍGENA, VIOLENCIAY JUSTICIA}

Pero es trabajar en los trabajos colectivos, que hay a nivel Zona.

No los tenemos en la cárcel, sino que están con libertad, y aportan nomás el trabajo. ${ }^{69}$

Cuando viene una persona a poner su demanda, se citan a las dos partes en tal fecha; por lo regular se dejan ocho días para que acudan al citatorio. También hay citatorios urgentes, dependiendo de la necesidad se le dan dos o tres días para que lleguen.

Una vez estando aquí tenemos que escuchar las dos partes, tanto el que está inconforme o que demanda como el acusado. Y son importantes las pruebas que presenten. ${ }^{70}$

Al final del proceso de resolución, en la comunidad o en un nivel superior, las dos partes firman un acta de acuerdo que se comprometen a respetar, sea que se haya llegado a la conciliación, sea que se haya decidido un castigo. Las autoridades han trabajado con las dos partes: para convencer al culpable que cometió un error y que no debe repetirlo; y para convencer al afectado que no guarde rencor y no exija un castigo injusto, que el error cometido se va a corregir. En el caso de que haya castigo, el culpable lo acepta y se compromete a cumplirlo. "Entonces deben estar de acuerdo las dos partes para firmar un acta de acuerdo". Según esto, hasta que se llegue al acuerdo el conflicto no termina, o el cumplimiento de lo acordado se tornará débil. ${ }^{71}$

No respetar los acuerdos representa una falta grave pasible de detención y castigo, como lo demuestra el caso de Flavio Jiménez, que la JBG dio a conocer públicamente en el año 2007. El hombre, chofer de una combi que realiza el transporte de pasajeros en la zona, fue responsabilizado de un accidente automovilístico acontecido en el 2004, en el que falleció el conductor del otro vehículo; un acta realizada por el Concejo Autónomo de Tierra y Libertad atestigua su compromiso a pagar la cantidad de 30.000 pesos, como compensación para los deudos y para los daños al vehículo. Dos años después, otra acta del Concejo da cuenta de los acuerdos entre las dos líneas de transporte que sirven la comunidad de San Isidro Zapotal, sobre los horarios a cubrir. En 2007, la Junta de Buen Gobierno, acusada por el Ayuntamiento de La Independencia y por los familiares de Flavio Jiménez de detención ilegal, da a conocer el caso junto con una declaración escrita por él mismo, en la que reconoce estar detenido por

\footnotetext{
${ }^{69}$ JBG, entrevista, La Realidad, 28/12/2007.

${ }^{70}$ JBG, entrevista, La Realidad, 11/12/2008.

${ }^{71}$ La misma dinámica y análoga importancia al proceso de construcción del acuerdo ha sido documentada por Gómez Valencia (2000) entre los paeces del Cauca, en Colombia, y por Collier (2004) entre los tzotziles de Zinacantán, en la zona Altos de Chiapas.
} 


\section{Capitulo 4. Justicia indigena e intercultural: la justicia según la Junta de Buen Gobierno de la Zona Selvar Fronteriza}

no haber respetado ninguno de los dos acuerdos. Su detención se prolongará hasta que se cumplirán los acuerdos. ${ }^{72}$

\section{Sanciones: reparación del daño y castigos}

En los casos que implican la reparación del daño la parte afectada es la que pide el monto de la reparación, y la autoridad avala o modifica su petición. Dependiendo de su gravedad, en el ámbito comunitario el problema se puede resolver únicamente con la reparación del daño, o a ésta se pueden juntar medio día o un día de cárcel en la comunidad, y unos días de trabajo comunitario.

Anteriormente a la instauración de los gobiernos autónomos, las autoridades comunitarias cobraban multas; ahora esta práctica se está reduciendo, y el castigo que se aplica por lo regular es el trabajo; de todos modos, nunca se aplica el cobro de multas en caso de delitos mayores. Al igual que en las comunidades no zapatistas, se usa la cárcel como punición, pero sin exceder las 24 horas. En los casos más graves, el castigo es el trabajo a favor de las comunidades, o reeducación, que se puede conminar tanto en la comunidad como a nivel municipal o regional (Zona), al igual que en el SSJRC de la Costa Chica y Montaña de Guerrero. En ambos casos, antes de la institución del gobierno autónomo, el trabajo como castigo se utilizaba solamente para delitos menores, y no era una práctica generalizada. Si no había acuerdo la sanción era muchas veces una multa, y los casos más graves se turnaban al Síndico Municipal o al Agente del Ministerio Público. La novedad de la justicia autónoma es retomar esta práctica comunitaria y ejercerla a nivel regional, reglamentando y uniformando su aplicación.

En la comunidad de La Realidad el castigo -que, dependiendo del problema, puede durar hasta un mes- es: para los hombres, abrir camino, despejar las brechas y las veredas de la comunidad; para las mujeres, cargar un camión de leña, o sea diez metros de largo por dos metros de alto. En la comunidad de San José del Río, los castigados trabajan en el mantenimiento del Hospital Autónomo, mientras las mujeres ayudan en la preparación de los alimentos. En la región Candelaria, prestan servicio en las obras de construcción que se realizan; y las mujeres preparan la comida para los trabajadores.

\footnotetext{
${ }^{72}$ Denuncia de la Junta de Buen Gobierno, 20 de marzo 2007, <http://enlacezapatista.ezln.org.mx/ 2007/03/20/junta-de-buen-gobierno-hacia-la-esperanza-20-de-marzo/>, consultado el 10 agosto 2014.
} 


\section{AUTONOMIAINDÍGENA, VIOLENCIAY JUSTICIA}

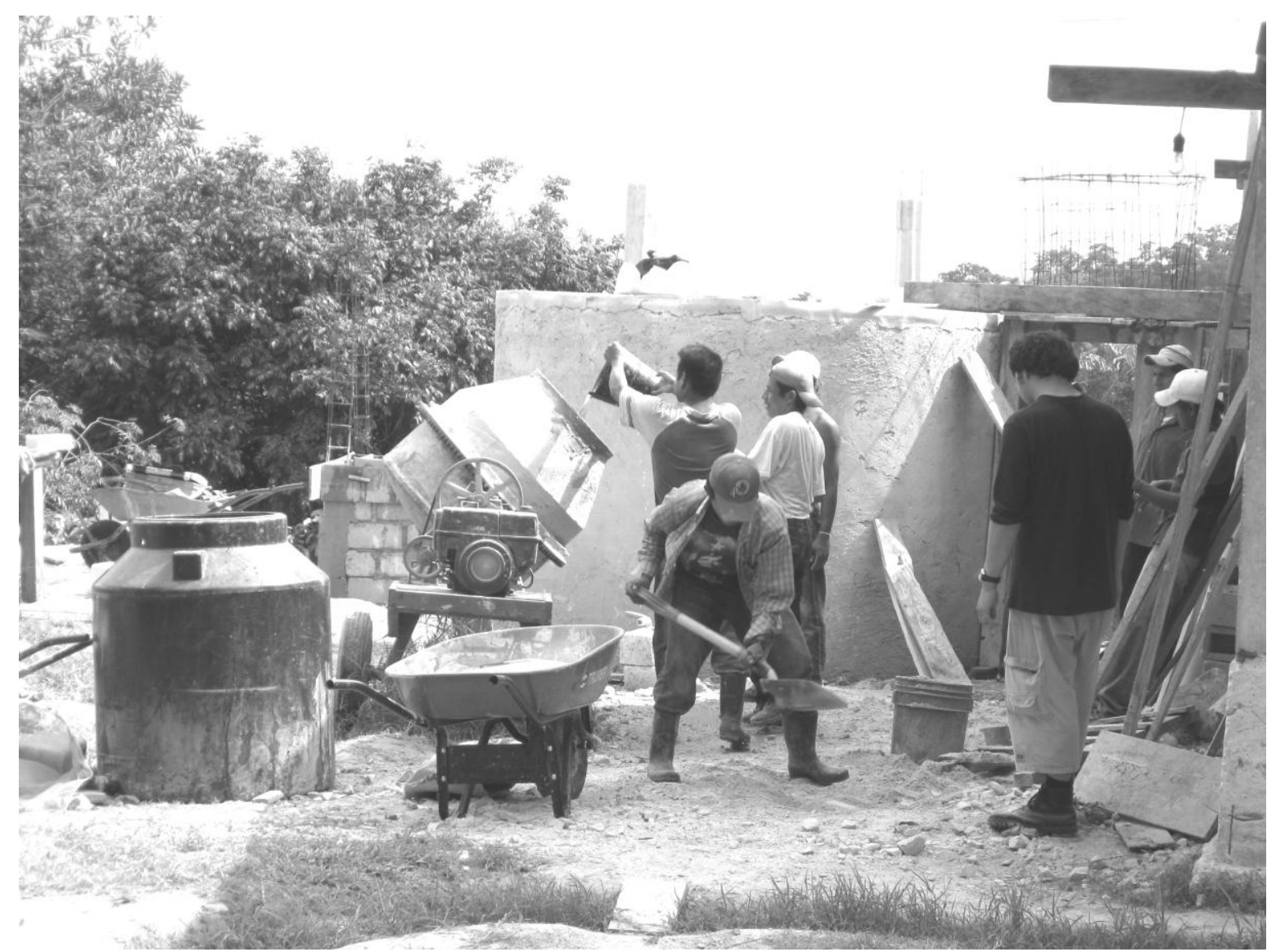

Castigados y brigadistas italianos construyen juntos una cisterna para la potabilización del agua, Caracol de La Realidad, enero 2009.

Cuando es la Junta que sentencia, el castigo se paga con trabajo en el Caracol, en el Hospital Autónomo de San José, o en "los colectivos que se manejen” en otros Municipios Autónomos. Los tiempos de castigo no son fijos. A continuación expongo, a manera de ejemplo, los castigos que han sido adoptados en algunos casos que me fueron relatados, cuya descripción ayuda también a entender el mecanismo de aplicación de la justicia autónoma.

El delito de embriaguez, dependiendo de la magnitud del problema que causa el borracho, se castiga en las comunidades.

Muchos acuerdan cono solo meterlo a la cárcel 24 horas, para aguardarlo, hasta que se le pase el alcohol; pero cuando ofende, la autoridad tiene que ver que tan grave es el error cometido. 


\section{Capitulo 4. Justicia indigena e intercultural: la justicia según la Junta de Buen Gobierno de la Zona Selvar Fronteriza}

En las comunidades se acostumbra que hagan un trabajo comunitario, y muchas veces se le advierte que para la próxima ya no lo dejarían así. ${ }^{73}$

El robo o asalto, en el Municipio de San Pedro de Michoacán, se ha castigado hasta con seis meses de trabajo. En este Municipio comentan que la violación se puede castigar hasta con un año, aunque en el único caso que ha sido atendido por las autoridades entrevistadas, éstas pidieron al culpable que cortara monte (abrir una vereda), y le dieron el plazo de un mes para cumplir el trabajo. Otro testimonio afirma que el violador puede llegar a ser expulsado de la comunidad, si así lo pide la afectada. ${ }^{74}$

El homicidio se puede castigar con tiempo diferente. El Municipio Autónomo Emiliano Zapata aplicó un castigo de un año (“después regresó a su casa porque reconoció el error"); en otro caso, ocurrido en 2003 en el MAREZ Libertad de los Pueblos Mayas, intervino la Junta. El homicida había actuado bajo los efectos del alcohol. Los deudos acudieron a la Junta de Buen Gobierno, pidiendo una reparación de 60.000 pesos. Las dos partes llegaron a un acuerdo por esa suma, pero las autoridades, que habían sido interpeladas para ejercer la mediación, consideraron que esto no era suficiente, que no se podía poner precio a la muerte de los hijos. Desconozco si este fue el monto de la reparación, pero además del pago, las autoridades autónomas también les conminaron seis meses de castigo.

Este caso muestra que la justicia que se aplica sirve para restablecer el equilibrio entre las personas y también al interior de la colectividad. La reparación del daño aplaca los afectados inmediatos, pero el trabajo comunitario sirve para que la comunidad recupere la confianza en quien falló, viendo que éste se puso a disposición de los demás.

Un caso muy mencionado por varias autoridades, sucedido en 2005, fue la detención por primera vez de unos polleros, traficantes de migrantes indocumentados, sancionados con seis o nueve meses de castigo; en caso de reincidencia, pagarán una pena más larga. Esto no fue una decisión de la Junta, sino el acuerdo de la Asamblea General donde se discutió el problema. El dinero requisado a los traficantes se devolvió a los migrantes, para que siguieran en su viaje o regresaran a su lugar de origen. Las autoridades zapatistas detectaron este tráfico desde la creación de los Municipios Autónomos, pero fue hasta diez años más tarde cuando pudieron detener a los primeros polleros. El gobierno autónomo estableció para las comunidades

\footnotetext{
${ }^{73}$ JBG, entrevista, La Realidad, 9/12/2008.

${ }^{74}$ Escuelita Zapatista, 28 de diciembre 2013.
} 


\section{AUTTONOMIIAINDÍGENA, VIOLENCIAY JUSTICIA}

zapatistas la obligación de apoyar a "los hermanos de Centroamérica": "lo único que hacemos es que si los migrantes pasan por nuestras comunidades, le vamos a dar alojamiento, a tratarlos bien, y le decimos por dónde ir, cuidando que no nos acusen que somos nosotros los traficantes de personas". ${ }^{75}$ Para los primeros tres polleros detenidos, un guatemalteco y dos mexicanos, la reeducación consistió en la edificación del puente que ahora une el Hospital Autónomo de San José del Rio con la comunidad y la carretera, junto con los albañiles y las demás bases de apoyo zapatistas encargados de la tarea. "Al final salieron agradecidos, porque habían aprendido el trabajo de albañil", comenta un representante de la Junta.

Un ámbito donde todas las autoridades zapatistas mencionan encontrar problemas es la resolución de los divorcios o separaciones, ya que la decisión de los mayores implica a niños, y esto lo consideran sumamente injusto, "no se permite abandonar a una familia", dicen. Pero también deben respetar la voluntad de las personas. En los casos en que un hombre deja la esposa por otra, se acostumbra castigar a los dos, el hombre y la nueva mujer. Es el caso de un ex-zapatista que pude entrevistar, que dejó la esposa y la organización, y se fue a la ciudad con una nueva mujer. Cuando quisieron regresar a la comunidad, debieron aceptar la resolución de las autoridades. El hombre entregó una vaca a la primera mujer, como capital que ella pudiera aprovechar o vender al momento de la necesidad; él y la nueva esposa pagaron dos meses de castigo en el Caracol (él ayudando en la construcción de letrinas secas, ella como cocinera en el comedor comunitario). El tabú del divorcio es aún muy fuerte, no obstante la Ley Revolucionaria de las Mujeres vigente desde 1993 les reconozca tajantemente la facultad de decidir sobre su vida. Se valora la unidad de la familia por encima del bienestar de las mujeres o de las decisiones individuales; tal sentido común hace que, de todos modos, los divorcios definitivos sean raros.

75 JBG, Escuelita Zapatista, 28 de diciembre 2013. 


\section{Capitulo 4. Justicia indigena e intercultural: la justicia según la Junta de Buen Gobierno de la Zona Selva-Fronteriza}

\section{Trato a los castigados, justicia comunitaria y expulsiones}

La reeducación de los castigados se realiza a través del trabajo comunitario, y también con conversaciones de las autoridades a los detenidos.

Aquí en estas oficinas están los compañeros de los Consejos, o los de la Vigilancia, y ellos se encargan de platicar con los castigados, les preguntan y lo hacen razonar, que está porqué tiene un delito. Y ellos lo reconocen de por sí, y se quedan conscientes de que hay compañeros que se ponen a platicar para que no se sientan mal que están aquí. Tenemos un dialogo abierto con el preso. Esto nos garantiza de que va a cumplir, porque no le estamos violando sus derechos humanos, lo tenemos libre; duermen donde consideren que quieren dormir, a partir de las dos de la tarde descansan, pueden ir a jugar o a bañarse. No acostumbramos tener en la cárcel los presos. $^{76}$

La jornada de trabajo de los castigados inicia a las 6 a.m. y termina a las 14 p.m., con una pausa para tomar el pozol $^{77}$. Terminado el día de trabajo reciben la comida, que le proporciona el Caracol, y tienen tiempo libre para sus actividades. No pasan la noche en la cárcel: uno de los entrevistados duerme en la casa de su suegro, otro en un cuarto que le pusieron a disposición en las instalaciones de la Junta de Buen Gobierno.

Pero no es que porque son castigados hay alguien atrás cuidándole que trabaje, se les deja libremente...pero se les anticipa que si ellos deciden escaparse, su castigo será el doble, así son los acuerdos de los pueblos. ${ }^{78}$

Los castigados pueden incluso obtener permisos para circular en el territorio:

Si vemos que es uno que va a tardar varios meses cumpliendo un castigo, y que está poniendo su responsabilidad y está cumpliendo bien, cuando necesita ir a visitar su familia se le faculta hasta 10 o 15 días, dependiendo. Por alguna enfermedad se le da permiso para irse a su casa o a

\footnotetext{
${ }^{76}$ JBG, entrevista, La Realidad, 11/12/2008.

${ }^{77}$ Bebida espesa y muy energética, preparada con masa fermentada de maíz nixtamalizado, y sucesivamente disuelta en agua. Es muy típico de la alimentación indígena chiapaneca.

${ }^{78}$ JBG, entrevista, La Realidad, 28/12/2007.
} 


\section{AUTONOMIAINDÍGENA, VIOLENCIAY JUSTICIA}

la clínica para curarse. Cuando la Junta da el permiso para irse, hace una constancia fijando la fecha de su regreso. ${ }^{79}$

Este trato particular que se da a los castigados refleja la excepcionalidad del sistema, y solo puede existir porque dicho sistema se basa en una estrecha colaboración entre la Junta, los Municipios y las comunidades. Se trata de una justicia comunitaria, en la cual la comunidad entera es parte afectada por el error de uno, y la entera comunidad participa del proceso de reeducación hasta su término, al recibir otra vez su miembro sin rencor ni prejuicio ("porque todos fallamos"). "Nuestra ventaja es la relación con el pueblo, con las autoridades comunitarias, y el acta de acuerdo que se firmó. Toda la comunidad está controlando, no solamente las autoridades". ${ }^{80}$ Se trata de una forma de control realmente capilar, pero que no proviene desde arriba sino que se genera de forma horizontal. Según la Junta de Buen Gobierno,

Principalmente cuando [el castigado] es zapatista, la misma comunidad no va a permitir que regrese a su pueblo, entonces nos garantiza que no se vayan, cuando son compañeros ellos hacen lo que se les indique.

Donde tenemos más cuidado es cuando no son zapatistas, porque muchas veces la autoridad del pueblo que no es zapatista es cómplice de lo que está haciendo esa persona. En estos casos la comunidad da oportunidad al que se fuga a que regrese allá, antes de cumplir con su castigo. También hay casos en que se da un acercamiento entre la Junta y la comunidad, allí también nos garantiza contra las fugas. ${ }^{81}$

Hacemos un compromiso con la autoridad del pueblo en caso de que si regresa antes del tiempo, ellos mismos lo vuelven a traer. Esto ha funcionado: dos polleros que no son zapatistas y que tuvimos presos nos quisieron probar como autoridades, si era verdad lo que le decíamos o no. Estuvieron cumpliendo [el castigo] unos meses, pero después se les ocurrió quererse escapar. Nosotros nos comunicamos inmediatamente para que los detengan en otra comunidad; uno lo lograron detener y le hicimos ver las cosas; el otro se escapó. Inmediatamente acudimos a la autoridad de su pueblo -que no es zapatista por supuesto- y le extendimos una carta invitándolos a detener esa persona. Si veíamos que la autoridad acataba y cumplía su parte, la comunidad quedaba libre de culpa; si no, se hacía cómplice del tráfico de indocumentados que estaba haciendo esa persona, y quien sabe qué otras cosas pudieran estar pasando allí.

\footnotetext{
${ }^{79}$ JBG, entrevista, La Realidad, 14/01/2009.

${ }^{80}$ Idem.

${ }^{81}$ Idem.
} 


\section{Capitulo 4. Justicia indigena e intercultural: la justicia según la Junta de Buen Gobierno de la Zona Selva-Fronteriza}

Inmediatamente, al otro día agarraron a los presos, y las mismas autoridades los vinieron a entregar. $^{82}$

Finalmente, cuando un detenido termina de pagar su castigo, la Junta o el Municipio expiden un acta de liberación.

Otra tarea que cumplen las autoridades zapatistas es la prevención del delito:

Es una costumbre de las comunidades, las autoridades advierten a toda la población que no cometan robos, que no hagan perjuicios a los cultivos, o sea tratan de concientizar a que no hagan lo que no beneficia, porque en una comunidad hay quienes se acostumbran a hacer algo que no esté acorde con los acuerdos de la comunidad, entonces el deber de la autoridad, cada vez que se hace asamblea - cada tarde, cada dos días o cada tercer día- tiene que hacer esa recomendación. También nosotros, cuando vemos que en alguna comunidad pasa algo, en asambleas generales tenemos que informar a la gente lo sucedido, y estar al pendiente de nuestros compañeros en las comunidades para que no se desarrolle ese problema. ${ }^{83}$

La expulsión de la comunidad es el recurso extremo cuando no se puede llegar al acuerdo, frente a la inconformidad de los afectados o del culpable, en caso de que éste no quiera aceptar su responsabilidad. También se utiliza cuando la gravedad del delito violenta demasiado los valores éticos de la comunidad, pues rebasa la capacidad comunitaria de volver a aceptar en su seno quien rompió las normas, aunque no siempre la expulsión es definitiva.

Las autoridades de la Zona denuncian que las expulsiones se han multiplicado en tiempos recientes, ya que, según su interpretación, los contactos con el exterior favorecen la proliferación de delitos que las comunidades no logran resolver internamente. ${ }^{84}$

El Comisariado Ejidal de La Realidad explica que cuando se arregla un problema:

se hace una acta donde firman o 'huellan' si no saben escribir, y la sella la autoridad. A las dos partes se da copia del acuerdo que se hace y quedan conformes, casi nunca ha habido inconformes. Si vemos que va a haber inconformidad, ya no se hace el acuerdo con el

\footnotetext{
${ }^{82}$ JBG, entrevista, La Realidad, 14/01/2009. Debido a la fuga, el castigo de seis meses fue incrementado hasta nueve meses.

${ }^{83}$ JBG, entrevista, La Realidad, 9/12/2008.

${ }^{84}$ JBG, entrevista, La Realidad, 14/1/2009: "Normalmente no suceden estos tipos de casos en la zona, las comunidades no están acostumbradas a esto. Pero ahora se habla mucho de la migración, está la televisión, entonces los jóvenes empiezan a tener esa curiosidad de saber que se siente a detener o asaltar a alguien. Antes no sucedía esto".
} 


\section{AUTOONOMIIAINDÍGENA, VIOLENCIAY JUSTICIA}

ofendido, sino que se ordena al que busca problemas que se vaya, no se permite que viva acá. Esto sucede cuando es un problema muy grave, que ya no tiene remedio. Para que no haya inconformidad se expulsa del pueblo, para que vaya sufriendo el doble, cuando sale del pueblo se le quita el derecho [a la tierra como ejidatario]. Dentro de un mes o dos regresa, pidiendo perdón, y ya, se vuelven a tomar otros acuerdos, y queda igual, normal. ${ }^{85}$

Uno de los casos relatados por la Junta de Buen Gobierno ilustra como el sistema de justicia autónoma trate de limar las asperezas y arbitrariedades de una justicia comunitaria cuyo alcance es limitado. El nuevo sistema, más amplio, confiere a la justicia comunitaria y a las mismas comunidades mayores recursos para resolver dialógicamente los conflictos, sin llegar a rupturas.

El caso se refiere a un asalto que cuatro jóvenes perpetraron en contra de unos chapines, comerciantes guatemaltecos que recorren a pie las comunidades selváticas ofreciendo objetos de utilidad cotidiana, respetados por toda la población. La intervención de la comunidad permitió devolver a los comerciantes lo robado, pero se determinó que se trataba de un delito grave, porque la comunidad:

No está acostumbrada a eso; pero como son jóvenes, hay muchas veces que por mirar la tele, o tener la idea del Norte, se crean otra visión. Resulta que asaltan a un comerciante y eso la comunidad no lo permite; no quiere que otras personas, los niños, aprendan a hacer eso. ${ }^{86}$

La comunidad decidió expulsar a los jóvenes, pero creando un grave problema con sus familias, quienes suplicaban no se les aplicara un castigo tan fuerte. En ese momento las autoridades interpelaron a la Junta, que ejerció su función de mediación.

Es allí donde nosotros tenemos que intervenir, hablar con las autoridades, para que quien hizo el error reconozca lo que hizo. Pero también la comunidad a veces comete errores: cuando no dan a conocer a la Junta o al Municipio decisiones como estas, cuando hay formas de encontrar una solución. Es que la gente, la comunidad, se encabrona, porque normalmente no existe en las comunidades hacer eso.

Se les dijo a los culpables que si ellos pagaban un tiempo de trabajo en la zona tal vez la comunidad los iba a aceptar de regreso después. Y la comunidad entendió, porque muchas veces se toman a la ligera decisiones que pueden afectar a otras personas, entonces logramos

\footnotetext{
${ }^{85}$ Comisariado Ejidal de La Realidad, entrevista, 14/12/2008.

${ }^{86}$ JBG, entrevista, La Realidad, 10/01/2009.
} 

Capitulo 4. Justicia indigena e intercultural: la justicia según la Junta de Buen Gobierno de la Zona Selva-Fronteriza

convencer a la comunidad que pagaran un castigo aquí por ocho meses y una vez cumplido ya regresaran a la vida normal. Ya si lo vuelven a hacer, entonces tendrá todo el derecho la comunidad a decidir lo que considere.

La gente que acepta pagar castigo reflexiona del error que comete y después vuelve a la vida normal con la comunidad. Ahora los jóvenes están cumpliendo cargos en su comunidad. ${ }^{87}$

\section{El "camino del buen pensamiento": valores de la justicia autónoma}

Dos elementos son fundamentales en la justicia autónoma: la participación de la comunidad, que hace de la justicia una construcción colectiva, y el hecho de que el culpable reconozca su error. La justicia zapatista muestra una profunda comprensión de las debilidades del ser humano, y la conciencia de que haber cometido un error no debe convertirse en un estigma indeleble:

Todos somos humanos y cometemos errores y con el castigo se corrige uno. Es diferente de lo que hace la policía: llega, captura uno y empieza a golpearlo, creyendo que con eso se paga o se soluciona el problema. Nosotros solucionamos por medio de la concientización. Como si fuera que alguien está en el barranco, entonces hay que traerlo de la mano y ponerlo en su lugar. $^{88}$

Se plantea que el delincuente no es la persona a 'eliminar' para que la comunidad pueda 'vivir en paz'. A través del análisis lingüístico, Lenkersdorf (2002:169) muestra que no existe en el idioma tojolabal una palabra que corresponda al concepto de castigo; para acercarse al término se usa, a veces, la palabra wokol: "pero es una aproximación muy relativa, porque corresponde a las voces de dificultades, sufrimientos, que no tienen ninguna connotación punitiva [...] Por ello, y para acercarse más al sentido del castellano, se suele emplear el término kastigo, voz adoptada del español. Con la aceptación de la palabra castellana, se subraya la concepción española de la justicia" caracterizada en términos punitivos.

Lenkersdorf recuerda que la presencia de las cárceles en las comunidades indígenas, en Chiapas como en otras regiones, es producto de la tradición establecida en tiempos de la Colonia: en las Cédulas Reales y las ordenanzas se conminó la construcción de "buena cárcel con cepo y grillos" en cada Pueblo de Indios donde fue congregada la población indígena

\footnotetext{
${ }^{87}$ Idem.

${ }^{88}$ JBG, entrevista, La Realidad, 28/12/2007.
} 


\section{AUTONOMIAINDÍGENA, VIOLENCIAY JUSTICIA}

(Lenkersdorf 2002:165). En la "genealogía del castigo" en tierras tojolabales, los abusos cometidos por los patrones de las fincas hacia los peones dejaron una marca importante en el imaginario colectivo de los indígenas de la región. Los testimonios recogidos por Ruz y Hernández (1992) dan cuenta de la forma de "castigo" común en las fincas, consistente en colgar a un hombre, ligado de pies y manos, a través de una barreta de hierro que se suspendía de un árbol, a una altura de dos o tres metros, hasta que “confesaba su delito". Si no lo hacía, o ya como castigo, se les dejaba caer "con todo y barreta al suelo. Si te mueres, te mueres" ${ }^{89}$ Por su parte, las mujeres eran sometidas a latigazos -"llevaban cuero"- por el caporal de la finca. La coerción en todos los aspectos de la vida de los peones baldíos, el control total sobre sus cuerpos y la violencia arbitraria que éstos debían soportar, contrastan tajantemente con la idea y la práctica de la justicia que los indígenas conservaron y construyeron al interno de sus propias comunidades.

En el idioma tojolabal, en lugar que "castigo", la expresión usada es apagar el delito, reestablecer el equilibrio, en un proceso vigilado por la comunidad (Lenkersdorf 2002:171). Cuando se comete un delito, todos son víctimas, no sólo el agraviado, sino también el delincuente -también sufre al estar escondiéndose, huyendo constantemente- y su familia, así como la comunidad. En esta visión, la justicia y la seguridad son responsabilidad de todos y se debe buscar maneras de restaurar la relación dañada, de restablecer el tejido social. ${ }^{90}$

El aspecto de la participación de la comunidad en la búsqueda de la verdad es muy interesante, ya que normalmente en el sistema positivo eso no es prueba fehaciente, mientras en el sistema zapatista toda la colectividad participa en la búsqueda de la verdad y la construcción del acuerdo.

Es indiscutible la importancia de la colectividad de la justicia, donde la asamblea de la comunidad o la Asamblea General tiene un papel fundamental en discutir las penas, y en el seguimiento del proceso de reeducación; asimismo, la autoridad encargada de la procuración e impartición de justicia es un órgano colegiado que toma las decisiones colectivamente,

\footnotetext{
${ }^{89}$ Testimonio de Enrique Espinoza Moreno, ex peón de la Finca Carme Yaxalá, en Ruz y Hernández (1992: 175).

${ }^{90}$ Lenkersdorf enfatiza el valor de la colectividad -el NOSOTROS- en la sociedad tojolabal, en la cual "cualquier tipo de grupo sigue considerando a todos los componentes suyos como miembros, independientemente del comportamiento de cada uno. Dicho de otro modo, el grupo es el corresponsable de cada uno de sus componentes, cuyo accionar afecta el todo grupal" (2002:177). Esta posición, un tanto idealizada, debería analizarse a la luz de las fracturas políticas intracomunitarias que actualmente marcan muchas comunidades de la región.
} 
Capitulo 4. Justicia indigena e intercultural: la justicia según la Junta de Buen Gobierno de la Zona Selva-Fronteriza

compuesto por indígenas de diversos pueblos, lo que hace más difícil que las posiciones individuales tengan un peso relevante en la resolución del caso. Ya en 1983 Mario Humberto Ruz, en un texto clásico dedicado a los tojolabales, había señalado que "la última palabra en la solución de tales problemas [locales] no la tienen el comisariado o sus ayudantes; esta queda siempre en poder de la asamblea"; asimismo, "en caso de conflictos mayores [...] el comisariado puede recurrir al consejo de los 'pasados' o antiguos, es decir, comisariados que le precedieron en el cargo. La última instancia es siempre la asamblea comunal" (Ruz 1983: 195-196).

Otra particularidad de estos sistemas son los criterios para la resolución de conflictos: la constante práctica de la negociación y la búsqueda de la conciliación entre las partes, realizada a través de repetidos "careos", como forma de desactivar los conflictos antes de llegar a la necesidad de aplicar una sanción; la gratuidad de la justicia, donde no hay gastos para abogados ni para procesos, no hay fianzas ni multas, y los culpables pagan su pena con trabajo a favor de la sociedad, además de la reintegración a la sociedad de los delincuentes como objetivo del castigo.

En la impartición de justicia, el papel de las autoridades es mediar y buscar una solución equitativa, sin imponer su decisión, sino buscar el consenso, el acuerdo de todas las partes sobre la resolución que se va a tomar. Nuestro papel es buscar y construir un acuerdo común, mas no aplicar la ley. Como autoridades de la Junta somos un puente, construimos un dialogo y no una negociación, y por medio del diálogo llegamos al arreglo, aunque no siempre resulta así de fácil. ${ }^{91}$

En esto, los guían principios concretos, que se desprenden de reflexiones articuladas alrededor del precepto básico del mandar obedeciendo y regulan la relación entre los ciudadanos y las autoridades.

Cuando se arregla un asunto, siempre se ve quien realmente tiene la culpa, tenemos que arreglar como es y no hacerlo a nuestra manera, si no estaríamos imponiéndonos. Esto sería el principio que no estamos mandando, porque debemos mandar obedeciendo. Si no obedecemos

\footnotetext{
${ }^{91}$ JBG, entrevista, La Realidad, 10/01/2009.
} 


\section{AUTONOMIAINDÍGENA, VIOLENCIAY JUSTICIA}

nunca vamos a saber cómo se arregla un problema, porque estaríamos faltando de respeto a esa persona, que también tiene el derecho a defenderse. ${ }^{92}$

"Hay acuerdos internos en la comunidad, que se tienen que cumplir; si alguien no los respetó, tiene que ser castigado. Porque aquí el pueblo manda, pero obedeciendo también. Porque si no, no puede mandar, y si no obedece, tiene que recibir su sanción". 93 En esta frase el entrevistado parafrasea el lema zapatista de que hay que mandar obedeciendo, o sea que las autoridades son los servidores del pueblo, son investidos de la autoridad para hacer cumplir en la práctica lo que se decide colectivamente en las asambleas. Pero también tienen la autoridad para que las personas obedezcan a los mismos acuerdos: no solamente los representantes, también el pueblo debe mandar obedeciendo. Es una relación que se debe respetar de los dos lados.

Para que este tipo de justicia -que busca restablecer el equilibrio social- pueda ser efectiva, es fundamental el reconocimiento de la responsabilidad por parte de la persona que se determinó culpable. Si la persona que está siendo procesada en un juicio, después de que entre todos se haya buscado la verdad (aunque nunca se puede encontrar "la verdad" pero sí elementos que se acerquen más a ella), reconoce que tuvo responsabilidad en el delito del cual se le acusa, pero no reconoce que tiene que ser sancionada por eso, no se puede llegar a un acuerdo. Y menos si no reconoce que tiene responsabilidad y no reconoce la sanción.

En la medida en que la persona reconoce su responsabilidad puede aceptar la sanción, que consiste en acciones ejemplares para la comunidad y para la persona, en aras de que no se vuelva a repetir el delito.

Es la tarea de la Junta: no cerrarnos, tampoco castigar injustamente, ya que todos cometemos errores, siempre y cuando reconozcamos que este error no lo volvamos a cometer. Pero si alguien es necio, sabiendo que comete un error y no reconoce la gravedad de lo que hizo, allí si va la justicia. La gente que acepta pagar castigo reflexiona del error que comete y después vuelve a la vida normal con la comunidad. ${ }^{94}$

Todos los entrevistados han puesto un enorme énfasis sobre este punto, que parece el centro de la concepción y la práctica de la justicia zapatista. Reconocer el error hace que la persona no

\footnotetext{
92 JBG, entrevista, La Realidad, 28/12/2007.

${ }^{93}$ Agente Municipal de San José del Río, entrevista, 15/01/2009.

${ }^{94}$ JBG, entrevista, La Realidad, 14/1/2009.
} 
Capitulo 4. Justicia indigena e intercultural: la justicia según la Junta de Buen Gobierno de la Zona Selva-Fronteriza

vuelva a incidir, y esto permite que la comunidad pueda otra vez tener confianza en él, mientras no reconocer la falta puede agravar la situación, e implicar un castigo más severo, como documenta el siguiente caso.

Se trata de un joven chol, cuya comunidad se encuentra en el MAREZ Libertad de los Pueblos Mayas, al que se le encontraron unas semillas de marihuana. Vistos los reiterados tentativos del Ejército mexicano de acusar a los zapatistas de narcotraficantes como plan contrainsurgente, y los múltiples episodios en que las Fuerzas Armadas mencionan haber encontrado sembradíos de marihuana en territorio zapatista, sin nunca mostrar las pruebas, el hecho era de extrema gravedad. El joven estaba perjudicando toda la comunidad, por lo que se decidió sancionarlo, a pesar de que se consideró verdadera la afirmación de que él ignoraba de que eran las semillas. El joven negó su responsabilidad, debida a la ignorancia y a la ingenuidad, y se empecinó en culpar a otra persona. Por no reconocer su error, su castigo fue aumentado de seis meses hasta un año.

La importancia de reconocer la propia responsabilidad va de la mano con la prioridad que se da a la conciliación y también con la concepción diferente del castigo. Esto tiene que ver con una idea de que la sociedad que no es compuesta por individuos aislados, sino por redes sociales y colectividades; por lo tanto la pena puede ser más corta pero el individuo se compromete a regresar a sus deberes familiares y comunitarios, reinsertándose en un contexto donde la comunidad toda seguirá vigilando su conducta. Así, el control (entendido en términos foucaultianos) no se limita a las instituciones represivas o carcelarias, sino es continuamente ejercido por toda la sociedad sobre los individuos que la conforman; de la misma manera en que dichas redes sociales sirven a que los individuos puedan hacer frente y superar sus problemas personales con la ayuda de los otros integrantes de la comunidad (reciprocidad). 


\section{AUTTONOMIIAINDÍGENA, VIOLENCIAY JUSTICIA}

Organización comunitaria y regional: persistencia, innovación, interculturalidad

El proceso analizado no propone un discurso esencialista o "purista" en términos identitarios, ya que se trata de una región "multiétnica", donde diversos pueblos comparten el territorio. Para la resolución de los conflictos se retoman elementos del derecho positivo, "readaptados" según el uso que de ellos hacen las autoridades en las comunidades, juntos a otros elementos propios de las culturas indígenas presentes en la zona. Se trata de un sistema normativo "híbrido", determinado por el contexto de interlegalidad en el cual se desarrollan.

En Chiapas, como en otros estados, los sistemas normativos autónomos se basan en la organización social de los pueblos que viven en la región, basada en el ámbito colectivo para la toma de decisiones (la asamblea comunitaria) y en el principio de reciprocidad y ayuda mutua, principalmente para las labores agrícolas pero que se extiende a otros ámbitos de la vida social. La construcción de una nueva jurisdicción y un espacio regional compartido fortalecen nuevos espacios interculturales.

Antes de la creación de los MAREZ la justicia se resolvía a nivel comunitario, cuando una comunidad no podía resolver su asunto, tenía que trasladarlo a Las Margaritas [cabecera municipal oficial]. Después del '94 estamos fortaleciendo y practicando a nivel de otras comunidades lo que nuestros antepasados ya practicaban, pero a un nivel más local. Ahora nosotros hablamos de la JBG que hace justicia para los zapatistas y no zapatistas en los cuatro Municipios Autónomos. Entonces la tarea es más que antes. ${ }^{95}$

En el territorio zapatista, la instauración de los gobiernos autónomos implica varios elementos de novedad que se han venido sumando o han modificado las prácticas de organización comunitaria anteriores.

En primer lugar, la posibilidad que ahora tienen las mujeres de cumplir cargos de autoridad, tanto a nivel comunitario, como en los niveles superiores, Municipio y Junta. Otro elemento es la diferencia entre la actual práctica de la justicia y la que se hacía antes de "la autonomía". Se menciona que el Agente Municipal no era nombrado por la asamblea sino por el Presidente Municipal, en la cabecera. Se trataba de alguien fiel al partido en el gobierno, y que ejercía un poder arbitrario en la comunidad, que ésta no podía controlar.

\footnotetext{
${ }^{95}$ JBG, entrevista, La Realidad, 9/12/2008.
} 
Capitulo 4. Justicia indigena e intercultural: la justicia según la Junta de Buen Gobierno
de la Zona Selva-Fronteriza

En ese entonces el Agente resolvía en la comunidad problemas menores, utilizando la cárcel por 12 o 24 horas y cobrando multas como castigo. "Más que nada en la comunidad se resolvían problemas internos, no se podía resolver otros tipos de asuntos. Se trataba de asuntos de separamientos de familias o divorcios, problemas de linderos que le decimos cuestiones agrarias entre familias, problemas e maltrato a la mujer por el alcoholismo, entre otros tipos de problemas". ${ }^{96}$ En caso de delitos mayores, el inculpado podía quedarse en la cárcel hasta por 15 días, para después ser trasladado a la cabecera municipal para el juicio.

Las autoridades de la Junta mencionan como elemento de novedad y gran importancia el hecho de que las formas de resolución de los conflictos que ellos aplican actualmente reflejan las prácticas de justicia que se utilizaban a nivel comunitario.

Yo creo que la impartición de justicia nace de nuestros antepasados, nuestros abuelos que vinieron practicando esta forma de hacer esta otra justicia, solamente que se daba a nivel comunitario. Una vez que surgen los Municipios Autónomos el Consejo Municipal empieza a practicar un nivel más alto de la cuestión de justicia, o sea que no solo resuelve un problema de una comunidad, sino de diferentes comunidades que abarca un municipio autónomo. Esta es la diferencia. Pero desde mucho antes se ha venido practicando la impartición de justicia donde el dinero no manda en la justicia, queda afuera. Más bien se actúa conforme a las razones y al delito que se encuentre a la persona, si es que es culpable o no. ${ }^{97}$

$\mathrm{Al}$ igual que en el caso de la Montaña y Costa Chica de Guerrero, se está creando un sistema de justicia con alcance regional, que nace de las practicas comunitarias. $\mathrm{Y}$ al igual que en la experiencia suriana, el castigo con trabajo o reeducación es una innovación de los pueblos indígenas, que iniciaron a practicar al organizarse de forma autónoma. "Es la nueva forma de hacer la justicia, la autoridad, la autonomía. Son los pueblos que dijeron así vamos a castigar a los que cometan delito". ${ }^{98}$

Finalmente, hay que considerar la interlegalidad cada vez más compleja y politizada que conlleva la diferenciación e incluso la división intracomunitaria de acuerdo a preferencias y militancias políticas distintas, junto con la proliferación de las instancias judiciales oficiales (a las Agencias del Ministerio Público y los Juzgados se añadieron los Jueces de Paz y

\footnotetext{
${ }^{96}$ Entrevista a la JBG, 9/12/2008.

${ }^{97}$ Entrevista a la JBG, 11/12/2008.

${ }^{98}$ Idem.
} 


\section{AUTONOMIAINDÍGENA, VIOLENCIAY JUSTICIA}

Conciliación Indígena en algunas cabeceras, así como las recién instaladas Unidades Integrales de justicia Restaurativa).

Hay muchas autoridades, el agente municipal, el presidente municipal; en Chiapas empieza a haber una secularización del PRI, la gente empieza a resolver conforme a los intereses de su partido político, los disidentes se dan cuenta que lo que pueda resolver la autoridad va a ser parcial en contra de ellos, peor si son zapatistas. Entonces para buscar una solución, si es zapatista, va con autoridad autónoma; si es entre zapatista y priísta el agente municipal busca diálogo con el priísta y a ver si pueden encontrar una solución. Si es un conflicto de tierras está el comisariado ejidal autónomo, y en el mismo ejido está el comisariado oficial, en algunos casos se juntan a platicar y en otros no $[\ldots]^{\prime} .{ }^{99}$

\section{Conflictos políticos y divisiones comunitarias. La disputa con la CIOAC}

En las entrevistas realizadas, la JBG declara que buena parte de los problemas o conflictos que atiende involucran individuos no zapatistas, lo que coincide con la situación documentada por Mora (2013) en el MAREZ 17 de Noviembre, ubicado en la Zona Totz Choj (municipio oficial de Altamirano). Escogerían la justicia autónoma porque, a decir de las autoridades zapatistas, no es corrupta, no hay gastos por el procedimiento jurídico ni multas en la resolución; además porque comparten las mismas lenguas y los mismos códigos culturales. Desde la instauración de las JBG, los representantes zapatistas han enfatizado su voluntad de ejercer un “gobierno para todos”, más allá de las distintas militancias políticas:

No es necesario ser zapatista para ser atendido y respetado por los municipios autónomos de cualquier parte de nuestro territorio. Por ser miembro de la comunidad o del municipio que pertenezca tiene derecho a ser atendido [...] Nosotros los zapatistas no vamos a agredir a nadie ni imponer nada a los hermanos que no son zapatistas. Seremos respetuosos con todos nuestros hermanos indígenas sin importar su organización, su partido o su religión, siempre y cuando nos respeten y respeten nuestras comunidades, a nuestros municipios autónomos y a sus

\footnotetext{
${ }^{99}$ Entrevista en el Centro de Derechos Humanos Fray Bartolomé de las Casa A. C., San Cristóbal de las Casas, Chiapas, cit. en El reconocimiento legal y vigencia de los Sistemas Normativos Indígenas en México, publicado por la Oficina en México del Alto Comisionado de las Naciones Unidas para los Derechos Humanos, México, 2008, p. 72
} 


\section{Capitulo 4. Justicia indigena e intercultural: la justicia según la Junta de Buen Gobierno de la Zona Selvar Fronteriza}

autoridades, para que nuestros pueblos indígenas puedan ejercer sus derechos a la autonomía y a la libre autodeterminación. ${ }^{100}$

He descrito hasta aquí el funcionamiento y los valores propios de la justicia zapatista, que reflejan la actitud incluyente expuesta en estas palabras del Comandante David; sin embargo, dicha apertura encuentra sus límites en las diferencias y los conflictos relacionados con distintas militancias y proyectos políticos presentes en el territorio. Mientras, en el discurso citado, los zapatistas pregonan respeto, no todos los otros actores políticos presentes en el territorio comparten este sentir.

Lejos de la intención demoledora de algunos textos recientes -que bien se podrían calificar de contrainsurgentes- que escudriñan las divisiones internas al zapatismo con la intención de señalar su debilidad y su irrelevancia como fuerza política territorial, considero que reflexionar sobre este tipo de conflictos permite entender los límites de la justicia zapatista y los problemas que encuentra en su desarrollo, buscando una visión crítica que no idealice los procesos sino que, a partir de un posicionamiento ya declarado, permita elaborar una argumentación propositiva.

Entre los conflictos que rebasan la capacidad de mediación de la JBG están los que no atañen a individuos sino que involucran organizaciones, y los que ocurren en comunidades o regiones donde las bases de apoyo zapatistas son la minoría. Gran parte de las denuncias públicas difundidas por la JBG de la Zona Selva Fronteriza (al igual que las de otras Zonas), desde el año 2010 a la fecha, corresponden a este tipo de conflictos. ${ }^{101}$ En particular en el MAREZ Tierra y Libertad, donde la presencia zapatista es muy diluida en el territorio, se han dado a conocer conflictos que han desembocado en el uso de la violencia en contra de los militantes zapatistas, su detención en las comunidades o su encarcelamiento en los penales estatales.

El control de las tierras o los predios "recuperados" y de los recursos comunitarios (agua, grava, madera, etc.) es el primer motivo de conflictividad, ya sea en los poblados donde los zapatistas son la minoría como en otros contextos. ${ }^{102}$

\footnotetext{
100 Comandante David, Ceremonia de nacimiento de los Caracoles, en revista Rebeldía, número 10, México, agosto de 2003, pp. 18-22.

${ }^{101}$ Véase las denuncias de la JBG en <http://enlacezapatista.ezln.org.mx/>.

102 Sobre los mecanismos que generan la conflictividad agraria entre zapatistas y no zapatistas, véase el Capítulo 3.
} 


\section{AUTONOMIAINDÍGENA, VIOLENCIAY JUSTICIA}

En segundo lugar, ha sido denunciado el hostigamiento y la detención de zapatistas por negarse a cumplir algunos acuerdos de la comunidad, así como a cubrir pagos y faenas determinadas por las autoridades ejidales, lo que remite a muchos casos análogos sucedidos en otras regiones, donde indígenas no católicos se rehusaron a participar y cooperar para las celebraciones religiosas, originándose conflictos muy violentos que en diversas ocasiones implicaron la expulsión de los disidentes. En el caso de los "disidentes” zapatistas, el conflicto es de naturaleza política y se explica por el rechazo a cualquier relación de colaboración con el gobierno estatal, así como a recibir apoyos gubernamentales. Esta decisión, que se puede manejar como una orientación ética individual, en una dimensión colectiva puede dificultar las acciones orientadas al gobierno y al desarrollo de la comunidad e incluso, si no se logran soluciones mediadas, imposibilitar el establecimiento de los acuerdos internos, núcleo del gobierno comunitario.

Debido a las militancias distintas y a los diversos tipos de relación con el Estado y las instituciones que las organizaciones plantean, que son aparentemente irreconciliables con la opción zapatista, se han generado divisiones y disputas en un gran número de comunidades de la región; en los casos en que la división es equilibrada, la relación de fuerza se desarrolla de manera dialéctica, y en eso es importante la actitud de respeto y tolerancia planteada por los zapatistas; sin embargo, en los casos donde éstos son minoría, con frecuencia creciente han sido víctimas de violencia; emblemáticos son los casos de los hermanos López Monzón, acusados injustamente y encarcelados por seis meses (2012), y de José Luis Solís, asesinado en una agresión colectiva (2014).

Este último hecho ha sucedido en la comunidad de La Realidad, uno de los "bastiones" del zapatismo, cuya población se integró a la "organización” ya desde 1984, y que por años fue sede del cuartel de la Comandancia General del EZLN. Desde la primera estancia en la comunidad, en el año 1999, me enteré de la división entre bases de apoyo zapatistas y "priistas", que en ese entonces representaban una minoría. Sin embargo, la comunidad conservaba mecanismos y espacios en los que se aplanaban las disputas: la asamblea ejidal y las funciones religiosas representaban ámbitos de discusión y sociabilidad que evitaban rupturas irreparables. Sucesivamente, observé la fragmentación del espacio público comunitario, lo que bien se puede entender como metáfora del mismo tejido social: en 2001, la Casa Ejidal ya no era accesible a los zapatistas, y en 2003 las familias "priistas" habían creado 
Capitulo 4. Justicia indigena e intercultural: la justicia según la Junta de Buen Gobierno

$$
\text { de la Zona Selva-Fronteriza }
$$

una escuela alterna para sus niños. Según diversos testimonios, en 2007 hacía casi un año que los habitantes zapatistas no frecuentaban la Iglesia, pues el grupo "priista" -que incluía también el catequista, responsable de la iglesia- estableció allí su hegemonía; por lo tanto, el grupo zapatista acudiría a otras comunidades, donde los religiosos fueran zapatistas, para celebrar los bautismos y los matrimonios. A partir de ese año, los grupos no zapatistas incursionaron en diversas ocasiones en el espacio donde se hospedan los visitadores (el Campamento), destrozando las construcciones, e incluso cortaron a la raíz la grande ceiba, símbolo del zapatismo en la comunidad.

Con el pasar de los años, la estrategia contrainsurgente y la pobreza generalizada de toda la población, hicieron que muchas familias dejaran el proyecto zapatista de autonomía y "la resistencia", abrazando otras militancias. En la región, el Estado no realiza las obras públicas y de utilidad social como una acción de gobierno, sino que las vincula a la afiliación a determinadas organizaciones sociales, como contraprestación para el trabajo de "compra de lealtades" que dichas organizaciones realizan con sus socios, en beneficio de uno u otro partido. Es decir que, para que una familia pueda beneficiarse de apoyos estatales o municipales, debe generalmente afiliarse a una organización que funge como "gestora" del partido político en turno. Tienen esta función muchas organizaciones de segundo nivel como la CIOAC, ORCAO, UES, ARIC, etc. Así, en La Realidad, pude observar el multiplicarse de las líneas de división: a los "priistas" se sumaron, unos años después, los "cioaquistas", afiliados a la Central Independiente de Obreros Agrícolas y Campesinos (CIOAC).

Desde su origen ésta fue una organización de masas adherida al Partido Comunista, y hoy al PRD. Según Hernández Navarro, "promotora en Chiapas de la lucha por la tierra, la sindicalización de jornaleros agrícolas y la organización de productores de café, la CIOAC entró en 1994 en un profundo proceso de descomposición. Muchas de sus bases la abandonaron para sumarse a las filas rebeldes. Buena parte de sus dirigentes se volvieron funcionales a las necesidades del gobierno. La organización dejó de lado sus antiguos ideales y se transformó en un aparato rural clientelar y corporativo, dedicado a negociar proyectos gubernamentales y buscar posiciones políticas". ${ }^{103}$ En Las Margaritas, el PRD buscó la alianza estratégica con la CIOAC, afianzada en la región, para concurrir a la presidencia municipal. Gracias al apoyo de la CIOAC, con la que estableció un pacto de gobierno y cuyos dirigentes

\footnotetext{
${ }^{103}$ Luis Hernández Navarro, La Jornada, 20 de mayo de 2014.
} 


\section{AUTONOMIAINDÍGENA, VIOLENCIAY JUSTICIA}

llegaron a cubrir importantes puestos en el Ayuntamiento -incluso la presidencia-, el PRD mantuvo el gobierno del municipio desde 2002 hasta 2010, cuando fue relevado por el Partido Verde Ecologista (PVEM).

El problema de las divisiones internas en las comunidades no representa un problema solo para el aprovechamiento de los recursos o la realización de las actividades comunitarias, sino que compromete los espacios de decisión como la asamblea: en muchas comunidades, ya se realizan dos asambleas, entre los zapatistas y entre los demás, y existen dobles autoridades, como en el caso de La Realidad: el Comisariado Ejidal zapatista, que entrevisté, cumple una función paralela al Comisariado Ejidal y al Agente Municipal, cargos que al menos desde 2008 son ocupados por no zapatistas de la comunidad. Aquí, a la pregunta expresa si se realizan aún asambleas generales, las autoridades contestaron "a veces. Pero más ya no, solo los que estamos en la resistencia. Ellos tienen sus nuevos acuerdos y al ratito los pisotean porque están borrachos. Ellos tienen sus propias autoridades y estas autoridades van con el Concejo [Municipal Autónomo], cuando ya no pueden resolver nada ellos". 104

Estas declaraciones revelan dos elementos importantes para la argumentación: por un lado, el real desgarre de los espacios de decisión comunitaria, lo que vuelve parciales y faltantes de legitimidad para todos los habitantes los acuerdos que tome una u otra parte. Por otro lado y en sentido opuesto, se afirma la legitimidad que las personas, incluso las no zapatistas, otorgan al sistema de autogobierno cuando recurren a él; en estos casos, según la Junta, “desde el momento en que vienen aquí respetan nuestra decisión”.

Considero que el núcleo problemático del fenómeno de las divisiones y diferencias políticas en el territorio de influencia zapatista reside precisamente en la cuestión de la legitimidad del autogobierno y del sistema normativo autónomo; esclarecer cuales procesos y conflictos fortalecen o ponen en discusión dicha legitimidad, cuales son los actores que intervienen en este proceso y sus motivaciones, permite entender los límites del autogobierno, tanto los que él mismo se pone como los que les son impuestos por las relaciones de fuerza que enfrenta.

En la Zona Selva Fronteriza, el actor que con más fuerza ha disputado la legitimidad del autogobierno zapatista es la CIOAC (en particular su fracción Histórica, de la que se separó en 1997 la fracción Democrática), organización que fue aliada del movimiento zapatista en sus

\footnotetext{
${ }^{104}$ Comisariado Ejidal de La Realidad, entrevista, 14/12/2008.
} 
Capitulo 4. Justicia indigena e intercultural: la justicia según la Junta de Buen Gobierno de la Zona Selva-Fronteriza

albores, y participó masivamente en las tomas de tierras en 1994. Sin embargo, frente al planteamiento de la autonomía radical, la Central optó por seguir gestionando los proyectos productivos y se distanció de los zapatistas, muchos de los cuales eran también miembros de esta organización, lo que creó un conflicto adicional sobre el uso y el reparto de la infraestructura de propiedad de la CIOAC. Ya desde 1997 un integrante de la CIOAC planteaba el conflicto de manera contundente: "en Las Margaritas no hay paramilitares. Nuestros enemigos allá como CIOAC son las bases del EZ, porque son los que nos impiden recibir algunos proyectos, tienen tomada la oficina de la CIOAC y algunos camiones". ${ }^{105} \mathrm{El}$ conflicto se hizo más fuerte en la medida en que el autogobierno se desarrolló en los ámbitos municipal y regional, pues las otras organizaciones con presencia regional cuestionan el control territorial que ejercen los zapatistas y la misma idea de "territorio zapatista" entendido como espacio homogéneo; de tal manera que no reconocen la legitimidad de la Junta de Buen Gobierno y de sus funciones.

El primer conflicto importante que se dio a conocer, conocido como "caso Armín Morales" tuvo lugar entre septiembre y octubre del 2003, inmediatamente después de la conformación de la Junta de Buen Gobierno, y su origen reside precisamente en una acción que implementó la JBG en el ámbito de administración de la justicia. El antecedente, bastante complicado, se puede resumir en estos términos: el señor Armín Morales vende un camión de propiedad del señor Rigoberto Hernández (integrante de la CIOAC-Independiente); éste acude al Ministerio Público en Las Margaritas, que exige 6.000 pesos para iniciar la averiguación previa, y por ende se dirige al Concejo Autónomo de San Pedro de Michoacán. El Concejo cita a las partes, y en la reunión el 2 de septiembre el padre de Armín se compromete a entregar en unos días la cantidad de 80.000 pesos, correspondiente al valor del camión; mientras, Armín se queda detenido en las instalaciones de la Junta, hasta que la deuda sea liquidada. A partir de este momento, la CIOAC Histórica (u Oficial) reivindica a Armín como su integrante, acusa a la JBG de haberlo secuestrado y, como represalia, el 12 de septiembre de 2003 incauta un camión de propiedad de la JBG y secuestra al chofer, José Luis Solís alias Galeano, a su ayudante, Oscar Lorenzo Méndez, y a cuatro integrantes de la CIOAC-D. Estos últimos fueron liberados dos días después, mientras los zapatistas siguieron desaparecidos e

\footnotetext{
105 Testimonio de Enrique Alvaro López, integrante de la CIOAC, en las memorias del Encuentro por la Reconciliación y la Paz, Región Selva y Frontera, Ocosingo, 8 y 9 de noviembre de 1997, CORECO, p. 98.
} 


\section{AUTTONOMIIAINDÍGENA, VIOLENCIAY JUSTICIA}

incomunicados por seis días; al respecto, la JBG declaró: "por hacer la justicia verdadera, pagamos con el secuestro de nuestros compañeros"106 y acusó a las autoridades municipales de cobijar y solapar el secuestro. Las declaraciones de los dirigentes de la CIOAC-H (estrictamente relacionados al gobierno municipal) difundidas por la prensa, desconocen claramente la autoridad de la JBG zapatista. El desenlace llegó un mes después tras la intervención del gobierno del Estado, que para desactivar el conflicto pagó al propietario del camión la cantidad requerida, por lo que la JBG, el 12 de octubre 2003, dejó en libertad a Armín Morales.

Este caso muestra que los límites de la justicia y del sistema normativo autónomo están en el reconocimiento: pero no solamente el reconocimiento por parte del Estado sino también por parte de la población. En términos jurídicos, son puestas en discusión lo la validez (reconocimiento que tiene fuerza vinculante) y la eficacia (seguimiento y acatamiento por parte de la población) del sistema normativo autónomo, dos características que junto con la justicia determinan su legitimidad. Asimismo, está en discusión también la legitimidad política de las autoridades encargadas de aplicar dicho sistema normativo. Los integrantes de la CIOAC no reconocieron la legitimidad de la justicia ejercida por la JBG, al afirmar que Armín estaba "secuestrado" mientras se encontraba detenido, situación temporánea aceptada por sus familiares como parte de un acuerdo conciliatorio. El uso de la violencia en contra de sus opositores políticos, zapatistas y CIOAC-D, es determinado por la voluntad de mostrar su mayor fuerza y preponderancia en la región, pero también por el hecho que, mientras el autogobierno zapatista es una institución estructurada que cuenta con varios mecanismos para hacer valer sus decisiones -y por esto siguió custodiando Armín hasta el pago de la deuda originaria- la CIOAC no puede más que recurrir al uso de la fuerza. La argumentación que sigue expresa el mecanismo del desconocimiento que, aunque en términos generales se queda más en las palabras de los dirigentes que en la vida cotidiana de los campesinos indígenas quienes acuden con frecuencia a las autoridades autónomas para resolver sus problemasexplica en parte los episodios de violencia homicida que se relatan en este apartado.

Cuando surge un problema [con un cioaquero] en una comunidad, digamos Tabasco o Buena Vista Pachán, donde tienen [los zapatistas] dos o tres gentes, a veces manda su Consejo

\footnotetext{
${ }^{106}$ La declaración aparece en el artículo de H. Bellinghausen, "Acusan zapatistas a los dirigentes de la CIOAC oficial de plagiar a dos indígenas", La Jornada, 15 de septiembre de 2003.
} 


\section{Capitulo 4. Justicia indigena e intercultural: la justicia según la Junta de Buen Gobierno de la Zona Selva-Fronteriza}

Autónomo una invitación para que vaya esa persona [de la CIOAC] a arreglar el problema en el Consejo Autónomo; pero nosotros no hacemos caso [al requerimiento zapatista] (integrante de la CIOAC, 2004, cit. en Estrada 2006:60)

La falta de reconocimiento de la legitimidad de una autoridad o de la validez de una norma implica que, para una parte de la población, no existan dichas normas y las sanciones que derivan de su incumplimiento. Esto marca los límites del sistema normativo autónomo, pues si las partes en conflicto no reconocen acuerdos, normas o bases de comportamiento comunes, la resolución de un conflicto no puede apelar a éstas, y se puede realizar solo a través de la negociación y el arreglo coyuntural para el problema específico en cuestión, negociación individual que en cualquier momento puede ser rota o incumplida pues no tiene un fundamento normativo. Sirva un ejemplo para esclarecer lo expuesto: en un conflicto agrario sobre una porción de "tierras recuperadas", los zapatistas reivindican su derecho a aprovecharlas y cultivarlas colectivamente en base a la Ley Agraria Zapatista; sin embargo, otro grupo puede reclamar el control del terreno en base a una titulación obtenida por el gobierno, al hecho de que participó en la ocupación, por colindancia etc. No reconociendo la otra parte en conflicto la validez de las normas zapatistas, no es posible para la autoridad autónoma establecer una conciliación basada en éstas ni imponer su respeto; lo que se puede lograr es una negociación especifica entre las dos partes, insuficiente para crear una suerte de “jurisprudencia” que afiance las mismas normas.

La cuestión es que los zapatistas sostienen que la Junta es para todos, pero el caso es que no todos aceptan estar dentro [de la jurisdicción] de la Junta de Buen Gobierno (Integrante de la unión de Ejidos de la Selva, 2004, cit. en Estrada 2006:60).

La falta de reconocimiento implica también los límites de la competencia de las autoridades autónomas, que reconocen ellas mismas su ineficacia y dificultad para enfrentar errores cometidos por no zapatistas, delitos graves, y conflictos que involucran organizaciones. En el primer caso, el desconocimiento de la legitimidad es ejercido tanto por la parte en conflicto cuanto por las instituciones gubernamentales que son llamadas a intervenir: "si tenemos un detenido en nuestra zona, y es alguien no zapatista que cometió abuso o violencia contra un zapatista, el gobierno nos acusa de secuestradores, cuando realmente no lo estamos 


\section{AUTOONOMIIAINDÍGENA, VIOLENCIAY JUSTICIA}

secuestrando, su familia sabe dónde está y estuvo de acuerdo que se le aplicara su castigo", 107 lo que sucedió en el caso citado de Armín Morales, en el que la Comisión Estatal de Derechos Humanos acudió a La Realidad para investigar sobre las condiciones de detención. "Por eso en ocasiones por la gravedad del delito no hemos podido aplicar la justicia autónoma, o a veces viene gente de las ciudades cercanas, y los que acusan están muy cercanos al gobierno, en ese caso no hemos podido aplicar justicia”. ${ }^{108}$ En esta declaración, la JBG admite los límites de su legitimidad como autoridad y aquellos de la justicia autónoma, determinados por el contexto de conflicto político que priva en la región: aun cuando tendrían la posibilidad de ejercer la justicia autónoma, y castigar delitos cometidos en su territorio, no lo hacen por la conciencia de que esto podría acrecentar el conflicto, como muestra el trágico caso que expongo a continuación.

El conflicto involucró nuevamente a los integrantes de la CIOAC Histórica (u Oficial) de La Realidad, quienes el 16 de marzo de 2014 detuvieron un camión de propiedad de la JBG y su cargamento de medicinas y material sanitario. El hecho fue motivado por la inconformidad de este grupo sobre el utilizo por parte del grupo zapatista de un banco de grava que por acuerdo sería comunal. Este "pretexto", que favoreció la explosión de un conflicto latente, es típico de los conflictos intracomunitarios; en este caso, los zapatistas argumentan que, al igual que los demás pobladores utilizan la grava para la construcción de las casas en parte subvencionadas por el programa gubernamental Piso Firme, ellos decidieron aprovecharla para la construcción de un anexo a la Clínica Autónoma. El camión permaneció en poder del grupo de la CIOAC, y la JBG tomó cartas en la resolución del conflicto, pues éste rebasó inmediatamente el ámbito comunitario al ser perjudicadas las actividades el sistema de salud regional.

Respaldada por el CDH Fray Bartolomé de Las Casas, la JBG emitió tres citatorios para llamar al dialogo las partes en conflicto; en la tercera solicitud dos dirigentes de la CIOAC acudieron a las instalaciones de la JBG para iniciar el proceso de negociación, que se prolongó por dos días (1 y 2 de mayo). En la tarde del segundo día, mientras proseguía la negociación con la presencia de dos enviados del CDHFBC- entre los dirigentes de la CIOAC, algunos de sus militantes locales y la JBG, un grupo de integrantes de la CIOAC y personas vinculadas al

\footnotetext{
107 JBG, Escuelita Zapatista, 28 de diciembre 2013.

108 JBG, Escuelita Zapatista, 28 de diciembre 2013.
} 
Capitulo 4. Justicia indigena e intercultural: la justicia según la Junta de Buen Gobierno de la Zona Selva-Fronteriza

PAN y el PVEM, cortaron el suministro de agua al Caracol y destruyeron la Clínica y la Escuela Autónomas, así como el camión objeto de la disputa. Poco después la comisión de negociación, que permanecía en las oficinas de la JBG, fue informada que unas 150 personas armadas habían asaltados tres vehículos en los que más de cincuenta zapatistas de otros Municipios estaban alcanzando el Caracol para participar en una actividad de formación. Los fuereños y quienes acudieron en su auxilio fueron atacados con armas de fuego, armas blancas y piedras; saldo de la emboscada fueron más de veinte heridos zapatistas, muchos de gravedad, y trece lesionados de la CIOAC, y el asesinato tumultuario de José Luis Solís, alias Galeano, quien fuera secuestrado en el conflicto del 2003.

La víctima no era un campesino cualquiera: como insurgente, participó en la toma de Las Margaritas el $1^{\circ}$ de enero de 1994, acción en la que falleció su hermano Jorge. Sucesivamente, se integró a la vida de su comunidad, pero al parecer mantuvo una posición en la estructura de los milicianos. Militante activo de la comunidad, participó e impulsó todas las actividades zapatistas en la región, hasta la última iniciativa política del EZLN, la Escuelita, en la que fungió como "maestro" para los visitantes. No es de extrañar que, en más de una ocasión, se volviera el blanco de una violencia política que rebasa las calificaciones simplistas de "conflicto intracomunitario" y que se vuelca sobre las estructuras regionales del zapatismo (JBG, Escuela y Clínica Autónomas, campañas de salud) delatando que el origen del conflicto reside en la hegemonía territorial.

Los agresores han sido definidos "paramilitares" por las autoridades zapatistas. No comparto totalmente esta definición por dos razones: en primer lugar, los cioaquistas de la Selva no responden a la caracterización de grupo paramilitar que propongo en el Capítulo 1, es decir grupos armados y entrenados directamente por el Ejército; en segundo lugar porque es una explicación que simplifica excesivamente el complejo entramado del conflicto político en la región y la disputa por la legitimidad. En esta perspectiva, los cioaqusitas armados representan más bien el grupo de choque de una organización estrictamente coludida con los ambientes políticos y de gobierno en la zona, que está adoptando métodos cada vez más violentos para adquirir poder en el territorio, en particular en contra de las organizaciones más 
cercanas. ${ }^{109}$ Un elemento adicional para entender la compleja relación entre el EZLN, la CIOAC y el gobierno local es que el actual secretario estatal de la Central (reelecto por tercera ocasión), José A. Vázquez Hernández, tojolabal, en la década pasada formó parte del Consejo Municipal Autónomo de San Pedro de Michoacán, y sucesivamente ganó la presidencia municipal del municipio oficial de Las Margaritas (2005-2007), tras un acuerdo político entre el PRD y la CIOAC.

Es en tal contexto que aparecen claramente los límites de un gobierno autónomo que quiere ser "para todos" y que sin embargo, debido a su caracterización política, corre el riesgo de gobernar solo para una parte. Frente a la conducta violenta y corrupta de los dirigentes de la CIOAC, la posición zapatista no ha traído buenos resultados, pues no ha alcanzado acuerdos de gobierno y de convivencia con los otros actores sociales activos en la región de la Selva.

El asesinato de Galeano muestra también los ya citados límites de la justicia autónoma en los conflictos entre organizaciones. Unos de los autores intelectuales y materiales del homicidio, el Comisariado Ejidal Javier López y el Agente Municipal Carmelino Rodríguez, autoridades de La Realidad, fueron arrestados el 18 de mayo de 2014 tras las investigaciones de la Fiscalía Especializada en Justicia Indígena. Desde los días inmediatamente sucesivos a la emboscada, las autoridades autónomas dieron a conocer la identidad de los dos acusados, que seguían en sus casas en La Realidad; sin embargo, no aplicaron la justicia autónoma sino que delegaron al poder judicial del estado su detención, la investigación y el juicio.

Los integrantes de la CIOAC bien conocen estos límites: en un testimonio difundido por el EZLN, se reportan las burlas de éstos hacia la función de la JBG y la justicia autónoma: "ustedes son la Junta de Buen Gobierno, son buenos gobiernos, aunque les hagamos lo que les hagamos no nos van a hacer nada. ¿Por qué? Porque son buenos gobiernos". ${ }^{110}$ Se aprecia en esta declaración una introyección de la violencia como única forma de dirimir los conflictos y su exaltación como calidad que caracteriza los actores "fuertes", en oposición a los "buenos gobiernos", considerados incapaces porque carecen del poder de coerción y no utilizan la violencia de manera arbitraria. A la afrenta, las autoridades zapatistas responden reafirmando

\footnotetext{
${ }^{109}$ El 14 de febrero del 2014 el Comité Ejecutivo de la CIOAC-Región Fronteriza difundió un boletín en el que anuncia la creación de grupos de autodefensa cuyo objetivo declarado es enfrentar a los ataques que puedan provenir de otras organizaciones sociales.

Véase <http://issuu.com/ust-mnci/docs/boletin_cioac_marcha_chiapas_14_de_>, consultado el 20 agosto 2014.

110 "Fragmentos de La Realidad I", comunicado del EZLN, mayo 2014, en <enlacezapatista.ezln.org.mx/2014/05/13/fragmentos-de-la-realidad-i/>, consultado el 10 de junio 2014.
} 
Capitulo 4. Justicia indigena e intercultural: la justicia según la Junta de Buen Gobierno
de la Zona Selva-Fronteriza una postura cívica que rechaza el uso de la violencia: "pero pues somos zapatistas y no se trata de venganza sino de que haya la justicia". ${ }^{111}$

Estos acontecimientos ponen ciertamente en discusión los supuestos de esta tesis. La autonomía y la justicia autónoma se desarrollan como una alternativa concreta a un cierto tipo de violencia vigente en las regiones indígenas, que se puede resumir en la violencia estructural, el racismo y la corrupción de las autoridades judiciales, y la vigencia de las instancias de gobierno y de justicia autónoma representa un logro en la contención de estas formas de violencia. Sin embargo, al parecer la autonomía en el territorio zapatista no ha podido superar la conflictividad política, que ha incrementado su nivel de violencia en todas las regiones; no ha sido posible aún establecer acuerdos políticos plurales que permitan la convivencia en el territorio, hecho en el que han jugado un papel importante -pero no exclusivo- las políticas contrainsurgentes analizadas en el Capítulo 3.

\footnotetext{
111 "El dolor y la rabia", comunicado del EZLN, mayo de 2014, en <http://enlacezapatista.ezln.org.mx/2014/05/09/el-dolor-y-la-rabia/>, consultado el 13 de noviembre 2014.
} 


\section{AUTONOMIAINDÍGENA, VIOLENCIAY JUSTICIA}

\section{Una experiencia paradigmática: el Sistema de Seguridad, Justicia y Reeducación Comunitaria de la Costa Chica y Montaña de Guerrero}

El Sistema de Seguridad, Justicia y Reeducación Comunitaria (SSJRC) de Guerrero y las Juntas de Buen Gobierno zapatistas en Chiapas son dos sistemas autónomos de resolución de los conflictos y administración de la justicia, que comparten los valores de colectividad, gratuidad y reintegración a la sociedad de los detenidos. Por la diversidad de los pueblos que comparten el territorio, y la situación de interlegalidad en la que se desarrollan, ambos representan un esfuerzo de construcción de sistemas jurídicos interculturales. Asimismo, la necesidad de la organización y de la construcción de la autonomía se justifica por una situación histórica de violencia, arraigada en un contexto de represión, impunidad, relaciones clientelares y discriminación étnica.

\section{Las dimensiones de la violencia en la Costa-Montaña}

Cuando se habla del estado de Guerrero, éste es frecuentemente definido con un estigma: el "Guerrero bronco". Armando Bartra define esta expresión como "despliegue de poderes discrecionales que chocan entre sí y se ejercen mediante la violencia” (Bartra 2000:15). El "Guerrero bronco", lejos de ser una justificación apriorística de la realidad, sirve como punto de partida para identificar las raíces y los impactos de la situación de violencia generalizada que desde hace décadas se vive en la entidad.

En la Montaña la y Costa Chica de Guerrero -como en muchas otras regiones indígenasla población vive una situación de violencia estructural, que se traduce en histórica injusticia social; ${ }^{12}$ la ONU define esta región como la más pobre de América Latina. ${ }^{113}$ La violencia estructural es fomentada por la actuación racista de las instituciones y por la ausencia del Estado en su función de proveer servicios básicos a la población. Los derechos fundamentales de las personas son violados por las condiciones de vida en las que éstas son obligadas a

\footnotetext{
${ }^{112}$ Expresiones de la violencia estructural son las desigualdades de poder y condiciones de vida. Véase Cejas Minuet (2000).

113 Programa de las Naciones Unidas para el Desarrollo/México, Índice de Desarrollo Humano Municipal en México 2000-2005, en <www.cinu.org.mx/prensa/especiales/2008/IDH/documento.html> (consultado el 29 abril 2010).
} 
Capitulo 4. Justicia indigena e intercultural: la justicia según la Junta de Buen Gobierno de la Zona Selva-Fronteriza

conducir sus existencias, y al mismo tiempo por las instituciones, las autoridades jurídicas, y los cuerpos policíacos y militares. La situación de miseria extrema, agravada por la falta de expectativas, desde hace décadas obliga a la migración, y representa un caldo de cultivo para una gran cantidad de conflictos agrarios.

Otra manifestación de la violencia corresponde a:

Lla particular lógica del poder y el ejercicio de la violencia estatal en Guerrero. En primer lugar porque a un poder central fincado en los tratos caciquiles regionales se le sobrepone una forma de Estado que en vez de permitir avanzar hacia la democracia, refuerza las ancestrales prácticas represivas y a la vez cierra las posibilidades de una mayor presencia y capacidad de decisión de la sociedad en los asuntos del Estado mismo; y en segundo término porque niega abiertamente la autorganización de las masas, por lo que todo intento por independizarse orgánicamente es transformado, en la lógica del poder, en un "otro"-enemigo a perseguir (López Sollano 2002:88).

En esta conexión entre poder autoritario, orden jurídico corrupto y represión hay un actor que juega un papel central: las fuerzas policíacas. Según los datos proporcionados por la Comisión de Defensa de los Derechos Humanos del Estado de Guerrero y el Centro de Derechos Humanos de la Montaña Tlachinollan, en la Montaña el Ejército y la Policía Judicial se ubican en primer lugar como autoridades responsables de violar derechos humanos, seguidas por la Policía Preventiva Municipal y los Agentes del Ministerio Público. El racismo y la arbitrariedad en el ejercicio de la justicia se encarnan en la corrupción. En la actuación de los Agentes del Ministerio Público, el principal vicio denunciado por la población es la costumbre de exigir dinero a cambio de la investigación y el ejercicio de la acción penal, lo cual beneficia a los adinerados (comerciantes o terratenientes) y excluye del sistema de procuración de justicia a la mayoría de la población, que carece de recursos económicos. Los habitantes de las comunidades mencionan la frecuencia con que, al poner una denuncia ante el Ministerio Público, se les pide que cubran el gasto de gasolina, para que la Policía Ministerial vaya hasta el lugar de los hechos a hacer la investigación.

En años recientes, la condición de vulnerabilidad de la población guerrerense y, en particular, de las regiones Montaña y Costa Chica se ha agravado debido a la creciente militarización, añeja estrategia contrainsurgente aplicada por el Estado a raíz de la aparición de grupos armados, como el Ejército Popular Revolucionario (EPR) y el Ejército 


\section{AUTOONOMIAINDÍGENA, VIOLENCIAY JUSTICIA}

Revolucionario del Pueblo Insurgente (ERPI). A principio de 1994, el Ejército incrementó su presencia en Guerrero, en particular en la sierra de Atoyac y en el municipio de Metlatonoc en la Montaña, peinando las regiones en busca de "zapatistas". Con el surgimiento del EPR, en 1996, la presencia militar y policíaca se redobló en algunas partes de Guerrero, aumentando exponencialmente la detención arbitraria de líderes de organizaciones y funcionarios del PRD. ${ }^{114}$ En la Costa-Montaña, el municipio de Ayutla de Los Libres es el que más padece dicha estrategia, luego de la masacre perpetrada por el Ejército en la comunidad de El Charco en 1998, donde según fuentes oficiales se encontraba una unidad del ERPI. La sucesiva ocupación de ejidos y comunidades por parte de militares ha encontrado la resistencia de la población de la región, que ha denunciado amenazas, detenciones arbitrarias, torturas y violaciones a mujeres indígenas. ${ }^{115}$

La otra motivación que aduce el gobierno para el despliegue militar, y que en muchos los casos encubre operaciones anti-guerrilla, es la lucha contra el narcotráfico. Durante los últimos años, el combate a las drogas se ha traducido en una lucha frontal contra la población: se hostiga e intimida a los trabajadores del campo, se atacan luchadores sociales y activistas, se militarizan las regiones rurales e indígenas y aumentan los casos de violaciones graves de derechos humanos cometidos por el Ejército.

Por lo tanto, de acuerdo con Rendón Alarcón, "los conflictos sociales que se manifiestan en Guerrero constituyen la expresión profunda de la insatisfacción social que priva a la entidad respecto a la estructura de poder" (Rendón 2005:136), y a la situación de violencia generalizada que afecta a todos los ámbitos de la sociedad.

\section{Origen y estructura del Sistema de Seguridad, Reeducación y Justicia Comunitaria}

El SSJRC es integrado por más de cien comunidades me'phaa (tlapanecas), ñu saavi (mixtecas), ñan'cue ñomndaa' (amuzgas), nahuas y mestizas de más de 15 municipios de las regiones Montaña y Costa Chica, en la parte oriental del estado de Guerrero. El territorio comunitario se divide en cuatro microrregiones, en cada una de las cuales hay una Casa de

\footnotetext{
${ }^{114}$ Informaciones detalladas sobre la presencia militar en la Montaña y las violaciones a los derechos humanos se encuentran en los Informes del CDH Tlachinollan y en Barrera Hernández y Sarmiento (2006).

${ }^{115}$ Véase los Informes del CDH Tlachinollan, <www.tlachinollan.org>.
} 
Capitulo 4. Justicia indigena e intercultural: la justicia según la Junta de Buen Gobierno
de la Zona Selva-Fronteriza

Justicia y Seguridad, donde prestan servicio representantes del Comité Ejecutivo de la Policía Comunitaria y de la Coordinadora Regional de Autoridades Comunitarias.

La estructura y el funcionamiento del Sistema Comunitario hunden profundas raíces en las formas organizativas propias de los pueblos indígenas; sin embargo, el detonante para la organización fue la necesidad de seguridad y de justicia verdadera. A partir de la década de los ochenta el aumento exponencial de la violencia y la criminalidad en la zona -debido a la ineficiencia y la corrupción de los sistemas de seguridad, procuración e impartición de justicia estatales- provocó una situación generalizada de violación de los derechos humanos fundamentales, como cuentan algunos campesinos -fundadores de la organización- en sus testimonios estremecedores:

Del ochenta al noventa fue cuando la delincuencia se puso más fuerte; ya no era solamente el despojo de dinero, el robo de toda clase de animales; ya se empezaban a meter a las casas, gente de las mismas comunidades... después empezaron a matar y a violar mujeres. En 1993 y 1994 fue cuando se empezó a platicar sobre la Policía [Comunitaria]. En los tiempos anteriores, para nosotros no hubo gobierno; las autoridades competentes no nos dieron una justicia legal. El primer impulso vino de las organizaciones, LuzMont y 500 Años, ${ }^{116}$ ya que les robaban productos en el camino. ${ }^{117}$

Para decir un ejemplo, venía en el camino un matrimonio: acostaron el hombre y en su lomo abusaron de la mujer... te imaginas... pero al final matan a ese matrimonio, así para tapar el ojo al macho, ya no podían denunciar a los delincuentes... hay gente que le sucedió lo mismo, incluso con sus hijas. Por eso nació este coraje de la gente, de los que vivieron esta situación; el que no lo vive te critica, de atribuirte un poder que no tienes, pero es una vil mentira... muchas veces un bien nace por un mal, y por ese mal nació la Policía Comunitaria, uniéndonos: como comunidades nos unimos, pensando que después nos iba a caer el Ejército, el gobierno, pero estábamos listos par a asumir el riesgo. ${ }^{118}$

\footnotetext{
${ }^{116}$ Se refiere a la cooperativa para la producción y acopio del café, Luz de la Montaña, pionera en la organización para la producción en la región, y al Consejo Guerrerense 500 Años, una de las primeras agrupaciones indígenas (véase Capitulo 2).

${ }^{117}$ Entrevista a Gelasio, tlapaneco, campesino, comandante del grupo de Policía Comunitaria en su comunidad en 1995 y comandante regional en 1997; Camalotillo, San Luís Acatlán, 27 julio 2006. Hace referencia a la organización campesina Luz de la Montaña y al Consejo Guerrerense 500 Años de Resistencia Indígena, Negra y Popular, ambos procesos organizativos de gran importancia en la región.

${ }^{118}$ Entrevista a Abad, mestizo, Coordinador de la CRAC en 2006; Capulín Chocolate, Marquelia, 4/08/2006.
} 


\section{AUTONOMIAINDÍGENA, VIOLENCIAY JUSTICIA}

La exasperación popular encontró su cauce en una más amplia movilización ciudadana en demanda de servicios y vías de comunicación, que se desarrolló en la Montaña y la Costa Chica en una coyuntura de crisis del sistema político y de seguridad a nivel nacional (la movilización que siguió al levantamiento del EZLN en 1994) y estatal (por las consecuencias de la "masacre de Aguas Blancas" en 1995). Así, después de un proceso de discusión y consulta, en la Asamblea Regional del 15 de octubre 1995 en la comunidad de Santa Cruz el Rincón se acordó formar la Policía Comunitaria en veinte comunidades, cuya función era, en los hechos, coadyuvar a los cuerpos policíacos estatales, patrullando a pie los caminos y reteniendo a los delincuentes, que después eran entregados a la autoridad ministerial. Se establece así un sistema de seguridad propio, donde cada comunidad integrada al sistema elige un grupo de Policías Comunitarios, coordinados a nivel regional por el Comité Ejecutivo de la Policía Comunitaria. ${ }^{119}$ Actualmente, son más de 1,000 los Policías Comunitarios que prestan servicio, protegiendo a una población de alrededor de 350.000 habitantes.

En 1998 se instituyó la Coordinadora Regional de Autoridades Comunitarias (CRAC), que tiene a su cargo las funciones de procuración e impartición de justicia, en un nivel superior al de las autoridades comunitarias: representa la "segunda instancia". 120

La CRAC es un órgano colegiado (cuenta con tres representantes por cada Casa de Justicia, cuyo cargo dura tres años) y es nombrada en la Asamblea Regional. Sus funciones, entre otras, son "atender todas y cada una de las denuncias que le sean planteadas por la ciudadanía, dándoles seguimiento hasta su conclusión que en todo caso será en términos de hacer justicia". ${ }^{121}$ Realiza su trabajo en estrecha colaboración con el Comité Ejecutivo, que desarrolla las investigaciones y ejecuta las órdenes de aprehensión emitidas por la CRAC. Las autoridades de las comunidades integradas al SSJRC, deben estar "en constate coordinación y comunicación con las instancias que estructuran el Sistema Comunitario”.

\footnotetext{
119 "Es el órgano principal del Sistema Comunitario encargado de la seguridad y la coordinación de los Grupos de Policía Comunitaria”, Reglamento Interno del SSJRC, art.6 apartado IV.

${ }^{120}$ Tradicionalmente, los Comisarios Municipales se han encargado de la resolución de los conflictos menores al interior de las comunidades; la organización autónoma conserva y valoriza esta función: según el Reglamento Interno de la Policía Comunitaria, "la función principal del Comisario o Delegado Municipal dentro del Sistema Comunitario será la impartición de justicia dentro de la comunidad, atendiendo en todo momento los asuntos, faltas o delitos que este reglamento marque como de la competencia comunitaria".

${ }^{121}$ Reglamento Interno del SSJRC, art.6 apartado III.
} 
Capitulo 4. Justicia indigena e intercultural: la justicia según la Junta de Buen Gobierno de la Zona Selva-Fronteriza

Estructura del Sistema de Seguridad, Justicia y Reeducación Comunitaria (SSJRC)

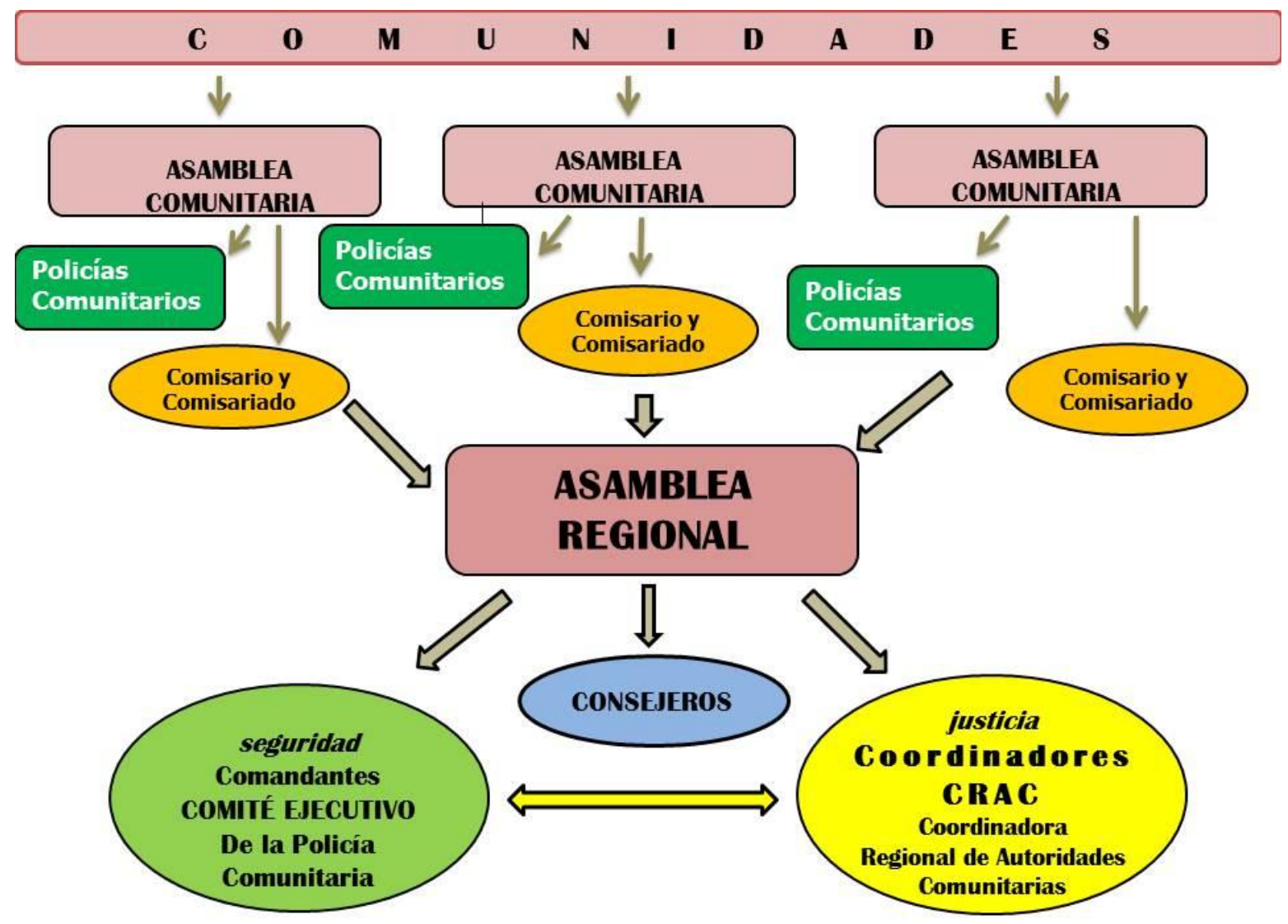

Al igual que en la justicia zapatista en Chiapas, destaca la importancia de la asamblea, como ámbito colectivo de discusión y de toma de decisiones. ${ }^{122}$ En las dos experiencias la práctica asamblearia se ha instituido como nueva herramienta de la organización autónoma, en el ámbito supracomunitario regional. La Asamblea Regional “A) Es la máxima instancia de dirección y mando del Sistema Comunitario de Seguridad, Justicia y Reeducación. B) Es la instancia de coordinación entre las comunidades integrantes del Sistema, con los ayuntamientos y las instancias del gobierno estatal y federal." Antes del 1995, fecha en que se instituye la Policía Comunitaria, no se habían realizado asambleas de este tipo; de modo que, en el proceso de organización de la seguridad, se origina un sistema articulado a nivel

\footnotetext{
${ }^{122}$ En las asambleas participan los hombres de la comunidad; en algunos lugares lo jóvenes como oyentes; y recientemente se ha abierto el espacio para la asistencia y participación femenina, aunque todavía no todas las mujeres participan y no en todos los espacios, no con la frecuencia con que lo hacen los hombres.
} 


\section{AUTOONOMIIAINDÍGENA, VIOLENCIAY JUSTICIA}

regional, que articula y se funda en las estructuras de organización de las comunidades. ${ }^{123} \mathrm{El}$ proceso de coordinación a nivel amplio entre las comunidades se enriquece a través de las diversidades de los pueblos y las organizaciones que confluyen en la Asamblea Regional; de tal discusión son producto original, por ejemplo, las normas a aplicar en la impartición de justicia o los procedimientos para la reeducación. El Reglamento Interno, elaborado a partir de 2001, representa un esfuerzo excepcional de los pueblos para sistematizar sus sistemas normativos, y que tiene la intención de sentar las bases de la legitimidad de la institución comunitaria, fundamentándolas en el derecho nacional e internacional. Asimismo, refleja la voluntad de uniformar la actuación de todas las autoridades de la región, para evitar la arbitrariedad y el abuso de poder que puede manifestarse en sus decisiones. Además de las funciones y atribuciones de cada una de las instancias que integran el Sistema, el reglamento establece el funcionamiento de la reeducación, las faltas y errores que deben ser resueltos en cada nivel (comunitario y regional), así como las sanciones correspondientes.

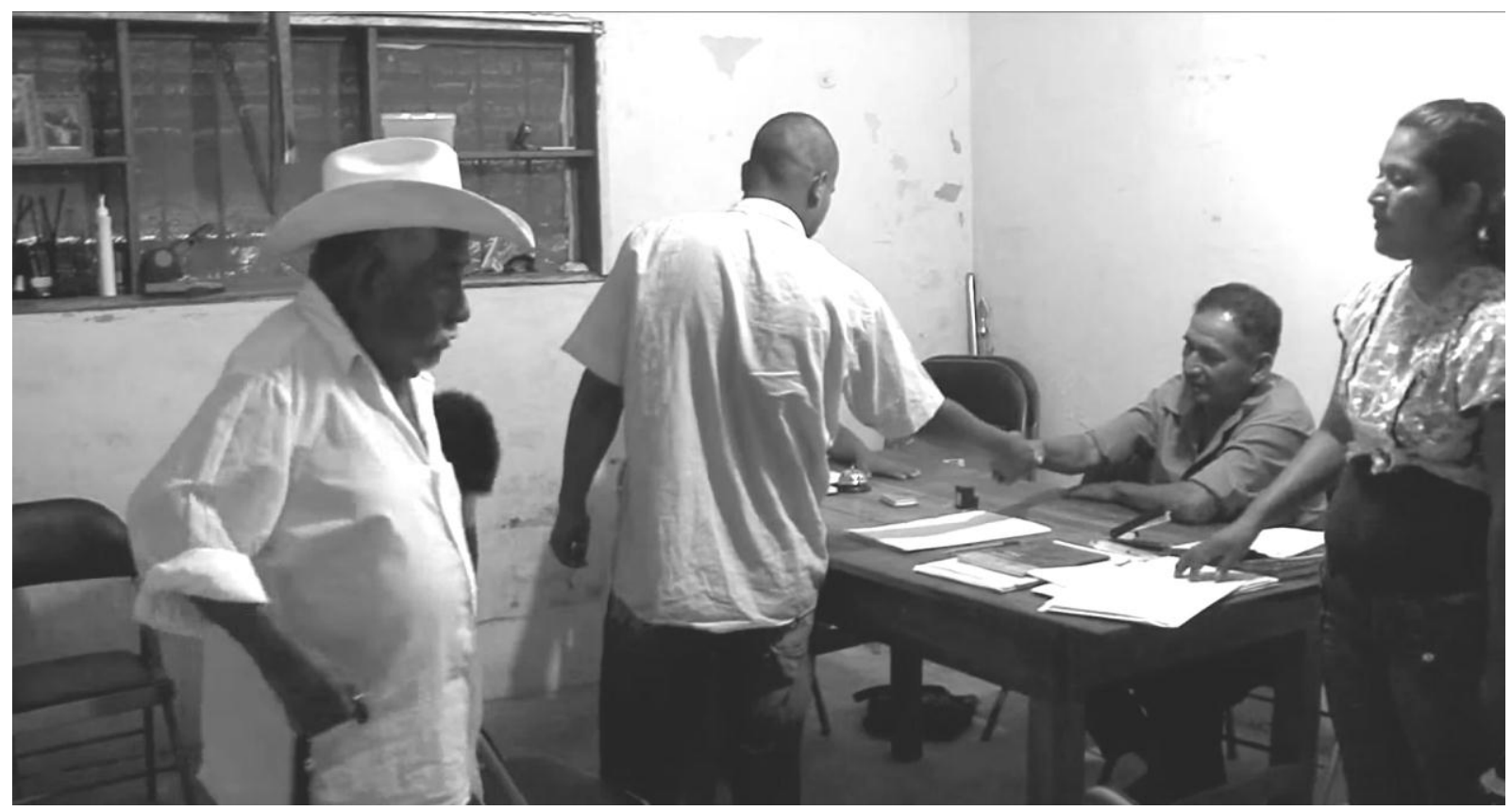

Conciliación, Casa de Justicia de San Luis Acatlán, octubre 2011. Foto: Raíces de Nuestra Justicia, Centro ProDh, 2014.

\footnotetext{
${ }^{123}$ Además que en la asamblea comunitaria, otro antecedente para las asambleas regionales quizás se puede encontrar en las reuniones periódicas de las organizaciones campesinas, en las que se reúnen todos los socios o adherentes a la organización; en Guerrero, y en mayor medida en Chiapas, éste representa una importante tradición organizativa.
} 


\section{Capitulo 4. Justicia indigena e intercultural: la justicia según la Junta de Buen Gobierno de la Zona Selva-Fronteriza}

Formas de resolución de los conflictos: conciliación y reeducación

Tanto en las comunidades cuanto en la instancia de la CRAC, la resolución de los conflictos prioriza la conciliación y la reparación del daño. Sin embargo, desde su institución la CRAC se ha abocado una competencia muy amplia, que incluye los delitos graves como homicidio, violación o asalto, para los cuales el castigo es el trabajo a favor de las comunidades o reeducación.

Antes de la institución del SSJRC, el trabajo como castigo no era una práctica generalizada: si no había acuerdo la sanción era generalmente una multa, y los casos más graves se turnaban al Síndico Municipal o al Agente del Ministerio Público. En las comunidades na saavi todavía existe la práctica de exhibir públicamente a quienes ha cometido un delito, haciéndoles cargar, si es culpable de robo, el objeto robado, y acompañado por la banda obligarlo a recorrer toda la comunidad para que sirva de ejemplo; se trata de una práctica donde la pena para el culpable es, precisamente, la pena, la vergüenza. La gran novedad del Sistema es retomar la práctica de la reeducación y ejercerla a nivel regional, reglamentando y uniformando su aplicación. Ahora, los delitos graves, que no se resuelven con conciliación ni reparación del daño, se pagan con trabajo comunitario, y es la autoridad regional (CRAC) quien puede dictar este tipo de castigo, así como tiene el deber de vigilar sobre la salud y la conducta de los castigados:

Se hace responsable de ellos, junto con las comunidades que los hospedan. La reeducación es el eje central del Sistema: de acuerdo a la duración de la reeducación impuesta, los presos cumplen con 15 días de trabajo en una comunidad y después son trasladados a otra; esto hasta cumplir el tiempo señalado. En las comunidades son vigilados por los policías comunitarios, alimentados por la comunidad, mientras la población en general, y los principales en particular, se encargan de la reeducación, o sea de platicar con ellos para hacerlos reflexionar sobre su conducta. $^{124}$

Al igual que en el sistema zapatista, los tiempos de castigo no son fijos: dependen de la gravedad del caso, de las complicaciones que tenga, de la conducta del que resulte ser culpable tanto en sede de juicio como durante el proceso de reeducación. Intentos de fuga o mala

\footnotetext{
${ }^{124}$ Claudio Carrasco, Coordinador Regional, na saavi, entrevista 2011.
} 


\section{AUTOONOMIIAINDÍGENA, VIOLENCIAY JUSTICIA}

conducta en las comunidades pueden hasta duplicar el tiempo de castigo; asimismo, si las constancias emitidas por las autoridades de cada comunidad al terminar el periodo de 15 días de servicio "todas dicen buena conducta, esto es lo mejor que puede abogar por él, y el tiempo de reeducación puede ser reducido". ${ }^{125}$ Incluso cuando se aplica la reeducación, el proceso de conciliación es fundamental, y para ello es necesario el reconocimiento mutuo entre las dos partes en conflicto:

El que cometió error tiene que pedir disculpa al que fue agraviado, y la parte agraviada tiene que aceptar el perdón, y todo eso, para que se libere el preso. Como autoridades apostamos a que las dos partes tienen que reconciliar; para que cuando salgan afuera de la casa de justicia, nadie tiene que molestarse. Para que no haya ningún pendiente se levanta una acta donde se asientan ciertos compromisos. $^{126}$

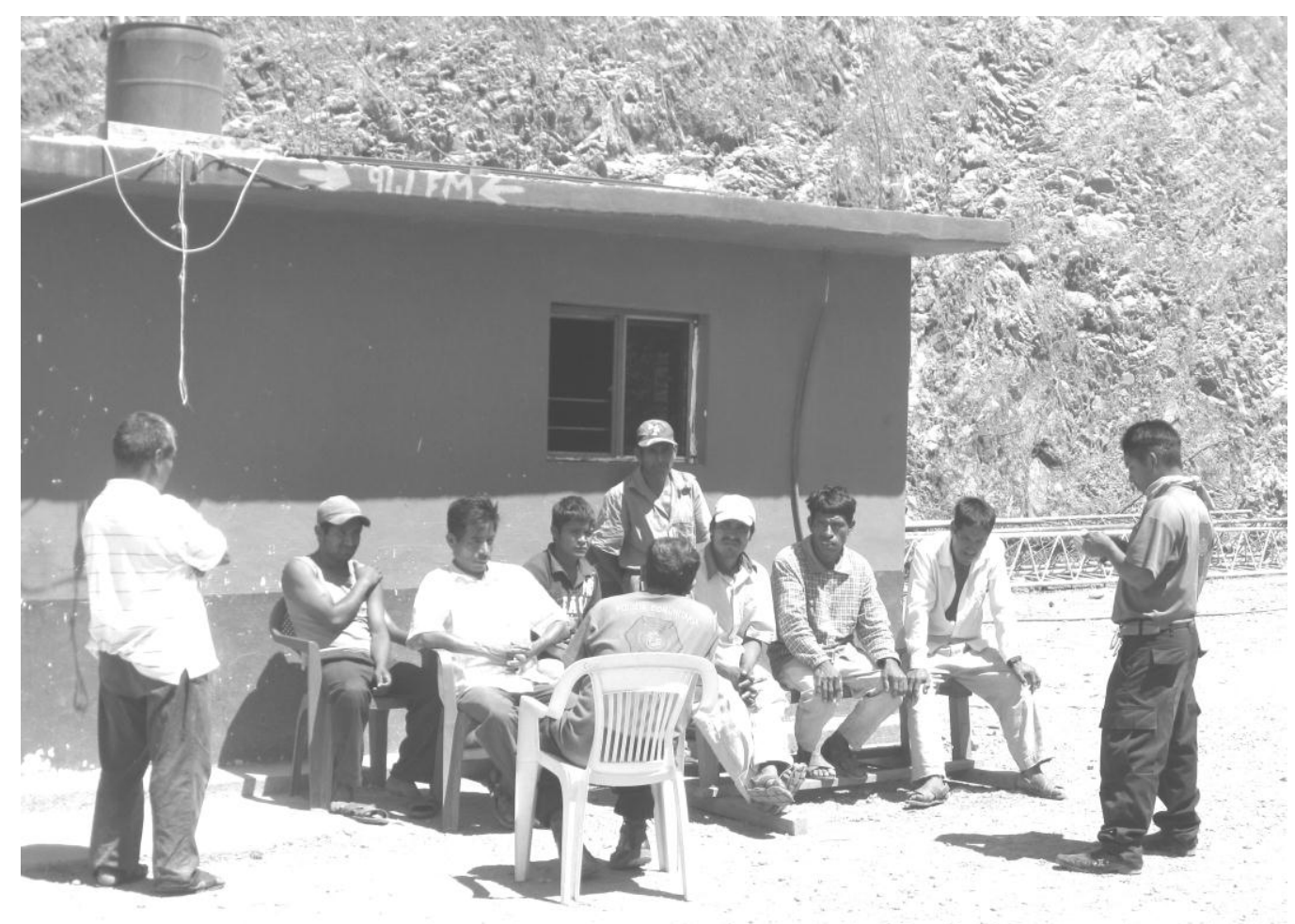

Coordinadores y Comandantes platican con los detenidos, Casa de Justicia de Espino Blanco, 2012.

\footnotetext{
125 Asunción Ponce, Coordinadora Regional, na saavi, entrevista, San Luis Acatlán, 2011.

${ }^{126}$ Claudio Carrasco, Coordinador Regional, na saavi, entrevista 2011.
} 
Capitulo 4. Justicia indigena e intercultural: la justicia según la Junta de Buen Gobierno de la Zona Selva-Fronteriza

La eficacia del Sistema Comunitario ha sido confirmada por las autoridades ministeriales de la zona, las que admiten que desde su institución ha disminuido del 95\% el índice delictivo en la región; por su parte, Claudio Carrasco, Coordinador Regional, afirma que "la mayor parte de los que han sido reeducados, no vuelven a reincidir".

$\mathrm{Al}$ igual que en la justicia zapatista, se ubica el origen del error y la responsabilidad de su corrección en la sociedad toda. En la experiencia guerrerense es generalizada entre todos los entrevistados (indígenas y mestizos) la idea de que el error -no se utiliza comúnmente la palabra delito- es fruto de un déficit de la colectividad -familia y comunidad- que no se preocupó por las acciones del individuo, porque 'no se dio cuenta que esta persona andaba en un mal camino' y 'no logró ponerlo otra vez en la buena dirección'. Así lo manifestó la autoridad de la comunidad me'phaa Potrerillo del Rincón, donde en 2010 acontecieron dos homicidios:

estos hechos que están sucediendo en nuestra comunidad nos apenan mucho, porque no solo los asaltantes o los matones, el pueblo entero está manchado; el nombre de nuestro pueblo ahora será citado en todas partes y no será por el reconocimiento que haya obtenido, por el esfuerzo de nuestro trabajo, sino porque uno de nuestros vecinos, cometió el peor daño en contra de su propio hermano, por lo que ruego a ustedes, presten atención, para que nosotros podamos encontrar solución a esta problemática. ${ }^{127}$

El sentido de colectividad que, a pesar de los elementos disgregantes, sigue sosteniendo las comunidades indígenas de la región es central en tal entendimiento: se asemeja el conjunto de personas que integran la comunidad a una familia, o más bien se perciben los lazos familiares -y el conjunto de valores, deberes y beneficios que éstos implican- como un tejido que va más allá de la familia misma y articula la entera vida comunal.

En las primeras asambleas [1995-1998] se inició a reflexionar sobre la manera de castigar a los detenidos, y había quienes clamaban por "colgarlos, lincharlos". Pero finalmente se entendió que eran paisanos, que era gente de las comunidades, familiares, que por alguna determinada razón no buscaba resolver su situación personal y familiar trabajando sino que se desviaron a

\footnotetext{
${ }^{127}$ Adelfo Genaro de Jesús, Comisario de Potrerillo del Rincón, Asamblea comunitaria, 29/03/2010.
} 


\section{AUTONOMIAAINDÍGENA, VIOLENCIAY JUSTICIA}

cometer faltas. Se dijo que estaba actuando así porque las familias que los criaron no los educaron bien y entonces es tarea de toda la comunidad reeducarlos, enseñarles a trabajar. ${ }^{128}$

\section{Problemas en la región}

El nivel de violencia y de conflictividad no ligada a motivos políticos difiere fuertemente entre la Costa-Montaña de Guerrero y la Zona Selva-Fronteriza en Chiapas. Aunque la organización de los pueblos en el SSJRC haya logrado disminuir el nivel de la violencia en la región, en las comunidades siguen siendo comunes los robos y las agresiones; aparecen esporádicamente casos de homicidio, y sigue muy frecuente la violencia intrafamiliar, en específico los maltratos a las mujeres. El alcoholismo es manifiestamente el problema más profundo que afecta a la vida social comunitaria en toda la zona; su arraigo en los hábitos cotidianos es más preocupante ya que no se vislumbra la voluntad de emprender acciones para su erradicación. Las autoridades comunitarias y regionales reconocen en el abuso de bebida alcohólica un gran problema, pero no han logrado ninguna estrategia para limitarlo.

De los casos resueltos por la CRAC en la Casa de Justicia en Espino Blanco, en la zona me'phaa, en los años 2007-2009, el 50\% (16 sobre 32) son de violencia y lesiones a familiares o vecinos a causa del abuso de alcohol; el porcentaje asciende al 70\% para los casos resueltos por la autoridad comunitaria en la comunidad me'phaa de Colombia de Guadalupe. El alcoholismo generalizado es, pues, la principal causa de violencia y conflictos intracomunitarios, de manera más evidente en la región na saavi. Por otro lado, la institución de la Policía Comunitaria y su función de resguardo durante las fiestas de las comunidades ha garantizado que estas se realicen siquiera con saldo blanco, cosa impensable antes.

Las industrias productoras y comercializadoras del alcohol, principalmente la cerveza, están conscientes del fructífero mercado que tienen en las zonas rurales; son frecuentes los convenios en los cuales dan a los Comisarios una cantidad de dinero a cambio de que este les garantice la exclusividad del mercado en la comunidad, y una cantidad mínima de ventas.

En años recientes, el aumento generalizado de la criminalidad ligada al narcotráfico ha generado también una escalda de crímenes en la región, enfrentando la CRAC a problemáticas

\footnotetext{
${ }^{128}$ Valentín Hernández Chapa, responsable de vinculación de la CRAC, entrevista, San Luis Acatlán, 4 de septiembre 2011.
} 
Capitulo 4. Justicia indigena e intercultural: la justicia según la Junta de Buen Gobierno

$$
\text { de la Zona Selva-Fronteriza }
$$

que no existían al momento de su creación: según denuncian los pobladores y las autoridades regionales, se han multiplicado los secuestros y las extorsiones en las comunidades y más aún en las cabeceras municipales, y al mismo tiempo han aumentado la siembra, el tráfico y el consumo de drogas. Este fenómeno salió a relucir en octubre de 2011 cuando la Policía Comunitaria detuvo dos camionetas que trasladaban $600 \mathrm{~kg}$ de marihuana en la región de Metlatónoc; las cinco personas detenidas fueron juzgadas en una Asamblea Regional, en la que también se destruyó el cargamento, y en éste ámbito se decidió no someterse a la solicitud de la Procuraduría General de la República de que le entregaran los detenidos, sino que estos se someterían a la reeducación según los mecanismos del SSJRC. Este episodio cuestionó profundamente a la CRAC, ya que puso de manifiesto los límites de la organización para enfrentar este tipo de criminalidad que se basa en una estructura organizativa y en un poder económico y de fuego que rebasa la organización indígena.

Sucesivamente, muchas comunidades -sobre todo en la región de la Costa Chicadecidieron aumentar el cuidado interno, redoblando el número de los Policías Comunitarios en cada comunidad y cerrando los accesos al pueblo durante las horas nocturnas.

\section{Actualidad del Sistema Comunitario}

A partir de 2013, el SSJRC enfrentó una grave crisis, y actualmente se encuentra profundamente fracturado en su interno; la región es objeto de nuevos y más fuertes intereses, entre los que destacan el narcotráfico y los proyectos de explotación minera, que disputan a los habitantes indígenas y mestizos el control de este vasto territorio. La presión de estos actores amplificó y exacerbó las contradicciones que se gestaban al interno del SSJRC, llevándolo a su implosión.

Entre varios factores de conflicto interno a la organización, destaca el crecimiento exponencial del Sistema en los años 2011-2013; en la situación de profunda crisis de la seguridad que vive todo el estado, el Sistema Comunitario se volvió una referencia para decenas de comunidades asoladas por una violencia insostenible. De tal manera que se incorporaron a la Policía Comunitaria comunidades de las regiones de Ayutla (Costa), Acatepec, Olinalá, Huamuxtitlán, Cualac (Montaña), Tlacoachistlahuaca y Cochoapa (Costa Chica), Cacahuatepec (Acapulco), zonas con procesos históricos y organizativos distintos que 
impactaron el Sistema, introduciendo elementos contradictorios de visiones y prácticas políticas distintas. Asimismo, el surgimiento de otras organizaciones (como la Unión de Pueblos y Organizaciones del Estado de Guerrero) que se abocaron al ejercicio de la seguridad popular en la misma región donde opera la CRAC, y en zonas limítrofes, y que utilizan un discurso y una práctica muy similar a ésta, abonó al conflicto y a la división.

Esta situación de violencia generalizada y de tensiones internas está siendo hábilmente utilizada por el gobierno estatal, cuya política es evidentemente subordinada a los intereses económicos y comerciales ya mencionados. Desde su fundación, el SSJRC mantuvo una relación fluctuante con el gobierno, que ha transitado desde la permisividad inicial, el enfrentamiento y la amenaza de desarme (1998-2001), la negociación y relativa coordinación (2002-2008). En todo momento, a través de la amenaza, la imposición o la negociación, el estado buscó la institucionalización de la Policía Comunitaria (función de seguridad), a la par del desconocimiento de la CRAC (función de justicia); frente a tal inveterada voluntad, la organización defendió un discurso público que sostenía la necesidad del respeto, más no del reconocimiento oficial. Sin embargo, la CRAC aceptó sin cuestionamiento la Ley de Reconocimiento, Derecho y Cultura de los Pueblos Indígenas del Estado de Guerrero (Ley 701), que reconoce su existencia, encontrando en ella un respaldo para su actuación.

El crecimiento de la organización, y con ella de las necesidades materiales y económicas para su funcionamiento, representaron una brecha para la cooptación que el estado no desaprovechó. El tamaño del Sistema, y la falta de un programa político que orientara su actuación, orillaron a la CRAC a depender del estado mismo para su funcionamiento. En tal contexto, el gobierno legitimó y empoderó a una fracción de la Coordinadora, creando un grupo de dirigentes leales a los intereses institucionales a través de una abundante derrama de recursos económicos que dicha fracción utiliza de manera discrecional, ahondando las divisiones internas y ostentando el ejercicio de su poder de manera corrupta y personal, lo que resquebrajó profundamente las estructuras colectivas y asamblearias. Por otro lado, el gobierno estatal impulsó una violenta campaña de represión en contra de las fracciones más radicales de la CRAC, en el marco de la cual se realizaron operativos militares en las regiones de Ayutla y Olinalá, que llevaron al arresto de más de treinta integrantes de la Policía Comunitaria y de la Coordinadora Regional, mucho de ellos todavía encarcelados en espera de proceso (septiembre 2014). 
Capitulo 4. Justicia indigena e intercultural: la justicia según la Junta de Buen Gobierno de la Zona Selva-Fronteriza 


\section{CAPÍtUlO 5}

\section{LA JUSTICIA AUTÓNOMA Y LA JUSTICIA DEL ESTADO}

El acceso a una justicia con dignidad, medular en el ejercicio del derecho a la ciudadanía, es sistemáticamente negado a la población indígena de México, donde el sistema jurídico estatal muestra frecuentemente una visión racista y prácticas corruptas. La Constitución, reformada en 2001, reconoce solo formalmente el derecho de los pueblos indígenas a la autonomía, pero en efecto ratifica la discriminación y el trato asistencialista hacia ellos. En el campo jurídico, sujeta la aplicación de los sistemas normativos indígenas a los principios constitucionales, e impone "la validación de dichos sistemas normativos por jueces y tribunales correspondientes". 1

En tal contexto, son innumerables las experiencias de ejercicio de la autonomía como práctica alternativa de gobierno en regiones indígenas. Una demanda central de los pueblos indígenas es que sean respetadas por el Estado la efectividad y la legitimidad de los sistemas normativos y las justicias propias. De acuerdo con Sierra, "históricamente, la justicia indígena ha sido subordinada, limitada generalmente a los asuntos 'menores' y al espacio reducido de las pequeñas comunidades, sin ser considerada por el Estado como justicia con un derecho propio" (Sierra 2005:306). Sin embrago, actualmente destacan experiencias que están yendo más allá de los márgenes establecidos por el Estado en las limitaciones de las reformas legales. A partir de su historia, de su cultura y de su realidad actual, estas experiencias están reinventando una justicia dinámica, que no rechaza la relación con el sistema estatal pero que, a diferencia de ello, goza de una gran legitimidad. De este modo los pueblos enfrentan la impunidad y el racismo, y sobre todo la conflictividad local y la inseguridad que los rodea,

1 Artículo 2, Constitución de los Estados Unidos Mexicanos. 
tratando de defender las estructuras comunitarias que, en contextos de fuerte violencia, representan la más fuerte defensa colectiva.

Para poder valorar en su dimensión efectiva los logros de los sistemas de justicia autónoma, en este caso la justicia administrada por la Junta de Buen Gobierno zapatista en la región selvática de Chiapas, considero útil realizar una incursión en las instancias de justicia estatales que se dedican específicamente a la atención de población indígena, lo que puede iluminar sobre las reales posibilidades de acceso a la justicia. Asimismo, relataré la excepcional lucha de muchos presos indígenas, "presos políticos, de conciencia e injustamente presos", desde las entrañas del sistema de (in)justicia del estado -es decir desde las cárceles- quienes dieron vida a un movimientos sin precedentes para la defensa de sus derechos en el sistema carcelario y para su libertad.

Finalmente, analizaré la relación entre las instituciones autónomas y sus sistemas de justicia con las instituciones del Estado, en la medida en que es un aspecto necesario para vislumbrar el desarrollo y la permanencia de la autonomía. Dicho analisis no pretende entonces detallar los conflictos e intersecciones de competencias políticas y judiciales para buscar un posible arreglo jurídico y legal, pues no me propongo estudiar exhaustivamente las articulaciones de la interlegalidad, o los detalles y perspectivas en la relación con el Estado.

\section{Mecanismos alternativos de resolución de conflictos y justicia para indígenas}

Las reformas económicas e institucionales implementadas en los países latinoamericanos a partir de la década de los ochenta, en aras de favorecer la globalización y el libre mercado, incluyen los procesos de "modernización" de los sistemas de justicia, frente a la declarada "crisis" de los aparatos jurídicos, insuficientes para enfrentar la aumentada conflictividad. Ardila Amaya, resumiendo las reflexiones de distintos teóricos del derecho, identifica tres distintas tendencias en la transformación de los sistemas y aparatos jurídicos de los Estados. En primer lugar, la que se puede definir "privatización del derecho", es decir que el Estado cede importantes porciones de soberanía y de "legalidad" a poderes transnacionales, "como ocurre con organizaciones multilaterales (OMC, BM, FMI), o con otros Estados (certificación norteamericana a otros países), o con empresas multinacionales (regímenes de maquila o de zonas francas)"; en segundo lugar "otorga reconocimiento jurídico a la actuación de 


\section{AUTTONOMIIAINDÍGENA, VIOLENCIAY JUSTICIA}

mecanismos de justicia no estatales dentro de su territorio, en dinámicas que se conocen como

de informalización, descentralización y alternatividad judicial"; finalmente, "el aparato judicial estatal se concentra en el manejo de cierto tipo de conflictos, en los cuales despliega con la mayor eficacia el potencial de su discurso jurídico, su poderosa capacidad operativa y la fuerza coercitiva de que dispone" (Ardila 2005: 24-25).

Las últimas dos estrategias son parte de un mismo proceso, en el cual el Estado "tiende a concentrarse en aquellos temas y conflictos directamente relacionados con las necesidades de acumulación capitalista, mientras se dirige a tolerar, promover o reconocer mecanismos de justicia no estatal, a los cuales les asigna valor jurídico ante el derecho estatal en asuntos que se consideran periféricos para la acumulación capitalista" (Ardila 2005:26-27). En tal contexto se pueden situar tanto las reformas dirigidas a institucionalizar espacios de "justicia indígena" como las que implementan mecanismos alternativos para la resolución de los conflictos, involucrando en ello la sociedad civil. Las primeras se justifican en el contexto del reconocimiento del carácter multicultural de las sociedades latinoamericanas, en muchos casos influenciado por los requerimientos neoliberales (véase la discusión en el capítulo 2); las segundas se impulsan con el objetivo declarado de simplificar el acceso a la justicia, desburocratizarla y descongestionar los tribunales, pero en ambos casos son orientadas por el principio administrativo de la descentralización, mismo que, en muchos casos, rige al reconocerse espacios de autonomía y autogobierno. Según Poole, “dentro de este modelo, el principio del derecho consuetudinario funciona para relegar la responsabilidad (y el riesgo) de la administración de justicia a las localidades y, de esta manera, liberar las judicaturas nacionales y federales de su ya legendaria ineficiencia y carga procesal” (2006: 13).

Aragón (2013) argumenta que las reformas que impulsan la institucionalización de los mecanismos alternativos para la resolución de los conflictos (ADR, por su sigla en inglés) o de la "justicia alternativa" (según la denominación que se ha adoptado en México), tienen una filiación directa de instituciones supranacionales cuales el Banco Interamericano de Desarrollo (BID), el Banco Mundial (BM) y la Agencia Estadunidense para el Desarrollo (USAID).

Según Mattei (2008), de los mecanismos utilizados en la "justicia alternativa", el arbitraje representa una forma de justicia "privada", costosa e impermeable a la jurisdicción oficial, y por lo tanto funcional a los intereses de la clase "opulenta". Como en los casos del multicutluralismo y del pluralismo jurídico, también la implementación de los ADR puede 


\section{Capitulo 5. La justicia autónoma y la justicia del Estado}

tener consecuencias positivas, en cuanto provee mecanismos de resolución de conflictos más rápidos y menos onerosos que la justicia "de los tribunales"; sin embargo, ya desde el principio de su implementación en los EEUU, en la década de los setenta, varios autores entre ellos antropólogas del derecho como Jane Collier y Laura Nader- advirtieron sobre los riesgos que conlleva la des-judicialización de cierto tipo de conflictos que involucran parte de la población. Según Nader (1989, cit. en Urteaga 2009:97-98), el énfasis puesto en la "armonía" que se debe alcanzar a través de la mediación apunta a que los sujetos opten por "negociar" sus derechos en lugar de exigirlos legalmente. Asimismo, Collier observó que, debido al alto costo de la litigación y de la justicia "institucionalizada", las personas de bajos recursos eran orientadas a los foros alternativos, con lo que "los foros informales solían preservar los desbalances de poder, previniendo a la gente pobre, cuyos derechos habían sido violados, de ganar el poder del derecho en su beneficio" (1995:63).

El contenido intrínsecamente positivo de la mediación y la conciliación, que enfaticé como eje principal de la justicia autónoma e intercultural, implica grandes peligros en la cultura individualista occidental, pues si entre las dos partes en disputa existe un diferencial de poder demasiado grande (por ejemplo entre marido y mujer, entre patrón y obrero, entre consumidor y corporación), la mediación puede favorecer el sujeto más fuerte. Estas reflexiones no quieren ser una crítica apriorística a la introducción de mecanismos como la mediación y la conciliación en la justicia oficial, sino una advertencia frente a lo que es presentado como una "panacea" para todos los males que afectan al sistema judicial; en tal contexto, los efectos indudablemente positivos de la mediación y la conciliación serán nulos si permanecerán la corrupción, el racismo y la ineficiencia en las instituciones encargadas de su ejercicio.

En México, la justicia alternativa se ha introducido formalmente en 2008 con la reforma constitucional en materia de justicia, misma que transforma el sistema penal en acusatorio, oral y adversarial, características que redundarían en una mayor celeridad y transparencia en la administración de justicia. El estado de Chiapas publicó la Ley de Justicia Alternativa en 2009, e inició la adecuación de los procedimientos penales y los órganos judiciales a partir de 2012. Es notable el hecho de que, a la par de la introducción de los mecanismos alternativos para algunos delitos, en el nivel nacional para la mayor parte de los demás delitos se endurecieron las penas y aumentó su duración (Azaola y Bergman 2007). 


\section{AUTONOMIAINDÍGENA, VIOLENCIAY JUSTICIA}

Según Aragón (2013) las reformas sobre la justicia indígena en México son parte del proceso que busca fomentar la mediación y la resolución alternativa de conflictos, y las justicias indígenas son entendidas como una instancia más de mediación alternativa, cuya eficacia sería sustentada por un derecho "tradicional" preexistente que serviría de base y respaldo para las instancias "alternativas" instaladas (lo que corresponde al proceso de institucionalización del derecho consuetudinario chagga documentado por Falk-Moore en su texto de 1986).

La oficialización de las "justicias indígenas" en México antecede de una década a la introducción de la "justicia alternativa": en 1997 se instituyó el Sistema de Justicia Indígena en Quintana Roo, y paulatinamente otros estados introdujeron en su estructura jurisdiccional distintas figuras destinadas al ejercicio exclusivo de la justicia "para" los indígenas: Campeche, Chiapas, Yucatán, Hidalgo, Michoacán, Oaxaca, Puebla y San Luis Potosí. Esto sucedió en el marco de las reformas constitucionales que, a nivel federal y de las distintas entidades federativas, reconocieron los derechos de los pueblos indígenas, entre ellos las competencias de sus autoridades, así como la existencia y el alcance de las justicias indígenas. En términos generales, se puede afirmar que el reconocimiento es parcial, implementándose un pluralismo jurídico aditivo en el que las justicias indígenas son consideradas como alternativas o adicionales a la justicia estatal, a la que siguen subordinadas (pluralismo unitario), sin representar espacios autónomos con jurisdicción plena. Asimismo, se promueve, más que el reconocimiento de la institucionalidad propia de los pueblos -las estructuras y los mecanismos organizativos que se han consolidado de forma independiente del poder estatal- la burocratización e institucionalización de las "justicias indígenas", en los términos de su inserción dentro de los aparatos de justicia del derecho estatal. La multiplicidad de intereses económicos y políticos y los actores involucrados en tales procesos de reforma (desde los estados hasta el BID y el BM) obligan a preguntarse:

Si las reformas subordinan a los pueblos a las lógicas institucionales del Estado o bien están permitiendo que los pueblos indígenas renegocien espacios de poder para reconstituirse en cuanto tales y para acceder a una relación más equitativa y de respeto con el Estado y la sociedad nacional. No se trata de desconocer los importantes avances que se han dado en la materia del reconocimiento de la diversidad cultural y de los derechos indígenas, y el hecho 


\section{Capitulo 5. La justicia autónoma y la justicía del Estado}

mismo que el Estado haya transformado su carácter asimilacionista, sino de situar en un horizonte crítico los alcances de dichos reconocimientos" (Sierra 2005:288).

Sierra considera que el espacio de reconocimiento es aún muy limitado, debido a que el Estado no ha logrado transformar su lógica política con respecto a la diversidad cultural, y aplica políticas de corte neoindígenista que no pretenden construir realmente una "nueva relación entre los pueblos indígenas, el Estado y la sociedad" como sancionan los Acuerdos de San Andrés. Sin embargo, este espacio limitado "ha posibilitado alternativas nada desdeñables aprovechadas por las comunidades y organizaciones indígenas para redefinir sus sistemas

normativos y usar las instancias del Estado para exigir derechos" (Sierra 2005:290) como en la Sierra Norte de Puebla o San Luis Potosí. En otras ocasiones, los procesos organizativos indígenas han producido estructuras autónomas que no se cruzan directamente con los espacios institucionales, cual es el caso de la Montaña de Guerrero y el sureste chiapaneco.

Una visión decididamente más crítica sobre las posibilidades ofrecidas por el reconocimiento de las "justicias indígenas" es la expresada por Aragón, quien estudia la oficialización de los Juzgados Comunales en Michoacán; según el autor "en este proceso se replica la lógica de la no transferencia de poder a los pueblos indígenas, sino de la concesión de un permiso para que dentro de las mismas estructuras burocráticas judiciales del Estado mexicano se abra un juzgado para las comunidades indígenas" (2013: 9). Como ilustraré para el caso de Chiapas, con frecuencia se han creado desde el estado instancias ex-novo que copian o se sobreponen en parte a las estructuras organizativas indígenas, y que representan una nueva forma de gobernabilidad hegemónica, siendo parte de la institucionalidad oficial. El estudio coordinado por Guillermo Padilla en cuatro estados constata que "se reproduce la ambigüedad y la diferenciación" entre las distintas instancias, cuyo alcance y competencia no queda claramente definido; mientras, al crear estructuras paralelas (mediador, juez indígena, etc.) las estructuras propias indígenas, no institucionalizadas, son debilitadas e incluso, indirectamente, ilegalizadas.

\section{Justicia ¿indígena? en Chiapas}

En el estado de Chiapas, posteriormente al levantamiento zapatista de 1994, se han promovido varias reformas legales, en aras de adecuar-siquiera formalmente- la normatividad y las 


\section{AUTONOMIIAINDÍGENA, VIOLENCIAYJUSTICIA}

instituciones chiapanecas a la nueva relación de fuerza que veía los pueblos indígenas organizados encarar directamente a los poderes del Estado. El primer paso en este sentido fue la Ley de Derechos y Cultura Indígenas del estado de Chiapas, reforma a la Constitución local aprobada en julio 1999, tras la presión política que, desde distinto ámbitos, se ejercía sobre el gobierno estatal para la implementación de lo pactado entre el gobierno federal y el EZLN en los Acuerdos de San Andrés. En el texto de la Ley, el gobierno chiapaneco manifestaba que, a través de la reforma indígena, estaba acatando las disposiciones de dichos Acuerdos; se creaba así una imagen democrática y abierta a las reivindicaciones indígenas. Menos de un año antes, en abril de 1998, el mismo gobierno había desencadenado una feroz represión contra las autoridades de varios Municipios Autónomos Zapatistas, que fueron encarceladas con las acusaciones de rebeldía, usurpación de las funciones del Estado, asociación delictuosa, sabotaje y ocupación de oficinas municipales, entre otros cargos.

La Ley de Derechos y Cultura Indígenas del estado de Chiapas identifica como sujeto de los derechos reconocidos a las comunidades indígenas, asentadas en un lugar determinado (hábitat). Dicha Ley reconoce los sistemas normativos indígenas (aunque no con esta denominación sino en los términos esencialistas de "usos, costumbres y tradiciones ancestrales") como "base fundamental para la resolución de sus controversias [...], y tendrán aplicación dentro de los límites de su hábitat, siempre que no constituyan violaciones a los derechos humanos". Sin embargo, dicho reconocimiento es mutilado por el hecho de que no se reconoce su eficacia e integridad, al no reconocer la competencia de las autoridades que las propias comunidades nombran para ejercer la función jurídica (jueces tradicionales y consejo de ancianos en Los Altos, Agentes Municipales en la Selva, jmeltsa'anwanej, asamblea comunitaria, etc.); en su lugar, la facultad de "resolver controversias" de acuerdo a los "usos y costumbres ancestrales" es transferida a los Jueces de Paz y Conciliación Indígena, ${ }^{2}$ figuras de nuevo cuño que dependen del Consejo de la Judicatura, tienen una competencia jurisdiccional

\footnotetext{
${ }^{2}$ El Art. 12 del Capitulo II de la Ley menciona que “el Supremo Tribunal de Justicia del Estado establecerá Juzgados de Paz y Conciliación Indígena en los municipios o comunidades con población indígena que por sus características lo requieran. La competencia jurisdiccional de dichos Juzgados será la establecida en los códigos de la materia y su procedimiento se regirá por los principios de oralidad, conciliación, inmediatez y pronta resolución".
} 


\section{Capitulo 5. La justicia autónoma y la justicía del Estado}

definida por la legislación, y deben ser de preferencia Licenciados en Derecho. ${ }^{3}$ Asimismo, el art.91 del Código de Organización del Poder Judicial del Estado de Chiapas establece que:

Los Jueces de Paz y Conciliación y de Paz y Conciliación Indígena y sus suplentes, serán nombrados por el Consejo de la Judicatura tomando en consideración las propuestas de los Ayuntamientos respectivos, quienes deberán estar sujetos a un programa de capacitación en materia de medios alternativos de solución de controversias, aprobado por el Centro Estatal de Justicia Alternativa del Poder Judicial del Estado (cursivas mías).

El texto enfatizado pone de manifiesto la asimilación, mencionada anteriormente, de las instancias oficiales de "justicia indígena" con los instrumentos de resolución alternativa de los conflictos, sustituyendo las autoridades tradicionales (que seràn consultadas en la resolución de disputas pero no tienen poder decisional) con los nuevos Jueces, entendidos como mediadores que deberán capacitarse para ejercer su función. En segundo lugar, aparece muy grave que estos empleados del Supremo Tribunal de Justicia del Estado sean finalmente escogidos por los ayuntamientos municipales, que representan los grupos de poder hegemónicos en los municipios. Un estudio publicado por el Alto Comisionado en Derechos Humanos de la ONU advierte de los riesgos que conlleva esta situación: “en un estado en donde la diversidad de posiciones y opciones es parte de la vida cotidiana de los pueblos, la lectura inmediata que surge sobre unos jueces que son propuestos por los municipios es que dichos jueces harán justicia conforme al interés de las autoridades municipales” (2008:82).

El ex director del Centro de Derechos Humanos Fray Bartolomé de las Casas (CDHFBC), Diego Cadenas, denuncia que frecuentemente los Juzgados de Paz y Conciliación Indígenas son órganos de represión contra militantes de los partidos políticos de oposición, contra los inconformes, muy a menudo contra las bases de apoyo zapatistas. "Se han usado los juzgados de paz para meter a la cárcel a gente por no participar en el evento del partido político en turno, para meter a la cárcel por ejemplo los chamulas que no practican el culto

\footnotetext{
${ }^{3}$ Aunque esta condición puede ser dispensada, dada la evidente dificultad a encontrar abogados indígenas residentes en sus comunidades (Art. 206 del Código de Organización de Procedimientos Penales del Estado de Chiapas)
} 


\section{AUTONOMIAINDÍGENA, VIOLENCIAY JUSTICIA}

ultra tradicionalista o para los que no son priistas, y siempre resuelven favoreciendo su gente". 4

La competencia de estos Juzgados, cuya función principal es la conciliación, es limitada. Pueden ocuparse "de la conciliación de conflictos en materia civil, mercantil y familiar"; en materia penal, intervenir en el proceso conciliatorio para delitos no graves.5 Las diligencias practicadas no requieren formalidades de ninguna especie $\mathrm{y}$, aunque basadas en los "usos y costumbres", deberán salvaguardar las garantías individuales asentadas en la Constitución y los derechos humanos. Pese a lo limitado de su competencia, se afirma que "sus resoluciones no admitirán recurso alguno, con excepción de la sentencia definitiva, de cuya apelación conocerá la sala de segunda instancia”. 6

La competencia de los Jueces de Paz y Conciliación Indígenas es apenas superior a la de los Jueces Municipales, figura instituida en 1989, presentes también en muchas regiones indígenas del estado, y es prácticamente la misma que la Ley Orgánica Municipal del Estado de Chiapas, expedida en 1988, otorga a los Agentes y Subagentes Municipales. Como en otras entidades del país, estas autoridades cumplen función jurídica: pueden "practicar en los lugares donde no haya Juez Municipal, o rural, las primeras diligencias en los casos de conductas que pudieren configurar algún delito, y procurar la captura de los presuntos responsables" y "actuar como conciliadores en los conflictos que se les presentaren". 7 Históricamente, las autoridades comunitarias han cumplido siempre esta función de resolución de conflictos. Es una norma que en las regiones indígenas buena parte de las comunidades se encuentre muy alejada de las cabeceras municipales, sedes de los Juzgados, de las Agencias del Ministerio Publico, etc. En estos lugares las autoridades comunitarias resuelven una gran tipología de conflictos, ya que representan muchas veces la única instancia a la que la población tiene acceso.

En el estado de Chiapas, la región de los Altos se caracteriza por una gran complejidad y arraigo de normas de convivencia y gobierno propias de los pueblos indígenas que la habitan.

\footnotetext{
${ }^{4}$ Diego Cadenas, entrevista, octubre 2008, San Cristóbal de las Casas. Chamulas: habitantes del municipio tzotzil San Juan Chamula, tristemente famoso por las expulsiones masivas de los habitantes que adoptaron el culto protestante. Las autoridades tradicionales de San Juan Chamula representan la clásica figura de los caciques, poderosísimos política y económicamente en la zona, y de probada fidelidad al ex partido de Estado, el PRI.

${ }^{5}$ Código de Organización del Poder Judicial del Estado de Chiapas, art. 92.

${ }^{6}$ Nuevo Código de Procedimientos Penales del Estado de Chiapas, art. 450, 451 y 452.

${ }^{7}$ Ley Orgánica Municipal del Estado de Chiapas, Capitulo IX, Art. 55.
} 


\section{Capitulo 5. La justicia autónoma y la justicía del Estado}

La estructura de gobierno que se ha venido estableciendo y que corrientemente se define "tradicional", organiza municipios de pequeñas dimensiones, donde el mismo presidente municipal hasta hace poco tiempo era nombrado por asamblea. Quien ejercía la función jurídica eran los jueces tradicionales, que resolvían buscando la conciliación la casi totalidad de los problemas. En el caso de Amatenango del Valle, documentado por Renard (2005), anteriormente "se recurría a las instancias jurídicas oficiales, es decir, al Ministerio Público estatal, en caso de delitos graves como los homicidios; sin embargo, casi nunca se investigaron ni sancionaron la mayoría de estos delitos" (2005:88). Renard analiza la relación entre los jueces tradicionales y el Juez de Paz y Conciliación Indígena instalado en Amatenango. Según ella:

Además de supervisar el proceder de los jueces tradicionales y someter la tradición a escrutinio, el Juzgado de Paz y Conciliación le quita materia de trabajo. [...] Antes, los jueces tradicionales resolvían la mayoría de los conflictos en el pueblo; ahora los pobladores se dirigen todavía a ellos en primera instancia, pero solamente para 'los casos más simples', para ‘lo más complicado’ o ‘si no saben resolver', acuden al Juez de Paz y Conciliación (2005:90).

Renard confirma que éste "en principio es elegido por el pueblo, pero en realidad se le nombra por afinidad con el grupo en el poder [...] Aunque tengan la autoridad, no tienen la legitimidad de los ancianos principales de antes" (2005:90). En cierta medida, los Juzgados de Paz y Conciliación arrebatan las competencias a las autoridades comunitarias -tradicionales o no- para concentrar aún más la procuración e impartición de justicia en los Municipios, centros del poder político. En este sentido, la Ley de Derechos y Cultura Indígena establece que:

Las autoridades tradicionales, quienes ancestralmente han aplicado los usos, costumbres y tradiciones de sus comunidades en la solución de conflictos internos, serán auxiliares de la administración de justicia y sus opiniones serán tomadas en cuenta en los términos de la legislación procesal respectiva para la resolución de las controversias que se sometan a la jurisdicción de los Juzgados de Paz y Conciliación Indígenas (cursivas mías).

El objetivo de desempoderar a las comunidades se entiende aún más en una situación de conflicto y división como la que se vive en las regiones indígenas de Chiapas. Los Juzgados 


\section{AUTOONOMIIAINDÍGENA, VIOLENCIAY JUSTICIA}

de Paz y Conciliación Indígena pueden representar, en esta óptica, un instrumento de control del estado sobre las comunidades. Se crean ex novo figuras que se presentan como autoridades de justicia indígena, similares a las que instituyen los pueblos, pero que no están respaldadas por los sistemas normativos indígenas existentes en la entidad. Estas figuras son nombradas por el sistema judicial estatal de acuerdo a requisitos que pocos comuneros indígenas tienen; su nombramiento no está en las manos de los pueblos, lo que los hace figuras ajenas e impuestas desde el poder estatal en las regiones indígenas, y leales a los intereses dominantes. Con estas figuras, el estado crea instituciones jurídicas que responden a su lógica, la del derecho positivo, llamándole ficticiamente "justicia indígena", lo que simplemente significa que atienden a personas indígenas, aunque no necesariamente aplicando una justicia que corresponde a los criterios culturales indígenas.

Diego Cadenas, ex director del Centro de Derechos Humanos Fray Bartolomé de las Casas; la abogada Martha Figueroa Mier, e incluso Mariano López Pérez, ex Fiscal Especializado en Justicia Indígena, entrevistados en los meses de agosto y octubre 2008, concuerdan en afirmar que los Juzgados de Paz y Conciliación Indígenas no cumplen su función. López Pérez analiza sus fallas inicialmente según la óptica institucional, para la cual un Juez debería tener profundo conocimiento del sistema jurídico positivo. Entonces si se le denomina Jueces (de Paz y Conciliación), estos no funcionan por falta de preparación jurídica. Pero al final, el mismo Fiscal, con experiencia decenal en su función, llega a afirmar que "se crean los Juzgados de Paz y Conciliación Indígenas, desde la óptica del poder, no desde las comunidades, por eso no funcionaron". Esta crítica es compartida por Cadenas, quien afirma que los Juzgados de Paz y Conciliación Indígenas "tienen un defecto de origen, son en algún modo ilegítimos. No son una figura de autoridad tradicional; [su institución] no fue consultada con las comunidades ni con los municipios". Es por lo tanto forzado considerar estos Jueces como una figura de impartición de justicia indígena, ya que responden más bien a una concepción occidental de la autoridad judicial: "las comunidades normalmente deciden en colectivo, en asamblea". Incluso cuando hay figuras de jueces tradicionales, como las registradas por Renard en Amatenango del Valle, estos no toman las decisiones individualmente, se trata de una autoridad colegiada o colectiva, lo que la hace menos sensible a la corrupción y a la arbitrariedad. 


\section{Capitulo 5. La justicia autónoma y la justicía del Estado}

Según Figueroa, "la creación de instancias especiales, propuestas como acciones positivas a favor de los pueblos indígenas, de nuevo es el mejor ejemplo de segregación y discriminación; agravan y no solucionan el problema de convivencia de dos sistemas jurídicos, uno dominante sobre el otro". 8 De esta forma el gobierno chiapaneco evita reconocer realmente el derecho a la autonomía de los pueblos indígenas, como recita el Art.4 del capítulo II de la Ley Indígena local, lo cual más bien implica el reconocimiento pleno de los sistemas normativos ya existentes en los pueblos.

No obstante estas importantes críticas, hay que reconocer la importancia que, a partir de la Ley de Derechos y Cultura Indígena, se da a la práctica de la conciliación como forma de resolución de conflictos. También es relevante que se reconozca la posibilidad de aplicar el trabajo comunitario como pena sustitutiva a la cárcel: "tratándose de delitos que no sean considerados como graves por las leyes vigentes, las autoridades judiciales podrán sustituir la pena privativa de la libertad que se imponga a un indígena, en los términos previstos en la legislación penal, por trabajos en beneficio de su comunidad [...]". 9

Asimismo, según Adonon y Orantes, quienes de manera separada investigaron distintos Juzgados de Paz y Conciliación en la región de Los Altos, estos espacios se caracterizan, en primer lugar, por una elevada porosidad jurídica derivada del cruce de referentes institucionales y de modelos de conducta y comportamiento (Adonon 2009), ligados tanto al sistema de justicia estatal como a las autoridades tradicionales, con su característica visión conciliatoria. Así, en la práctica, los indígenas están reinterpretando las normas estatales y adaptándolas a la lógica y a las normas vigentes en las comunidades, en un proceso de continua y creativa hibridación jurídica (Orantes 2007).

\section{La ijusticia? del Estado en Chiapas}

Desde hace décadas se han denunciado las fallas estructurales del sistema de justicia en Chiapas, mismas que, con algunas diferencias ligadas a la estructura de poder regional, se encuentran en el contexto federal. Si bien es el estado con el más bajo índice delictivo del

\footnotetext{
8 Martha Figueroa, "La justicia no es para los indígenas”, Ojarasca, núm.77, septiembre 2003, México, <http://www.jornada.unam.mx/2003/09/22/oja77-chiapas.html>, consultado el 10 de septiembre 2014.

${ }^{9}$ Ley de derechos y cultura indígenas del estado de Chiapas, Art. 16.
} 
país ${ }^{10}$ y, según la Encuesta Nacional de Victimización y Percepción sobre Seguridad Pública (ENVIPE, INEGI, 2013), entre 2011 y 2013 Chiapas es considerado el estado más seguro, presenta sin embargo una muy alta cifra negra (el $90.4 \%$ de los delitos cometidos en la entidad no fueron denunciados o no se inició averiguación previa). Según la misma encuesta, en el $53.4 \%$ de los casos los delitos no se denunciaron por motivos atribuidos a la autoridad: miedo a la extorsión, pérdida de tiempo, trámites largos y difíciles, desconfianza a la autoridad y actitud hostil de la misma. Asimismo, es muy elevada la percepción de corrupción de varios funcionarios y cuerpos de seguridad pública: 78\% para la Policía de Tránsito, 63\% para la Policía Ministerial, 62\% para los Agentes del Ministerio Público, y 61\% para los Jueces y las Policías Estatal y Municipal.

La corrupción generalizada y la falta de independencia e imparcialidad, vicios del sistema de justicia mexicano, en Chiapas se insertan en un contexto donde las instituciones políticas han sido históricamente coludidas y dependientes de los grupos de poder regionales; el poder judicial no es ajeno a tal situación, y sus representantes entienden y aplican el derecho con un sesgo racial y de clase. La dependencia del poder político y de la clase dirigente local permitió por lo tanto, según el Centro de Derechos Humanos Fray Bartolomé de las Casas (CDHFBC), que "el sistema de procuración y administración de justicia fuera uno de los instrumentos $[\ldots]$ del gobierno para llevar adelante un plan contrainsurgente, de contención del movimiento social, intensificado por la presencia del EZLN" (2001: 111). Dicha estrategia descansa en la negación, por parte del ejecutivo, de la situación de conflicto armado en el estado: "por lo tanto los rebeldes no se consideraron insurgentes, sino transgresores de la ley. En este aspecto del conflicto armado se inserta el estratégico papel del sistema de justicia" (CDHFBC 2001:114). La parcialidad del sistema de justicia y el uso excesivo de la fuerza pública, que deviene en abusos y violaciones a los derechos humanos, se hacen más evidentes pero no aparecen en la situación de guerra, sino que representan un elemento de continuidad con los métodos utilizados desde los años setenta para reprimir y castigar las ocupaciones de tierras y las organizaciones campesinas, y respaldar los privilegios de los terratenientes ligados al gobierno estatal (véase cap. 3). La dependencia del poder político y económico y la consecuente politización de la justicia son las causas de los principales problemas del sistema

\footnotetext{
${ }^{10}$ La tasa de delitos por cada 100.000 habitantes registrado en el 2012 fue del $12.8 \%$, frente al índice nacional que alcanzó el 35.1\%; asimismo, la tasa de victimas por 100.000 habitantes en el mismo año fue de $12.6 \%$ (frente al $27.3 \%$ en la media nacional). ENVIPE 2013, INEGI.
} 


\section{Capitulo 5. La justicía autónoma y la justicía del Estado}

de justicia en Chiapas: por un lado la impunidad y por el otro la manera en que aquella se imparte, pues el sistema de impartición y procuración de justicia en Chiapas se ha caracterizado por ser selectivo y depender discrecionalmente de la filiación política de víctimas y agresores.

El análisis de los informes anuales elaborados por el CDHFBC en el periodo 1993-2014 muestra que las violaciones a los derechos humanos más frecuentes han sido, y siguen siendo, la privación ilegal de la libertad o detención arbitraria; la tortura; el abuso de autoridad y los delitos con impunidad. Las tres primeras violaciones involucran principalmente a las fuerzas de seguridad pública (Policías) y a las instancias de procuración de justicia (Ministerios Públicos), mientras la impunidad "se refiere al funcionamiento irresponsable de las instituciones de administración de justicia frente a ofensas, delitos y actos ilícitos realizados por servidores públicos" (CDHFBC 1993: 17). Asimismo, las estadísticas del Centro coinciden con la encuesta del INEGI, identificando a los Policías Judiciales y los Agentes del Ministerio Público como las instancias que recibieron más denuncias por violaciones de los derechos humanos.

De esto resulta que la corrupción del sistema judicial chiapaneco inicia en la discrecionalidad con la que actúan los órganos de procuración de justicia, en dos sentidos: "las instancias de investigación criminal declaran la improcedencia de las denuncias hechas por personas que se oponen al régimen en contra de simpatizantes del partido oficial" y se niegan generalmente a recibir denuncias ciudadanas, especialmente si son presentadas por mujeres o indígenas, "mientras que las denuncias en sentido inverso", es decir por parte de personas cercanas o afines a los gobiernos locales o a los partidos en el poder, "proceden con particular rapidez, dando pie incluso a detenciones arbitrarias" (CDHFBC 2000:63). Esta situación estructural, que precede al conflicto y perdura hasta la fecha, a partir de 1994 se ha imbricado con la elevada militarización, que implica violaciones a derechos humanos específicos, y ha favorecido la impunidad de la violencia paramilitar; repetidamente, las instancias de investigación y persecución de delitos se han alineado con las directrices políticas y han encubierto las acciones y las responsabilidades del Ejército y de los funcionarios locales, estatales y federales en los múltiples episodios de violencia y asesinatos cometidos por soldados y civiles armados (un ejemplo por todos es la impunidad que permanece sobre la masacre de Acteal). Esta situación ha sido denunciada repetidamente incluso por organismos 


\section{AUTONOMIAINDÍGENA, VIOLENCIAY JUSTICIA}

internacionales como la Oficina en México del Alto Comisionado de las Naciones Unidas para los Derechos Humanos (1998, 2008), la Fundación para el Debido Proceso y la Comisión Civil Internacional de Observación sobre los Derechos Humanos (2008), así como en las recomendaciones emitidas por la Comisiones Nacional y Estatal de Derechos Humanos (CNDH y $\mathrm{CEDH}$ ), instancias que han puesto en evidencia también las responsabilidades de los jueces en el uso represivo de la justicia y en la perpetuación de la impunidad.

En cuanto a las violaciones a los derechos humanos cometidas por las autoridades judiciales, la situación de conflicto y la estrategia contrainsurgente implementada después de 1994 determinaron un incremento de las ejecuciones extrajudiciales y los atentados a la vida y a la integridad física, de la tortura y de las incursiones y hostigamiento a las comunidades indígenas. A partir del año 2001, en coincidencia con el reacomodo de la presencia militar en el estado, el CDHFBC registra un incremento de las denuncias de detención arbitraria o privación ilegal de la libertad, ${ }^{11}$ cometidas por fuerzas policiales y agentes del Ministerio Público. ${ }^{12}$ En estos casos, la mayoría de las víctimas son retenidas en prisión por tiempos que rebasan lo previsto en la ley; otros son retenidos violando todas sus garantías judiciales (tener un defensor y, en caso de ser indígenas, un traductor; comunicarse con los familiares); otros más declararon presión de funcionarios de gobierno estatales o municipales. Según Miguel Ángel de los Santos, desde hace décadas defensor de derechos humanos y abogado de presos indígenas:

Las detenciones arbitrarias y la tortura como medios para obtener confesiones son comunes. Obedecen a un intento de las autoridades judiciales por mostrar eficiencia en la resolución de procesos. Si bien son prácticas generalizadas, en el caso de los indígenas (la tercera parte de la población en el estado) se agrava por las diferencias culturales y desventajas económicas. ${ }^{13}$

La privación arbitraria de la libertad se ha ejercido también bajo la figura del arraigo, una medida que nunca fue asentada en la Constitución mexicana, y que sin embargo fue utilizada

\footnotetext{
${ }^{11}$ Con esto se entiende privar de la libertad a una persona sin orden de autoridad competente, fuera de los casos establecidos por la ley, o sin respetar los términos legales.

${ }^{12}$ Ya en 1993 la detención arbitraria era la segunda causa de las denuncias recibidas por el Centro de Derechos Humanos. Entre 2001 y 2002 éste registró 229 víctimas de detención arbitraria, de las cuales 68 en Marqués de Comillas y 65 en Comitán (ambos municipios en la región Selva Fronteriza); en el 2005 registró 78 víctimas; esta cifra se mantiene alta en los años siguientes.

${ }^{13}$ Entrevista reproducida en Bellinghausen, H. y Mariscal, A., "En evidencia, desventajas jurídicas para los pueblos nativos de México", La Jornada, 6 de abril de 2008.
} 


\section{Capitulo 5. La justicia autónoma y la justicía del Estado}

frecuentemente por los Fiscales del Ministerio Público, que solicitan su aplicación a un Juez Penal; se justificaba el uso de tal medida para evitar la fuga de las personas durante el tiempo necesario para la integración de la averiguación previa, aunque se podía prolongar hasta por 90 días. La victima de oficialmente no se encuentra detenida aunque de hecho lo esté, ya que no ha sido acusada de delito alguno, ni está bajo un proceso judicial; no tiene derecho a comunicarse con un abogado ni con los familiares, que incluso desconocen el lugar de su detención. Según el CDHFBC, "se constata que la figura del arraigo es utilizada como forma de desgaste psicológico y de presión hacia la víctima así como para la fabricación de delitos”, en muchos casos ligados a motivos políticos.

La privación arbitraria de la libertad está estrechamente ligada a la tortura, otra tipología de violación a los derechos humanos que ha aumentado en años recientes, también en relación a la estrategia de combate a la delincuencia organizada iniciada por el ejecutivo federal en 2006. ${ }^{14}$ La tortura es, lamentablemente, una acción que las fuerzas policiales mexicana utilizan con frecuencia y facilidad, para la obtención de pruebas ilícitas que son aceptadas por los jueces para dictar sentencias condenatorias. No obstante la figura del arraigo haya sido formalmente eliminada del Código Penal estatal para los casos del fuero común, los casos de tortura no han disminuido, permaneciendo activas "casas de seguridad" extralegales; asimismo, se ha denunciado la ineficacia de la recién creada Fiscalía Especializada en Derechos Humanos Atención a Víctimas del Delito, y las autoridades procuran no sancionar a los funcionarios responsables, preservando el círculo de la impunidad (CDHFBC 2014).

La descomposición del sistema de administración de justicia y la tasa muy elevada de violación a los DDHH cometidas por las autoridades judiciales se hicieron tan evidentes que el gobierno estatal encabezado por Juan Sabines (2006-2012), cuya intención fue la de construir la imagen de un estado "pacificado", “desarrollado" y abierto a la inversión económica, no pudo omitir la problemática en su programa "modernizador". Reconociendo los lastres del sistema judicial estatal, ${ }^{15}$ el gobierno estatal emprendió, en conjunto con varias instancias de

\footnotetext{
${ }^{14}$ Entre 2006 y 2014 el CDHFBC ha recibido denuncias por 120 casos de tortura.

15 El Plan Estatal de Desarrollo 2007-2012 reconoce que "en el estado, son más frecuentes las quejas sobre presuntas violaciones de derechos humanos relacionadas con la seguridad jurídica, toda vez que sobresalen el abuso de autoridad, la detención arbitraria, ejercicio indebido del cargo,

dilación en la procuración de justicia, trato cruel y/o degradante, irregular integración de la averiguación previa, incumplimiento de orden de aprehensión, cobro indebido a reclusos e internos, y empleo arbitrario de la fuerza pública" (página 268).
} 


\section{AUTOONOMIIAINDÍGENA, VIOLENCIAY JUSTICIA}

las Naciones Unidas, el llamado "Programa conjunto para una cultura de paz" en algunos municipios de la Zona Norte golpeados por la violencia paramilitar. Aunque focalizado en la situación de los desplazados, el programa enfatiza la necesidad de fortalecer los sistemas legales y judiciales y facilitar el acceso a la justicia para la población interesada, como una medida para interrumpir los ciclos de la inseguridad y el conflicto. Tanto la implementación del programa como el inicio de la reforma de la justicia en el estado han sido realizados en el mismo año, el 2009, por lo que destaca un interés político local orientado por las directrices de la política trasnacional, como confirma el balance del programa, elaborado por la Oficina de las Naciones Unidas para la Droga y el Delito (Hrovatin 2012).

Estos importantes esfuerzos de transformación institucional pueden representar un avance en el mayor respeto de los derechos humanos y el acceso a la justicia, sin embargo, su alcance es limitado por la reproducción de los mecanismos de dependencia y colusión entre los distintos poderes, y por la permanencia de una cultura discriminatoria y represiva en las autoridades, en particular hacia la población indígena, como detallaré en el siguiente apartado.

\section{El acceso a la (in)justicia del Estado para los pueblos indígenas}

El conjunto de fallas que afectan el sistema de justicia en el estado de Chiapas se hace evidente al estudiar las posibilidades y las limitaciones del acceso a la justicia para la población indígena. Es una constante que las instituciones para la procuración e impartición de justicia sean escasas en las regiones indígenas, y que el trato hacia la población sea discriminatorio y violatorio de sus derechos, no solo colectivos, sino individuales. Esto es, no sólo hace falta que la gente pueda acudir físicamente a las instituciones; sino que estas apliquen una justicia respetuosa y equitativa, y que así se puedan resolver realmente los conflictos y los problemas que vive la población.

En términos generales y apegados a una interpretación de la justicia como función de estado, la ministra Sánchez Cordero ha definido el acceso a la justicia como "la posibilidad de que cualquier persona, independientemente de su condición, pueda acudir a los sistemas de

justicia si así lo desea", contando con la igualdad de oportunidades para el acceso y presumiendo que dichos sistemas son efectivos, es decir darán resultados "individualmente y 


\section{Capitulo 5. La justicia autónoma y la justicía del Estado}

socialmente justos". ${ }^{16}$ De acuerdo a esta interpretación formalista -que de todos modos pone en evidencia dos puntos centrales en el debate- el cumplimiento del derecho al acceso a la justicia implica entonces, en primer lugar, que no existan dificultades económicas para ello, es decir la disponibilidad de una defensa pública, gratuita y profesionalmente eficaz, y la gratuidad de los costos procesales, pues la desigual situación económica de los litigantes se refleja en una desigual posibilidad de defenderse en un juicio. En segundo lugar, es fundamental la localización de las instancias de procuración y administración de la justicia, pues la distancia es un factor que puede redundar en la imposibilidad de acceso a ésta.

En la región de investigación, que se encuentra en la zona de la Selva Lacandona ubicada en los municipios de Las Margaritas, Maravilla Tenejapa y Ocosingo, la lejanía es uno de los elementos que determinan el escaso acceso a las instituciones de procuración e impartición de justicia del estado. Hay que considerar que se trata de una región muy extensa y poco comunicada; muchas de las comunidades carecen de todos los servicios básicos, y tienen acceso solamente con veredas que se recorren a pie y que en tiempo de lluvia se vuelven impracticables. Su distancia de los centros de población "mestizos" hace que el estado las "olvide" cuando hay que proporcionar los servicios básicos; pero la densidad poblacional de la región la hace muy presente en los tiempos de campaña y para fines políticos de los partidos y de las instituciones.

Actualmente, se han instituido en Chiapas 22 Juzgados de Paz y Conciliación Indígena, de los cuales 15 se encuentran en la zona Altos, tres en la región Centro y cuatro en la Selva (Maravilla Tenejapa, Marqués de Comillas y Las Margaritas). La institución de los Juzgados en esta región es muy recién y por lo tanto no he podido realizar en ellos actividades de investigación; se instalaron después del 2011 en el marco del impulso a los mecanismos de “justicia alternativa” establecidos por la Ley análoga publicada en 2009. En tal contexto, se han instituido nuevas instancias jurídicas y multiplicado también las instancias para la procuración de justicia.

La región de la Selva Fronteriza estudiada corresponde al Distrito Judicial FronterizoSierra, cuya cabecera se encuentra en la ciudad de Comitán. Aquí reside el Fiscal del

\footnotetext{
${ }^{16}$ Olga Sánchez Cordero, "La Constitución como defensa. El acceso a la justicia y la Suprema Corte", ponencia en el Congreso Acceso a la Justicia, Instituto Tecnológico Autónomo de México, México D.F., 30 de marzo 2000 .
} 


\section{AUTONOMIAINDÍGENA, VIOLENCIAY JUSTICIA}

Ministerio Público, responsable distrital de la función de procuración de justicia, del cual dependen siete agencias del Ministerio Público (tres de éstas se encuentran en los municipios de Frontera Comalapa, La Trinitaria y Motozintla, parte del territorio de influencia de la Junta de Buen Gobierno). En Las Margaritas existe una Agencia del MP que no depende del Fiscal de Distrito sino de la Fiscalía Especializada en Justicia Indígena, cuya coordinación reside en San Cristóbal. ${ }^{17}$ Por lo que concierne a la impartición de justicia, hay que ir hasta las cabeceras de los distritos judiciales, Comitán y Ocosingo, para encontrar las sedes de los Juzgados de Primera instancia Penal y Civil, y las Salas Regionales Mixtas.

En el 2012 el sistema de justicia del estado inició su adecuación al nuevo sistema de justicia de corte acusatorio-adversarial, y en tal contexto se crearon las Unidades Integrales de Investigación y Justicia Restaurativa, presididas por Agentes del MP, que unen a las tradicionales facultades para la investigación de los delitos también el uso de medios alternos y reparatorios para buscar la solución de los conflictos, apoyándose en mediadores y conciliadores especializados, proporcionados por el Centro Estatal de Justicia Alternativa. En la región de estudio, entre 2013 y 2014 se crearon tres Unidades de Justicia Restaurativa: en Comitán, La Trinitaria y Las Margaritas (esta última adscrita a la Fiscalía Especializada en Justicia Indígena). Asimismo, a partir de marzo 2014 se instituye el Juzgado de Garantía y Juicio Oral en el Distrito Judicial de Comitán, que tiene la cobertura total de los delitos no graves cometidos en el distrito. Considero un interesante objeto de futura investigaciones el estudio de la eficacia de las nuevas instancias, así como de la atención y el trato reservado a los indígenas, para poder evaluar si representan realmente un avance en facilitar el acceso a la justicia para este sector de la población.

En el caso de los pueblos indígenas, la condición de poder acudir a la justicia en igualdad de oportunidades -expresada al principio de éste apartado- exige el respeto de otros derechos (individuales y colectivos) y la consecuente transformación del sistema de justicia estatal, lo que implicaría un cambio cultural tanto en el derecho mismo, pero sobretodo en los funcionarios encargados de aplicarlos, es decir una transición hacia un sistema que reconozca de manera igualitaria la pluralidad jurídica. En primer lugar, la garantía del acceso a la justicia para los indígenas implica el reconocimiento pleno del sistema jurídico indígena: éste es la

\footnotetext{
${ }^{17}$ Durante las estancias de investigación he tratado varias veces de concertar una cita con el Agente del PM de Las Margaritas, pero nunca me fue concedida.
} 
instancia jurídica más cercana y a la que con más frecuencia recurren, por lo tanto el reconocimiento de la validez de dicho sistema en el marco de una relación de autonomía, sería el primer elemento para garantizar, en este caso, el respeto de las decisiones tomadas por las instancias jurídicas indígenas, y su carácter definitivo. ${ }^{18}$ En relación con esto está la necesidad de contar con mecanismos para resolver los conflictos de competencias que emergen entre el sistema indígena y el sistema oficial, es decir una ley de coordinación o deslinde jurisdiccional, que sancione la igualdad jurídica de ambos sistemas y los ámbitos de competencia exclusivos de uno u otro.

El reconocimiento pleno de la jurisdicción indígena se debe entender como derecho colectivo y como derecho individual, lo cual implica que sean tomados en cuenta la cultura, las prácticas y el sistema normativo de los indígenas que se encuentran sometidos a la jurisdicción estatal.

Finalmente destacan los derechos a la aplicación a una pena alternativa a la prisión, el derecho a una defensa adecuada y a contar en todo momento con un traductor y/o intérprete.

Lamentablemente, la violación sistemática de todas las garantías expuestas es una constante en todos los estados de la república: la vulnerabilidad de los indígenas involucrados en procesos judiciales, la discriminación y los abusos a los que son sometidos han sido denunciados por distintos organismos defensores de derechos humanos nacionales e internacionales, entre ellos el Relator sobre los Derechos de los Pueblos Indígenas de la ONU, quién afirmó en 2003:

Es precisamente en el campo de la procuración y administración de justicia donde se expresa mayormente la vulnerabilidad de los pueblos indígenas [...] Los juicios en que se ven involucrados los indígenas están con frecuencia plagados de irregularidades, no solamente por la falta de intérpretes y defensores capacitados, sino también porque el ministerio público y los

\footnotetext{
${ }^{18}$ En este sentido, el Comité CERD (Convención Internacional sobre la Eliminación de todas las formas de Discriminación Racial) en su Recomendación General 31 exige a los Estados "velar por el respeto y el reconocimiento de los sistemas tradicionales de justicia de los pueblos autóctonos, de conformidad con la normativa internacional de derechos humanos." Comité CERD. Recomendación general No 31 sobre la prevención de la discriminación racial en la administración y el funcionamiento de la justicia penal, párr. 5(e), 2005; disponible en: <http://www2.ohchr.org/english/bodies/cerd/docs/GC31Rev_Sp.pdf>, consultado el 10 de septiembre 2014. Asimismo, el Estudio sobre el acceso a la justicia en la promoción y protección de los derechos de los pueblos indígenas, emitido por el Consejo de Derechos Humanos de la ONU, afirma que "el derecho a la libre determinación es un derecho fundamental para los pueblos indígenas del que se derivan otros derechos. En relación con el acceso a la justicia, la libre determinación afirma su derecho a mantener y reforzar las instituciones jurídicas indígenas y a aplicar sus propias costumbres y leyes" (ONU 2013: 7).
} 


\section{AUTONOMIAINDÍGENA, VIOLENCIAY JUSTICIA}

jueces suelen ignorar las costumbres jurídicas indígenas. En ocasiones las sentencias dictadas están fuera de toda proporción a los delitos imputados... ${ }^{19}$

Analizando el sistema de justicia del estado de Chiapas en relación al respeto de las cuatro garantías antes expuestas (reconocimiento pleno, coordinación y deslinde, que sean tomadas en cuenta la cultura y las normas, contar con defensor y traductor que conozcan la cultura), se puede fácilmente afirmar, en base a los elementos expuestos en los capítulos anteriores, que la justicia indígena no es reconocida ni respetada de manera integral, al igual que el más amplio derecho a la autonomía indígena.

Con respecto a la consideración de la cultura propia, el análisis de las leyes y de las funciones de las instituciones, muestra que aparentemente hay en Chiapas una gran atención a los derechos de los pueblos indígenas. En 1999 se instituyó la Subprocuraduría de Justicia Indígena, que en 2004 cambió denominación a Fiscalía de Justicia Indígena y desde 2007 se llama Fiscalía Especializada de Justicia Indígena, siempre con las mismas funciones y el mismo funcionario como responsable, Mariano López Pérez. Este, indígena tzotzil, manifiesta una posición abierta al reconocimiento de las diferencias culturales y jurídicas, aunque sostiene la posición dominante que los sistemas jurídicos indígenas se deben aplicar exclusivamente en conflictos menores. Según afirma el Fiscal, la institución cumple funciones de conciliación:

En materia de conciliación seríamos la autoridad de apelación, se podría decir, de los Juzgados de Paz. Cuando atendemos casos de inconformidad hacia los dictámenes de los Juzgados de Paz, modificamos o confirmamos el criterio de ellos, y a veces también anulamos, porque muchas veces son parciales los jueces. Si es un delito grave, como violación, no entramos en plano de conciliación, sino ya de integración de la averiguación previa, de investigación, consignamos al juzgado competente. ${ }^{20}$

Según la ley correspondiente, las funciones de la Fiscalía Especializada deberían ser, entre otras, "garantizar que los miembros de los grupos indígenas gocen del principio de igualdad, en el acceso a la procuración de justicia" y "garantizar el derecho de los indígenas acusados

\footnotetext{
${ }^{19}$ Informe del Relator Especial sobre la situación de los derechos humanos y las libertades fundamentales de los Indígenas, Rodolfo Stavenhagen, sobre su misión a México, 23 de diciembre de 2003, E/CN.4/2004/80/Add.2, $<$ http://ap.ohchr.org/documents/alldocs.aspx?doc_id=9180>, consultado el 3 de agosto 2014.

${ }^{20}$ Mariano López Pérez, Fiscal Especial de Justicia Indígena, entrevista, San Cristóbal de Las Casas, 6/10/2008.
} 


\section{Capitulo 5. La justicia autónoma y la justicía del Estado}

por delitos del orden común, a ser asistidos por intérpretes y defensores que tengan conocimiento de su lengua y cultura".

A la pregunta si hay resistencias de los Ministerios Públicos (MP) para integrar averiguaciones previas cuando acuden a ellos personas indígenas, una situación que he observado con frecuencia en la Montaña de Guerrero, el ex director del Centro de Derechos Humanos Fray Bartolomé de las Casas (Frayba) afirmó:

En general, indígena o no indígena, es una reacción normal que tiene el MP. Hay ahora en Chiapas para el fuero común ministerios supuestamente especializados, como la Fiscalía de Justicia Indígena, y estos procuran no atender los casos. Muchos de los casos que llegan al Frayba, fueron allá y no le quisieron recibir su denuncia. ${ }^{21}$

La recepción del discurso de respeto a los derechos indígenas, propiciado formalmente por el gobierno estatal, es desigual entre los funcionarios entrevistados. En algunos casos han manifestado una sensibilidad con tintes indigenistas, en el sentido de un pluralismo aditivo, expresando opinión favorable a la institución de instancias especializadas en los municipios indígenas (Juzgados de paz y conciliación indígena) que liberen a las otras instancias judiciales de la atención a los indígenas, como el Juez primero del ramo penal de Comitán:

Siempre he dicho: un trato igual a los iguales y desigual a los desiguales, el sector indígena requiere un trato especial, por las condiciones en que viven y por su cultura. Este trato especial debería consistir en hacerles llegar información sobre las instituciones que están a su cargo y que de una u otra forma son ex profeso para ellos, y tengan esas puertas abiertas porque por lo regular cuando llegan a las ciudades son un poco subestimados [...] el hecho de que tengan a su alcance las instituciones en sus mismas comunidades cambiaría las cosas para ellos y también para los mismos ciudadanos que están en las ciudades. ${ }^{22}$

En otros casos, prevalece la visión monista del derecho, que desconoce la legitimidad de las justicias indígenas y el mismo derecho a la diferencia, por lo que se percibe el problema de la falta de coordinación entre los distintos sistemas jurídicos en la medida en que los indígenas

\footnotetext{
21 “Al incumplir su obligación de asistir jurídicamente a la persona que presenta una denuncia, el Ministerio Público deja de cumplir su obligación de procurar justicia, incurriendo no sólo en una falta administrativa de responsabilidad de servidor público, sino incluso en un acto de abuso de autoridad." (CDHFBC 2002:42)

${ }^{22}$ Hermann Omar Villavider, Juez primero del ramo penal, Comitán, entrevista, 25/01/2010.
} 


\section{AUTONOMIAINDÍGENA, VIOLENCIAY JUSTICIA}

no se acoplan a las resoluciones emitidas por la justicia estatal, y la coordinación se entiende en términos de integración de la justicia indígena al sistema oficial. Expresa esta posición el Juez primero del ramo civil de Comitán:

Hay un problema de conceptualización de la ley: ellos [los indígenas] creen tener determinados derechos que no son congruentes con la ley vigente. Entonces por ello los indígenas a veces no aceptan las resoluciones judiciales que están apegadas a la ley vigente. Ellos tienen sus formas distintas de solucionarlo. Pero eso se debe a una falta de información, a una falta de cultura: por ejemplo en la tenencia de la tierra ellos no buscan la asesoría adecuada para redactar un documento que sea legalmente válido. Y entonces hay que trabajar mucho con ellos para darles a conocer la Ley. ${ }^{23}$

Esta posición netamente monista y formalista redunda en el racismo pues el desapego a "La Ley" del Estado se entiende como una "falta de cultura" que hay que colmar "inculcando una cultura jurídica”, según las palabras del otro magistrado entrevistado (Juez primero penal).

A pesar de ser opiniones en cierta medida personales, considero relevante lo expresado por los jueces entrevistados, pues demuestra la distancia que existe entre el reconocimiento formal asentado en las leyes, y la práctica de la justicia real a la que se enfrentan los indígenas, donde la visión de los funcionarios es fundamental en las resoluciones dictadas.

Las autoridades indígenas entrevistadas, tanto en Chiapas como en Guerrero, Oaxaca y Durango, perciben el hecho de que la cultura y las normas propias no sean tomadas en cuenta por las autoridades oficiales como una distancia, difícilmente superable, entre la justicia propia y aquella del Estado, como lo expresa el Comisariado Ejidal de La Realidad: "lo que hace diferente la justicia entre nosotros es que somos los mismos, compañeros indígenas. Si vas a Las Margaritas quién te atiende es un licenciado, que simplemente hace su trabajo, sin corazón". ${ }^{24}$ En un sentido parecido, el Coordinador general de los jmeltsa'anwanej afirma: "la justicia indígena es en nuestra cultura, en la lengua. No es tanto que sean malos los cargos del MP, pero se distingue porque ellos no nos entienden, no conocen la cultura de nosotros, entonces no pueden tratarnos tal como queremos que se trate a una persona". ${ }^{25}$

\footnotetext{
${ }^{23}$ Joel Roda Pérez, Juez primero del ramo civil, Comitán, entrevista, 30/01/2010.

${ }^{24}$ Comisariado Ejidal, La Realidad, entrevista, 14/12/2008.

${ }^{25}$ Juan Méndez Gutiérrez, Coordinador general de los jmeltsa ’anwanej, San Jerónimo Tulijá, Chilón, entrevista, $1 / 07 / 2011$.
} 


\section{Capitulo 5. La justicia autónoma y la justicía del Estado}

El hecho de que, según los entrevistados, en las instancias estatales se aplique una justicia que no corresponde a la visión indígena de la sociedad y de la justicia misma, conlleva que la justicia del Estado sea considerada ineficaz: "a veces se arregla la problema en el MP, pero regresando a la comunidad sigue todavía la problema"; "26 "si vamos con el MP sale muy caro y luego no se resuelve el problema, y a veces es pura mentira lo que se va a declarar". ${ }^{27}$

Junto con el deber enfrentarse a una justicia -la del Estado- construida sobre códigos culturales distintos, los indígenas enfatizan que dicha justicia se desarrolla en un idioma distinto que, al igual que la cultura dominante, no les pertenece y no dominan a cabalidad, como explica Rebeca Gutiérrez, jmeltsa'anwanej: "si vamos con el ministerio los que traducen no nos traducen todo, y tampoco lo traducen bien. Nosotros todo lo hacemos en nuestra lengua". ${ }^{28}$ Todos los entrevistados coincidieron en que éste, junto con el costo de la justicia y la distancia cultural, son los principales problemas que encuentran al relacionarse con la justicia estatal. Entonces las personas indígenas son discriminadas en tal sistema por varios motivos: "porque no tienes dinero, porque no hablas la castilla, porque sos indígena". 29

En Chiapas, tanto la Ley de Derechos y Cultura Indígena como el Nuevo Código de Procedimientos Penales, reconocen los derechos de los indígenas a contar en cada momento con traductor y con un defensor de oficio que conozca su idioma y su cultura; sin embargo, también el cumplimiento de estas garantías es carente, lo que pone a los involucrados en una grave situación de indefensión, con el resultado de un número elevadísimo de condenas falsas por delitos que las personas no cometieron. ${ }^{30}$ Según el ex director del Centro de Derechos Humanos Fray Bartolomé de Las Casas:

Los Juzgados estatales y federales normalmente cumplen con que el acusado tenga un abogado y un traductor, aunque en términos ineficaces. Muchas veces ocurre que el traductor habla otro idioma u otra variante del idioma de la persona; en la lógica del derecho positivo el significado preciso de las palabras tiene una gran relevancia. Por ejemplo, me tocó escuchar un proceso en

\footnotetext{
${ }^{26}$ Pedro Demeza Gutiérrez, jmeltsa'anwanej bankilal, San Jerónimo Tulijá, Chilón, entrevista, 1/07/2011.

${ }^{27}$ Gerónima Guzmán, jmeltsa 'anwanej bankilal, San Jerónimo Tulijá, Chilón, entrevista, 1/07/2011.

${ }^{28}$ Rebeca Gutiérrez, jmeltsa'anwanej xhut, San Jerónimo Tulijá, Chilón, entrevista, 1 de julio de 2011.

${ }^{29}$ Escuelita Zapatista, 28 de diciembre 2013.

30 Según un estudio realizado por el Centro de Derechos Humanos Miguel Agustín Pro (ProDh) sobre 289 mujeres indígenas que estaban en prisión a finales de 2009, solo el $11 \%$ gozaron del derecho a un intérprete (ProDH 2012:17). Asimismo, un diagnóstico sobre 1000 indígenas recluidos, realizado en Oaxaca por la ONU, encontró que solo el 16\% tuvo la asistencia de un intérprete (ONU 2007:93-94)
} 
que se preguntaba de qué color era la camioneta, y en tzotzil azul y verde se definen con la misma palabra. Esto puede implicar que esté declarando con falsedad, por ejemplo.

En donde se violan las dos garantías - tener un traductor y un abogado- es en los Ministerios Públicos. Los indígenas que son señalados por algún delito, en el $99 \%$ de los casos no tienen abogado, y quizás un $70 \%$ no tienen traductor. Entonces las declaraciones ante un MP normalmente resultan ser autoinculpatorias. Aunque después, llegando frente al Juez, este pregunta si el inculpado ratifica su declaración, el mismo traductor es insuficiente: pregunta al acusado ‘¿ratificas tu declaración?’ en castellano, porque no existe una traducción para eso.

En los casos que nosotros asistimos, imponemos que se lea toda la declaración, además siempre llevamos alguien que sepa el idioma, y explicamos más al procesado que termina diciendo 'yo no dije eso'. Resulta que por lo regular el MP no escribe lo que el acusado está diciendo sino lo que más conviene; al MP le conviene que confiese porque es menos trabajo, o porque recibió un dinero de la otra parte, o simplemente porque alguien tiene que pagar un delito que se cometió. Aunque llegues ante el juez y digas que no ratificas esa declaración, después de que te hayan explicado muy bien, resulta que cuando te dictan sentencia el juez sí va a tomar en cuenta tu confesión: aunque no hayas tenido traductor, abogado, aunque hayas dicho que fuiste torturado, aunque no lo ratifiques en tu declaración preparatoria; esto porque desgraciadamente hay una jurisprudencia en la suprema corte de justicia de la nación que da mayor valor probatorio a la primera declaración, es el 'principio de inmediatez' ${ }^{31}$

Hasta el año 2009, se contaba solamente con un defensor social indígena y un traductor por cada distrito judicial. En el Juzgado de primera instancia de Comitán, región donde el idioma indígena predominante es el tojolabal, el defensor domina el tzeltal y el tzotzil, por lo que de vez en vez se solicita un traductor a la Secretaría de Pueblos Indios (SEPI) o a la Comisión Estatal de Lenguas Indígenas, con sede en San Cristóbal. Según un estudio elaborado por la Fundación para el Debido Proceso, la evaluación de la Defensoría Indígena "no es positiva, porque están colapsados por la cantidad de casos, la escasez de recursos y la inactividad del defensor" (DPLF 2012:65).

Finalmente, otro gran problema endémico del sistema de justicia es el elevado costo económico que implica, tanto en términos legales (pago de la fianza, parcela del abogado, monto de las multas) cuanto en el aspecto, lamentablemente estructural, de la corrupción, es decir las inevitables "mordidas" que en cada instancia y momento se exigen a los

\footnotetext{
${ }^{31}$ Diego Cadenas, entrevista, San Cristóbal de Las Casas, octubre 2008.
} 
involucrados, tanto para que su demanda proceda (si son los denunciantes) como para que no proceda (si son los acusados). Es entonces sentido común entre los entrevistados que "el gobierno compra y vende la justicia"; "la problema de llegar con el MP es que allí deben pagar, deben gastar un dinero", y en esto, según ellos, reside la gran diferencia con la justicia indígena, en la cual "no se maneja el dinero" en ningún momento del proceso de resolución de conflicto. "Esto responde a nuestra cultura, y también a la condición de pobreza de nuestros pueblos". Entre los indígenas entrevistados, todos los que comentaron haber tenido contacto con la justicia del Estado, tanto en calidad de acusados como de agraviados, sin excepción atestiguaron que la resolución del caso se obtuvo por medio de sobornos entregados por una $u$ otra parte al agente del Ministerio Público encargado de la averiguación previa.

Un primo vivía en la ciudad de Ocosingo: fue atropellado y murió, pero había testigos y se reconoció al culpable. La familia del difunto fue al MP a pedir justicia, pero se encontró con que a otra parte ya había "comprado" el MP y ese no quiso abrir ninguna averiguación previa. Contrataron un estudio legal para que los ayudara, y los abogados les confirmaron que la otra parte estaba versando dinero a las autoridades para que la cosa no pasara a mayores. Finalmente, la familia del difunto logró ganar el juicio, en el cual obtuvo una cantidad de dinero para resarcir el daño, o sea la muerte de su familiar. Pero más de las dos terceras partes se quedaron en las manos de los abogados, como pago... ${ }^{32}$

Yo tuve conocimiento del caso de mis tres primos, que viven en un ranchito, se llama Guadalupe las Nubes. Tres fueron, los agarraron y los llevaron al reclusorio en Comitán. Porque el papá tuvo dos mujeres, se estaban peleando la tierra entre meros hijos y los medios hermanos. Cuando el señor se murió, los meros hijos de este señor, como tenían dinero, vivían en el rancho, los otros estaban afuera y alegaban su derecho a la tierra, entonces fue que le metieron la policía y se los llevaron. Los golpearon, las autoridades, en el MP, yo veía como era la forma de tratar a la gente, tenían un licenciado que estaba abogando por ellos. En ese tiempo, en 1990, les pedían siete mil pesos, y no era justo, y el licenciado decía van a salir, pero que paguen. Yo acudí dos veces con el MP. Las autoridades no nos entienden, no nos hacen caso a quienes no tenemos dinero. Vi como llegaban los otros, con su dinero, su licenciado, nos echaron afuera nosotros. Hasta que al final tuvieron que pagar, para salir de la cárcel: sin arreglo, nada más salir de la cárcel. La tierra finalmente... cuando fue el

\footnotetext{
${ }^{32}$ Lucio, tzeltal, base de apoyo zapatista, vive en El Guanal. Entrevista, diciembre 2008
} 


\section{AUTOONOMIIAINDÍGENA, VIOLENCIAY JUSTICIA}

levantamiento en 1994, los otros se fueron y los que habían estado en la cárcel están viviendo allí... ¡la justicia se dio la vuelta! ${ }^{33}$

Resume tal situación el abogado Miguel Ángel de los Santos:

En Chiapas, particularmente en la zona indígena, las sentencias de libertad cuestan hasta 50.000 pesos, sea culpable o no el acusado. Secretarias, actuarios y hasta jueces piden dinero para agilizar procesos a conveniencia. Gran porcentaje de los detenidos vive en lugares lejanos, no puede pagar un abogado, y las familias raramente cuentan con medios para hacerse presentes y coadyuvar presentando pruebas para la defensa. Los presos son abandonados literalmente, sometidos a procesos que les son ajenos, $y$, al final, muchas veces sentenciados sin que sepan cuál fue su delito. ${ }^{34}$

\section{Los presos indígenas y la lucha por la dignidad en las cárceles de Chiapas}

Las fallas estructurales y las deplorables condiciones del sistema carcelario mexicano han sido ampliamente documentadas en trabajos periodísticos y académicos, y denunciadas por los organismos defensores de los derechos humanos; sin embargo, las emociones que genera el ingreso en una de estas "escuelas del crimen" son difícilmente previsibles, aún sea como un visitador que permanecerá en la estructura unas cuantas horas, frente a las tragedias de aquellos que seguirán padeciendo por años la reclusión y la alienación. Como parte de la investigación, realicé dos visitas a reclusos, ambas en el mes de enero de 2008: en los Centros Estatales para la Reinserción Social de Sentenciados (CERSS) número 14 de Cintalapa (El Amate) y número 5 de San Cristóbal (Los Llanos). Las dos visitas fueron muy distintas; en El Amate se trató de un evento sui generis pues participé a un evento festivo para celebrar el $\mathrm{II}^{\circ}$ aniversario de La Voz del Amate, organización de presos políticos; mientras la visita a Los

\footnotetext{
${ }^{33}$ Emiliano, Agente Municipal, San José del Río, entrevista, diciembre 2009.

34 Entrevista reproducida en Bellinghausen, H. y Mariscal, A., "En evidencia, desventajas jurídicas para los pueblos nativos de México", La Jornada, 6 de abril de 2008.
} 


\section{Capitulo 5. La justicia autónoma y la justicía del Estado}

Llanos, en la que acompañaba los familiares de un interno, fue más cercana a la rutina que éstos cumplen en cada ocasión.

La "visita" inicia con el cacheo y revisión física que cumplen los custodios a los que entran en el penal, acto sencillo que sin embargo se puede llevar un tiempo interminable dependiendo de lo que, arbitrariamente, se encuentre como "no permitido" para el ingreso al penal: desde la ropa que traes puesta a la comida que llevas para tu preso, todo puede ser prohibido y por lo tanto objeto de pago indebido por obtener el permiso -discrecional cuanto la prohibición- de pasar. En este espacio se cometen arbitrariamente sobre los familiares actos considerados tortura (registros íntimos), que reflejan, aunque con intensidad distinta, las violencias ejercidas sobre los internos mismos.

Desde ese primer "filtro", se percibe que la corrupción es omnipresente, al igual que el ejercicio de un poder vejatorio de las autoridades carcelarias, los custodios y los presos más poderosos hacia los familiares y los internos "diferentes". Este poder que se basa en la humillación es el necesario complemento de la corrupción y de la violencia que permea cualquier acto y actividad de la vida en la cárcel.

Ya pasada la "revisión", el ingreso al patio de la cárcel arroja situaciones contrastantes: allí se encuentran muchos puestos que venden comida, manejados por los presos más poderosos, en cuyas mesas comen y conviven los internos con sus familias. El espacio recuerda un mercado y el bullicio transmite una sensación de alegría, sin embargo la necesidad de hablar en voz baja, de cuidar lo que se dice y lo que se escribe en los apuntes, de cuidarse de todos los vendedores que se acercan, no dejan olvidar el poder coercitivo del sistema carcelario. Durante la visita a los Llanos, al igual que en El Amate, se reunieron los presos políticos organizados y, robando tiempo a la convivencia con sus familiares, contaron sus experiencias. Cuando me introdujeron a una de las celdas que compartían trece personas (aunque en origen fuera destinada sólo a seis reclusos), pude comprobar las condiciones extremas en las que los internos permanecen, el hacinamiento y las carencias, pero también su esfuerzo para crear un espacio lo más posible acogedor. La tensión extrema entre la defensa extenuante de la humanidad y la dignidad, que estos presos organizados oponen a toda una institución corrupta, que busca de manera avasalladora corromper a todos los que entran en contacto con ella, es algo que con dificultad se explica pero que se siente con fuerza y mueve 


\section{AUTONOMIAINDÍGENA, VIOLENCIAY JUSTICIA}

las cuerdas profundas, aquellas donde reside la conciencia de nuestra humanidad y la necesidad de defenderla.

Un ingente número de instrumentos jurídicos, estatales, nacionales e internacionales, vigentes en México, ratifican las garantías para las personas encarceladas. El texto constitucional dedica varios artículos del Título primero al funcionamiento del sistema de justicia; en particular, el artículo 18 afirma que "el sistema penitenciario se organizará sobre la base del respeto a los derechos humanos, del trabajo, la capacitación para el mismo, la educación, la salud y el deporte como medios para lograr la reinserción del sentenciado a la sociedad y procurar que no vuelva a delinquir", y el articulo 19 sanciona que "Todo mal tratamiento en la aprehensión o en las prisiones, toda molestia que se infiera sin motivo legal, toda gabela o contribución, en las cárceles, son abusos que serán corregidos por las leyes y reprimidos por las autoridades". Asimismo, el artículo 5 de la Convención Americana sobre Derechos Humanos enuncia que "toda persona tiene derecho a que se respete su integridad física, psíquica y moral. Nadie debe ser sometido a torturas ni a penas o tratos crueles, inhumanos o degradantes. Toda persona privada de libertad será tratada con el respeto debido a la dignidad inherente al ser humano". 35

No obstante el reconocimiento formal de los derechos de las personas implicadas en procedimientos judiciales o privadas de la libertad, éstos son violados sistemáticamente en todo el país. ${ }^{36}$ A partir del año 2006, el Centro de Derechos Humanos Fray Bartolomé de Las Casas mantuvo una especial atención a la situación del sistema carcelario en Chiapas, documentando "un fracaso en la integración social de las y los internos, así como en la vigencia de los derechos humanos de la población carcelaria”. El CDHFBC ha constatado que "la mayoría de las y los internos son personas pobres, pertenecientes a algún pueblo indígena, migrantes, con escasa educación escolar, que desconocen las implicaciones del proceso judicial, colocándolos en una situación vulnerable en cuanto al acceso a la justicia y, que en mucho de los casos, sea en su detención o en situación de cárcel han sufrido tortura por parte de algún funcionario público" (2012: 63-64)

\footnotetext{
${ }^{35}$ Convención Americana sobre Derechos Humanos, adoptada en San José Costa Rica, el 22 de noviembre de 1969, ratificada por México el 2 de Marzo de 1981, <http://www.oas.org/juridico/spanish/tratados/b-32.html>, consultado el 2 septiembre 2014.

${ }^{36}$ Véase CNDH, 2004 y 2010; Azaola, 2008; Azaola y Bergman, 2007; Azaola, Bergman et al., 2005.
} 
A través de visitas constantes en los penales, así como de las denuncias de los mismos presos (solo en 2010, éstos lograron dirigir al Centro 2.142 denuncias) el CDHFBC documentó la incidencia sistemática de dichas violaciones: sobrepoblación y hacinamiento; tratos o penas crueles, inhumanos o degradantes producto de la violencia y las malas condiciones de detención; tortura; corrupción, privilegios y cobros indebidos; imposición indebida de sanciones disciplinarias; infraestructura y condiciones higiénicas y sanitarias deficientes; falta o insuficiencia de atención médica; escasez y/o inadecuada calidad de alimentos; falta de acceso a la educación, trabajo y recreación; traslados forzados; violencia sexual (CDHFBC 2007, 2008 y 2011). Según la Comisión Nacional de Derechos Humanos (2010), diez de los 21 Centros Penitenciarios chiapanecos presentan sobrepoblación (el segundo es el de Comitán); mientras nueve presentan "autogobierno", palabra que en tal contexto significa distintas aberraciones ligadas a la presencia de grupos de poder, en colusión entre algunos presos y las autoridades carcelarias. Estos "representantes" de los presos son llamados precisos y, entre otras cosas, organizan las extorsiones a los presos de nuevo ingreso, cuyas ganancias -según denuncian los internos- son repartidas con las autoridades del penal. La CNDH denuncia la presencia de internos que realizan funciones exclusivas de la autoridad o del personal de seguridad (manejo de llaves, organización de actividades, limpieza y vigilancia); que ejercen violencia y control sobre el resto de la población, controlan las actividades laborales remuneradas, y emplean a otros para su servicio personal. Según algunos internos del penal de Los Llanos, en San Cristóbal "los precisos tienen la mayoría de los puestos: comedores, cafeterías, tiendas... A los nuevos que entran los ponen como esclavos, a quebrar piedras: nadie dice nada por miedo del traslado". ${ }^{37}$

La perversión del sistema carcelario es la consecuencia necesaria de la corrupción en el sistema de procuración e impartición de justicia, como mencioné en el apartado precedente. El testimonio de Aureliano, indígena chol y ex preso político, que recogí en San Cristóbal unos meses después de su liberación, es una muestra de la mayor parte de las irregularidades mencionadas; por tal motivo lo reproduzco casi integralmente.

Yo caí [preso] el 5 de mayo del 2006, me encontraba trabajando en mi comunidad. Llegó la judicial a sacarme violentamente, yo no sabía de qué me acusaban, es una historia triste.

\footnotetext{
${ }^{37}$ Integrante de La Voz de los Llanos, San Cristóbal de las Casas, entrevista, 10 de enero 2008.
} 


\section{AUTOONOMIIAINDÍGENA, VIOLENCIAY JUSTICIA}

Llegaron los judiciales, de la Agencia Estatal de Investigación, disfrazados de gente civil, salieron del monte, de los cafetales. Me esposan, me amarran las manos, los pies, me vendan la cara y me llevan arrastrando, ellos tenían ya la camioneta preparada, tenían varias camionetas, se encontraban un kilómetro antes de llegar a la comunidad.

Yo no tenía idea de cómo los policías debían actuar cuando agarran a una persona. Después supe que debían traer una orden de aprehensión, pero nunca la presentaron. Me subieron a la camioneta y me aplastaron con varias colchas, me estaba asfixiando. Llegamos a Yajalón, escuché que el carro se metió a una terracería y me bajaron. Me metieron a una casa, bajé unas gradas y me sentaron en una silla. Mis ojos seguían vendados. Empezaron a amenazarme, empezaron las torturas, a preguntarme de un delito que yo no sabía, cada pregunta era como media hora de golpes, me ponían plástico en la cabeza, me metían en un tambo de agua, y golpes, patadas, puñetazos.

Yo pensaba que las preguntas eran acerca de un problema que había en la comunidad, que había desaparecido un señor, yo también estuve participando con las autoridades en la búsqueda. Pero no fue así. Las preguntas que me empezaron a hacer fueron alrededor de la organización [el EZLN], quien eran los dirigentes de la organización en la comunidad. Yo le dije vayan a investigar... Cada pregunta es un golpe. También me preguntaban qué tipo, y cuantas armas había, y donde las tenían; en que parte se encontraban los campamentos zapatistas. De lo que yo sé, es que no hay armas; y si hay, que vayan a buscarlas. Yo que tenía que ver en esto...

Sacaron una lista donde ya tenían todos los nombres, incluso salía quien los había dado, una familia de la comunidad, que saben quiénes son los responsables, de que si hay armas...Allí es donde me di cuenta de lo grande que era el problema.

Me torturaron por cuatro o cinco horas. Por fin perdí el conocimiento. Me desperté que estaba más acá de Ocosingo. Tenía las manos amarradas pero ya no estaba vendado. Quise sentarme pero no pude. Me di cuenta que en la camioneta venía "XX", que era presidente [municipal], que hizo la demanda, junto con los judiciales y el MP, a quien dio la lana ${ }^{38}$ para que fabricaran todo eso.

Ya me trajeron a San Cristóbal, donde me llegó la sorpresa de que la declaración ya estaba hecha, y me amenazaron con más tortura si no la firmaba. Ni lo pensé: fui cobarde, tengo mi familia, mis dos hijos, eso fue mi error, allí se complicaron las cosas. El siguiente día me llevaron a Tuxtla, a la oficina de la AFI, me tomaron muchas fotos. Allí encontré detenidas a

\footnotetext{
${ }^{38}$ El dinero.
} 


\section{Capitulo 5. La justicia autónoma y la justicía del Estado}

mis dos hermanas y a mi papá. No lograba entender que estaba pasando, no me dejaron platicar con ellos.

Nos trasladan a la casa de arraigo, que se encuentra en una comunidad acerca de Chiapa de Corzo. ${ }^{39}$ No nos permitían hablarnos, hiciéramos preguntas, nada, para saber que está pasando, ya que no nos habían presentado ningún abogado de oficio. Supuestamente estaban haciendo las investigaciones, pero en realidad estaban fabricando más delitos, mientras aquél estaba pagando al MP; entonces llegaba el MP a amenazarnos, a preguntarnos quienes participaban. Yo le decía que no sabía, inventar nombres es mentir y yo no sé mentir. Yo siempre he permanecido trabajando, la misma gente del pueblo me conoce....

Nos quedamos en la casa de arraigo durante 90 días, mis hermanas duraron menos. Sabían las autoridades lo que estaban haciendo, que no teníamos ningún delito. Luego me quedé solo, y el asunto cada vez se iba complicando más. No dejaban que mi familia me visitara. Llegaba gente del CDH Fray Bartolomé y no los dejaban entrar. Pasaron los tres meses y llegó el actuario a anunciar que ya se levantaba el arraigo. Yo pensaba que me dieran la libertad pero me trasladaron a [el penal de ] El Amate, aunque me hubiera pertenecido el penal de San Cristóbal, o el de Yajalón.

En El Amate ya me estaban esperando, sabían la hora etc. Creo que ya había salido una denuncia en el periódico, donde decía que me tenían como rehén, para sacarme información sobre el movimiento zapatista. Ya con más coraje me esperaban. El Director, el Alcaide y sus precisos que les llaman, ya que no lo hacen directamente ellos [las autoridades]. En ese tiempo cuando caí todo estaba muy oculto, no se daba a conocer lo que sucedía en los penales.

Yo no tenía idea de lo que era la cárcel. Pensaba que guardadito y ya... Pero se empezaba a vivir una vida peor, la represión.

El Centro de Observación y Clasificación, COC, es una parte del penal, donde llevan primero los que van entrando, para ver si es una persona de alta peligrosidad, o si es una persona tranquila, o política; los van seleccionando.

Llegando ya me esperaban; lo primero que me pidieron fue dinero. Empezaron a venir los maltratos. Yo nunca he tenido dinero, pero en ese momento, en el COC, me pedían 10 mil pesos. Nos engañaban de que si pagábamos nos iban a posicionar en un lugar más seguros, con gente tranquila, donde no estaba gente que golpea. Como no tenía empezaron a presionar más. Nos dieron la tarjeta para hablar por teléfono y presionar la familia, pedir el dinero.

\footnotetext{
${ }^{39}$ La llamada Finca Pitiquitos.
} 


\section{AUTONOMIAINDÍGENA, VIOLENCIAY JUSTICIA}

Allí querían lana, si no dábamos el dinero nos metían al baño, después que lo había usado la gente sin bajarle la suciedad, y nos metían a lavar la taza con la mano, sin protección. Lo hicimos, no teníamos con que pagar. Estaba con otra gente desconocida que caímos al mismo tiempo, nos trasladaron al mismo tiempo.

Ya pasamos por todo eso, duramos allí 72 horas, pero si ven que no damos el dinero nos tienen hasta una semana, o 15 días. Como nunca tuvimos el dinero, pasó el tiempo, nos chingaron feo pero luego nos pasaron al penal, a la población, a los edificios, después de darnos el auto de formal prisión.

Allí empieza otro infierno más difícil, con más castigo, más tortura. Entre varios "representantes", que representan cada edificio, son como cuatro edificios y cada edificio tiene su preciso, y a parte estos precisos tienen un representante general, que recibe todas las órdenes del alcaide, y el alcaide recibe las órdenes del Director. No utilizan los custodios para robar, pedirle dinero a los presos que van entrando, sino que usan la gente que ya desde hace tiempo está recluida allí. En El Amate hay ocho precisos, dos en cada edificio, el mero preciso y otro que queda como reserva. También está el preciso general, que recibe órdenes de los alcaides, y el alcaide recibe órdenes del director.

Me empezaron a pedir la cantidad de 200 mil pesos, cosa que en toda mi vida he tenido, ni cinco mil pesos he tenido. Allí ya ellos hablan directamente con la familia, nos piden el número de teléfono a punta de patadas, y hablan presionando, amenazando nuestra salud.

Empezaron entonces una serie de presiones muy fuertes. Yo trataba de detenerlas, decía que iba a haber dinero pero que esperaran, era mucho y necesitaba tiempo para reunirlo. Así pasó una semana, durante la que siguieron golpeándome, haciéndome lo mismo que la judicial al principio: me metían al tambo de agua, me embolsaban, golpeaban, me metían en el drenaje, lleno de mugre. Hay un baño especial, no sé qué se le pueda llamar: es un cuarto encerrado, sin ninguna ventilación; allí me encerraron, llenaron veinte litros de cloro y me hicieron lavar con las simples manos, tenía que rascar el piso, las paredes. El cloro es como el ácido, quedaron mis manos quemadas. Me sacaron a golpes y otra vez me llevaron al teléfono a pedir dinero.

Estuve allí ocho días. El último día fue cuando, con una tarjeta que me dieron para hablar a la familia, aproveché y hablé en tzotzil ${ }^{40}$ para que no me entendieran, y pedí a la familia que vieran la forma de ayudarme, porque allí me iban a matar.

Así se empezaron a hacer más denuncias, juntos con los del Frayba. Ese día llegó una visita, una compañera y un compañero

\footnotetext{
${ }^{40}$ Aureliano es bilingüe (chol y tzotzil).
} 
Cuando ellos estaban allí el alcaide y el director supieron que era gente de Derechos Humanos. Antes aquellos decían "aquí nadie puede entrar, ni el gobernador, mucho menos derechos humanos". El director los corrió y los sacó afuera. . El director no quería que se denunciara, que se supiera lo que estaba pasando. Pero ya había salido en el periódico, y la compañera llegó a animarme; que iban a haber más presiones y torturas, pero solo así podíamos dar a conocer públicamente las anomalías que había adentro del penal.

Los compañeros que me visitaron me dijeron que platicara, que encontrara un acuerdo con los presos integrantes de La Voz del Amate que estaban en el plantón. Ya habíamos hablado, pero estábamos secuestrados, no nos dejaban salir de aquel lugar ni para ir al baño. Yo sabía más o menos donde tenían su campamento, había una persona, un doctor que también estaba preso, creo que simpatizaba con La Voz del Amate, y me llevaba información a mí, y también daba la información al plantón de lo que estaba pasando.

Yo me quedé solo y fue el momento más difícil. Me golpearon y me internaron en la clínica. Pero los compañeros y mi familia ya habían hecho muchas denuncias. El director ya le bajó. Antes nadie hizo esto; los derechos humanos del estado, los jueces, los MP, los médicos tienen la misma visión, los mismos intereses. Nunca se sabía nada afuera.

El director nos empezó a hacer regalías para que dejáramos de denunciar. Pero yo tenía un gran coraje...Se hizo denuncia ante la Corte Interamericana, en la ONU, de cómo estaban coordinados para hacer ese tipo de corrupción en el penal, y la noticia llego a manos del gobernador y el gobernador manda al fiscal y el fiscal manda a los jueces y al director. Ya luego empezaron a pensarle, a querer comprarnos, a regalarme cositas, y a preguntarme que quería, en donde quería estar, me llevaban al médico para ver si estaba bien...

Muchos intentaban hacer sus denuncias pero estas nunca salían, pero con nosotros fue diferente, salió a la luz todo lo que pasaba y eso es lo que les duele, muchos se quedaron sin trabajo, otros tienen orden de aprensión o están detenidos, porque pesó la denuncia que se hizo. A pesar de todo yo considero que salimos ganando, lo importante fue que yo resistí, aunque con el miedo de que nos mataran. Yo vi durante que yo estuve como la gente se moría, se morían no porque se suiciden o se enfermen, porque los mataban a golpes, si no hay dinero para darles. Me di cuenta que es un lugar donde hay mucho dinero, droga de todo tipo, supuestamente está prohibida en todo el penal pero no es así... también hay mucho dinero, lo que le sacan a la gente que va entrando.

Pero pues es una historia muy triste... 


\section{AUTONOMIAINDÍGENA, VIOLENCIAY JUSTICIA}

Estuve allí ocho meses; después de todas las torturas me dejaron en un lugar más seguro, donde supuestamente me vigilaban, empezaron a preocuparse más por nosotros, por mi principalmente, el director dio orden que no me tocaran, que no me pasara nada.

Con el tiempo tuve la necesidad de acercarme, porque ya no me visitaba la familia, estaba muy lejos. El Frayba hicieron esa solicitud de traslado al Cereso 5, llegó el permiso y me traen. Mientras estaba en El Amate preguntaba cómo era un traslado: si el traslado era llegar a otro penal y todo era tranquilo, decían "si es un traslado voluntario sí, llegas tranquilo, pero si es un traslado por orden de las autoridades, entonces otra vez a sufrir". Como era voluntario, yo estaba tranquilo.

Pero no fue así, los directores tenían mala imagen de mí por todo lo que se había hecho, ya me habían "recomendado" con el otro director corrupto que está a cargo del Cereso 5.

Empezaron nuevamente una serie de castigos, me encerraron, me sacaban al sol y ahí me tenían durante varios días, los que me visitaban veían que estaba quemado por el sol, y no me pasaban a la población. Y me empecé a imaginar que lo que querían era dinero, y sí, es lo que querían. Me encierran en el espacio de castigo y allí me tienen durante varios días.

Al final me pasan a población, con orden del director y el alcaide me llevan a un lugar encerrado donde estaban todos los precisos y me dicen "las reglas de este penal es que todos los que llegan tienen que pagar un dinero". Les dije "yo no soy nuevo, vengo del Amate". "De todos modos debes dar diez mil pesos".

Yo estaba más despierto, les dije "No tengo, si quieren castigarme o pegarme adelante, háganlo". Finalmente les dije que me dejaran ver si la familia podía apoyarme. Pasaron varios días, me llamaban para preguntarme si lo había conseguido.

Nuevamente hicimos denuncias de lo que estaba pasando.

Tanto coraje les dio a las autoridades que me acusaron de intento de fuga y amotinamiento. Estaba yo encerrado en mi celda, en la cueva, abajo, en el piso, ya que nunca tuve dinero y no pude comprar una "plancha", o sea un lugar en un dormitorio. Allí estaba sin imaginar lo que estaban planeando contra mí.

A las 3 o 4 de la tarde me llaman los precisos y los alcaides, ya habían avisado al director que yo estaba amotinando la gente, que me estaba fugando. Llegó el director a preguntarme qué pasaba. Yo le respondí que estaba durmiendo y no sabía, simplemente me estaban pidiendo un dinero y ahora me están fabricando este delito porque no pagué.

En ese momento, además del delito que me fabricaron para meterme a la cárcel, también me estaban inculpando de otro delito, me querían dar 60 años de cárcel.

En ese momento llegó un representante del Frayba, y se empezaron a hacer investigaciones. 


\section{Capitulo 5. La justicia autónoma y la justicía del Estado}

Entonces las autoridades ya le bajaron. ${ }^{41}$

En el testimonio, junto con la descripción detallada de las torturas y la detención arbitraria, así como de la corrupción que priva en la cárcel por medio del "autogobierno" de los precisos, destaca el uso político de la justicia, ya que Aureliano fue detenido y encarcelado sin una acusación clara, y fue interrogado por meses sobre las redes organizativas del EZLN. Sin embargo, la alta concentración de presos políticos -es decir militantes ligados a alguna organización campesina o indígena- en las cárceles chiapanecas, encarcelados con el objetivo de restar fuerza a los movimientos sociales, resultó ser contraproducente para el mismo gobierno que impulsó la estrategia. Entre 1995 y 2011 estos presos politizados dieron vida a diferentes procesos de organización y lucha para los derechos humanos al interior de las cárceles, una experiencia inédita que no se ha reproducido en ningún otro estado de la república.

La organización de los presos inicia en el penal de Cerro Hueco, en Tuxtla Gutiérrez, según el testimonio de Javier Elorriaga (militante zapatista que allí estuvo encarcelado por más de un año):

A principios del '95, cuando el gobierno de Zedillo rompe unilateralmente la tregua con el EZLN, en Cerro Hueco podíamos encontrar sobre todo, hablando de los presos indígenas, a los pobres, $[\ldots]$ acusados mayoritariamente por delitos relacionados con la siembra de mariguana, y a los miembros de las organizaciones que se enfrentaban a los latifundios, disfrazados y no tanto, de la familia revolucionaria chiapaneca. La mayoría de ellos pertenecían al PRD. A partir de marzo de ese mismo año, luego que dos presuntos zapatistas detenidos en la ofensiva de febrero de '95 se vuelven huéspedes famosos de la cárcel, empiezan a llegar detenidos de la zona norte del estado, varios de ellos ya acusados indirectamente de pertenecer a las bases de apoyo del EZLN. ${ }^{42}$

En 1996 se conforma la Voz de Cerro Hueco, integrada por un grupo de presos zapatistas y de otras organizaciones; se realizó la primera huelga de hambre en demanda de su libertad, logrando que también las comunidades de origen de los presos, más allá de sus familias u

\footnotetext{
${ }^{41}$ Aureliano Álvarez, entrevista, San Cristóbal de las Casas, diciembre 2007.

42 Javier Berdegue Elorriaga, "Cerro Hueco y la lucha por la transición democrática", Motion Magazine, 12 de septiembre 1998, <http://www.inmotionmagazine.com/ello2.html>, consultadoel 25 agosto 2014.
} 


\section{AUTONOMIAINDÍGENA, VIOLENCIAY JUSTICIA}

organizaciones de referencia, se integraran a las movilizaciones por su liberación y reivindicaran públicamente a sus presos. Según Elorriaga:

Era muy común que los presos te contaran que en su comunidad existían cerca de 100 órdenes de aprehensión, por lo que era imposible para sus compañeros el salir de sus refugios e ir a visitarlos. [...] En el verano del '96 y a lo largo del '97, fue cuando se dieron las primeras negociaciones entre las comunidades desplazadas y el gobierno chiapaneco y fue en esas reuniones donde las propias comunidades condicionaron cualquier arreglo para ellas a la libertad de sus presos políticos.

En el año 2000 eran casi ochenta los presos políticos organizados en Cerro Hueco, y en esa fecha se conformó otro grupo, compuesto por integrantes del magisterio encarcelados por su activismo: La Voz de la Dignidad Rebelde, que mantuvo una estrecha colaboración con el grupo zapatista. ${ }^{43}$

La Voz de Cerro Hueco permaneció activa, con viejos y nuevos integrantes, hasta 2004, cuando el penal fue cerrado y los internos trasladados a El Amate, en Cintalapa. Antonio, indígena tzeltal, fue encarcelado en Cerro Hueco desde principio de 2002. Entrevistado un mes después de su liberación, en abril 2008, relató que, al ser aislado del grupo de detenidos organizados en La Voz de Cerro Hueco, se abocó a denunciar las extorsiones y las torturas que estaba padeciendo, más crueles por su condición indígena y haberse declarado como base de apoyo zapatista.

Cuando empecé a denunciar abarqué todas las autoridades, cuando salió el periódico al siguiente día me mandó a llamar el director de porque hice esa denuncia. Le dije que era necesario para mí, porque soy indígena no pueden abusar de mi cultura. Allí me empezaron a amenazar más, tú no eres preso político. Saben de por sí quienes somos, si no nos quieren reconocer con más razón vamos a denunciar. Con el tiempo muchos de los internos se dieron cuenta que sí, que dentro de la cárcel se puede organizarse.

En el 2005, ya en el Amate, iniciamos a organizarnos también, pero clandestinamente, porque allí los precisos cuando ven que te organizas te mandan a golpear. Pero vimos que es necesario

\footnotetext{
${ }^{43}$ Alberto Patishtán, entrevista, penal de El Amate, 6 de enero de 2008.
} 


\section{Capitulo 5. La justicia autónoma y la justicía del Estado}

denunciar todas las anomalías adentro de la cárcel, y yo ya tenía la experiencia de organización de La Voz de Cerro Hueco. Y había compañeros al exterior que nos respaldaban. ${ }^{44}$

Nació así La Voz del Amate, conformada por trece presos políticos, que el 6 de enero de 2006 (fecha en que arrancó la iniciativa política del EZLN llamada Otra Campaña) declararon su existencia, abandonaron las celdas y se instalaron en un plantón permanente en el patio abierto del penal. "La Voz del Amate nació para ser un puente, un cobijo para los que sufren. Es una voz que sale, y cuando sale denuncia lo que está pasando adentro del penal", relató un integrante del grupo entrevistado en enero del 2008. Las denuncias de la Voz del Amate sobre la situación de violencia, corrupción y violación a los derechos de las personas cometidas en el penal, difundidas por el CDHFBC y otras organizaciones, lograron la destitución del director del penal:

Las autoridades carcelarias se dieron cuenta que no estamos solos e iniciaron a respetar y fueron reduciendo el maltrato de los internos. Ahora a cada nuevo preso que entra, le dan el número de teléfono del CDHFBC para que se comunique si recibe amenazas. Entonces los precisos ya no pueden presionarlos más. Por el trabajo de la Voz del Amate fue cambiando la situación en la cárcel. Eso es lo que vivimos nosotros, es la vida de un preso, que es difícil enfrentar pero todo es posible hacer. ${ }^{45}$

Pero la semilla de organización nacida en Cerro Hueco, cuya lucha por la libertad se fue enriqueciendo con la lucha en defensa de la dignidad de las personas encarceladas, no creció solo en El Amate. Aureliano, al que no le fue permitido encontrar los integrantes de La Voz del Amate, pero que de manera individual y respaldado por el comité de los familiares y el CDHFBC logró difundir muchas denuncias, al ser trasladado al penal núm. 5 de San Cristóbal, Los Llanos, comenta:

Mucha gente de comunidades pobres me comentaba su situación. Allí conocí a varios compañeros, que también simpatizaban en la organización. Así me vino la idea que para estar mejor debíamos unirnos, y así formamos la agrupación La Voz de Los Llanos. Nace el 6 de abril del 2006 por la iniciativa de cinco presos, a principio de 2008 ya son 14 personas.

\footnotetext{
${ }^{44}$ Antonio Díaz Ruiz, entrevista, México D.F., mayo 2008.

${ }^{45}$ Idem.
} 


\section{AUTONOMIAINDÍGENA, VIOLENCIAY JUSTICIA}

Empezamos y cualquier problema que había nos defendíamos como grupo, y teníamos más fuerza. Todo lo que pasaba lo sacamos a la luz pública, la corrupción de los funcionarios, como le robaban a la gente, a las visitas, el negocio de los puestos que venden chicle, café, comida. El director que estaba allí cuando llegué fue despedido, y el alcaide fue arraigado creo, a raíz de todas las denuncias que también había hecho otra gente.

Pasó el tiempo y llegó la Contraloría del Estado a verificar lo que estaba pasando, ya tenían mucha información de lo que había salido en los periódicos. La Contraloría tomó una serie de declaraciones y las cosas empezaron a cambiar, fue más tranquilo, los precisos limitaron su prepotencia, entró un nuevo director que sabía que tenía que actuar con precaución.

Estuve todavía seis u ocho meses más en la cárcel, durante los cuales cambiaron como tres directores, porque la gente aprendió a hacer su denuncia, acudían con nosotros a preguntarnos como debían actuar.

El último director es el que sigue ahora. Inmediatamente al siguiente día de su entrada yo hablé con él, para plantearle la realidad del grupo La Voz de los Llanos, que nosotros vamos a respetar las autoridades siempre y cuando éstas respeten nuestros derechos. Porque en la cárcel también tenemos derechos, aunque limitados.

Cuando se realizó la reforma del estado llegó el director estatal de todos los penales, a preguntar por la situación, nosotros les comentamos que íbamos a seguir luchando contra todas las injusticias. Ahora disminuyó mucho la corrupción, todavía hay, pero es menos. ${ }^{46}$

La lucha al interior de las cárceles chiapanecas alcanzó su máxima fuerza entre febrero y marzo del 2008, cuando rebasó la función de denunciar las irregularidades y retomó con fuerza la lucha por la libertad incondicional de todos los presos "políticos, de conciencia e injustamente presos". Esta última etapa de las Voces inició el 12 de febrero de 2008, cuando Zacario Hernández, encarcelado junto con otras personas de la comunidad alteña de Tres Cruces por disidencia política y religiosa, inició una huelga de hambre indefinida demandando la libertad propia y la de sus compañeros. La iniciativa tuvo un éxito inesperado: con el pasar de los días, decenas de presos en distintas cárceles se declararon en huelga de hambre o ayuno, hasta sumar, a principios de marzo, 46 personas, entre hombres y mujeres, recluidos en las cárceles de El Amate, Los Llanos, Playas de Catazajá y la cárcel municipal de Tacotalpa en Tabasco. Apoyando la lucha de los internos, sus familiares mantuvieron por varias semanas un plantón frente al Palacio de Gobierno en Tuxtla Gutiérrez. La liberación de Zacario

\footnotetext{
${ }^{46}$ Aureliano Álvarez, entrevista, San Cristóbal de las Casas, diciembre 2007.
} 


\section{Capitulo 5. La justicia autónoma y la justicía del Estado}

Hernández, después de 34 días de huelga de hambre y 5 años de internamiento, puso en evidencia que desde el principio no existían elementos suficientes para su detención y condena, y que en su caso, como en miles más, la "justicia” se había ejercido de manera arbitraria y facciosa.

La excepcional movilización de los presos logró que, el 31 de marzo, fueran liberadas 137 personas que cumplían condenas o estaban procesadas por delitos del fuero común. De los que estaban en huelga de hambre, 17 personas quedaron en la cárcel, ${ }^{47}$ siendo liberados paulatinamente en los cinco años siguientes. ${ }^{48}$

La mayoría de los presos movilizados, así como de los liberados, son indígenas, proporción que refleja la composición de los internos en las cárceles chiapanecas, como he podido constatar personalmente en las visitas a los penales de El Amate y Los Llanos. Los presos con quienes he podido hablar confirman este dato: “acá casi todos somos indígenas, porque no tenemos dinero para los abogados, y los traductores de oficio no sirven. Nos tratan como animales por no entender la castilla". Algunos de los internos que se reunieron para platicar con quienes entramos en la cárcel de Los Llanos no entendían el español, así que uno de ellos traducía la plática al tzotzil. De tal manera conocí uno de los miles de casos de ausencia de justicia que caracterizan el sistema judicial en México: el de dos jóvenes tzotziles, monolingües, que después de un proceso plagado de irregularidades y torturas, en el que nunca tuvieron un traductor, fueron sentenciados por homicidio a 25 años. Uno de ellos ya tenía casi 6 años en la cárcel. Ambos fueron liberados al ser revisado su expediente, después de pasar 35 días en huelga de hambre.

Según un estudio de las Naciones Unidas, "el hecho de que los pueblos indígenas estén sobrerrepresentados en la población carcelaria es un problema de alcance mundial” (2010:3). En México, según cifras de la Comisión Nacional de Derechos Humanos (CNDH), el 5\% de la población carcelaria (entre sentenciados y procesados) son indígenas, ${ }^{49}$ de los cuales el $35.5 \%$

\footnotetext{
${ }^{47}$ Estos siguieron la huelga de hambre hasta el 5 de abril de 2008 cuando, tras el llamado del Obispo emérito de San Cristóbal Samuel Ruiz García, suspendieron la protesta. Los detenidos en El Amate tenían más de 40 días en huelga y los de Los Llanos más de 30, durante los cuales tuvieron insuficiente atención médica, y su salud estaba ya fuertemente comprometida.

${ }^{48}$ El último que alcanzó la libertad fue Alberto Patishtán, indígena tzotzil, recluido desde el 2000 al 2013.

498.486 personas sobre un total nacional de 163.929 presos (fuente de datos: Comisión Nacional de derechos Humanos, Informe de Actividades 2013). En el total de la población mexicana, los indígenas representan el 14\%, pues se declararon indígenas 15.7 millones de un total nacional de 112,336,538 (fuente de datos: INEGI, Instituto Nacional de Estadística y Geografía, Censo de Población y Vivienda 2010).
} 


\section{AUTONOMIAINDÍGENA, VIOLENCIAY JUSTICIA}

están recluidos aún sin sentencia condenatoria. Chiapas es el estado con el mayor número de indígenas encarcelados, siendo el $24 \%$ del número total de internos en el estado. ${ }^{50}$

Estos datos, junto con los testimonios de abuso y las experiencias de lucha en los penales -impulsadas principalmente por presos indígenas- expresan de manera contundente la situación de indefensión que estos padecen cuando entran en contacto con el sistema judicial y penal oficial. Asimismo, el panorama que he detallado quiere representar, lejos de esencialismos teóricos o idealizaciones de las sociedades indígenas, el más contundente argumento en defensa de los sistemas de justicia indígena e intercultural. En este sentido, Jane Collier, destacada antropóloga jurídica con casi cincuenta años de trabajo de campo en Chiapas, comenta:

Quienes critican dichos sistemas [indígenas] necesitan compararlos con los juzgados estatales existentes, en vez de con una noción idealizada del derecho occidental. Cuando se hacen las comparaciones correctas, resulta evidente que quienes buscamos justicia tenemos más probabilidades de encontrarla con los jueces indígenas que en los tribunales estatales (2009:94).

\section{La relación entre la justicia autónoma zapatista y el Estado}

A pesar de que, formalmente, los representantes de las Juntas de Buen Gobierno zapatistas afirman no tener ninguna relación con las autoridades gubernamentales, existen en el ejercicio cotidiano del autogobierno inevitables puntos de contacto, relación e incluso negociación. Esto se debe a la amplia extensión territorial de los gobiernos autónomos, y a la situación de diversidad política y de interlegalidad que caracteriza estos territorios. Así, en el mismo espacio (región o incluso comunidad) hay quienes reconocen la autoridad del agente municipal y del presidente municipal "oficial", quienes se identifican con la autoridad zapatista, el Concejo Municipal Autónomo y la Junta de Buen Gobierno, y los que acuden a una u otra instancia dependiendo del asunto a resolver, de los resultados esperados, y de los equilibrios políticos coyunturales. De tal manera que las autoridades autónomas y las gubernamentales en

\footnotetext{
${ }^{50} 1.222$ personas en un total de 5.088 presos en el estado (fuente de datos: Comisión Nacional de derechos Humanos, Informe de Actividades 2013; INEGI, Instituto Nacional de Estadística y Geografía, Censo de Población y Vivienda 2010).
} 


\section{Capitulo 5. La justicia autónoma y la justicía del Estado}

más de una ocasión se han encontrado ambas involucradas en la resolución de un conflicto, ya sea con posiciones enfrentadas, ya sea por la necesidad de articulación en el desempeño de sus funciones.

El área de justicia es la única donde las bases de apoyo han mantenido vínculos directos o indirectos con las autoridades oficiales, pues en el caso de la educación, la producción o la salud, los zapatistas rechazan cualquier relación con las autoridades y los programas sociales gubernamentales. Asimismo, el ámbito de la justicia es el único en el que se han otorgado servicios también a la población no zapatista.

En un análisis sobre la práctica jurídica de las instituciones indígenas, Donna Lee Van Cott afirma que:

La ley indígena puede ser sustitutiva en comunidades donde la ley del Estado es esencialmente inexistente; donde las comunidades indígenas y campesinas están geográficamente distantes de las instituciones formales y son completamente responsables de la administración de justicia y la resolución de disputas. Puede ser complementaria donde hay más coordinación entre las autoridades indígenas y estatales (Van Cott 2003: 9).

Frente a esta tipificación, la autora sugiere que las dos categorías no se vean como separadas, sino como dos polos de un continuum, en medio del cual "hay casos de instituciones informales de justicia, que coordinan su trabajo con los funcionarios estatales en la medida que sea necesario, dada la presencia de presión interna o externa y la disponibilidad de tales servicios" (Van Cott 2003: 35). Entonces, un sistema de justicia indígena puede moverse hacia el extremo sustitutivo o hacia el complementario, dependiendo de las condiciones particulares y de las relaciones de fuerza que se instauran con las instituciones oficiales en un momento dado. En segundo lugar, hay que considerar que "un sistema legal indígena puede ser complementario con relación a ciertos aspectos (por ejemplo: la organización comunitaria interna) y competitivo con respecto a otros (por ejemplo: la ley penal)" (Van Cott 2003:9), pues las relaciones entre los sistemas no se dan de forma homogénea, ya que el desarrollo de las instituciones indígenas no se realiza uniformemente en todos los aspectos. El caso del Sistema de Justicia, Seguridad y Reeducación Comunitaria del estado de Guerrero es un claro ejemplo de dicha afirmación, pues se constituye de manera autónoma y actúa en los hechos de forma sustitutiva con el sistema de seguridad y de justicia estatal, pero la forma de gobierno 


\section{AUTOONOMIIAINDÍGENA, VIOLENCIAY JUSTICIA}

indígena en las comunidades se mantiene en términos de articulación complementaria con la organización del estado.

La ley indígena entonces puede ser también competitiva:

Donde las autoridades tienen relaciones hostiles con las instituciones formales- particularmente en países donde no ha sido todavía formalmente reconocida. Aún más, la categoría de competitiva está abierta a la interpretación. Las sanciones indígenas que se interpreta violen la ley del Estado -como el castigo corporal o el trabajo comunitario forzado [o la encarcelación por dos o tres días] pueden ser interpretados como no competitivos, si el intérprete evalúa dichas prácticas en el contexto de la cultura indígena (Van Cott 2003: 9).

Más que interpretar la actuación de las autoridades indígenas en un momento dado con una sola de estas definiciones (sustitutivas, complementaria, analítica), creo más bien que se pueden encontrar, incluso en la misma coyuntura espacio-temporal, situaciones en las que la justicia indígena actúa de una forma, y situaciones distintas en que actúa en otra, dependiendo de los actores implicados, o bien en momentos distintos de un mismo conflicto se puede encontrar uno u otro comportamiento.

A una primera mirada, la justicia autónoma zapatista aparece sustitutiva y competitiva, sin embargo, en situaciones específicas ha desempeñado un papel complementario, o más bien ha establecido cierta coordinación con las instancias judiciales del estado. En un documento muy conciliatorio, que refleja la importante apertura del EZLN hacia los representantes gubernamentales en el periodo siguiente a la creación de las Juntas de Buen Gobierno (20032004), el vocero del EZLN plantea de tal manera la relación con el gobierno del estado:

Respetar es reconocer, y las Juntas de Buen Gobierno les reconocen existencia y jurisdicción al gobierno del estado y a los municipios oficiales y, en la mayoría de los casos, las autoridades oficiales municipales y el gobierno del estado reconocen la existencia y jurisdicción de la JBG. $^{51}$

Analizando la realidad e incluso los discursos de las Juntas de Buen Gobierno, se observa que esta posición conciliatoria no ha prosperado, debido a las múltiples amenazas y afectaciones, directas y encubiertas, que los indígenas chiapanecos tuvieron que enfrentar en los últimos

\footnotetext{
${ }^{51}$ SubComandante Insurgente Marcos, "Leer un video. Cuarta parte: cuatro falacias", agosto del 2004.
} 


\section{Capitulo 5. La justicia autónoma y la justicía del Estado}

diez años. Sin embargo, en el aspecto específico de la justicia, sí se ha cumplido, aunque no en todos los casos, lo que plantea el mismo documento:

Las JBG mantienen un canal de comunicación, mediante la Secretaría de Pueblos Indios, con el gobierno del estado de Chiapas. Cuando se presenta una agresión a zapatistas y no hay comunicación con los agresores para determinar por qué fue el problema y tratar de llegar a un arreglo dialogado, las Juntas de Buen Gobierno indican a la autoridad autónoma que inicie una investigación y, al mismo tiempo, turnan los datos del caso a las autoridades estatales. Mientras no se determine con claridad de qué va el asunto no se recurre a las denuncias, a la movilización o a las represalias.

Según el comunicado, este mecanismo de coordinación se implementó con el objetivo específico de resolver conflictos entre organizaciones, que muchas veces encubren problemas individuales. Para evitar que el conflicto adquiera dimensiones colectivas y se busque resolver en base a una relación de fuerza (a través de movilizaciones o del secuestro de militantes del grupo opositor), se implementó el mecanismo de la investigación de manera sistemática para averiguar "si algo tuvo causas políticas o si se trata de crímenes del fuero común [...] Si el asunto no es político y es penal, entonces se espera un tiempo razonable para que la justicia estatal ejerza su acción. Si no, pues entonces entra en acción la justicia zapatista". 52

En la investigación realizada en el archivo de expedientes de la Fiscalía Especializada en Justicia Indígena, ubicada en San Cristóbal, encontré las evidencias de la coordinación que se ha logrado entre las autoridades autónomas y las del estado.

Se trata de un caso de violación ocurrido en una comunidad del Municipio Autónomo 16 de Febrero (Zona Altos) en el otoño 2004, pero conocido por la Fiscalía muchos meses después (junio 2005). ${ }^{53} \mathrm{He}$ realizado una sintética reconstrucción de los hechos y de la actuación de los distintos actores basándome en los documentos que integran el expediente. Después de la violación de una joven de 14 años, los padres (bases de apoyo zapatistas) acuden con el Agente Municipal autónomo, quien los remite con la autoridad comunitaria; ésta considera que el hecho no era de su competencia y los dirige con el Juez Municipal Autónomo

\footnotetext{
52 Ídem.

${ }^{53}$ Fiscalía Especial del Estado, Subprocuraduría de Justicia Indígena, Fiscalía del Ministerio Público del Primer Turno, Acta administrativa núm. 000434/IA01/2005, fecha de inicio: 17 de junio de 2005, delito: posible violación.
} 


\section{AUTONOMIAINDÍGENA, VIOLENCIAY JUSTICIA}

del MAREZ 16 de febrero. Considerada un delito grave, la violación es de competencia de la Junta de Buen Gobierno, con quienes llega finalmente la familia agraviada. En fecha 25 de octubre de 2004, la JBG expide un documento, firmado por sus cinco representantes y el Juez Municipal Autónomo, y dirigido a la Secretaría de Pueblos Indios (SEPI) y al gobierno del estado, para "darles a conocer el problema" y "esperar una solución justa". Muchos meses después, el 17 de junio del 2005, el documento, junto con un referto médico que atestigua la violación, es entregado a la Fiscalía Especializada por un funcionario de la SEPI. La Fiscalía asume el caso y realiza las investigaciones; los peritos y el médico legal son recibidos, en la comunidad, por la Junta al completo y los padres de la joven, que se somete a un nuevo examen médico. Sucesivamente, una delegación del Municipio Autónomo acude a las oficinas de la SEPI en San Cristóbal para conocer el desarrollo del procedimiento legal, y allí se les informa que, al día siguiente (29 de noviembre 2005), la joven y sus padres deben acudir a la Fiscalía y rendir la declaración para que se abriera la averiguación previa. En consecuencia, la Fiscal del Ministerio Público de la mesa especializada en delitos sexuales pide al Juez mixto del ramo penal de Simojovel liberar la orden de aprensión en contra del acusado de la violación.

El caso expuesto muestra distintos mecanismos de coordinación: entre la Junta de Buen Gobierno y la Secretaría de Pueblos Indios, que sirve como intermediario con la Fiscalía. A su vez, la Junta de Buen Gobierno al emitir el documento inicial, y los integrantes del MAREZ al acudir a las oficinas de la SEPI, actúan como intermediarios y facilitadores para que los agraviados puedan tener un efectivo acceso a la justicia estatal. Asimismo, este caso muestra una de las formas en las que se concreta la interlegalidad: los agraviados acuden a la instancia de justicia autónoma y ésta considera remitir el caso o colaborar con la instancia oficial para su resolución; así el problema termina en la jurisdicción oficial.

Hay casos en que la articulación funciona en el sentido contrario, es decir que las personas, después de acudir a alguna instancia oficial, se dirigen a la autoridad autónoma esperando mejores resultados. El caso siguiente, relatado por la JBG en entrevista y también dado a conocer por medio de un comunicado oficial ${ }^{54}$ de la misma instancia, ilustra también uno de los mecanismos adoptados por las autoridades autónomas para no entrar directamente

\footnotetext{
54 "Denuncia de la Junta de Buen Gobierno Hacia la Esperanza, 15 de abril del 2007", <http://enlacezapatista.ezln.org.mx/2007/04/16/denuncia-de-la-junta-de-buen-gobierno-hacia-la-esperanza-15-deabril/>, consultado el 13 de julio 2014.
} 


\section{Capitulo 5. La justicia autónoma y la justicía del Estado}

en contacto con las autoridades oficiales, es decir difundir públicamente la información y, por medio de la denuncia, deslindar responsabilidades y fincarlas en las instancias oficiales. El caso ocurrió el 9 de abril 2007, cuando:

Dos personas, papá e hijo, mataron con pistola a otras dos personas [también padre e hijo, hiriendo a un hijo más] de la misma comunidad [La Esperanza, anexo de Guadalupe el Tepeyac]. Inmediatamente se reportó al Ministerio Público (MP) de Las Margaritas para que interviniera. Este dio largas y dejó pasar los días para que no se pudiera llevar a cabo la orden de aprensión, porque están dentro de nuestro territorio.

Quienes cometieron el delito se querían cobijar pasándose de zapatistas, mientras no lo son. Inmediatamente nosotros tuvimos que denunciar públicamente, que los zapatistas no cubrimos a asesinos, y que se autorizaba la detención de esta familia que no son zapatistas [en el comunicado, además del deslinde, la Junta da a conocer los nombres de los presuntos culpables del dúplice homicidio]. Pero como en la ciudad se trabaja a través de dinero, no hicieron caso a la familia que puso su demanda porque no conseguía el dinero que tenía que dar a las autoridades. Entonces acudieron a nosotros para saber que orientación les podíamos dar. Les preguntamos por qué habían decidido irse para allá [con el MP] y contestaron que ellos pensaron que allá iban a actuar inmediatamente, pero vieron que no y hasta que se cansaron y lo dejaron así. Cuando vinieron a consultarnos esa persona que había matado ya se había ido a los EEUU, sin que la autoridad de las Margaritas hiciera nada de justicia. ${ }^{55}$

El relato pone en evidencia que el mecanismo del "fórum shopping" es, en muchos casos, determinado por la decepción hacia las autoridades oficiales, lentas y corruptas. Asimismo, es emblemático el caso de las personas que, para evadir a la justicia oficial, se declaran zapatistas, utilizando instrumentalmente un supuesto "espacio extralegal" en el cual, según esta visión, se ubicarían las autoridades y las bases de apoyo zapatistas. Este punto tiene cierta relevancia porque pone al descubierto el uso político de la identidad rebelde que hacen no tanto los rebeldes mismos, sino los "otros" que con ellos comparten el territorio, e incluso las mismas autoridades oficiales. En entrevista, el Juez primero del ramo penal de Comitán explica, utiliza la misma lógica de la supuesta "extralegalidad" de los zapatistas, el motivo por el cual las instancias judiciales en muchas ocasiones no intervienen en el territorio. Desde otro punto de vista, esto puede aparecer un pretexto de las instancias oficiales -marcadas por el

\footnotetext{
55 Junta de Buen Gobierno, entrevista, 2009.
} 


\section{AUTOONOMIIAINDÍGENA, VIOLENCIAY JUSTICIA}

racismo y la discriminación- para desentenderse de sus obligaciones y evitar la labor de procuración de justicia en zonas indígenas:

Hay partes en un proceso que viven en esos lugares donde hay zapatistas, y allí las autoridades y las organizaciones civiles no tienen un fácil acceso, porque ellos son muy celosos, incluso la Policía Ministerial no tiene acceso, ellos nos informan que para no crear conflicto social porque son un poco agresivos, no dan cumplimiento a esos casos, cuando por ejemplo deben ir a citar alguien que está implicado en un juicio y vive en esos lugares que les llaman municipios autónomos. No se puede llevar a cabo esas diligencias. A veces hay que canalizar por medio de sus agentes municipales si es que los tienen, o si no simplemente ver como otras personas puedan llegar a esos lugares en un ambiente de compañerismo, no con la orden como citatorio por parte de la autoridad oficial. Son muy pocas veces que se ha logrado de que comparezcan. En la mayoría de los casos se cierra el caso y se escribe de que nos impiden el acceso a sus comunidades y ya. Pero me refiero a gente que vive en las comunidades zapatistas, no a personas que sean o se digan zapatistas: ellos no han venido nunca, no ha habido ningún procesado ni nos han llegado casos en que alguna parte que se declare zapatista. ${ }^{56}$

En la mayoría de los casos, particularmente en la Zona Selva-Fronteriza, los inevitables contactos entre las autoridades autónomas y las oficiales se realizan a través de la intermediación de otros actores, en particular los integrantes (sobre todo los abogados del Área de Defensa) del Centro de Derechos Humanos Fray Bartolomé de Las Casas (Frayba). Es también por este medio que la JBG envía comunicaciones a la autoridad oficial, como lo explican sus integrantes:

También mandamos a decir con carta al Ministerio Público que investiguen realmente el problema. Es el caso de un compañero que es de aquí cerca de Comitán, tenía orden de aprehensión. Los mismos hermanos se fueron a quejar en el MP para capturarlo y llevarlo a la cárcel. Entonces empezamos a investigar y vimos que era por un terreno, que lo están invadiendo a nuestro compañero: pero el MP ya había girado la orden de aprehensión sin investigar, sin saber si era cierto el delito. Entonces nosotros mandamos a cartear para decirle "sabes que, tienes que investigar el problema", y conseguimos el amparo para que el Ministerio Público empiece a investigar el problema. Y eso lo hacemos mediante los compañeros de

\footnotetext{
${ }^{56}$ Hermann Omar Villavider, entrevista, Comitán, enero 2009.
} 


\section{Capitulo 5. La justicia autónoma y la justicía del Estado}

derechos humanos, el Frayba. Ellos siempre nos visitan, cuando tenemos un problema grave, ellos son los que tramitan toda la documentación, los abogados, apoyan a investigar e mediar el problema, allá en la ciudad. Y sí se ha logrado liberar a muchos compañeros, con el apoyo de derechos humanos, el Frayba. ${ }^{57}$

En meses recientes, después del asesinato de un militante zapatista, Galeano, ocurrido en La Realidad en mayo de 2014, la postura de las autoridades autónomas de la región hacia las oficiales se ha tornado más estricta y más explícita. En un documento expuesto en la comunidad durante el homenaje público al fallecido, la Junta proporciona las siguientes indicaciones:

- Ninguna de las tres instancias civiles autoridad del pueblo, Concejos y JBG puede tener relación con el gobierno ni instituciones.

- Concentrarse a resolver problemas de compañeros bases de apoyo.

- Los problemas [de] zapatistas o no zapatistas se resolverán entre la JBG y autoridades del pueblo o representantes del grupo sin la presencia del personal de gobierno, presidente municipal o delegado.

Ya mencioné, en el capítulo 4, que en el caso del asesinato de Galeano la justicia zapatista manifestó los límites de su competencia, delegando el arresto de los homicidas a las instancias oficiales, desde luego, a través de la intermediación del CDHFBC, cuyos integrantes presenciaron al episodio violento.

He observado un especial cuidado por parte de las autoridades autónomas en evitar, en la medida de lo posible, los conflictos de competencias con las autoridades estatales (y el correspondiente "cuidado" de las autoridades estatales que alegan la "extralegalidad" de los zapatistas para evitar confrontaciones); éstos, sin embargo, son inevitables y han ocurrido en distintos momentos de la historia del movimiento zapatista en Chiapas. En los años posteriores al levantamiento la política gubernamental se caracterizó por un uso indiscriminado de la violencia y de todos los mecanismos represivos a su alcance: ejemplo de ello es la citada acción de desmantelamiento de varias cabeceras de Municipios Autónomos en 1998, entre ellas Amparo Aguatinta, en la frontera con Guatemala, donde fueron torturados y arrestados

\footnotetext{
${ }^{57}$ JBG, entrevista, La realidad, 29 de diciembre 2007.
} 


\section{AUTONOMIAINDÍGENA, VIOLENCIAY JUSTICIA}

53 indígenas; ocho de ellos, los integrantes del Concejo Autónomo, fueron encarcelados en Cerro Hueco acusados, entre otros cargos, de usurpación de funciones (por su labor de autoridad autónoma) y de privación ilegal de la libertad (por haber detenido un individuo).

En su trabajo sobre la administración de justicia informal comunitaria en América Latina, Van Cott (2003) evidencia tres tipos de conflictos que suelen emerger entre las instituciones estatales y las instituciones jurídicas informales. ${ }^{58}$

En primer lugar, están los conflictos relacionados a los procesos o procedimientos de resolución de conflictos. Éstos se crean porque los sistemas indígenas son más flexibles y dinámicos que la justicia formalizada, preocupándose más de proporcionar la solución adecuada para un caso específico que un precedente jurídico; y también porque los procedimientos pueden violar los estándares democráticos liberales de un debido proceso, tales como el derecho a un abogado, que frecuentemente no son parte de la cultura indígena.

Los conflictos de normas se deben a que los sistemas indígenas y occidentales pueden estar basados en distintos conjuntos de significados y valores culturales (Stavenhagen 1988:102). Primero, hay transgresiones en la ley indígena que no son consideradas como delitos en la ley occidental -tales como el chisme, la brujería y el disenso religioso, que son sancionados porque pueden quebrar el orden social del pueblo en cuestión, de la misma forma que acciones que para la racionalidad dominante representan una ruptura del orden social -por ejemplo el consumo de sustancias alucinógenas, no son consideradas de la misma forma en determinadas culturas. En segundo lugar, la ley indígena tiende a dar prioridad a la paz en la comunidad sobre los derechos de los individuos. El trabajo comunitario, como forma de reeducación de los delincuentes adoptado por la justicia zapatista, es considerado legítimo por los habitantes de las comunidades de la Selva, ya que el valor atribuido a la comunidad en su conjunto los lleva en este caso a poner en un plano inferior los "derechos individuales". Esta consideración tiene que ver también con los conflictos sobre el castigo; la sanción es seguramente uno de los elementos comunes a todos los sistemas normativos existentes en el mundo, pero la idea que se tiene sobre la sanción y las diversas formas que se usan para aplicarla cambian de conformidad con los principios y valores que tiene cada sociedad.

\footnotetext{
${ }^{58}$ La autora asimila la justicia informal a la justicia indígena, posición en la que difiero fundamentalmente; sin embargo, su propuesta de análisis bien se puede aplicar al caso de justicia indígena que estoy estudiando.
} 


\section{Capitulo 5. La justicia autónoma y la justicía del Estado}

El Estado interviene más frecuentemente cuando los defendidos y observadores reclaman que las sanciones impuestas violan los derechos humanos o constitucionales del defendido. Tales acusaciones han causado problemas a las organizaciones indígenas, aunque éstas, en su mayoría, reconocen la autoridad de las convenciones internacionales sobre derechos humanos, y regularmente hacen reclamos basados en ellas. Las acusaciones han generado debates dentro de las comunidades, particularmente con respecto al rol de la mujer en los sistemas de autoridad indígena. En muchos casos, las prácticas que no han soportado un escrutinio han sido modificadas (Van Cott 2003).

\section{Justicia indígena y "derechos humanos"}

Alrededor del campo político y discursivo de los derechos humanos, y de las interpretaciones y usos que se da a esta herramienta desde distintas posiciones (Estado, autoridades indígenas, organismos defensores de los derechos humanos), se articula otro nudo de la relación entre la justicia autónoma y el Estado, el último que tomaré en consideración.

En dos de los conflictos mencionados ha aparecido el tema de los derechos humanos como campo de disputa: el "caso Armín Morales", expuesto en el Capítulo 4, y el de Amparo Aguatinta (Capítulo 3). En éste último caso, la intervención violenta del Ejército, aunque orquestada de acuerdo a una agenda política independiente, tuvo como pretexto la "protección de los derechos humanos", lo que involucró entre los presuntos responsables incluso al Alto Comisionado de las Naciones Unidas para los Refugiados (ACNUR). De acuerdo a una reconstrucción hemerográfica de los hechos, en abril 2008 dos hermanos de origen guatemalteco, refugiados residentes en la zona, fueron acusados frente al Concejo Autónomo de tala ilegal de madera, por lo que uno de ellos fue detenido y recluido en la cárcel de la comunidad por una semana, mientras las autoridades autónomas buscaban un arreglo conciliatorio con los acusadores; tarea que se complicó, pues el acusado negó su responsabilidad y rechazó la reparación del daño. Pasada una semana, llegó al Concejo el segundo acusado, quien fue detenido y se dejó en libertad al hermano. Mientras, la ACNUR había sido informada del suceso y pidió la intervención de la Comisión Mexicana de Ayuda a Refugiados (COMAR) para solucionar la detención del guatemalteco. En su lugar, llegó el operativo militar, del cual la ACNUR se deslindó inmediatamente. No obstante este deslinde, 


\section{AUTONOMIAINDÍGENA, VIOLENCIAY JUSTICIA}

queda el hecho de que una supuesta violación a los derechos humanos, en lo específico la detención por más de 36 horas como sanciona la Constitución, haya sido usada para justificar un acto cuya razón era más bien política, es decir la voluntad gubernamental de arrasar con el proyecto autonómico zapatista, cuyas autoridades fueron encarceladas durante un año y medio por "usurpación de funciones" y "secuestro".

Según Sousa Santos (1996), el discurso sobre los derechos humanos, aunque siga siendo abanderado por los movimientos de resistencia, fue apropiado por el Estado, que pretende ahora ser el garante de éstos. La movilización social alrededor de los derechos humanos y de la dignidad puede tener un valor emancipatorio sólo si se apropia de los contextos culturales locales: de no ser así, continuarán siendo políticas que imponen el modelo de la "globalización desde arriba", como advierte Speed considerando que el discurso sobre los derechos humanos se ha ido difundiendo al mismo tiempo que el viraje hacia las políticas neoliberales de los Estados. En este contexto, los derechos humanos asumen una valencia regulatoria y hasta auto-regulatoria, siendo utilizados para obstruir o cooptar demandas políticas más radicales (Speed 2005).

De acuerdo con Collier y Speed (2000), frecuentemente el discurso de los derechos humanos se utiliza instrumentalmente como un mecanismo de control por parte de los gobiernos, con el fin de acusar a las autoridades indígenas de violaciones y limitar su legitimidad, y no para sancionar los abusos cometidos por las fuerzas policíacas y los poderes institucionales. Frecuentemente, cuando las autoridades indígenas actúan de acuerdo a su propio sistema jurídico y aplican las sanciones consecuentes, vienen acusadas de violación a los derechos humanos individuales. ${ }^{59}$ Es por ejemplo el caso de la práctica común a muchos pueblos de México de tener preso en la cárcel de la comunidad hasta por dos o tres días quien haya cometido una falta menor, como emborracharse (les toca una noche de cárcel) o un pequeño robo; esto por lo regular representa toda la pena, sin implicar más deberes para el acusado (pago de multas, etc.). Pero dicha práctica, reconocida por los pueblos, es considerada

\footnotetext{
${ }^{59}$ Según Collier y Speed (2000), "Paradójicamente, la Declaración Universal de los Derechos Humanos resulta proveer al gobierno estatal un arma efectiva para combatir las aspiraciones indígenas por controlar la administración de justicia en sus comunidades. El artículo 7, que estipula que 'todos son iguales ante la ley y tienen el derecho sin discriminación a una protección igual ante la ley’, puede ser utilizado por el gobierno como pretexto para negar a las autoridades indígenas el derecho a dar fuerza a normas consuetudinarias que entran en conflicto con las leyes estatales y nacionales. [...] El artículo 9, que ofrece protección contra 'detenciones arbitrarias, arrestos o exilios', provee a los funcionarios estatales de un arma potente contra jueces indígenas por exceder las 24 horas de cárcel o las multas minúsculas permitidas por la ley”.
} 
ilegal por las instituciones oficiales, que se apegan estrictamente a la "Ley" cuando quieren limitar el poder autónomo de algunas instituciones autónomas particularmente eficaces y “contrahegemónicas”. Es el caso de los Municipios Autónomos Zapatistas relatado por Collier y Speed, o del Sistema de Seguridad y Justicia Comunitaria de Guerrero, cuyas autoridades han sido demandadas y encarceladas por "violación de los derechos humanos", "abuso de autoridad" o "secuestro". Se trata de lo que Van Cott define como los conflictos sobre el castigo, que con gran facilidad dan pie a la politización de la acción persecutoria.

Por otro lado, hay una atención por parte de las autoridades autónomas hacia la temática de los derechos humanos, en parte como respuesta a la centralidad de ésta en el discurso oficial, y en parte como consecuencia de la labor cercana de acompañamiento y asesoría realizada por el Centro de Derechos Humanos Fray Bartolomé de las Casas, entre otras organizaciones, como lo confirma Blanca Martínez, ex coordinadora de dicho Centro:

En esta última etapa [2005-2008] lo que hemos venido desarrollando también desde un interés del Frayba, es ir hablando con las Juntas de cómo se va construyendo el sistema de justicia con la incorporación de una perspectiva de derechos humanos, en aras de fortalecer el proyecto autonómico $[\ldots]$

El acuerdo que tenemos ahorita con diferentes Juntas es a partir de las problemáticas que ellos van viendo en los que ellos tienen que intervenir como gobierno autónomo y que necesitan una valoración o un aporte, un apoyo del Frayba para atender equis casos, nos piden nuestra opinión o intervención o nosotros a ellos también. Cuando hay casos donde están implicados, por ejemplo, bases [de apoyo zapatistas], como agresores no como víctimas, hemos empezado a tender puentes de comunicación para ir abordando, a partir de casos, cómo van construyendo su sistema de justicia y cómo lo van viendo desde la perspectiva de derechos humanos.

Para nosotros es muy importante este proceso, creemos que es urgente y necesario tender puentes de diálogo intercultural, que el fortalecimiento de los sistemas de justicia de los pueblos indígenas es necesario [...] y que podemos aportarnos mucho en la misma actualización de la concepción de derechos humanos. ${ }^{60}$

Una muestra de esta evolución intercultural de los derechos humanos desde la práctica se encuentra en las valoraciones expresadas por la JBG al relatar el caso de la detención de Armín Morales, cuando:

\footnotetext{
${ }^{60}$ Blanca Martínez, entrevista, en AMV 2009: 56-57.
} 


\section{AUTONOMIAINDÍGENA, VIOLENCIAY JUSTICIA}

Una Comisión de Derechos Humanos nos vino a dar recomendaciones porque los familiares de la persona que teníamos detenido se fueron a quejar antes derechos humanos, que no hay buena alimentación, que la cárcel no tiene buenas condiciones. [...] han venido con la idea de la ciudad, exigiendo a que es injusto tener una persona en una cárcel de tierra, y quejándose de las condiciones de la cárcel. Pero nosotros les decimos que pasen en las casas de las familias, cuántas de ellas tienen piso. Y esto es más injusto todavía. Así se le explica porque, y nos dan la razón. ${ }^{61}$

Esta argumentación, que por su sencillez resulta aún más contundente y cruda, muestra el proceso de reflexión sobre un discurso -cuya recepción en las comunidades indígenas es relativamente reciente- y su adopción no de acuerdo a los estándares dominantes, sino de acuerdo a una lógica cultural propia y, sobretodo, desde una realidad concreta que, de alguna manera, contextualiza la "universalidad" de los derechos humanos. Dicha contextualización, el proceso de entender el discurso y situarlo en la vida cotidiana, enriquece una posición de defensa "abstracta" y proporciona las herramientas para construir una estrategia propia de defensa de los derechos humanos y de construcción de la justicia social, que pasa por la afinación de los mecanismos jurídicos a la vez que por el mejoramiento de la calidad de vida global de las personas.

Se necesita entonces que los principios y las formas, con base en las cuales se articulan las reivindicaciones por los derechos humanos, provengan del interior de las diferentes sociedades. Esto nos remite a la necesidad de la creación de marcos jurídicos que permitan ejercer libremente el derecho a la libre determinación en sus innumerables formas y a la necesidad de reconocer los procesos autonómicos ya en camino, que representan el sistema más viable de ejercer y garantizar los derechos que cada pueblo percibe como propios. Mientras debemos tomar distancia de los "usos y costumbres" que son lesivos a la dignidad humana de los sujetos (como las prácticas comunitarias que denigran a las mujeres), también es necesario poner énfasis en los procesos de resignificación de dichas "tradiciones", que amplían la plataforma de los derechos sociales. La defensa de los derechos humanos en las regiones indígenas ha abierto espacios importantes para canalizar injusticias ante el Estado $\mathrm{u}$ otras instancias, e incluso en el ámbito mismo de las comunidades. Dichas situaciones

\footnotetext{
${ }^{61}$ JBG, La Realidad, entrevista, 9/12/2008.
} 
repercuten en los propios sistemas normativos que debieron actualizar sus formas de regulación.

Siguiendo el modelo procesual con el que he definido varios conceptos, puedo afirmar que tampoco los derechos humanos son algo fijo, sino que su forma y contenido son constantemente negociados en contextos sociales e históricos específicos. Como ha señalado Binion (1995), los derechos humanos no son derechos "naturales" universales, sino que son reclamos políticamente peleados que ganan fuerza y legitimidad precisamente porque están enmarcados en un lenguaje universal. En una literatura sugerente se está explorando cómo los distintos actores entienden, accionan y disputan los derechos humanos en contextos particulares (Pitarch 2001). Desde hace años, las organizaciones indígenas demuestran su voluntad y capacidad de apropiarse del discurso sobre los derechos humanos como instrumento político, quitando al Estado y a las ONG's el monopolio de su defensa y construyendo un concepto más amplio y rico de derechos humanos.

Los procesos de autogobierno y de administración autónoma de la justicia, incluyendo en el sistema cultural indígena el discurso por los derechos humanos en una perspectiva propia y autodirecta, muestran su capacidad de valorar lo interno y construir nuevos derechos.

La indiferencia política de los gobiernos frente a los pueblos originarios se refleja en las condiciones materiales y sociales de marginación, pobreza, discriminación, falta de estructuras de salud y falta de acceso a la justicia de la población indígena. Problemas de ese tipo representan por sí mismos evidentes violaciones a los derechos humanos causadas por la falta de voluntad política para resolverlos en conjunto con la población. Además, llevan a la descomposición interna de las comunidades indígenas, mientras involucran estos sectores marginados en problemas más graves como la prostitución, el alcoholismo, la drogadicción, el narcotráfico, etcétera. Si se suman estos efectos con los problemas que están en la raíz, se produce una completa fragmentación social y la disolución de los vínculos comunitarios, que tienen como directa consecuencia las infracciones a la ley, la intervención indiscriminada de policía y Ejército y las consecuentes violaciones a los derechos humanos.

Actualmente, el enfrentamiento de los indígenas ante la justicia revela el choque de sistemas jurídicos que el sistema legal muestra como contrapuestos. Las referencias culturales a partir de las cuales los indígenas dirimen cotidianamente sus controversias son sistemáticamente negadas durante el proceso judicial. Sus patrones de disputa, sus creencias y 


\section{AUTONOMIAINDÍGENA, VIOLENCIAY JUSTICIA}

sistemas normativos, el sentido de lo justo y lo injusto, lo permitido y lo prohibido, no funcionan ya como referentes de validez para enfrentar el peso de la legalidad y la institución judicial. Se trata en efecto de una ruptura con sus esquemas de acción y representación, y el trasplante a una situación desconocida, lo que también representa una evidente violación de los derechos humanos. 
Capitulo 5. La justicia autónoma y la justicia del Estado 


\section{CONCLUSIONES}

Mientras escribo estas líneas, la situación social y política en México parece dirigirse hacia un derrotero en el cual la violencia ejercida por algunos actores sobre el conjunto de la sociedad aumenta día tras día, y al mismo tiempo el proceso de naturalización de las prácticas violentas implica, por un lado, que disminuyan la indignación y la exigencia hacia el Estado de garantizar una vida digna para los ciudadanos; por otro lado, las relaciones sociales y el comportamiento de los individuos se hacen más violentos, en un proceso de mimetismo y de defensa. Esta situación de violencia social generalizada, y las atrocidades que estamos viviendo, solo pueden encontrar un parecido en países que viven situaciones de guerra civil.

Precisamente en tal coyuntura es fundamental investigar y difundir experiencias que, desde contextos sociales y culturales diferentes al sistema dominante, buscan modificar el entramado de la violencia y desactivarla sin recurrir a una respuesta igualmente violenta. Esto es el propósito principal de este trabajo.

La trascendencia de la experiencia de organización social y de justicia autónoma que he analizado debe entenderse en este contexto de violencia desbordada que se vive a nivel nacional. La construcción de un proyecto social basado en el autogobierno y la autorganización resalta frente a la actuación de un Estado que, emprendiendo una verdadera guerra en contra de sectores de la delincuencia organizada, ha suspendido los derechos civiles en todo el país. Se ha visibilizado de manera inequivocable la ya sabida colusión de los cuerpos policiales y de las autoridades con el crimen organizado, lo que genera masacres impensables en una sociedad democrática y que, sin embargo, apenas generan molestias en las esferas del poder. Por otro lado, las fuerzas armadas actúan abiertamente con modalidades de guerra, ejecutando civiles de manera arbitraria como si fueran enemigos en un campo de batalla, en lugar de entregar los posibles delincuentes a las instancias encargadas de administrar la justicia. Todo esto es permitido y avalado por las instituciones, que, en lugar de fortalecer el sistema de justicia, ensanchan los espacios donde rige el estado de excepción del 
que habla Calveiro, fortaleciendo la impunidad de la que gozan las corporaciones de seguridad y las autoridades. Observando la actuación de sectores estatales en perspectiva diacrónica, se puede atrever la hipótesis de que, mientras en las dos décadas pasadas se trató de encubrir los escenarios de guerra en el país, como el de Chiapas, con una estrategia contrainsurgente que fomentaba la creación de grupos de civiles armados (paramilitares), en la actualidad el Estado se apoya en algunos de los grupos armados presentes en el escenario de conflicto generalizado, pero al mismo tiempo las fuerzas de seguridad ejercen abiertamente una violencia arbitraria en contra de sectores cada vez más amplios de la población, lo que remite a un escenario parecido al de la guerra sucia de los años setenta, y sin embargo con elementos de complejidad ausentes en aquella época.

La supuesta guerra contra la delincuencia organizada se muestra cada día más como una guerra de algunas estructuras del Estado en contra de la sociedad toda, lo que genera una sensación de indefensión y de aniquilamiento cuya consecuencia es que la prioridad de gran parte de la población es cuidar su propia incolumidad. El concepto acuñado por Taussig de la cultura del terror resulta entonces útil para entender como el miedo resulta una deliberada herramienta de dominación que, junto con la coerción, impide las manifestaciones del disenso. Disenso que, en el México actual, tiene motivaciones de sobra para expresarse. El actual gobierno priista impulsa una agresiva política neoliberal que, en aras de la competitividad, ha avanzado con pasos de gigante en la privatización de los bienes de la nación, por medio de reformas al texto constitucional en ámbitos centrales como la educación, los recursos energéticos, las telecomunicaciones y el trabajo.

Las consecuencias en términos de violencia estructural para amplios sectores de la sociedad, en primer lugar para los pueblos indígenas, que implica este modelo de Estado "otorgador de franquicias", ya se están manifestando, y con ellas la violencia directa que encarna la represión así como la violencia criminal que actúa con la misma función coercitiva.

La sociedad mexicana muestra distintas respuestas a dicho contexto. Por un lado, involucrarse en las redes de la delincuencia se muestra como una opción para quienes interiorizaron la violencia y su normalización. Por otro lado, en algunos estados, sectores de la sociedad buscaron, de una manera coyuntural y no siempre transparente, asumir la tarea abandonada por el Estado de garantizar la seguridad de los ciudadanos, dando vida al fenómeno de las autodefensas. En tercer lugar, como mencionaba arriba, para muchos la 
violencia tiene un efecto paralizante y desmovilizador, ocasionando incluso emergencias sociales como los desplazados internos y el aumento de la migración. Finalmente, y es el aspecto que nos ocupa aquí, existen una multitud de respuestas positivas que buscan conservar y fortalecer los lazos y las estructuras de solidaridad para construir alternativas al Estado, revitalizando raíces culturales que se articulan alrededor de la colectividad y el consenso, y movilizando aquella voluntad afirmativa que Devalle define como cultura de la resistencia, y que está en la raíz de los procesos de autonomía.

Este trabajo se articula en dos grandes bloques. Por un lado están el análisis teórico del universo de la violencia, y el estudio de sus manifestaciones en perspectiva histórica en la Selva Lacandona y en el estado de Chiapas. En la misma línea, se encuentra la descripción del sistema judicial y penal chiapaneco, que representa una de las expresiones de la violencia, la corrupción y la impunidad que caracterizan las estructuras del Estado. Por otro lado, analizo la evolución histórica de las políticas del Estado mexicano hacia los pueblos indígenas, enfatizando el carácter violento de los dos principales paradigmas que las atraviesan, el desarrollismo y el racismo, los que he definido como expresiones de la violencia de Estado hacia los pueblos indígenas. Al mismo tiempo, he relatado el desarrollo de los procesos organizativos indígenas, desde las rebeliones y los movimientos insurgentes prerrevolucionarios, pasando por la larga etapa del movimiento agrarista y campesino, hasta llegar a la lucha por el reconocimiento de derechos colectivos y a la construcción de la autonomía, que identifico como la reivindicación más madura de los procesos de movilización indígena. Examinando el debate sobre la autonomía y las distintas formas en las que esta se puede articular, hice particular énfasis en algunas experiencias que, surgiendo como respuesta positiva a contextos violentos, buscan incidir en ellos y transformarlos. La hipótesis central, es decir que la autonomía es una respuesta positiva frente a las múltiples dimensiones de la violencia que viven los pueblos indígenas, es confirmada por todos los casos estudiados, que sin embargo no lograron resistir en su totalidad a los embates de la violencia misma y sus actores, por lo que no siempre es una respuesta efectiva.

Uno de los retos de este trabajo ha sido construir una lectura antropológica de los problemas estudiados que articulara constantemente visones generales y particulares, en una trayectoria de ida y vuelta que se mueve una y otra vez entre la teoría y la etnografía, entre el espacio nacional y aquello regional, entre la actualidad y el pasado reciente que la determina, 
entre la sociedad en su conjunto y un sector específico, los indígenas. Los temas centrales de la violencia, la autonomía y la justicia están presentes en cada capítulo aunque abordados desde perspectivas diferentes, a nivel teórico o bien en algunas de sus expresiones concretas.

\section{Violencia de Estado, autonomía y justicia autónoma}

Después del análisis teórico sobre las distintas manifestaciones de la violencia que operan en la sociedad, abordé el estudio, en el contexto nacional y en perspectiva histórica, de la relación entre los pueblos indígenas y el Estado mexicano. He ubicado a la violencia como uno de los elementos característicos de la política de Estado hacia los pueblos indígenas, que ha sido y sigue orientada por una ideología racista y prácticas discriminatorias. He argumentado que el racismo, partiendo del desprecio o de la negación de la diversidad, está en la base de múltiples manifestaciones de violencia: el prejuicio racista encarna una forma poderosa de violencia cultural, que a su vez se manifiesta en términos de violencia directa en las prácticas discriminatorias o bien en la represión de quienes reivindican una cultura y un territorio.

He tratado de demostrar que las políticas indigenistas de los años cincuenta y sesenta, el etnicismo o indigenismo de participación de los años setenta y el multiculturalismo neoliberal en los años noventa, aunque de maneras distintas, generan un espacio de aceptación para la diferencia cultural, invisibilizando la exclusión social y la desigualdad económica que caracterizan la población indígena. El paradigma desarrollista, que sigue acompañando las políticas hacia los pueblos indígenas, implica la imposición de programas y proyectos que responden a las prioridades estatales, y nunca son propuestos por, o consultados con, la población indígena destinataria. De tal manera se ejerce, se perpetúa y se profundiza la violencia estructural, que se alimenta precisamente de la exclusión, la desigualdad y la negación de la identidad.

Los indígenas mexicanos, a lo largo de los últimos cincuenta años, han desarrollado distintas formas de organización para enfrentar al Estado y reivindicar los que consideran sus derechos en la nación mexicana. El discurso y la práctica de la autonomía, en sus distintas formulaciones, reivindica el reconocimiento y la legitimidad de las culturas y las formas de organización indígena, lo que implica el derecho a la diferencia en contra de la exclusión; 
asimismo, reivindica el derecho a la igualdad en el acceso a los recursos, a los derechos sociales y a la participación ciudadana plena.

Consideré central ahondar en el debate sobre las perspectivas y las formas de la autonomía en México, y aportando algunos ejemplos de otras experiencias latinoamericanas, pues ésta no sólo tiene el valor de práctica de lucha, de resistencia y de construcción social, sino que es también, y sobre todo, un proyecto político articulado que plantea la transformación social y la construcción de relaciones distintas entre los pueblos indígenas y el Estado mismo. Cada proceso autonómico se desarrolla en una continua relación con el Estado, por lo tanto los logros y los alcances de la organización de los pueblos se deben medir siempre en correlación con las particulares políticas estatales, con la presión (política, militar, económica) y la violencia que el Estado ejercen hacia el proceso autonómico, y con el nivel de madurez y peso político que tiene la organización (lo que determina la calidad de la negociación). Asimismo, los procesos de autonomía tienen un carácter dinámico, pues se desarrollan en contextos en continua mutación, y particular, pues sus expresiones dependen del contexto histórico y social en el que se desarrollan. La autonomía se construye desde dentro de los procesos, sobre la base de problemas y exigencias concretas, cuya resolución por parte de los pueblos organizados constituye la fuerza de las instituciones autónomas. Estas características (la relacionalidad, la dinamicidad y la particularidad) constituyen lo que he definido como el carácter procesual de las autonomías, en el que incluyo también la posibilidad de entender como autonomías aquellos procesos inacabados, en construcción o en crisis, que no siempre logran corresponder al carácter ideal de la autonomía integral.

Alternativamente al ámbito nacional, he abordado el estudio del contexto chiapaneco desde dos perspectivas, cruzadas entre sí: la de la autonomía y la de la justicia.

Por una parte, ubicar a los pueblos indígenas como sujeto político, en una perspectiva histórica, me ha permitido identificar algunos momentos claves en la construcción del espacio social de la Selva Lacandona, y del contexto estatal en general; esta lectura establece una relación casi necesaria entre el "memorial de agravios" de los indígenas chiapanecos y el proyecto de autonomía indígena zapatista. Lo expuesto en el capítulo 1 me permite identificar las distintas formas de violencia ejercidas hacia los indígenas que habitan la Selva Lacandona: la cultura de la opresión (Devalle) en las fincas, la colonización de la Selva como esperanza de liberación y de acceso a la tierra, recurso históricamente negado; el racismo como violencia de 


\section{Conclusiones}

Estado que enfrentaron los indígenas en las sucesivas relaciones con las instituciones estatales; la violencia directa de la represión en contra de las organizaciones campesinas y la violencia estructural de los programas de desarrollo, que mantienen la desigualdad y la dependencia; la violencia militar y paramilitar que siguió al levantamiento zapatista. Asimismo, expongo las características del proceso de autonomía zapatista, que adquiere trascendencia a la luz del debate sobre el tema expuesto en el capítulo 2. La discusión sobre distintas formas de entender la autonomía, su evolución histórica, y la exposición de otras experiencias autonómicas, enfatizan la particularidad del proceso zapatista y lo sitúan en un horizonte más amplio, en el que la autonomía representa la más madura propuesta política y organizativa de los pueblos indígenas frente a las políticas del Estado mexicano.

Asimismo, y como una de las respuestas la hipótesis central que he proporcionado a lo largo del trabajo, argumento que hay una relación inversamente proporcional entre la organización comunitaria y la violencia, por esto la necesidad de fortalecer las estructuras de gobierno y de representación propias, que son expresión de la historia y de la cultura compartidas, y que funcionan como elemento de cohesión. La disminución de la violencia interna, permite entonces desarrollar una mejor capacidad de enfrentar y defenderse de las múltiples violencias que atraviesan las comunidades indígenas: el narcotráfico y la violencia estructural, la militarización y la violencia política, etc. Sin embargo, en muchas ocasiones los poderes violentos rebasan la capacidad de resistencia de la autonomía, provocando su implosión como en el caso de San Juan Copala u Ostula. Los conflictos políticos que agrietan la organización zapatista desde el interno de la misma sociedad indígena son otro ejemplo de las violencias que la autonomía no siempre logra desactivar y que la amenazan desde su interior; creo que en la capacidad de manejar positivamente tales conflictos y en el empeño hacia la reconstrucción de los lazos sociales residen la fuerza y el futuro mismo de los procesos autonómicos en sus territorios.

Por otro lado, las experiencias expuestas muestran que la seguridad y la resolución de conflictos están en la base de cualquier intento de organización autónoma. Marcar un alto a la violencia, significa restituir la libertad a los individuos y a la colectividad. Una vez que hayan reconstituido las relaciones de convivencia y la confianza, los pueblos pueden edificar su futuro: organizarse para construir sus instituciones educativas, de salud, producción y comercio. 
El tema de la justicia articula entre sí los otros grandes temas de la violencia y de la autonomía, pues argumento que la desactivación de la violencia parte de ideas y prácticas distintas alrededor del delito, del castigo y de la responsabilidad de quienes infringen el orden social. Por lo tanto, a través del estudio etnográfico de la justicia autónoma zapatista en la Junta de Buen Gobierno de La Realidad, he descrito algunas de las diversas formas en que los pueblos resuelven situaciones de violencia desde la raíz, antes de que se vuelvan problemas de seguridad comunitaria o pública.

La reflexión sobre la justicia autónoma también se articula desde dos argumentos: como necesidad y como raíz de identidad. Lo expuesto en el capítulo 5, en particular la caracterización del sistema judicial chiapaneco en relación con la población indígena, y el análisis del universo carcelario, sirven como argumentación contundente de la necesidad de la justicia autónoma. Por un lado, la falacia de la justicia "para indígenas" que representan los Juzgados de Paz y Conciliación Indígena y la Fiscalía Especializada que, lejos de favorecer el acceso de los indígenas a la justicia del Estado, profundizan la discriminación y la negación de sus derechos. Se trata de instancias construidas desde el Estado que no respetan y hasta suplantan las formas de organización propias de los pueblos; no garantizan el respeto a las exigencias básicas de que se tomen en cuenta los sistemas normativos propios, ni que los indígenas cuenten con un traductor y un defensor que conocen su cultura; en síntesis, no salen de la visión monista y etnocéntrica que caracteriza el sistema jurídico mexicano. La corrupción, la ineficiencia, la ineficacia y el racismo predominante en todos los ámbitos de la justicia chiapaneca son un corolario a dicha falla de fondo, e incrementan las violaciones a los derechos colectivos e individuales que padecen los pueblos indígenas al acudir o al ser demandados ante la justicia estatal. He fundamentado mi argumentación en datos estadísticos y en denuncias difundidas por instituciones con autoridad reconocida, al igual que el panorama del sistema carcelario esbozado en el mismo capítulo. Para este último tema, me valí también de preciosos testimonios que dan cuenta de la impunidad y la violencia que caracterizan el mundo de la cárcel, pero también del valor de los presos indígenas, "presos políticos e injustamente presos" para reclamar su dignidad y sus derechos desde el interno de las cárceles.

El mundo de la cárcel y el sistema judicial en general encarnan una expresión particular de la violencia que ha sido definida como crímenes de paz, no menos crueles que los que se perpetran en situaciones de conflictos bélicos. Tribunales y prisiones son ejemplos de las que 


\section{Conclusiones}

Basaglia ha definido instituciones de violencia oficial y legalizada, a través de las cuales el Estado ejerce la coerción para mantener la "paz” y la “estabilidad” interna.

En tal perspectiva, la justicia autónoma, indígena e intercultural, representa una respuesta necesaria e inevitable para resolver los conflictos sin ser víctimas de dichas instituciones de violencia; su legitimidad destaca también en la contraposición con el sistema estatal, irremediablemente corrupto e inadecuado para garantizar los derechos individuales y, aún más, para reconocer la pluralidad jurídica y los derechos colectivos. Esta argumentación sustenta la legitimidad de los procesos autonómicos en su conjunto, que frecuentemente se originan como respuesta a problemas específicos y crean estructuras propias para hacer frente a tales problemas.

Sin embargo, las autonomías indígenas en su conjunto, y el ámbito de la justicia como parte de ellas, no nacen de manera coyuntural para hacer frente a una necesidad, sino se desarrollan a partir de contextos particulares y se nutren de la diferencia y de la identidad, elementos que marcan su trascendencia.

Así, si nos remontamos hacia atrás en las respuestas a la violencia, encontramos la resolución de los conflictos y la administración de la justicia. La resolución de los conflictos es clave, pues busca desactivarlos de forma pacífica, a través del acuerdo, la conciliación y la concientización de las partes involucradas. Es una constante en todas las experiencias de justicia indígena e intercultural, y es el corazón mismo de éstas. Hay experiencias que se abocan principalmente a la resolución de los conflictos comunitarios, como los jmeltsa'anwanej -arregladores de conflictos- de Bachajón (Chiapas), influidos por el profundo trabajo cumplido en tal sentido por la Diócesis de San Cristóbal y organizaciones civiles como CORECO. En otras experiencias, la conciliación es parte de un sistema de administración de justicia más complejo que incluye también el juicio de los que cometieron algún error, y su reeducación por medio del trabajo comunitario, como en la Coordinadora Regional de Autoridades Comunitarias en Guerrero o en las Juntas de Buen Gobierno en Chiapas.

Estos sistemas de justicia y de resolución de conflictos, vigentes en las regiones indígenas e interculturales, hunden profundas raíces en las estructuras organizativas de los pueblos, en los sistemas de cargos, en las comisiones que articulan la vida comunitaria, y en ellos reside la principal razón de su legitimidad y de su eficacia para resolver los problemas que se presentan. Al igual que las autonomías en general, las justicias autónomas implican 


\section{AUTONOMIAINDÍGENA, VIOLENCIAY JUSTICIA}

también la participación de los implicados en el proceso de construcción de la justicia, pues se basan sobre mecanismos que los involucrados reconocen como parte de la cultura propia:

Porque antes del '94 nada: sólo te dicen "cuidado porque te va a caer la ley", solo existía eso de que "te va a caer la ley”, y ¿qué era la ley? Era el castigo, y nadie se preguntaba quien hizo esa ley y porqué está escrito así. Nadie se cuestionaba eso, pero ahorita ya no, ya hay algo que al parecer no es así, el pueblo ya dice “a ver, pregúntale al Concejo porqué lo está haciendo así", o sea, reflexiona. ${ }^{1}$

Las justicias "autónomas" no necesariamente vienen de una herencia ancestral, son incluso muy innovadoras, pero lo que las caracteriza es el arraigo en las estructuras asamblearias y en la toma colectiva de las decisiones; y el ser una justicia ejercida por autoridades colegiadas, y que responden a la comunidad que los ha elegido.

En el territorio zapatista, la instauración de los gobiernos autónomos implica varios elementos de novedad que se han venido sumando o han modificado las prácticas de organización comunitaria anteriores. En primer lugar, la posibilidad que ahora tienen las mujeres de cumplir cargos de autoridad, tanto a nivel comunitario, como en los niveles superiores, Municipio y Junta. Las autoridades de la Junta mencionan como elemento de novedad y gran importancia el hecho de que las formas de resolución de los conflictos que ellos aplican actualmente a nivel regional reflejan las prácticas de justicia que se utilizaban a nivel comunitario.

Se trata entonces de una justicia cercana a la gente, que refleja valores y normas que las personas entienden y comparten porque son los que ordenan la vida diaria en las comunidades. Esto es otro elemento que he destacado en este trabajo, la abismal diferencia de la justicia propia, basada sobre la búsqueda de la conciliación y sobre normas entendibles y compartidas, y la justicia oficial o del Estado, que viene invariablemente definida por todos los entrevistado, pero también por estudios e investigaciones de instancias reconocidas (como la $\mathrm{ONU}$ ) como corrupta, injusta, inaccesible e incomprensible.

\footnotetext{
${ }^{1}$ JBG, La Realidad, en Colectivo Situaciones 2005: 38.
} 


\section{Conclusiones}

Autonomías contra-hegemónicas en perspectiva y la relación con el Estado

En este trabajo he detallado las distintas formas de violencia que atraviesan la sociedad mexicana y, en particular, los pueblos indígenas que constituyen un importante sector de ésta. He analizado la evolución de las políticas estatales que han tratado, en maneras distintas, de "disciplinar" a los pueblos indígenas, por medio de la violencia directa o de acciones dirigidas, de formas distintas, a borrar el valor contrahegemónico de la diferencia.

Sirva lo expuesto como la expresión de una de las facetas del complejo escenario en el cual se desarrollan las actuales autonomías mexicanas: neo-indigenismo y políticas focalizadas de atención a la pobreza, extractivismo, violencia e impunidad, son algunos de los factores que marcan la siempre más difícil relación con el Estado y la sociedad nacional. En la actualidad, el Estado parece no ser el único ni el principal contrincante o referente en la negociación, sino una poderosa instancia que aboga para intereses ajenos a los ciudadanos, en este caso los pueblos indígenas.

Las experiencias descritas muestran la variedad que adquiere la práctica de la autonomía y la diferencia de ideas o conceptualizaciones que los mismos protagonistas elaboran al respecto.

Frente a esta diversidad, es insuficiente la postura que ve la autonomía principalmente como acciones de reconocimiento legal y transferencia de poderes, facultades y recursos desde el Estado hacia las instancias de gobierno autónomas. Esta posición olvida que estas acciones van de la mano con la construcción desde la base de dichas instancias de gobierno, que son expresión de un sujeto colectivo autónomo (pueblo, organización, municipio, región, etcétera). Confirman esta constatación las experiencias de países como Nicaragua, Panamá, Colombia o Ecuador, donde existen diferentes marcos legales de reconocimiento, y sin embargo las autonomías se ven igualmente amenazadas, restringidas y erosionadas por las acotaciones que progresivamente realiza el Estado a los marcos legales, por los poderes fácticos y los crecientes intereses del mercado. ${ }^{2}$ El reconocimiento legal, pues, ¡no es garantía de sí mimo!,

\footnotetext{
${ }^{2}$ Un ejemplo es el caso de la Reserva de la Biosfera Yasuní, Ecuador, declarado "zona intangible” pues es habitado por indígenas que rechazan el contacto, y que sin embrago es por mitad incluido en la zona de explotación petrolera, pues hay decenas de pozos activos adentro de la zona "intangible". Véase: www.geoyasuni.org; Pappalardo, de Marchi y Ferrarese, "Uncontacted Waorani in the Yasuní Biosphere Reserve: Geographical Validation of the Zona Intangible Tagaeri Taromenane (ZITT)", en
} 


\section{AUTOONOMIAAINDÍGENA, VIOLENCIAY JUSTICIA}

ya que es frecuentemente impulsado por los Estados para levantar su legitimidad, más que para abrir reales espacios de democracia o reconocer derechos. ${ }^{3}$

Ya que la autonomía siempre es fruto de una negociación, los avances en la construcción de las facultades autonómicas serán mayores en la medida en que este sujeto colectivo se fortalezca organizativamente y se desarrolle interiormente de acuerdo a sus necesidades, acumulando fuerza para presionar y gestionar hacia el Estado los espacios para el ejercicio del poder autónomo. En esto, siempre hay que tener presente la constante intención del poder estatal de englobar las disidencias y desactivar su potencial transformador; los procesos autonómicos que, en un cierto momento, se vuelcan exclusivamente hacia la negociación y abandonan la resistencia, pierden su carácter transformador y el sentido mismo de su autonomía, como ha sucedido, en parte, para el caso del SSJRC y la Coordinadora Regional de Autoridades Comunitarias en Guerrero.

En el mismo sentido, el debate antropológico alrededor del pluralismo jurídico y la interlegalidad indican que no se puede pensar una justicia originaria excluyendo su relación con la justicia estatal. Pero, tampoco hay que suponer que esta relación es armónica e igualitaria, sino controversial y desequilibrada, lo cual motiva a las comunidades en hacer esfuerzos de independencia judicial frente a la justicia estatal.

Con respecto a la relación con el Estado, la autonomía zapatista es una experiencia sui generis, pues surge como parte de una organización político-militar que marca una ruptura con el Estado por medio de una declaración de guerra y acciones de combate. En segundo lugar, rechaza formalmente cualquier relación con las instituciones, pues no se recibe ningún tipo de recurso o apoyo estatal. Es necesario considerar que esta visión de la autonomía es muy peculiar y sólo se lleva a cabo en la región zapatista, aunque en muchos espacios, colectivos y organizaciones filo-zapatistas se sostenga la idea de que es la única forma de autonomía consecuente y legítima, y se descalifican los otros procesos autonómicos. Lo que pude aprender en largos periodos de trabajo de campo, en la convivencia con diversos pueblos indígenas, es que no necesariamente cuenta - por ejemplo- no recibir ningún tipo de recurso

<http://www.plosone.org/article/info\%3Adoi\%2F10.1371\%2Fjournal.pone.0066293;jsessionid=BE951C2281C7 C38AF6E7A6CD121CB45A>, consultado el 10 enero 2014.

${ }^{3}$ González afirma que "las autonomías y regímenes autonómicos no son inmunes a los efectos del llamado multiculturalismo neo-liberal, el que procura su normalización, subordinación, o en forma directa, un estado de inoperancia" (2010: 58). 
económico por parte del Estado, sino la calidad de la negociación que se tiene con el Estado mismo (que puede imponer la transferencia de recursos como un derecho de los pueblos, o bien dejar que sea utilizada como instrumento de cooptación por parte del Estado) y la manera en que los recursos son utilizados (de manera comunitaria y para el beneficio de las comunidades, o derrochados por los líderes).

En México, en un contexto legal que ha visto al Estado aprobar en 2001, como resultado de una excepcional movilización indígena a nivel nacional, unas reformas constitucionales en materia de Derechos y Cultura Indígenas que ratifican la discriminación y la desigualdad, los indígenas están tratando de construir sus propias razones de lo que entienden como sus derechos a partir de su historia y de sus experiencias. En este sentido, se habla de autonomías de facto, o sea que existen aunque no dentro de un marco legal para su reconocimiento. Tal concepto es sugerente, aunque también se basa sobre una idea de la autonomía como integral. Para los procesos analizados en este trabajo, creo más útil pensar a las autonomías como prácticas contra-hegemónicas, procesos particulares que, en un espacio hegemonizado por las estructuras estatales, disputan a éstas competencias y facultades de acuerdo a los diferentes contextos y a las necesidades particulares de quienes habitan los territorios. Pueden ser

procesos limitados a algunos ámbitos de la vida social, pero que tratan de construir otra relación ciudadana a partir de la apropiación y el ejercicio del poder desde abajo.

Los procesos que realmente podemos definir como autonómicos están creando instituciones y espacios organizativos que se sitúan en cierta medida fuera del Estado pero dentro de la Nación, ya que el Estado no ha influido en su construcción ni en las ideas que los caracterizan; y en la medida en que operan desde lógicas que se oponen a las dinámicas del poder estatal, y responden a las carencias mismas del Estado y a las agresiones, de diversa índole, que sufren los pueblos y frente a las cuales el Estado hace caso omiso.

Para poder evaluar el significado y la trascendencia de estas prácticas autonómicas es necesario analizar atentamente las formas que asume la presencia del Estado en las regiones específicas, las acciones que impulsa tanto en términos positivos cuanto negativos (programas sociales, aprovechamiento de los recursos naturales, militarización, etcétera) así como la medida de sus ausencias, ya que en varios casos los procesos de organización autónoma surgen como respuesta a una efectiva ausencia del Estado, y representan caminos de 


\section{AUTOONOMIIAINDÍGENA, VIOLENCIAY JUSTICIA}

construcción de "Estado" (entendido en términos de estructura social, política, de servicios básicos) desde abajo.

Cabe señalar aquí dos aspectos complementarios con respecto al papel y las obligaciones del Estado para con las autonomías. Por un lado la autonomía debe ser apoyada activamente por el Estado, el cual debería dotar las instituciones autónomas de recursos suficientes para garantizar su buen funcionamiento, satisfacer sus demandas y lograr sus objetivos. El Estado no puede limitarse a un reconocimiento formal de derechos (a esto se refiere la expresión mencionada del reconocimiento retórico del multiculturalismo), cuanto abrir espacios en su interior y dotar a las instituciones autónomas de recursos para el ejercicio concreto de tales derechos.

Por otro lado, las autonomías no se pueden reducir a una mera transferencia de competencias jurídicas o normativas, o sólo un arreglo administrativo para una región en el interior de un Estado-nación, ya que implican más bien la construcción de nuevas relaciones entre el Estado y los sujetos colectivos autónomos: nuevas relaciones políticas que replanteen las posiciones de poder en un nivel horizontal. Esto es, que el cambio va más allá de la “descentralización”, la cual en cierto sentido hasta podría aliviar el Estado de la obligación de atender a las demandas (sociales, políticas, de derechos y servicios básicos) de algunos sectores de la población, por lo regular los más desiguales que son los pueblos indígenas. Se trata pues de la construcción de "una nueva relación entre los pueblos indígenas, el Estado y la sociedad", 4 la cual pasa por la transformación de la misma sociedad en términos ideológicos, políticos y éticos, hasta acabar con las marcas racistas y discriminatorias que están arraigadas no sólo en las estructuras políticas sino en las conciencias de muchos ciudadanos.

Este trabajo quiere ser un llamado al reconocimiento pleno y efectivo de la autonomía entendida como derecho, y también de las prácticas de autonomía que se desarrollan en todos los territorios indígenas. En esto, es urgente reconocer la legitimidad de las justicias indígenas y la competencia plena de las autoridades que los pueblos nombran para desarrollar tal función, lo que significaría un importante paso hacia la justicia social, que tanta falta hace en el México de estos días.

\footnotetext{
${ }^{4}$ Acuerdos de San Andrés, 1996.
} 


\section{Conclusiones}

Posdata. Enfoque, encuadre y "fieldwork under fire"

Recientemente, en un congreso de antropología, platicaba con un conocido investigador, ya mayor, quien al conocer el tema de mi trabajo doctoral preguntó: "y tú, ¿por qué te dedicas a la literatura fantástica?" La pregunta me hizo mucha gracia y me recordó mis propias reflexiones al escribir sobre el proceso de autonomía y de justicia zapatista, cuyas conclusiones he asentado en este trabajo. La simple pregunta del viejo antropólogo engloba varios puntos de cierta importancia.

1. En primer lugar, es innegable que sobre el movimiento zapatista y su proceso de autonomía se han escrito ríos de palabras y torres de libros y artículos, académicos, de divulgación, políticos y anti-políticos... Definitivamente, es un tema copiosamente investigado, usado y abusado, lo que ocurre con muchos temas; pero sobre todo, considero que mucha de la literatura que se ha escrito representa una interpretación muy personal de los investigadores o escritores, que tal vez rebasaron los límites del conocimiento situado mencionado en la introducción y más bien se adentraron en el universo contiguo y opuesto de la "profecía auto-cumplida". Esto es, que muchos textos producidos sobre el movimiento zapatista reflejan mucho más las inquietudes y los temas que interesan los autores, y sus opiniones propias, que la realidad de las comunidades zapatistas o la práctica política del EZLN, y los investigadores cayeron -inocentemente o intencionalmente- en el ordinario error de meter las palabras y las ideas propias en boca de los sujetos estudiados, o de querer encontrar evidencias de lo que se quiere afirmar en una realidad que a todas luces no muestra ningún rasgo de tal tema o arista. Me refiero, por ejemplo, a estudios sobre "el discurso zapatista como poética literaria de la posmodernidad" o los que teorizan el pacifismo neogandhiano del EZLN, etc., cuyos productos me parecen de dudosa utilidad.

Otra lamentable forma de mistificación del zapatismo se refleja en la también cuantiosa literatura que exagera en la parcialidad, produciendo textos que apuntan a la descalificación completa, o a la idealización acrítica. Los primeros abundaron más en los primeros años después del levantamiento, aunque hay investigadores que hicieron de la crítica al zapatismo su razón de ser académica y siguen abonando en esa línea; mientras los segundos se multiplicaron a la par del afianzamiento del movimiento zapatista, creándose un grupo de "intelectuales orgánicos" a cuya producción probablemente hacía referencia la pregunta del 


\section{AUTONOMIAINDÍGENA, VIOLENCIAY JUSTICIA}

antropólogo mencionada al principio. Creo que ambas posturas resultan poco útiles para la comprensión del proceso de autonomía zapatista y su trascendencia, pues alejándose de la realidad concreta, de sus contradicciones y de los logros realmente conseguidos, disimulan el proceso de construcción de la autonomía que se basa sobre inevitables errores, autocríticas, y una fuerte lucha ideológica interna. En particular, la idealización es una trampa que minimiza los avances porque no muestra la realidad compleja, las tensiones, y los problemas realmente vividos; por lo tanto, los logros ensalzados pueden parecer pequeños porque no se hace evidente el largo camino recorrido para alcanzarlos, los procesos de lucha interna que están llevando a cabo las mujeres, por ejemplo, para imponer su participación en todas las estructuras del gobierno autónomo, proceso inacabado que lidia con el machismo y la inhibición, pero que adquiere valor precisamente en su ser inacabado y en la magnitud del objetivo propuesto.

2. Por lo tanto, al escribir un texto más sobre la autonomía zapatista, enfrenté el problema de cómo realizar un trabajo de investigación antropológica, útil a la elaboración de conocimiento crítico y de propuestas sociales, en lugar de un panfleto idealizador o "contrainsurgente", dependiendo del punto de vista prevaleciente. Consciente de este reto, y desde mi evidente compartición de la causa zapatista, traté de estudiar el proceso desde una perspectiva crítica y a la vez productiva, sin omitir el análisis de las contradicciones y enfrentando los nudos problemáticos, las debilidades y los puntos de quiebre de la organización. Considero que es necesario poner en luz los problemas concretos que enfrenta el movimiento, para tratar de entender las causas y buscar posibles soluciones. Las interpretaciones propuestas con tal intención corresponden a una interpretación personal frente a una $(\mathrm{R})$ realidad a veces opaca y contradictoria, que sin embargo hace visible el sufrimiento de las personas y los esfuerzos para construir un mejor futuro de convivencia y de justicia social.

3. En la Introducción, junto con las reflexiones, complementarias a éstas, sobre la falacia de la pretendida "objetividad científica", mencioné las limitaciones que sufre el trabajo etnográfico que se desarrolla en contextos de conflicto. Actualmente, cualquier investigador que realice o aspire a realizar trabajo de campo etnográfico en los territorios indígenas, se enfrenta a limitaciones parecidas e incluso mayores, debido al mencionado contexto de violencia generalizada que se ha extendido más allá de las "zonas de conflicto" (como era 


\section{Conclusiones}

considerado el oriente chiapaneco) e embiste todo el país. Quienes pretendemos realizar trabajo etnográfico en muchas regiones de México, nos encontramos ahora en contextos parecidos a los relatados en el citado Fieldwork under fire, de Nordstrom y Robben, que no solamente ponen en discusión la viabilidad de las investigaciones y representan un riesgo para la vida misma del antropólogo, sino que cambian radicalmente los patrones de relación con los sujetos estudiados. Según un grupo de etnógrafos argentinos, quienes elaboraron una reseña al volumen, la violencia:

Pone en cuestión [...] las premisas de comprensión antropológica del respeto a la diversidad. Contextos de represión masiva, de terrorismo, atrapan al etnógrafo en la urgente inmediatez y lo exponen a la amenaza omnipresente de su muerte como profesional y como persona biológica y sociocultural (IDES 1998: 483).

Lo vivido en campos (fieldworks) violentos impone muchas veces la urgencia inmediata de la denuncia sobre el análisis antropológico, mientras la transformación del universo de estudio, en donde se amplían los ámbitos inaccesibles a la investigación, impone un trabajo creativo e interpretativo capaz de conocer los límites de seguridad para sí mismos y para los sujetos estudiados, que la presencia o las declaraciones del investigador podrían poner en situaciones de riesgo aún mayor. Así, el miedo propio (real e ilusorio) al acudir a los lugares que anteriormente visitábamos con frecuencia, y el miedo de las personas con las que establecimos relaciones de confianza y solidaridad a lo largo de las estancias de investigación, para darnos acogidas en sus vidas o para platicar de muchos aspectos de su realidad, va mermando el acceso a las fuentes de información y las posibilidades de seguir el trabajo antropológico desde el campo. Por otro lado, la relación con los sujetos estudiados cambia también porque la violencia experimentada por el investigador y sus "otros" es la misma, por lo que "los investigadores y los nativos se equiparan en el desconcierto, en las dificultades para dar sentido a cotidianeidades alteradas" (IDES 1998: 482). Esto vuelve borrosa la distinción nosotros/otros durante la vivencia en el campo, pero al mismo lado profundiza la misma distinción, ya que, en el mejor de los casos, el investigador tiene la posibilidad de abandonar el campo y suspender o cancelar el proyecto de investigación, mientras los sujetos con los que trabaja permanecen en esa "realidad de pesadilla" en la que se ha transformado su vida cotidiana. 


\section{AUTONOMIA INDÍGENA, VIOLENCIAY JUSTICIA}

La situación de violencia e impunidad descrita ha transformado muchas profesiones en "trabajos de alto riesgo", desde los maestros a los conductores de autobús, desde los periodistas a los antropólogos, lo que se ha vuelto una denuncia recurrente en los congresos y coloquios de antropología desde hace algunos años.

Una reflexión en perspectiva sobre el futuro de nuestra disciplina no puede omitir esta situación, que pone en entredicho el desarrollo de futuras investigaciones; siendo el ejercicio de la violencia algo que se ha vuelto común en el manejo de contextos sociales distintos, los trabajos que pretenderán abordar procesos sociales y organizativos indígenas, el impacto de proyectos extractivos o incluso del turismo, se enfrentarán y por lo tanto deberán tomar en cuenta de antemano la problemática.

Por otro lado, y lo que es más grave, es urgente reflexionar, denunciar y buscar la manera de revertir una situación social que, por lo dicho anteriormente, impacta negativamente en la producción y la difusión del conocimiento, lo que es un campo fundamental para el avance de un país democrático y plural en el cual todos merecemos vivir. 


\section{Conclusiones}




\section{BIBLIOGRAFÍA}

Acevedo, Marina

(1995), "Margaritas: una experiencia de frontera", en Guillén, D. (coord.) Chiapas, una modernidad inconclusa, México, Instituto Mora, pp.148-192.

Adonon Viveros, Akuavi

(2008), "La conciliación: ¿un medio o un fin en la resolución de conflictos?”, en Huber, R., Martínez, J.C., et al., Hacia sistemas jurídicos plurales, Bogotá, Konrad Adenauer Stiftung, pp.87-116

(2009), "Estado, derecho y multiculturalismo. Un enfoque de antropología jurídica en México", Nueva Antropología, vol. XXII, núm. 71, julio-diciembre 2009, México, UAM/INAH/Conacyt, pp.51-71

Alonso Bolaños, Marina

(2008), "Sistemas normativos indígenas", en Nolasco, M., et.al. (coords.), Los pueblos indígenas de Chiapas. Atlas etnográfico, México, INAH-Gobierno del Estado de Chiapas, pp.349-360

Acosta Urquidi, Mariclaire

(2011), "El legado autoritario y la falta de acceso a la justicia" y "El desafío de la seguridad pública y la impunidad", en Acosta, M. (coord.), Superar la impunidad. Hacia una estrategia para asegurar el acceso a la justicia en México, México, Centro de Investigación y Docencia Económicas (CIDE)Fundación Ford, pp.11-134

Agostino, Ana

(2009), “Alternativas AL desarrollo en América Latina: ¿Qué pueden aportar las universidades?”, América Latina en movimiento, Quito, junio 2009, año XXXIII, II época, pp. 14-17

Alvarado Solís, Neyra P. (coord.)

(2010), Sistemas normativos indígenas huichol, cora, tepehuano y mexicanero, México, CDI

AMV, García, Juan y Hijar, Cristina

(2009), Los acompañantes tienen cara y nombre, México, Arte Música y Video

Anderson, Benedict

(1993), Comunidades imaginadas. Reflexión sobre el origen y la difusión del nacionalismo, México, FCE

Aragon Andrade, Orlando

(2013a), De la "vieja" a la "nueva" justicia indígena. Transformaciones y continuidades en las justicias indígenas de Michoacán, Tesis de Doctorado, Departamento de Antropología, México, UAMI

(2013b), "El derecho en insurrección. El uso contra-hegemónico del derecho en el movimiento purépecha de Cherán", Revista de Estudios e pesquisas sobre as Américas, Brasil, CEPPAC/UnB, pp. 37-69

Ardila Amaya, Edgar

(2005), "La justicia comunitaria en la nueva etapa de la administración de justicia: ¿respuesta a la crisis o reorganización de un campo de gestión social?", en Ardila, E. et al. (coords.), Memorias de la II 
conferencia internacional de Justicia Comunitaria "Construir democracia hoy", Red de Justicia Comunitaria y Tratamiento del Conflicto, Bogotá, 2005, pp. 15-36

Arendt, Hannah

(2005), Sobre la violencia, Madrid, Alianza Editorial

Arizpe, Lourdes; Paz, Fernanda y Velázquez, Margarita

(1993), Cultura y cambio global: percepciones sociales sobre la deforestación de la Selva Lacandona, México, UNAM/Porrua

Aróstegui, Julio

(1994), "Violencia, sociedad y política: la definición de violencia", Revista Ayer, no.13, Madrid Asociación de Historia Contemporánea- Marcial Pons,

Arteaga Botello, Nelson

(2003), "El espacio de la violencia: un modelo de interpretación social”, Sociológica, núm.52, México Universidad Autónoma Metropolitana-Azcapotzalco, pp.119-145

Arzate Salgado, Jorge

(2008), "Política social y cambio social en América Latina. Una evaluación teórico-normativa", en Violencia, ciudadanía y desarrollo: perspectivas desde Iberoamérica, México, Universidad Autónoma del Estado de México-Porrúa, pp.107-126

Arze Quintanilla, Oscar

(1988), "Del indigenismo a la indianidad. Cincuenta años de indigenismo continental" en Instituto Nacional Indigenista 40 años, México, INI, pp.105-120

Asad, Talal

(2005), "Tortura e trattamenti crudeli, inumani e degradanti", en Dei, F. (coord.), Antropologia della violenza, Roma, Meltemi, 2005, pp. 183-214

Assies, Willem

(1999), "Pueblos indígenas y reforma del Estado en América Latina", en W. Assies, G. Van der Haar y A. Hoekema, (eds.), El reto de la diversidad. Pueblos indígenas y reforma del estado en América Latina, México, COLMICH, 21-54

(2000), "La oficialización de lo no oficial: ¿Re-encuentro de dos mundos?”, en <www.alertanet.org> (2003), "La descentralización en perspectiva", en Assies, W. (ed.), Gobiernos locales y reforma del Estado en América Latina, El Colegio de Michoacán, México, pp.13-34, consultado on-line el 20 abril 2013 en < http://iglom.iteso.mx/wassies.PDF>

-y Van der Haar, Gemma; Hoekema, André

(1999), "La diversidad como desafío: una nota sobre los dilemas de la diversidad", en Assies, W., Van der Haar, G. y Hoekema, A. (eds.), El reto de la diversidad. Pueblos indígenas y reforma del estado en América Latina, México, COLMICH, 505-542

Aubry, Andrés

(1982), "Indigenismo, Indianismo y movimientos de liberación nacional", Inaremac.

(2005), Chiapas a contrapelo. Una agenda de trabajo para su historia en perspectiva sistémica, México, Contrahistorias-Centro (de estudios, información y documentación) I. Wallerstein

(2007), "Los intelectuales y el poder", Contrahistorias, núm. 8, México, Jitaniáfora Morelia Editorial, pp. 111-116. 


\section{AUTOONOMIIAINDÍGENA, VIOLENCIAY JUSTICIA}

Azaola, Elena

(2008), Crimen, castigo y violencias en México, Quito, FLACSO - MDMQ

-y Bergman, Marcelo

(2007), "Cárceles en México: Cuadros de una Crisis", Urvio, Revista Latinoamericana de Seguridad Ciudadana. No. 1, Quito, FLACSO, mayo 2007, pp. 74-87

- y Bergman, M., Magaloni, A.L., y Negrete, L.,

(2005), "Una fotografía del crimen y su prevención. Encuesta a la población en prisión en el D.F., Morelos y Estado de México", Renglones, núm. 58-59, noviembre 2004-abril 2005, México, ITESO, pp.67-72

Ayora Díaz, Steffan

(1995), "Globalización y región: reflexiones sobre un concepto desde la antropología", Cuadernos de arquitectura y urbanismo, núm. 1, pp. 9-40.

Báez Landa, Mariano

(1989), "La Frontera Sur y el caso del Soconusco", en Hernández Palacios, L. y Sandoval, J.M. (compil.), El redescubrimiento de la frontera sur, México, Universidad Autónoma de Zacatecas/Universidad Autónoma Metropolitana, pp.197-212

Barabas, Alicia

(2002), Utopías indias. Movimientos sociorreligiosos de México, México, Plaza y Valdés

(2005), “Autonomías indígenas en México: ¿utopías posibles?”, en Escárzaga, F. y Gutiérrez, R. (coords.), Movimiento indígena en América Latina: resistencia y proyecto alternativo, México, Gobierno del DF-Juan Pablos-UAP-UNAM-UACM, pp.151-170

Barrera Hernández, Abel y Sarmiento, Sergio

(2006), "De la Montaña Roja a la Policía Comunitaria: violencia y militarización en la Montaña de Guerrero", en Oikón, V. y García, M. (coords.) Movimientos armados en México: siglo XX, Zamora, El Colegio de Michoacán-CIESAS

Bartolomé, Miguel

(1995), "Movimientos etnopoliticos y autonomías indígenas en México", en Gruberg, G. (coord.) Articulación de la diversidad. Pluralidad étnica, autonomías y democratización en América Latina, Quito, Abya-Yala, pp.227-256

(1997) Gente de costumbre y gente de razón, México, Siglo XXI

-y Barabas, Alicia (coords.)

(1998), Autonomía étnica y estados nacionales, México, CONACULTA-INAH

Bartra, Armando

(1995), "Origen y claves del sistema finquero del Soconusco", Revista Chiapas, núm. 1, ERA-IIEc/ UNAM, < http://www.revistachiapas.org/No1/ch1bartra.html>, consultado el 20 enero 2014.

(1996), Federalismo y democracia. El papel de los municipios en el desarrollo social, México, Instituto de Estudios para el Desarrollo Rural Maya

(1996), Guerrero bronco. Campesinos, ciudadanos y guerrilleros en la Costa Grande, México, ERA (2000), (compilador) Crónicas del Sur. Utopías campesinas en Guerrero, México, ERA

-y Otero, Gerardo

(2008), "Movimientos indígenas campesinos en México: la lucha por la tierra, la autonomía y la democracia", en Moyo, S. y Yeros, P. (coords.), Recuperando la tierra. El resurgimiento de movimientos rurales en África, Asia y América Latina, Buenos Aires, CLACSO, pp. 401-428 
Bastos, Santiago; Hernández Yxcoy, Domingo y Méndez, Leopoldo

(2008), "Resarcimiento y reconstitución del pueblo maya en Guatemala: entre la acción autónoma y el reconocimiento estatal". En: Leyva, X., Burugete, A. y Speed, S. (coords.), Gobernar (en) la diversidad: experiencias indígenas desde América Latina. Hacia la investigación de co-labor, México, CIESAS-FLACSO 2008

Becauge, Pierre

(2000), "Más allá de lo jurídico. Reflexiones sobre procesos autonómicos indígenas en América", en Reina, L. (coord.), Los Retos de la etnicidad en los estados nación del siglo XXI, México, CIESASINI-Porrúa, pp. 299-321

(2008), “Es el desarrollo una violencia estructural? El Estado y los mediadores externos en dos proyectos de desarrollo en regiones multiétnicas de México", en Martínez, M. y Rodríguez, E. (coords.), Intelectuales, mediadores y antropólogos. La traducción y la reinterpretación de lo global en lo local, Serie XI Congreso de Antropología de la FAAEE, Donostia, Ankulegi Antropologia Elkartea, pp. 83-112, <http://www.ankulegi.org/7-intelectuales-mediadores-y-antropologos-latraduccion-y-la-reinterpretacion-de-lo-global-en-lo-local/>, consultado el 05-09-2013.

Bellino, Michelle

(2010), "A history of violence, not a culture of violence. Finding historical consciousness in Guatemala”, ReVista, vol. X, núm. 1, Cambridge, Harward University, pp. 13-16

Bello, Alvaro

(2009), “Multiculturalismo, ciudadanía y pueblos indígenas. Un debate pendiente en América Latina?”, en Valladares, L., Pérez-Ruiz, M. L., Zárate, M. (coords.), Estados plurales: los retos de la diversidad y la diferencia, México, UAM/ Juan Pablo Editores, pp. 62-85.

Bengoa, José

(2005), "Violencia y emergencia indígena en América", en Identidades en juego, identidades en guerra, en Reyna, L.; Lartigue, F.; Dehouve, D.; Gros, C. (coords.) México, CIESAS- INAH 2005, pp. $125-167$

(2009), “Una segunda etapa de la Emergencia Indígena en América Latina?”, Cuadernos de antropología social, n. 29, jul. 2009, Buenos Aires, pp. 07-22, en <http://www.scielo.org.ar/scielo.php?script=sci_arttext\&pid=S1850275X2009000100001\&lng=es\&nr m=iso>, consultado el 28 octubre 2013.

Benjamin, Thomas

(1981), "El trabajo en las monterías de Chiapas y Tabasco 1870-1946", Historia Mexicana Vol. 30, No. 4 (Apr. - Jun., 1981), pp. 506-529

(1995), Chiapas: tierra rica y pueblo pobre, México, Grijalbo.

Benjamin, Walter

(1921) "Para una crítica de la violencia", Edición Electrónica de la Escuela de Filosofía, Santiago de Chile, Universidad ARCIS, <www.philosophia.cl/biblioteca/Benjamin/violencia.pdf>, consultado el $27 / 05 / 2011$

Binion, Gale

(1995), "Human Rights: A feminist perspectiva", en Human Rights Quarterly, vol. 17, pp. 509-526

Blair Trujillo, Elsa

(2005), "La violencia frente a los nuevos lugares y/o los otros de la cultura", Revista Nueva Antropología, vol. XX, núm.065, México, UNAM, pp.13-28 


\section{AUTONOMIAINDÍGENA, VIOLENCIAY JUSTICIA}

(2009) “Aproximación teórica al concepto de violencia: avatares de una definición”, Revista Política y Cultura, núm.32, México, UAM-Xochimilco, pp.9-33

Böehm de Lameiras, Brigitte

(1997), "El enfoque regional y los estudios regionales en México", Relaciones. Estudios de Historia y Sociedad núm. 72, otoño de 1997, Zamora, El Colegio de Michoacán, pp. 15-47.

Bonfil Batalla, Guillermo

(1987), Mexico profundo. Una civilizacion negada, México, Grijalbo.

(1995), "El etnodesarrollo: sus premisas jurídicas políticas y de organización", en Obras escogidas, Tomo 2, México, INI-CIESAS-INAH

Booth, David, Clisby, Suzanne y Widmark, Charlotta

(1997), Popular Participation: Democratizing the State in Rural Bolivia, SIDA, Stockholm

Bretón, Víctor

(2007), "A vueltas con el neo-indigenismo etnófago: la experiencia Prodepine o los límites del multiculturalismo neoliberal", Iconos. Revista de Ciencias Sociales, núm. 29, Quito, septiembre 2007, pp. $95-104$

Brunnegger, Sandra

(2007), "El camino de conflicto a autonomía en Nicaragua: lecciones aprendidas", Minority Rights Group International, abril 2007

Buenrostro Alba, Manuel (2013), "Reformas legales, espacios y modalidades de la justicia indígena de los mayas en Quintana Roo", en Sierra, T., Hernández, A. y Sieder, R. (coords.), Justicias indígenas y Estado. Violencias contemporáneas, México, CIESAS/FLACSO, pp.89-121

Burguete Cal y Mayor, Araceli

(1999), México: experiencias de autonomía indígena, Guatemala, IWGIA.

(2002), "Procesos de autonomías de facto en Chiapas. Nuevas Jurisdicciones y gobiernos paralelos en rebeldía", en Mattiace, S.; Hernández, A. y Rus, J. (coords.), Tierra, Libertad y Autonomía, México, CIESAS-IWGIA, pp.269-317

(2008), "Multiculturalismo y gobierno permitido en San Juan Cancuc, Chiapas: tensiones intracomunitarias por el reconocimiento de 'autoridades tradicionales"”. En Leyva, X., Burguete, A. y Speed, S. (coords.), Gobernar (en) la diversidad: experiencias indígenas desde América Latina. Hacia la investigación de co-labor, México, CIESAS-FLACSO, pp.343-390

(2010), "Autonomía: la emergencia d eun paradigma en las luchas por la descolonización en América Latina”, en González, M., Burguete, A. y Ortiz-Tejeda, P. (coords.), La autonomía a debate. Autogobierno indígena y Estado plurinacional en América Latina, Quito, FLACSO/GTZ/IWGIA/CIESAS/UNICH, pp. 63-94.

Cajas, Juan

(2005), "Violencia y narcotráfico. Reflexiones desde la antropología", Fractal núm. 38, en <http://www.mxfractal.org/F38Cajas.htm>, consultado el 10 septiembre 2013.

Calveiro, Pilar

(2008), “Acerca de la difícil relación entre violencia y resistencia”, en López Maya, M.; Iñigo Carrera, N.; Calveiro, P., Luchas contrahegemónicas y cambios políticos recientes de América Latina, Consejo Latinoamericano de Ciencias Sociales - CLACSO, Buenos Aires, pp.23-46. 
Canabal Cristiani, Beatriz

(2001), "Introducción general", "Estrategias de sobrevivencia y el contorno regional", "Conclusiones" en Canabal Cristiani, B. (coord.), Los caminos de la Montaña. Formas de reproducción social en la Montaña de Guerrero, México, UAM-CIESAS-Porrúa, pp.15-62; pp.281-289

Carlsen, Laura

(1999), “Autonomía indígena y usos y costumbres”, Chiapas, núm. 7, México, ERA-UNAM, pp.4570.

Carrillo Trueba, César

(2011), "El racismo en México, su origen y actualidad", La Jornada del campo, núm. 49, México, <http://www.jornada.unam.mx/2011/10/15/cam-asedio.html>, consultado el 10 octubre 2011

Casanova, Pablo González

([1965] 1974), La democracia en México, México, Ed.Era

(2003), "Los 'Caracoles' zapatistas: redes de resistencia y autonomía”, Memoria, Núm. 176, México, octubre de 2003, pp. 14-19.

Castellanos Guerrero, Alicia

(2000a), "Antropología y racismo en México", Desacatos, núm. 4, CIESAS, México, en <http://www.ciesas.edu.mx/desacatos/04\%20Indexado/Saberes_3.pdf>, consultado el 10 enero 2012. (2000b), "Racismo, multetnicidad y democracia en América Latina", Revista Nueva Antropología, diciembre, vol. XVII, núm. 58, México D.F., pp. 9-25

(2001a), "Pueblos indios, racismo y Estado", en Sánchez, G. (coord.) ¿Estamos unidos mexicanos? Los límites de la cohesión social en México, Editorial Planeta, México, en <http://www.latautonomy.org/RACISMO.PDF>, consultado el 22 septiembre 2011 (2001b), "Notas para estudiar el racismo hacia los indios de México", Papeles de Población, núm.28, Centro de Investigación y Estudios Avanzados de la Población de la Universidad Autónoma del Estado de México, México, pp.165-179

(2012), "Los pueblos indígenas en la nación y su relación con el Estado", ponencia presentada en el congreso La dis-unitá d'Italia e delle altre nazioni: spinte disgregatrici e nuovi miti di fondazione identitaria, Salerno, Italia, 2-6 de marzo de 2012.

-y López y Rivas, Gilberto

(1997) "Autonomías y movimiento indígena en México: debates y desafíos", en Alteridades, Núm. 7

(13) pp. 145-159, Universidad Autónoma Metropolitana-Iztapalapa, México

Castro Apreza, Inés

(2002), "Violencia y justicia en Chiapas. Los operativos policíaco-militares de 1998”, en Briceño León, R. (comp.) Violencia, sociedad y justicia en América Latina, Buenos Aires, CLACSO, pp. 179199

Castro Escudero, Teresa; Mussali Galante, Rina; Oliver Costilla, Lucio

(2005), "Revisitando al Estado. Los Estados populistas y desarrollistas: poner las cosas en su lugar", en Oliver, L. y Castro, T. (coords.), Poder y política en America Latina, México, UNAM-Siglo XXI, pp.17-49

Cejas Minuet, Mónica

(2000), "Pensar el desarrollo como violencia: algunos casos en África", en Devalle, S. (comp.), Poder y cultura de la violencia, El Colegio de México, México, pp. 69-117 


\section{AUTOONOMIIAINDÍGENA, VIOLENCIAY JUSTICIA}

Clastres, Pierre

([1977] 2009) Arqueología de la violencia. La guerra en las sociedades primitivas, Buenos Aires, Fondo de Cultura Económica, en

<https://docs.google.com/file/d/0B14Synwe1mHzSUN0MWFyUnNDdW8/edit?pli=1>.

Colectivo Situaciones

(2005), Bienvenidos a la selva: diálogos a partir de la sexta declaración del EZLN, Buenos Aires, Tinta Limón

Collier, George

(1998), ¡Basta!: tierra y rebelión zapatista en Chiapas, México, Food First Books, UNACH

Collier, Jane F.

[(1973) 1995], El derecho zinacanteco. Procesos del disputar en un pueblo indígena de Chiapas, México, UNICACH/CIESAS

(1995), "Problemas teórico-metodológicos en la antropología jurídica", en Chenaut, V. y Sierra, M.T. (coords.), Pueblos indígenas antes el derecho, México, CIESAS/CEMCA

(2001), "Dos modelos de justicia indígena en Chiapas, México: una comparación de las visiones zinacantecas y del Estado", en León Pasquel, L. (coord.), Costumbres, leyes y movimiento indio en Oaxaca y Chiapas, México, CIESAS-Porrúa, pp.189-201

(2004), "Cambio y continuidad en los procedimientos legales zinacantecos", en Sierra, M.T. (coord.), Haciendo justicia. Interlegalidad, derecho y género en regiones indígenas, México, CIESAS-Porrúa, pp.57-113

(2009), “Comentario", en Desacatos, núm. 31, septiembre-diciembre 2009, México, CIESAS, pp. 8996

-y Speed, Shannon

(2000), "Autonomía indígena, el discurso de los derechos humanos y el Estado: dos casos en Chiapas", Cemos Memoria n.139, México, pp.5-11.

Comaroff, John y Robert, Simon

(1981), Rules and Processes: The Cultural Logic of Dispute in an African Context, Chicago, University of Chicago Press

Concha Malo, Miguel

(1998), "El catolicismo y la violencia", en Sánchez Vázquez, A. (ed.), El mundo de la violencia, UNAM-FCE, México, pp.15-30

Cordera Campos

(1998), "Violencia y economía", en Sánchez Vázquez, A. (ed.), El mundo de la violencia, UNAMFCE, México, pp. 251-261

Cordero Avendaño de Durand, Carmen

(2001), El derecho consuetudinario indígena en Oaxaca, Oaxaca, Instituto Estatal Electoral

Correas, Oscar (coord.)

(2007), Derecho indígena mexicano 1, México, CEIICH/UNAM-Ediciones Coyoacán

Corte Ibáñez, Luis

(2006), "Violencia en la política", en Suplemento del Boletín Diario de Campo, No. 40, Nov-Dic 2006, México, Instituto Nacional de Antropología e Historia, pp.79-85 
Cruz Rueda, Elisa,

(2013), "Derecho a la tierra y al territorio, demandas indígenas, Estado y capital en el Istmo de Tehuantepec", en Sierra, T., Hernández, A., y Sieder, R. (coords.), Justicias indígenas y Estado. Violencias contemporáneas, FLACSO-CIESAS, México, pp.341-382

Das, Veena

(1991), “Composition of the Personal Voice: Violence and Migration", Studies in History, 7, (1), pp. $65-77$

(2005), “L'Atto del testimoniare. Violenza, conoscenza avvelenata e soggettività", en Dei, F. (coord.), Antropologia della violenza, Roma, Meltemi, pp. 215-246

-y Poole, Deborah (2004), Anthropology in the Margins of the State, Santa Fe, SAR Press

Dei, Fabio

(1999) "Interpretazioni antropologiche della violenza, tra natura e cultura", en

Crepet, P., Parmigiani S., y Schön, A., Alle radici delle violenza. Per spiegare l'inumanità dell'uomo,

Ed. Paolo Gaspari, Udine, pp. 31-55

$<$ http://www.fareantropologia.it/sitoweb/index.php?option=com_content\&view=article\&id=62:interpre tazioni-antropologiche-della-violenza\&catid=51:violenza-memoria-testimonianza\&Itemid=65>, consultado el 10 octubre 2011.

(2004), "Antropologia della violenza nel XX secolo", en F. Masotti (coord.), Le guerre del XX secolo e le violenze contro i civili, Roma, Aracne, pp. 29-50

(2005), "Introduzione. Descrivere, teorizzare, testimoniare la violenza", en Dei, F., Antropologia della violenza, Roma, Meltemi, en <http://www.fareantropologia.it/sitoweb/index.php?option=com_content\&view=article\&id=103:descri vere-interpretare-testimoniare-la-violenza\&catid=51:violenza-memoria-testimonianza\&Itemid=65>, consultado el 13 septiembre 2013.

De Gyves, Leopoldo

(1995), "Juchitán, primer ayuntamiento libre de México", en Etnicidad, democracia y autonomía, UNAM, San Cristóbal de las Casas, pp.31-44.

De Marinis, Natalia

(2009), Entre la guerra y la paz. Intervención política partidista, el conflicto armado y la autonomía como paz entre los Triquis de San Juan Copala, Oaxaca, Tesis de Maestría en Antropología Social, México, CIESAS

Devalle, Susana

(2000), "Violencia: estigma de nuestro siglo" en Devalle, S. (comp.) Poder y cultura de la violencia, El Colegio de México, México, pp. 15-31

De Vos, Ian

(1994), Vivir en la frontera. La experiencia de los indios de Chiapas, México, CIESAS-INI.

(1988), Oro Verde: La Conquista de la Selva Lacandona Por Los Madereros Tabasqueños, 18221949, Gobierno del Estado de Tabasco

(2002), Una tierra para sembrar sueños. Historia reciente de la Selva Lacandona 1950-2000, México, CIESAS-FCE.

Díaz, Floriberto

(2007), Floriberto Díaz. Escrito, México, UNAM. 


\section{AUTOONOMIIAINDÍGENA, VIOLENCIAY JUSTICIA}

Díaz-Polanco, Héctor

(1981), El desarrollo rural en América Latina. Notas sobre el caso mexicano, México, Cuadernos del Centro de Investigación para la Investigación Social, núm.3

Ditchl, Sigrid

(1987), Cae una estrella: desarrollo y destrucción de la Selva Lacandona, México, SEP/FronteraPrograma Cultural de la Frontera.

(1989), "Historia reciente de la Selva Lacandona. Un breve análisis", en Hernández, L. y Sandoval, J. M. (coords.), El redescubrimiento de la frontera sur, UAZ-UAM, pp.165-173

Dietz, Gunther y Mateos Cortés, Laura Selene

(2009), "El discurso intercultural ante el paradigma de la diversidad: estructuraciones subyacentes y migraciones discursivas del multiculturalismo contemporáneo", en Valladares, L., Pérez Ruiz, M.L. y Zárate, M., (coords.) Estados plurales. Los retos de la diversidad y la diferencia, México, Universidad Autónoma Metropolitana-Juan Pablos Editor, pp.289-322

Echeverría, Bolívar

(1998), "Violencia y modernidad", en Sánchez Vázquez, A. (ed.), El mundo de la violencia, UNAMFCE, México, pp. 365-382

Escalona Victoria, José Luis

(2009), "Cambio social y actores políticos en el medio rural. Una experiencia en Las Margaritas, Chiapas", en Estrada, M. (ed.), Chiapas después de la tormenta, México, COLMEX/Gobierno de Chiapas/Cámara de Diputados, LX legislatura

Escárzaga, Fabiola

(2005), "La comunidad indígena en las estrategias insurgentes en México, Perú y Bolivia", en Escárzaga, F. y Gutiérrez, R. (coords.) Movimiento indígena en América Latina: resistencia y proyecto alternativo, México, BUAP/SedesolDF/Juan Pablos, pp. 181-218

-y Gutiérrez, Raquel (coords.)

(2005), Movimiento indígena en América Latina: resistencia y proyecto alternativo, México, BUAP/SedesolDF/Juan Pablos

(2006), Movimiento indígena en América Latina: resistencia y proyecto alternativo Vol. II, México, Juan Pablos/CEAM/BUAP

Escobar, Arturo

(2009), "Una Minga para el postdesarrollo", América Latina en movimiento, Quito, junio 2009, año XXXIII, II época, pp. 26-30

Esteva, Gustavo

(1998), "Autonomía y democracia radical: el tránsito de la tolerancia a la hospitalidad", en Bartolomé, M. y Barabas, A., Autonomía étnica y estados nacionales, México, CONACULTA-INAH, pp.307-332. (2002), "Sentido y alcances de la lucha por la autonomía", en Mattiace, S., Hernandéz, A. y Rus, J., Tierra, libertad y autonomía: impactos regionales del zapatismo en Chiapas, México, CIESAS IWGIA, pp. 365-402

(2001), "Desarrollo", en Sachs, W. (coord.), Diccionario del desarrollo. Una guía del conocimiento como poder, México, Galileo Ediciones- Universidad Autónoma de Sinaloa, pp. 65-92

(2009), "Más allá del desarrollo: la buena vida", América Latina en movimiento, Quito, junio 2009, año XXXIII, II época, pp. 1-5 
(2010), "La insurrección en curso", en <http://unitierradeoaxaca.files.wordpress.com/2011/07/lainsurreccion-en-curso.pdf>, consultado el 20 abril 2013.

Estrada Martínez, Rosa I. y González Guerra, Gisela (1997), Tradiciones y costumbres jurídicas en comunidades indígenas de México, México, Comisión Nacional de los Derechos Humanos

Estrada Saavedra, Marco (2006), "Entre utopía y realidad: historia de la Unión de ejidos de la Selva", Liminar. Estudios Sociales y Humanísticos, vol. IV, núm. 1, junio, 2006, pp. 112-135, México, Centro de Estudios Superiores de México y Centro América, en <http://www.redalyc.org/articulo.oa?id=74540109>, consultado el 20 diciembre 2013.

Fazio, Carlos (2000), "Guerra sucia y paramilitarización en México y Colombia", en Krunitzky, H. (comp.), Globalización de la violencia, Ed. Colibrí, México, pp.55-70

Fernández Christlieb, Paulina (2003), "El EZLN y la GBI en Chiapas: derechos indígenas contra corporaciones transnacionales",

Revista Mexicana de Ciencias Políticas y Sociales, vol. XLVI, núm. 189, mayo-diciembre, 2003, México, UNAM, pp. 213-262

(2009), "Gobierno autónomo zapatista. Características antisistema político mexicano", ponencia presentada en el Seminario Internacional de Reflexión y Análisis, Universidad de la Tierra, San Cristóbal de las Casas, Chiapas, 31 diciembre 2009.

Ferrándiz Martin, Francisco y Feixa Pampols, Carles

(2004), "Una mirada antropológica sobre las violencias", Alteridades, vol.14, núm.27, Universidad Autónoma Metropolitana-Iztapalapa, México, pp.159-174

Figueroa Mier, Martha

(2003), "La justicia no es para los indígenas". Ojarasca n.77 septiembre 2003, <http://www.jornada.unam.mx/2003/09/22/oja77-chiapas.html>, consultado el 3 diciembre 2011.

Frühling, Pierre; González, Miguel y Setter Buvollen, Hans

(2007), Etnicidad y nación. El desarrollo de la autonomía de la Costa Atlántica de Nicaragua (19872007), Guatemala, F\&G Editores

Gabriel, Leo

(2008), "Introducción. La unidad de la diversidad: hipótesis para una nueva democracia", en Gabriel, L. y López y Rivas, G. (coords), El universo autonómico. Propuesta para una nueva democracia, México,UAM-I/ Plaza y Valdés, pp. 23-58.

-y López y Rivas, Gilberto (coords.)

(2005), Autonomías indígenas en América Latina. Nuevas formas de convivencia política, México, UAM-I/Plaza y Valdés

(2008), El universo autonómico. Propuesta para una nueva democracia. México, UAM-I/ Plaza y Valdés

Gall, Olivia

(2004), "Identidad, exclusión y racismo: reflexiones teóricas y sobre México", Revista Mexicana de Sociologia, año 2004, Abril - Junio, núm. 2, Instituto de Investigaciones Sociales- UNAM, México, pp.221-258 


\section{AUTOONOMIIAINDÍGENA, VIOLENCIAY JUSTICIA}

(2005), "Desigualdad, diferencialismo, asimilacionismo, segregacionismo y exterminio: racismos ordinarios en el mundo y en México", en La discriminación racial, CONAPRED, México, pp. 7-52

Galtung, Johan

(1975), Essays in peace research, Copenhaguen, Christian Ejlers

(1981), "Contribución específica de la irenología al estudio de la violencia: tipologías", en La violencia y sus causas, París, UNESCO, pp.91-10

(1990), “Cultural violence”, Journal of Peace Research, vol. 27, núm. 3, agosto, pp.291-305

García, Clara Inés

(2009) "Limites y posibilidades de la construcción de ciudadanía en Colombia", Política y Cultura, otoño 2009, núm.32, México, UAM-Xochmilco, pp.79-102.

García de León, Antonio

s/f, y Liza Rumazo, Igualdad en la justicia. Primer Congreso Indígena Fray Bartolomé de Las Casas, Chiapas, octubre de 1974 , folleto

(1995), "La vuelta del Katún (Chiapas: a veinte años del Primer Congreso Indígena)", Chiapas, núm. 1, México, ERA.

(1985), Resistencia y utopía, Tomo 2, México, ERA.

(1994a), "Introducción”, en EZLN: documentos y comunicados, vol.1, México, ERA.

Gasparello, Giovanna

(2005), L'autonomia possibile. Chiapas: la costruzione dell'autogoverno nelle comunitá indigene della Selva Lacandona, Venezia, Editoria Universitaria

(2007), Administración autónoma de la justicia y su relación con el Estado. El Sistema de Seguridad y Justicia Comunitaria de la Costa-Montaña de Guerrero, México, Tesis de Maestría en Ciencias Antropológicas, México, Universidad Autónoma Metropolitana-Iztapalapa

-y Quintana, Jaime

(2010), Otras geografías. Experiencias de autonomías indígenas en México, México, RedeZ [1 edición: 2009, México, UAM-Iztapalapa]

(2012), "No morirá la flor de la palabra... La radio comunitaria indígena en Guerrero y Oaxaca", Nueva Antropología, vol.XXV, núm.7, julio-diciembre 2012, pp.133-154, México, UAM-INAHColmex-CONACYT, ISSN: 0185-0636

Giménez, Gilberto

(1999), "Territorio, cultura e identidades: la región sociocultural", Revista Estudios sobre las culturas Contemporáneas: Época II, Vol. V, Núm. 9, Colima, junio 1999, pp. 25-57.

Girard, René

([1972] 1986), La violencia y lo sagrado, Barcelona, Anagrama

Gledhill, John

(2001), "La dialéctica región-centro-Nación a fin de siglo: poderes regionales, poderes trasnacionales y transformación del Estado", en Maldonado Aranda, S. (ed.), Dilemas del Estado nacional, México, Colmich-CIESAS, pp.27-54

(2004), "Indigenous autonomy as a strategy for social inclusion: some paradoxes of social policy in contemporary Mexico", en <http://jg.socialsciences.manchester.ac.uk/ESRC_Sem_Gledhill.pdf >, consultado el 10 noviembre 2013.

(2004) Cultura y desafío en Ostula. Cuatro siglos de autonomía indígena en la costa-sierra nahua de Michoacán, Zamora, Colegio de Michoacán 
(2013), "Límites de la autonomía y autodefensa indígena: experiencias mexicanas", Oxímora. Revista internacional de ética y política, No. 2 (2013), Universitat de Barcelona, pp. 1-21

Gómez, Magdalena

(2005), "La autonomía en la antesala: la paz inconclusa (el caso mexicano, 1995-2003)", en Movimiento indígena en América Latina: resistencia y proyecto alternativo, México, Gobierno del DFJuan Pablos-UAP-UNAM-UACM, pp.221-236

Gómez Cruz, Patricia y Kovic, Christina

(1994), Con un pueblo vivo, en tierra negada. Un ensayo sobre los derechos humanos y el conflicto agrario en Chiapas, 1989-1993, México, Centro de Derechos Humanos Fray Bartolomé de las Casas

Gómez Hernández, Antonio y Ruz Sosa, Mario Humberto

(1992), Memoria baldía. Los tojolab'ales y las fincas. Testimonios, México, UNAM/IIFL/CEM/ $\mathrm{UNACH} / \mathrm{CEI}$

Gómez Valencia, Herinaldy

(2000), De la justicia y el poder indígena, Colombia, Universidad del Cauca

(2008), "D-escribiendo las justicias orales indígenas", en Gómez, H. y Gnecco, C. (eds.), Representaciones legales de la alteridad indígena, Colombia, Colciencia-Universidad del Cauca, pp.189-286

González, Miguel

(2004), "Autonomías territoriales Con Permiso y Sin Permiso del Estado: Un Análisis Comparativo Preliminar de los Procesos Autonómicos en Chiapas y Nicaragua", $V$ Congreso Centroamericano de Antropología, UNAN, Managua, Nicaragua, 23 al 27 de febrero 2004

- y Burguete, A., Ortiz-Tejeda, P. (coords.),

(2010) La autonomía a debate. Autogobierno indígena y Estado plurinacional en América Latina, Quito, FLACSO/GTZ/IWGIA/CIESAS/UNICH, 2010

(2010), "Autonomías territoriales indígenas y regímenes autonómicos (desde el Estado) en América Latina”, en González, M., Burguete, A., y Ortíz-Tejeda, P. (coords.), La autonomía a debate. Autogobierno indígena y Estado plurinacional en América Latina, Quito, FLACSO/GTZ/IWGIA/CIESAS/UNICH, pp. 35-64.

González Calleja, Eduardo

(2010) “Violencia política. ¿Por qué la Política es escenario de violencia?”, en Sanmartín, J.; Gutiérrez, R. et al. (coords.) Reflexiones sobre la violencia, México, Siglo XXI-Centro Reina Sofía, pp.277-301

González Casanova, Pablo

(1967), La democracia en México, México, ERA

(1995), “Causas de la rebelión en Chiapas”, La Jornada, 5/09/1995.

(2003), "Los caracoles zapatistas. Redes de resistencia y autonomía. Ensayo de interpretación", Perfil de La Jornada, México, 26 septiembre 2003, <http://www.jornada.unam.mx/2003/09/26/pertexto.html>.

González Esponda, Juan y Pólito, Elizabeth

(195), "Notas para comprender el origen de la rebelión zapatista", Chiapas, núm.1, México, ERA. 


\section{AUTOONOMIIAINDÍGENA, VIOLENCIAY JUSTICIA}

Gorza, Piero

(2002), "El anhelo de conservar y la necesidad de perderse: 'cortacabezas' en San Pedro Chenalhó, México, 1996”, en Jacorzynsky, W. (coord.), Estudios sobre la violencia, México, CIESAS-Porrúa, pp.169-181

Griffiths, John

(2007), ¿Qué es el pluralismo jurídico?”, en Merry, S., Griffiths, J., Tamanaha, B. (eds.), Pluralismo jurídico, Bogotá, Siglo del Hombre ed., pp. 160-212

Gros, Christian

(2000), "Ser diferente para ser moderno, o las paradojas de la identidad. Algunas reflexiones sobre la construcción de la frontera étnica en América Latina", en Reina, L. (coord.) Los Retos de la etnicidad en los estados nación del siglo XXI, México, CIESAS-INI-Porrúa, pp. 171-195

(2004), Políticas de la etnicidad: identidad, Estado y modernidad, Bogotá, Instituto Colombiano de Antropología e Historia

(2005), "Introducción", en Reyna, L.; Lartigue, F.; Dehouve, D.; Gros, C. (coords.), Identidades en juego, identidades en guerra, CIESAS-INAH, México, pp.17-23

Grupo Trascend

(2006), "Trascender los conflictos. La perspectiva de Johan Galtung", Revista Futuros, vol. IV, núm.13, www.revistafuturos.info

Guerrero, Javier y López y Rivas, Gilberto

(1982), "Las minorías étnicas como categoría política en la cuestión regional", Boletín de Antropología Americana, núm. 5, México, Instituto Panamericano de Geografía e Historia, pp. 35-49.

Gutiérrez Ávila, Miguel Ángel

(2006), "La autonomía indígena frente al cacicazgo: el caso de los nann'cue ñomndaa' de Guerrero", en Escárzaga, F. y Gutiérrez, R. (coords.) Movimiento indígena en América Latina: resistencia y proyecto alternativo Vol. II, México, Juan Pablos/CEAM /BUAP, pp.137-149

Gutiérrez Chong, Natividad (coord.)

(2008), Estados y autonomías en democracias contemporáneas, México, UNAM-Plaza y Valdés

Hale, Charles R.

(2007) “Puede el multiculturalismo ser una amenaza? Gobernanza, derechos culturales y política de la identidad en Guatemala", en María L. Lagos y Pamela Calla (compiladoras), Antropología del Estado: Dominación y prácticas contestatarias en América Latina, La Paz, PNUD, pp. 285-346, <http://www.centrodesarrollohumano.org/pmb/opac_css/doc_num.php?explnum_id=1458>, consultado el 10 de noviembre 2014.

(2004) "Rethinking indigenous politics in the age of the "indio permitido", NACLA Report of Americas, vol. 38 (2), New York, septiembre- octubre 2004, <https://nacla.org/node/4137>, consultado el 3/12/2011.

Haraway, Donna

(1991[1995]), Manifesto cyborg. Donne, tecnologie e biopolitiche del corpo, Milano, Feltrinelli. 
Harvey, Neil

(1992), "La Unión de Uniones en Chiapas, y los retos políticos del desarrollo de base", en Autonomía y nuevos sujetos sociales en el desarrollo rural, México, Siglo XXI.

(1995), "Rebelión en Chiapas: reformas rurales, radicalismo campesino y los límites del salinismo", en Viqueira e Ruz (coord.), Chiapas. Los rumbos de otra historia, México, UNAM/CIESAS/CEMCA, pp.447-480.

(2000), La rebelión de Chiapas. La lucha por la tierra y la democracia, México, ERA

(2001), "La rebelión zapatista y el proceso de paz frustrado 1994-2000", en Gall, O., Chiapas: sociedad economía, interculturalidad y política, México, UNAM, pp.155-177.

Hébert, Martin

(2006a), "Présentation : paix, violences et anthropologie". Anthropologie et sociétés, vol.30, núm.1, pp. 7-28, en <http://www.erudit.org/revue/as/2006/v30/n1/>, consultado el 10 enero 2012.

(2006b), "Ni la guerre, ni la paix: Campagnes de "stabilisation » et violence structurelle chez les Tlapanèques de la Montaña du Guerrero (Mexique)", Anthropologica, vol.48, núm. 1, pp. 29-42.

Héritier, Françoise (coord.)

(1997), Sulla violenza, Roma, Meltemi

Hernández, Tosca

(2002), "Des-cubriendo la violencia”, en Briceño-León, R. (comp.) Violencia, sociedad y justicia en América Latina, Buenos Aires, Clacso, pp.57-75

Hernández Castillo, Rosalva Aída (2001), La otra frontera. Identidades múltiples en el Chiapas postcolonial, México, Porrúa-CIESAS. -y Garza Caligaris, Ana María (1998), "Encuentros y enfrentamientos de los tzotziles pedranos con el Estado mexicano. Una perspectiva histórico-antropológica para entender la violencia en Chenalhó", en Hernández Castillo, A., La otra palabra. Mujeres y violencia en Chiapas, antes y después de Acteal, México, CIESAS-IWGIA, pp. 39-62

(2002), "¿Guerra fratricida o estrategia etnocida? las mujeres frente a la violencia política en Chiapas", en Jacorzynsky, W. (coord.), Estudios sobre la violencia, México, CIESAS-Porrúa, pp.97-122

(2003) "¿Conocimiento para qué? Antropología Socialmente comprometida: entre las resistencias locales y los poderes globales", ponencia presentada en la reunión anual de LASA, Dallas, Texas

-y Garza Caligaris, Ana María

(1998), "Encuentros y enfrentamientos de los tzotziles pedranos con el Estado mexicano. Una perspectiva histórico-antropológica para entender la violencia en Chenalhó", en Hernández Castillo, A., La otra palabra. Mujeres y violencia en Chiapas, antes y después de Acteal, México, CIESASIWGIA, pp. 39-62

-y Paz, Sarela; Sierra, María Teresa

(2004) El estado y los indígenas en tiempos del PAN, México, CIESAS -Porrúa

Hernández Navarro, Luís

(1992), Las convulsiones sociales, en Moguel, J.; Botey, C.y Hernández, L. (coords.), Autonomía y nuevos sujetos sociales en el desarrollo rural, México, Siglo XXI, pp. 235-260.

(1995), Chiapas: la guerra y la paz, México, ADN.

(1997), "La autonomía indígena como ideal. Notas a La rebelión zapatista y la autonomía de Héctor Díaz-Polanco", Chiapas, núm. 5, ERA/UNAM.

- y Vera, Ramón

(1997), Los Acuerdos de San Andrés, México, ERA. 


\section{AUTOONOMIIAINDÍGENA, VIOLENCIAY JUSTICIA}

Hidalgo, Onécimo y Castro, Gustavo

(1999), Población desplazada en Chiapas, México, CIEPAC/Consejería en Proyectos

Hijar González, Cristina

(2008), Autonomía Zapatista: otro mundo es posible, (texto de Cristina Híjar González, fotografías de Juan E. García), México, AMV

Hobsbawm, Eric

(2002 [1983]), "Introducción: la invención de la tradición", en Hobsbawm, E. y Ranger, T. (eds.), La invención de la tradición, Barcelona, Editorial Crítica, pp.7-21.

Hooker, Juliet

(2010), “¿De la autonomía multiétnica a...? Supervivencia cultural, relaciones inter-étnicas, autogobierno y el modelo de autonomía en la Costa Atlántica de Nicaragua", en Burguete, A., González, M. y Ortíz-Tejeda, P. (coords.), La autonomía a debate. Autogobierno indígena y Estado plurinacional en América Latina, Quito, FLACSO/GTZ/IWGIA/CIESAS/UNICH, pp. 177-200

Houtart, Françoise

(2008), "Las autonomías multiculturales en el contexto de la mundialización", en Gabriel, Leo y López y Rivas, Gilberto, El universo autonómico, México, Plaza y Valdés, pp.11-21.

Hrovatin, Ian

(2012), Estrategia para promover el acceso a la justicia en Chiapas, Oficina de las Naciones Unidas contra la Droga y el Delito (UNODC)

Huber, Rodolfo, Martínez, Juan Carlos, et al.

(2008), Hacia sistemas jurídicos plurales. Reflexiones y experiencias de coordinación entre derecho estatal y el derecho indígena, Colombia, Konrad Adenauer Stiftung.

Instituto de Desarrollo Económico y Social (IDES), Grupo-taller de trabajo de campo etnográfico (1998), "Campos Minados", Desarrollo Económico, vol. 38, núm. 149, enero-abril 1998; Buenos Aires, pp. 481-484

Iturralde Blanco, Ignacio

(2012), Autonomía comunitaria y caciquismo: identidad étnica, control social y violencia en una comunidad mixe de Oaxaca, Barcelona, Institut Català Internacional per la Pau.

Jacorzynsky, Witold

(2002) "Sacrificio, capital y violencia: temas simbólicos de la narrativa sobre 'cortacabezas' en los Altos de Chiapas", en Jacorzynsky, W. (coord.), Estudios sobre la violencia, México, CIESAS-Porrúa, pp.205-235

Jaramillo, Ana María, Villa, Martha Inés y Ceballos, Ramiro

(2001), “Actores recientes del conflicto armado en Medellín”, en Sousa Santos, B. y García Villegas, M. (coords.), El caleidoscopio de las justicias en Colombia vol.2, Bogotá, Ed. Siglo del Hombre, pp.423-460.

Kaplan, Marcos

(1998), "Nueva violencia latinoamericana", en Sánchez Vázquez, A. (ed.), El mundo de la violencia, UNAM-FCE, México, pp.69-92 
Korsbaek, Leif y Florencia Mercado Vivanco

(2005), "La sociedad plural y el pluralismo jurídico, un acercamiento desde la antropología del Derecho", en Ordoñez Cifuentes, J. (coord.), Pluralismo jurídico y pueblos indígenas. XIII Jornadas Lascasianas Internacionales, México, UNAM, Instituto de Investigaciones Jurídicas, pp. 153-177.

Kraemer Bayer, Gabriela (2003), Autonomía indígena región mixe. Relaciones de poder y cultura política, México, Plaza y Valdés-Universidad de Chapingo (2008), Autonomía de los zapotecos del Istmo, México, Plaza y Valdés

Leal, Alejandra (2006), "Burocracia, justicia y pluralismo jurídico. Una exploración de los espacios del poder en Oaxaca”, Alteridades año 16, núm. 31, enero-junio 2006, México, UAM-I, pp.39-48

Le Bot, Yvon (2006), "Movimientos identitarios y violencia en América Latina", en Gutiérrez, D. (coord.), Multiculturalismo. Desafios y perspectivas, México, Siglo XXI-UNAM-El Colegio de México, pp.189-212

Leyva Solano, Xochitl (2001), "Las "autoridades-concejo" en las Cañadas de la Selva Lacandona: la excepción que cumple la regla", Cuadernos del Sur, núm. 16, mayo de 2001, Oaxaca, México, pp. 49-64.

-y Ascensio, Gabriel

(1991), "Los municipios de la Selva Chiapaneca. Colonización y dinámica agropecuaria", Anuario del Instituto Chiapaneco de Cultura, Tuxtla Gutiérrez, Gobierno del Estado de Chiapas-Consejo Estatal de Fomento a la Investigación y Difusión de la Cultura (1996), Lacandonia al filo del agua, México, FCE, CIESAS, UNICACH, CIHMECH-UNAM. - y Speed, Shannon (2008), "Hacia la investigación descolonizada: nuestra experiencia de co-labor", en Leyva. X. et al. (coords.), Gobernar (en) la diversidad: experiencias indígenas desde América Latina. Hacia la investigación de co-labor, México, CIESAS/FLACSO Ecuador/FLACSO Guatemala, pp. 34-59.

Lenkersdorf, Carlos

(1996), Los hombres verdaderos, México, Siglo XXI.

(2002), Filosofar en clave tojolabal, México, Porrúa.

León Portilla, Miguel

(2011), Independencia, Reforma, Revolución, ¿y los indios qué?, México, Conaculta-UNAM

Lerma Rodriguez, Enriqueta

(2009), "Concepción y práctica de la autonomía yaqui: una lucha constante", en. Gasparello, G. y Quintana, J., Otras Geografías. Experiencias de autonomías indígenas en México, México, UAM-I, pp. 87-102.

Lewis, Stephen E.

(2001), ¿Patria (chica) o muerte? Tres episodios de lucha por la 'soberanía’ chiapaneca, 1914-1940”, en Gall, O. (coord.), Chiapas: sociedad, economía, interculturalidad y política, México, UNAM, pp. 95-116. 


\section{AUTONOMIAINDÍGENA, VIOLENCIAY JUSTICIA}

Lombardo Toledano, Vicente

(1973), "El problema de las minorías oprimidas", en Lombardo, V., El problema del indio, México

Sep-Setentas, 1973, págs. 101-108, disponible en <http://www.uom.edu.mx/rev_trabajadores/pdf/

62/62_Vicente_Lombardo.pdf>, consultado el 10 febrero 2013.

Longo, Roxana y Korol, Claudia

(2008) "Criminalización de los movimientos sociales en Argentina", en Buhl, K. y Korol, C. (orgs.), Criminalización de la protesta y de los movimientos sociales, Instituto Rosa Luxemburgo y Rede Social, São Paulo, 2008

López Bárcenas, Francisco

(2005), "Rostros y caminos de los movimientos indígenas en México", en Movimiento indígena en América Latina: resistencia y proyecto alternativo, México, Gobierno del DF-Juan Pablos-UAPUNAM-UACM, pp. 171-188

(2009a), Autonomías y derechos indígenas en México, México, MC Editores

(2009b), San Juan Copala: dominación política y resistencia popular, México, MC Editores/UAMXochimilco

(2011), "Las autonomías indígenas en América Latina", en Pensar las autonomías, México, SísifoBajo Tierra Ediciones, pp. 71-106.

López y Rivas, Gilberto

(1995), Nación y pueblos indios en el neoliberalismo, México, Plaza y Valdés-Universidad Iberoamericana

(1999), "Paramilitarismo e insurgencia en México", Memoria, núm. 133, junio de 1999, México, Centro de Estudios del Movimiento Obrero y Socialista, pp. 44-48.

(2004), "Presentación", en Martí I Puig, S. y Sanahuja, J., Etnicidad, autonomía y gobernabilidad en América Latina, Ediciones Universidad de Salamanca, Salamanca, pp. 9-12

(2004b), "Contrainsurgencia y paramilitarismo en el gobierno de Vicente Fox", en López y Rivas, G., Autonomías, democracia o contrainsurgencia, México, Ediciones Era, pp. 113-144

(2008) "Etnomarxismo y antropología", Ponencia presentada en el Simposio La Antropología y la formación de la conciencia nacional mexicana, Colegio de Jalisco, del 9 al 11 de diciembre de 2008.

(2010a), "Tesis en torno a la autonomía de los pueblos indios", Rebelión, 29/05/2010. (2011), “México, Estado fallido?” Ponencia para el Primer Congerso Nacional Historia y práctica de las drogas: una visión antropológica, Escuela Nacional de Antopología e Historia, México, 13 de marzo de 2011, a partir del capítulo del libro en alemán coordinado por Herbert Berger y Leo Gabriel, Democracias en revuelta, Viena, Editorial Mandelbaum, 2010, en <http://rebelion.org/noticia.php?id=126700> consultado el 10 septiembre 2011.

López Sollano, Saúl

(2002), Insurrección cívica, insurgencia guerrillera y luchas campesinas por autonomía y democracia frente a la violencia de Estado en Guerrero, México, Tesis de Maestría en Desarrollo Rural, Universidad Autónoma Metropolitana-Unidad Xochimilco.

Machuca, Jesús Antonio

(2008), "Estrategias turísticas y segregación socioterritorial en regiones indígenas", en Castellanos, A. y Machuca, A. (coords.), Turismo, identidades y exclusión, México, Juan Pablos-UAM, pp.51-95 
Maíz, Ramón

(2008), "XI tesis para una teoría política de la autonomía", en Gutierrez Chong, N. (coord.), Estados y autonomías en democracias contemporáneas, México, UNAM-Plaza y Valdés, pp. 17.41

Maldonado Alvarado, Benjamín

(2002), Autonomía y comunalidad india. Enfoques y propuestas desde Oaxaca, Oaxaca,ConacultaINAH/SAI/CEDI/CMPIO, 2002.

Maldonado Aranda, Salvador

(2012), "Droga, violencia y militarización en el México rural. El caso de Michoacán", en Revista Mexicana de Sociología, vol. 74, núm.1 (enero-marzo, 2012), México, UNAM-Instituto de Investigaciones Sociales, pp.5-39.

(2010), "Narcotráfico y militarización en México. Territorios, economías regionales y trasnacionalismo", en Vargas Velásquez, A. (coord.), Seguridad en Democracia. Un reto a la violencia en América Latina, Buenos Aires, CLACSO, pp.345-372

(2009), "Territorios, ilegalidades y soberanías de los estados-nación en torno de las drogas", en Quaderns-e, revista electrónica del Institut Catalá d'Antropologia, núm. 13/2009a, en <http://www.antropologia.cat/quaderns-e-136>, consultado el 8 septiembre 2013.

Marcos, Subcomandante y Le Bot, Yvon

(1997), El sueño zapatista, Barcelona, Plaza y Janés, versión electrónica citada:

<http://www.so000260.ferozo.com/pdf/suenio-zap.pdf>, consultado el 1 de agosto 2014.

Martínez, Juan Carlos

(2003), "Las Juntas de Buen Gobierno. Autonomía y gobernabilidad no estatal", Boletín Chiapas al Día, núm. 379, 17 octubre 2003, México, CIEPAC,

<http://www.ciepac.org/boletines/chiapasaldia.php>, consultado el 10/12/2010

(2006), "Los límites del reconocimiento de sistemas normativos y jurisdicción de los pueblos indígenas en Oaxaca", Alteridades año 16 núm.31, México, UAM-I, pp.49-59

(2013), "El derecho de los indígenas a conservar un sistema político propio y su brecha de implementación. El caso de Santa María Peñoles", Revista de Estudios e pesquisas sobre as Américas, Brasil, CEPPAC/UnB, pp.70-104

Martínez Novo, Carmen (compil.)

(2009), Repensando los movimientos indígenas, Quito, FLACSO/Ministerio de Cultura de Ecuador

Martínez Rodríguez, Francisco Miguel y Gabriel Carmona Orantes

(2009), "Globalización, violencia estructural y pobreza", Revista Científica del Equipo Federal del Trabajo, Núm. 48, mayo 2009, Buenos Aires, en <http://www.newsmatic.epol.com.ar/index.php?pub_id=99\&sid=2106\&aid=41300\&eid=48\&NombreS eccion=Pobreza\&Accion=VerArticulo $>$, consultado el 15 enero 2012.

Mattei, Ugo

(2008), "L'industria dell'armonia e il mercato della giustizia”, Il Manifesto, Roma, 8 de febrero 2008

Mattiace, Shannan, Hernandez, Aída y Rus, Jan (eds.)

(2002), Tierra, libertad y autonomía: impactos regionales del zapatismo en Chiapas, México, CIESAS/IWGIA 


\section{AUTOONOMIIAINDÍGENA, VIOLENCIAY JUSTICIA}

Medina Hernández, Andrés

(1987a), "El etnopopulismo y la cuestión nacional en México: el espacio político de los grupos étnicos", Anales de Antropología, Vol. 24, Núm. 1 (1987), México, Instituto de Investigaciones Antropológicas-UNAM, pp. 171-198,

<http://www.revistas.unam.mx/index.php/antropologia/article/view/10003〉, consultado el 10 noviembre 2012.

(1987b), "La cuestión étnica en México: una reconsideración histórica", Boletín de Antropología Americana, núm. 16, diciembre 1987, Instituto Panamericano de Geografía e Historia-OEA, pp.5-20

Megchún Rivera, Rodrigo

(2008), "Depende de la semilla. Cambios en la estructura agraria chiapaneca", pp.105-112 y "Conflicto agrario entre la población indígena", pp. 201-206, en Nolasco, M., et.al. (coords.), Los pueblos indígenas de Chiapas. Atlas etnográfico, México, INAH/Gobierno del Estado de Chiapas.

Merry, Sally Engle

(2007), "Pluralismo jurídico", en Merry, S., Griffiths, J. y Tamanaha, B., Pluralísmo jurídico, Bogotá, Siglo del Hombre eds. /Universidad de los Andes/ Instituto Pensar, pp. 89-131

(2011), "Derechos humanos, género y nuevos movimientos sociales: debates contemporáneos en antropología jurídica", en Chenaut, V., Gómez, M., Ortíz, H. y Sierra, T. (coords.), Justicia y diversidad en América Latina. Pueblos indígenas antes la globalización, México, CIESAS-FLACSO

Mendoza Ramírez, Martha Patricia

(1995), "La intervención gubernamental en la Selva Lacandona", en Guillén, D. (coord.), Chiapas, una modernidad inconclusa, México, Instituto Mora, pp. 115-147

Moguel, Julio

(1992), "Reforma constitucional y luchas agrarias en el marco de la transición salinista", en Moguel, J.; Botey, C. y Hernández, L. (coords.), Autonomía y nuevos sujetos sociales en el desarrollo rural, México, Siglo XXI, pp. 261-275

Montemayor, Carlos

(1998), "La guerrilla en México hoy", Fractal n¹1, octubre-diciembre, 1998, año 3, volumen III, pp. 11-44.

(1999), "Guerrero: la guerrilla recurrente", en Neri Quevedo, E. (compil.), Guerrero 1849-1999, Chilpancingo, Gobierno del Estado de Guerrero, pp.279-288

(2001), Los pueblos indios de México hoy, México, Planeta

(2008), "La violencia de Estado en México", periódico La Jornada, 23 octubre, 27 octubre, 31 octubre, 6 noviembre, 10 noviembre, en <www.lajornada.unam.mx>, consultado el 3/09/2012

(2009), "Prefacio", en Gasparello, G. y Quintana, J., Otras Geografías. Experiencias de autonomía indígenas en México, México, UAM-I, pp.15-17.

Moore, Sally Falk

(1986), Social Fact and Fabrication: Customary Law on Kilimanjaro, Cambridge University Press.

Mora, Mariana

(2013), "La politización de la justicia Zapatista frente a la Guerra de baja intensidad en Chiapas", en Sierra, T., Hernández, R. y Sieder, R. (coords.), Justicias indígenas y Estado. Violencias contemporáneas, México, FLACSO-CIESAS, pp. 195-227. 
Morales Bermúdez, Jesús

(1998), "Las rutas de la Selva: de la memoria a la promesa", Revista Académica para el estudio de las religiones, Tomo II: Chiapas: el factor religioso, México, pp.147-169, disponible en

<http://www.revistaacademica.com/TII/Capítulo_8.pdf>.

Muñoz, Gloria

(2003), 20 y 10: el fuego y la palabra, México, La Jornada-Rebeldía.

Nader, Laura

[1990 (1998)], Ideología armónica. Justicia y control en un pueblo de la montaña zapoteca, México, Instituto Oaxaqueño de las Culturas/CIESAS.

Nagengast, Carole

(1994), "Violence, Terror, and the Crisis of the State", Annual Review of Anthropology, Vol. 23, pp. 109-136.

Nahoum-Grappe, Véronique

(1997), “L'uso político della crudeltá: l'epurazione etnica in ex-Iugoslavia (1991-1995)”, en Heritier, F., Sulla violenza, Roma, Meltemi, pp.191-227.

Navarro, Alejandra; Bravo, Yacotzin y López, Catalina

(2013), "Legislación de pesca y obstáculos para el reconocimiento de derechos al uso preferencial de recursos naturales del pueblo cucapá", Revista de Estudos e Pesquisas sobre as Américas, vol. 7, no. 2, Brasil

Negri, Antonio

(1992), Il potere costituente, Varese, Sugarco.

- y Hardt, Michael

(2001), Il lavoro di Dioniso. Per la critica dello Stato postmoderno, Roma, Manifestolibri.

(2002), Impero, Milano, Rizzoli.

(2004), Moltitudine, Milano, Rizzoli.

Nerio Monroy, Ana Luisa

(2011) "La militarización de la seguridad pública y su impacto en los derechos humanos de la población en situación de vulnerabilidad", Defensor, núm.8, año IX, agosto 2011, México, Comisión de Derechos Humanos del Distrito Federal, pp.19-22.

Nolasco, Margarita et al.

(2003), "El territorio de la frontera sur: espacio apropiado fáctica y simbólicamente", en Barabas, A. (coord.), Diálogos con el territorio. Simbolizaciones sobre el espacio en las culturas indígenas de México, vol.1, México DF, INAH

(2002), "Identidad y reproducción cultural en áreas de frontera", Seminario Permanente de Etnografía Mexicana, volumen II: Relaciones interétnicas e identidad, México, INAH

Nordstorm, Caroline y A. Robben (eds.)

(1995), Fieldwork Under Fire: Contemporary Studies of Violence and Survival, Berkeley, University of California Press

Núñez Rodríguez, Violeta

(2009), Análisis del presupuesto en materia indígena 2001-2009, Centro de Estudios para el Desarrollo Rural Sustentable y la Soberanía Alimentaria, Cámara de Diputados, LX Legislatura, México 


\section{AUTOONOMIIAINDÍGENA, VIOLENCIAY JUSTICIA}

Oemichen Bazán, Cristina

(1999), Reforma del estado. Política social e indigenismo en México (1988-1996), México, UNAM, Instituto de Investigaciones Antropológicas.

Olivera Bustamante, Mercedes

(1998), "Acteal: los efectos de la guerra de baja intensidad", en Hernández Castillo, A., La otra palabra. Mujeres y violencia en Chiapas, antes y después de Acteal, México, CIESAS-IWGIA, pp. 114-124.

Orantes García, José

(2007), Derecho pedrano: estrategias jurídicas en Los Altos de Chiapas, México, UNAM.

Ortega Hegg, Manuel

(2005), "La autonomía regional en Nicaragua", en López y Rivas, G. y Gabriel, L. (coords), Autonomías indígenas en América Latina, México, Plaza y Valdés, pp. 195-261.

Palacios, Juan José

(1983), "El concepto de región: la dimensión espacial de los procesos sociales", Revista Interamericana de planificación, vol. XVII, núm. 66, México, disponible en <http://www.ucla.edu.ve/dac/Departamentos/AdmPubII/materiales/EL\%20CONCEPTO\%20DE\%20R EGION.pdf>, consultado el 23 de junio 2014.

Paoli, María Cecilia (2003), "Imprese e responsabilitá sociale: gli intrecci della cittadinanza in Brasile", en Sousa Santos, B., Democratizzare la democrazia, Troina, Cittá Aperta Edizioni, pp.289-328

Paris Pombo, María Dolores

(2000), "La mujer, el indio y la patria en el discurso político chiapaneco (1970-1993)", Desacatos [en línea] núm. 4, México, CIESAS. Disponible en:〈http://www.redalyc.org/articulo.oa?id=13900406>

(2002), "Estudios sobre el racismo en América Latina", Política y cultura, núm. 17, México, UAM-X, pp.289-310

Pérez Moreno, María Patricia

(2012), Corazón. Una forma de ser-estar-hacer-sentir-pensar entre los tseltaletik de Bachajón, Chiapas, México, Tesis de Maestría en Antropología, FLACSO-Ecuador

Pérez Ruiz, Maya Lorena

(2007), "Disyuntivas del movimiento indígena en México: algunas reflexiones", en Tarrío, M., Comboni, S. y Diego, R. (coords.), Mundialización y diversidad cultural: Territorio, identidad y poder en el medio rural mexicano, México, UAM-X, pp.277-300.

Pérez Ruiz, M.L. Valladares, L., y Zárate, M., (coords.) (2009), Estados plurales. Los retos de la diversidad y la diferencia, México, UAM-Juan Pablos Editor

Piccoli, Emmanuelle (2009), "Las Rondas campesinas y su reconocimiento estatal, dificultades y contradicciones de un encuentro: un enfoque antropológico sobre el caso de Cajamarca, Perú", Nueva Antropología, vol. XXII, núm. 71, julio-diciembre 2009, México, UAM/INAH/Conacyt, pp. 93-113

Poole, Deborah 
(2006) "Los usos de la costumbre. Hacia una antropología jurídica del estado neoliberal”, Alteridades año 16, num. 31, enero-junio 2006, México, UAM-I, pp.39-48

Porto-Gonçalvez, Carlos Walter

(2001) Geo-grafías. Movimientos sociales, nuevas territorialidades y sostenibilidad, México, Siglo XXI

(2009) "Del desarrollo a la autonomía: la reinvención de los territorios", América Latina en movimiento, Quito, junio 2009, año XXXIII, II época, pp.10-13

Regalsky. Pablo y Quisbert, Francisco

(2008), "Bolivia indígena: de gobiernos comunitarios en busca de autonomía a la lucha por la hegemonía". En: X. Leyva, A. Burguete y S. Speed, Gobernar (en) la diversidad: experiencias indígenas desde América Latina. Hacia la investigación de co-labor, México, CIESAS-FLACSO, pp. $151-187$

Regino Montes, Adelfo

s/f, "La Comunalidad. Raíz, pensamiento, acción y horizonte de los pueblos indígenas", $<$ http://www.redindigena.net/ser/departamentos/documentos/comunarealidad.html $>$.

Renard H, María Cristina

2005 Tzo?hontahal los caminos de la tradición. Relaciones de poder y cultura política, México, Plaza y Valdés-Universidad de Chapingo

Rendón Alarcón, Jorge:

(2003), Sociedad y conflicto en el estado de Guerrero, 1991-1995, México, Plaza y Valdés

Restrepo, Darío I.

(2003), "Las prácticas participativas: entre la socialización y la privatización de las políticas públicas", Revista del CLAD Reforma y Democracia, $\mathrm{n}^{\circ} 25$ (2003), <http://www.clad.org/portal/publicacionesdel-clad/revista-clad-reforma-democracia/articulos/025-febrero-2003/0045400>, consultado el 20 febrero 2013.

Reyes Ramos, Maria Eugenia

(1992), El reparto de tierras y la política agraria en Chiapas, 1914-1988, México, UNAM

(2005), "Conflictos y violencia agraria en Chiapas", Revista Estudios Agrarios, núm. 29, mayo-agosto 2005, México, Procuraduría Agraria, pp. 51-84

Reyna, Leticia

(2000), "Raíces y fuerza de la autonomía indígena", en Reina, L. (coord.), Los retos de la etnicidad enlos Estados-nación del siglo XXI, México, CIESAS-INI-Porrúa, págs. 245-277.

Riches, David (ed.)

([1986] 1988), El fenómeno de la violencia, Madrid, Pirámide

Riella, Alberto

(2001), "Violencia y control social: el debilitamiento del orden social de la modernidad", Papeles de Población, vol. 7, núm. 30, octubre-diciembre, Universidad Autónoma del Estado de México, pp.183204. 


\section{AUTOONOMIIAINDÍGENA, VIOLENCIAY JUSTICIA}

Rodríguez, Clemencia

(2011), Citizens' Media Against Armed Conflict: Disrupting Violence in Colombia, Minneapolis, The University of Minnesota Press.

(2004), "Comunicación para la Paz: Enfoques Encontrados", Son de Tambora, n. 88, <http://www.comminit.com/la/drum_beat_88.html>, consultado el 8 de julio 2010.

Rodríguez Araujo, Octavio

(1998), "Violencia social (un intento conceptual para el México actual)", en Sánchez Vázquez, A. (ed.), El mundo de la violencia, UNAM-FCE, México, pp.93-105

Rodríguez Rejas, María José

(2010), "El proceso de militarización en México: un caso ejemplar", en Calderón Rodríguez, J.M. (coord.) América Latina: Estado y sociedad en cuestión, Editorial Edimpo, México

Román Román, Salvador

(2001), Revuelta cívica en Guerrero (1957/60), México, INHERM

Sachs, Wolfgang

(2001), "Introducción”. En: Sachs, W. (coord.), Diccionario del desarrollo. Una guía del conocimiento como poder, México, Galileo Ediciones-Universidad Autónoma de Sinaloa, pp.13-19

Saldívar Tanaka, Emiko

(2007), "Empoderamiento o disciplina: la política de participación indígena en programas de desarrollo en México", México, Universidad Iberoamericana,

<http://www.uia.mx/campus/publicaciones/IIDSES/iidses20.pdf>, consultado el 10 febrero 2013.

(2008), Prácticas cotidianas del Estado: una etnografía del indigenismo, México, Plaza y ValdésUniversidad Iberoamericana

Sánchez Botero, Esther

(2009), "La realización del pluralismo jurídico de tipo igualitario en Colombia", Nueva Antropología, vol. XXII, núm. 71, julio-diciembre 2009, México, UAM/INAH/Conacyt, pp.31-49

Sandoval Forero, Eduardo Andrés

(2003), "Violencia y paz imposible para los indígenas en Colombia", en Sandoval Forero, E. A. y Salazar Pérez, R. (coords.), América Latina: conflicto, violencia y paz en el siglo XXI, Insumisos Latinoamericanos - Libros en Red.

(2008), La guardia indígena Nasa y el arte de la resistencia pacífica, Bogotá, Fundación Herrera.

Sanmartín, José

(2006), “Qué es esa cosa llamada violencia?”, en Suplemento del Boletín Diario de Campo, No. 40, Nov-Dic 2006, México, Instituto Nacional de Antropología e Historia, pp.11-29.

Sarmiento Silva, Sergio

(1996), "Movimiento indio, autonomía y agenda nacional", en De Grammond, H.C. (coord.) Neoliberalismo y organización social en el campo mexicano, UNAM-Plaza y Valdés.

(1998a), Voces indias y modernización: de la protesta social a la revuelta india, Tesis de Maestría en Sociología, México, Facultad de Ciencias Políticas y Sociales-UNAM.

(1998b), Voces indias y V centenario, México, INAH. 
(2001), "Procesos y movimientos sociales en la Montaña de Guerrero. Entre el corporativismo y la violencia", en Canabal, B. (coord.), Los caminos de la Montaña. Formas de reproducción social en la montaña de Guerrero, México, UAM-CIESAS-Porrúa, pp.239-256

(2004), "El movimiento indígena de Guerrero en el umbral del nuevo milenio", en Décimo Informe, Centro de Derechos Humanos Tlachinollan, <www.tlachinollan.org>

Scheper-Hughes, Nancy

(2005), "Questioni di coscienza. Antropologia e genocidio", en Dei, F. (coord.) Antropologia della violenza, Roma, Meltemi, pp. 247-302.

-y Bourgois, Philippe (eds.)

(2004), Violence in War and Peace: An Anthology, Oxford, Blackwell

Schmidt, Bettina y Schroeder, Ingo (eds.)

(2005), Anthropology of Violence and Conflict, London Routledge

Schmidt, Donatella

(1993), Do you have an opy? Politics and identity among the Mbya-Guarani of Argentina and eastern Paraguay, Bethseda, Austin and Winfield.

Sieder, Rachel

(2006), "Del indigenismo institucional integracionista a la gestión pluralista de las políticas públicas", Revista del Instituto de Estudios Interétnicos, núm. 19, octubre 2006, Universidad San Carlos, Guatemala

Sierra, Maria Teresa

(1997), "Esencialismo y autonomía: paradojas de las reivindicaciones indígenas", Alteridades, n. 14, UAM-Iztapalapa

(2005), "Derecho indígena y acceso a la justicia en México: perspectivas desde la interlegalidad", Revista IIDH volumen 41, San José de Costa Rica, pp. 287-314.

(2006), "La renovación de la justicia indígena en tiempos de derechos: etnicidad, género y diversidad", en Stanley, R. (coord.), Estado, Violencia, Ciudadanía en América Latina, Frankfurt/Madrid, Vervuert.

(2011), "Pluralismo jurídico e interlegalidad. Debates antropológicos en torno al derecho indígena y las políticas del reconocimiento", en Chenaut, V., Gómez, M., Ortiz, H. y Sierra, T. (coords.), Justicia y diversidad en América Latina. Pueblos indígenas antes la globalización, México, CIESAS-FLACSO, pp.385-401

(2013a), "Desafíos al Estado desde los márgenes: justicia y seguridad en la experiencia de la policía comunitaria de Guerrero", en Sierra, T., Hérnandez, R. y Sieder, R. (coords.), Justicias indígenas y Estado. Violencias contemporáneas, México, CIESAS/FLACSO, pp. 159-193

(2013b), "Seguridad y justicia bajo acoso en tiempos de violencia neoliberal", Revista de Estudios e pesquisas sobre as Américas, Brasil, CEPPAC/UnB, pp. 11-36

-y Chenaut, Victoria

(2002), "Los debates recientes en la antropología jurídica: las corrientes anglosajonas", en Krotz. E.

(ed.), Antropología jurídica: perspectivas socioculturales en el estudio del derecho, Barcelona, Anthropos/UAM-I

-y Speed, Shannon

(2005), "Critical perspectives of human rights and multiculturalism in neoliberal Latin America", PoLAR Political and Legal Anthropology Review, Vol. 28 No.1 


\section{AUTONOMIAINDÍGENA, VIOLENCIAY JUSTICIA}

Sosa Elízaga, Raquel

(2004), "Pobreza, violencia y seguridad pública en los años neoliberales", en Sosa Elízaga, R. (coord.), Sujetos, víctimas y territorios de la violencia en América Latina, México, UACM, pp.115-132

Sousa Santos, Boaventura

(1994), "Hacia un entendimiento postmoderno del derecho", Frónesis, año 1 núm. 2, Maracaibo, Venezuela, Universidad del Zulia, 163-17.

(2001), "Pluralismo jurídico, interlegalidad e hibridación jurídica", en El caleidoscopio de las justicias en Colombia vol.1, Bogotá, Ed. Siglo del Hombre, pp.132-145

(2003), La caída del Angelus Novus: Ensayos para una nueva teoría social, Colección En Clave de Sur, Bogotá, ILSA

(2009), "La reinvención del Estado y el Estado plurinacional", en M. L. Pérez-Ruiz, L. Valladares, M. Zárate, Estados plurales: los retos de la diversidad y la diferencia, México, UAM-I/ Juan Pablos Editores, pp. 157-179.

(2012a), De las dualidades a las ecologías, Cuaderno de Trabajo núm. 18, Red Boliviana de Mujeres Transformando la Economía, La Paz

(2012b), "Cuando los excluidos tienen Derecho: justicia indígena, plurinacionalidad e interculturalidad", en Sousa Santos, B. y Exeni Rodríguez, J.L. (eds.), Justicia indígena, plurinacionalidad e interculturalidad en Bolivia, Quito, Fundación Rosa Luxembourg/Ed. Abya-Yala, pp.11-48

Speed, Shannon

(2005), "Dangerous discourse: Human rights and multiculturalism in neoliberal Mexico", PoLAR Political and Legal Anthropology Review, Vol. 28 No.1

(2006), "Entre la antropología y los derechos humanos. Hacia una investigación activista y comprometida críticamente", en: Alteridades num.31, enero-julio 2006, México, UAM-Iztapalapa, pp.73-85.

Starr, June y Collier, Jane

(1989), History and power in the study of law. New directions in legal anthropology, Ithaca NY/ Cornell University Press.

Stavenhagen, Rodolfo

(1988), Derecho indígena y derechos humanos en América Latina, México, El Colegio de MéxicoInstituto Interamericano de Derechos Humanos

(1992), "Pueblos y derechos indígenas", América Indígena, México

(2000), Conflictos étnicos y Estado nacional, México, UNRISD/Siglo Veintiuno Editores

(2006), "La presión desde abajo: derechos humanos y multiculturalismo", en Gutiérrez, D. (coord.), Multiculturalismo. Desafios y perspectivas, México, Siglo XXI-UNAM-El Colegio de México, pp. 213-224

-e Iturralde, Diego (comp.)

(1990), Entre la Ley y la Costumbre. El Derecho Consuetudinario Indígena en América Latina, México, Instituto Indigenista Interamericano- Instituto Interamericano de Derechos Humanos

Stephen, Lynn

(1997), "Redefined nationalism in building a movement for indigenous autonomy in southern Mexico", Ethnicity, Identity and Citizenship in the wake of the Zapatista rebellion, Journal of Latin American Anthropology, vol.3, No. 1, Arlingtonn, pp. 72-101 
Stern, Steve

(2000), "La construcción histórica: los indígenas como colonizadores", en Reina, L. (coord.) Los retos

de la etnicidad, México, CIESAS-INI-Porrua, pp.73-91

Taylor, Charles

(1993), El multiculturalismo y “la política del reconocimiento”, México, Fondo de Cultura Económica

Tejera Gaona, Héctor

(1989), “Organización comunal y conflicto político en Chiapas", en Hernández, L. y Sandoval, J.M. (compil.), El redescubrimiento de la frontera sur, México, Universidad Autónoma de Zacatecas/Universidad Autónoma Metropolitana, pp. 247-306

Tello Díaz, Carlos

(1995), La rebelión de las cañadas, México, Cal y Arena.

Terven, Adriana

(2009), Justicia indígena en tiempos multiculturales. Hacia la conformación de un sujeto colectivo propio: la experiencia organizativa de Cuetzalan, Tesis de Doctorado en Antropología social, México, CIESAS

- y Chávez, Claudia

(2013), "Las prácticas de justicia indígena bajo el reconocimiento el Estado. El caso poblano desde la experiencia organizativa de Cuetzalan”, en Sierra, T., Hernández, R. y Sieder, R. (coords.), Justicias indígenas y Estado. Violencias contemporáneas, México, CIESAS/FLACSO, pp.51-87

-y Maldonado, Korinta

(2008), Los juzgados indígenas de Cuetzalan y Huehuetla: vigencia y reproducción de los sistemas normativos de los pueblos de la Sierra Norte de Puebla, México, CDI/CIESAS/Conacyt

Thompson, Richard

(1997), "Ethnic minorities and the case for collective rights", American Anthropologist, Vol.99, No.4

Toledo Tello, Sonia

(2004), "Las fincas de Simojovel: relaciones de género en un mundo jerárquico, 1900-1975", Mesoamérica núm. 46, pp. 86-109

Thwaites Rey, Mabel

(2011), "La autonomía: entre el mito y la potencia emancipadora", en Pensar las autonomías, México, Sísifo-Bajo Tierra Ediciones, pp.151-213

Ulloa, Astrid

(2010), "Colombia: autonomías indígenas en ejercicio. Los retos de su consolidación”, en La autonomía a debate. Autogobierno indígena y Estado plurinacional en América Latina, Quito, FLACSO/GTZ/IWGIA/CIESAS/UNICH, pp. 149-176.

Urteaga Crovetto, Patricia

(2009), Re-imaginado el derecho: visiones desde la antropología y otras ciencias sociales (1950-

2000), Lima, PROJUR

Valdivia Dounce, María Teresa

(2009), Pueblos Mixes: sistemas jurídicos, competencias y normas, México, UNAM 


\section{AUTOONOMIIAINDÍGENA, VIOLENCIAY JUSTICIA}

Van Cott, Donna Lee

(2000a), The Friendly Liquidation of The Past. The Politics of Diversity in Latin America, Pittsburgh University Press

(2000b), "A political analysis of legal pluralism in Bolivia and Colombia", Journal of Latin American Studies, vol. 32 (1), pp. 207-234

(2004), "Los movimientos indígenas y sus logros: la representación y el reconocimiento jurídico en los Andes", América Latina hoy, abril, núm. 036, Universidad de Salamanca, España, pp.141-159

(2005), "Pluralismo legal y administración de la justicia comunitaria informal en América Latina", presentado en la conferencia Instituciones informales y política latinoamericana, Universidad de Notre Dame, Indiana, 24-25 abril 2005

Van Dijk, Teun

(2002), "Discurso y racismo", Persona y Sociedad, Universidad Alberto Hurtado, Instituto Latinoamericano de doctrina y estudios sociales ILADES, Vol. XVI, no 3, diciembre de 2002, pp. 191205.

(2004), "Discurso y dominación”, Universidad Nacional de Colombia, Bogotá. Grandes conferencias en la Facultad de Ciencias Humanas, 4 Febrero de 2004, en

<http://www.discursos.org/oldarticles/Discurso\%20y\%20dominaci\%F3n.pdf>, consultado el 25 octubre 2013.

Vargas Collazos, Mónica

(2005), Nunca más un México sin nosotros. Expresiones etnopolíticas oaxaqueñas, México, INAH

Velasco Cruz, Saúl

(2003), El Movimiento indígena y la autonomía en México, México, UNAM

(2011), "Ecoturismo y conflicto social en Chiapas", en Calixto, R., García-Ruíz, M., Gutierrez, D., (coords.), Educación e investigación ambientales y sustentabilidad, México, Universidad Pedagógica Nacional-El Colegio Mexiquense, pp. 107-143

Velasco Orozco, Juan Jesús

(2008), "Cultura y desarrollo: elementos para una valoración de los efectos sociales del desarrollo", en Violencia, ciudadanía y desarrollo: perspectivas desde Iberoamérica, México, Universidad Autónoma del Estado de México-Porrúa, pp.275-292

Vélez-Pelligrini, Laurentino

(2006), "En torno a la violencia. Entrevista a Michel Wieviorka", El Viejo Topo núm. 222-223, Mataró, pp.59-65

Vitale, Ermanno

(2004), "El derecho constitucional indígena. Algunas consideraciones (filosóficas)", Revista Nexos, junio 2004, México.

Villa, Willliam y Houghton, Juan

(2004), Violencia política contra los pueblos indígenas en Colombia 1974-2004, Bogotá, CECOIN/OIA/IWGIA

Villoro, Luís

(1996), "Igualdad y diferencia: un dilema político", en Villoro, L. y Olivé, L. (eds.), Filosofía moral, educación e historia. Homenaje a Fernando Salmerón, México, UNAM

(1998), Estado plural, pluralidad de culturas, México, Paídos-UNAM 
(2002a) "Multiculturalismo y derecho", en Krotz, E. (ed.), Antropología jurídica: perspectivas socioculturales en el estudio del derecho, Barcelona, Anthropos/UAM, pp.213-233

(2002b), "El Estado-nación y las autonomías indígenas”, en González Galván, J. (coord,), Constitución y derechos indígenas, México, UNAM-IIJ, 231-240

Viqueira, Juan Pedro y Ruz, Mario Humberto (coords.)

(1995), Chiapas. Los rumbos de otra historia, México, CEM/UNAM; CIESAS; CH/UNAM; CEMCA; Universidad de Guadalajara.

(1997), "Regiones naturales, regiones nominales y regiones vividas", Sotavento, vol.2, núm. 3, invierno 1997-1998, Jalapa, Instituto de Investigaciones Histórico-Sociales-Universidad Veracruzana, p. 107-117.

Yashar, Deborah

(2005), Contesting citizenship in Latin America, Cambridge University Press

Yrigoyen, Raquel

(2000), Pautas de coordinación entre el derecho indígena y el derecho estatal, Guatemala, Fundación Myrna Mack

Walsh, Catherine

(2002) "Interculturalidad, reformas constitucionales y pluralismo jurídico", <http://icci.nativeweb.org/boletin/36/walsh.html>

Washbrook, Sarah

(2005), "Desarrollo económico y reclutamiento y control de mano de obra en el norte de Chiapas, 1876-1911", en Olivera, M. y Palomo, D. (coord.), Chiapas: de la Independencia a la Revolución, México, CIESAS/COCYTECH, pp. 289-300

Wieviorka, Michel

(2003), "The new paradigm of violence", en Friedman, J. (ed.), Globalization, the State and violence, Altamira Press, Walnut Creek, pp.107-139

(2005), La violence, Hachette, Paris.

(2007), "Violencia y paz", Revista Colombiana de Sociología, núm. 28, Bogotá, Universidad Nacional de Colombia, pp. 17-26.

Womack, John Jr.

(2008), Rebelión en Chiapas. Una antología histórica, México, Debate

Zarate Hernández, Eduardo

(2005), "La comunidad imposible. Alcances y paradojas del moderno comunalismo", en Lisbona, M. (coord.), La comunidad a debate. Reflexiones sobre el concepto de comunidad en el México contemporáneo, Zamora, COLMICH-UNICACH

Zebadúa Carbonell, Miguel Ángel

(2001), "El ejército y la cuestión chiapaneca", en Gall, O. (coord.), Chiapas: sociedad economía, interculturalidad y política, México, UNAM, pp. 197-234

Zibechi, Raúl

(2008a), Autonomía y emancipaciones: América latina en movimiento, México, Sísifo-Bajo tierra ediciones 


\section{AUTONOMIAINDÍGENA, VIOLENCIAY JUSTICIA}

(2008b), Territorios en resistencia Cartografía política de las periferias urbanas latinoamericanas, Buenos Aires, lavaca editora

(2010), Contrainsurgencia y miseria. Las políticas de combate a la pobreza en América Latina, México, Pez en el Árbol

Žižek, Slavoj

(1998), "Multiculturalismo o la lógica cultural del capitalismo multinacional", en: Jameson, F. y Žižek, S. (coords.), Estudios Culturales. Reflexiones sobre el multiculturalismo, Buenos Aires, Paidós, pp. 137-188.

Zuñiga, Gerardo

(2000), "La dimensión discursiva de las luchas étnicas. Acerca de un artículo de María Teresa Sierra", en Alteridades n.19, México, UAM-I

\section{Documentos}

Blom, Frans

(1953), La selva lacandona y tierras colindantes. Mapa, San Cristóbal las Casas.

Centro de Derechos Humanos Fray Bartolomé de Las Casas, AC (CDHFBC)

(2000), La Guerra en Chiapas ¿Incidente en la Historia? Informe Anual de 1999

(2002), Informe especial sobre detenciones arbitrarias

(2003), DESPLAZADOS POR EL CONFLICTO ARMADO EN CHIAPAS

2004 La paramilitarización en la Zona Norte de Chiapas.El desarrollo de Paz y Justicia, de acuerdo a Paz y Justicia.

2005 La Política Genocida en el conflicto armado en Chiapas. Reconstrucción de hechos, pruebas, delitos y testimonios

2006 BALANCE ANUAL 2005 SOBRE LA SITUACIÓN DE LOS DERECHOS HUMANOS EN CHIAPAS

2007a Balance Anual 2006 Sobre los Derechos Humanos en Chiapas

2007 b Informe de seguimiento al caso de desalojo forzado y desplazamiento de las comunidades Buen Samaritano y San Manuel, en Montes Azules

2010 Balance Anual 2009, sobre la situación de los derechos humanos en Chiapas

(2012), Entre la política sistémica y las alternativas de vida. Informe sobre la situación de los

derechos humanos en Chiapas durante los gobiernos federal y estatal 2006-2012

(2014), La tortura, mecanismo de terror. Informe Especial sobre Tortura en Chiapas

Centro de Derechos Humanos Miguel Agustín Pro Juárez, A.C. (ProDh)

(2008), Asedio a los derechos humanos: seguridad pública y justicia penal en México, en <http://www.cejamericas.org/portal/index.php/es/biblioteca/biblioteca-virtual/cat_view/43-

documentos/73-otros-documentos $>$

(2010), Sociedad amenazada. Violencia e impunidad, rostros del México actual, en $<$ http://centroprodh.org.mx/index.php?option=com_docman\&task=doc_details\&gid=50\&Itemid=28\&l ang=es>

(2012), En nombre de la "guerra contra la delincuencia". Un estudio del fenómeno de la tortura en México, en <http://centroprodh.org.mx/index.php?option=com_docman\&task=doc_details\&gid= $147 \&$ Itemid=28\&lang=es $>$

(2012b), Discriminados y encarcelados: detenciones y condenas arbitrarias a personas indígenas inocentes en México 
Centro de Análisis Político e Investigaciones Sociales y Económicas (CAPISE)

(2007), Informe "Cara de guerra: un Ejército Federal mexicano, unos pueblos indígenas, su territorio", San Cristóbal de Las Casas, Chiapas, julio 2007.

Comisión de Apoyo a la Unidad y Reconciliación Comunitaria (CORECO)

(2005), Cuaderno núm.5 ¿Por qué formamos comisiones?, San Cristóbal de Las Casas, CORECO.

Comisión Nacional de Derechos Humanos (CNDH)

(2004), Informe Especial sobre la situación de los centros de reclusión de la república mexicana

(2010), Recomendación General núm. 18 sobre la situación de los derechos humanos de los internos

en los centros penitenciarios de la república mexicana

Consejo Latinoamericano de Apoyo a las Luchas Indígenas (CLALI)

(1984), "Declaración de México. La cuestión étnico-nacional en América Latina" en: Díaz Polanco, H., La cuestión étnico nacional, Fontamara, México, 1998

Fundación para el Debido Proceso (DPLF)

(2012), La protección de los derechos de los pueblos indígenas a través de un nuevo sistema de justicia penal. Estados de Oaxaca, Chiapas, Guerrero,

Maderas del Pueblo del Sureste, A.C.

(2002), Breve historia de la llamada "Comunidad Lacandona", fotocopiado

(2003), El caso de la Reserva Montes Azules

Organización Nacional Indígena de Colombia (ONIC)

(2002), Los indígenas y la paz. Pronunciamientos, resoluciones, declaraciones, Bogotá, Turadakke/CECOIN

Organización de las Naciones Unidas (ONU)

-Consejo de Derechos Humanos

(2013) Estudio sobre el acceso a la justicia en la promoción y protección de los derechos de los pueblos indígenas, documento A/HRC/EMRIP/2013/2

-Oficina en México del Alto Comisionado de las Naciones Unidas para los Derechos Humanos

(2007), Informe del Diagnóstico sobre el acceso a la justicia para los indígenas en México. Estudio de

caso en Oaxaca

(2008), El reconocimiento legal y vigencia de los sistemas normativos indígenas en México

-Programa de las Naciones Unidas para el Desarrollo (PNUD)

(2000), Informe de desarrollo humano 2000. Equidad para Superar la Vulnerabilidad, Managua, PNUD

(2005), Informe de desarrollo humano 2005. Las regiones autónomas de la Costa Caribe ¿Nicaragua asume su diversidad?, Managua, PNUD

(2014), Índice del desarrollo humano municipal en México: nueva metodología, México, PNUD 


\section{AUTONOMIIA INDÍGENA, VIOLENCIAY JUSTICIA}

Siglas

EZLN: Ejército Zapatista de Liberación Nacional

JBG: Junta de Buen Gobierno

MAREZ: Municipio Autónomo Rebelde Zapatista

BAEZ: Base(s) de Apoyo del Ejército Zapatista

CNI: Congreso Nacional Indígena

SSJRC: Sistema de Seguridad, Justicia y Reeducación Comunitaria (de la Costa Chica y Montaña de Guerrero)

CRAC-PC: Coordinadora Regional de Autoridades Comunitarias-Policía Comunitaria

CIOAC: Central Independiente de Obreros Agrícolas y Campesinos

ORCAO: Organización Regional de Cafeticultores de Ocosingo

UES: Unión de Ejidos de la Selva

ARIC: Asociación Rural de Interés Colectivo

ProDh: Centro de Derechos Humanos Miguel Agustín Pro Juárez, A.C.

CDHFBC, Frayba: Centro de Derechos Humanos Fray Bartolomé de Las Casas, A.C.

CORECO: Comisión de Apoyo a la Unidad y Reconciliación Comunitaria

MP: Ministerio Público

ACNUR: Alto Comisionado de las Naciones Unidas para los Refugiados

INI: Instituto Nacional Indigenista

CDI: Comisión para el Desarrollo de los pueblos Indígenas

CNDH: Comisión Nacional de Derechos Humanos

CIDH: Comisión Interamericana para los Derechos Humanos

PRI: Partido Revolucionario Institucional

PRD: Partido de la Revolución Democrática

PAN: Partido de Acción Nacional

OMC: Organización Mundial del Comercio

BM: Banco Mundial

BID: Banco Interamericano de Desarrollo 
Bibliografia 